(1)

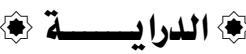

\title{
مناسبة اللفظ للمعنى عند الأصوليين وأثرها في توجيه خطاب المجتهلين
}

\author{
اللكةتـــور

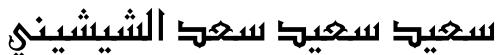 \\ مخرسر أهول الفقه بكلية اللراسات الإسلامية والهربية
}

للبنير بلسوق - جامهة الأزهر 
( ()

مناسبة اللفظ للعنى عند الأصوليين وأثرها في توجيه خطاب المجتهلين 


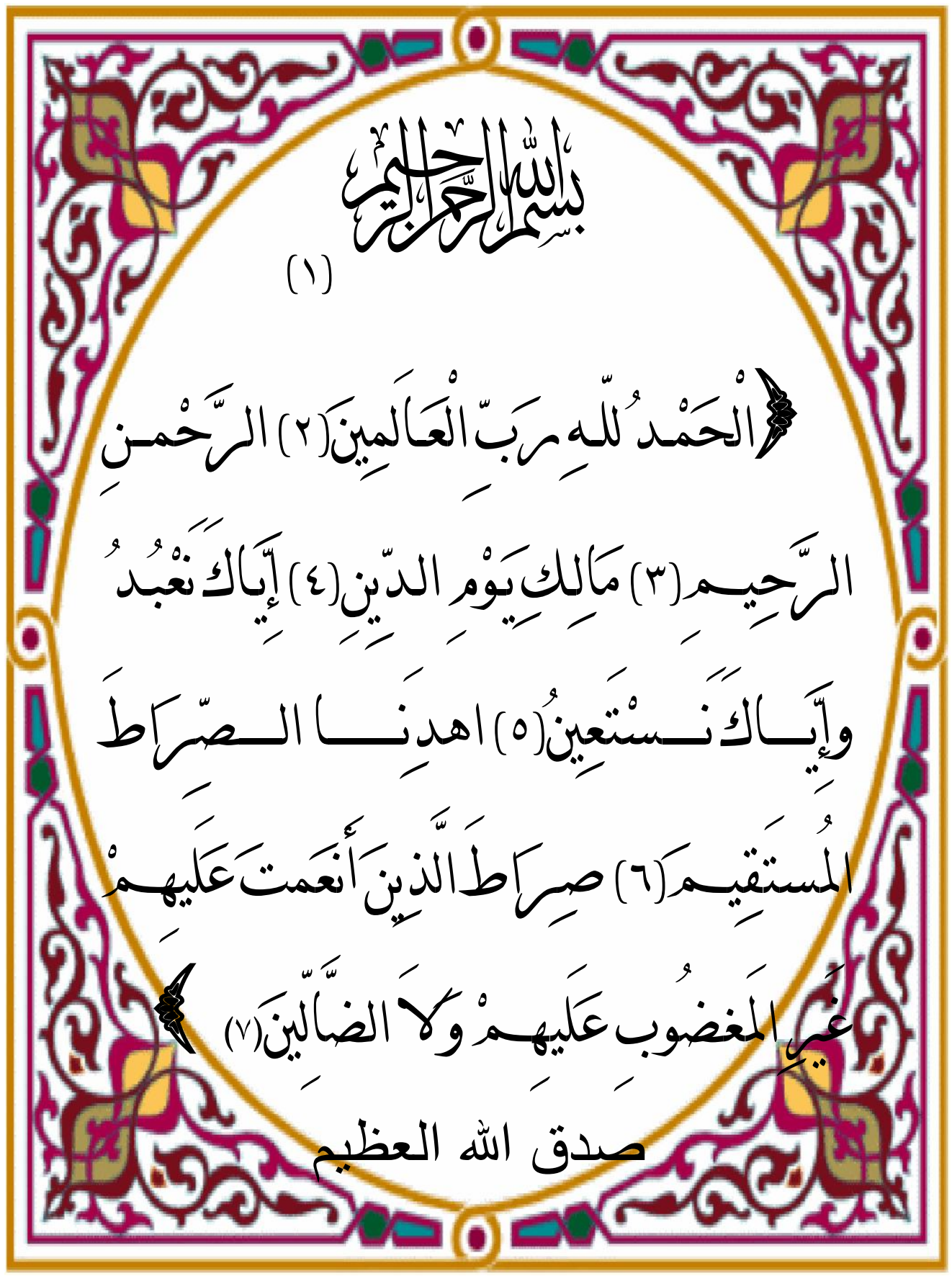


(0)

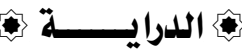

المقيطهية 
( 7 ) مناسبة اللفظ للعنى عند الأصوليين وأثرها في توجيه خطاب المجتهلين

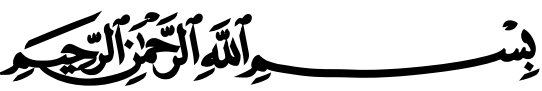

الحمــد لله رب العــالمين، أحمــــك ربي وأشــكرك، وأتــوب إليـك وأستغفرك، وأشـهـد أن لا إله إلا الله وحـده لا شريـك لـه، ولا ندلـه، ولاعـين تراه، وأشهد أن محمدا عبده ورسوله، وصفيه مـن خلقهه وحبيبه، بلغ رسـالة ربه حتى أتاه اليقين، فكان خير رسول لخير أمة أخرجت للنـاس، اللهم صـل

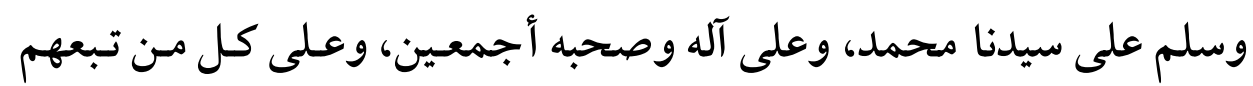

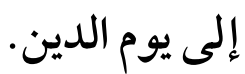

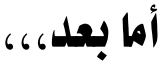

فقــد اعتنى الأصسوليون بدلالـة اللفظظ عـلى معنـاه أيـما اعتنـاء، وأفـردوا لاستعمال اللفظظ في المعنى عـدة مباحـث، حيـث إن اللفظ إذا استعمل في

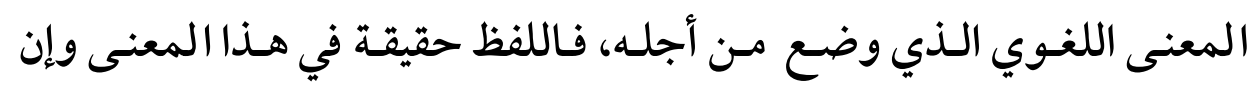
استعمل في غير المعنى الذي وضع من أجله، فإن اشتهر في المعنى المنقول

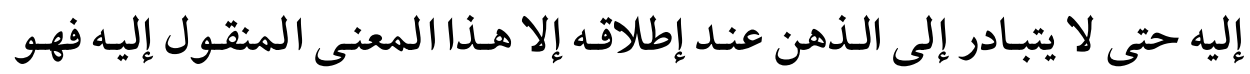
حقيقة فيه، فقد يكون حقيقة شرعية إذا كان الناقل له هـو الشرع، وقـديكون حقيقة اصطلاحية إذا كان الناقل له أهل كل فن إلى فنهم. وإن لم يشتهر اللفظ في المعنى المنقول إليه فهو مجاز في هـذا المعنى، وعند نقل الألفاظ لابد من خيط رفيع يربط اللفظ ومعنـاه في اللغـة بمعنـاه بعـد النقل، وهذا الر ابط هو ما يعرف بمناسبة - أي: ملاءمة - اللفظ للمعنى. وتبـدو الحاجـة الماسـة إلى نقـل الألفـاظ مـن معانيهـا اللغويـة إلى معـان أخرى ضرورة لغوية، ودينية، وفكرية. 
(V)

أما الضرورة اللفويــة: فإن اللغـة تقوم في أصـل مـن أصـولها على مبـداً

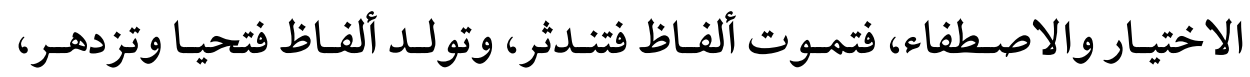

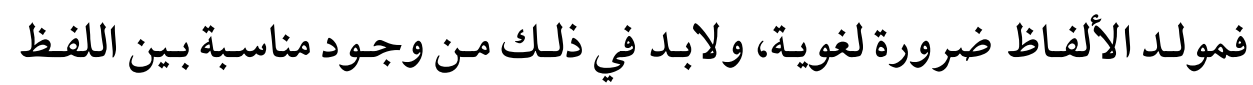
ومعناه في أصل اللغة. أما الضرورة الدينية: فإن الإسلام حينما جـاء استعمل ألفاظـا عربية في

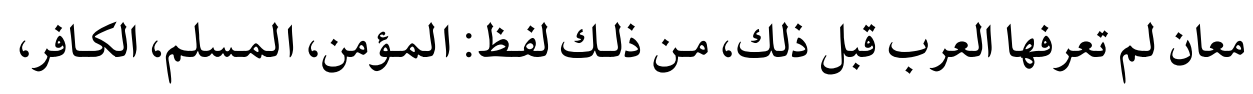
المنافق، الصلاة، الصيام، ... إلخ.

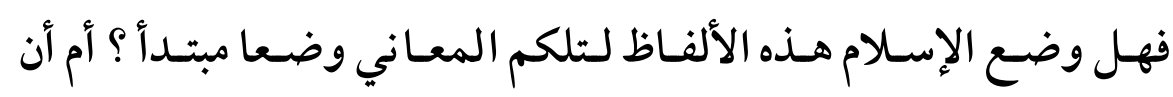
الإسلام نقلها من المعاني اللغويـة إلى المعاني الشرعية لمناسبة بين تلكـم

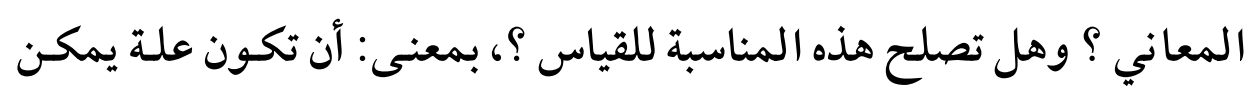

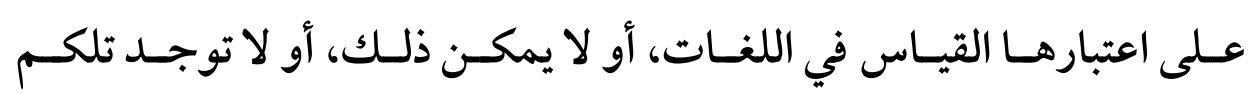

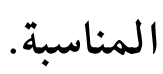
وهل أثر اعتبار هذه المناسبة على المجتهدين فوجهوا خطابهم إلى بيان

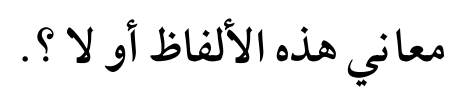
وأمـا الـضرورة الفكريــة المعاصــرة: فإنــا في عـالم يمسوج بالمفــاهيم المغلوطة، والمقالات المغالية، والمصطلحات التي تجـاوزت ميـدان الفكر إلى ميدان الواقع، حيث فجرت عنفا دمويا عانى ويعاني منه ملايسين العبـاد في

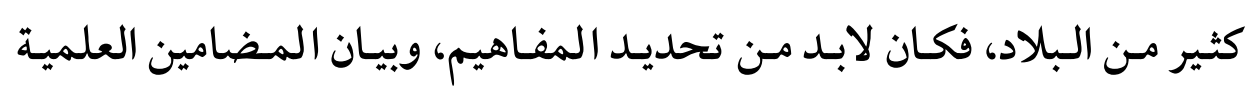

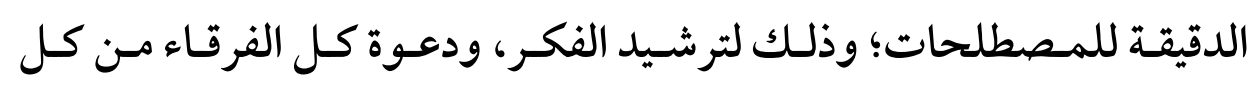
الديانات والمذاهب والاتجاهات إلى كلمة سواء. 
(A) مناسبة اللفظ للعنى عند الأصوليين وأثرها في توجيه خطاب المجتهلين

و تحديد هذه المصطلحات المنقولة من المعـاني اللغويـة إلى المعاني

الاصطلاحية في المجال الفكري لكل أهل فـن مـن الفنون لابـد لـه مـن قـانون يضبط عملية النقل هذه؛ حتى لا يحيد الناقل بالمصطلح فيستعمله في غير معنـاه، وهـذا القـانون هو اعتبـار المناسبة التي تربط المعنى المستعمل فيـه اللفظ بالمعنى اللغوي الموضوع له اللفظ. مثل مصطلح: الجهاد، فإنه في أصل الوضع لا يعني القتال والإرهـاب، إنما يعني: بذل الجهد في نشر الدعوة بالحسنى، ولكـن كثير امـن الناس نقله إلى معنى القتال أو الإرهاب، وأدى ذلك إلى ما أدى إليه. فإذا اعتبرنا المناسبة اتضح المصطلح، وظهر مفهومه، و تجنبنا كثيرا مسن الفساد الذي قد يحدث إذا لم تعتبر تلكم المناسبة (1). وسوف نقـوم ببحـث هـذه المناسبة بيـن اللفظ والمعنى، وأثرهـا في توجيـه خطاب المجتهدين قديما وحديثا، وقد آثرت أن يكون عنوان البحث : " مناسبة اللفظ للمعنى عند الأصوليين وأثرها في توجيه خطاب المجتهدين ".

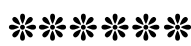

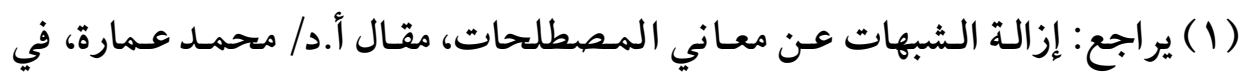

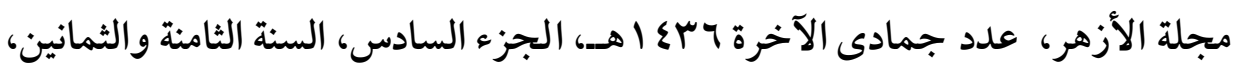

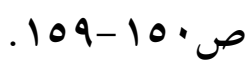


(9)

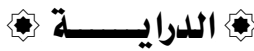

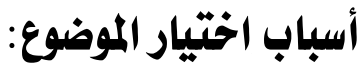

$$
\begin{aligned}
& \text { اخترت هذا الموضوع لعدة أسباب، منها: } \\
& 1 \text { - ضبط فكر مستعمل الألفاظ في المعاني المر ادة. } \\
& \text { r - تقييد السامع في حمله الألفاظ على المعاني المرادة. }
\end{aligned}
$$

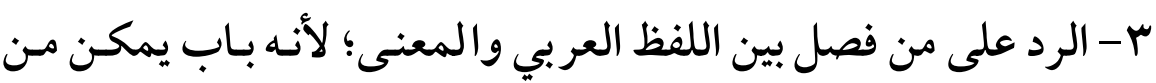

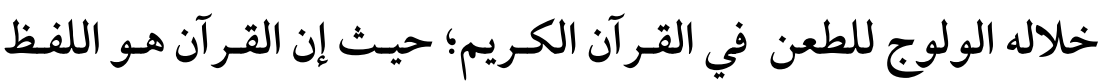

$$
\text { والمعنى معا. }
$$

ع - الرد على من فرط فألغى مناسبة اللفظ للمعنى.

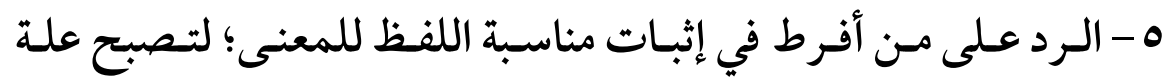

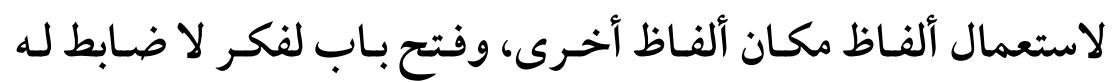
يهوي بالأمة إلى مدى لا يعلمه إلا الله تعالى.

خطة البحث:

يشتمل هذا البحث على مقدمة، وتمهيد ، و وخمسة مباحث، وخاتمة.

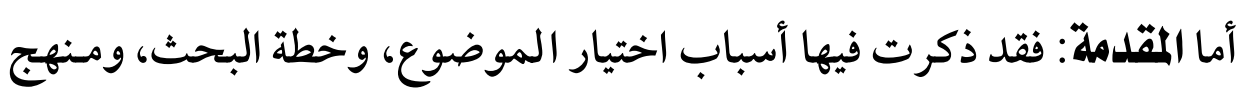
البحث.

$$
\text { تقهيد في : تعريف العلة ، وطرق إثباتها. }
$$

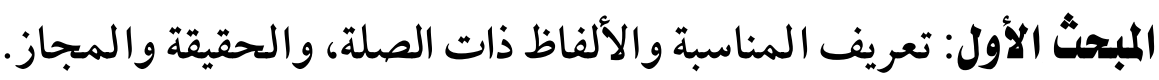

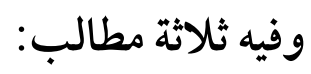

المطلب الأول: تعريف المناسبة في اللغة وعند الأصوليين.

وفيه:

أولا: تعريف المناسبة في اللغة. 
(1·)

مناسبة اللفظ للعنى عند الأصوليين وأثرها في توجيه خطاب المجتهلين

$$
\text { ثانيا: تعريف المناسبة عند الأصوليين. }
$$

المطلب الثاني :التعريف بالألفاظ ذات الصلة .

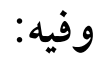

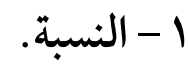

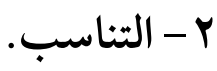

$$
\text { r- (- م- العلاقة. }
$$

المطلب الثالث: وضع اللفظ واستعماله.

$$
\text { وفيه فرعان: }
$$

$$
\text { الفرع الأول: تعريف الوضع. }
$$

الفرع الثاني: نقل الألفاظ للمعاني.

$$
\text { وفيه: }
$$

$$
\text { r - r- تعريف النقل. }
$$

المبحـث الثـاني: مناسبة اللفظ للمعنى في الوضـع وأثره في توجيـه خطـاب

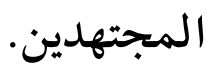

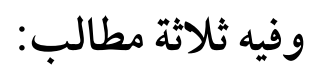

المطلب الأول: مناسبة اللفظ للمعنى عند جمهور الأصوليين في الوضع. المطلب الثاني: مناسبة اللفظ للمعنى عند عباد بن سليمان الصيمري. 
(11)

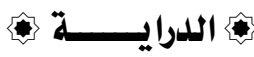

المطلب الثالث: أثر مناسبة اللفظ للمعنى في أصل الوضع في توجيه خطاب

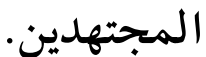

المبحث الثالـث: مناسبة اللفظ للمعنى في الحقيقة العرفية وأثره في توجيه

$$
\text { خطاب المجتهدين. }
$$

$$
\text { المطلب الأول: تعريف الحقيقة العرفية. }
$$

المطلب الثاني: شروط نقل اللفظ اللغوي إلى العرف وتحقق المناسبة.

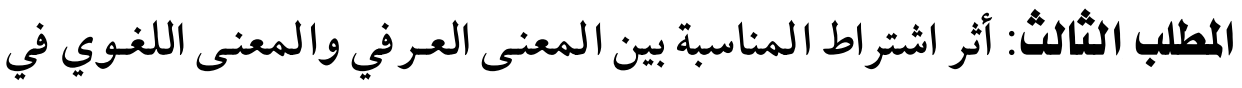
توجيه خطاب المجتهدين بالتطبيق على مصطلح الجهاد.

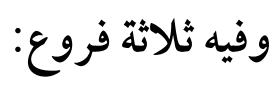

$$
\begin{aligned}
& \text { الفرع الأول: تعريف الجهاد في اللغة وفي عرف المتثرعة. } \\
& \text { الفرع الثاني: أقوال العلماء وأدلتهم في علة الجهاد. }
\end{aligned}
$$

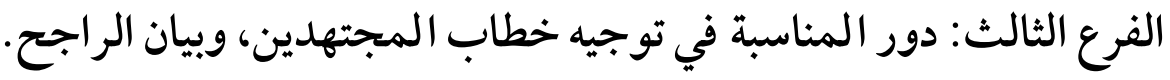

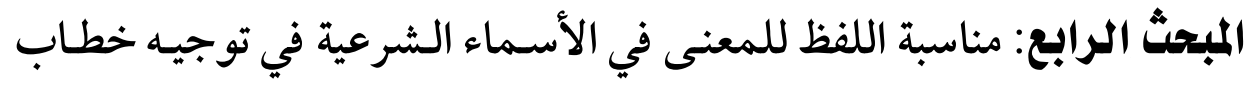

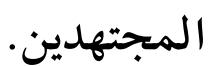

$$
\text { وفيه مطلبان : }
$$

المطلب الأول: مناسبة اللفظ للمعنى في الأسماء الشرعية.

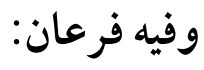

الفرع الأول: مذاهب العلماء في وجود الحقيقة الشرعية. الفرع الثاني: أدلة المذاهب والر اجح منها. 
(Ir) مناسبة اللفظ للعنى عند الأصوليين وأثرها في توجيه خطاب المجتهلين المطلسب الثـاني: أثر مناسبة اللفظط للمعنى في الأسـماء الشرعية في توجيـه

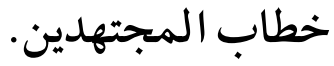

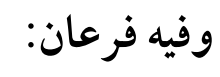

الفرع الأول: أثر مناسبة اللفظ بمعناه اللغوي للمعنى الشرعي المنقول إليه

$$
\text { هي الفيصل في قضية التكفير. }
$$

الفرع الثاني : أثر مناسبة اللفظ بمعناه اللغوي للمعنيه الثعى الشرعي المنقول إليه

$$
\text { في إثبات الأسماء الثرعية بالقياس. }
$$

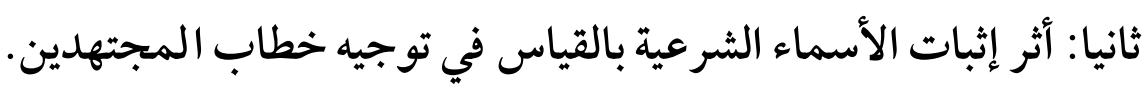

وفيه ثلاثة مسائل:

المسألة الأولى: قياس النباش على السارق.

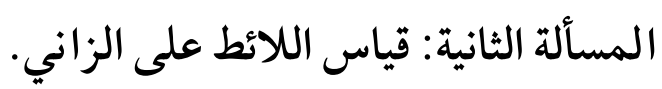

المسألة الثالثة: قياس النبيذ على الخمر.

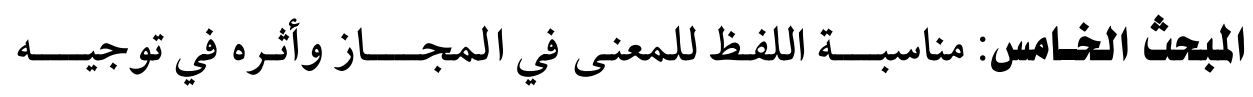

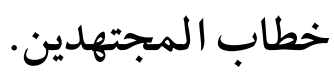

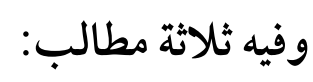

المطلب الأول: تحقق مفهوم المجاز باشتر اط المناسبة.

المطلـب الثـاني: شروط مناسبة اللفظ للمعنى في المجـاز وأثره في توجيسه

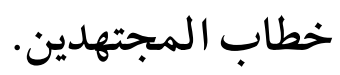


(Ir)

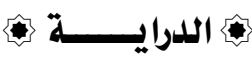

المطلب الثالث: علاقات المجاز.

الخاتمة:

وفيها:

1 - أهم نتائج البحث.

r- فهارس البحث:

وتشمل:

- فهرس الآيات القر آنية.

- فهرس الأحاديث النبوية.

- فهرس الآثار .

- فهرس الأعلام.

- فهرس الفرق.

- فهرس المراجع.

- فهرس الموضوعات.

منهج البحث:

اتخذت منهج البحث العلمـــي الذي هو متبع في البحـث في أصــــل الفقـه وهو المنهج الاستقرائي؛ وذلك كما يلي:

1 - استقريت أقوال الأصوليين في كل مسألة أصولية مع تحقيق نسبة الأقوال

إلى أصحابها وذلك من كتب الأصول المعتمدة لكل قول أذكره.

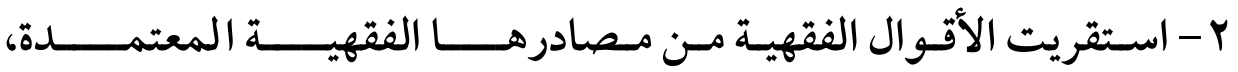

ونسبــــة الأقوال إلى أصحابها. 
(।६) مناسبة اللفظ للعنى عند الأصوليين وأثرها في توجيه خطاب المجتهلين

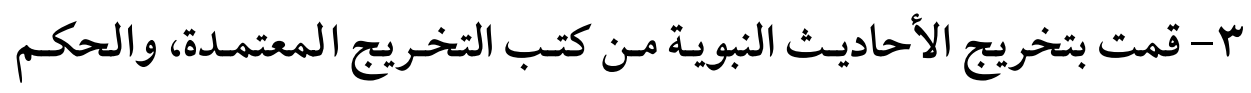
عليها. ع - عند ذكر الآيات القرآنية أذكر عقب الآية في الحاشية رقـم الآيـة والسورة

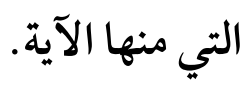

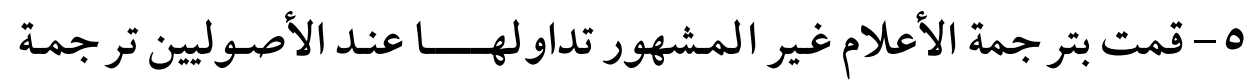
موجزة تتـضمن: اسـم العلـم، وولادته، ووفاته، وأهـم آثـاره؛ حتى يتميز بذلك عن غيره من الأعلام.

צ- رجعت عند ذكر الآثار إلى المصادر الأصيلة التي ذكر فيها الأثر. V Vمت بذكر الأبيات الشعرية، وقائلها، والبحر الذي منه البيت الشعري،

$$
\text { وبيان موضع الاستشهاد في البيت. }
$$

وبعلد، وبيان

هذا هو جهد المقل، لا أدعي فيه بلوغ الكسمال أو مقاربتـه، فـالكمال لله - تعالى - وحده، و العصمة للملائكة والأنبياء عليهم السلام. فإن كان ثمة توفيتق فهو مـن رب العـالمين - جـل وعـلا- ، وإن كـان غير ذلك فمن النفس الأمارة بالسوء والشيطان الرجيم، والله - تعـالى - أسـأل أن يحفظنا مـن الزلل، وأن يتجـاوز بفضضله عـن الخطأ، إنه نعـم المـولى ونعـم النصير. وصل اللهم وسلم وبارك على سيدنا محمل وعلى آله وصحبه وسلم 


\section{تمهيد}

\section{تعريف العلة وطرق إثباتها}

بـادئ ذبـدء نلفـت الانتبـاه إلى أن موضـوع البحـث هـو مناسـبة اللفظط للمعنى، والكلام عن المناسبة يلزمه التمهيد بـالكلام عن العلة ، وبيـان طرق إثباتها إجمالا، حيث إن المناسبة طريق من هـذه الطرق ، وسـنعرض في هـذا لهن التمهيد لتعريف العلة لغـة ، واصطلاحا ، وبيان طرق إثبات العلة إجمالا،

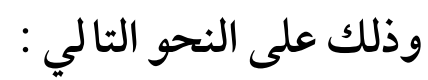
أولا: تعريف العلة في اللفة: يطلق لفظ العلة في اللغة على عدة معان ،منها: 1 -الشرب الثاني يقال :علل - بفتح العين - بعد نهل ، إذا عـاود الشرب مرة

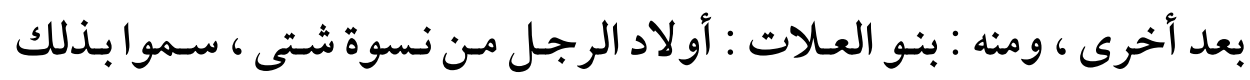

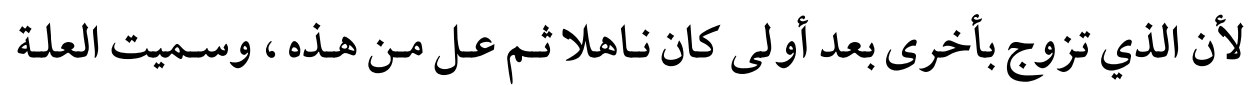

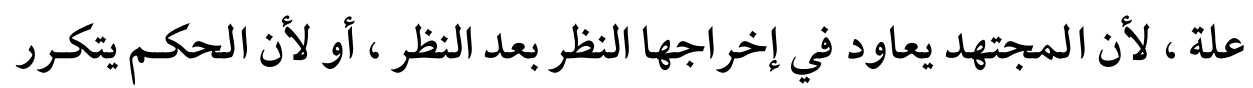

$$
\text { بتكرر وجودها. }
$$

ץ-أن العلة اسم لما يتغير حكـم الشئ بحصوله، مأخوذة مـن العلة - بكسر

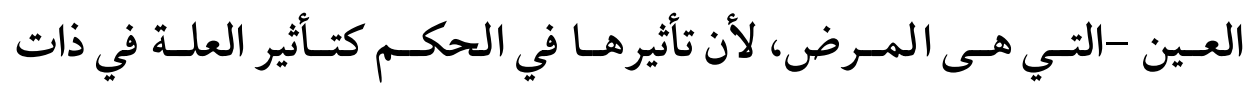

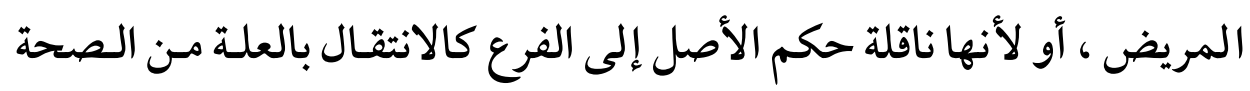

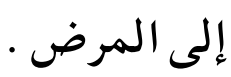


(17) مناسبة اللفظ للعنى عند الأصوليين وأثرها في توجيه خطاب المجتهلين

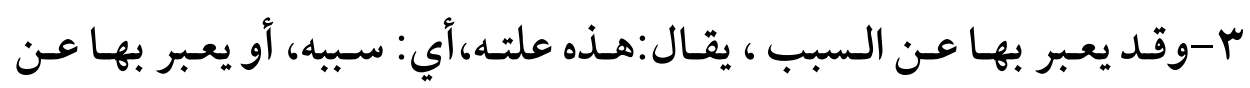

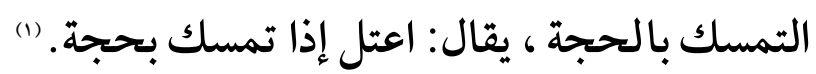
ثانيا: تصريف العلة في اصطلاح الأصوليين:

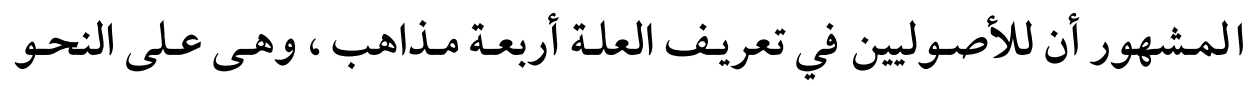
التالي:

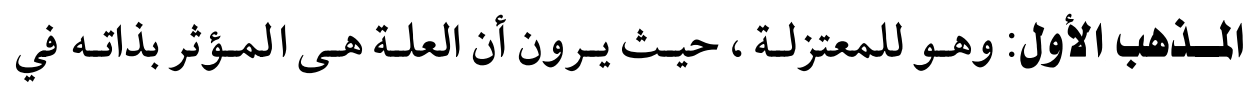
الحكم ، بدون خلق الله تعالى هذا التأثير .

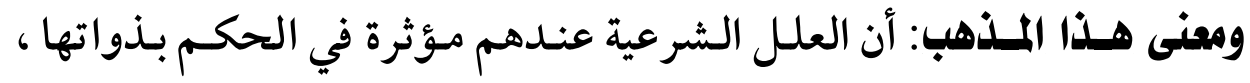
كالقتل العمد العدوان مؤثر في وجـوب القصاص عقدلا ،كما أن النار مؤثرة

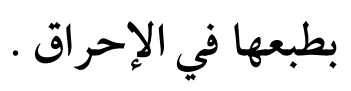
ويرد عليه: بأن هذا المذهب مبني على قاعـدة التحسين والتقبيح العقليين ، وقد علم بطلانها في موضعها (r).

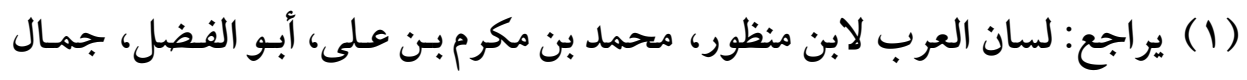

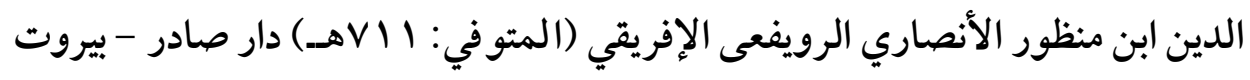

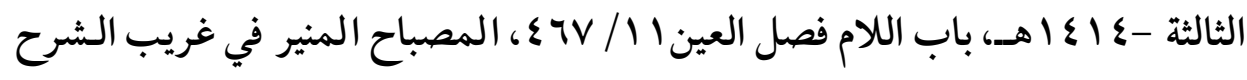

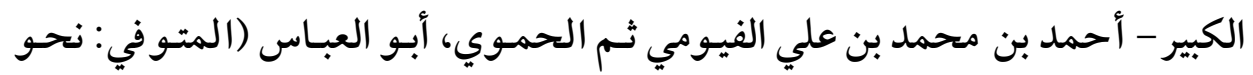

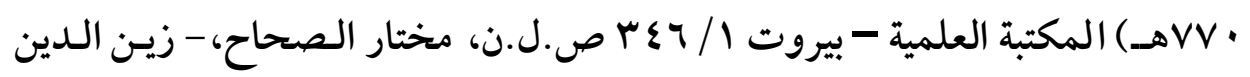

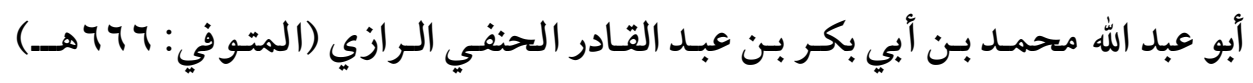

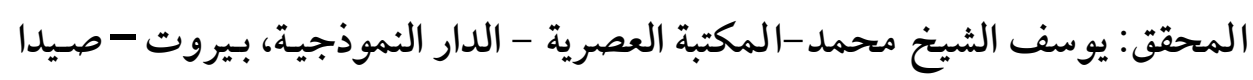

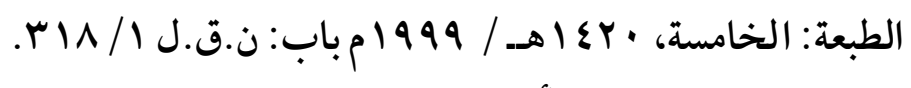

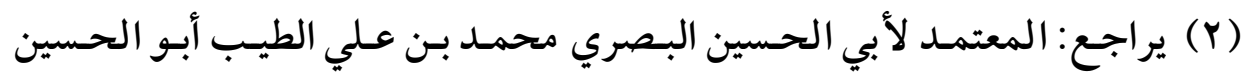

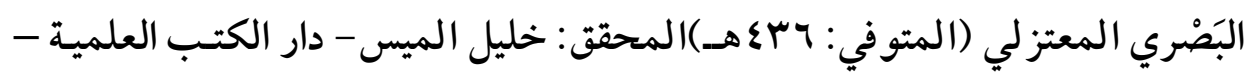


المذهب الثاني : وهو للغزالي ، حيث إنه يـرى أن العلة هـى المؤثر بجعل الله

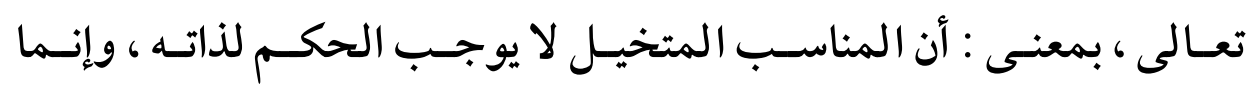

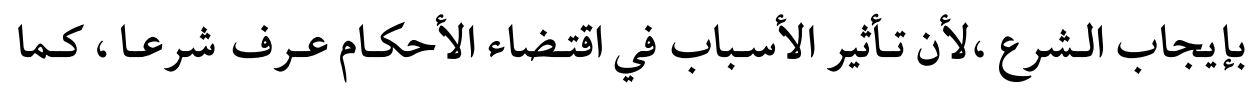
عرف كون مس الذكر مؤثرا في إيجاب الوضوء وإن لم يناسب .

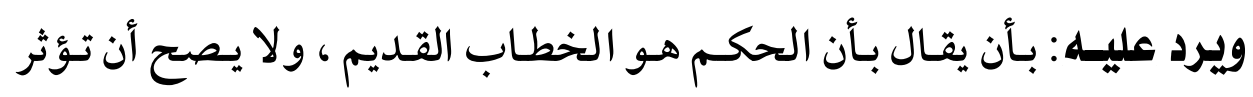
الصفة الحادثة فيه'".

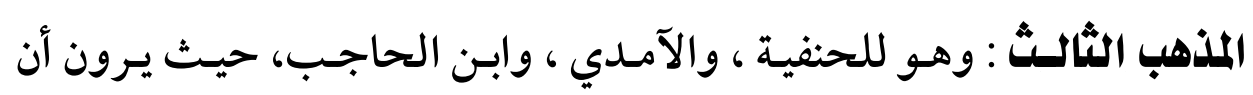

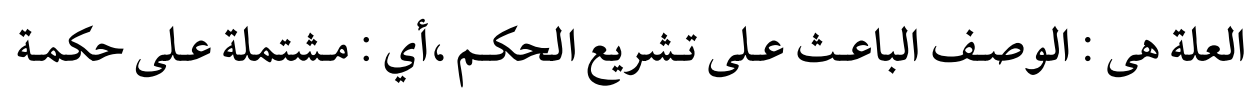

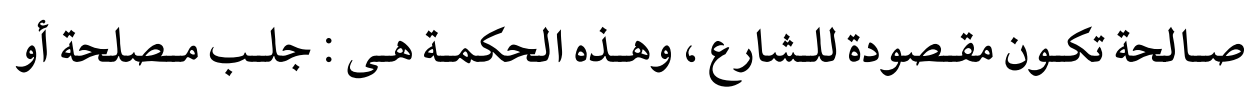
تكميلها، أو دفع مفسدة أو تقليلها.

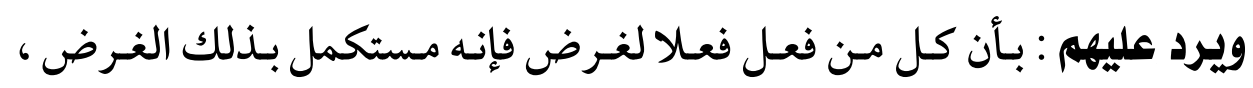
والمستكمل بغيره ناقص بذاته ، وهو محال على الله تعالى (r).

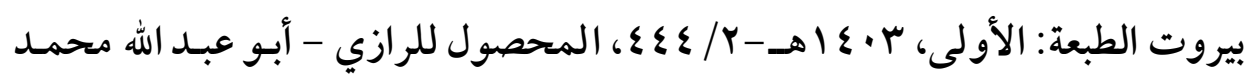

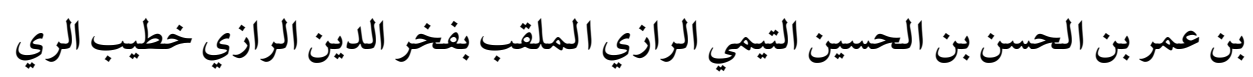

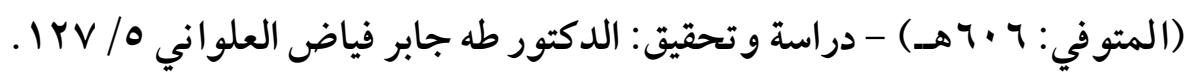

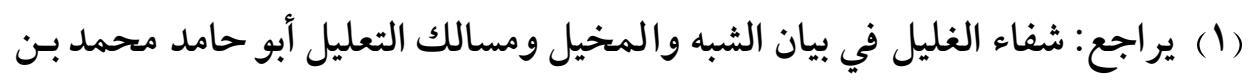

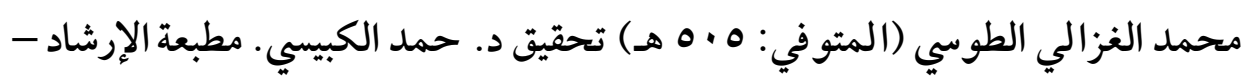

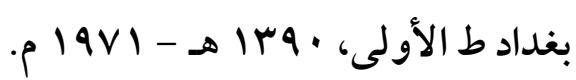

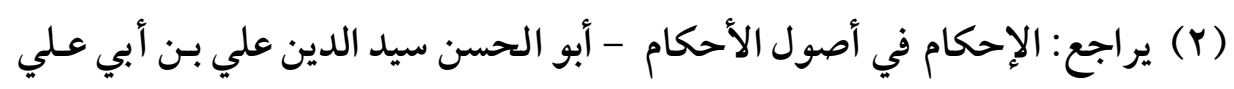

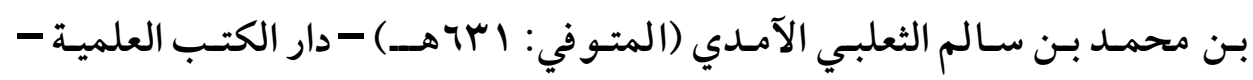


(1A)

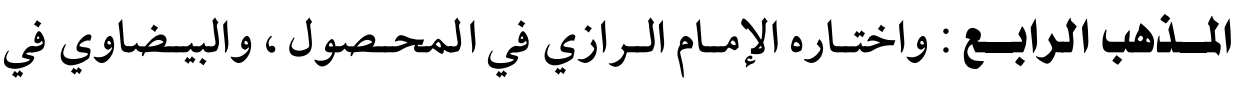

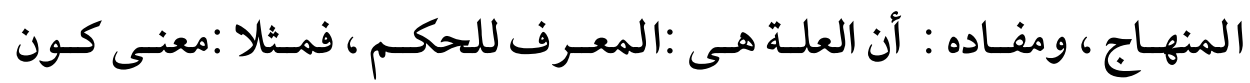
الإسكار علة :أنه معرف ،أي: علامة على حرمة المسكر، كالخمر والنبيذل). وهو التعريف الراجح، لسلامته من الرد عليه ، وللرد على التعريفات السابقة .

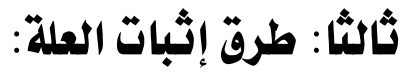

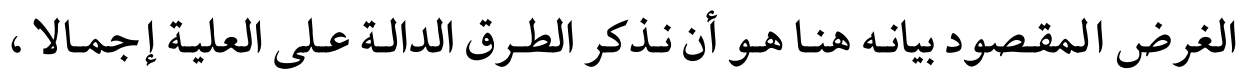

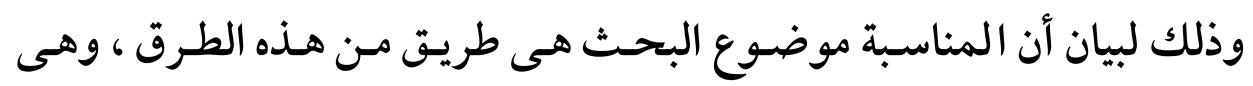
طرق كثيرة ، أشهرها طرق عشر، وهى على النحو التالي :

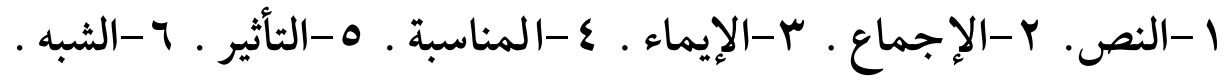

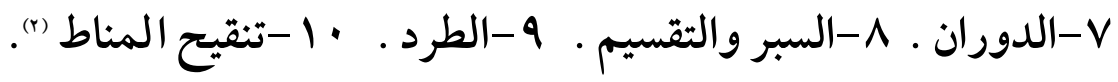
فلا يكتفي في القياس بمجرد وجـود العلة ، ولكن لابـد مـن دليل يشهد لـه

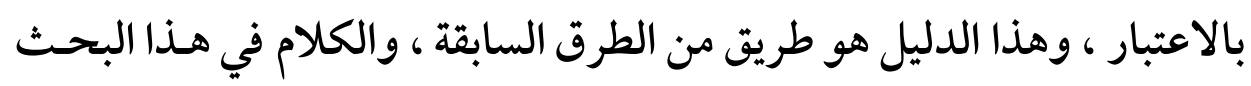

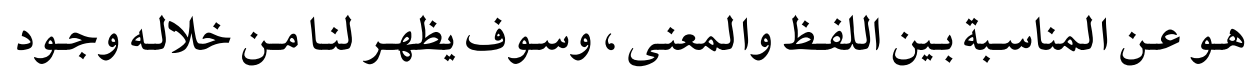

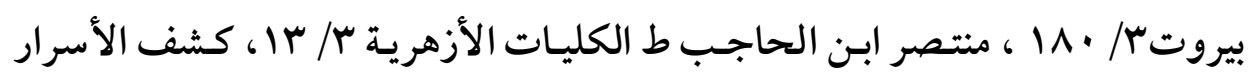

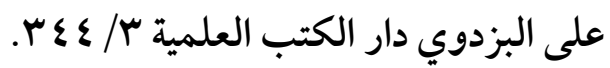

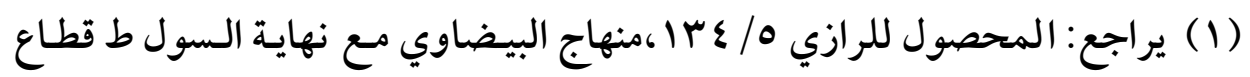

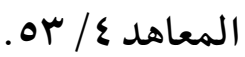

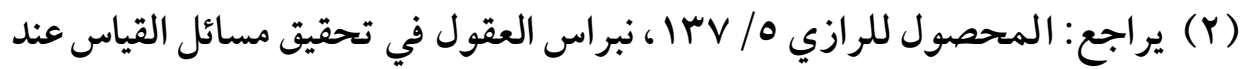

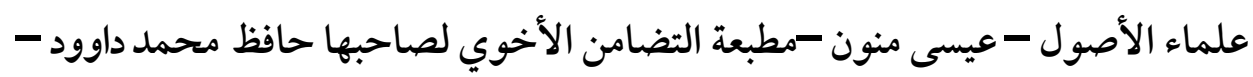

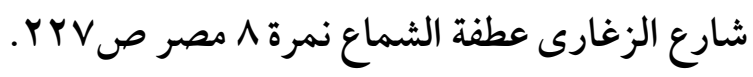


(19)

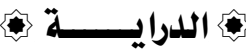

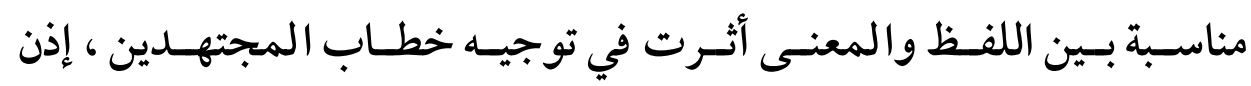
المناسبة هناطريق من طرق إثبات العلة في القياس اللغوي وليس الشرعي · 
$(r \cdot)$ مناسبة اللفظ للعفنى عند الأصوليين وأثرها في توجيه خطاب المجتهلين

\section{المبحث الأول}

تعريف المناسبة والألفاظ ذات الصلة، والهقيقة والمجاز

إن من أراد الثروع في شيء عليه أن يتصوره بحـده أو رسـمه، وقبـل أن نتـكلم

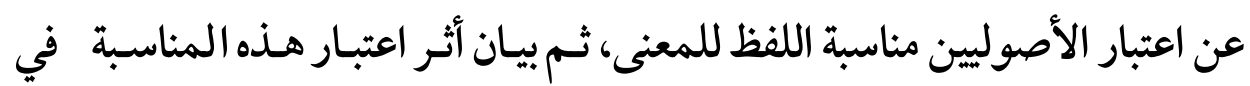

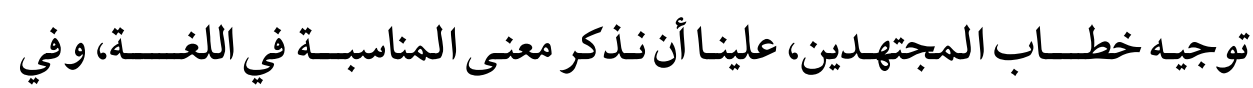
الاصطلاح.

ثم إن لفظة "المناسبة " تتشابه مـع ألفـاظ أخــى، وتكون هـذه الألفـاظ

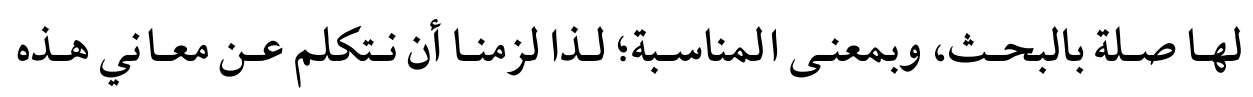

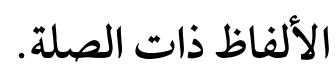

وإذا كان استعمال اللفظ في معنى مـن المعـاني هـو من صـفة المـتكلم،

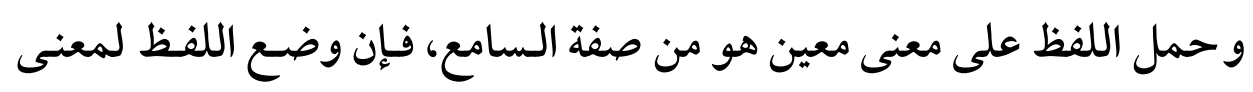
يأتي قبل الاستعمال وقبل الحمل.

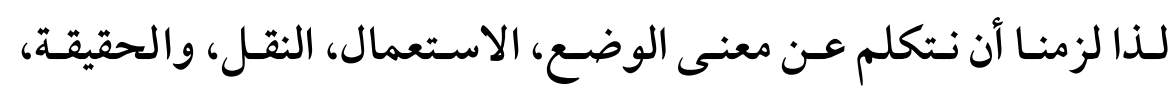

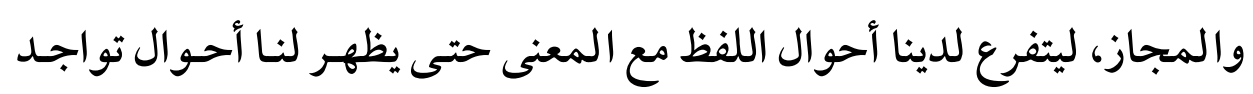
هذه المناسبة بينهما، وما يترتب على ذلك من أثر في الفقه الإسـلامي، وسـوف يتضح لنا ذلك من خلال المطالب التالية:

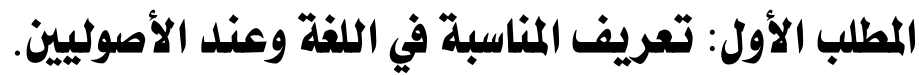

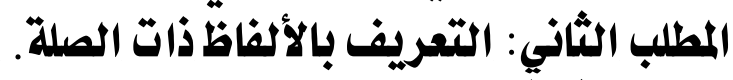
المطلب الثالث: وضع اللفظ واستعماله. 


\section{الامطاب الأول}

\section{تمريف المناسبة في اللغة وعند الأصواليين}

عندما نريد أن نعرف لفظا من ناحية اللغـة فسوف نأتي بأصله ومشتبنقاته

$$
\text { فيظهر لنا معناه عند أهل اللغة. }
$$

أما تعريفه عند الأصوليين فهو تعريف عر في في مصطلحهم، يكون بـرد

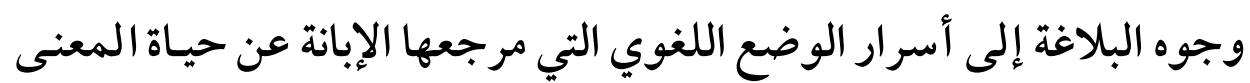

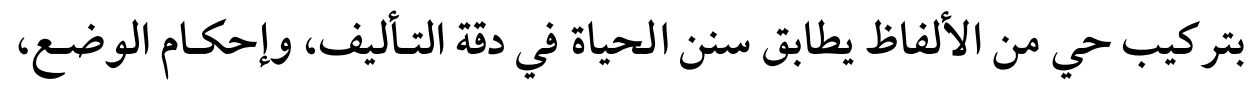
و جمال التصوير، وشدة الملائمة.

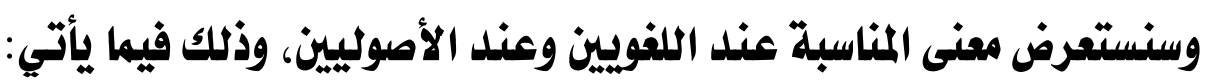
أولا: تعريف المناسبة في اللفة:

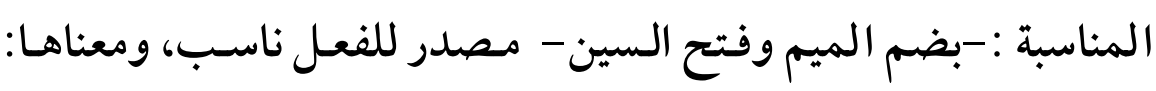

الملاءمـة، والملاءمـة بــضم المـيم - مفاعلـة مـن: لاءم، ومعناهـا: الموافقـة وإيجاد المناسبة (1) ففي المخصص : (" قال أبو عبيد: واءمته مواءمة ووئاما وهي: الموافقة )|) ().

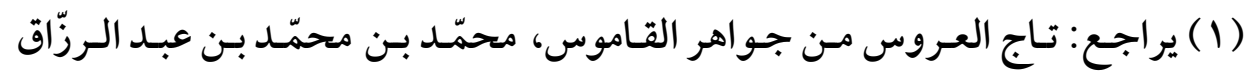

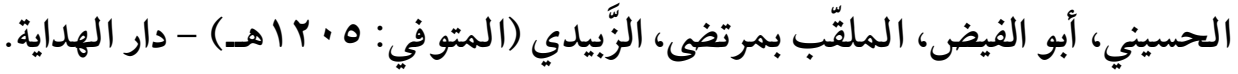

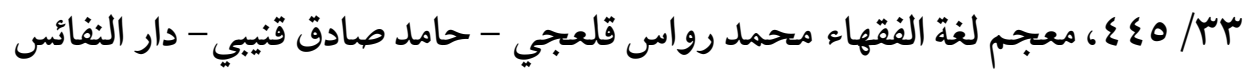

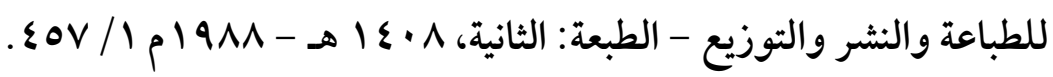

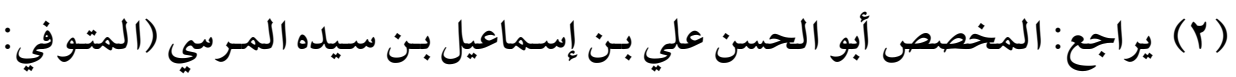

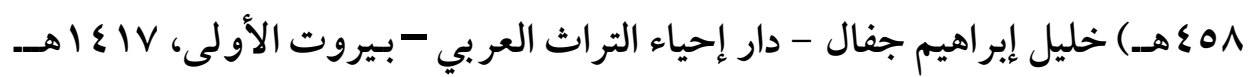
rVY/r-1997 


$$
\text { وفي لسان العرب: ( الملاءمة وهي: الموافقة ) ) (1). }
$$

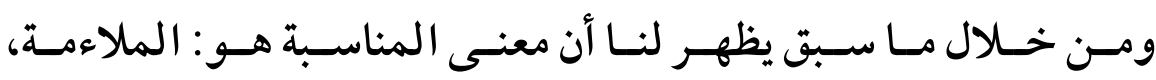

$$
\text { والملاعمةمعناها: الموافقة. }
$$

إذن فالمناسبة هي: الموافقة، فبإذا قلنا: إن بين اللفظ ومعناه مناسبة أي:

$$
\text { مولإجاجة، فما نوع هذه الموافقة ؟. }
$$

- اتفاق الشيئين في الخاصة يطلق عليه: مشاكلة.

$$
\text { - - ماتفاقهما في الكيفية يطلق عليه: مشابهة. }
$$

تعرض الأصوليون لتعريف المناسبة في باب القياس، وجعلوهـانيا مسلكا

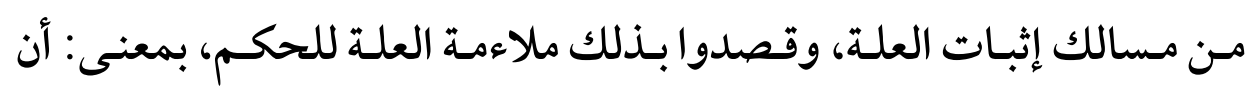
العلة يجب أن تحقق مقصد الشارع الذي أراده من الحكم.

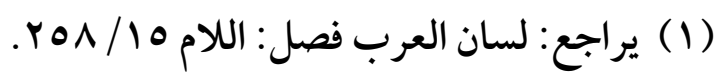

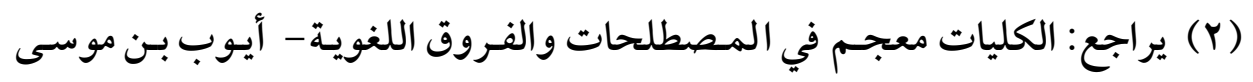

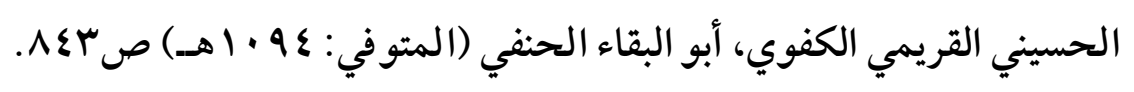


وهي من الطرق العقلية في إثبات العلة، ويعبر عنها بالإخالة -بكسر

الهمزة- لأنه يخال -أي: يظن - كون الوصف علة، ويعبر عنها -أيضات بالاستدلال ورعاية المقاصد (1).

وقد ألفيت للأصوليين منهجين في تعريف المناسبة؛ وذلك على النحو الآتي: المنهج الأول: منهج الحنفينة منهين.

لقد جعل الحنفية المناسبة بمعنى : الملاءمـة، وهي موافقـة الوصف الوفية - أي: العلة- للحكم، بحيث يصح إضافة الحكم إليه، ولا يكون نائبا عنه. مثال ذلك: إضافة ثبوت الفرقة في إسلام أحسد الزوجين إلى إبـاء الآخـر؛

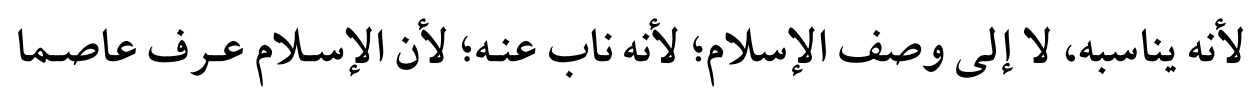
للحقوق لا قاطعا لها.

وكذا المحظور يصلح سـبيا للعقويـة، والمباح سـببا للعبـادة لا العكس؛ لهـ لعدم الملاءمة.

وهذا معنى قـولهم: الملاكمـة: أن يكون الوصف علمى وفق مـا جـاءعن

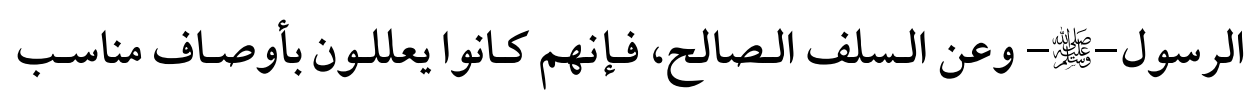
وملائمة للأحكام غير نائبة عنه.

ووجود الحكم عند وجـود الوصف مـن غير اشتر اط ملاءمـة وتأثير، أو

وجوده عند وجوده، وعدمه عند عدمه، يسمى بالطرد، وهو يقابل المناسبة (r).

(1) يراجع: نبراس العقول في تحقيق مسائل القياس عند علماء الأصول -عيسى

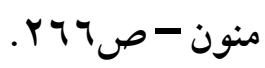
ير (Y) يجع: تيسير التحرير - محمد أمين بن محمود البخاري المعروف بأمير بادشاه الحنفي 
(Y乏)

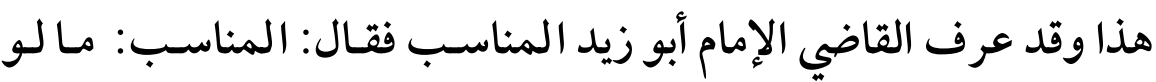

عرض على العقول لتلقته بالقبول (1).

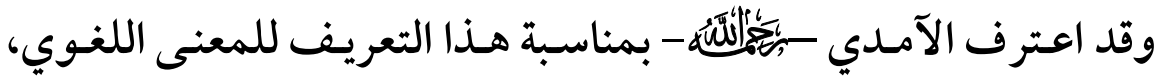
ولكنه اعترض عليه.

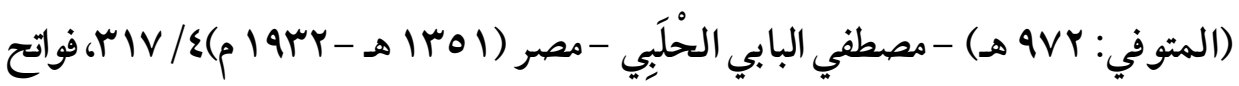
الرحموت شرح مسلم الثبوت لعبد العلى محمد بن نظام الدين الأنصاري - مؤسسة التاريخ

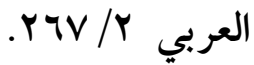

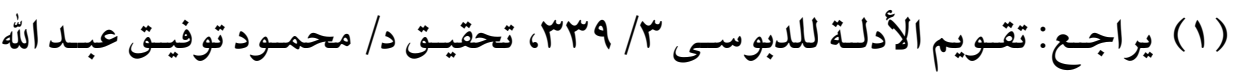

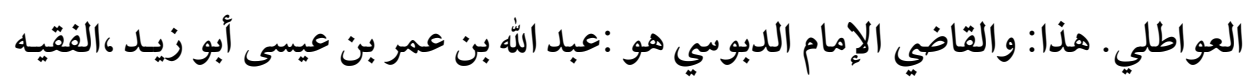

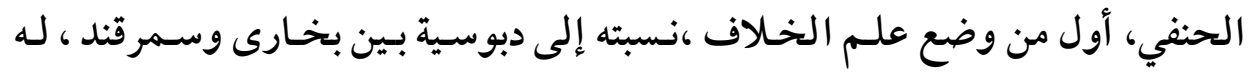

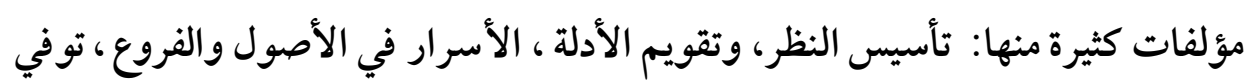

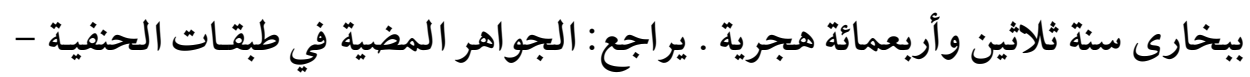

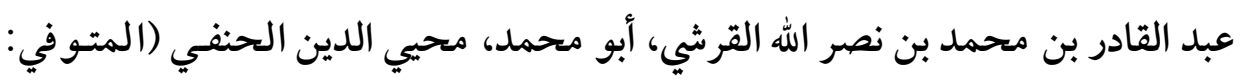

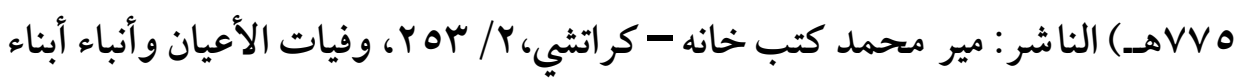

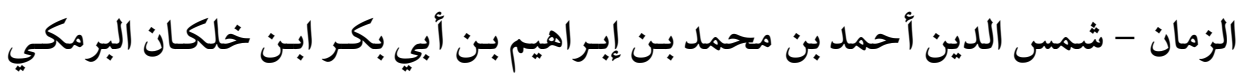

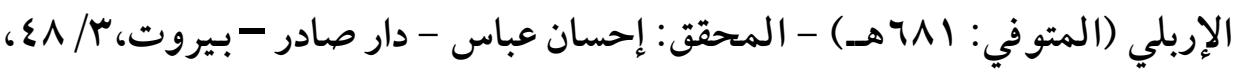

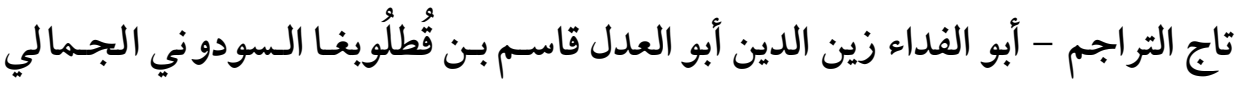

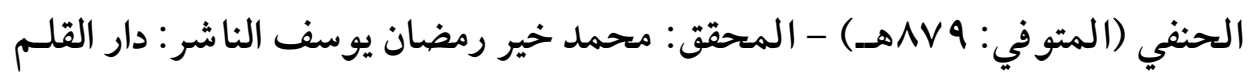

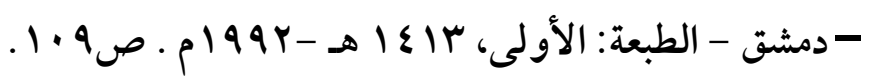


(Yo)

وحاصل اعتراضه: إن المناسب بهذا المعنى، وإن أمكـن أن يكـون حجـة

للناظر مع نفسه؛ لأن العاقل لا يكابر نفسه فيما يقضي بـه عقله؛ لأنه لا يمكن أن يكون حجة للمناظر على خصمه؛ لجواز أن يقول له الخصم: هـذا ممـا لم يتلقه عقلي بالقبول، وتلقي عقلك لـه بـالقبول ليس بـأولى في الاحتجـاج مـن عدم تلقي عقلي له بذلك (1). ويجاب عنه: بأن المـراد: تلقي العقـول السليمة مـن حيـث هي، لاعقل المناظر (r) - (1) - (1)

\section{المنهج الثاني: منهج جمهور العلماء.}

يـرى جمهـور العلـماء غـير الحنفيـة أن المناسـبة أعـم مـن الملاءمــة، المهاء. ويقسمون المناسب إلى: ملائم، وغير ملائم.

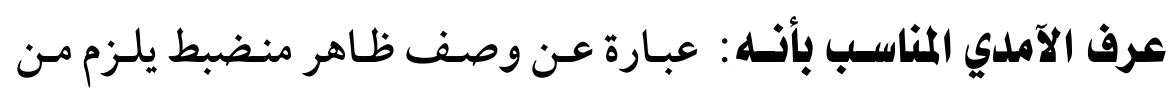
ترتيب الحكم على وفقه حصول ما يصلح أن يكون مقصودا مـ شرع ذلك ولك

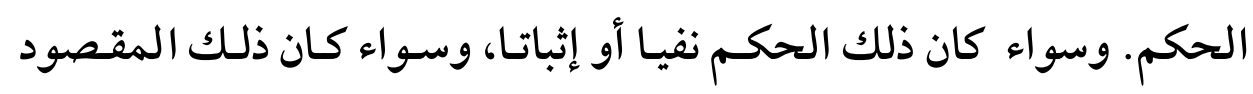
جلب مصلحة أو دفع مفسدة. واعترض عليه: بأنه عرف المناسبة بمعنى المناسب تجوزا. والأولى أن يقول: المناسبة: كون الوصف ظاهر ا منضبطا ........ إلخ.

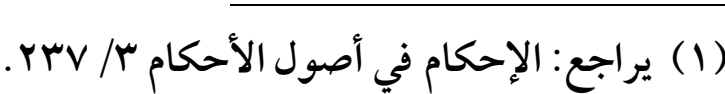

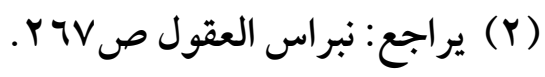


(YY) مناسبة اللفظ للعنى عند الأصوليين وأثرها في توجيه خطاب المجتهلين

واحترز بالظاهر عن الوصف الخفي، وبالمنضبط عن غير المنضبط،

وبقوله: " يصلح أن يكسون مقـصـودا" عـن الوصــف المستبقي في السبر

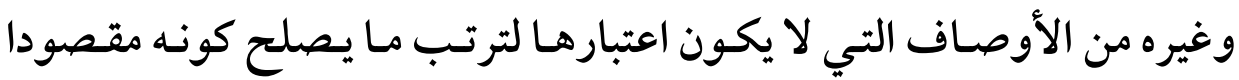

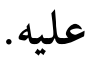

أما تفسيره "بما يكون مقصودا للشارع من شرع الحكم .... " . فيلزم منه الدور ؛ لأن ذلك إنما يعرف بكونه مناسبا، فلو عرف كونـه مناسبا بذلك كان دورا. وذكر الآمدي أن بين تعريفه والتعريف اللغوي مناسبة؛ لوجود التعلق والارتباط بين الوصف والحكم "(.). وعرف العضد المناسب بأنه: وصف ظـاهر منضبط يحصل عقلا مـن ترتيب الحكم عليه ما يصلح أن يكون مقصودا للعقلاء.

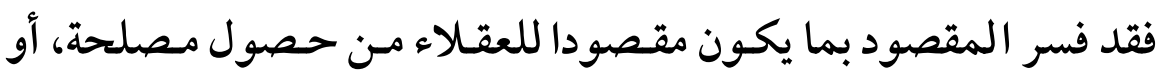
اندفاع مفسدة؛ لـئلا يتوهم أن المـراد: مـا يكسون مقصود دما من شرعية الحكـم

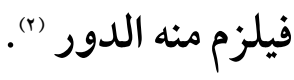

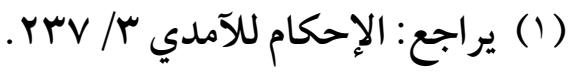

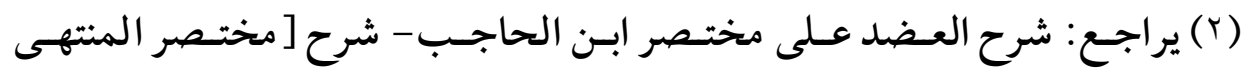

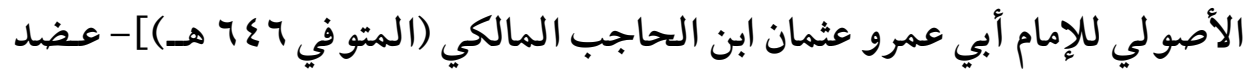

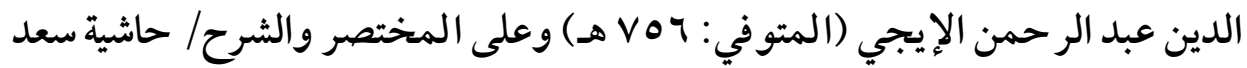

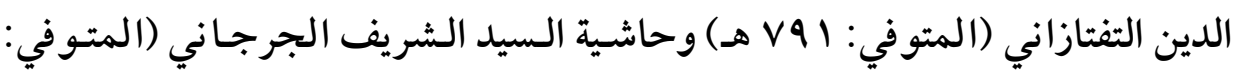


هـذا كلـه عنــد مـن يجعـل الأحكـام الثابتـة بالنـصوص متعلقـة بـالحكم

$$
\text { والمصالح. }
$$

أما من يرى خلاف ذلك يـرى أن المناسـب هـو الملائم لأفعـال العقلاء

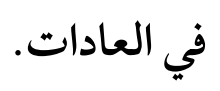

\section{الفرق بين المعنى اللفوي والاصطلاحي:}

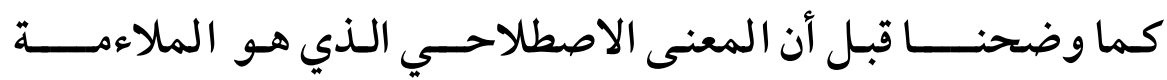
المخصوصة هي فرد من أفراد المعنى اللغوي، وهو مطلق الملاءمة. فقد نقل المعنى اللغوي إلى المعنى الاصطلاحي وخصص، مـن بـاب أبراب

$$
\text { نقل الثيء إلى فرد من أفراده (1). }
$$

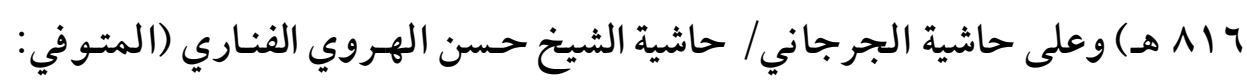

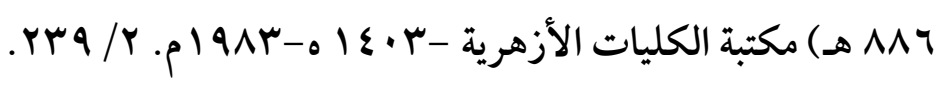

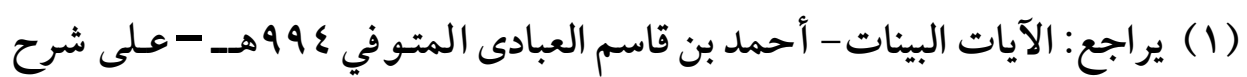

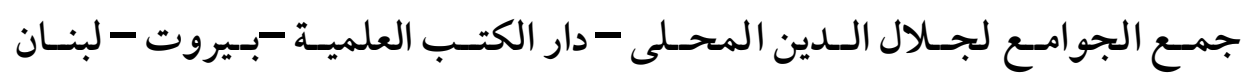
. $\wedge \vee \wedge \wedge / \varepsilon$ 
$(Y \wedge)$

مناسبة اللفظ للعنى عند الأصوليين وأثرها في توجيه خطاب المجتهدين

\section{الاطلب الثاني}

\section{التعريف بالألفاظ ذات الصلة}

استعمل العلماء بعض الألفـاظ في اصطلاحاتهم وهـذه الألفـاظ تحمل

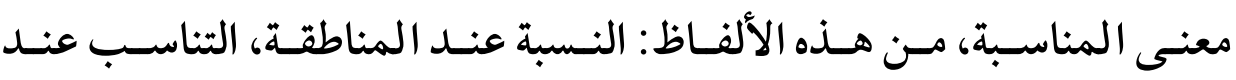
البلاغيين، العلاقة عند البلاغيين أيضا، وسوف نستعرض معاني هذه الألفاظ

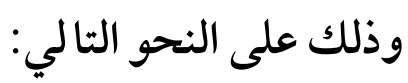

اـ النسبة النة

النسبة: النسبة: مصدر الثلاثي نسب ، بنفس معنى المناسبة.

والنسبة: الربط، وهي تامة خبرية وإنشائية، وغير تامة (1).

وتسمى عنــ المناطقـة النسبة الحكميـة، وهـي: ثبـوت شيء لـشيء، أو

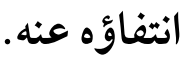

وإدراك أن النسبة الحكميـة واقعـة أو غير واقعـة جـزء مـن التصديق عندـ الإمام الرازي، وهي كل التصديق عند الحكماء.

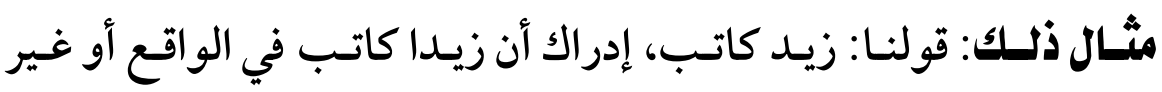

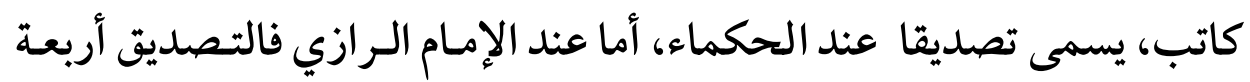

(1) يراجع: معجم الصواب اللغوي دليل المثقف العربي - الدكتور أحمد مختار عمر

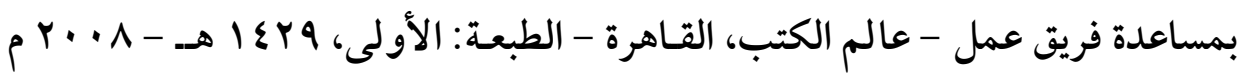

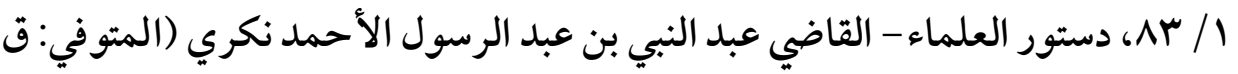

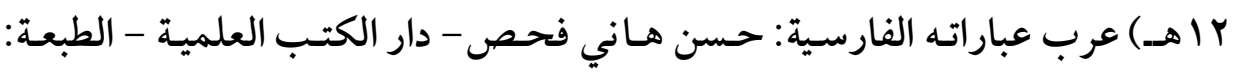

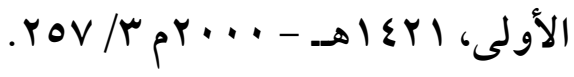


إدراكـات هي: إدراك المحكـوم عليسه، وإدراك المحكـوم بـه، وإدراك النسبة

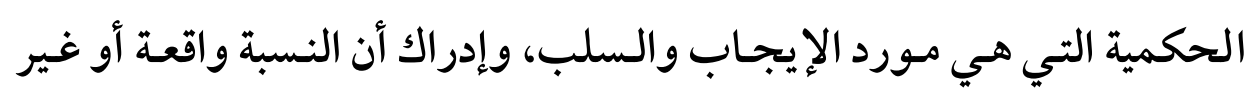

rـ التناسب

التناسب عنـد علـماء البلاغـة هـو مـا يسمى بمر اعـاة النظير، والائتلاف،

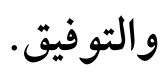

وهو أن يجمع في الكلام بين أمر وما يناسبه لا بالتضاد.

وقولنا: لا بالتضاد؛ ليخرج الطباق؛ لأن المناسبة فيه بالتضاد.

مثال ذلك: قول بعضهم لأحسد الوزراء: (" "أنـت أيها الوزير إسـماعيلي

الوعد،شعيبي التوفيق، يوسفي العفو، محمدي الخلق" ").

فالتناسب بين: إسماعيل، وشعيب، ويوسف، و محمد، أنهم أنبياء.

وبين الوعد، التوفيق، العفو، الخلق، أنها أخلاق.

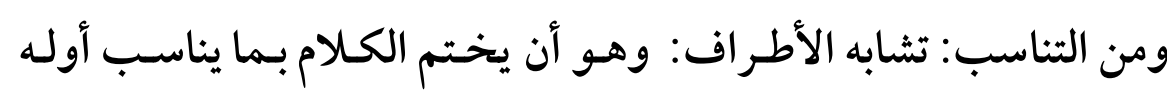

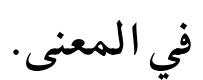

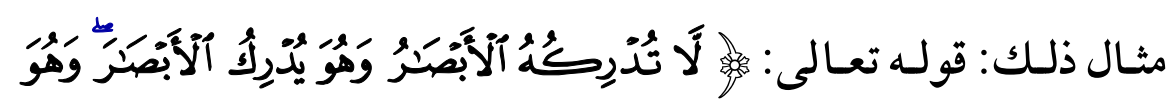

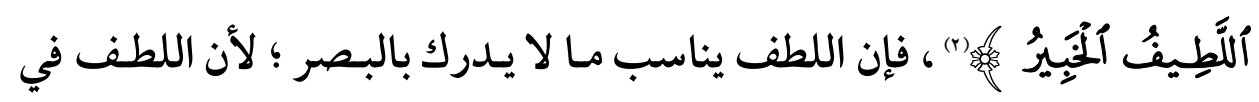

(1) يراجـع: شرح السلم للملوي طبـع على نفقـة قطاع المعاهـــ الأزهريـة • 199 1م 
(r.) مناسبة اللفظ للعنى عند الأصوليين وأثرها في توجيه خطاب المجتهلين

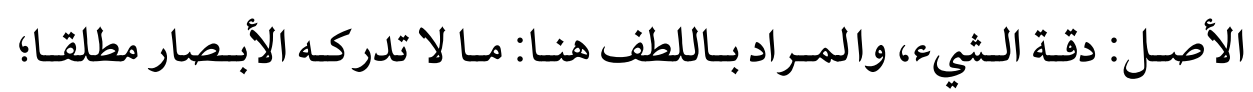

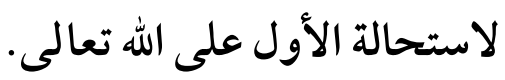
ويجوز أن يكون اللطف بمعنى: الر أفة، فيكون من إيهام التناسب. والخبرة تناسب من يدرك شيئا؛ فإن من يدرك شيئا يكون خبيرا به.

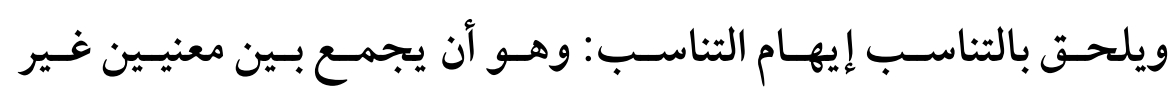
متناسبين بلفظين يكون لهما معنيان متناسبان، ولكنهما غير مقصودين.

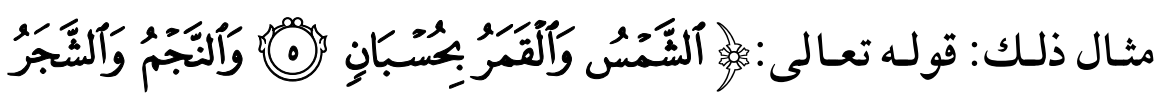

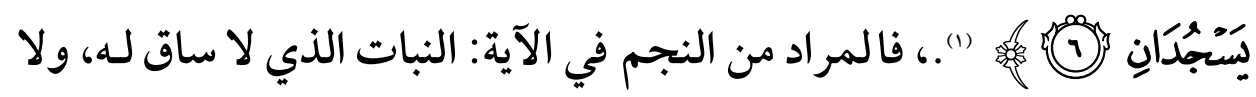

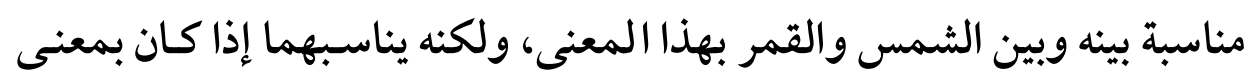

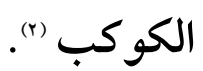

\section{rـ العلاقة}

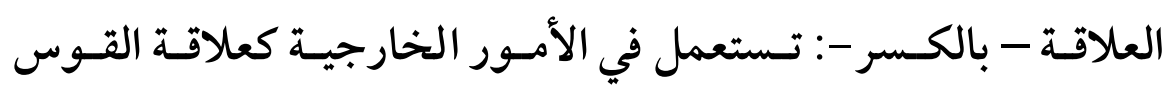
والـسوط ونحو همــا، والعلاقـة بـــالفتح -: تـستعمل في الأمـور الذهنيــة

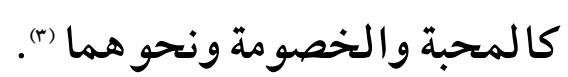

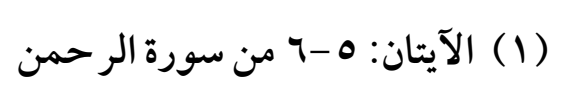

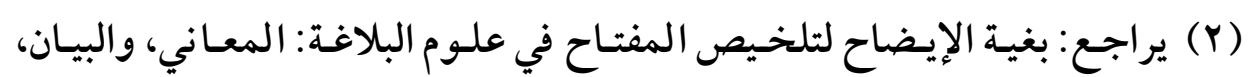

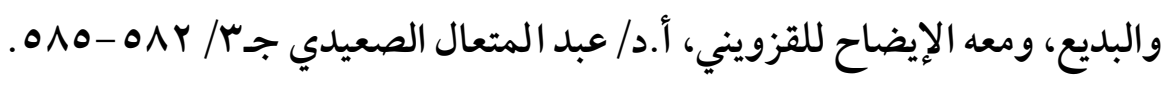

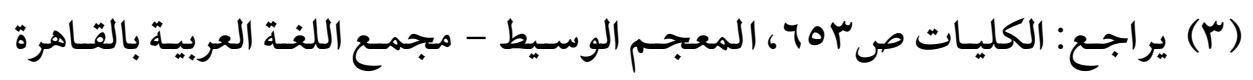

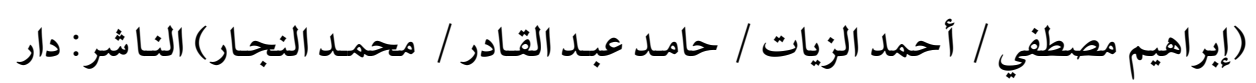

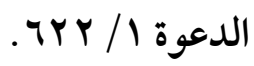


(MI)

والعلاقة - بـالفتح- عرفها الشريف الجرجـاني في حاشيته على شرح العضد المختصر لابـن الحاجـب فقـال: هي اتصال مـا بين المعنيـين، معتبر بحسب نوعه (1) شرح التعريـف: قولـه "اتصال مـا بـين المعنيـين" جـنس في التعريـف

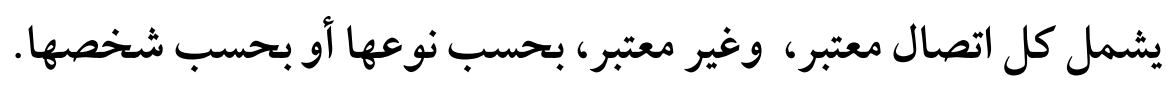

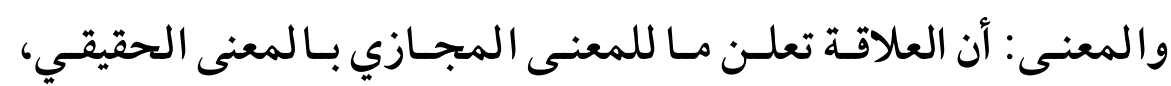
وسوف يأتي تصور هذا الاتصال. قوله: "معتبر " قيد في التعريف أخرج الاتصال غير المعتبر.

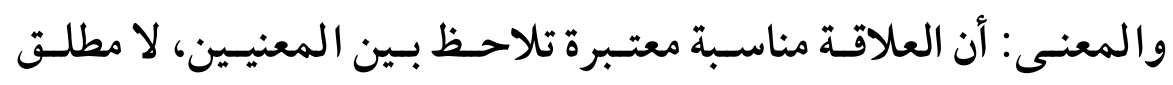

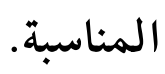
وأنه لا يلزم من عدم ملاحظة المناسبة عدمها، وحينئذ جـاز أن يكـون بين

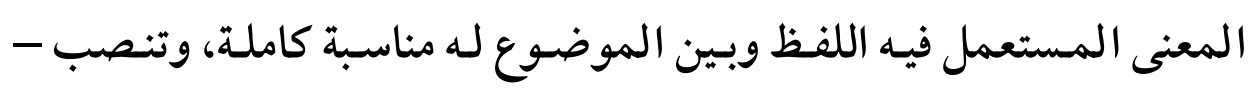

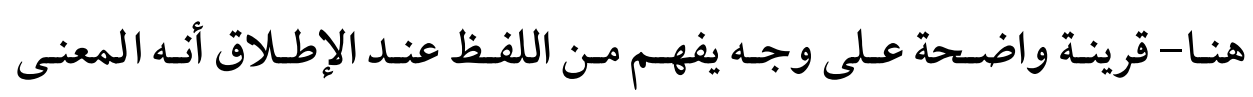
المقصود.

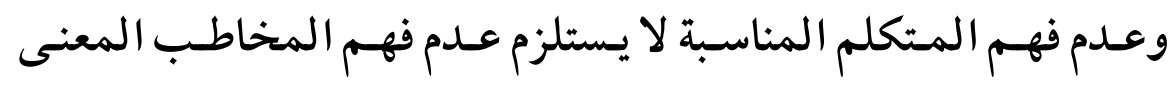
المجازي المقصود من اللفظ بحسب الوضع. و يجب أن تكون هذه المناسبة ظاهرة الثبوت للمعنى الحقيقي، ولهاب بـهـ

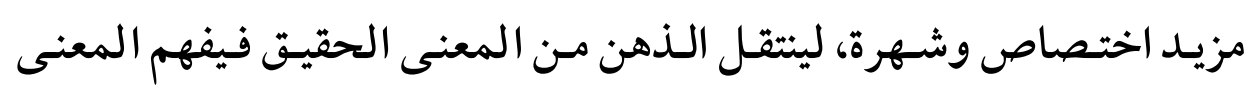
الآخر أعني - المجازي-. (1) يراجع: حاشية الشريف الجرجاني على شرح العضد / / ؟ ا. . 
(rY) مناسبة اللفظ للعنى عند الأصوليين وأثرها في توجيه خطاب المجتهلين

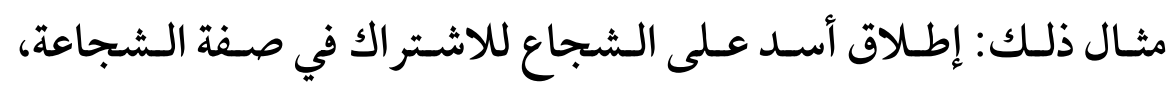
صحيح إذ لها فيه ظهور ومزيد اختصاص. بخلاف إطلاق أسد على الأبخـر فإنه لا يصح؛ لعـدم ظهـور هـذه الصفة في الأسد وإن كانت فيه (1).

قوله: "بحسب نوعه " جريا على القول بـأن الذي يعتبر مـن العلاقـة في المجاز نوعها لا شخصها. وقيل: إن المجـازات اللغويـة المفـردة يجـب إقرارهـا حيـث وردت، ولا يجوز التصرف فيها إلا بتوقيف وإذن من أهل اللغة (r).

米楼楼

(1) يراجع: حاشية الشيخ حسن الهروي على حاشية الجرجـاني، المرجع نفسه، الموضع نفسه.

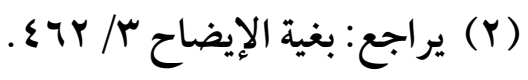




\section{المطاب الثالث}

\section{وضع اللفظ واستعماله}

إن استعمال اللفظ مـن صـفة المـتكلم، وحمـل اللفظ على المعنى مـن

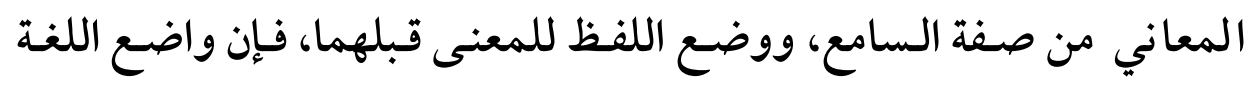
وضع لكل معنى من المعاني لفظا يدل عليه، ثم جـاء الإنسان الذذي يستعمل

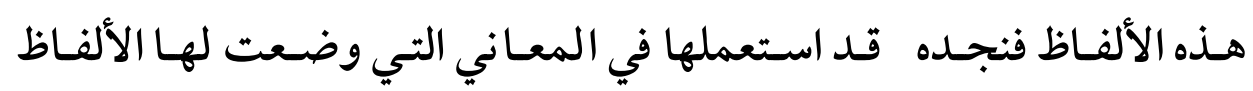
أحيانا، واستعملها في غير هذه المعاني أحيانا أخرى.

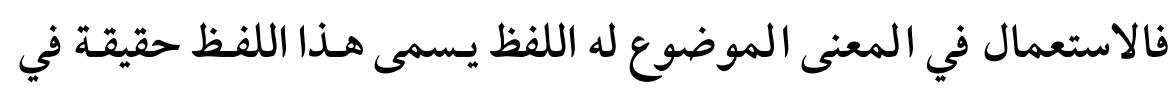

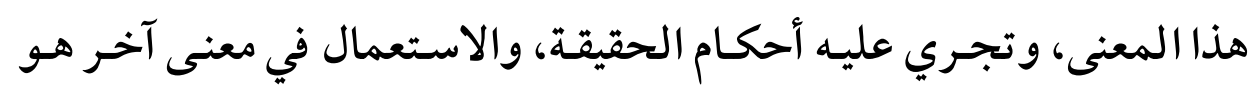
نقل ا المستعمل للفظ من معناه الذي وضع له إلى معنى آخر، ويسمى اللفظ حينئذ لفظا منقو لا. فاللفظ قبل الاستعمال لا يوصف بكونه حقيقة أو مجـازا، وبعـد الاستعمال قسم الأصوليون اللفظ باعتبار استعماله في المعنى إلى أقسام وهي:

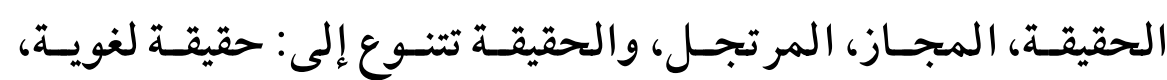
وحقيقة عرفية، وحقيقة شرعية، والضابط الفارق بين هذه الأقسام هـو اعتبار مناسـبة المعنـى المنقـول إليـه اللفـظ للمعنـى الموضـوع لـهـ اللفــ أو عـدم

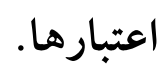

وسوف يتضح ذلك من خلال الفرعين التاليين:

$$
\text { الفرع الأول: تعريف الوضع. }
$$

الفرع الثاني: نقل الألفاظ للمعاني. 
(rq)

مناسبة اللفظ للعنى عند الأصوليين وأثرها في توجيه خطاب المجتهلين

\section{الفرع الأول}

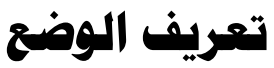

لما كان الإنسان مدنيا بالجبلة، مفتقر ا إلى الصحبة بالضرورة؛ لأنه خلـق خلقا لا يستقل بمعاشه، ولا يستبد بمنافعه، بل هو مفتقر في ذلك إلى غيره، و ذلك الغير إما مجتمعا معـه وإمـا مباينا عنه، والمنفعـة التي يفتقـر إليها إمـا حاضرة وإما غائبة، فوضست الإثـارة لسد الخلة في الحـاضر، ووضست العبارة لتقوم مقام ذلك في الغائب (1). وتعبير الألفـاظ عـن المعـاني بالوضـع يجـب أن يكـون في إطـار محـدد المصادر، ومصادر الألفاظ للمعاني إما الوحي وإما الوجود. فالوحي: هو الكتاب والسنة. وأما الوجود: فيفرق العلماء بين الواقع ونفس الأمر.

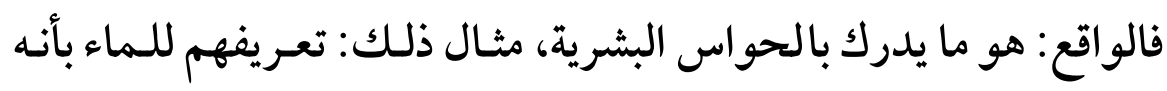
سائل شفاف لا لون ولا طعم ولا رائحة له، يتلون بلون الإناء الذي هو فيه. ونفس الأمر: هو ما وراء الحواس، مثال ذلك: القطرة مـن المـاء تحتوي على هيدروجين وأكسجين وملايين من البكتيريا وغير ذلك .... والوحي: يخاطبنا طبقا للواقع، ولا يمنعنا من معرفة نفس الأمر.

(1) يراجع: المحصول لابن العربي - القاضي محمد بن عبد الله أبو بكر بـ العربي

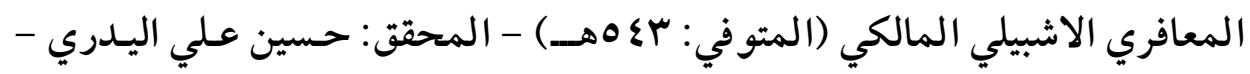

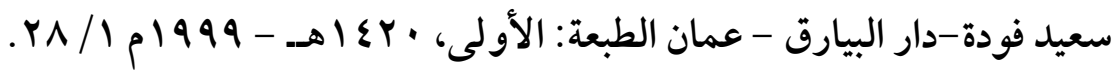


(ro)

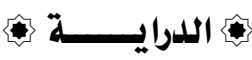

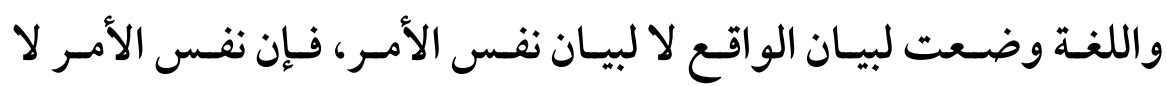

تحتمله الألفاظ اللغوية (1).

\section{تعريف الوضع:}

$$
\text { الوضع: تعيين اللفظ للدلالة على معنى بنفسه ().". }
$$

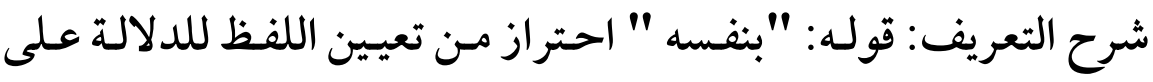

$$
\text { معنى بقرينة. }
$$

واللغة التي وضعت للمعاني واستقر وضعها هي لغة القـر آن الكـريم؛ لأن

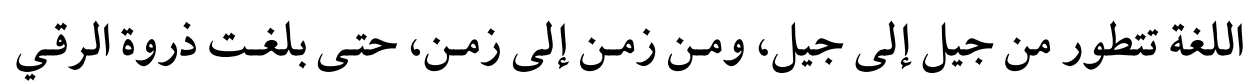

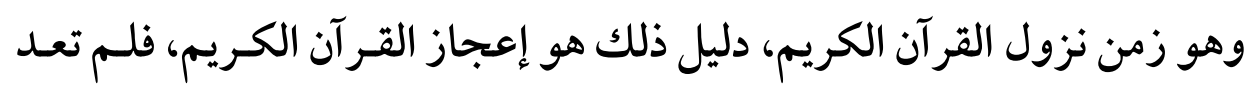
هناك مر احل من الترقي تستشرف اللغة إليها (r).

(1) يراجع: المصطلح الأصولي ومشكلة المفاهيم أ.د/ علي جمعس- دار الرسـالة -

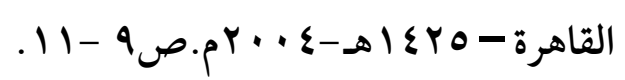

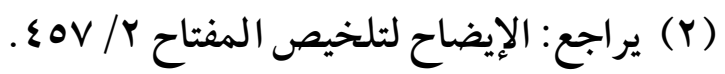

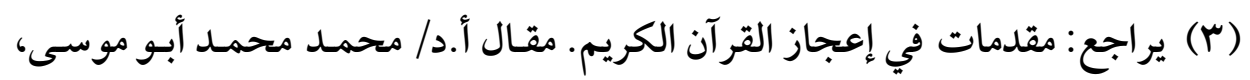

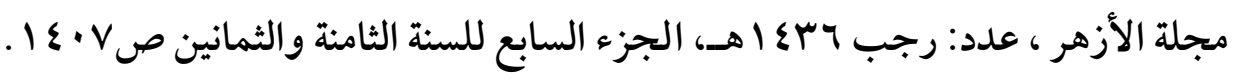




\section{نقل الألفاظ للمهعاني}

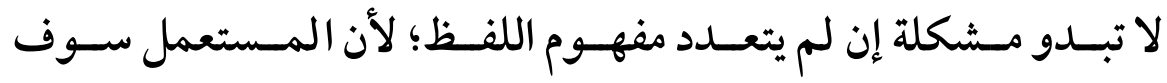

يستعمل اللفظ في معنـاه الذي وضـع لـه، ويعتبر هـذا اللفظ حقيقـة في هـذا لهـا المعنى، لا يحتاج إلى مناسبة بينه وبين معناه غير المناسبة التي اعتبرت عند وفئ وضعه للمعنى.

أمـا إذا تعـدد مفهـوم اللفظظ فإمـا أن يكـون اللفظظ تعـدد مفهو مـه بأوضـاع

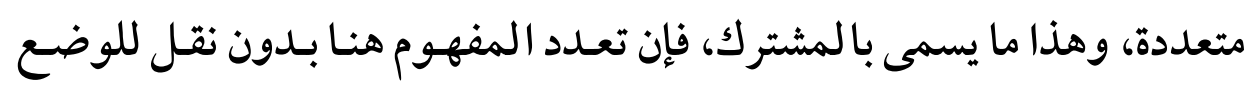

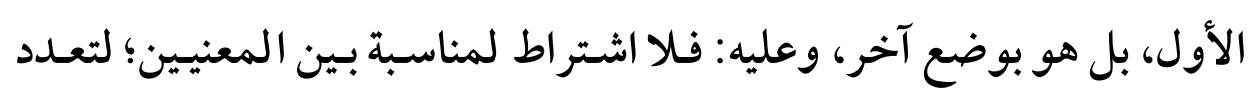

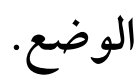
وإما أن يتعدد مفهوم اللفظ بوضع واحـد بـأن ينقل استعمال اللفظ مـن المعنى الذي وضع من أجله إلى معنى آخر، فإن لم يكن بين المعنيين مناسبة يسمى اللفظ مر تجلا. وإن كان بين المعنيين مناسبــــة فإما أن لا يغلب الاستعمــــــال المنقول

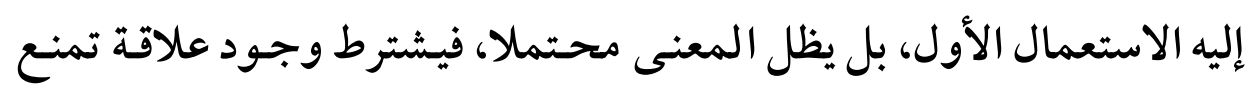

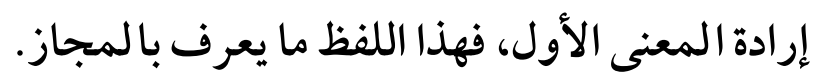

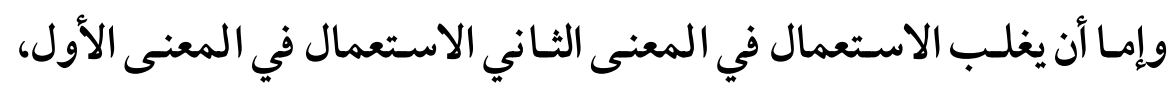
مع هجران المعنى الأول، فهذا ما يعرف بالحقيقة العرفية، أو الشرعية (1).

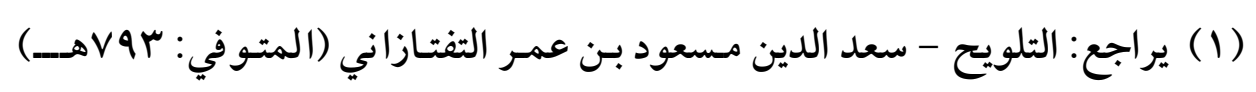

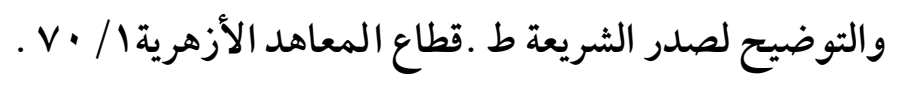


(rv)

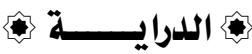

وسوف يتضح ذلك من خلال تصريف ما يأتي:

$$
\begin{aligned}
& 1 \text { - النقل. } \\
& \text { Y - المرتجل. } \\
& \text { r- الحقيقة. } \\
& \text { ع - المجاز. }
\end{aligned}
$$

وسوف أرجئ الكلام في تعريفه إلى المبحث الخامس.

| النقة

النقل في اللفة: التحويل. - التص

ونقل الثيء: تحويل الثيء من موضع إلى موضع (1).

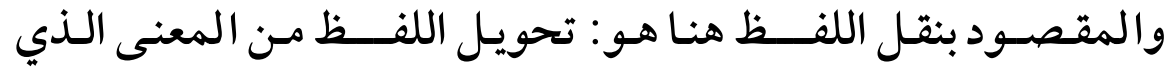

وضــ له إلى معنى آخر.

فإن كان الناقل للفظ أهل اصطلاح أو فـن معين، واستعملوه فيما بيـهم

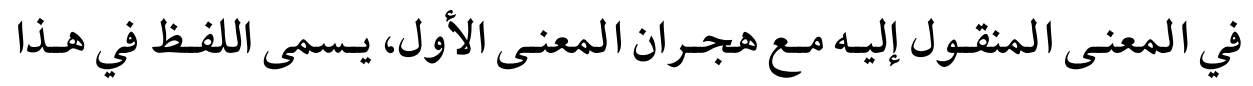

المعنى حقيقة عرفية.

(1) يراجع: مجمل اللغة لابن فارس - أحمد بن فارس بن زكرياء القزويني الرازي،

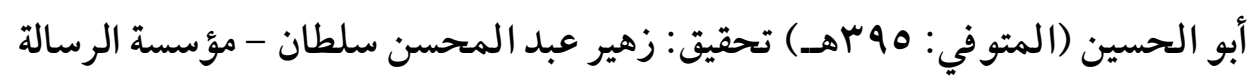

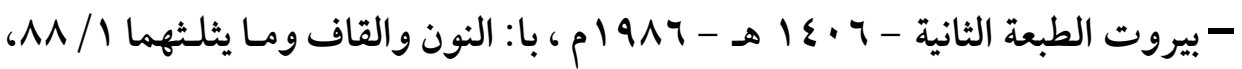

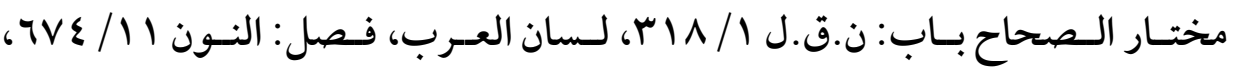

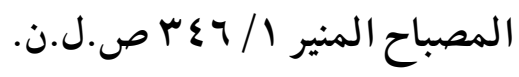


(rA) مناسبة اللفظ للعنى عند الأصوليين وأثرها في توجيه خطاب الججتهلين وإن كان الناقل له الشارع يسمى حقيقة شرعية.

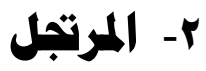

المرتجل في اللفة: -بفتح الجيم - اسم مفعول من الارتجال.

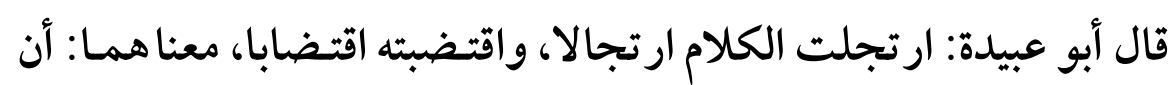

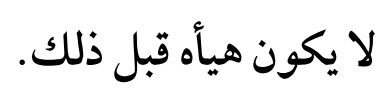

واصـطلاحا هـو: لفـظ نقـل مـن معنـاه الموضسوع لـه إلى معنى آخـر، لا لمناسبة بينهما، مثل: جعفر، علما بعد وضعه للنهر.

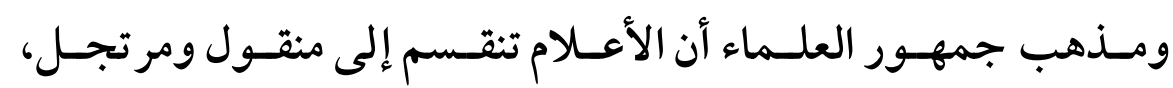
وخالف سيبويه وقال: الأعلام كلها منقولة.

\section{شرح التعريف:}

قوله: "اللفظ " بمنزلة الجنس، وقيد بالنقل؛ احترازاعن المشترك، فلا نقل فيه. وقيد بعدم المناسبة؛ احترازاعن المنقول والمجاز. فالمرتجل قسم من أقسام الحقيقة؛ لأنه يستعمل في غير مـا وضـع لـه لا

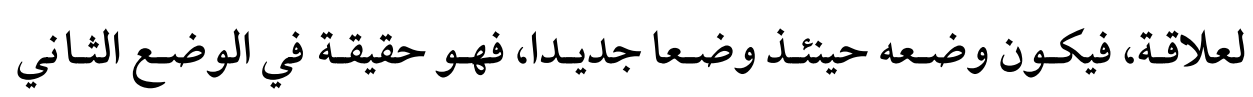
بسبب الوضع الثاني. 
(rq)

لكنه يكـون مجـازا -أيـضـا - باعتبـار أن استعمالــــه في الوضـــع الثاني

$$
\text { سبق بوضع أول (1). }
$$

مثال ذلك: الجوهر : فإنه وضـع في اللغـة للنفيس مـن كل شيء، ثـم نقل

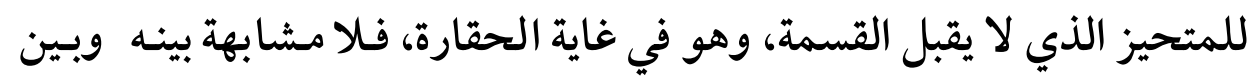

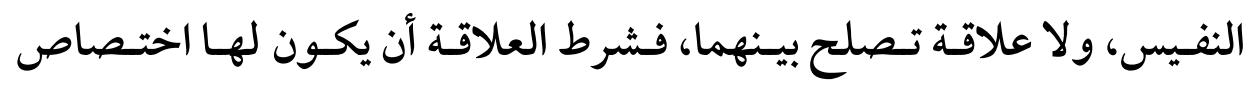
وشهرة على نحو ما سيأتي (r).

\section{r- تعريف الحميقة}

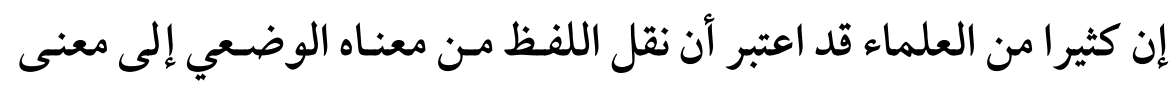

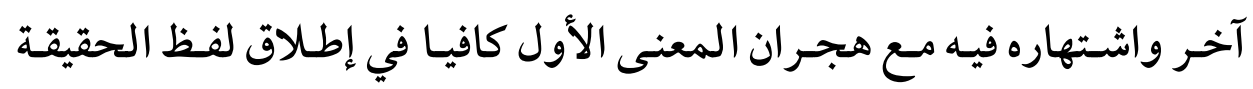

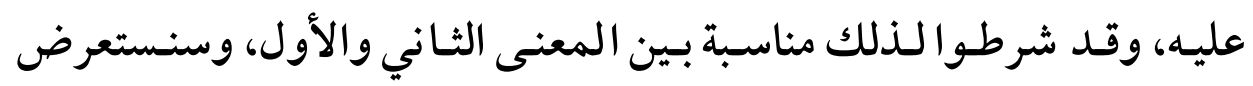
معنى الحقيقة وذلك النحو التالي:

\section{أولا: تعريف الحقيقة في اللفة:}

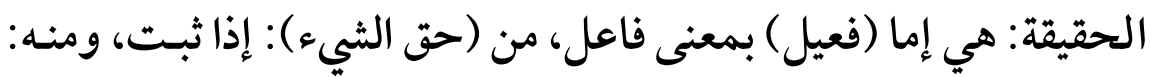
(الحاقة) ؛ لأنها ثابتة كائنة لا محالة.

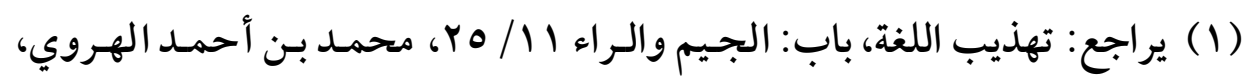

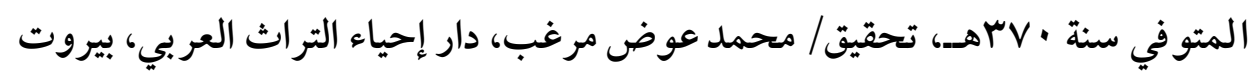

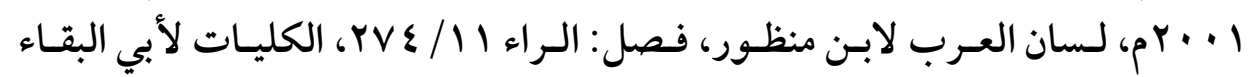

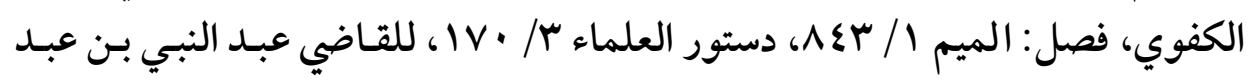

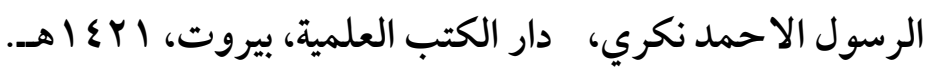

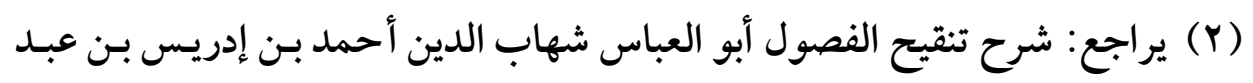

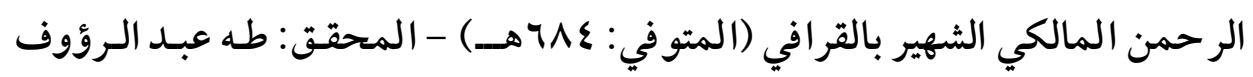

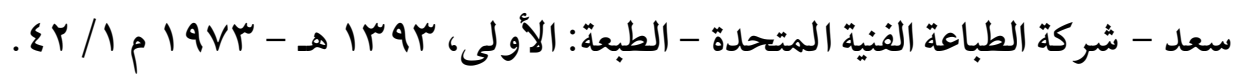


$(\varepsilon \cdot)$ مناسبة اللفظ للعنى عند الأصوليين وأثرها في توجيه خطاب المجتهلين وإما (فعيل) بمعنى (مفعول)، من (حققت الثيء): إذا أثبته. فيكون معناها: الثابتة والمثبتة في موضعها الأصلي.

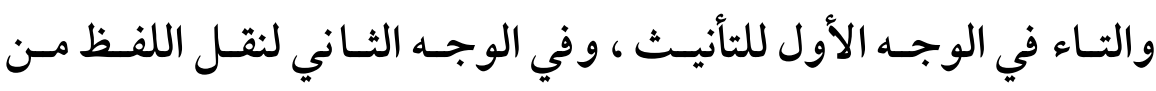

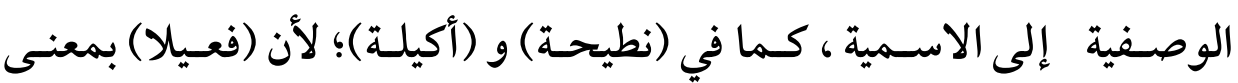
المفعول يستوي فيه المذكر والمؤنث.

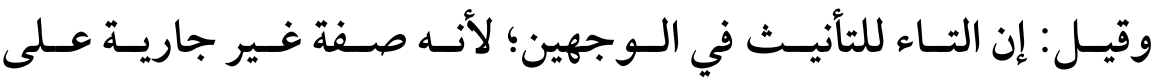
موصوفها، والتقدير كلمة حقيقية. وإنما يستوي المذكر والمؤنث في (فعيل) بمعنى مفعول إذا كان جاريا

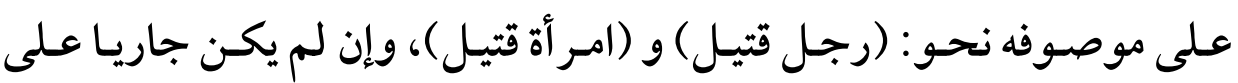

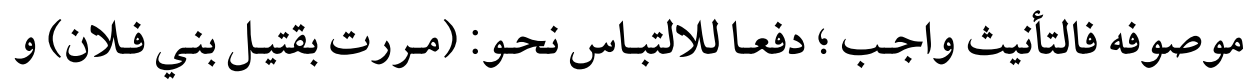

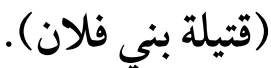
و (فعيل) بمعنى (فاعل) يـذكر ويؤنـث سواء أجـري على موصـوفه أو لا مثل: (رجل ظريف) و (امر أة ظريفة) (1). فحقيقـــة الـثيء هـي ذات الـثيء كـالحيوان النـاطق للإنســــان، وأمـا ذاتيتـــه وهي الحيوانية والناطقية فتسمى ماهية (r).

(1) يراجع: الصاحبي في فقه اللغة العربية ومسائلها وسنن العرب في كلامها أحمد بن

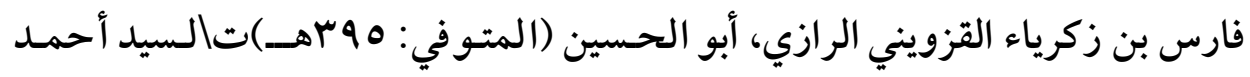

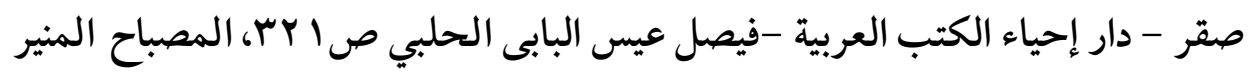

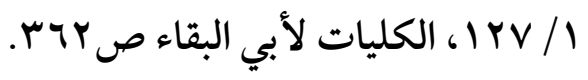

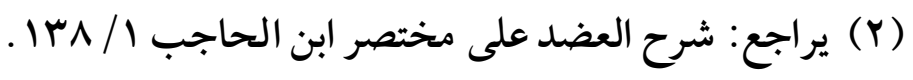


(₹1)

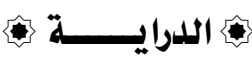

\section{ثانيا: تعريف الحقيقة في اصطلاح الأصوليين:}

اعلم أن الأسماء الحقيقية قد يطلقها الأصوليون على لغوية وشرعية. واللغوية تنقسم إلى: وضعية، وعرفية، ولقد تنوعت عبارات الأصسوليين

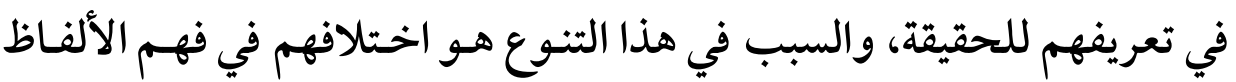
المتداولة شرعا، وقـد استعملت في غير معانيها اللغويـة، فهل ذلك بوضـع

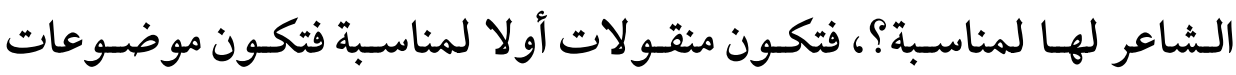

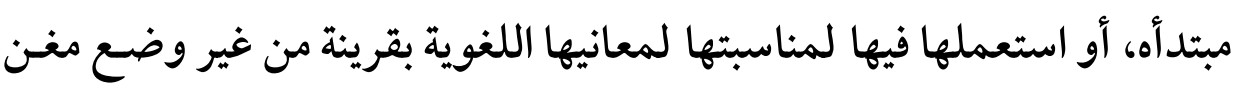
عن القرينة فتكون مجازات لغوية، ثم غلبت في المعاني الشرعية فصارت حقيقة عرفية لهم (1).

وسوف نستعرض بعض هذه التعريفات للحقيقة عند الأصوليين، وذلك على

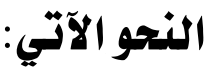

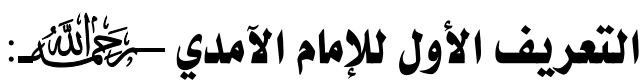

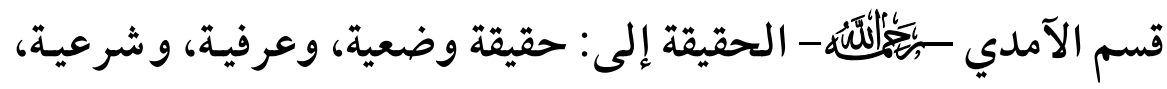
وقـام بتعريـف كـل واحـدة منهـا، ثـم ذكـر تعريفـا يجمـع ويعـم جميـع هـــهـ الاعتبارات. 1 - الحقيقـة الوضـعية: هي اللفظظ المستعمل فيما وضـع لـه أولا في اللغة. (1) يراجع: شرح العضد على مختصر ابن الحاجب -المرجع السابق - / س 1 1. 


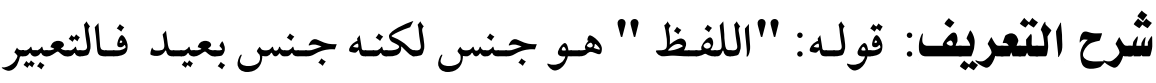

بالقول أصوب، وفيه إشارة إلى أن الحقيقة وكذلك المجـاز همـا مـن صـفات

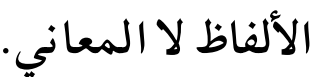

قولـه: "المـستعمل " خــرج عنـه المهمــل واللفــ الموضـوع قبـل

الاستعمال، فإنه ليس بحقيقة ولا مجاز.

وقوله: "فيما وضع له " يخرج به المجاز والغلط.

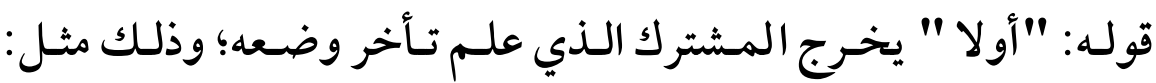

كلمة "الأسد " فإنها وضـت للحتهيوان المفترس الشجاع، فيإذا استعملت فيما وضعت له كان هذا اللفظ حقيقة في هذا المعنى. ومثل: استعمال كلمة "الإنسان" في الحيوان الناطق "(1).

Y - الحقيقة العرفية: وهي اللفظ المستعمـل فيما وضـع لــــه بعرف

الاستعمــــال اللغوي.

وهي قسمان:

الأول: أن يكون الاسم قد وضع لمعنى عام ثم يخصص بعـرف استعمال

أهل اللغة ببعض مسمياته.

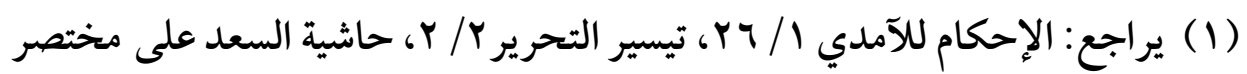

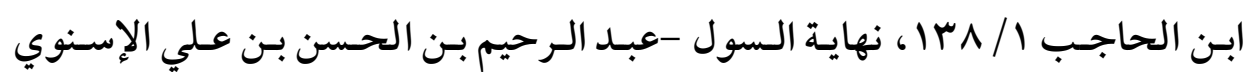

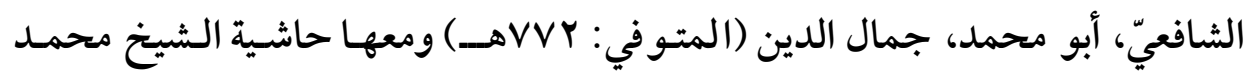

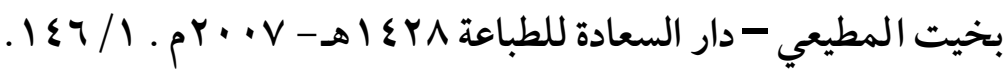


(₹r)

مثل: لفظة "دابة " فهي في أصل اللغة اسم لكل مـا يـدب على الأرض،

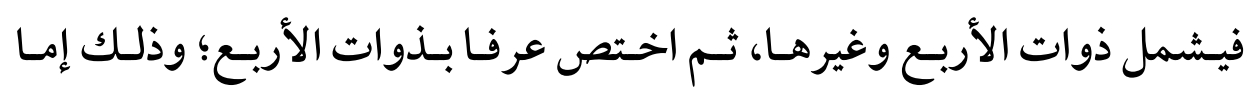
لسرعة دبيبه أو كثرة مشاهدته أو كثرة استعماله.

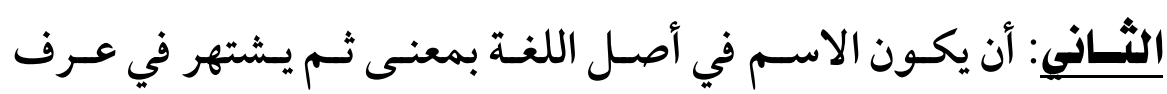

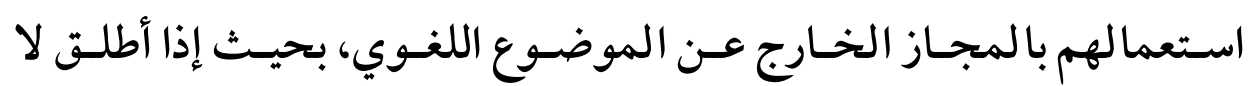
يتبادر إلى الذهن غيره. - مان. مثـل : "الغـائط " فهـو في أصـل اللغــة : اسـم للمكــان المــخفضض مـن الأرض، غير أنه قد اشتهر في عرفهم بالخـارج المستقذر مـن الإنسان، وعند إطلاقه لا يفهم منه غيره.

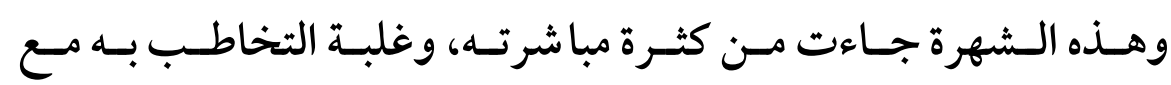
الاستنكاف من ذكر الاسم الخاص به لنفرة الطباع عنه، فكنوا عنه بلازمه. ب- الحقيقــة الــشرعية: هـي اسـتعمال الاسـم الـشرعي فـيما كـان موضوعـــا له أولا في الشرع.

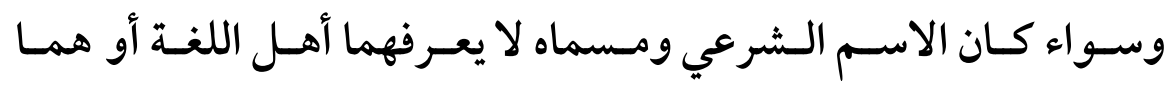

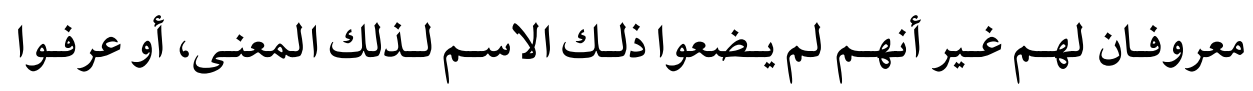

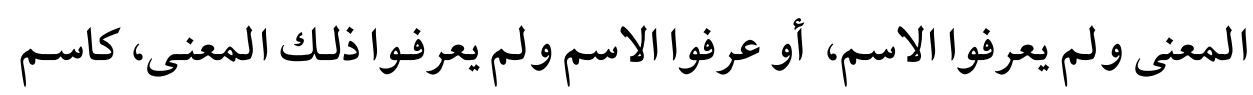
الصلاة، الحج، الزكاة ونحوه، الإيمان، الكفر.

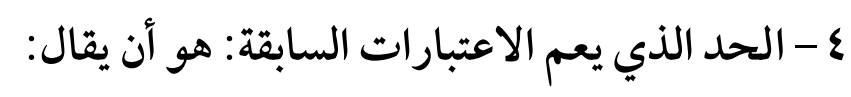

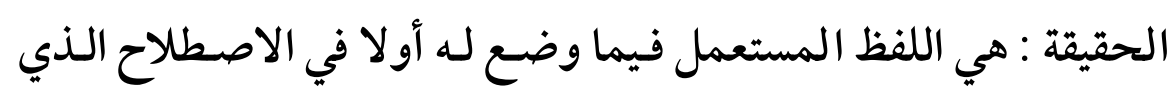
به التخاطب. 
(₹₹) مناسبة اللفظ للعنى عند الأصوليين وأثرها في توجيه خطاب المجتهلين

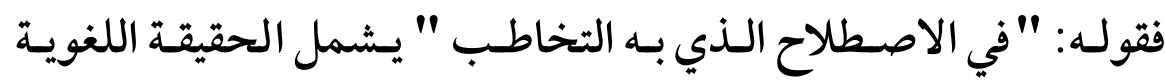
والعرفيـة والـشرعية؛ لأن الشارع حيـنما وضـع اسـم الـصلاة لأقو ال و أفعـال

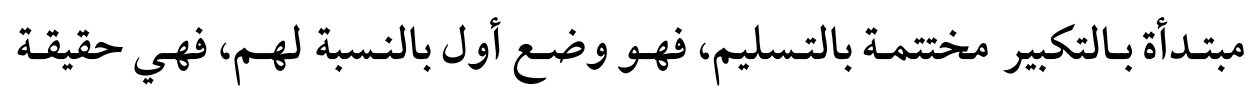
شرعية لذلك. "). التعريف الثاني: لابن الهمام. الحقيقة: هي اللفظ المستعمل فيما وضع له، أو ما صدق عليه في عرف الهف

$$
\text { شه ذلك الاستعمال. }
$$

قوله: (أو ما صدق عليه ) أي: ما صدق ما وضع له عليه، فالمستعمل

$$
\text { فيه حينئذ فرد من أفراد الموضوع له. }
$$

وقوله: (في عرف به) أي: بذلك العرف، وقوله: (ذلك الاستعمال) أي:

$$
\text { بناء الاستعمال على ذلك العرف. }
$$

وعلى هذا التعريف فإن الحقيقة تنقسم بحسب الوضع إلى:

$$
1 \text { - حقيقة لغوية: إذا كان الواضع لها أهل اللغة. }
$$

r- حقيقة شرعية: إذا كان الواضع لها الشارع كالصلاة.

ץ- حقيقة عرفية عامة: إذا كان الواضع لها أهل العرف العام كالدابة: في

$$
\text { ذوات الأربع و والحافر. }
$$

(1) يراجع: الإحكام للآمدي / / YV، شرح العضد على ابن الحاجب / / ـ ـ . 
(₹0)

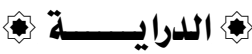

צ - حقيقة عرفية خاصة: إذا كان الواضع لها أهل العرف الخاص كالرفع

للحر كة (')

التعريف الثالث: لأبي الحسيز البصري.

الحقيقة هي: ما أفيد بها ما وضعت له في أصل الاصطلاح الذي وقع

التخاطب به.

والفرق بين هذا التعريف وما قبله: هو أن أبا الحسين البصري لم

يشترط الاستعمال، واللفظ بعد الوضع وقبل الاستعمال لا يتصف بكونه

حقيقة ولا مجازا؛ لخروجه عن حدهما؛ إذ لا يتناوله جنسهما وهو

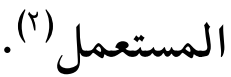

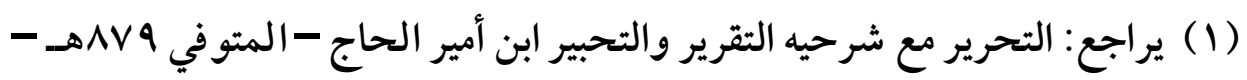

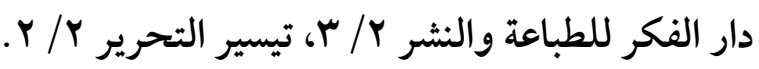

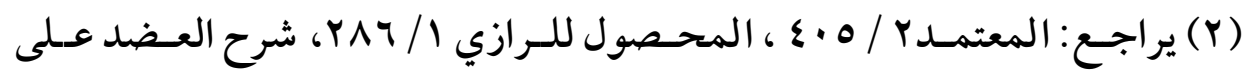

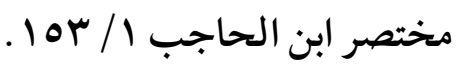




\section{المبحث الثاني}

\section{هناسبة اللفظ للمعنى في الوضع وأثرها}

في توجيه خطاب المتهدين

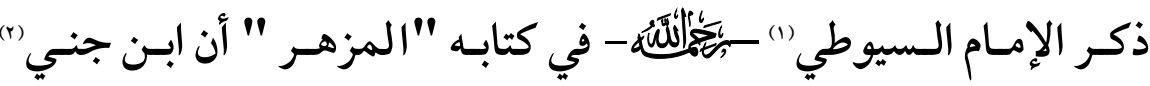

(1) السيوطي هو: الحافظ عبد الرحمن بـن أبي بكر الأسيوطي، أبو الفضل شيخ

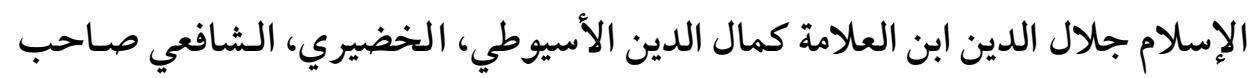

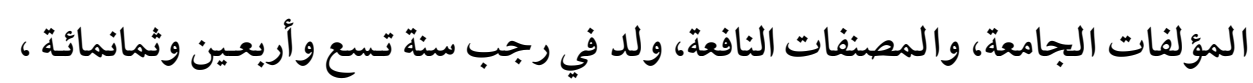

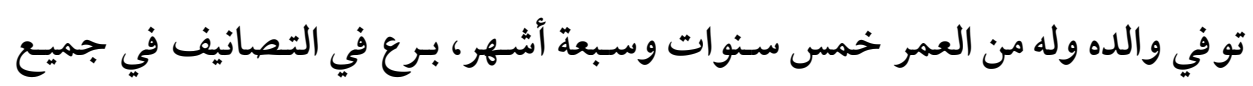
العلوم، وتوفي سنة اله1/ هـ، وله ما يقرب من ستمائة مؤلف.

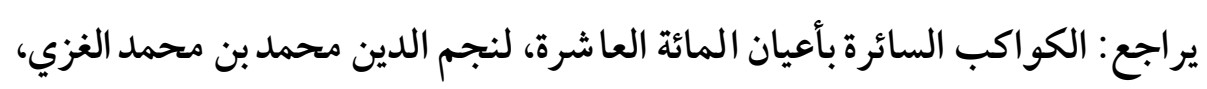
المتوفي |ף + اهـ، المحقق: خليل منصور، الناشر : دار الكتب العلمية، بيروت، لبنان،

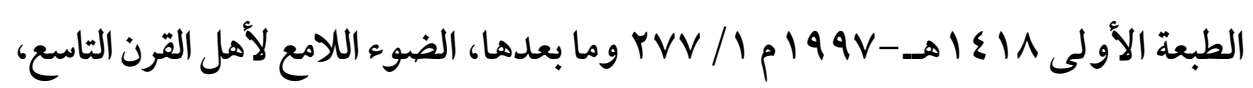

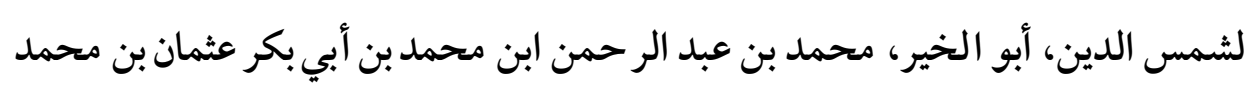

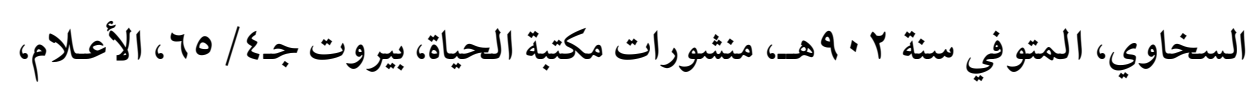

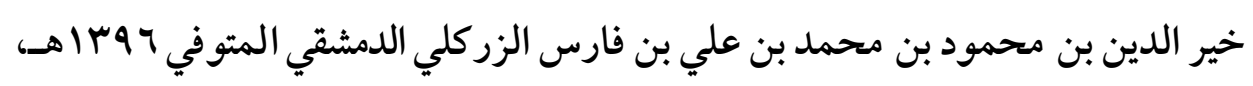

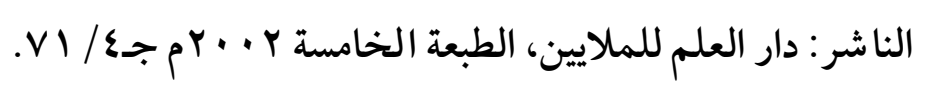

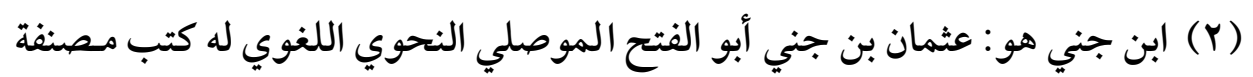

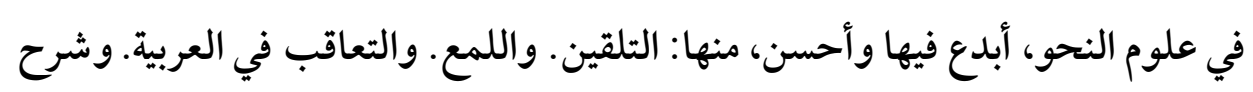
القوافي: والمذكر والمؤنث. وسر الصناعة. والخصائص. 


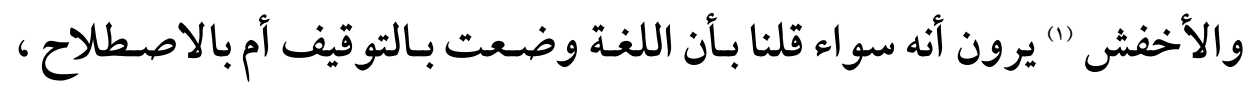
فإنها لم توضع كلها في وقت واحد، بل وقعت متلاحقة متتابعة.

وغير ذلك، وكان يقول الشعر، ويجيد نظمه، وأبو جني كـان عبدا روميا مملوكـا.

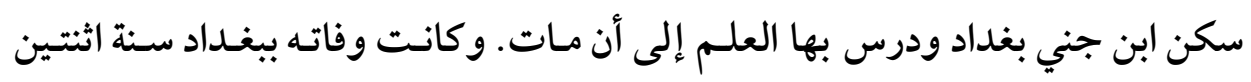
وتسعين وثلاثمائة.

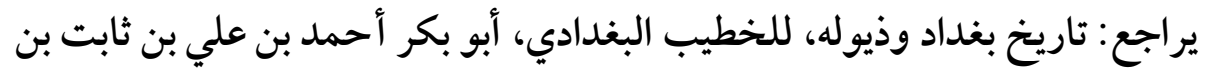

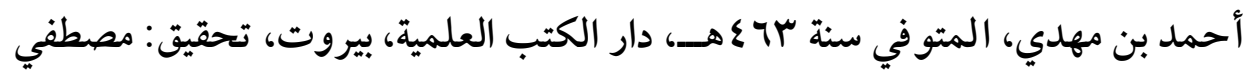

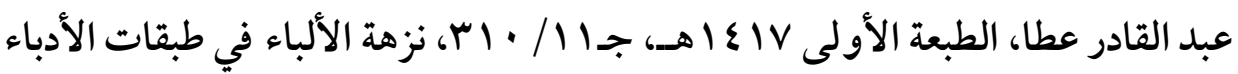

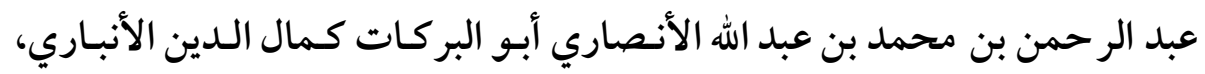
المتوفي سنة VVVهـ، المحققى: إبراهيم السامرائي، مكتبـة المنار، الزرقاء، الأردن،

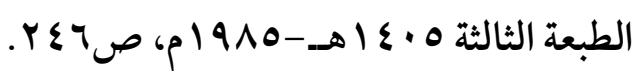

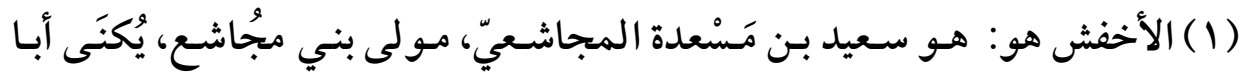

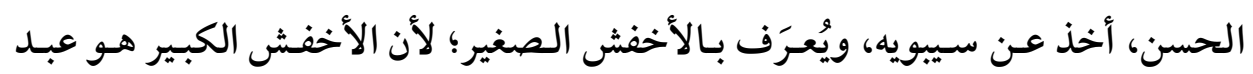
الحميد بن عبد المجيد، ويُكنَى أبا الخطاب.

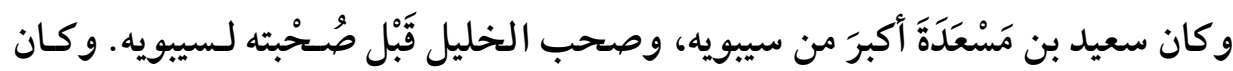

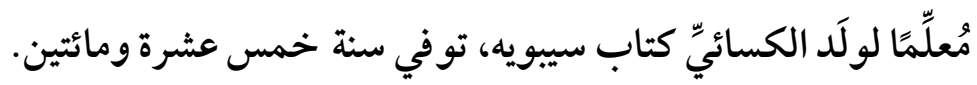

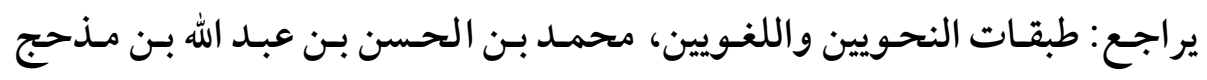

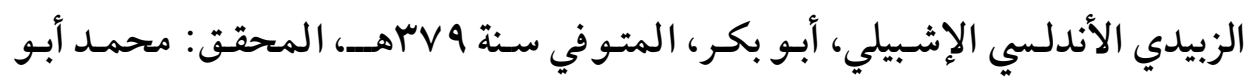

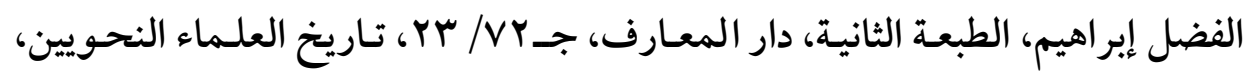

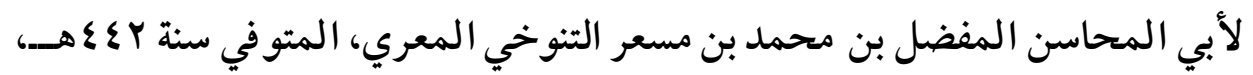

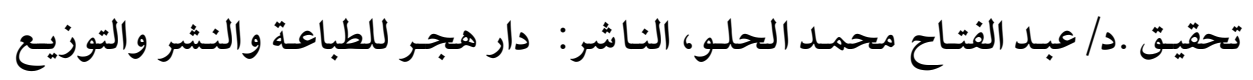

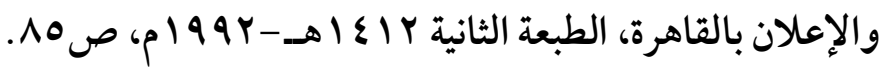


$(\varepsilon \wedge)$ مناسبة اللفظ للعنى عند الأصوليين وأثرها في توجيه خطاب المجتهلين

وأن اختلاف لغات العرب إنما جاء من قبل أن أول ما وضـع منها وضـع

على خـلاف، وإن كـان كله مسوقا على صحة وقيـاس، ثـم أحسدثو امـن بعـــ أشياء كثيرة للحاجـة إليها، غير أنهـا عـلى قيـاس مـا كـان وضـع في الأصـل مختلفا (1) مخت

ولا يمكـن ذلك إلا بوجـود مناسبة بين اللفظ والمعنى الموضسوع لـه،

ويكاد يجمع أهل العربية على وجود هذه المناسبة.

و لمعرفة هذه المناسبة ونوعها أثر كبير في توجيه خطاب المجتهـدين،

حيث إن اكتساب اللفظ للمعنى ظل يتطور على مر العصور حتى نزل القـرآن الكـريم، فلـم يعـد يكتسب اللفظظ معنى آخـر في أصـل الوضـع؛ لأن القـرآن الكـريم الـذي هـو كـلام الله -تعـالى - يطلـق عـلى اللفــ والمعنى معـا، ولا يمكننا أن نخضع ذلك للواقع واكتساب اللفظ معنى في أصل الوضـع زائدا، حيث إن المعنى واللفظ معا صفة من صفات الله -تعالى - وهي صفة الكلام، وهي صفة قديمة قدم الله --تعـالى -، وسـوف يـزذداد الأمسر وضـوحا مـز خـلال

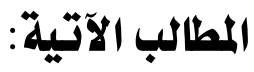
المطلب الأول: مناسبة اللفظ للمعنى عند جمهور الأصوليين في أصل الوضع. (1) ير اجع: المزهر في علوم اللغة وأنواعها- عبد الر حمن بن أبي بكر، جلال الدين

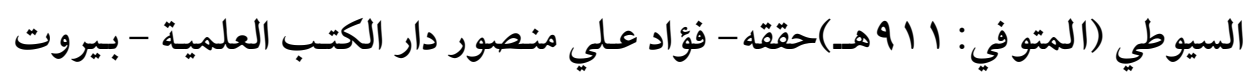

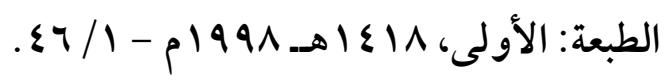


المطلب الثاني: مناسبة اللفظ للمعنى عند عباد بن سليمان المعتزلي في أصل الوضع.

المطلب الثالث: أثر مناسبة اللفظ للمعنى في أصل الوضع في توجيه خطاب المجتهدين. 


\section{المطاب الأول}

\section{هناسبة اللفظ للمعنى في أصل الوضع عند جمهور الأصوليين}

اختلف جمهور العلماء في واضع اللغات على النحو التالي:

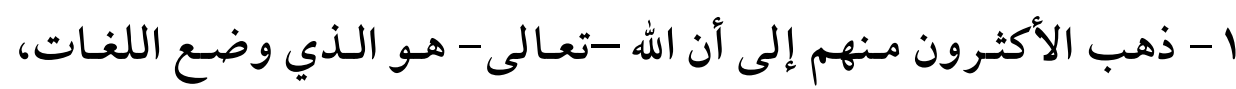

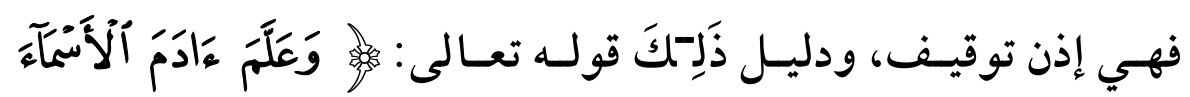

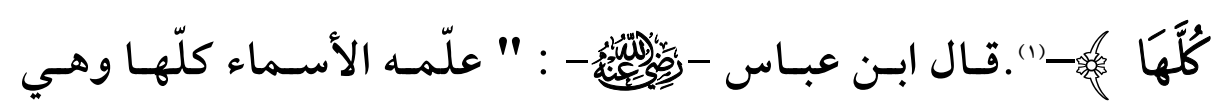

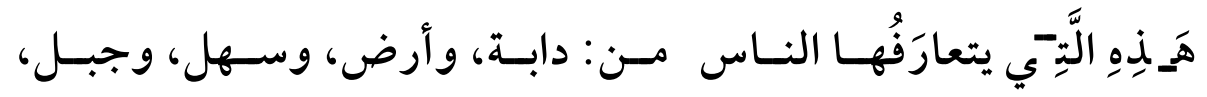

$$
\text { و حمار، وأشباه ذَِكَكَ من الأمم وغيرها " (r). }
$$

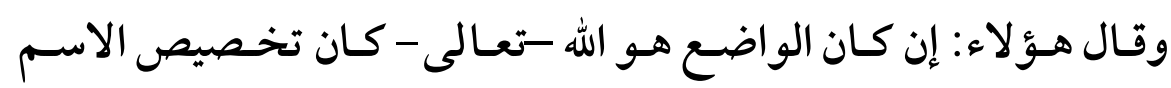

المعين بالمسمى المعين كتخصيص وجـود العـالم بوقـت مقدر دون مـا قبله

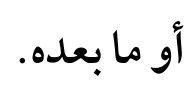

يعني: أنهم أثبتوا المناسبة بين اللفظ والمعنى على نحو ما ذكروه.

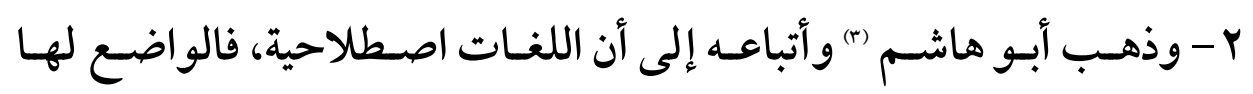

الناس.

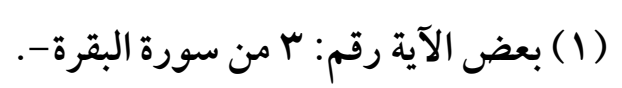

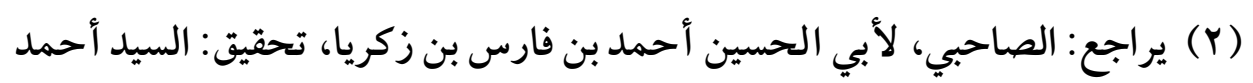
صقر، دار إحياء الكتب العربية صاحب، لابي الحسين.

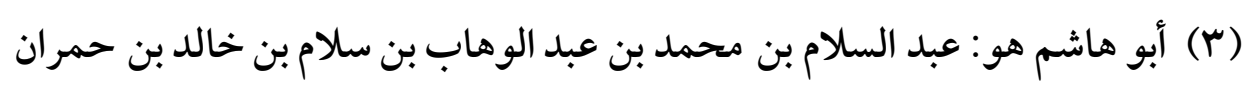

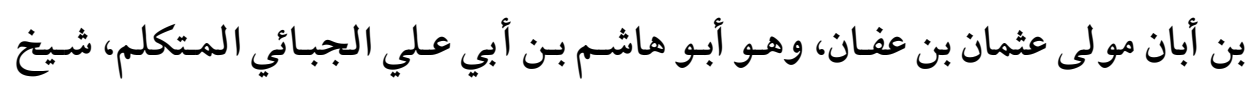

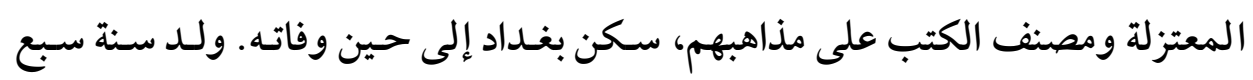


(01)

وحينئذ تكون المناسبة حاصلة من احتمال أن يكون السبب خطورة ذلك هلك

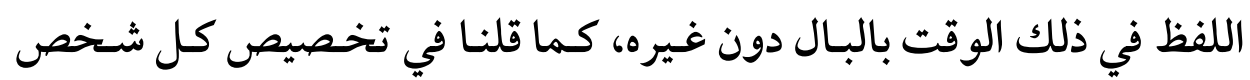
بعلم خاص من غير أن يكون بينهما مناسبة.

هـ وذهــب بعـض العـــماء إلى أن اللغــة بعـضها تـوقيفي والـبعض الآخــر اصطلاحي، وفيه قولان:

القول الأول: مـنهم مـن قـال: ابتداء اللغـات يقـع بالاصطلاح والباقي لا يمتنع أن يحصل بالتوقيف. القول الثاني: ومنهم من عكس الأمر، وقال: القدر الضروري الذي يقـع به الاصطلاح توقيفي والباقي اصطلاحي · والمناسـبة عندئــن تكسون مـن إمكـان أن يخلـق الله فيهم علـما ضروريـا بالألفاظ والمعاني، وبأن الواضع وضع تلك الألفـاظ لتلك المعاني، ثـم إنه يعرف الغير ذلك الوضع بالإيماء والإشارة، ويساعده الآخر عليه (1).

وسبعين ومائتين، وولد أبوه أبو علي سنة خمس وثلاثين ومائين، ومات سـنة إحـدى وعشرين وثلاث مائة بيغداد.

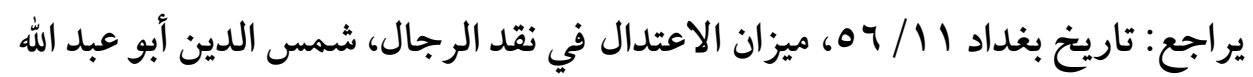

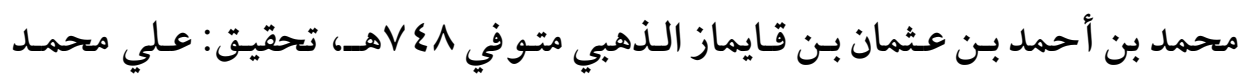

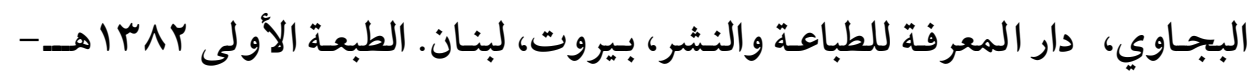

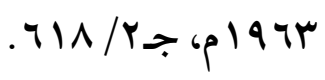

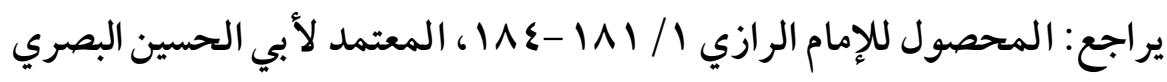


(or) مناسبة اللفظ للعنى عند الأصوليين وأثرها في توجيه خطاب المجتهلين

والميع الأقوال.

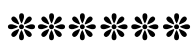




\section{الإطلب الثاني}

\section{هناسبة اللفظ للمعنى في أصل الوضع

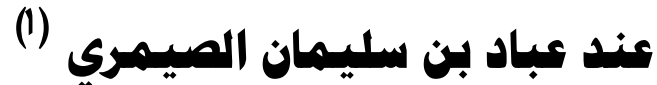

ذهب عباد بن سليمان الصيمري إلى أن دلالة اللفظ على المعنى ذاتية

موجبة.

(1) جاء في لسان الميزان: " عباد بن سليمان الضمري من كبار المعتزلة ".

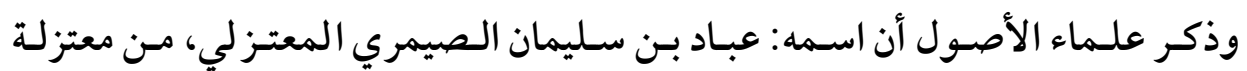

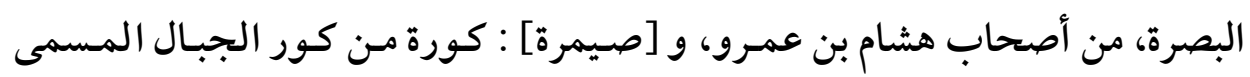

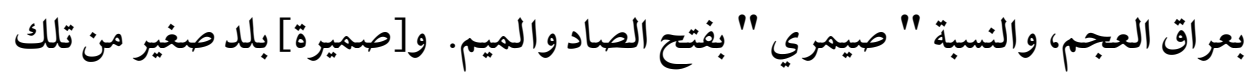

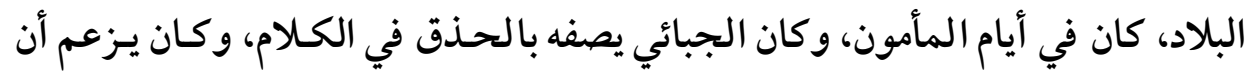
بين اللفظ والمعنى مناسبة طبيعية، فردوا قوله، ومن معتقداته أنه كان يقول: إن الله لم الم المان يخلق الكفر ولا الإيمان.

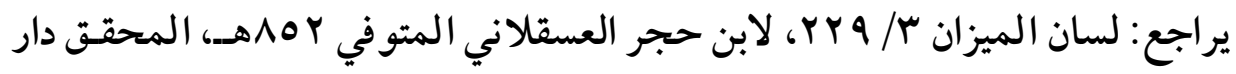
المعرفة النظامية، الهند، الناشر : مؤسسة الأعلى للمطبوعات، بيروت، الطبعة الثانية،

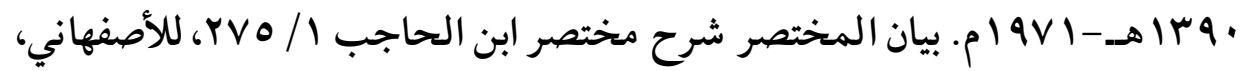

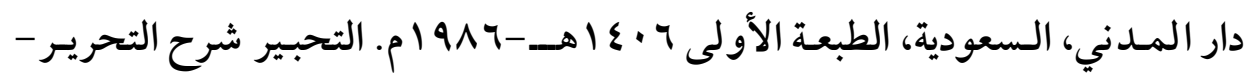

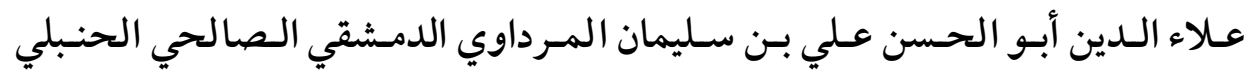

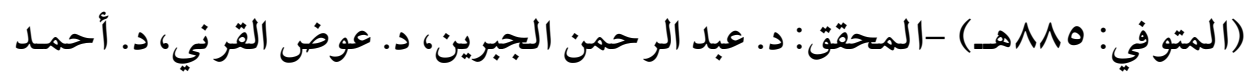

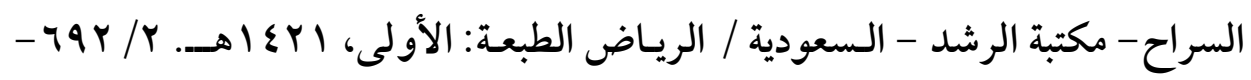


(०६) مناسبة اللفظ للعنى عند الأصوليين وأثرها في توجيه خطاب المجتهلين

دليله: استدل على ما ذهب إليه بأنه لو لم يكن بين الأسماء والمسميات

مناسبة بوجـه مـا لكـان تخصيص الاسـم المعسين بالمسمى المعين ترجيحـا

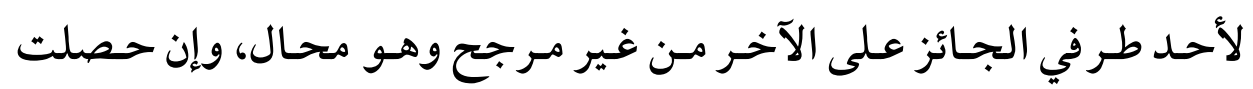
بينهما مناسبة فذلك هو المطلوب.

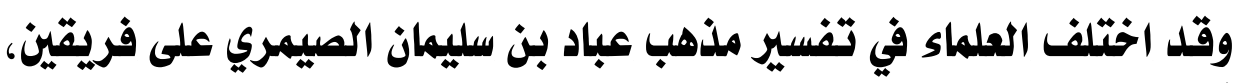
أبيز وجهة نظرهما على النحو التالي:

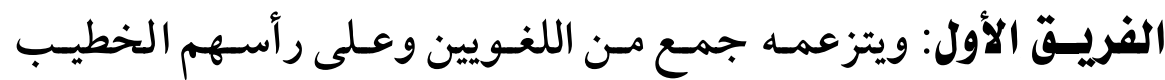
القزويني (1) وجمع من الأصوليين على رأسهم الإمام الرازي والإمام الآمدي.

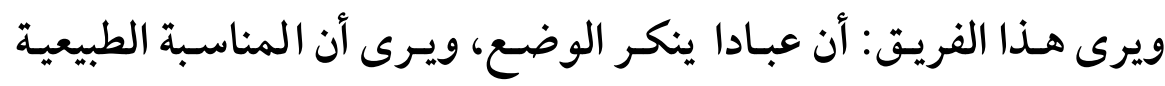

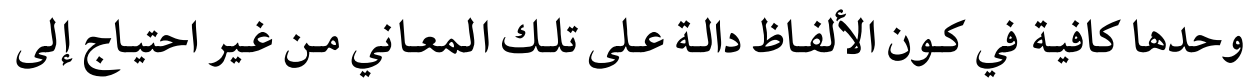
الوضع. وهذا الذي اقتضاه نقل الإمام الرازي، ورد عليه قائلا:

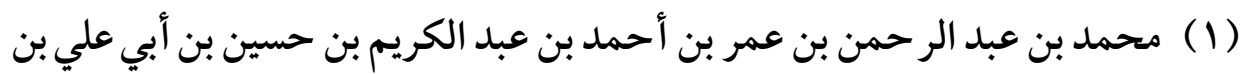

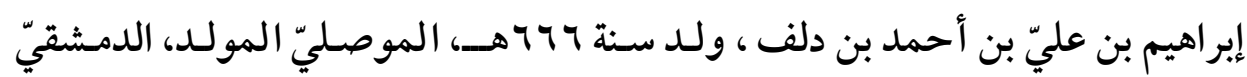

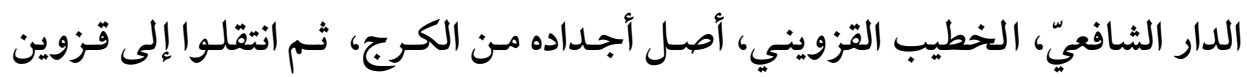

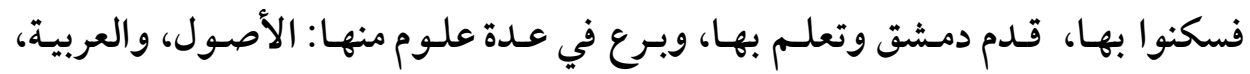

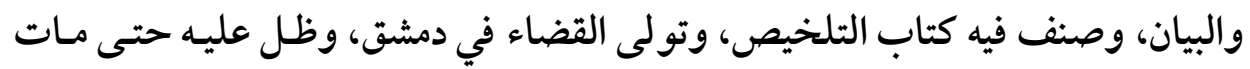
سنة تسع وثلاثين وسبعمائة.

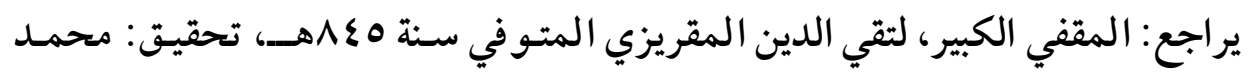

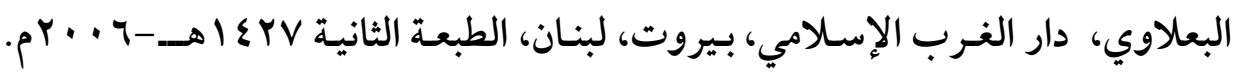
r r r r r r 
إن دلالة الألفاظ لو كانت ذاتية لمـا اختلفـت بـاختلاف النواحي والأمـم،

ولاهتدى كل إنسان إلى كل لغة، وبطلان اللازم يدل على بطلان الملزوم (1).

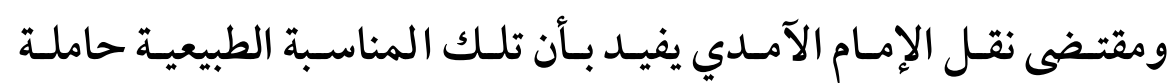

$$
\text { للواضع على الوضع (r). }
$$

وهو -أيضا- ظاهر الفساد؛ لاقتضائه أن يمنع نقله إلى المجاز ، ووضعه

للمضادين؛ كالجون للأسود والأبيض؛ فإن ما بالذات لا يزول بالغير (r).

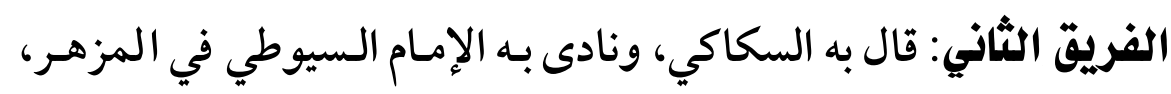

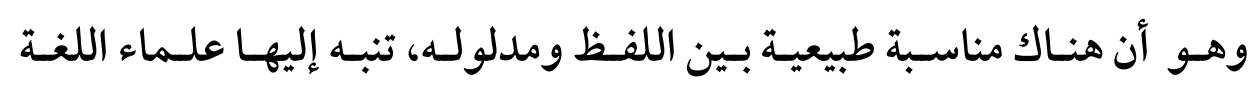

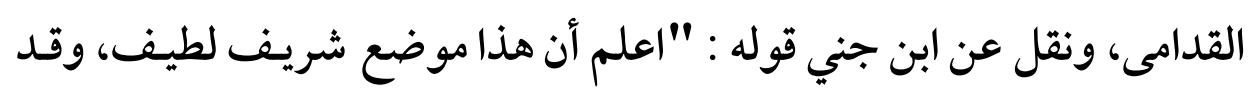

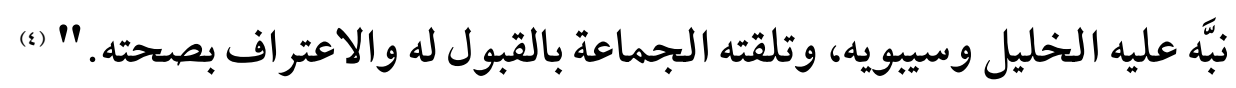

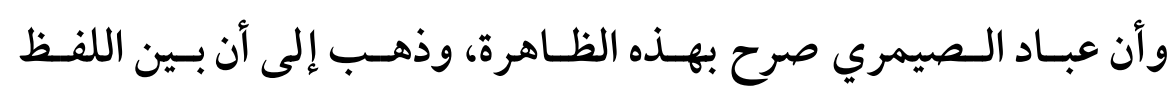
ومدلوله مناسبة طبيعية حاملة للواضع على أن يضع.

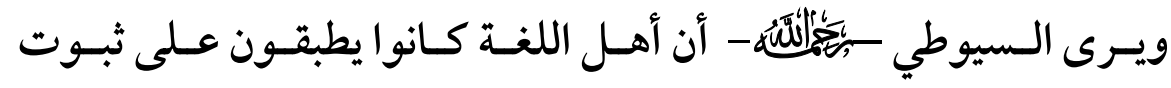
المناسبة بين الألفاظ والمعاني عند أصل الوضـع، لكـن الفـرق بين مـذهبهم

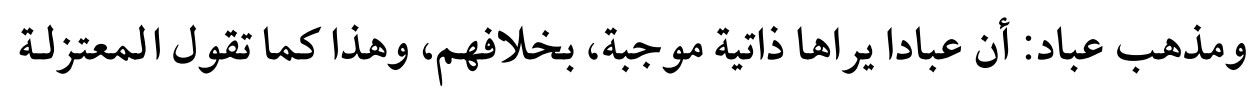

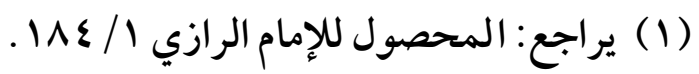

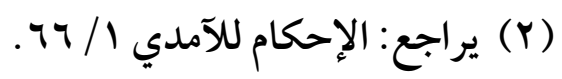

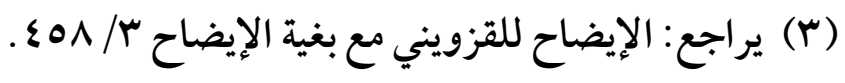

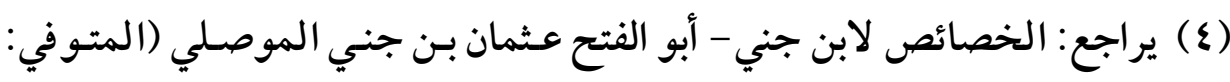

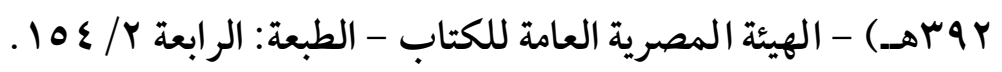


(07) مناسبة اللفظ للعنى عند الأصوليين وأثرها في توجيه خطاب المجتهلين

بمر اعاة الأصلح في أفعال الله -تعالى - وجويا، حيث إنه كـان معتزليـا. وأهـل

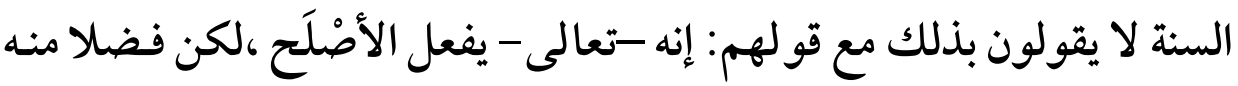
ومَنَّاً لا وجويا، ولو شاء لم يفعله (1). فهو إذن لا ينكـر الوضـع، ويتفـق مـع بـاقي العلماء في وجـود المناسبة، ويختلف معهم في كونها ذاتية موجبة على حسب أصله الاعتزالي. ولاحظظ هـذا الفريـق مناسبة حـروف العربيـة لمعانيها، ومـا لمحسوه في الحرف العربي مـن القيمة التعبيريـة الموحية، إذ لم يفهـم في كل حـرف أنه

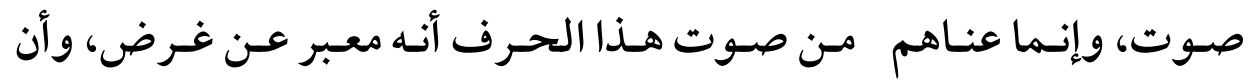
الكلمة العربية مركبة من هذه المادة الصوتية (r).

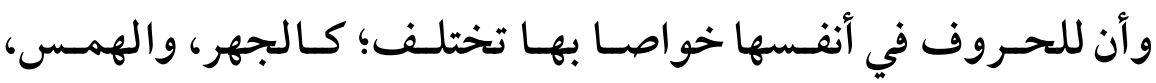
والشدة، والرخـاوة، وغير ذلك، مستدعية أن العـالم بها إذا أخـذ في تعيين الهين شيء منها لمعنى لا يهمل التناسب بينهما (r). وقـد مـالوا إلى الاقتنـاع بوجـود التناسـب بـين اللفظ ومدلوله في حـالتي البساطة والتركيب، وطوري: النشأة والتوليد، وصورتي: الذاتية والاكتساب.

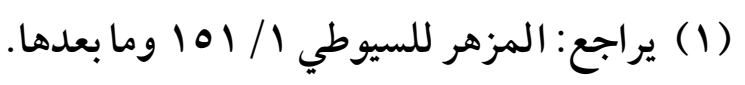

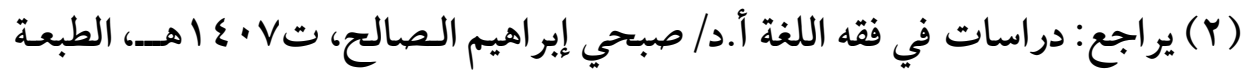

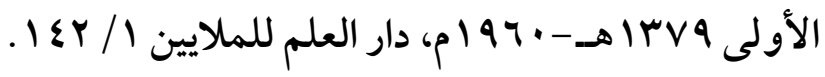

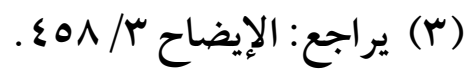




\section{أ - فني حالة البساطة:}

رأوا الحرف الواحد -وهو جزء من كلمـة - يقع على صسوت معين، ثم

يوحي بالمعنى المناسب سواء كان في أول اللفظ أو وسطه أو آخره.

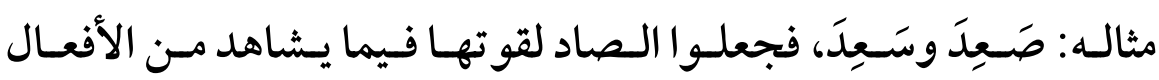

المتجشمة، وجعلوا السين لضعفها فيما تعرفه النفس، وإن لم تره العين.

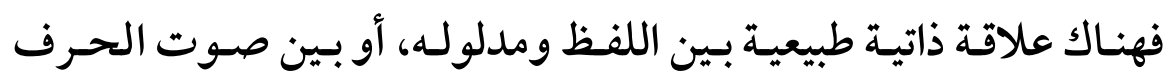

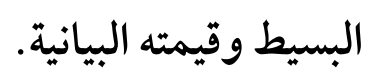

بـ وفي حالة التركيب:

لاحظ العلماء القيمة التركيبية للحرف مع آخيه في لفظ ثنائي على القول

بثنائية اللفظ.

جـ وأما صورتي: الذاتية والاكتساب:

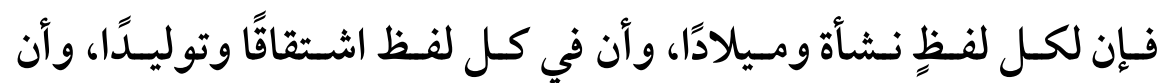

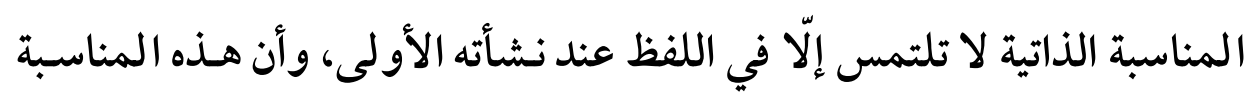

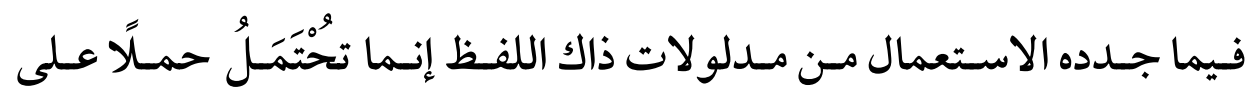
المعنى الأصلي الأقـدم، ولا يخفي حينئذ أن المناسبة الأخـيرة لم تنشأ مـع

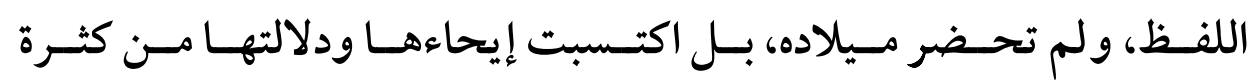
الاستعمال. 
$(0 \wedge)$ مناسبة اللفظ للعنى عند الأصوليين وأثرها في توجيه خطاب المجتهلين

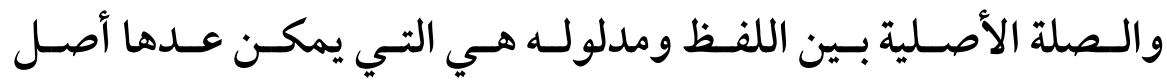

الاشتقاق، فالاشتقاق يكون من الدلالة الذاتية (1).

وهكذا فسر هذا الفريق كلام عباد على أنه يعني أن أصل الحرف يحكي

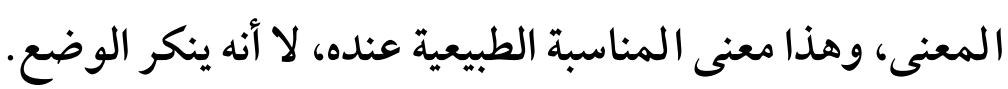

التزجيح

والذي أراه راجحا هو أن هذا التأويل خلاف مـاصـح نقله عـن عبـاد

بن سليمان من أنه يقصد ظاهر ما روي عنه، وكان بعض أتباعه يدعي أنه

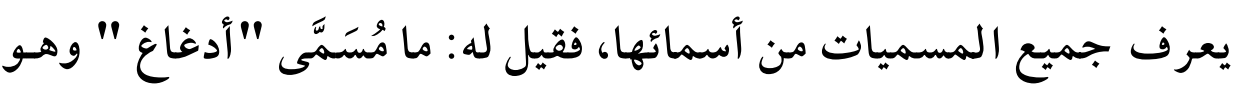

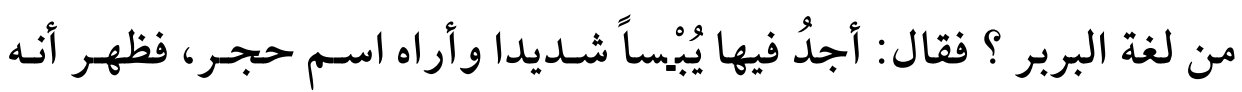
اسمه في تلك اللغة (r).

\section{米楼粠}

(1) يراجـع: الخـصائص لابـن جنـي Y/99 19، ودراسـات في فقـه اللغسة د/ صـبحي

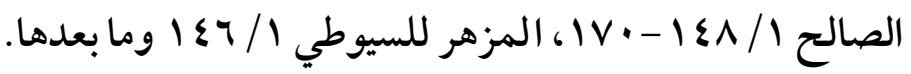

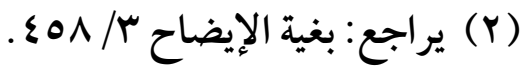




\section{المطلب الثالث}

\section{أثر هناسبة اللفظ للمعنى في أصل الوضع}

\section{في توجيه خطاب الجمتهدين}

لقد انتهينا فيما سبق إلى أن بين اللفظ ومعنـاه في أصـل الوضـع مناسبة

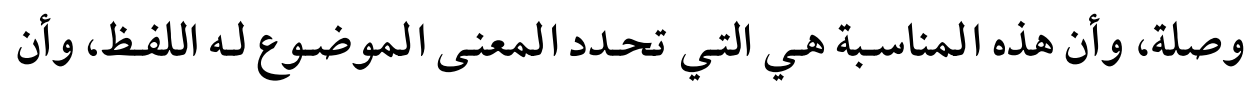

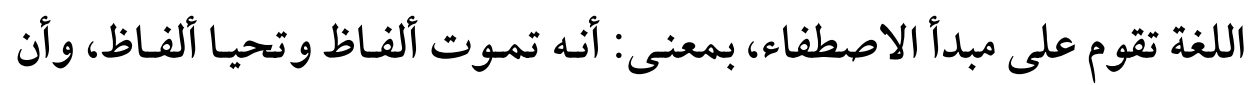
اللفظ يرتبط بالمعنى بمناسبة مكتسبة من الواقع، ويكاد يجمع اللغويون على ذلك.

لكـن المجتهـدين البـاحثين في كـلام الله -تعالى - باعتبـاره لفظا عربيا، وأنه كلام الله -تعالى - غير مخلوق، وأنه يطلق على اللفظ والمعنى معـا، لم

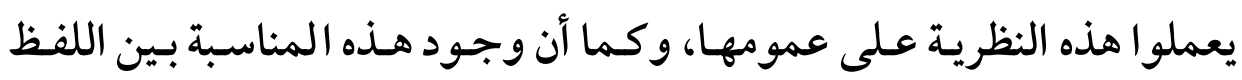

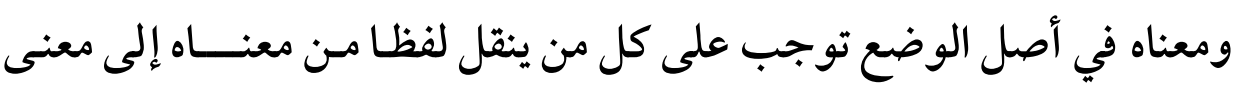

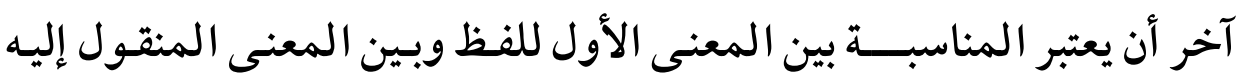
اللفظ، وذلك على نحو ما سنرى في المباحث التالية. وقد حـاول بعض المحـدثين أن يطبق نظريـة مناسبة اللفظ للمعنى في

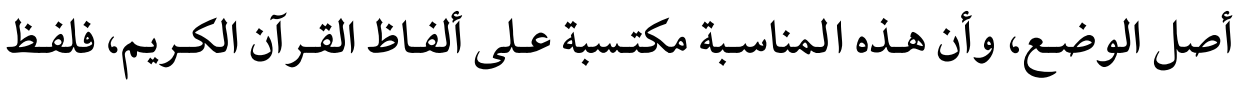
القرآن الكريم لفظ عربي يمكننا من خلال الواقع إكسابه معنى يوافق الواقع، ويستدل عـلى التفرقـة بـين اللفظظ والمعنى بـالخلاف الواقع بـين الأشـاعرة والمعتزلة حول المر اد بكلام الله تعالى. 


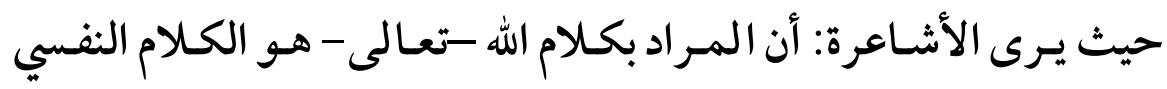

الأزلي القديم، وأن الكلام نوعان: نفسي ولفظي.

بينما يرى المعتزلة: أن المر ادبكلام الله -تعالى - هو الكلام اللفظي (1).

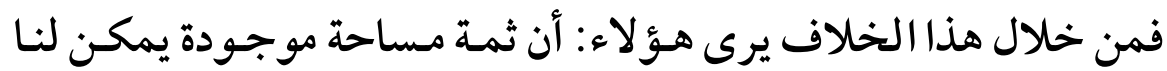

من خلالها أن نكسب هذا اللفظ معنى في أصل الوضع غير المعنى الأول. ونقول في أصل الوضع احترازاعـن المعنى الذي يمكننا استنباطه مـن

اللفظ، وأن اللفظ في أصل وضعه يحتمله، فهذا لا خلاف في جوازه. وهذا كلام خطأ جملة وتفصيلا، وهو خلاف ما أجمـع عليه المسلمون

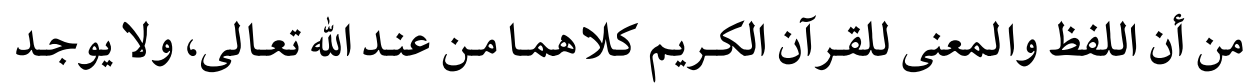

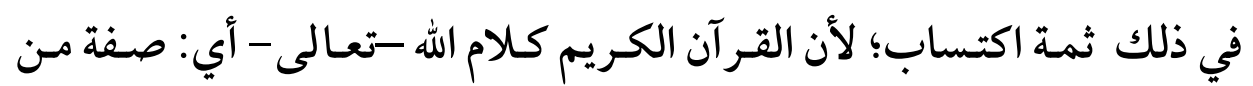
صفاته، وصفة الله -تعالى - قديمة قدم الله تعالى. ونستدل على ذلك: بأن القر آن الكريم ثبت إعجازه، ومعنى كونه معجزا

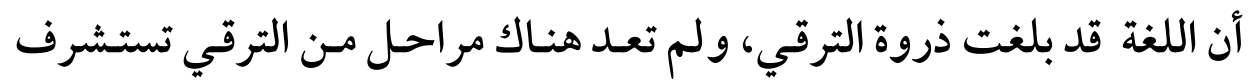
اللغة إليها بعد نزول القرآن الكريم. فلـيس لعلم الإعجاز عندنا نظير في علدوم الأمـم؟ لأن الله -تعـالى - لم

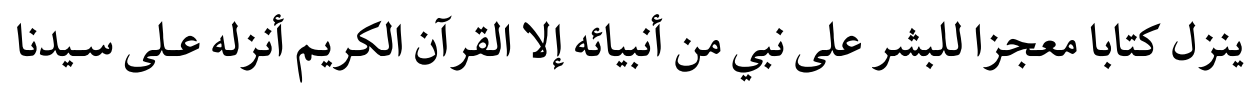

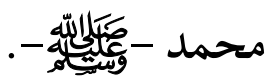


(7I)

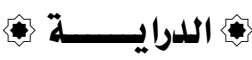

وأن القـر آن أمسك بهـذه العربية وأبقاهـا على حالتها التي كانـت عليها

وقت نزوله، وترتب على ذلك بـأن هـذا مـا كـان يمكـن أن يكون إلا إذا كانتـ

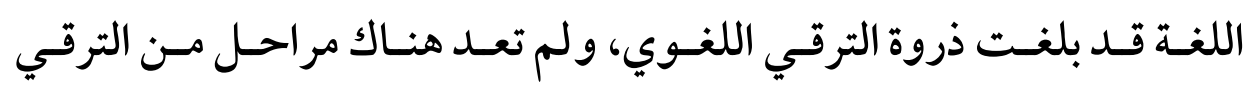

تستشرف اللغة إليها (1)

فأصبحت مناسبة اللفظ لمعناه في أصل الوضع أساسا يبنى عليه اشـتر اط

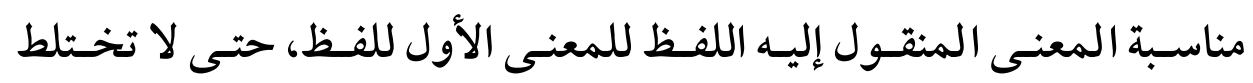

المفاهيم، وذلك على النحو التالي في المباحث التالية:

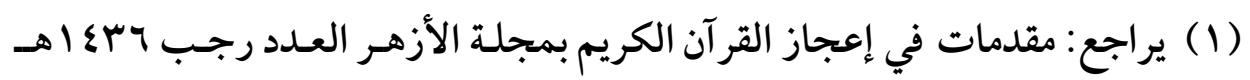

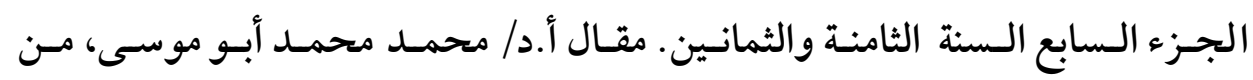

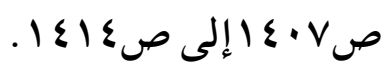




\section{المبحث الثالث}

\section{هناسبة الافظ للامعنى في الهقيقة العرفية}

\section{وأثرها في توجيه خطاب المجتهدين}

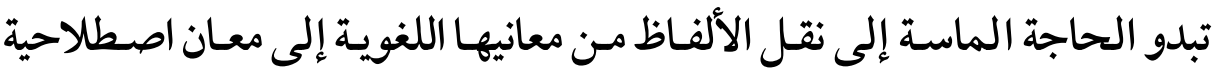

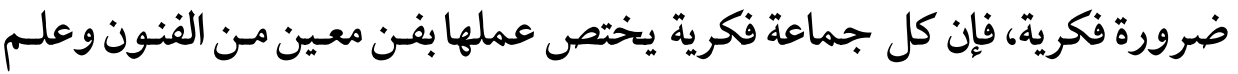

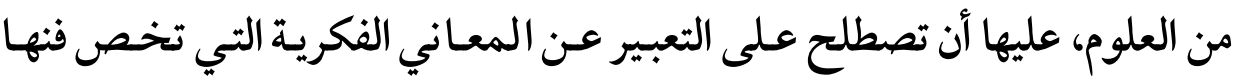

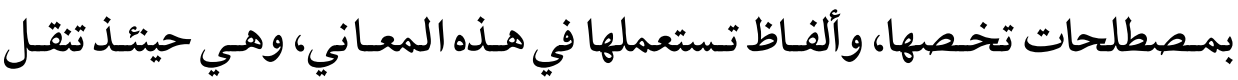
ألفاظا من حقائقها اللغوية إلى المعاني التي تقصدها.

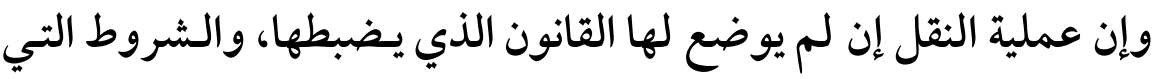

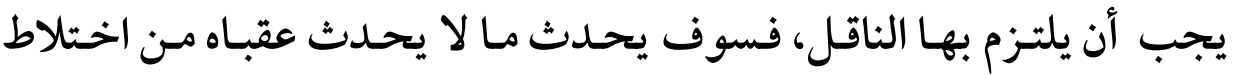

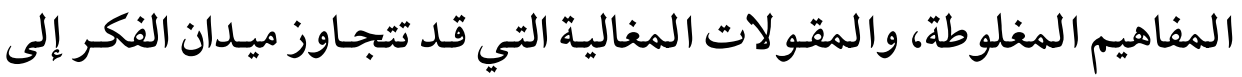
مجال التطبيق، فتفجر عنفا دمويا يعاني منه العباد والبلاد.

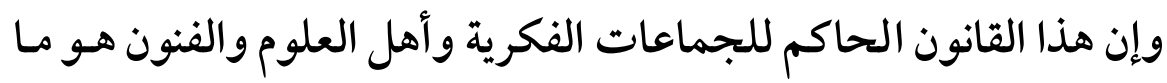

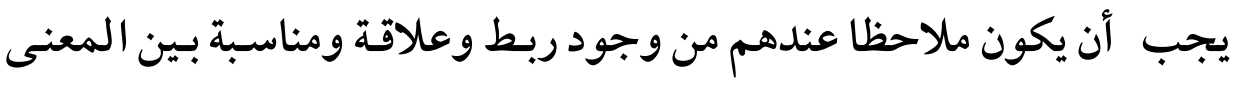

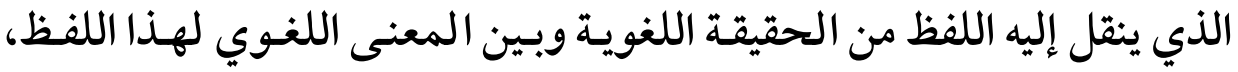

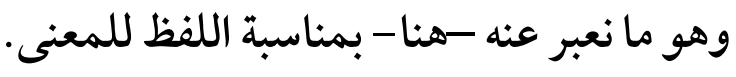

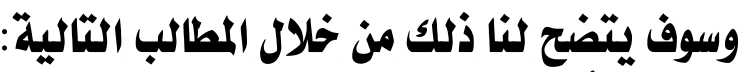
المطلب الأول: تعريف الحقيقة المئي العرفية.

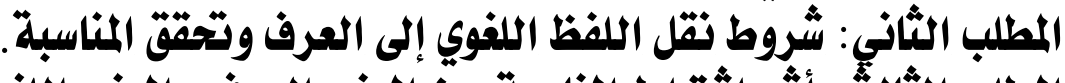

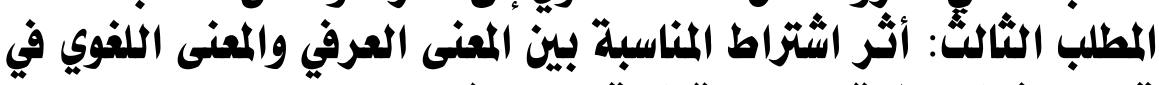
توجيه خطاب المجتهلين بالتطبيق على معنى الجهاد. 


\section{الامطاب الأول}

\section{تعريف المقيقة العرفية}

يلزمنا - هنا- أن نبين المقصود بلفظي: الحقيقة، والعرفية.

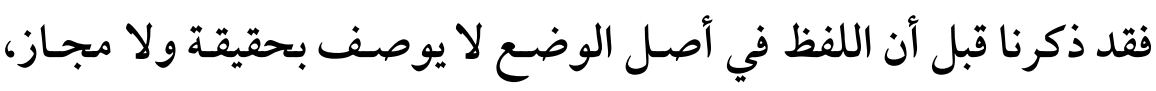

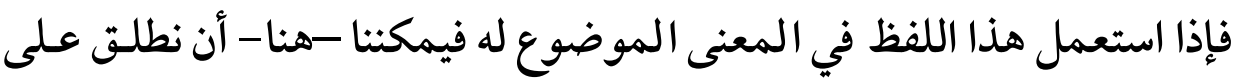

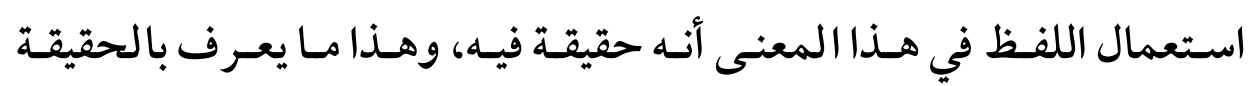
اللغوية، أي: عند أهل اللغة.

وإذا نقل أهل فن معين من الفنون هذا اللفظ مـن معنـاه اللغوي إلى معنى معين عندهم، واشتهر هذا اللفظ في هذا المعنى المنقول إليه بحيـث لا يتبـادر

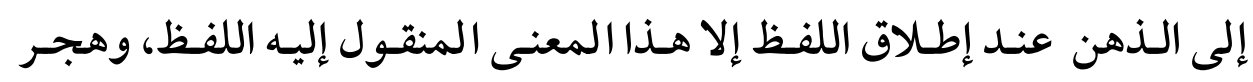

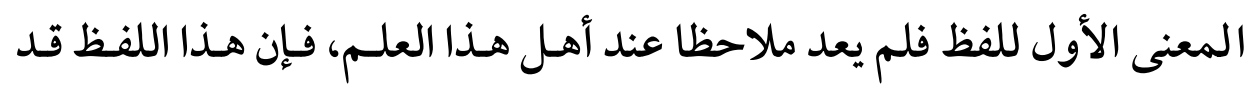
وضع في اصطلاحهم لهذا المعنى، فأصبح حقيقة عندهم بشرطين: 1 - اشتهاره في المعنى المنقول إليه، بحيـث يكون عند إطلاقه لا يتبادر منه إلا هذا المعنى، والاشتهار والتبادر علامة كونه حقيقة.

Y - هجران المعنى الأول عند أهل هذا الفن، فلم يعد ملاحظا في ذهنهم.

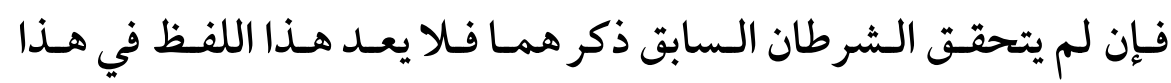
المعنى حقيقة، وسوف يزداد الأمر وضوحا في المطلب التالي.

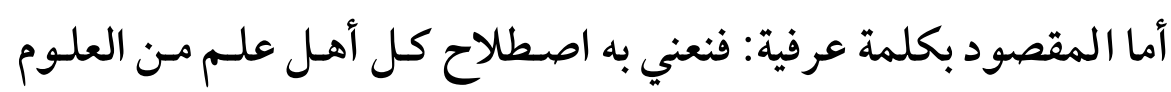

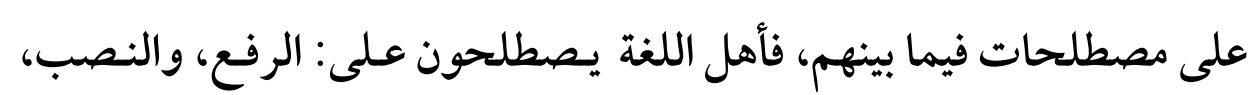

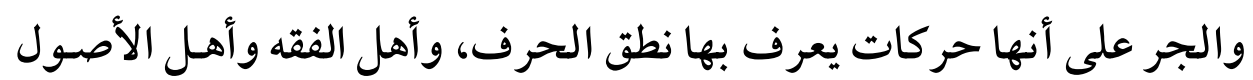


(7६) مناسبة اللفظ للعنى عند الأصوليين وأثرها في توجيه خطاب المجتهلين

حـين يـصطلحون عـلى معنى : الـنقض، القلـب، العلـة .... إلـخخ (1)، فـإنهم يستعملو نها في معان غير معانيها اللغوية .

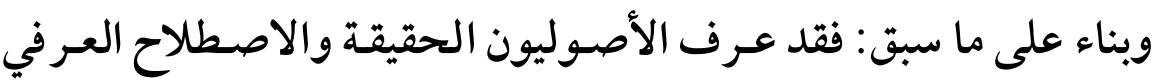

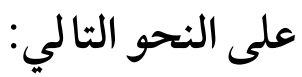
تعريــف الحقيقــة: عـــف البيـضاوي الحقيقـة فقـال: هـي "اللفـظ المستعمل فيما وضع له في اصطلاح التخاطب" (r). شرح التعريف: قوله: "اللفظ " كالجنس، ولكنه جـنس بعيـد، والتعبير بالقول أصوب؛ لأنه جنس قريب. ورد: بأن القول يطلق على الاعتقاد، وليس مر ادا، فاللفظ أولى منه (r).

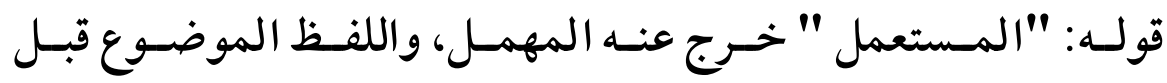
الاستعمال، فإنه ليس بحقيقة ولا مجاز. وقوله : "فيما وضع له " يخرج به المجاز . والمراد بالوضع في الحقيقة الشرعية والعرفية هو غلبة الاستعمال، وفي اللغوية هو تخصيصه به، وجعله دليلاعليه.

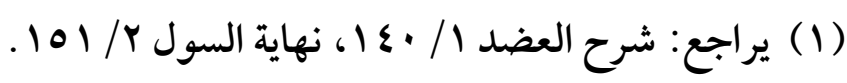

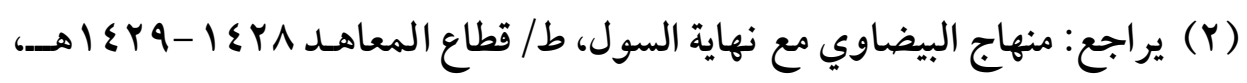
. $1 \leqslant V-1 \leqslant T / Y$ (r) يراجـع: سـلم الوصـول شرح نهايـة السول، للشيخ: محمـد بخيـت المطيعي،

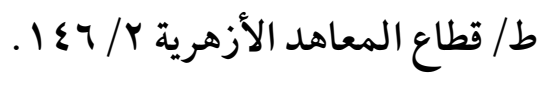


(70)

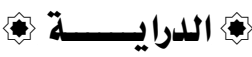

وقوله: "في اصطلاح التخاطب " يتناول اللغوية، والشرعية، والعرفية (1). تعريف الاصطلاح العرفي: الاصطلاح في اللغة: الاتفاق.

واصطلاحا: هو إخـراج اللفظ مـ معنى لغوي إلى معنى آخـر لمناسبة

بينهما.

وقيل: اتفاق طائفة على وضع اللفظ بإزاء المعنى (r).

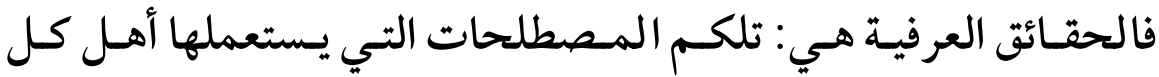

صناعة أو فن أو علم في صناعاتهم أو فنهم أو علمهم.

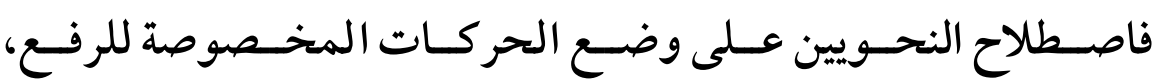

والنصب، والجر، يسمى عندهم حقيقة عرفية.

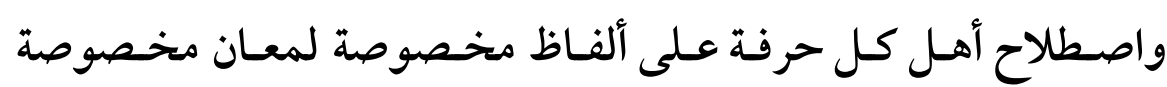

يسمى عندهم حقيقة عرفية.

واصطلاح أهل الشريعة بمختلف تخصصاتهم على ألفـاظ معينة لمعان

معينة عندهم يسمى حقيقة عرفية.

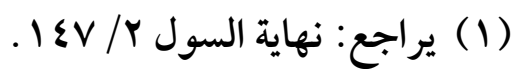

(Y) يراجع: الهداية الكافية الشافية لبيان حقائق ابن عرفة الوافية، لمحمـد بـن قاسـم

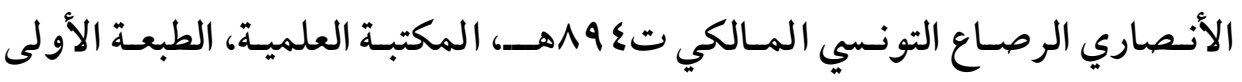

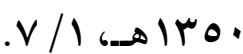


(77) مناسبة اللفظ للعنى عند الأصوليين وأثرها في توجيه خطاب المجتهلين

ونفـرق - هنـا- بـين المتـشرعة وبـين الشرع، فالمتشـرعة: هـم العلـماء

الذين يشتغلون بعلوم الشريعة، فما يصطلحون عليه يسمى حقيقـة عرفية أو

$$
\text { اصطلاحية لديهم. }
$$

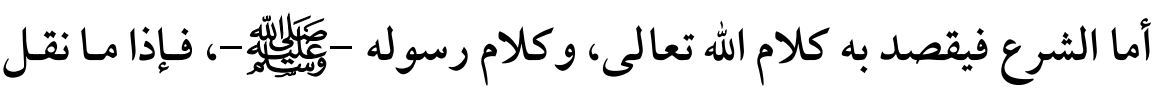

$$
\text { اللفظ من معناه اللغوي إلى معنى شرعي فهذا يسمى حقيقة شرعية (1). }
$$

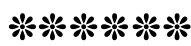

(1) يراجع: المصطلح الأصولي أ.د/ علي جمعه ص\& r. 


\section{الإطلب الثاني}

\section{شروط نقل الالفظ اللغوي إلى العرف وتمقق المناسبة}

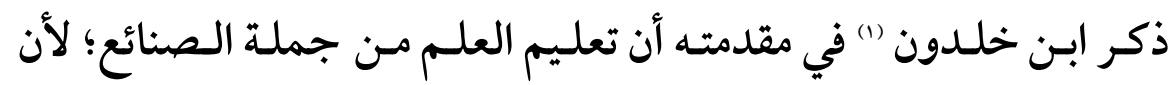

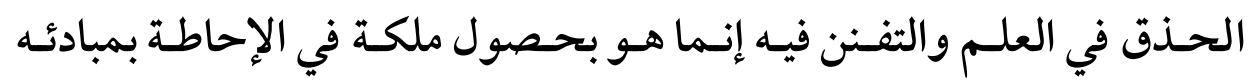

وقواعده، والوقوف على مسائله، واستنباط فروعه من أصوله (().

والملكة هي: هيئة راسخة في النفس حاصلة باستجماع المآخـذوالأسباب

والشروط التي يكفي المجتهد الرجوع إليها في معرفة الأحكام الشرعية، التي

( (1) ابن خلدون: هو عبد الر حمن بن محمد، ابن خلدون أبو زيد، الفيلسوف المؤرخ،

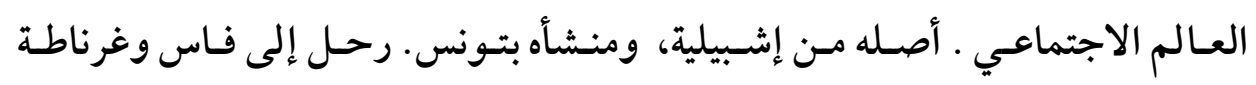

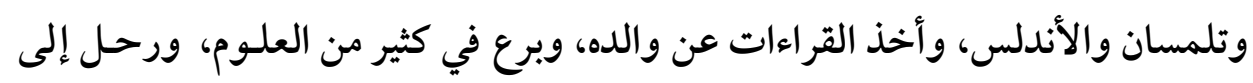

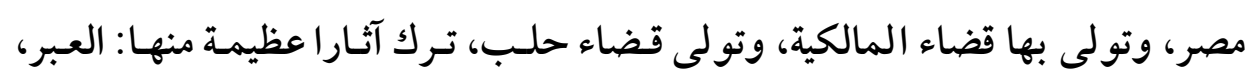

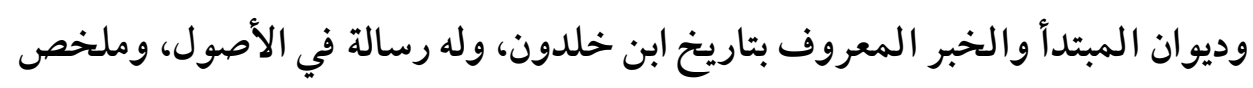

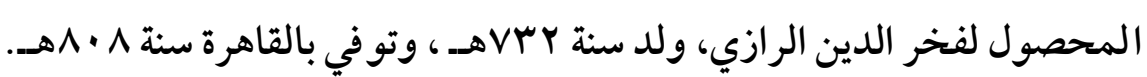

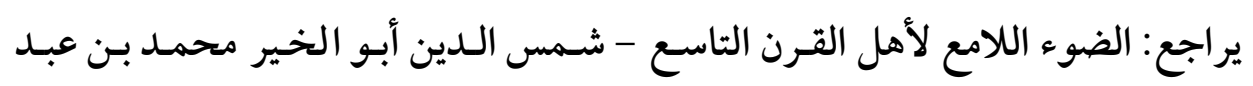

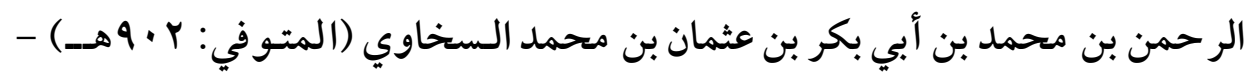

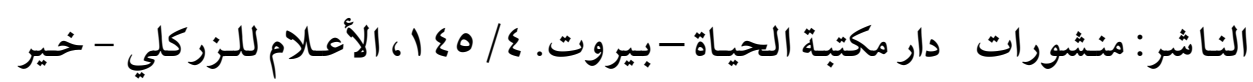

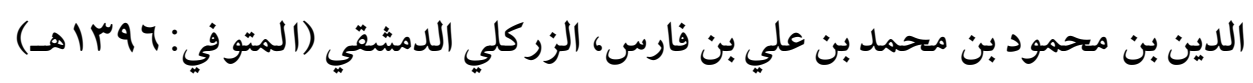

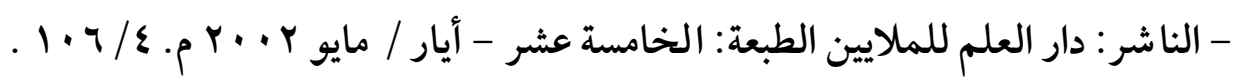

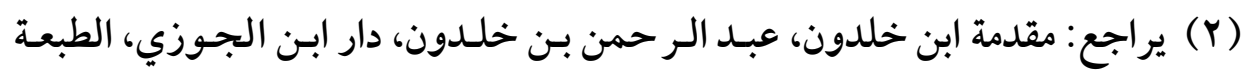

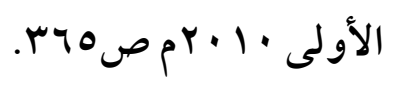


(TA) مناسبة اللفظ للعنى عند الأصوليين وأثرها في توجيه خطاب المجتهلين

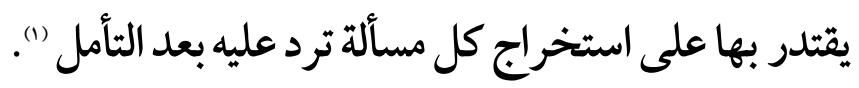

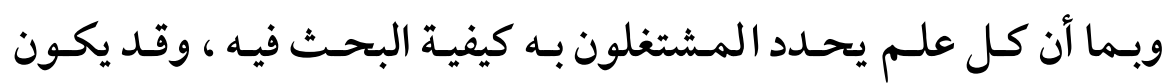
لأحدهم منهج يخالف منهج الآخـر، وعليه فسوف يختلف المصطلح تبعا لاختلاف المناهج. ولكي ينـضبط المـصطلح فلابــد مـن شروط لوضـع المـصطلح بـإزاء المعنى المراد في كل فن من الفنون، وهذه الشروط على النحو الآتي: الشرط الأول: وجود المناسبة.

لكي يكسون هنـاك ضـابط يرجـع إليسه، ويكـون حـاكما عـلى عمليـة نقـل

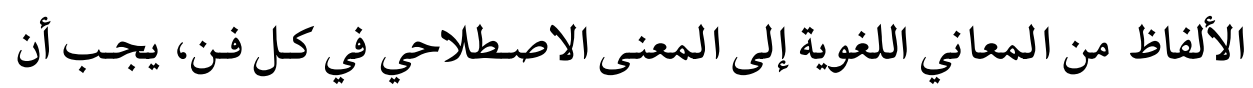
توجد ثمة علاقة ومناسبة بين معنى اللفظ في العرف ومعنـاه في اللغة، وإذا لم توجد هذه العلاقة نكون بصدد قضية الرمز، وهي قضية لا تصح في العلوم. هذا، وقد قسم العلماء الحقيقة العرفية قسمين: الأول: الحقيقة العرفية العامة : وهي التي انتقلت مـن مسماها اللغوي إلى غيره للاستعمال العام بحيث هجر الأول، وتظل المناسبة بين المعنيين قائمة، وتكون هذه المناسبة بما يأتي: اـ بتخصيص الاسم ببعض مسمياته.

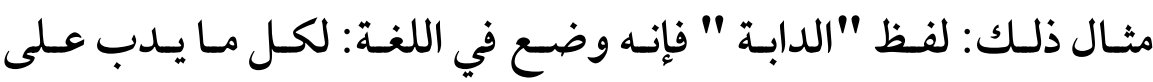
الأرض، فخصصها العرف العام بما له حـافر فقط، فقد وضست فئ المناسبة في ذلك حيث إن المعنى العرفي جزء من المعنى اللغوي.

(1) يراجع: تيسير التحرير /11 (1) 


\section{rـ بتعميي الاسم لجميع مسمياته.}

مثال ذلك: "اليمين " فإنها في اللغة: قسم بالتاء أو إحدى أخواتها. ونقل إلى عرف المتشرعة لأعم من ذلك، كالحلف بالطلاق، وغيره.

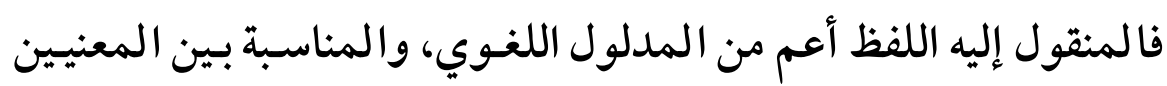

للفظ ظاهرة أيضا.

\section{rـ باشتهار المجاز بحيث يستنكر معه استعمال الحقيقة.}

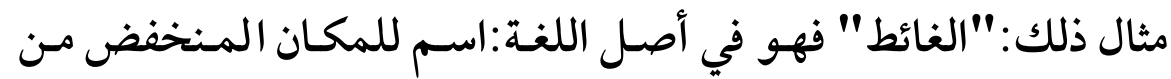
الأرض،غير أنه قد اشتهر في العـرف بالخـارج المستقذر مـن الإنسان، وعند اصند إطلاقه لا يفهم غيره.

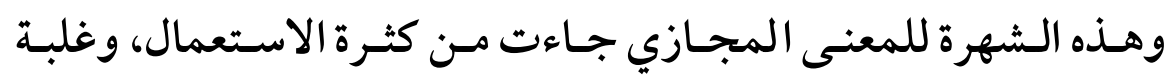
التخاطب بـه مـع الاسـتنكاف مـن ذكر الاسـم الخـاص بـه لنفـرة الطبـاع عنه، فكنوا عنه بلازمه (1) الثاني: الحقيقة العرفية الخاصة: وهـو مـا لكل طائفـة مـن العلـماء مـن اصـطلاحات تخــصهم، كاصـطلاح الأصــوليين عـلى: الــنقض، القلـب، واصطلاح النحاة على: الرفع، والنصب، والجر، وغيرهم (). وهنا لابد من وجود صلة وعلاقة ومناسبة بـين المعنى العرفي والمعنى اللغوي للفظ.

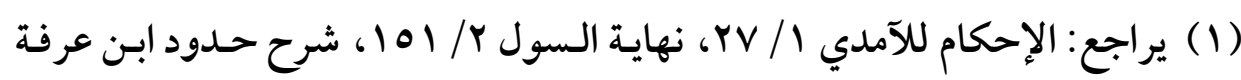
$. v / I$ (Y) يراجع: شرح العضد // / ـ (1، نهاية السول Y/ / 101. 
(V.) مناسبة اللفظ للعنى عند الأصوليين وأثرها في توجيه خطاب المجتهلين الشرط الثاني: أن تقوم به طائفة من أهل فن أو عله. فإن قام به فرد أو فردان فلا يصير هذا المصلح حقيقة عرفية، وإنما يكون ال اصطلاحا شخصيا.

الشرط الثالث: أن يشتهر ذلك اللفظ في المعنى المنقول إليه ويظهر. الشرط الرابع: أن يخرج اللفظ من معناه اللفوي إلى معنى جلديلد.

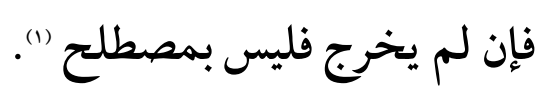

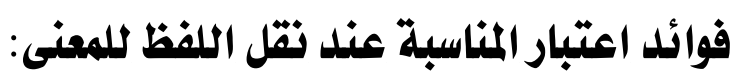

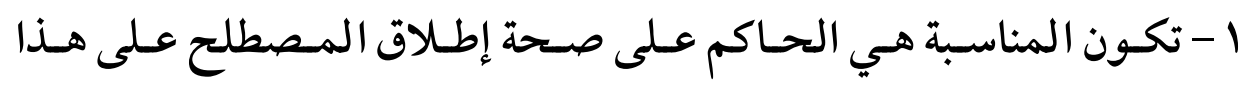

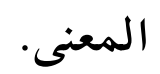

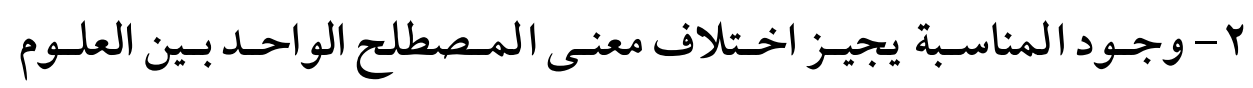

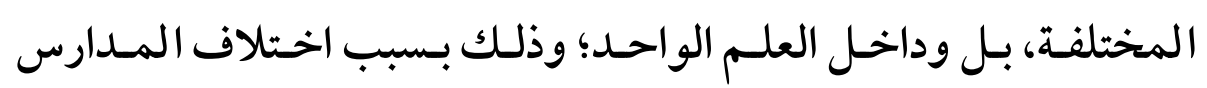

$$
\text { الفكرية. }
$$

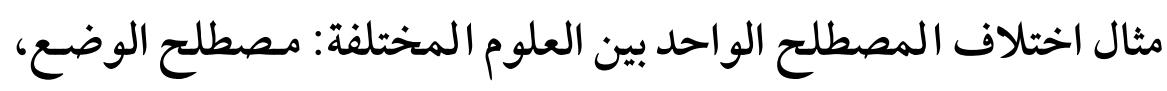

$$
\text { ومنه لفظ: الموضوع. }
$$

فهذا اللفظ عند علماء الحـديث يعني: القول المكذوب المنسوب إلى لى

وعند علماء المنطق يعني: ما عليه الحمل.

(1) يراجع: المصلح الأصولي لأستاذنا الدكتور علي جمعه صبr-• ؛ . 
(VI)

ومثال اختلاف المصطلح في داخل العلم الواحـد: الخـلاف الدائر بين الجمهـور والحنفيـة في معنى الفـرض والواجـب في تبـاينهما أو تــرادفهما، وكذلك لفظي: الفاسد والباطل.

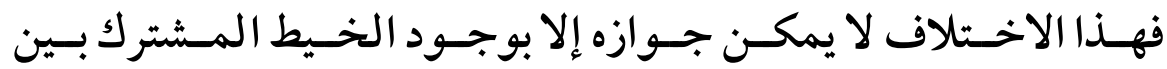
الدلالات، والذي يعد المناسبة التي يصح بها نقل المصطلح ووضعه بـإزاء

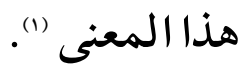
r- اعتبـار المناسـبة بــن معنيـي اللفــ الأول والمنقــول إليـه يتـيح تطـور المصطلحات، وتطور المصطلح يكون بالبحـث عـن التطور والاشـتقاق

$$
\text { الدلالي للفظ. }
$$

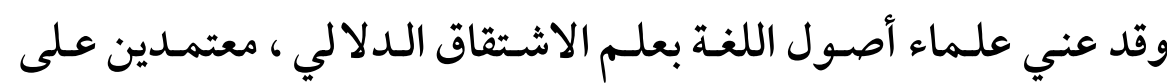
المناسبة بين اللفظ والمعنى الموضوع بإزائه اللفظ.

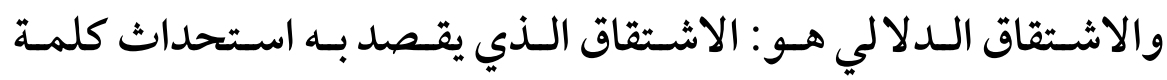
جديدة المعنى من كلمة أخرى مع تناسب الكلمتين في المعنى (().

(1) ير اجع: كثاف اصطلاحات العلوم والفنون، محمـد بـن علي بـن القاضي محمـد

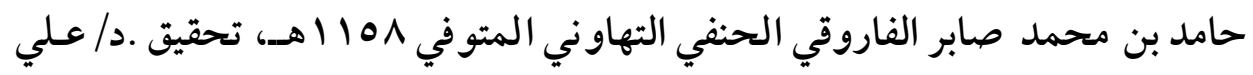

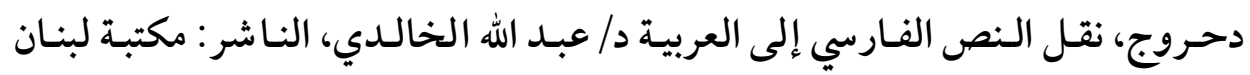

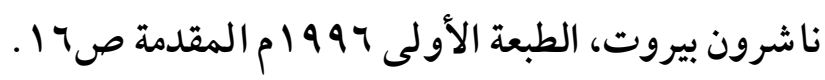

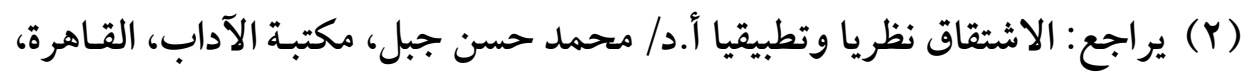
صזr. 
( $r$ r) مناسبة اللفظ للعنى عند الأصوليين وأثرها في توجيه خطاب المجتهلين

\section{وللعناية عند البحث عن تطور المصطلح بالاشتقاق الدلالي منافع منها:}

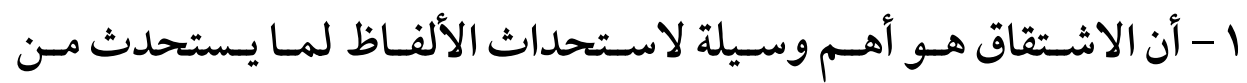

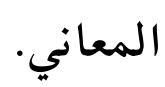

Y - هو وسيلة لكثف معاني الكلمات الغامضة المعنى.

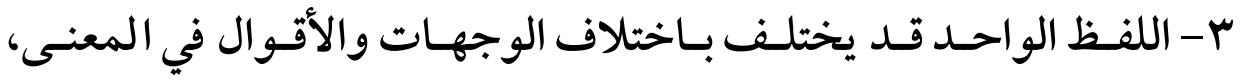
وذلك تبعا للمأخذ الاشتقاقي.

ع - الرجوع إلى الاشتقاق يحسم الاختلاف في المعنى للكلمة. ه- يعين على التحقق من صحة اللفظ المروي، وعدم تعرضه للتصحيف. T- يعين من قصد حفظ الألفاظ ومعانيها (1)

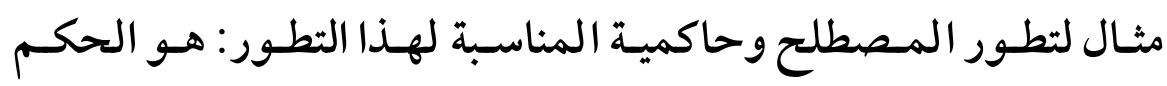

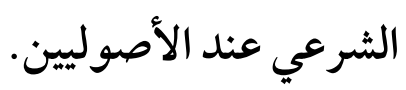

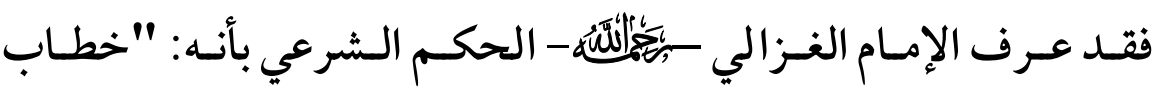
الشرع إذا تعلق بأفعال المكلفين "((). وهو متوفي في أوائل القـرن السادس بــي

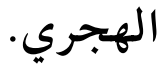

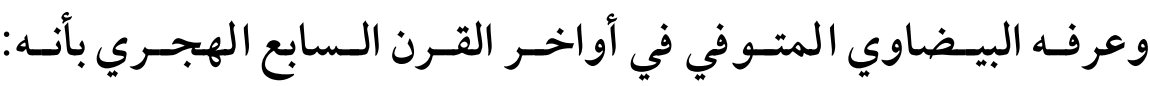

"خطاب الله -تعالى - المتعلق بأفعال المكلفين بالاقتضاء أو التخيير" (r).

$$
\begin{aligned}
& \text { (1) يراجع: المرجع السابق نفسه ص Y79 (Y إلى ص YVA. }
\end{aligned}
$$

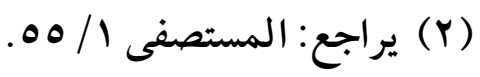

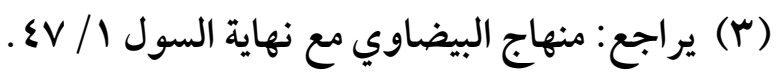


(Vr)

ثم عرفه ابـن الحاجب المتوفي في أواخـر القـرن الثامن الهجري بأنه:

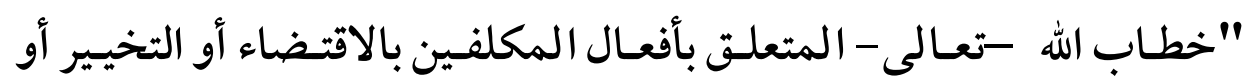
الوضع" (1)

فحكمـت المناسبة هـذا التطور ، يقـول ابـن الحاجـب: " الحكـم : قيـل

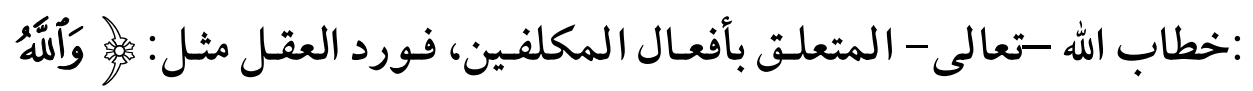

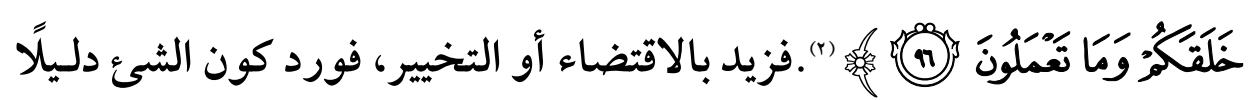

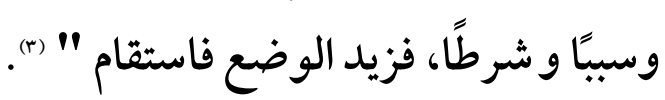

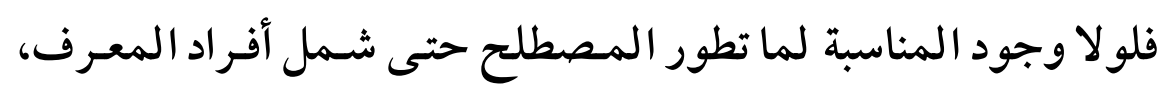

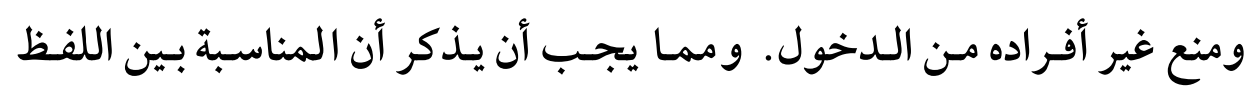

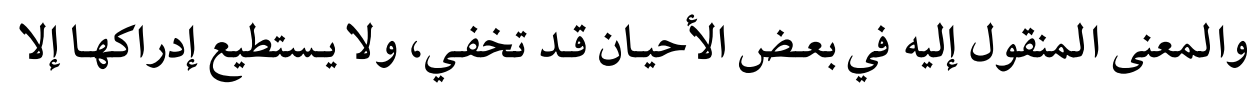

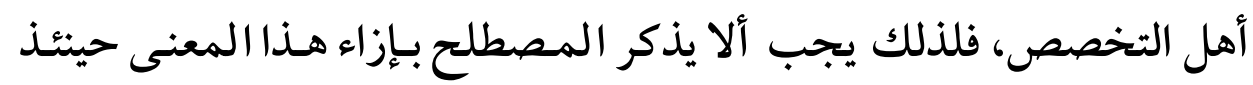

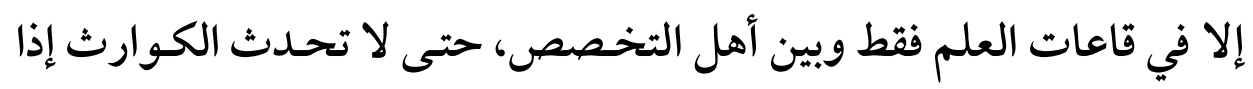

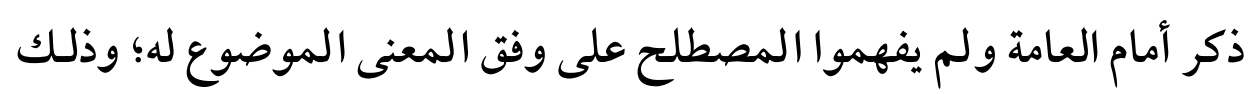

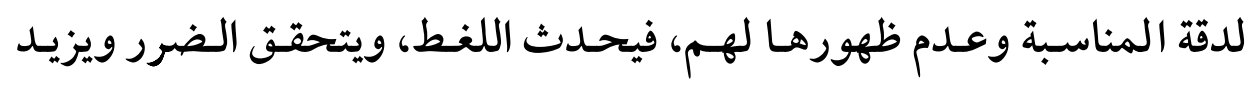

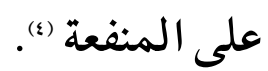

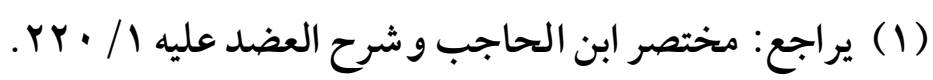

$$
\begin{aligned}
& \text { (Y) [الصافات: بـ4]. }
\end{aligned}
$$

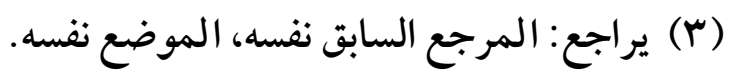

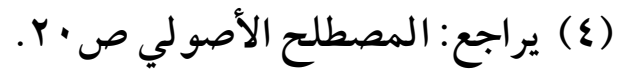


(V\&) مناسبة اللفظ للعنى عند الأصوليين وأثرها في توجيه خطاب المجتهدين

ع - اعتبـار المناسـبة يفــق بـن الخـلاف اللفظـي والخـلاف المعنـوي بـين

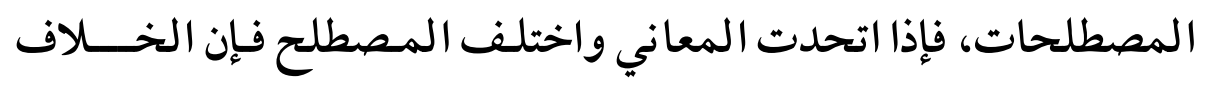

يكون لفظيــا لا يترتب عليه أثر.

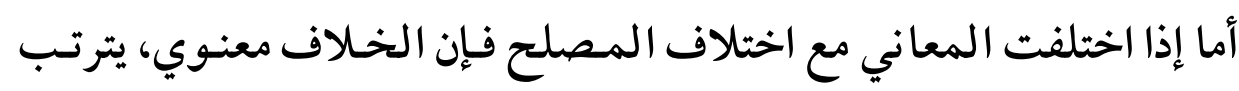

عليه أثر، وما ذلك إلا لاعتبار المناسبة بين اللفظ والمعنى (1).

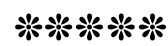

(1) يراجع: المرجع السابق نفسه، ص^\ا. 


\section{المطلب الثالث}

\section{أثر اشتراط المناسبة بين المعنى العرفي والمعنى اللغوي \\ في توجيه خطاب الجمتهدين بالتطبيق على هعنى الجهاد}

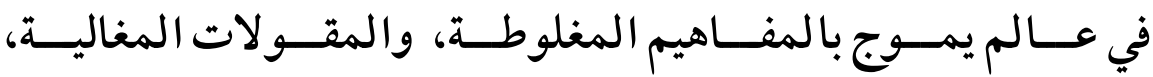

والمصطلحات التي يتسم تحرير مضامينها، وبعد أن تجاوزت هـذه المفـاهيم والمقالات والمصطلحات ميدان الفكر إلى حيـث فجرت عنفـا دمويـا عـانى منه ويعاني ملايين العباد في كثير مـن البلاد، كـان لابـد مـن تحديـد المفـاهيم،

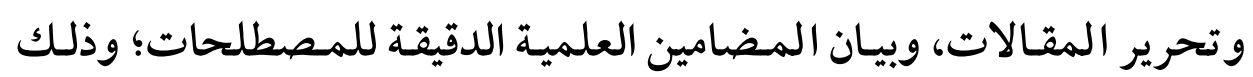
لترشيد الفكر، ودعوة كل الفرقاء مـن كل الـديانات والمـذاهب والاتجاهـات إلى كلمة سواء.

فيجب تجلية المضامين الدقيقـة لأهـم المصطلحات والمقولات التي

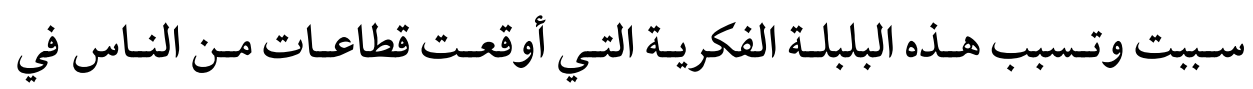

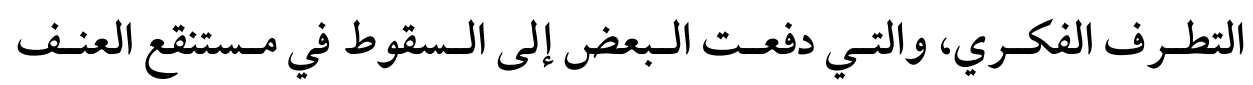
الدموي (1)

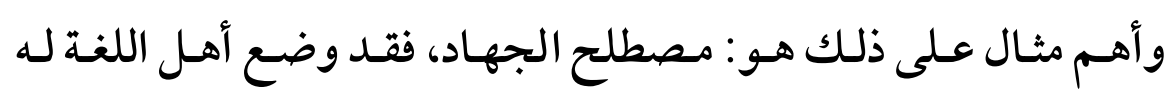
معنى، ثم تم نقله إلى معنى في عرف أهـل الشرع، وقد اختلفوا في معنـاه في عرف المتشرعة.

(1) يراجع: مقـال بعنوان "إزالة الشبهات عـن معاني المصطلحات" أ.د/ محمـد

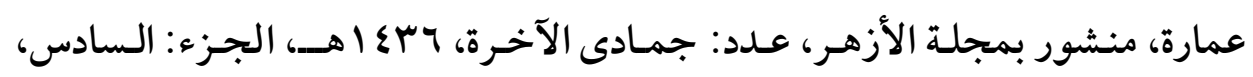

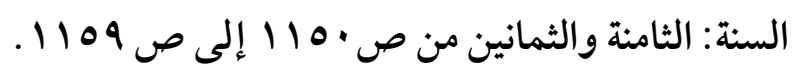


(VY) مناسبة اللفظ للعنى عند الأصوليين وأثرها في توجيه خطاب المجتهلين

و كان سبب اختلافهم في معناه في الحقيقة العرفية هو مر اعـاة المناسبة

$$
\text { بين المعنى العرفي والمعنى اللغوي، أو عدم اعتبارها. }
$$

فلما انتقل معناه العرفي من ميدان الفكر إلى ميـدان الواقع والتطبيق أدى ألى

$$
\text { عدم اعتبار المناسبة إلى ما أدى. }
$$

لكنتـا إذا اعتبرنـا المناسبة اتضخح المـصطلح، وظهر مفهومسه، و تجنبنـا

$$
\text { كثيرا من الفساد الذي قد يحدث إذا لم نعتبر تلكم المناسبة. }
$$

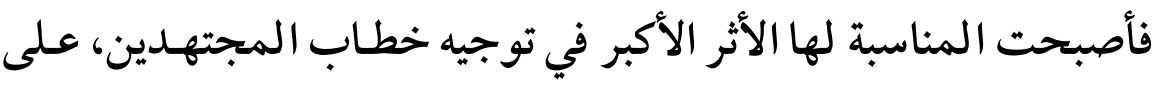

$$
\text { نحو ما سنرى. }
$$

وسوف يتضح ذلك من خلال الفروع التالية:

الفرع الأول: تصريف الجهاد في اللفة، وفي عرف المتشرعة الفئ.

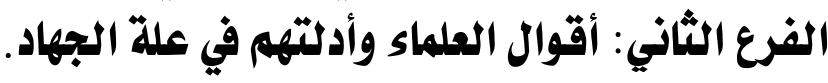

الفرع الثالث: دور المناسبة في توجيه خطاب المجتهلين، وبيان الراجح. 


\section{الفرع الأول \\ تعريف الجهاد في اللغة، وفي عرف أهل الشريعة}

أولا: الجهاد في اللفة:

مـصدر جاهــد جهـادا، و مجاهــدة، ومجاهـــ اسـم فاعـل إذا بــالغ في

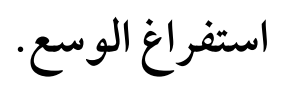

وهو عبارة عن: بذل الجهد -بضم الجيم - وهو الوسع والطاقة، أو بـذل

$$
\text { الجهد -بفتح الجيم - إذا كان على سبيل المبالغة في العمل (1). }
$$

ففي لسان العرب: " الجهاد: المبالغة واستفراغ الوسع في الحرب، أو

$$
\text { باللسان، أو ما أطاق من شيء" (r) }
$$

فأصل الجهاد لغـة: استفراغ الوسـع، فهو معنى أعـم مـن ان يطلق عـلى لـ القتال فقط.

\section{ثانيا: الجهاد في عرف أهل الشرع:}

لقد اختلف الفقهاء في تحديد معنى الجهاد شرعا؛ تبعا لاختلافهم في

$$
\text { مر اعاة المعنى اللغوي. }
$$

عرفه الحنفية بتعريف يستندون فيه على المعنى اللغوي. قال الكاساني الحنفي: "الجهاد يستعمل في بذل الوسع والطاقة بالقتال في

$$
\begin{aligned}
& \text { (1) يراجع: تاج العروس ، باب: جهد / (rv / }
\end{aligned}
$$

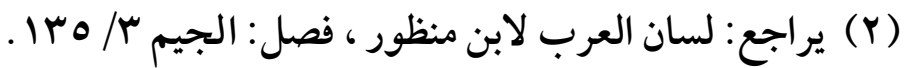


( $\vee \wedge)$ مناسبة اللفظ للعنى عند الأصوليين وأثرها في توجيه خطاب المجتهلين سبيل الله - عز وجل - بالنفس ، والمال، واللسان، أو غير ذلك " (1).

\section{تعريف الجهاد عند المالكية:}

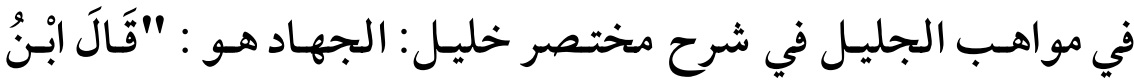

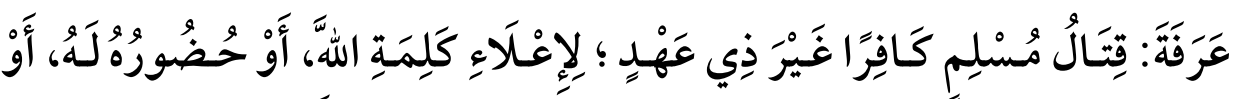

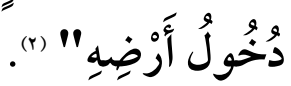

\section{تصريف الجهاد عند الشافية:}

في حاشية البجيرمي على الخطيب: "الجهاد أي: القتال في سبيل الله" ("). تعريف الجهاد عند الحنابلة: في المبدع شرح المقنع لابـن مفلح: "الجهاد شرعـا: عبارة عـن قتال الكفار خاصة" (s).

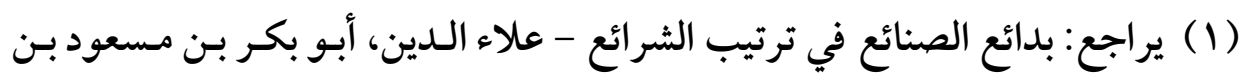

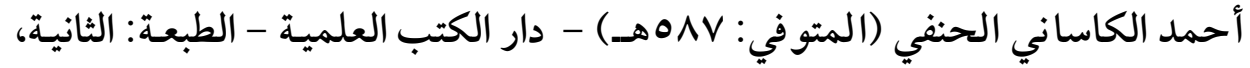

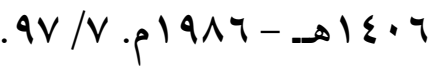

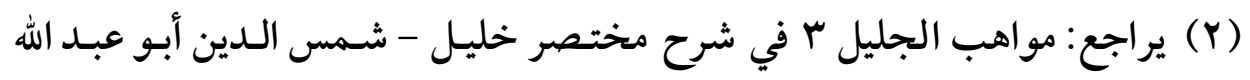

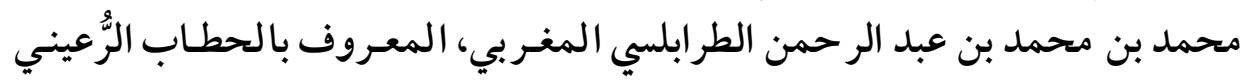

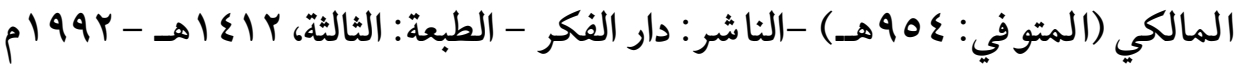
$. r \leqslant V / r$

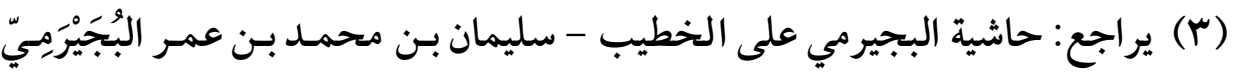

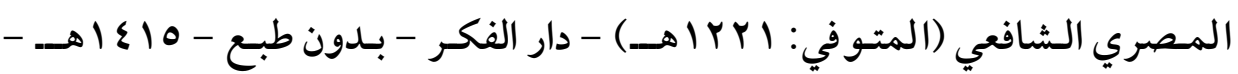

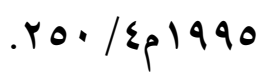
( ) يراجع: المبدع شرح المقنع - إبراهيم بن محمد بن عبد الله بن محمد ابن مفلح،

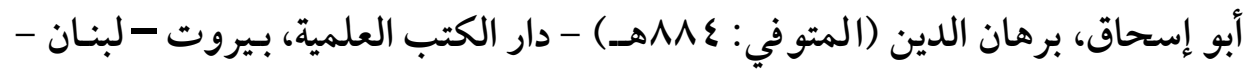

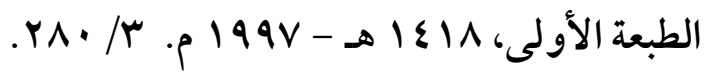


(Vq)

نخلص مما سبق أن الجهاد عند عرف أهل الشريعة يأتي بمعنيين:

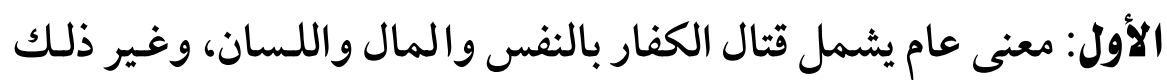
كما عرفه به الحنفية استنادًا على المعنى اللغوي للجهاد، وعلى ما جـاء في بعض النصوص الشرعية من إطلاق الجهاد على غير قتال الكفار بالنفس.

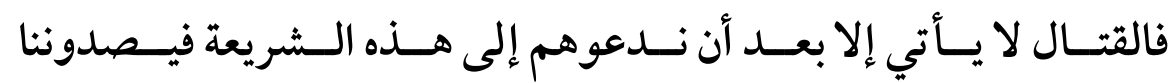

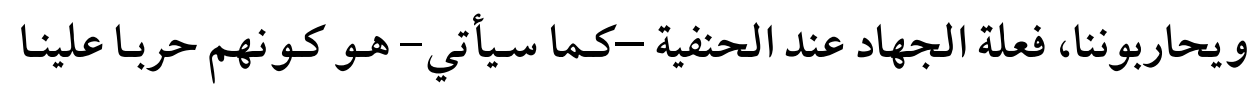

$$
\text { وليس لكفرهم. }
$$

الثـاني: معنى خـاص وهـو: قتـال الكفــار بـالنفس (1)، فالجهاد عنـدهم

يرادف القتال، وهم بذلك لم يراعوا المناسبة مع المعنى اللغوي، فأدى ذلك

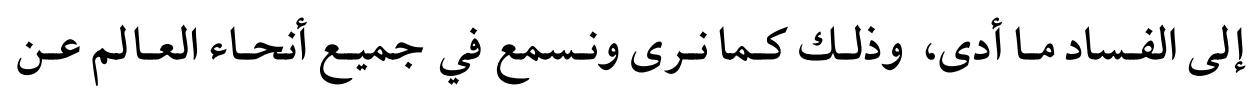
الإرهاب الذي يحدث ويسمونه جهادا، وهذا من فهم البشر وليس هو حقيقة الإسلام.

(1) يراجـع: موسـوعة الإجمـاع في الفقـهـ الإسـلامي إعــاد: د. أسـامة بـن سـعيد

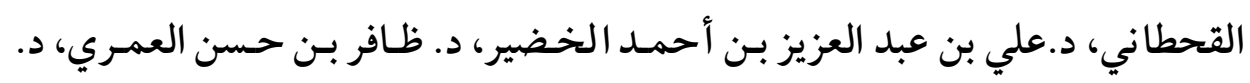

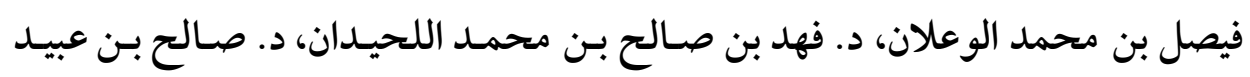

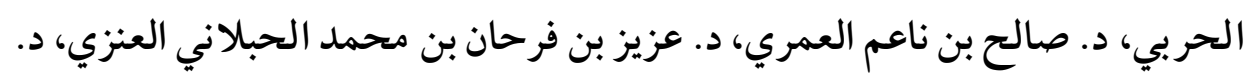

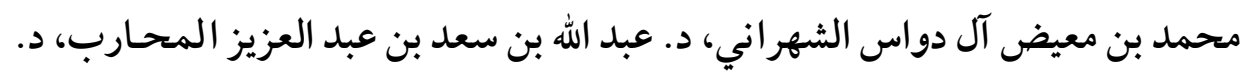

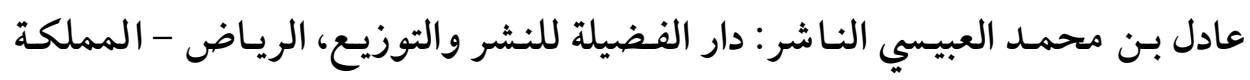

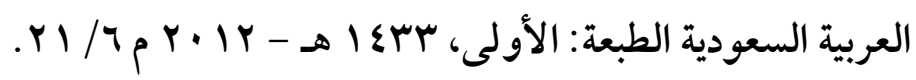


$(\Lambda \cdot)$

مناسبة اللفظ للعنى عند الأصوليين وأثرها في توجيه خطاب المجتهلين

\section{الفرع الثاني}

\section{أقهال العلمهاء وأدلتهم في تهديد علة الجهاد}

الجهاد حكمه أنه فرض كفاية، وقد يكون فرض عين -كما هـو مبين في

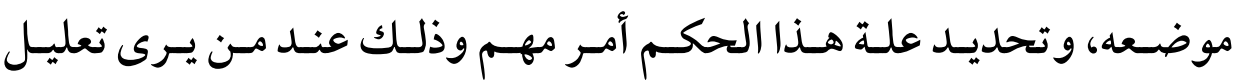

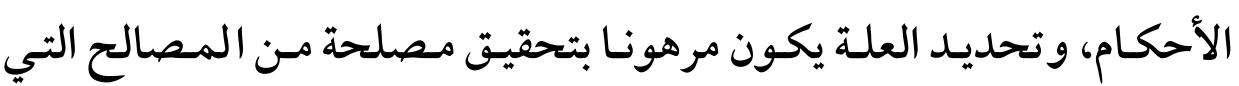
راعاها الشرع الحنيف، والتي قيل عنها: إنها مر اعاة في كل ملة. وهي مصلحة حفظ الدين، فقد شرع الله -سبحانه وتعالى - تشريعات بها يوجد الدين مثل: وجوب الإيمان بالله - تعالى - ورسله، ووجوب الفـروع التي تنثأ عنه، وبذلك يحفظ الثارع الدين من ناحية الوجود. وشرع الله -سبحانه وتعالى - تشريعات تحفظ الدين من الضياع، مثل : الجهاد في سبيل الله تعالى. وعليه فإن العلة التي ينشأ عنها تحقيق المصلحة هي العلة الصحيحة. وقد انقسم العلماء في تحديلد علة الجهاد إلى فريقين:

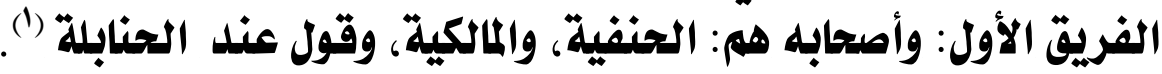

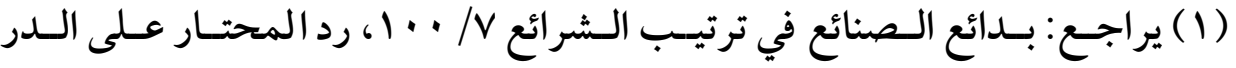

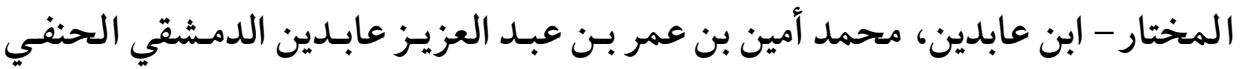

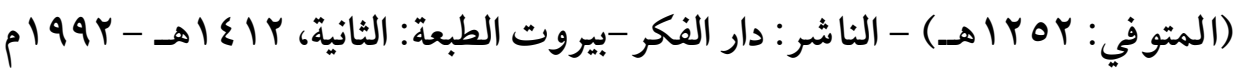

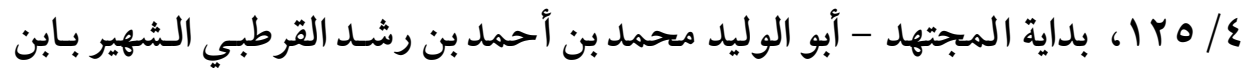

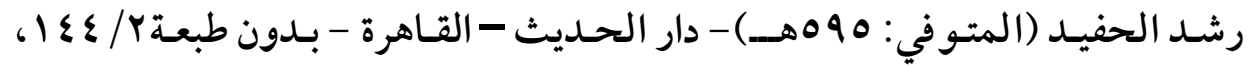

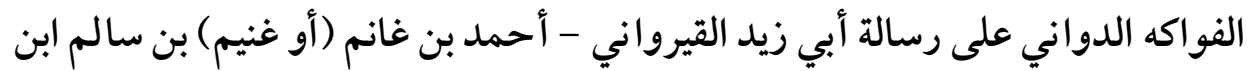

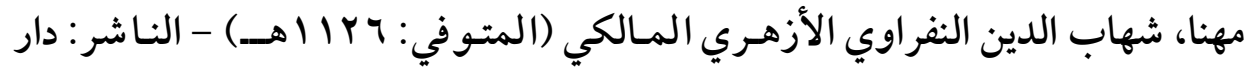

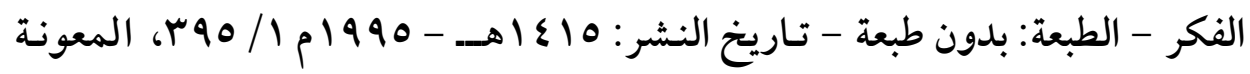

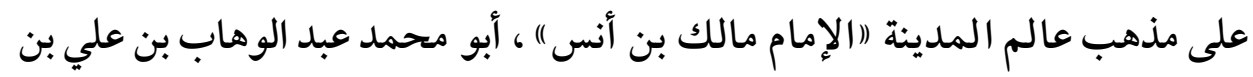


(AI)

قالوا: إن علة الجهاد هي: نصرة الإسـلام؛ لكسون الكفـار حربـا علينا، لا لكفرهم؛ لأن الذي يهدم الدين هو حربهم علينا واعتداؤهم (1). أما مجرد كفرهم فلا يهدم الدين، فلا يصح أن يكون علة للجهاد.

أدلتهه:

\section{استدلوا على ما ذهبوا إليه بالأدلة الآتية:}

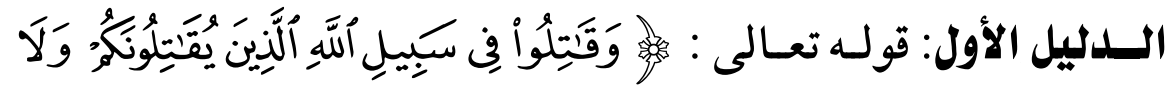

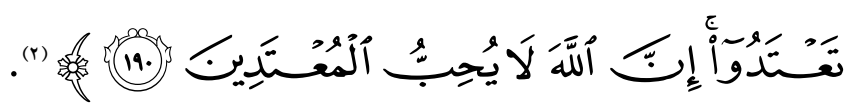

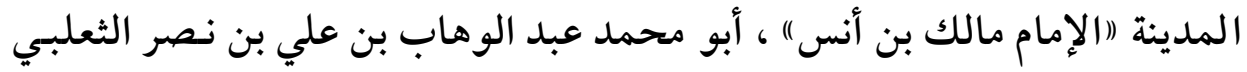

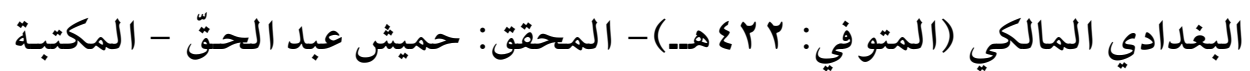

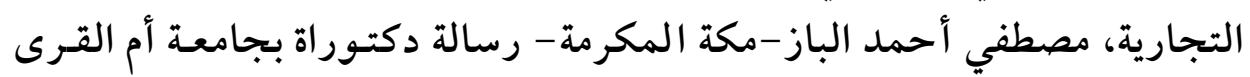

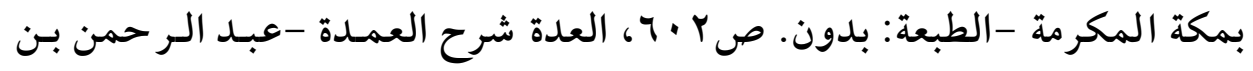

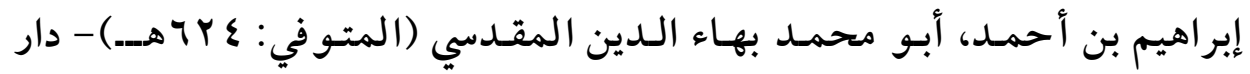

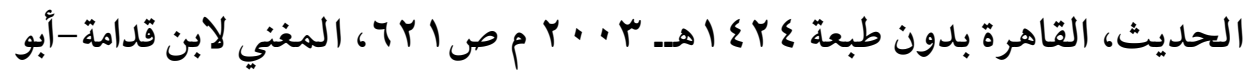

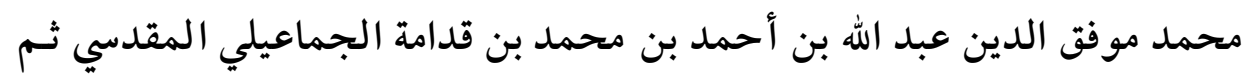

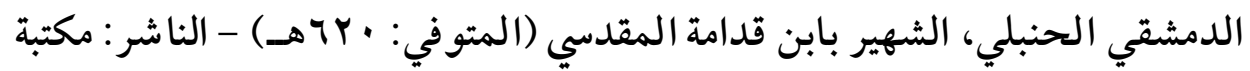

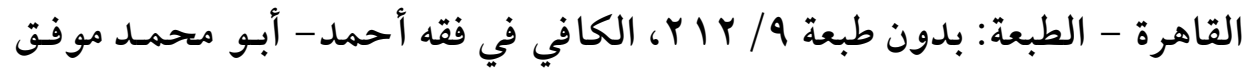

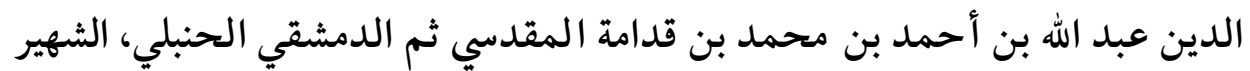

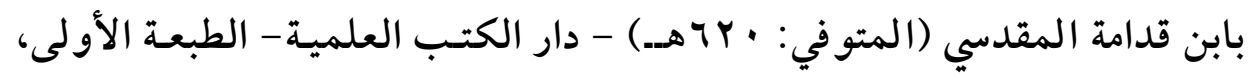

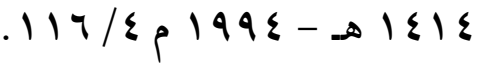

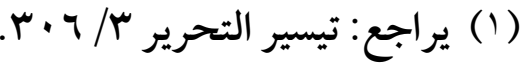

$$
\begin{aligned}
& \text { (r) (البقرة: • 19 (19). }
\end{aligned}
$$


وجسه اللدلالــة: أن الله -تعـالى - أمـر المسلمين بقتـال مـن قـاتلهم مـن

المشـركين، والكـف عمـن كـف عـنهم، ونهـاهم عـن الاعتـداء عـلى النساء

$$
\text { والذراري، وهذا الحكم ثابت إلى اليوم لم ينسخ ". }
$$

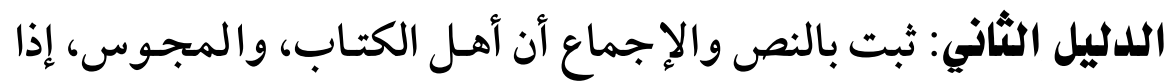

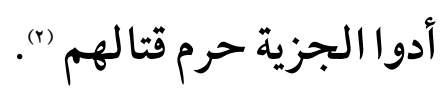

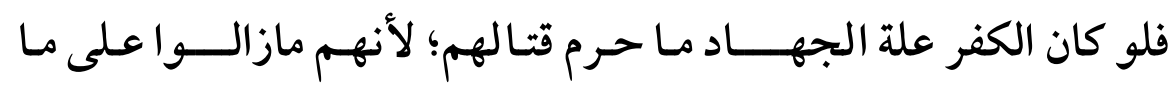
هم عليه من الكفر.

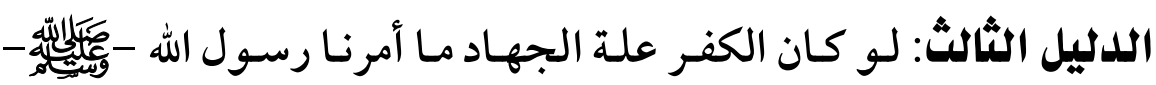

$$
\text { بالكف عن محاربة المرأة والشيخ الكبير من المشر كين. }
$$

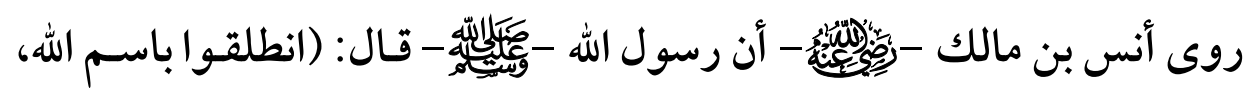
وباله، وعلى ملة رسول الله، ولا تقتلوا شيخا فانيا، ولا طفلا، ولا امر أة) (م).

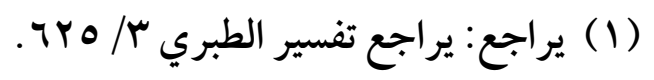

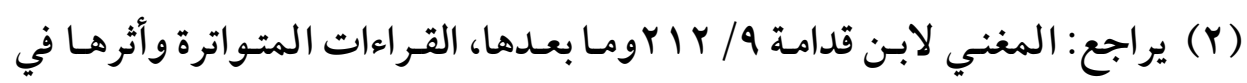

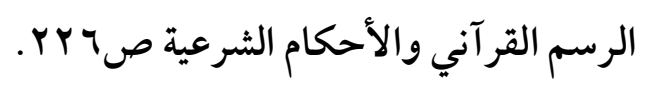

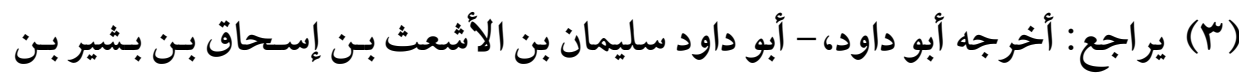

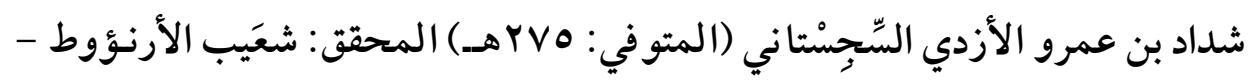

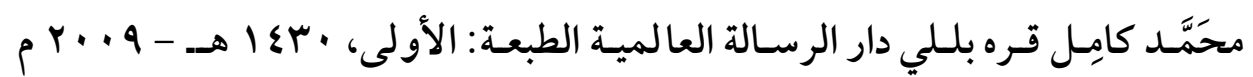

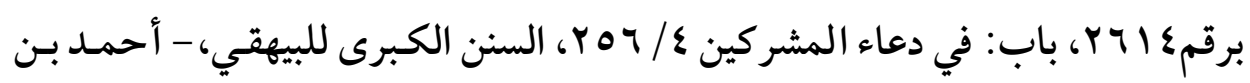

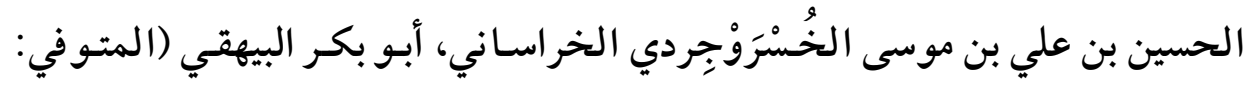

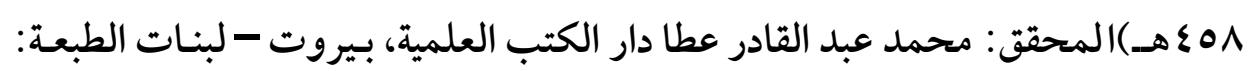


(Ar)

الثريق الثاذي: وأصحابه هم: الشافعية، وأغلب الحنابلة (1).

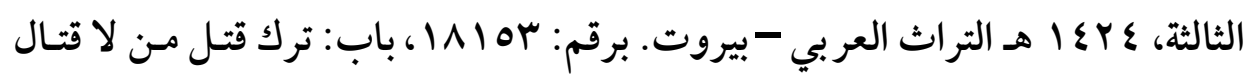
فيه من الرهبان 9/ / 1 ـ مصنف ابن أبي شيبة- أبو بكر بن أبي شيبة، عبد الله بن محمد

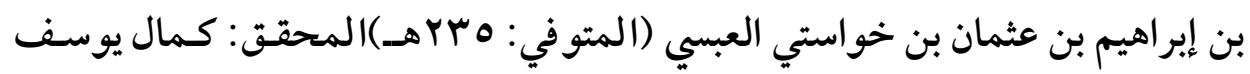

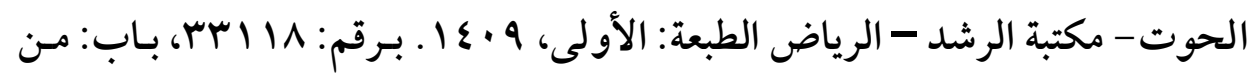

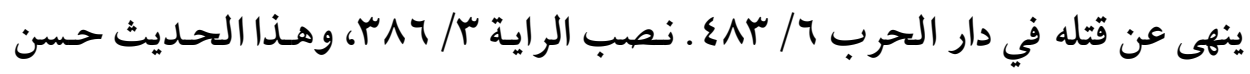
لغيره، إسناده ضعيف، لجهالة خالد بن الفزر. الدراية في تخـريج أحاديـث الهدايـة مـع حاشيته بغية الألمعي في تخريج الزيلعي جمال الدين أبو محمد عبد الله بن يوسف بن

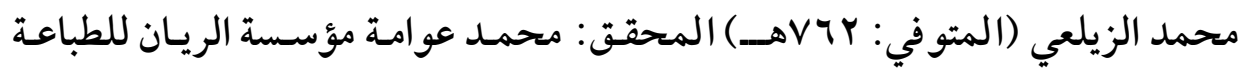
والثشر - بيروت -لبنان/ دار القبلة للثقافة الإسلامية- جدة - السعودية الطبعة: الأولى، $.117 / r_{p} 199 V / 1 \leqslant 11$ (1) يراجع: الحاوي الكبير في فقه مذهب الإمام الشافعي وهو شرح مختصر المزني - أبو الحسن علي بن محمد بن محمد بن حبيب البصري البغدادي، الثهير بالماوردي (المتوفي : · عـهـ) - المحقق: الشيخ علي محمد معوض - الشيخ عادل أحمد عبد

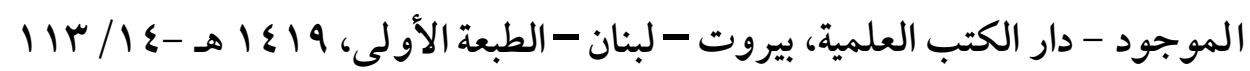
المهذب في فقه الإمام الشافعي- أبو إسحاق إبر اهيم بن علي بن يوسف الشيرازي

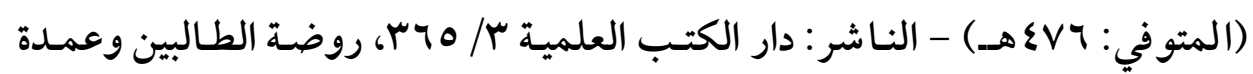
المفتيين - أبـو زكريـا محيي الـدين يحيسى بـن شرف النووي (المتوفي : TVIهــ) تحقيق: زهير الشاويش المكتب الإسـلامي، بيروت-دمـشق -عـمان-الطبعة :الثالثة

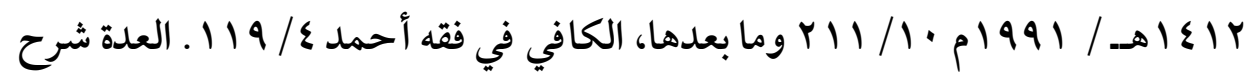

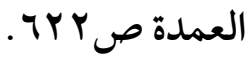




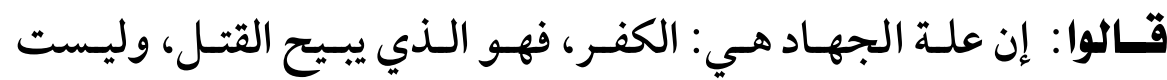
الحرابة، وعليه فقد عرفوا الجهاد بأنه: قتال الكفار لنصرة الإسلام.

\section{أدلتهم:}

\section{استدلوا على ما ذهبوا إليه بالأدلة الآتية:}

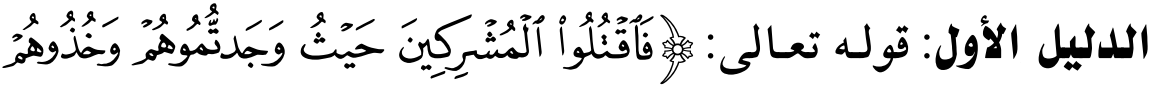

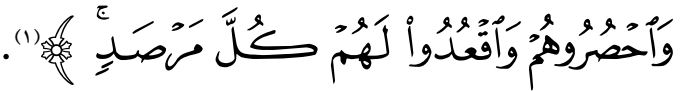

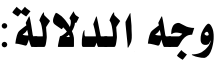

دلت الآية بمنطوقها الصريح على وجوب قتل المشر كين، وهي دلالة عبارة، ولا تقبل منهم جزية إذا كانوا عبدة الأوثان من العربـ

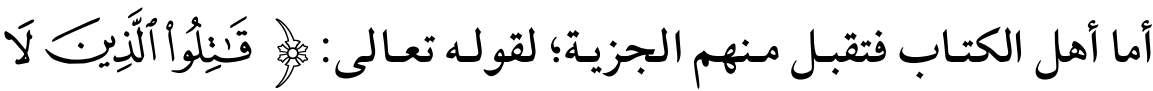

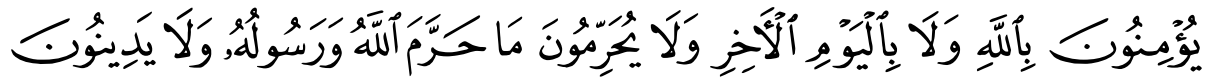

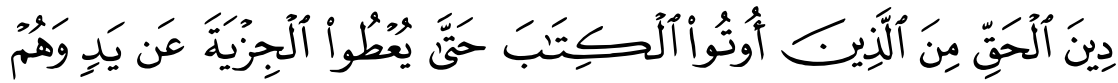

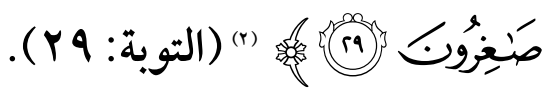

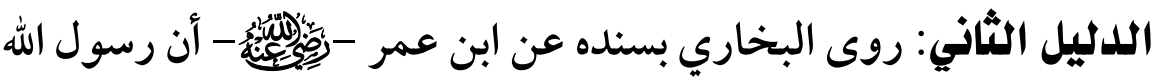

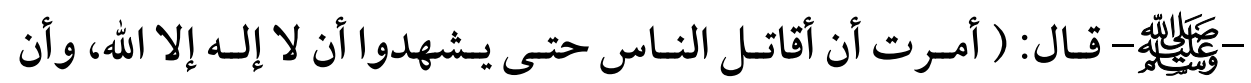

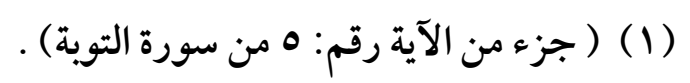

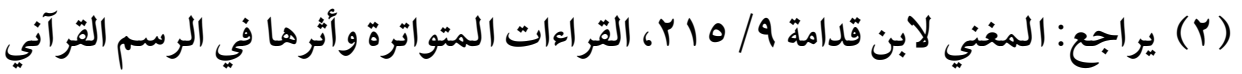

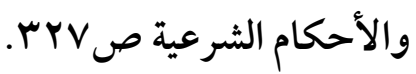


محمدا رسول الله، ويقيموا الصلاة، ويؤتوا الزكاة، فبإذا فعلوا ذلك عصموا مني دماءهم وأمو الهم إلا بحق الإسلام، وحسابهم على الله) (1).

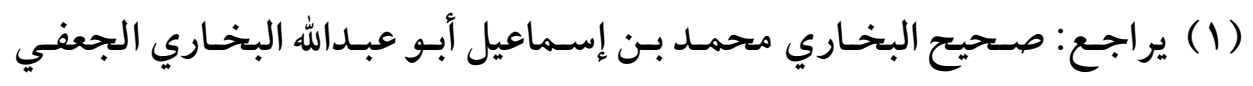

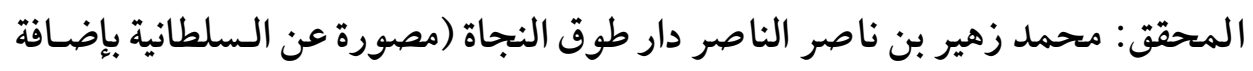

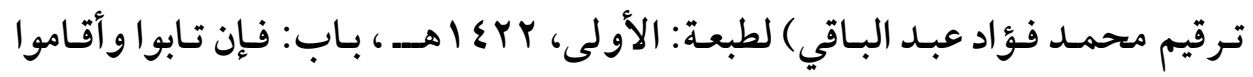

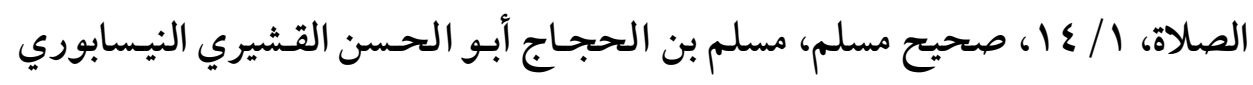

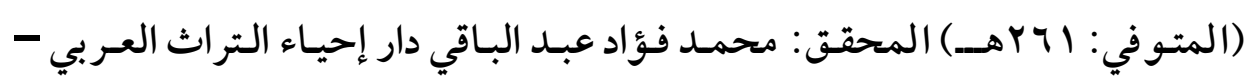

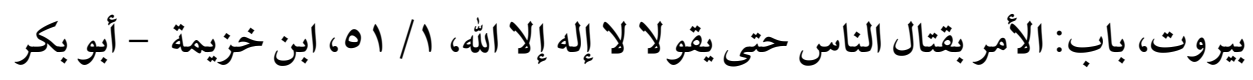

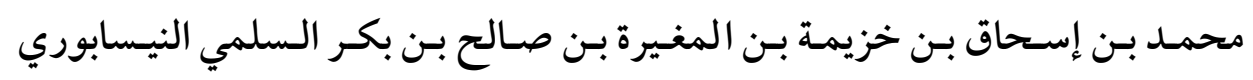

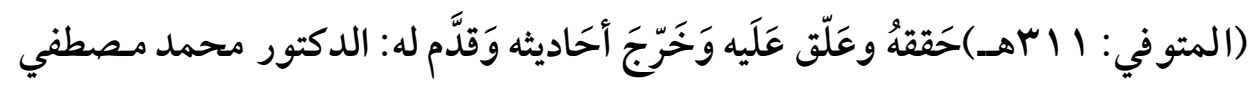

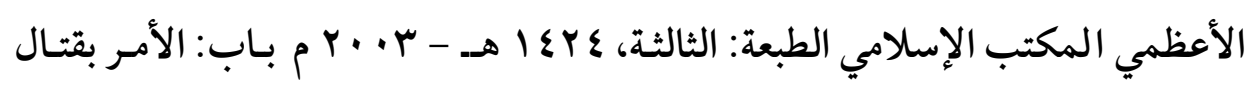

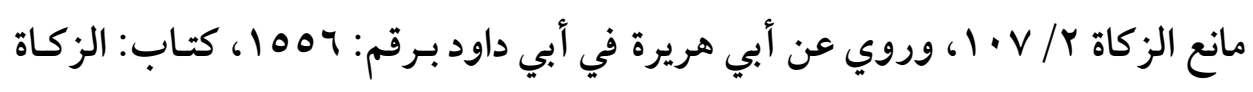

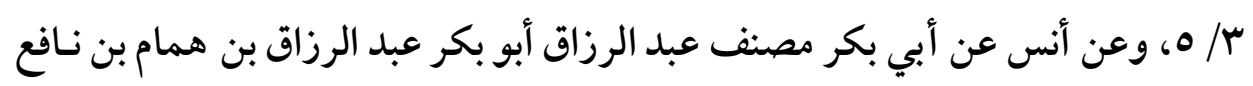

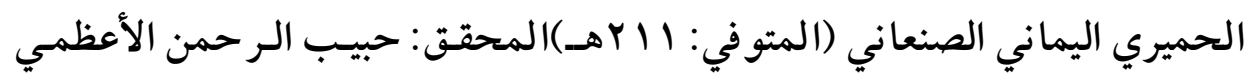

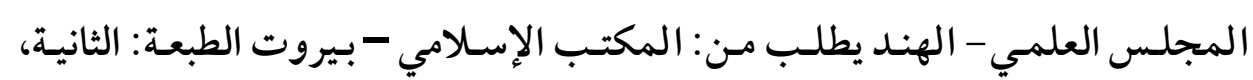

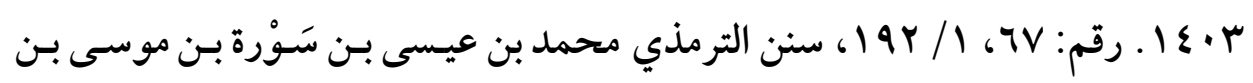

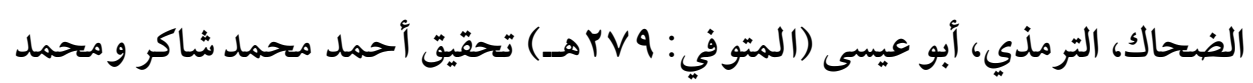

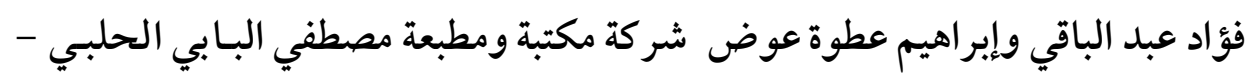

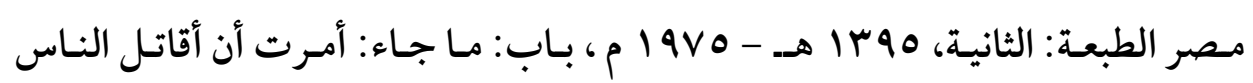
.01V/0 
وجه اللدلالة: إن هذا الحديث يوجب مقاتلة الناس الكفار، وما ذلك إلا

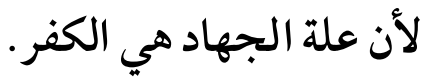
اللدليل الثالـث: روى أبو داود في سـننه قـال: حـثنا سعيد بـن منصور، حدثنا هشيم، حدثنا حجاج، حدثنا قتادة، عن الحسن، عن سـمرة بـن جندب،

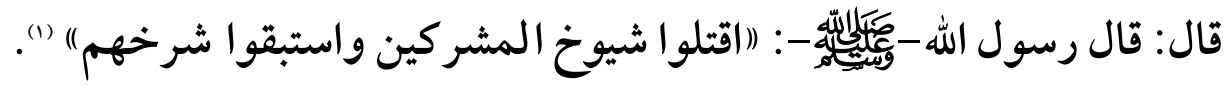

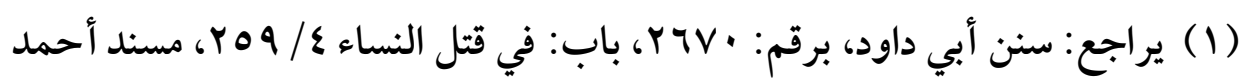

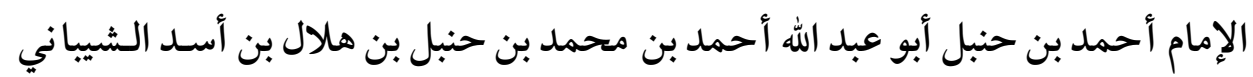

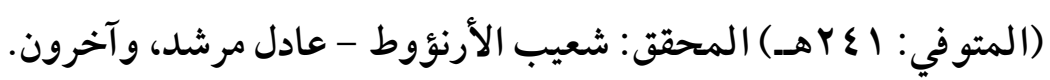

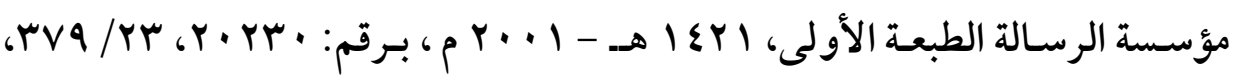

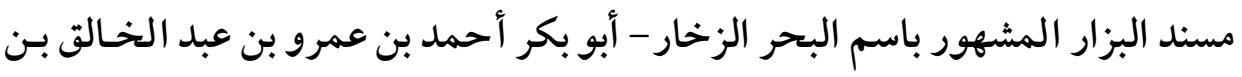

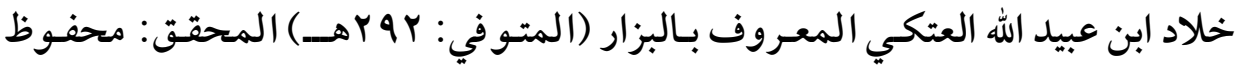

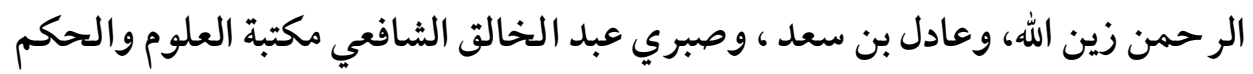

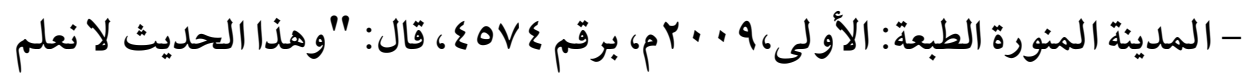

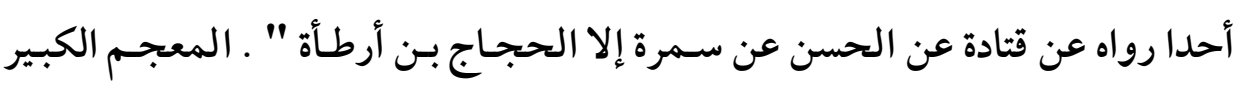

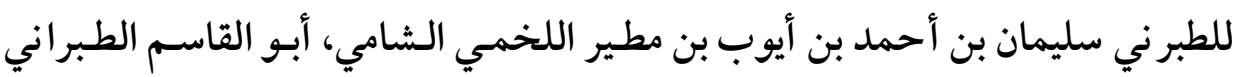

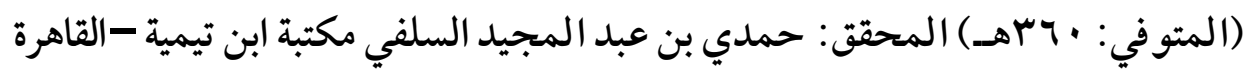

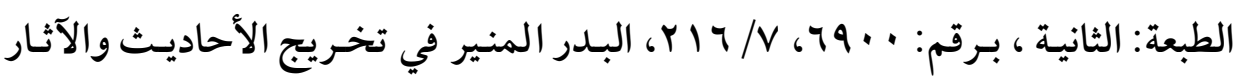

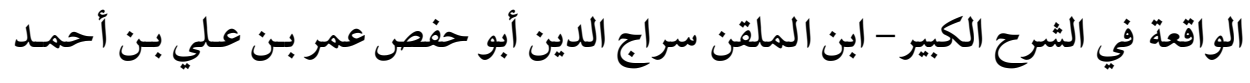

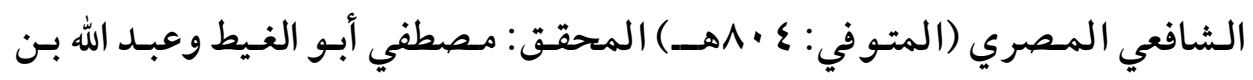

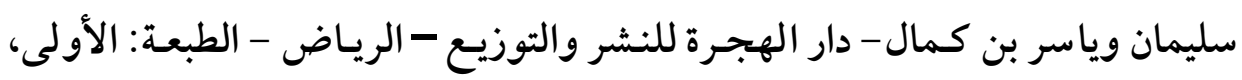

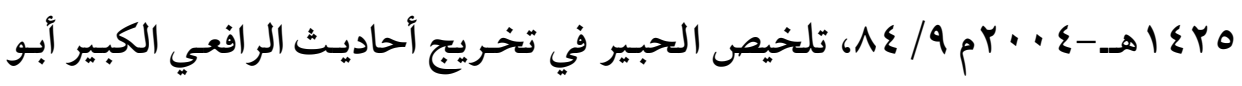


وجه اللدلالة: دل الحديث بمنطوقه على وجوب قتال المشر كين، ممـا

$$
\text { يدل على أن الكفر هو علة المقاتلة لهم. }
$$

\section{楼楼楼}

الفضل أحمد بن علي بن محمد بن أحمد بـن حجر العسقلاني (المتوفي: بهـهــ

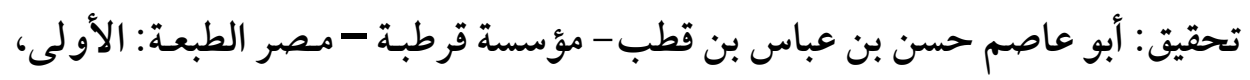
.rVT/\& p $1990 /$ / 
$(\wedge \Lambda)$ مناسبة اللفظ للعنى عند الأصوليين وأثرها في توجيه خطاب المجتهلين

\section{الفرع الثالث}

دور المناسبة في توجيه خطاب المبتهدين، وبيان الراجح

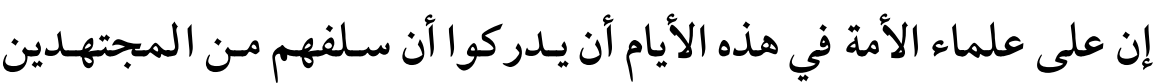

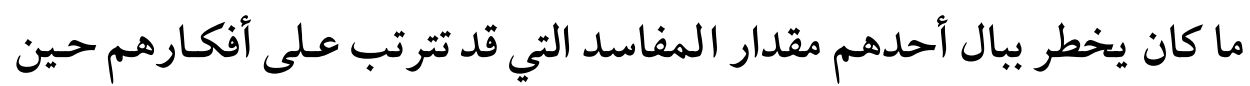
تنتقل المصلحات التي اصطلحوا عليها من ميدان الفكر إلى الواقع.

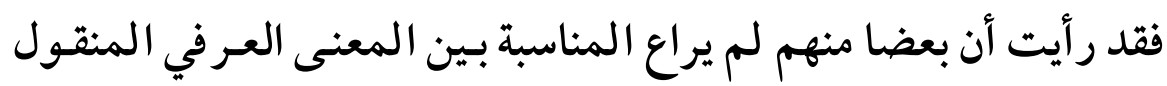

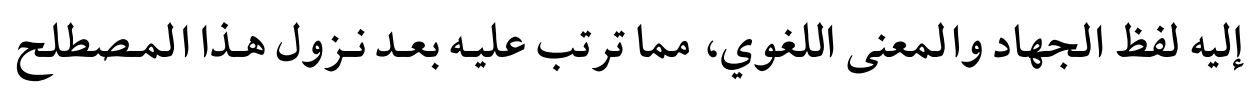

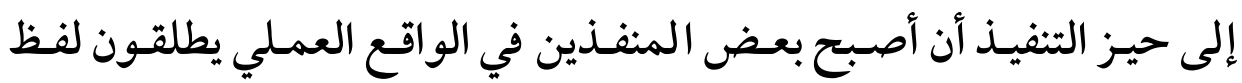

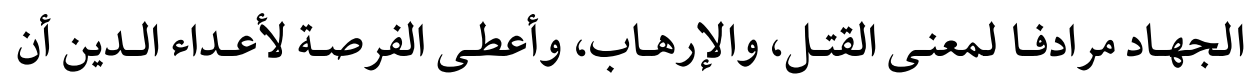
يصفو الإسلام بذلك. بينما الإسلام وسلفنا مـن المجتهـدين لم يقصدوا ذلك ولم يرموا إليه،

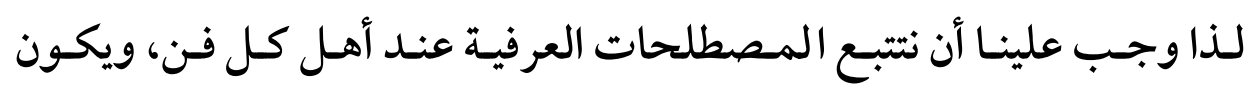

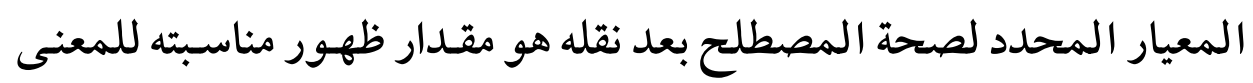
اللغوي للفظ. وإذا طبقنا هذه القاعدة على المصطلح الذي أردنا التمثيل بـه هنـا وهو مصطلح الجهاد، فإن تعريف الحنفية للجهاد في عـرفهم هو الأولى بـالقبول؛ لمناسبته المعنى اللغوي. وإن علة الجهاد هي: نصرة الإسـلام و محاربـة الكفـار ؛ لكسونهم حربـا علينا، لا لكفرهم، فلا يقتل شخص لمخالفته الإسلام أو لكفره، وإنما يقتل 
(19)

لاعتدائه على الإسلام، فغير المقاتل لا يجوز قتاله، وإنـما يلتزم معسه جانسب

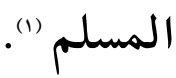
وهذا أيضا هو مذهب الحنفيـة، فهو الر اجح؛ لأن ذلك يناسـب المعنى اللغوي، كما أنه يناسب تحقيق مصلحة حفظ الدين على نحو ما بينا. ولسلامة الأدلة -أيضا - من الاعتر اض عليه، ولردهم -أيضا - على أدلة الشافعية ومن معهم. رد الحنفية على الشافعية: رد الحنفية على الشافعية وذلك على النحو الآتي:

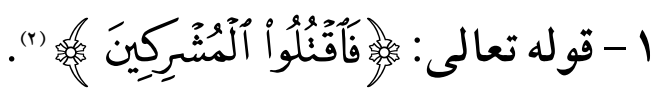

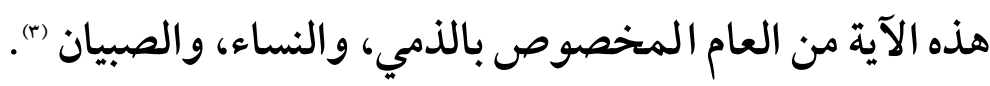

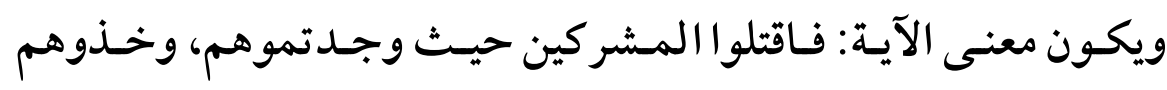
للقتل أو المنّ أو الفداء، واحصروهم (s). وعليه: فإن المر اد بقتال المشركين هو قتال من يقاتلنا.

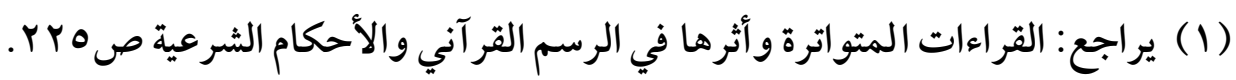

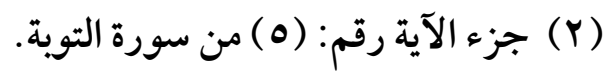

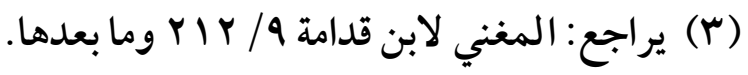

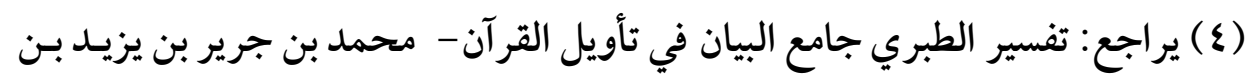

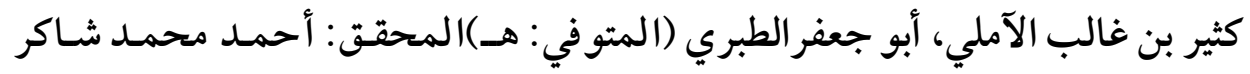

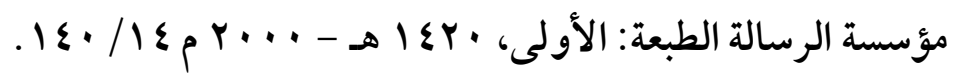


(9.)

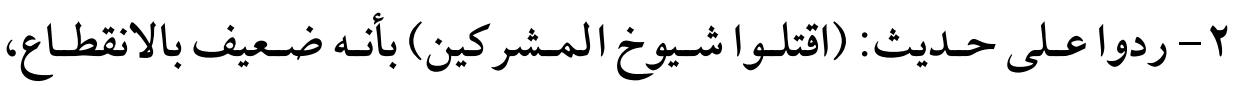

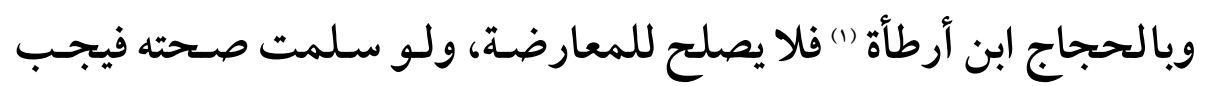
تخصيصه.

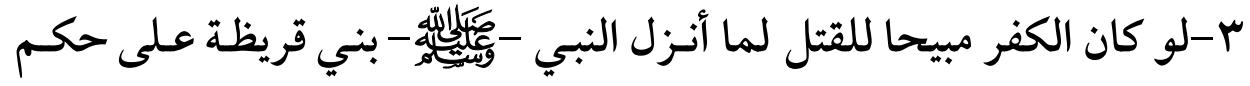
سعد بن معاذ فيهم، ولو حكم فيهم بغير القتل لنفذ حكمه (r).

(1) الحجاج بن أرطأة هو: الحجاج بن أرطأة بن ثور بن هبيرة بن شراحيل بـن كعب

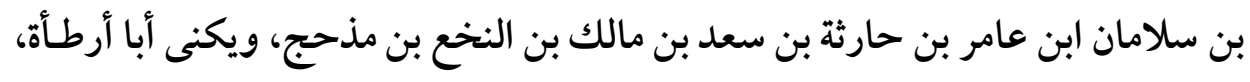
كان ضعيفا في الحديث.

يراجع: التاريخ وأسماء المحدثين وكناهم محمـد بـن أحمـد بـن محمـد، أبو عبد الله

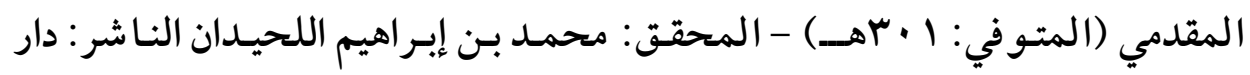

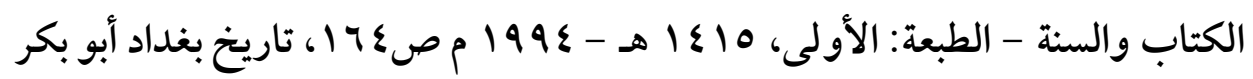

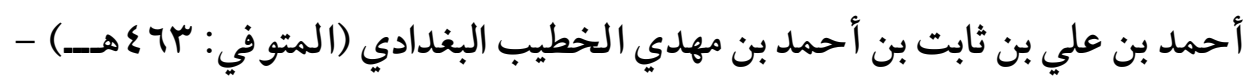

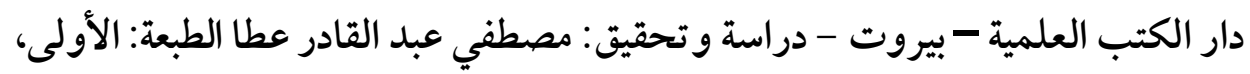

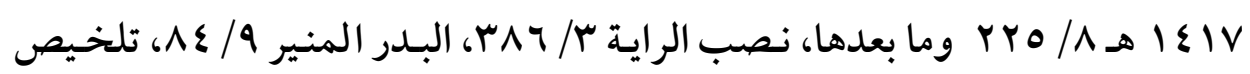

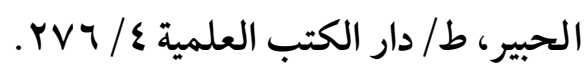

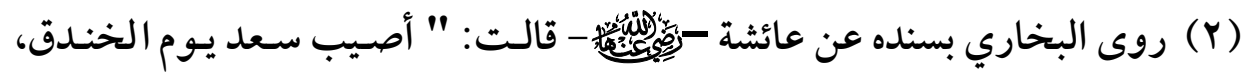

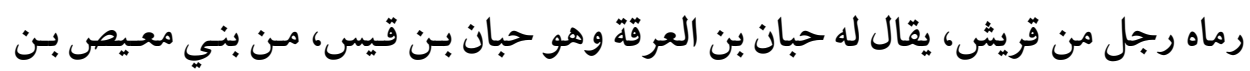

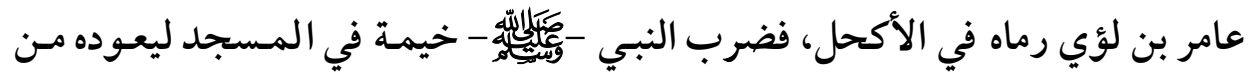

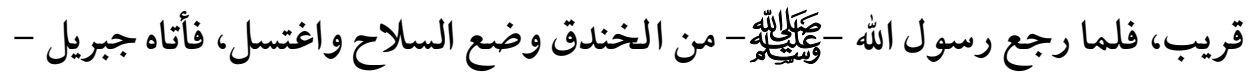

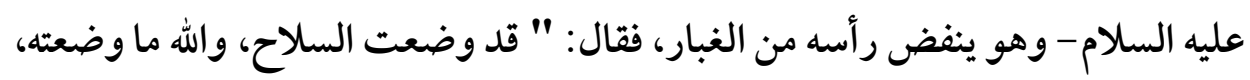

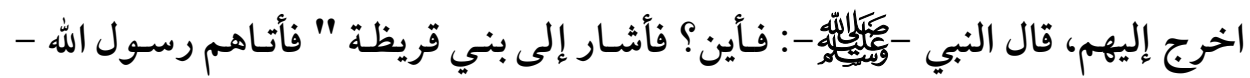


(91)

ع - أما حديث ابن عمر : ( أمرت أن أقاتل الناس .... إلخ) . هاله هذا الحديث ذكر للغايـة التي يبـاح قتـالهم إليها بحيـث إذا فعلوهـا حرم

قتالهم، والمعنى: أني لم أؤمر بقتالهم إلا إلى هذه الغاية (1). ه- الرد على أن آية سورة التوبة ناسخة لآية سورة البقرة. أ- النسخ لابد له من دليل، ولا دليل يدل على ذلك.

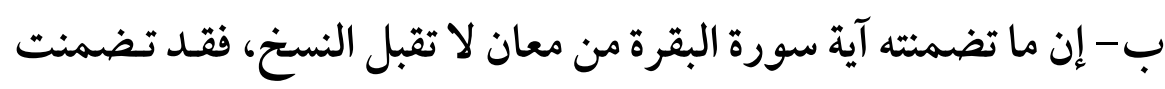

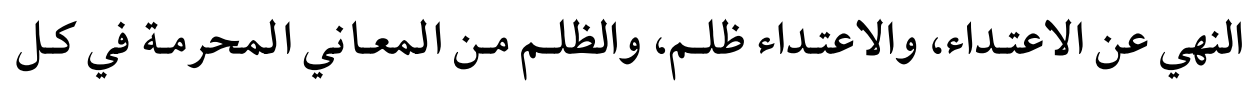
الشرائع. ج -لو كان القتل للكفر جـائزا، وأن آيـة منـع الاعتداء منسوخة، لكـان الإكـراه

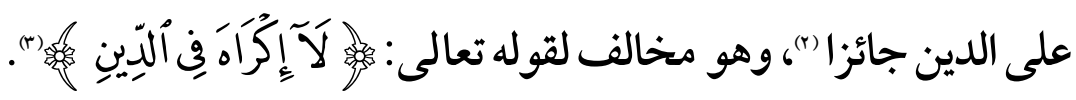

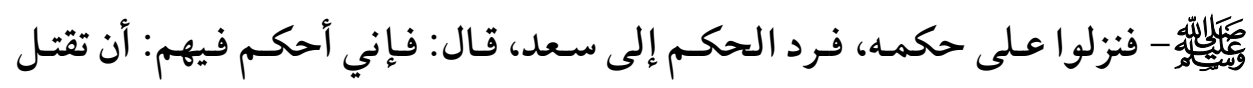
المقاتلة، وأن تسبى النساء والذرية، وأن تقسم أمو الهم.... ".

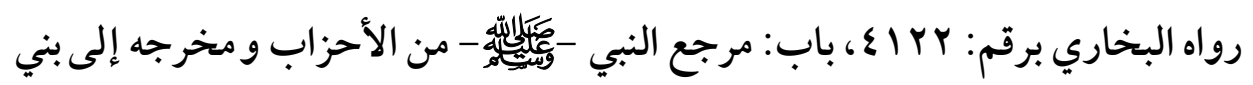
قريظة و محاصرته إياهم.

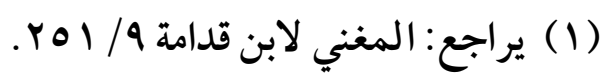

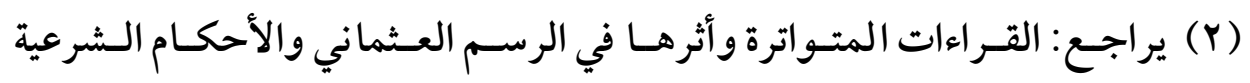

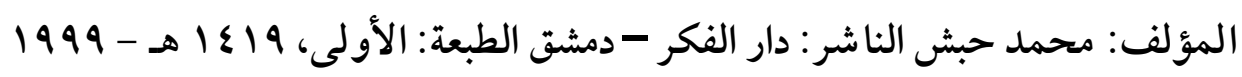

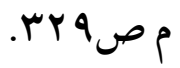

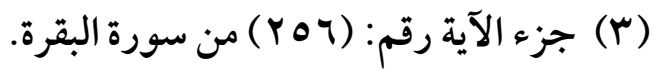


$(9 r)$ مناسبة اللفظ للعنى عند الأصوليين وأثرها في توجيه خطاب المجتهلين

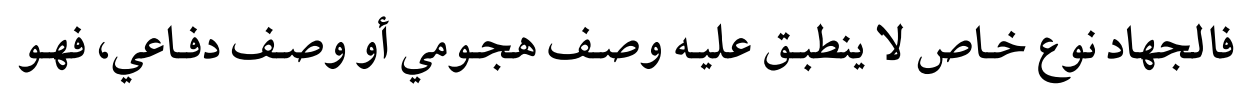
ليس هجو ميا ظالما للعالم، وليس مجرد دفاع عن حدود الوطن والمصالح.

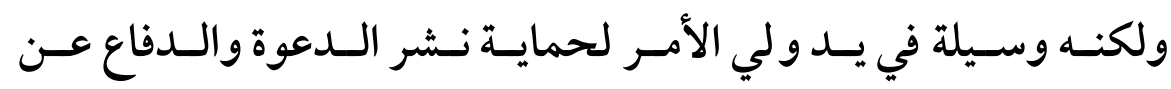
المسلمين (1) وما ذكرناه في مصطلح الجهاد يطبق على جميع مصطلحات أهل كل فن. 米米深粠

(1) يراجع: الفقه الإسلامي وأدلته أ. د. وَهْبَّة بن مصطفي الزُّحَيْليّ، أستاذ ورئيس قسم

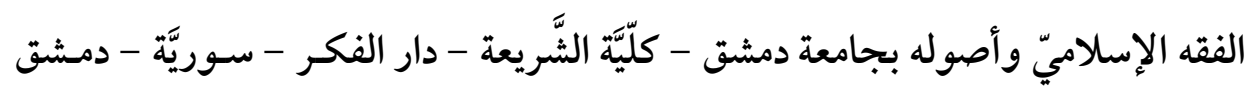

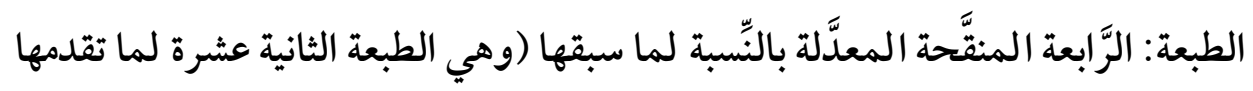

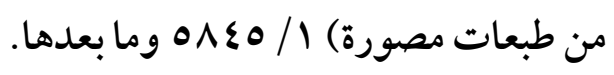




\section{البمثث الرابع}

\section{هناسبة اللفظ للمعنى في الأسماء الشرعية}

\section{وأثرها في توجيه خطاب المجتهدين}

كانــت العـرب في جاهليتهـا عـلى إرث مـن إرث آبـائهم في لغــاتهم

وآدابهم. فلـما جـاء الإسلام حالت أحسوال، ونسخت ديانات، ، ونقلت مـ إنـ

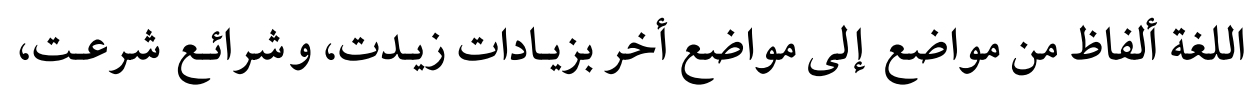
و شرائط شرطت.

فعفي الآخـر الأول، وشـغل القوم بالتفقه في ديـن الله -تعـالى -، وحفظ

سنن رسول الله - فئس فسبحان من نقل أولئك في الزمن القريـب -بتوقيفهـ - عما ألفوه ونشأوا عليه إلى ما جاء به الإسلام "(1).

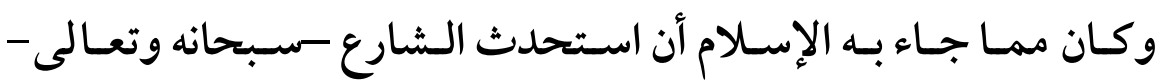

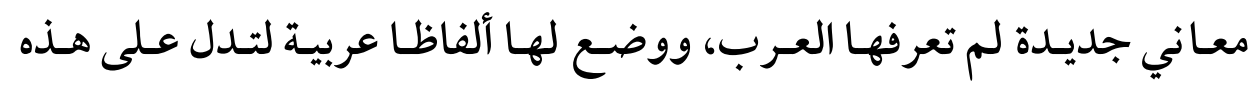
المعاني، سواء كان اللفظ والمعنى معلومين للعرب، لكنهم لم يضعوا ذلك الاسم لذلك المعنى، مثل : لفظة "الر حمن " لله تعـالى، فإن كـلا مـنهما كـان معلوما لهم، ولكنهم لم يضعوا اللفظ له تعالى. وسـواء كانـت الألفــاظ معلومـة لهـم والمعنسى غـير معلـوم مثـل : لفــ الصلاة، الصوم، الزكاة، الكفر، الإيمان، الفسق، النفاق (().

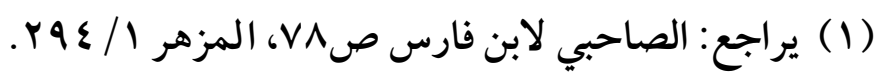

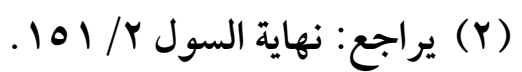


(9६) مناسبة اللفظ للعنى عند الأصوليين وأثرها في توجيه خطاب المجتهلين

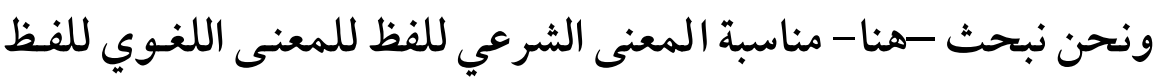

في أصل وضعه، فهل راعى الشارع المعنى اللغوي للفظ عند وضعه للمعنى في الثرع ؟.. وبمعنى آخر: هل توجد مناسبة مرعية بين اللفظ بمعناه اللغوي

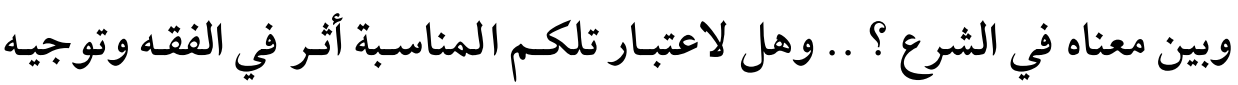

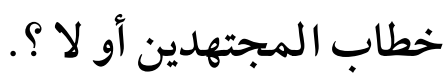
وسوف نستعرض ذلك في المطلبين الآتيين: المطلب الأول: مناسبة اللفظ للمعنى في الأسماء الشرعية. المطلب الثاني: أثر مناسبة اللفظ للمعنى في الأسماء الشرعية في توجيه

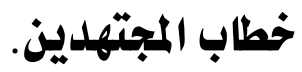

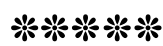




\section{الامطاب الأول}

\section{هناسبة اللفظ للمعنى في الأسمهاء الشرعية}

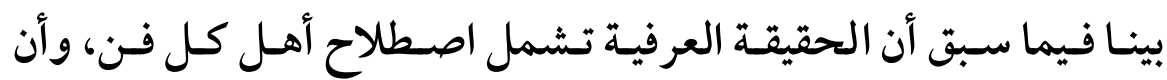

الاصطلاح الذي اتفق عليه علماء الشريعة وكان مستفادا من قبلهم هـو مـن

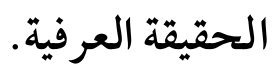

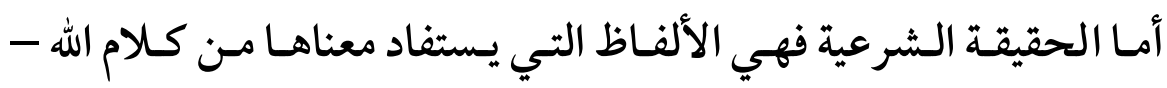

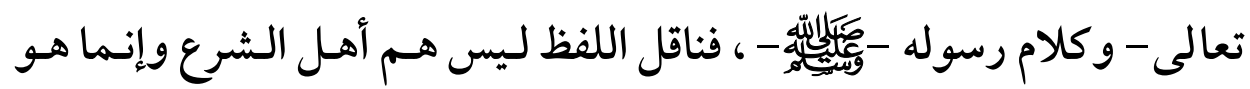

$$
\text { صاحب الشرع. - مانع }
$$

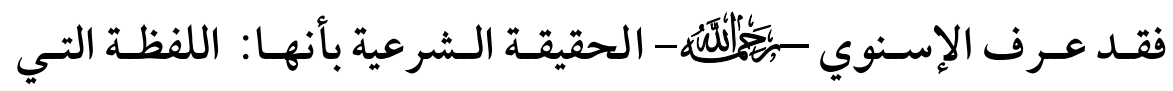

استفيد من الشارع وضعها كالصلاة للأفعال المخصوصة (1).

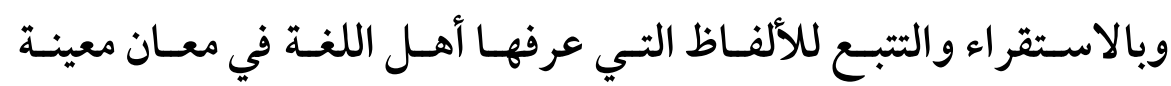

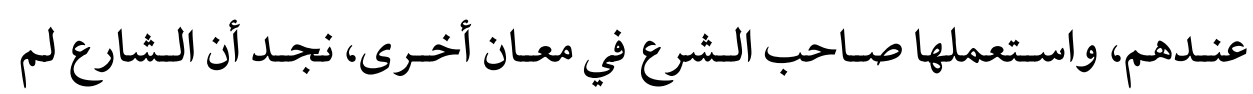

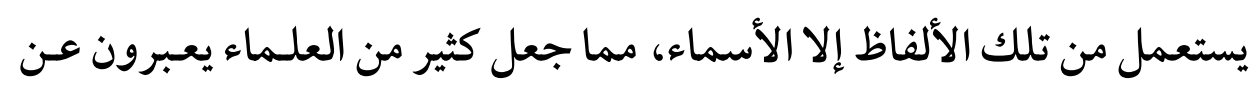

$$
\text { هذه المسألة بمسألة الأسماء الثرعية. }
$$

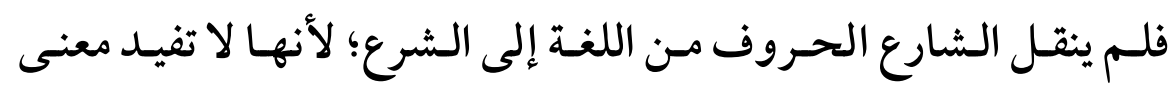

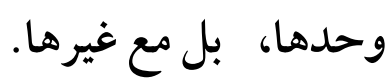

وأمـا الأفعـال فلـم توجـــ أفعـال منقولـة مـن اللغـة إلى الشرع بالأصـالة؛ للاستقر اء، ووجد بالتبع نحو: صلى الظهر، فإن الفعل عبـارة عـن المصدر 
والزمان، فإن كـان المصدر شرعيا استحال أن يكـون الفعل إلا شرعيا، وإن

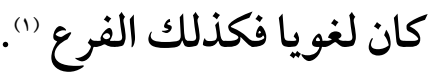
وأما نقل الشارع للأسماء مـن اللغـة إلى معـان شرعية حتى جعلت هـذه الألفاظ حقيقة في المعاني الشرعية، فقـد حـدث تفصيل عند الجمهور مـن أهل السنة، وعند المعتزلة، وذلك على النحو الآتي: أما عندل جمهور العلماء: فقـد حـدث تفصيل في وجـود الحقيقة الشرعية عندهم على حسب الأسماء الثرعية نفسها. فالأسماء المتباينة: الحقيقة الشرعية موجودة فيها مثل: الصلاة، الصوم.

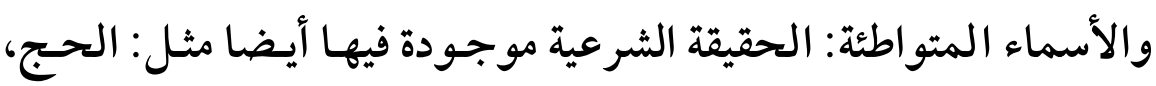
فإنه يطلق على الإفر اد، والتمتع، والقران، وهـذه الثلاثـة مشتركة في الماهيـة، وهي: الإحرام، والوقوف بعرفة، والطواف والسعي. وأمـا الأســماء المـشتر كة: فقــــ اختلـف الأصـوليون في وقـوع الحقيقـة الشرعية فيها، يقول الإسنوي: "والحق وقوعها". ومثل لذلك: بأن اسم الصلاة صادق على المشتركة في الأركان كـالظهر وغيرها، وعلى الخالية عن الركوع والسجود كصلاة المصلوب والجنازة، والخالية عـن القيـام كصلاة القاعـد، وليس بين هـذه الأنـواع قـدر مشترك،

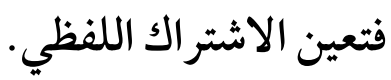


و أيضا مثل: الطهور الصادق على الماء، والتراب، وآلة الدباغ "(1).

$$
\text { والأسماء المتر ادفة: لم ينقل منها شيء إلى الشرع. }
$$

وأما عند المقتزلة: فالأسماء المستعملة في الشرع على مـذهبهم حقيقة

شرعية، لكنهم يقسمونها إلى قسمين: أسماء شرعية، وأسماء دينية.

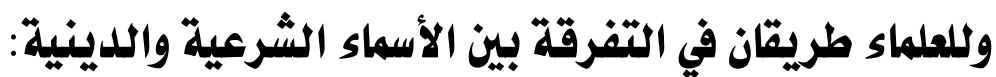

الطريق الأول: وهو تقسيبم الأسماء المستفاد معناها من قبل الأسئ الشرع إلى قسمين:

القسم الأول: الأسماء الدينية، وهي الأسماء المستفاد معناها من أصل

الدين، كالإيمان، والكفر، والفسق، وهي عندهم مستعملة في معنى لا يـرتبط

ولا يناسـب المعنى اللغوي، ولهذا أثبتوا المنزلة بين المنزلتين، فمرتكـب

$$
\text { الكبيرة عندهم ليس بمؤمن ولا كافر -كما سيأتي بيانه-. }
$$

القسم الثـاني: الأسمساء السشرعية، وهي الأسـماء المستفاد معناهـا

ومستعملة في فروع الشريعة مثل: لفظ الصلاة، الزكاة، الحج، الصيام (().

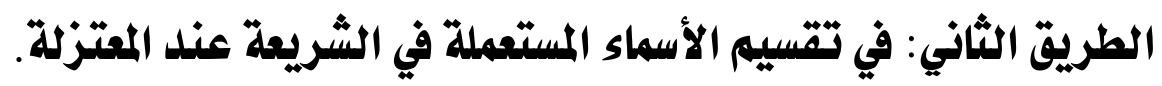

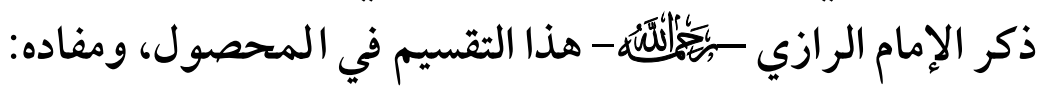
أن المعتزلة يقسمون الأسماء الشرعية (الحقيقة الشرعية) إلى قسمين:

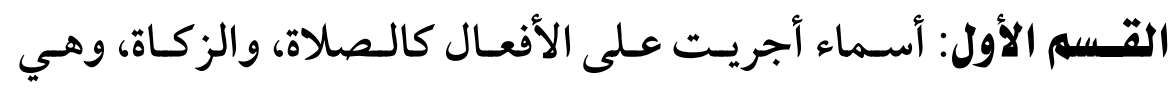

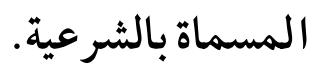

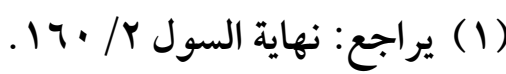

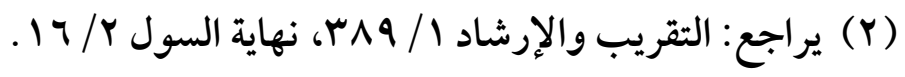


(91) مناسبة اللفظ للعنى عند الأصوليين وأثرها في توجيه خطاب المجتهلين

القـسم الثـاني: أسـماء أجريـت عـلى الفـاعلين كـالمؤمن، والكـافر،

والفاسق، وهي المسماة بالدينية.

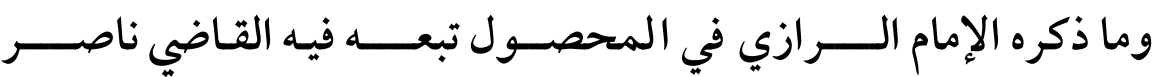

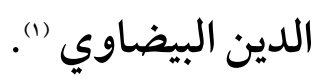

وهو مخالف لمـا نقله غيره مثل: إمـام الحـرمين، والغـزالي، ولم يـذكر

الآمدي قسم الدينية، وذكره ابن الحاجب في المختصر، ولم يبينه (().

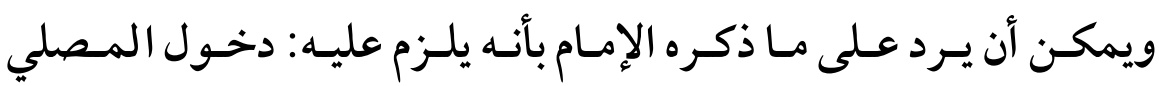

والمزكي في الأسماء الدينية؛ لأنها أسماء فاعلين، ويلزم منه -أيضا - دخول

الإيمان، والكفر، والفسق في الأسماء الشرعية؛ لأنها أسماء أفعال (م).

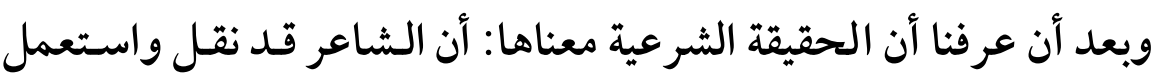

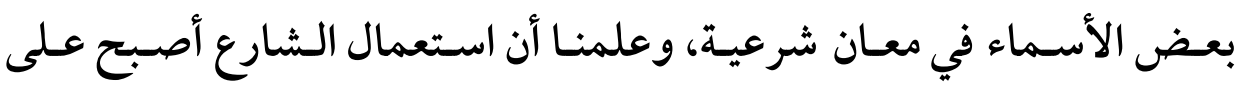

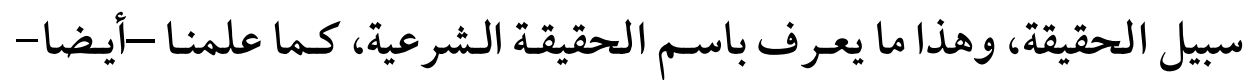

الأسماء المستعملة في الشرع من قبل الشارع عند أهل السنة والمعتزلة.

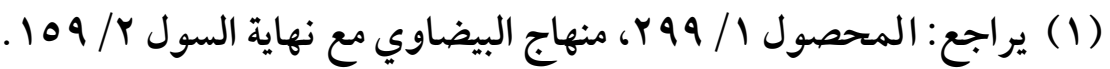

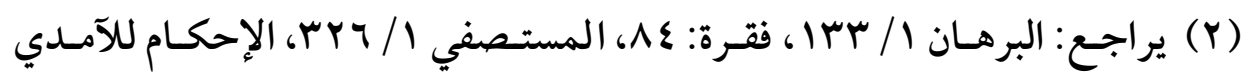

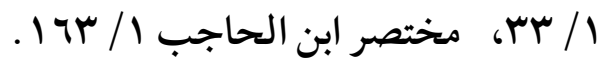

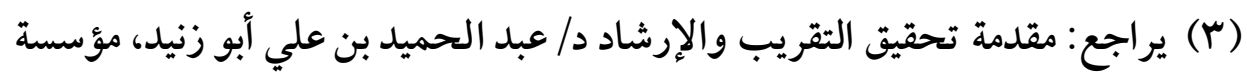

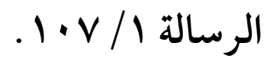


(99)

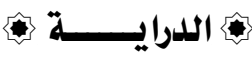

بقي لنا أن نقف على مناسبة اللفظ للمعنى في ذلك، وسوف نتكلم عـن

وجود الحقيقة الشرعية ومذاهب العلماء في ذلك؛ لنبين مـن خـلال ذلك مـن

اعتبر هذه المناسبة ومن لم يعتبرها، وذلك فيما يأتي:

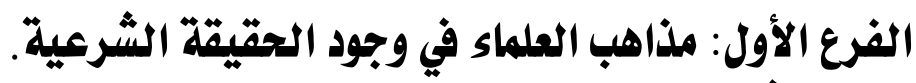

الفرع الثاني: أدلة المذاهب والراجيح. 


\section{الفرع الأول}

\section{هذاهب العلماء في وجود الهقيقة الشرعية}

اعلم أن العلماء قد اختلفوا في إمكان الحقيقة الشرعية، وفي وقوعها. وقال الإمام الرازي: "إن الإمكان متفق عليه "، وقال الآمدي: "لا شك فيه" (1).

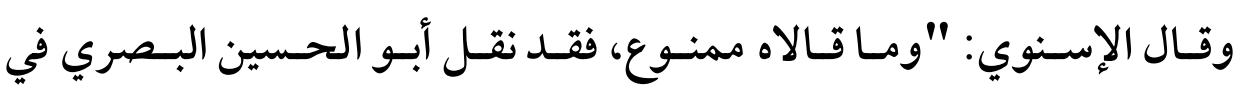
المعتمد عن قوم أنهم منعوا إمكانه "(r). وعلى كل حـال، فِإن بعض العلـماء عـد المـذاهب مـذهبين فقطُ، وبعضهم

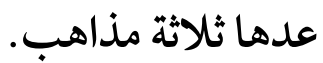
يقول صاحب فواتح الرحموت: "والحق أنه لا ثالث لهذه المذاهب "(r).

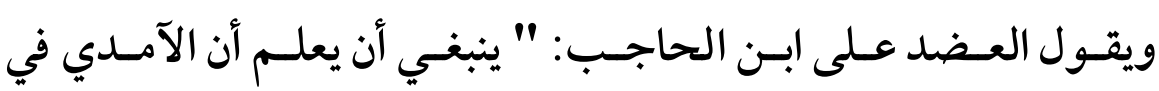
الإحكام والإمام في المحصول له يذكرا سوى مذهبين: أحلدهما : إثبات كونها حقائق شرعية، ونسبه كل مـنهما إلى المعتزلة، مع تصريح الآمدي بنسبته إلى الفقهاء أيضًا. وثانيهما: نفي ذلك، ونسبة كل مـنهما إلى القـاضي، وكلام المـتن يوافق ذلك، ولما كان في كلام المنهاج ما يشعر بأن هناك مذهبًا ثالثًا حيـث قال بعـد

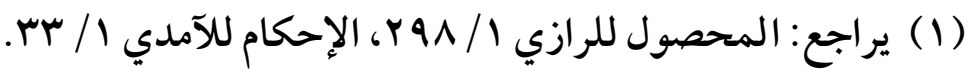

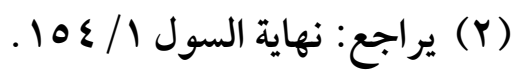

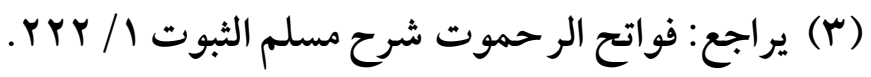


تقرير المـذهبين: والحقى أنها مجـازات اشـتهرت لا موضـوعات مبتـدأة نفـاه الشارح؛ لأنه مذهب القاضي بعينه " (1). وسوف نسير في عرض المذاهب على أنه ثلاثة مذاهب: الماهب:

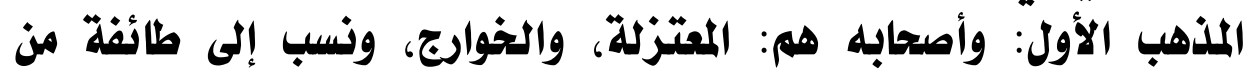
الفققهاs (r) قـالوا: إن الألفــاظ المتداولـة في الـشريعة موضـوعة في الـشرع ابتـداء، وضعها الشارع لمعان لم تعرفها العرب بدون مناسبة بين هـذه المعاني وبين المعنى الذي وضعت له في الثرع. وذلك مثل لفظ: الإيمان، الفسق، الكفر.

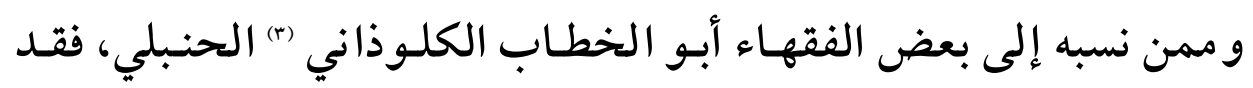

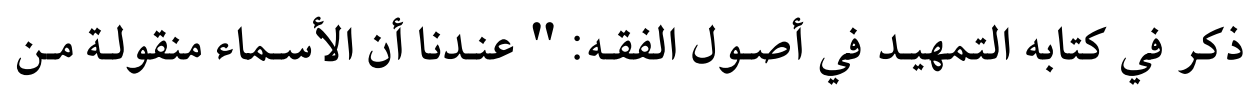

$$
\begin{aligned}
& \text { (1) يراجع: شرح العضد على مختصر ابن الحاجب / / \& } 1 \text { - 170. }
\end{aligned}
$$

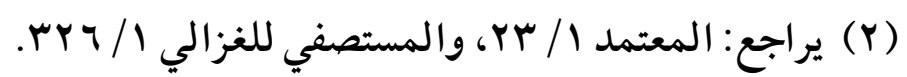

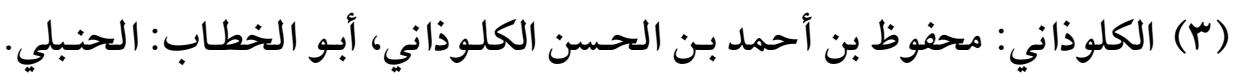

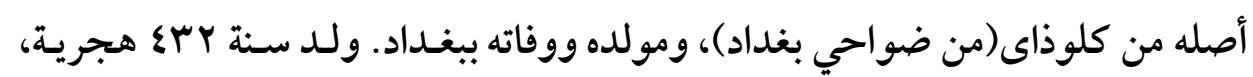

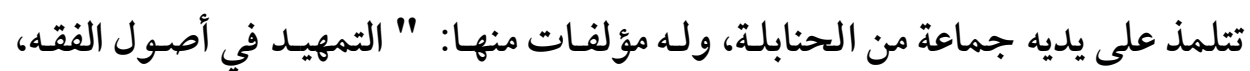

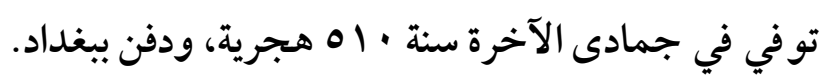

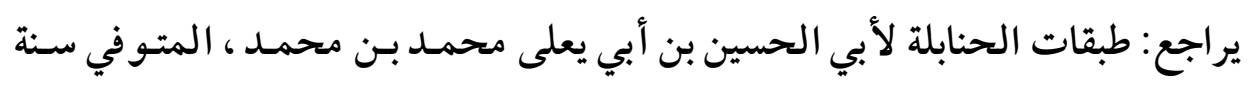

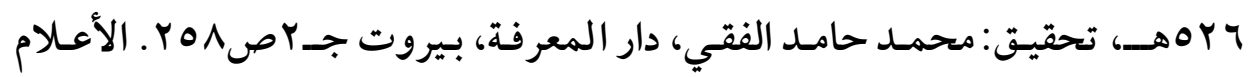

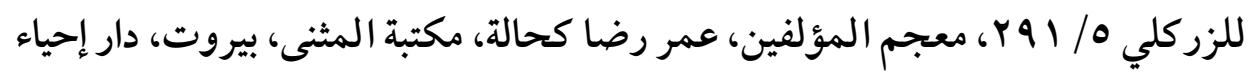

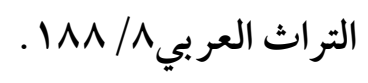


$(1 \cdot Y)$

مناسبة اللفظ للعنى عند الأصوليين وأثرها في توجيه خطاب المجتهلين

اللغة إلى الشرع وهي حقيقة فيه، وبهذا قال أبـو حنيفة والمعتزلـة، وهـو اختيار شيخنا" (1)

ويعلق محقق كتاب التمهيد على كلام الكلوذاني فيقول: "إن نسبة هـذا

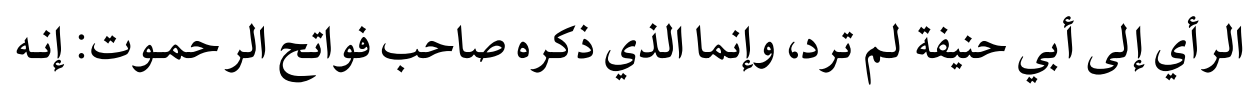

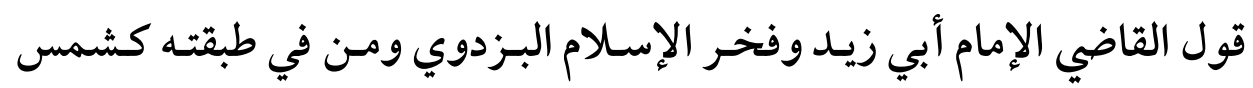
الأئمة (r).

ويعلق أيضا على قوله: "وهـو اختيـار شـيخنا " فيقول: " مـا نسبه إلى ألى شـيخه القـاضي أبي يعـلى (r) مخـالف لمـا في العـدة، حيـث يقـول: "وكـذلك

(1) يراجع: التمهيد للكلوذاني محفوظ بن أحمد بن الحسن أبو الخطاب الكلوذانى

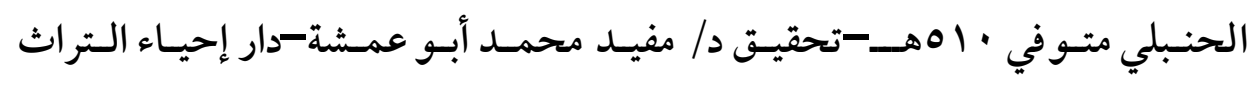

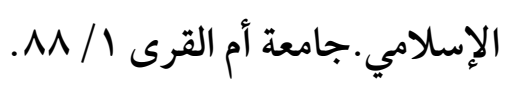

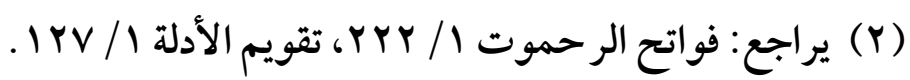

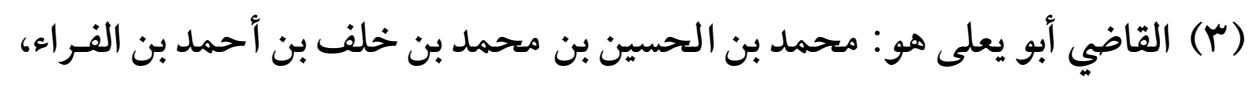

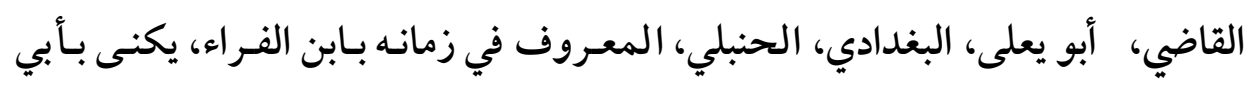

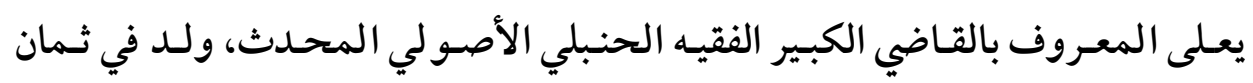

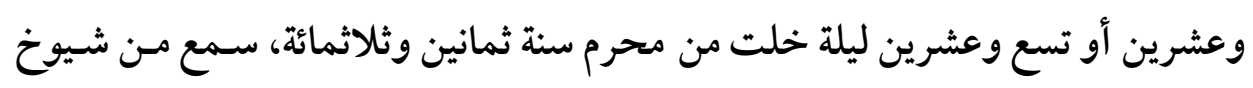

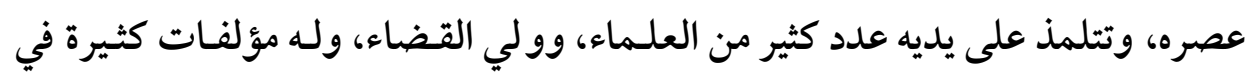

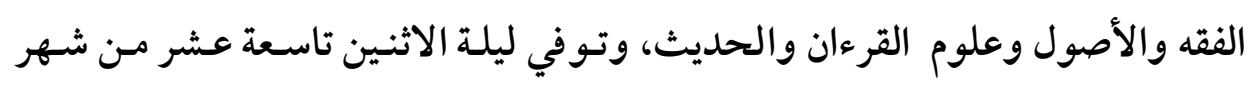
رمضان سنة ثمان وخمسين وأربعمائة.

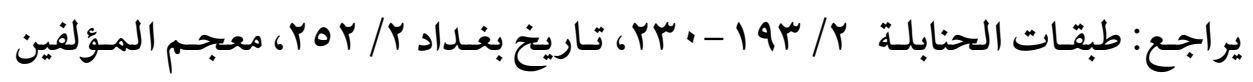
r $0 \leqslant / 9$ 
الحـج عبـارة: عـن القـصد في اللغـة، وهـو في الـشريعة: عبـارة عـن أفعـال مخصوصة، فهو في الشريعة كما كان في اللغة، وضمت إليه شروط شرعيـة، ولا نقول: بأنها منقولة من اللغة إلى معاني أحكام الثريعة" (1).

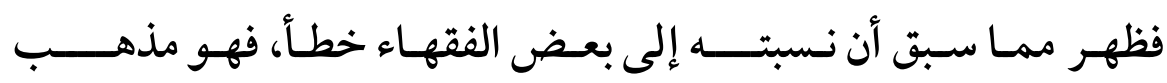

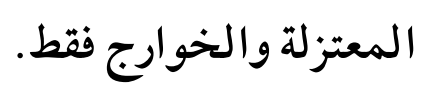
المذهب الثاني: وأصحابه هم جمهور العلماء.

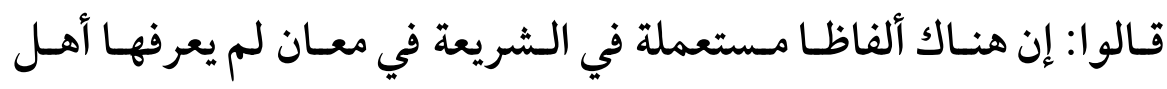
العربية، ولا وضعوها لها.

فقد استعمل الشارع الحكيم -سبحانه وتعالى - اللفظ اللغـوي في معنى وهن شرعي لمناسبة بين المعنى الشرعي والمعنى اللغوي.

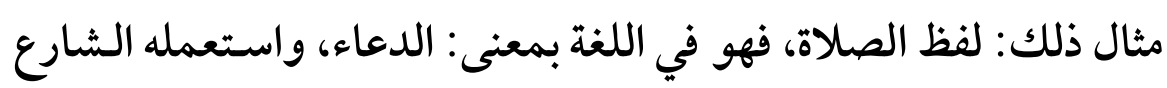

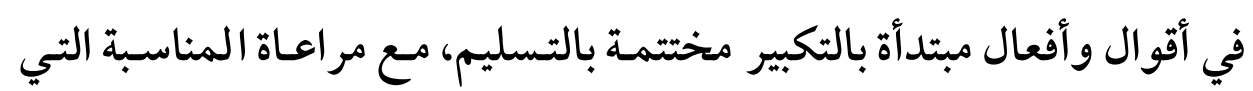
تربط المعنى الشرعي بالمعنى اللغوي (r).

(1) يراجع: العدة للقاضي أبي يعلى محمد بن الحسين بن محمد بن خلف ابن الفراء

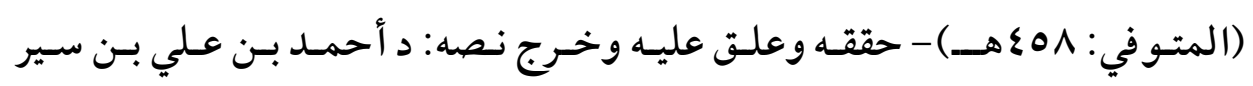

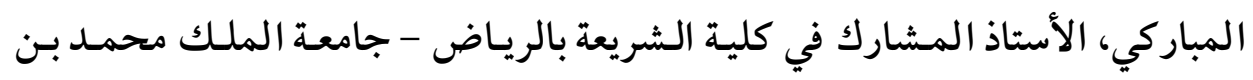

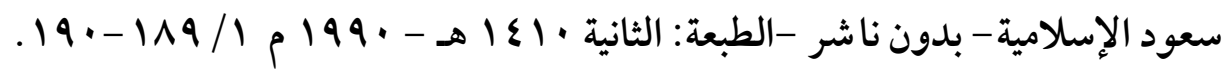

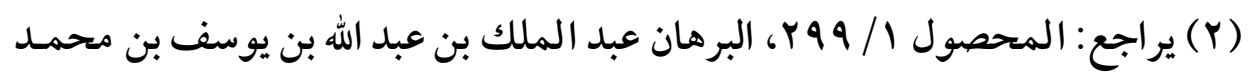

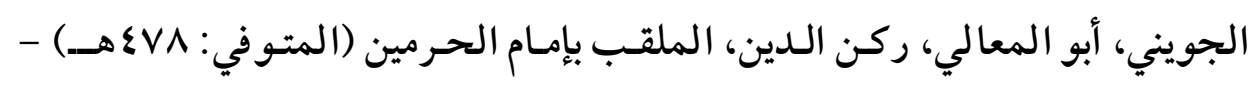

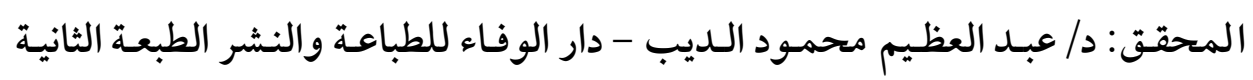

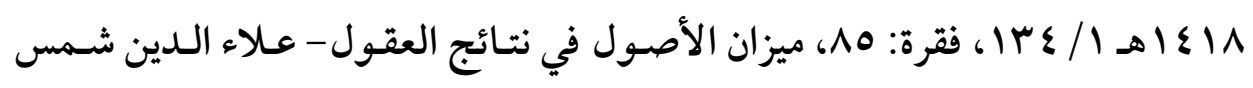




\section{واختلفوا في تسمية هذا الاستعمال على وجهين:}

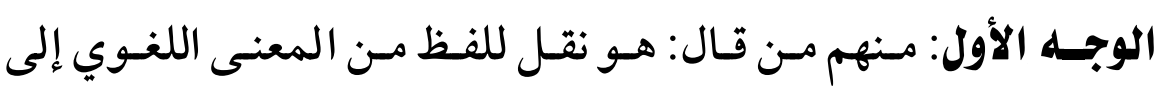

$$
\text { المعنى الشرعي، روعيت فيه المناسبة. }
$$

وهذا قول أبي الخطاب الكلوذاني، وهـو قريـب مـن مـذهب المعتزلة،

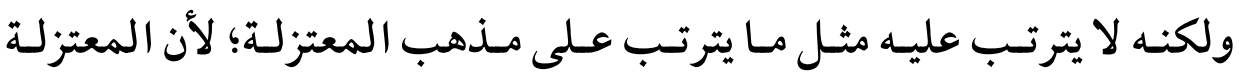
يقولون: إن النقل للفظ نقـل كلي دون اعتبار للمناسبة، ومـذهب الكلوذاني ومن معه يعتبر المناسبة، ولـذلك حـدث خلط بيـن هـذا الوجه وبين مـذهب

\section{المعتزلة، وقلد جاء هذا الخلط من أمرين:}

الأمر الأولِ: أن الكلـوذاني قـد سـمى وضع الشرع لهذه الألفـاظ لتلكم

المعـاني الـشرعية نقـلا، أي: نقـل اللفـظ مـن المعنـى اللغـوي إلى المعنى الشرعي. بينما يرى المعتزلة أنه وضـع للفظظ في المعنى الشرعي ابتداء، ومـن ثم

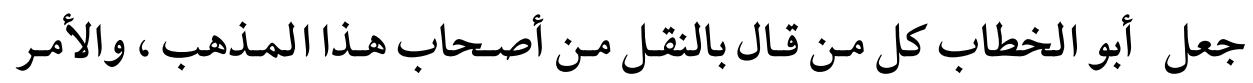

النظر أبو بكر محمد بن أحمد السمرقندي (المتوفي: 9 9هه هـ) - حققه وعلق عليه

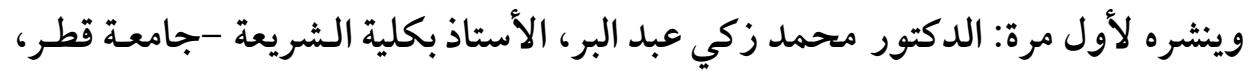

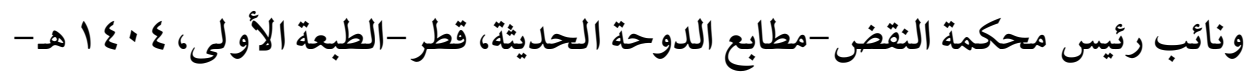

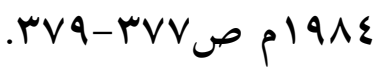


$(1 \cdot 0)$

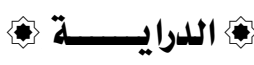

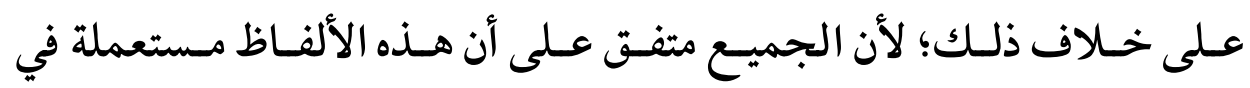
المعاني الشرعية (1).

يقول صـاحب فواتح الرحموت: "للقطع بأنها مستعملة في المعاني

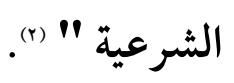

والخلاف في نوع هذا الاستعمال على سبيل الحقيقة الشرعية، بمعنى:

أن الشارع ابتدأ وضعها لهذه المعاني كما يقول المعتزلة والخوارج.

أو أنها مبقاة على وضعها اللغوي في المعنى الشرعي، كما سيأتي أنه

$$
\text { قول القاضي أبي بكر الباقلاني. }
$$

أو أنها خرجت من المعنى اللغوي إلى المعنى الشرعي لمناسبة بينهما،

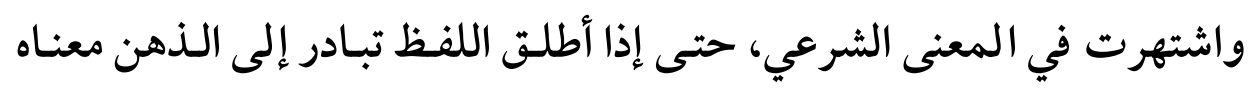

$$
\text { الشرعي بدون قرينة كما هو قول جمهور العلماء. }
$$

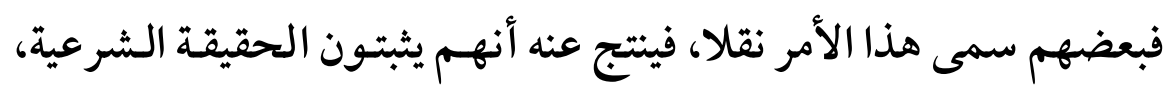

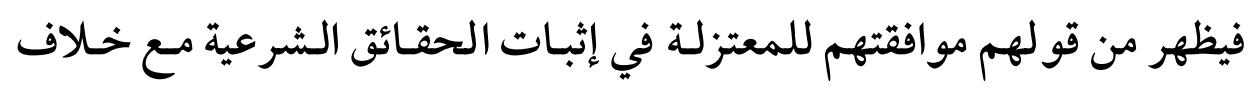

$$
\text { لهم في طريقة الإثبات، والفيصل هو اعتبار المناسبة. }
$$

(1) يراجع: التمهيد لأبي الخطاب / / / 1، المسودة في أصول الفقه آل تيمية [بدأ

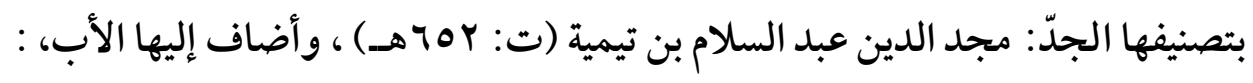

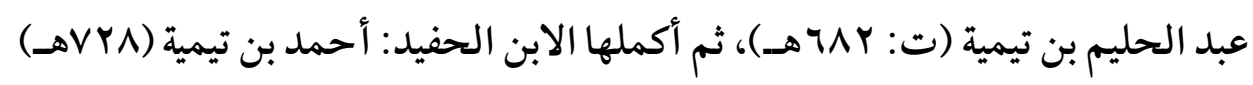

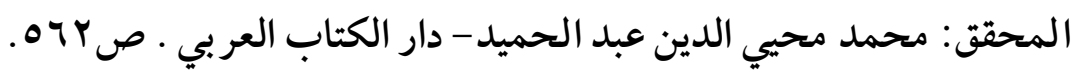

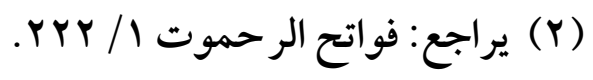


$(1 \cdot 7)$

مناسبة اللفظ للعنى عند الأصوليين وأثرها في توجيه خطاب المجتهلين

الأمر الثاني: أن بعض علماء الشرعية لا يسميه نقلا، وإنما هـو مجـاز

اشتهر في المعنى الشرعي حتى صار لا يتبادر إلى الذهن عند إطلاقه إلا هـذا المعنى الشرعي، وتكفي الشهرة في اعتبـار هـذا اللفـظ حقيقـة في المعنى

الشرعي فالكلوذاني عندئذ يعتبر هؤلاء قد نفوا الحقيقة الشرعية (1). وهذا اصطلاح ولا مشاحة في الاصطلاح.

الوجه الثاني: وهو ما ذكرته في الأمـر الثاني سـابقا مـن أن هـذه الألفـاظ المستعملة في الشرع مجازات لغوية، ثم اشتهرت في المعاني الشرعية حتى لا يتبـادر إلى الـذهن عنــ الإطـلاق إلا هـي فـتفهم بــدون قرينـة، وصـارت الحقائق اللغوية للفظ عند أهل الشريعة مهجورة. وهـو مـذهب وسط بـين مـذهب المعتزلـة في إثبـات الحقيقـة الـشرعية

$$
\text { ومذهب الباقلاني الآتي ذكره. }
$$

فهو يشبه مذهب المعتزلة في إثبات الحقيقة الشرعية، ويشبه مذهب الباقلاني في كون اللفظ لا بـد له مـن اعتبـار الحقيقـة اللغويـة، وذلك بوجـود المناسبة بينها وبين ما نقل إليه اللفظ.

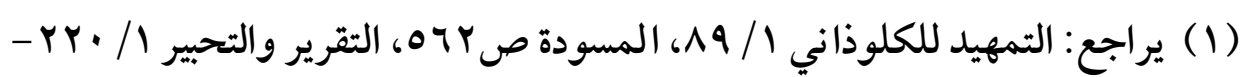


وهــو اختيـار الإمـام الــرازي، وإمـام الحــــين، والغـز الي، والبيـضاوي، وابـن

الحاجب، وأبي زيد الدبوسي، والسرخسي، وتوقف الآمدي ولم يختر شيئا (')

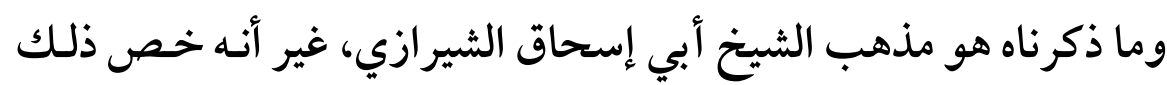

بفروع الشريعة فقط.

وقد ذكر في اللمع عند الكلام على آيات الصلاة، والزكاة، والصيام، والحـج

أنها ألفاظ مجملة؛ لأن المراد بها معان لا يدل اللفظ عليها في اللغة (ه).

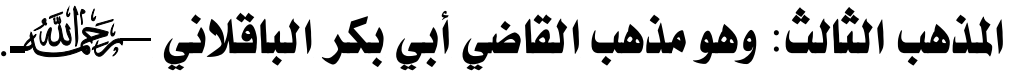

وقد حـدث خلط كبير بـين العلـماء في تحقيـق مـذهب البـاقلاني في

مسألة وجود الحقيقة الشرعية، حيث إنه قد اشتهر على ألسنة العلماء مـن

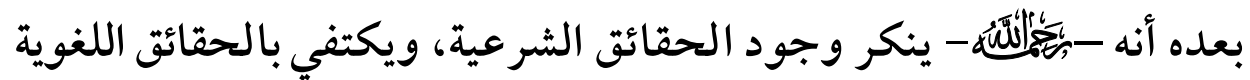
للأسماء التي استعملها الشرع. وبدأ هذا الخلط مـن اعتماد العلماء على معرفة مـذهب البـاقلاني على الى كتب تلميذه إمـام الحـرمين الجـويني، فقـد لخص الجـويني كتاب التقريـب

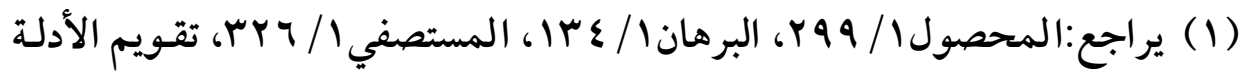

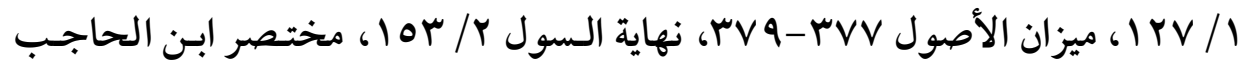

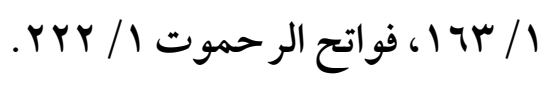

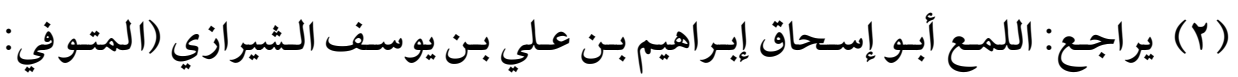

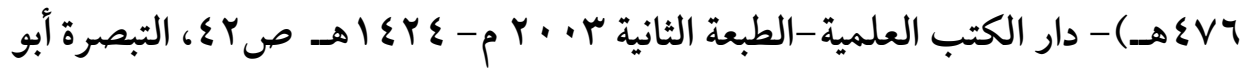

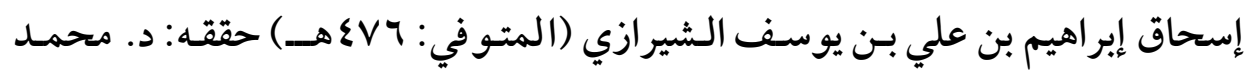

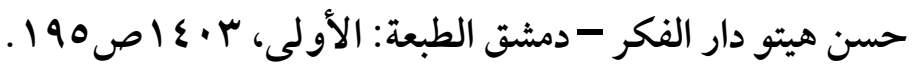


$(1 \cdot 1)$ مناسبة اللفظ للعنى عند الأصوليين وأثرها في توجيه خطاب المجتهلين

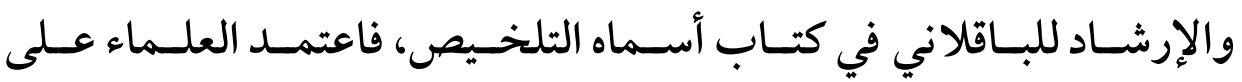
التلخيص لإمام الحرمين في بيـان مذهب البـاقلاني؛ لأن كتـاب الباقلاني لم

$$
\text { يحقق و يخرج للنور إلا منذ زمن قريب. }
$$

وقـد وضـح إمـام الحـرمين مـذهب البـاقلاني في هـذه المسألة في كتابـه

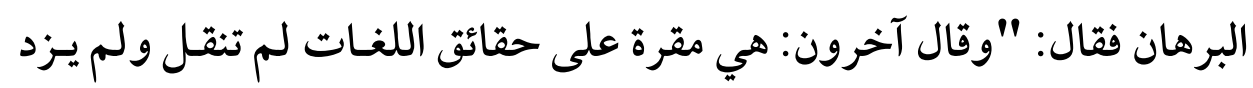

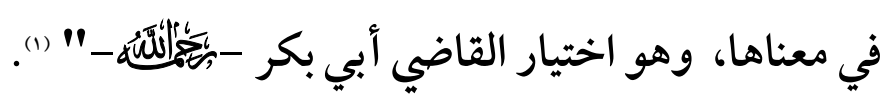

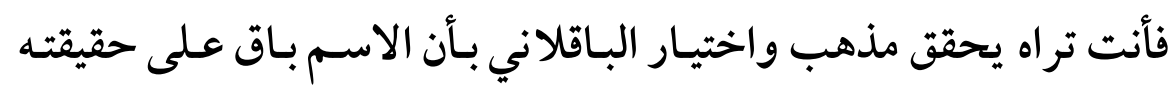

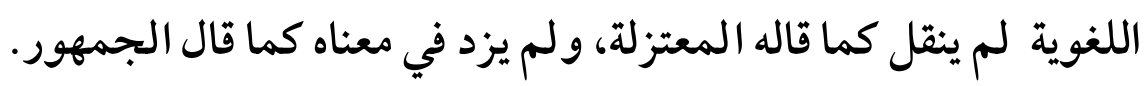

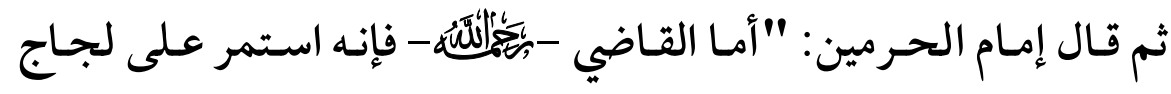
ظاهر فقال: الصلاة: الدعاء والمسمى بها في الشرع: دعاء عند وقوع أقوال وأفعال، ثم الشرع لا يزجر عن تسمية الدعاء المحض صلاة .... " (ه).

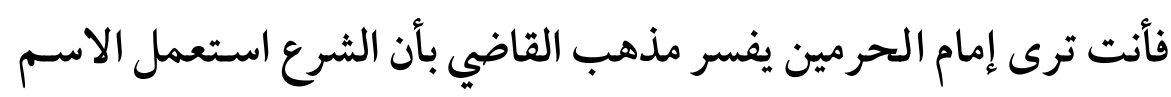
الشرعي في نفس معناه اللغوي، فالدعاء المحض عنده يسمى صلاة. وما ذكره إمام الحرمين في حكاية مذهب الباقلاني وتفسيره لـه قـد جانبه

$$
\text { الصواب فيه؛ وذلك لما يأتي: }
$$

1- نقل إمام الحرمين في نفس الفقرة السابقة قول كالقاضي أن (( الصلاة : الدعاء والمسمى بها في الشرع دعاء عندوقوع أقوال و أفعال )) فالصلاة لغة الدعاء ،و شرعا :دعاء عند وقوع أقوال وأفعـال فتـد اعترف أن هنـاك

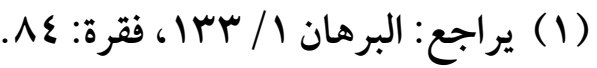

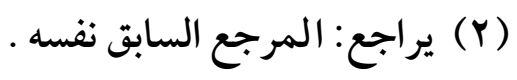


فرقا بين الاسم في اللغة وبين معناه في الشرع وأنه مبقى علمى وضعه في

$$
\text { اللغة وزيد عليه في الشرع شروط وأركان . }
$$

ץ - ما جاء في كتاب التقريب والإرشاد، فقد جاء ما يدل على أنه يوجـد تغيير عند استعمال الاسم في المعنى الشرعي عن معناه في اللغة.

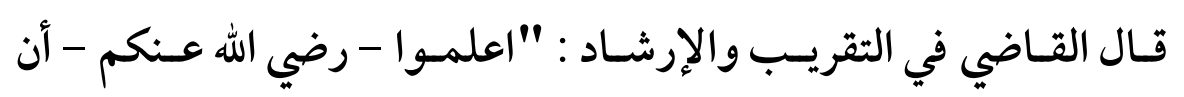
الـذي عليـه أهـل الحـق و جميـع سـلف الأمـة مـن الفقهـاء وغـيرهم أن الله -

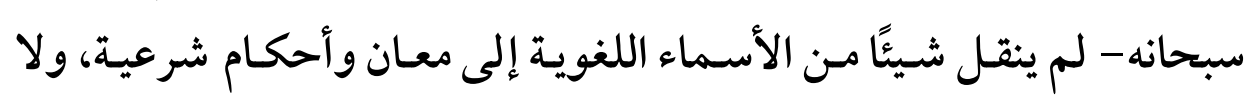

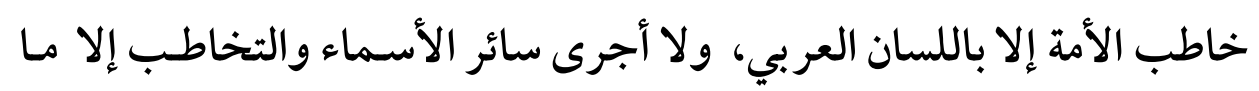
كان جاريًا عليه في وضع اللغة" (1).

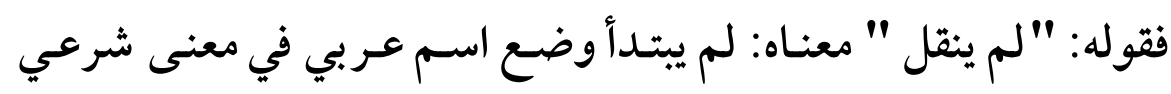
دون النظر إلى معناه اللغوي، وذلك ليرد على المعتزلة.

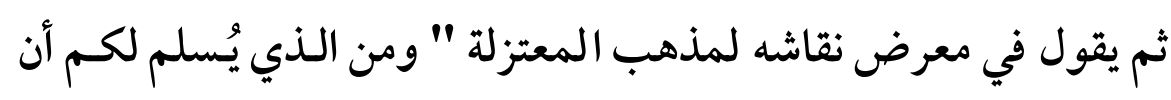

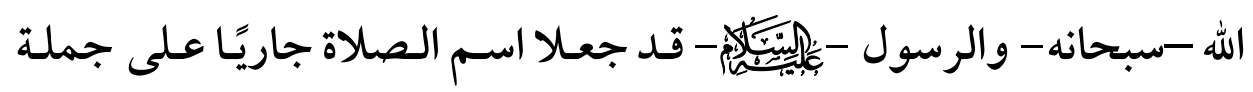

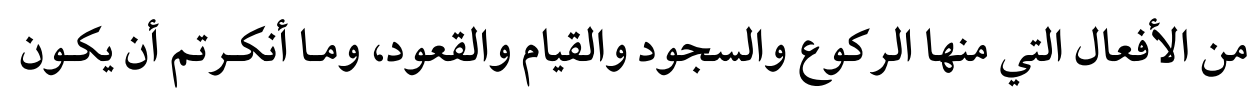
اسم الصلاة إنما يقع منها على الدعاء فقط والرغبة إلى الله -سببحانه-؛ لأن

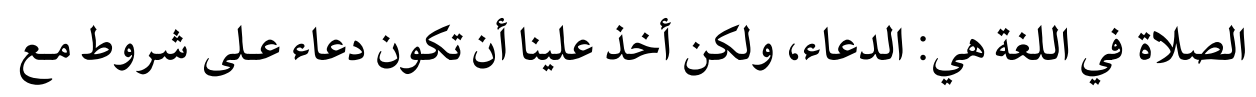
نية وإحرام وركوع وسجود وقراءة وتشهد وجلوس. فالاسـم في الشريعة لما

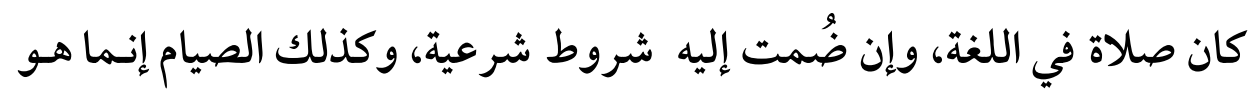

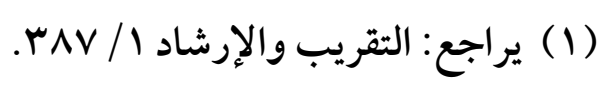


(11.)

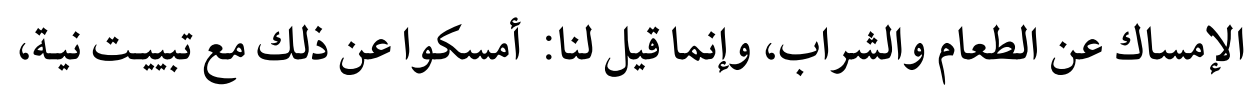

$$
\text { ومن وقت إلى وقت. (1). }
$$

فأنت ترى: أن في هذا النص مـا يـدل عـلى أن الاسـم اللغوي المستعمل

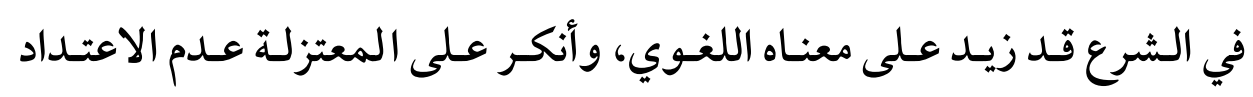

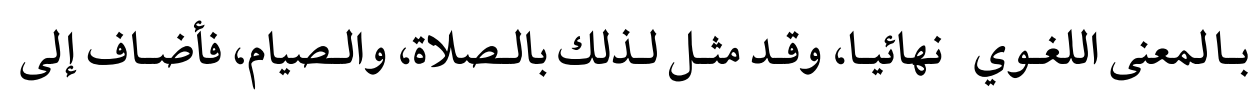
معنا هما في اللغة معاني في الشرع.

وبضم هذا الكلام إلى سابقه يزول الخلط، ويتضح إن مـذهب البـاقلاني

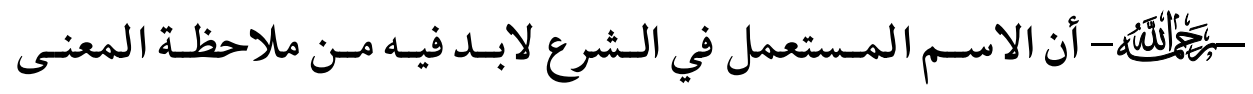
اللغوي وزيادة المعنى الشرعي (r). وبذلك يكون قد وافق مذهب الجمهور من اعتبار المناسبة بين المعنى

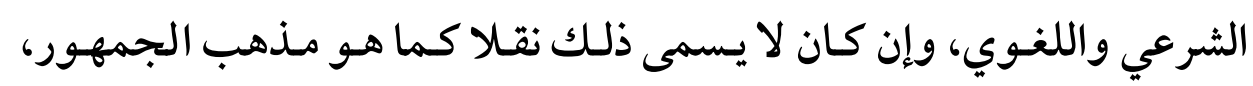
ويقول: اللفظ في الشرع مبق على المعنى اللغوي مع زيادة المعنى الشرعي.

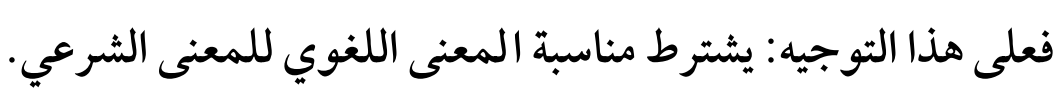

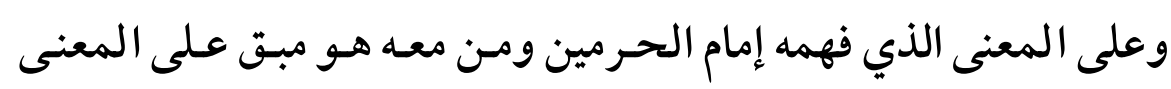

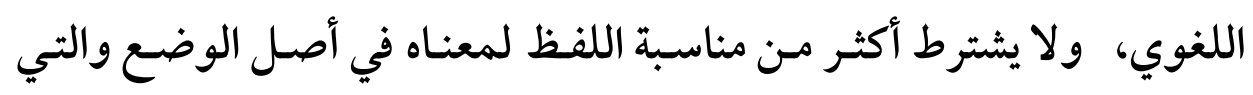
تكلمنا عنها قبل ذلك.

米楼楼

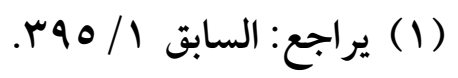
(Y) ير اجع: مقدمة تحقيق التقريب والإرشاد / / 1 • اوما بعدها. 
(III)

\section{الفرع الثاني}

\section{أدلة المذاهب والراجح}

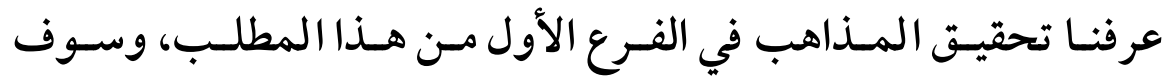

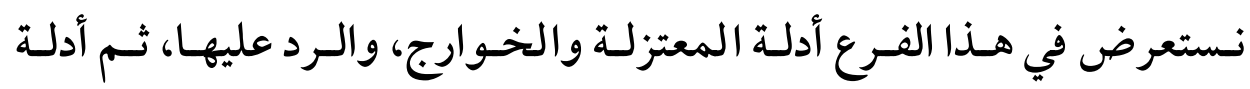

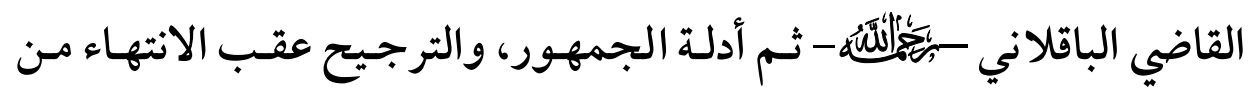
ذكر الأدلة والردود إن كان ثمة ردود، وذلك كله على النحو الآتي:

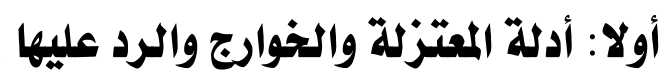
استلدل المعتزلة ومن معهم على ما ذهبوا إليهل بالأدلة الآتية:

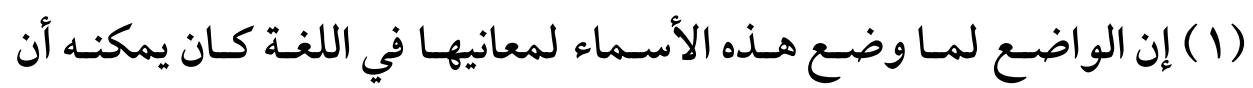
يضعها على غير هذه المعاني، بأن يسمى الأسود أبيض، والأبيض أسود،

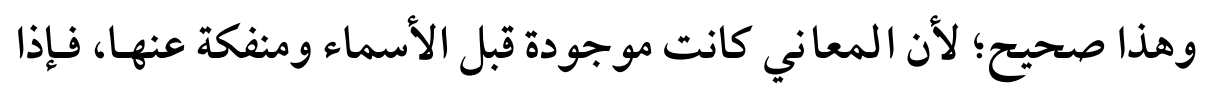
كان يمكنه ذلك أمكنه لأن ينقلها (1) الرد: يرد عليهم بأنه: كان يكفي ذلك التجوز؛ ليكون ذلك جاريـا على وفق

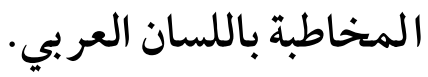
وهذا الرد على وفق مذهب الباقلاني، والجمهور يقول: هـذه المجازات اشتهرت في معانيها حتى صارت حقيقة ().

$$
\text { (1) يراجع: المعتمد /9 / 19، التمهيد للكلوذاني / / •9. }
$$

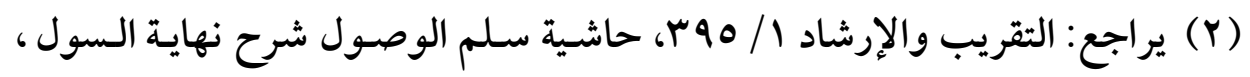

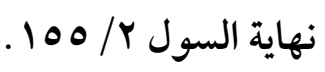


$(11 r)$

مناسبة اللفظ للعنى عند الأصوليين وأثرها في توجيه خطاب المجتهلين

(Y) قد جاءت الشريعة بعبادات لم تكن معروفة في اللغـة، فلـم يكن بـد مـن

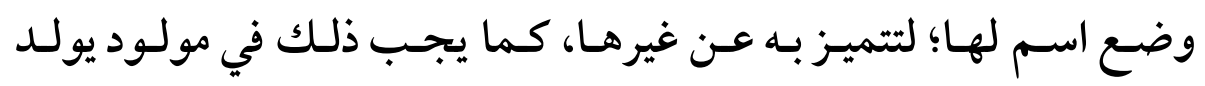

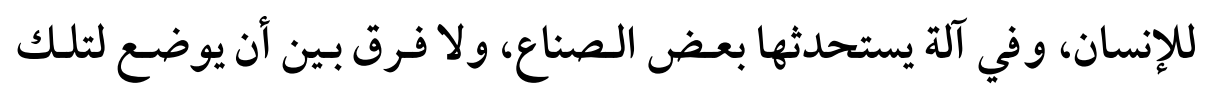

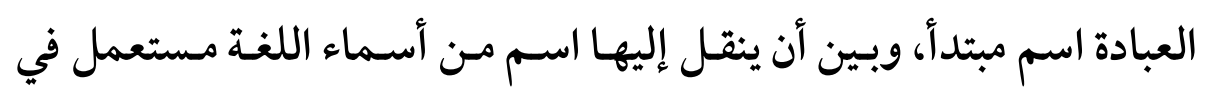

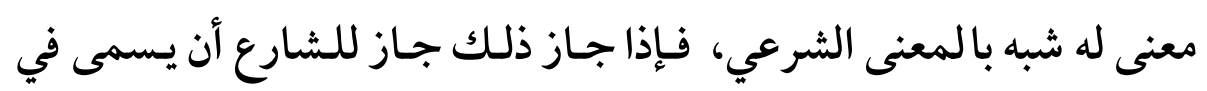

الشرع أسماء تكون حقيقة فيما سماه،وإن كانت موجودة في اللغة (1).

الـرد: رد علـيهم الإمـام البـاقلاني فقـال: " ومـن أيـن لكـم أنـه قـد حـدثت في

الشرع عبـادة لم يكـن لهـا في اللغـة اســم؟، ومـن الـذي يُسلم لكـم أن الله -

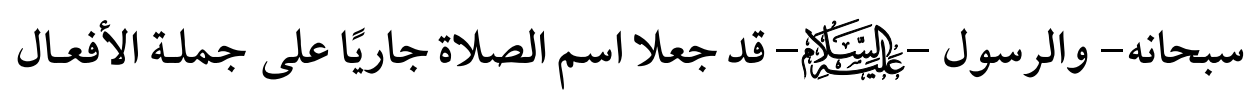
من ركوع وسجود وغيرها فقط؟، وما أنكرتم أن يكون اسـم الصلاة إنما يقع منها على الدعاء فقط؟، فالصلاة معناهـا : الـدعاء في اللغـة وفي الشرع، لكنه في الشرع دعـاءعلى شروط مـع نيـة، وإحـرام، وركـوع، وسـودو، وقـراءة، و كذلك الصيام، والزكاة، وغيرها" (r).

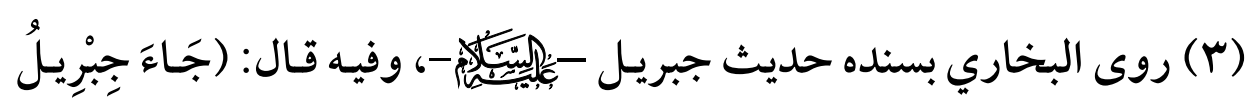

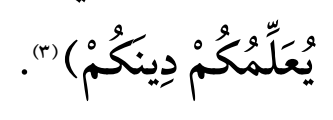

وجه الدلالة: أنهم لو كانوا يعلمون ذلك لما احتاجوا إلى من يعلمهم.

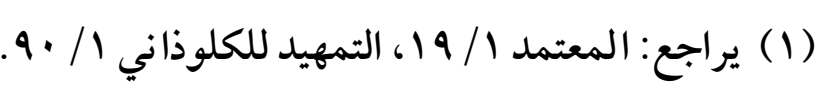

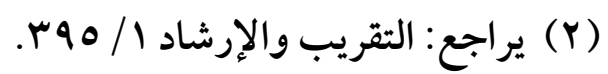

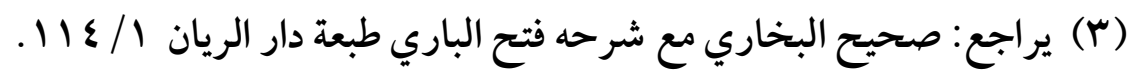


(IIr)

فإن قيل : جبريل لم يعلمهم الأسماء وإنما علمهم المعاني.

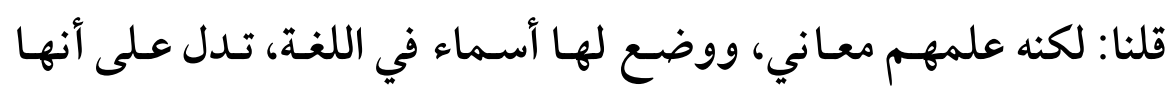
حقيقة فيها (1). (1)

( ) ) استدل المعتزلة والخوارج ومن معهم على أن لا مناسبة بين معنى الاسـم

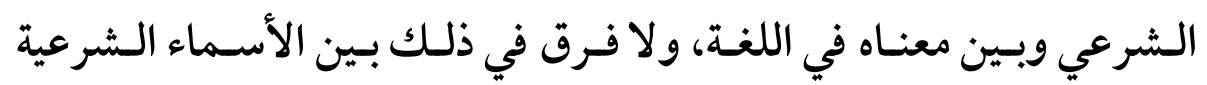

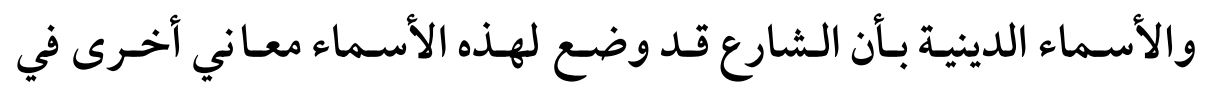
الشريعة تختلف عن معانيها في اللغة.

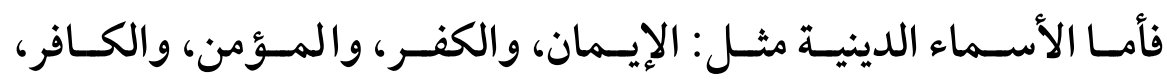
والفاسق، فاسم الإيمان: جار في اللغة على الإقرار والتصديق فقط. واسم الكفر : جار في اللغة على الجحد والإنكار وهو التغطية. واسم الفسق: جار في اللغة على فعل كل معصية يستحق عليها العقـاب

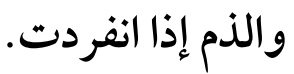

\section{وأما في الشرع فالمعتزلة يقولون:}

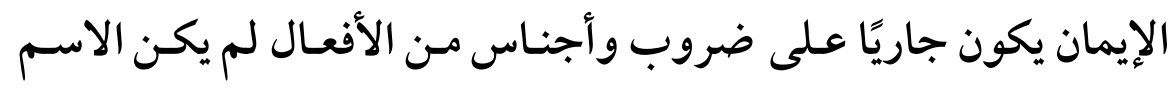
في اللغة جاريًا عليها، فهو في الثرع فعل الواجبات. وأن القول مؤمن: وضع في الشرع لمن يستحق ثوابا عظيما. والقول كافر : وضع في الشرع لمن يستحق ضربا من العقاب عظيما. فمرتكب الكبيرة عندهم في منزلة بين المنزلتين -كما سيأتي -. 
(1)乏) مناسبة اللفظ للعنى عند الأصوليين وأثرها في توجيه خطاب المجتهلين

وأما الخوارج: فاسم الكفر في حكم الشرع: جار على كل معصية. والقول كافر : جار على كل عاص، فمرتكب الكبيرة عندهم كافر. ولا عبرة عندهم بالمعنى اللغوي وهو التصديق والإقرار (1).

(0) وقد استدلوا على أذ الإيعان يستعمل شرعا في غير معناه اللفوي بما يأتي:

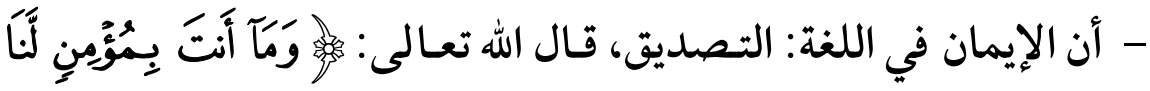

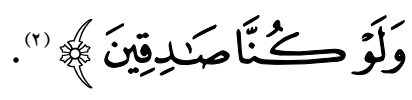
الإيـمان هـو الإسـلام، والإسـلام هـو الـدين، ينتج أن الإيمان هـو الـدين، والدين فعل الواجبات، ينتج أن الإيمان: فعل الواجبات.

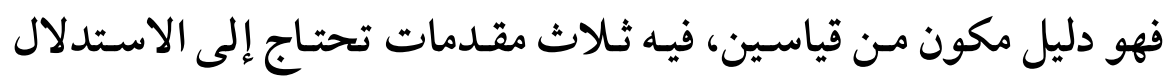
على صحتها. قأما المقدمة الأولى: وهي أن الإيهان هو الإسلام، فالدليل عليها من وجهين: الوجه الأول: أن الإيمان لو كان غير الإسلام لما كان مقبولا ممـن ابتغاه؛

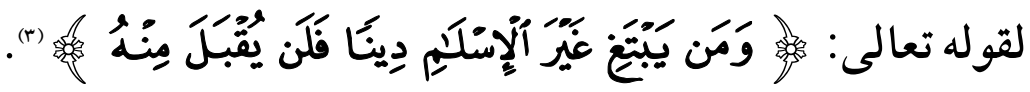

$$
\begin{aligned}
& \text { (1) يراجع: يراجع: التقريب والإرشاد / / (1) }
\end{aligned}
$$

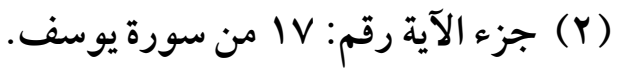

$$
\begin{aligned}
& \text { (Y) جزء الآية رقم: ه1 من سورة آل عمران. }
\end{aligned}
$$


(110)

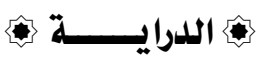

الوجه الثاذي: أنه لو كان مغـاير اله لامتنع استثناؤه منه؛ لأن الاستثناء إخـراج

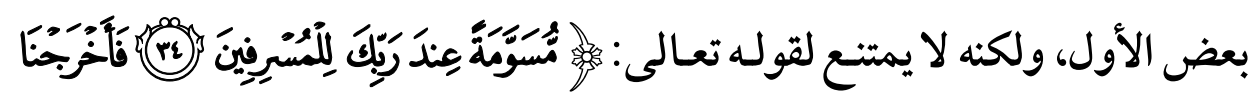

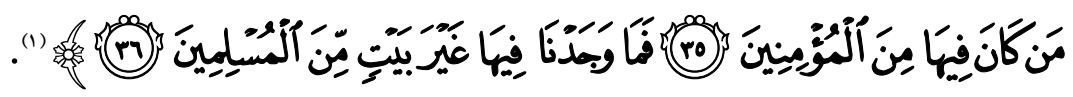

وجه الدلالة: أن غير -هنا- بمعنى إلا، إذلو كانت على ظاهرهـا لكان

التقدير: فما وجـدنا فيها المغـاير لبيـت المؤمنين، فيكون المنفي هو بيوت الكفار، وهو باطل، فتقرر أنه استثناء.

ثم إن هذا الاستثناء مفرغ، فلا بد له من تقدير شيء عام منفي يكون هور لهو

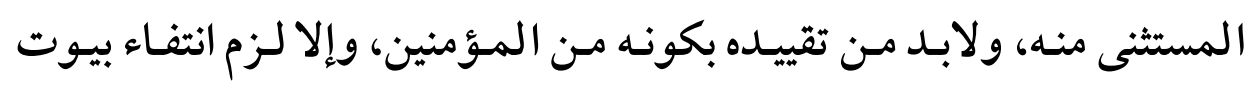
الكفار وهو باطل لما قلناه.

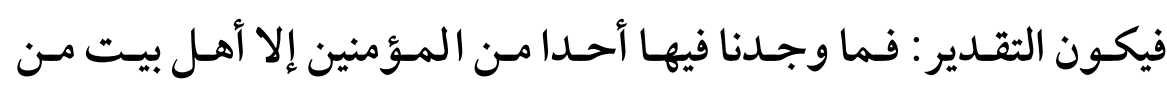
المسلمين، أي: منهم.

وأوقع الظاهر موقع المضضمر، وذلك اسـثثناء المسلمين مـن المؤمنين،

$$
\text { فثبت أن الإيمان هو الإسلام. }
$$

أما الدليل على المقدمة الثانية وهي أن الإسلام هو الـدين: لمنطوق قوله الإسله

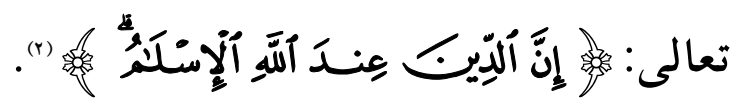

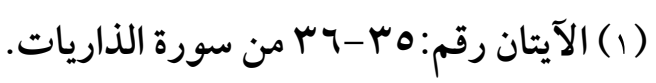

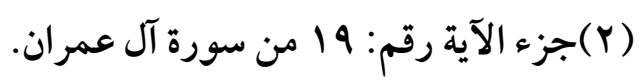


(117)

وأما دليل المقدمة الثالثة وهي أن الدين فعل الواجبات: فهو قوله تعالى

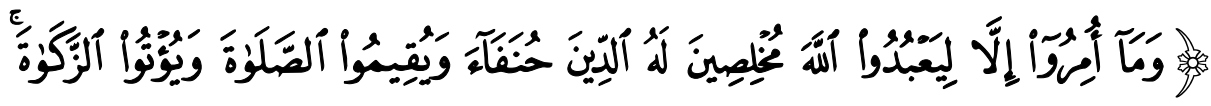

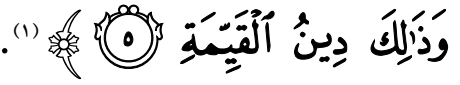
أي: دين الملة المستقيمة، فقوله: "ذلك " إشـارة إلى كـل مـا تقـدم مـن إقامة الصلاة وإيتاء الزكاة بتأويل المذكور فيكون دينا (). وأما الأسماء الشرعية: مثل: الصلاة، والصيام، والزكاة إلخح، فلها معان التهان في اللغة ومعان في الشريعة.

فأما الصلاة فهي في اللغة: الدعاء، وقيل: قولنا: صـلاة موضسوع في اللغـة

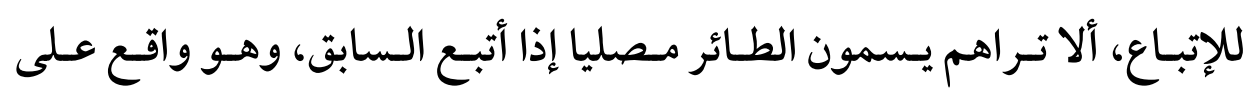
الصلاة؛ لأنها إتباع للإمام. وقد وضعت في الشرع لمعان غير معانيها اللغويـة، ولا توجـد علاقة بين المعنى اللغوي والمعنى الشرعي. فإن قيل: إن المعنى اللغوي هو المعنى الشرعي وهو الدعاء.

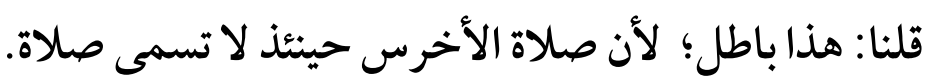
وإن قيل : صـاة في اللغـة موضسوع للإتبـاع، فهـا باطل؛ لأنه يقتضى ألا تسمى صلاة الإمام وصلاة المنفرد صلاة لعدم الإتباع (r).

$$
\text { (1) (1) (الآية رقم: (0) من سورة البينة. }
$$

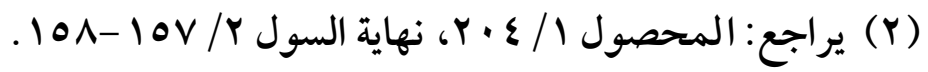

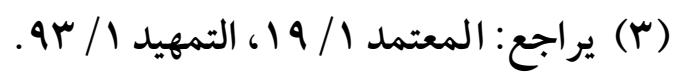


(T) قالوا: إن القرآن والسنة فيهما ما يدل على نقل الأسماء اللغويـة إلى معـان شرعية لا علاقة بينها وبين المعنى اللغوي، من ذلك:

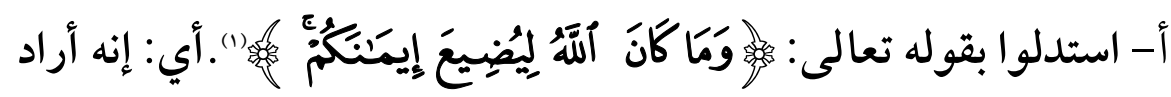
صلاتكم إلى بيت المقدس. الرد: ما ذكروه باطل؛ لأنه عنى سـبحانه - أنه لا يضيع تصديقكم بالصلاة نحو بيت المقدس (r) - (r)

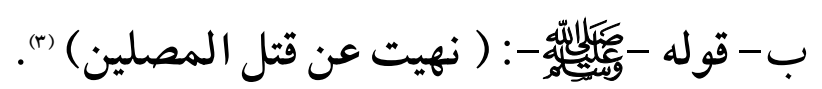
وجه اللدلالة: فقد نقل اسـم المصلى إلى معنى شرعي، وجعله حقيقة

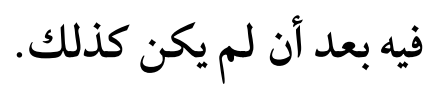

$$
\text { (1) (1) جزء من الآية رقم: بـ إ من سورة البقرة. }
$$

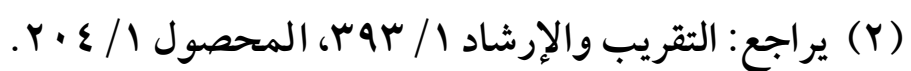

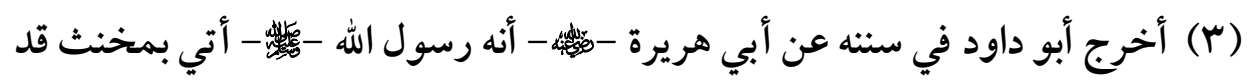

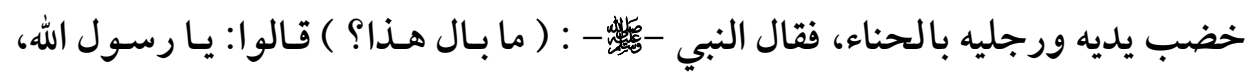

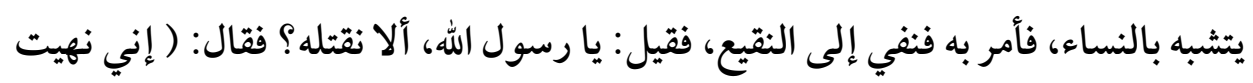

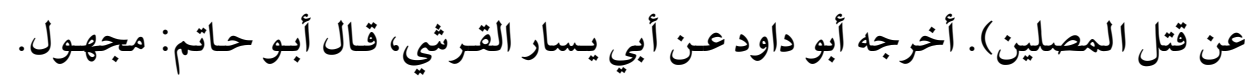

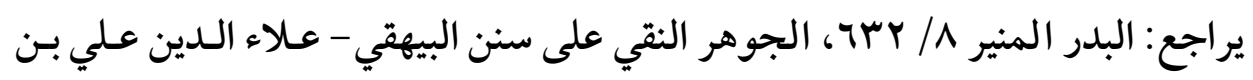

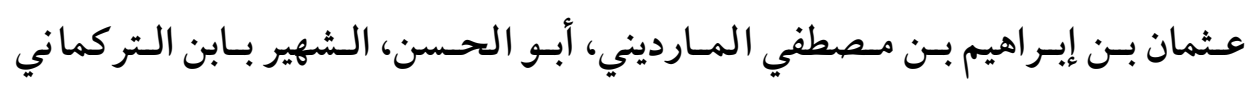

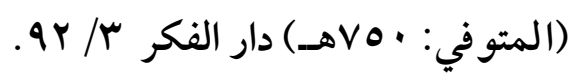


(11A)

مناسبة اللفظ للعنى عند الأصوليين وأثرها في توجيه خطاب المجتهلين

الرد: وهذا -أيضا- باطل؛ لأنه عنى المصدقين بوجوب الصلابلاة باتفاق،

فيوصف التصديق بالصلاة صـلاة على طريـق المجـاز والاتساع، وذلك مـن

موجب اللغة على طريق التجوز (1).

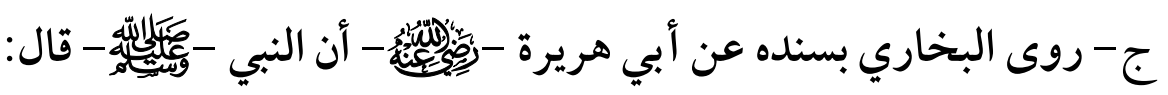

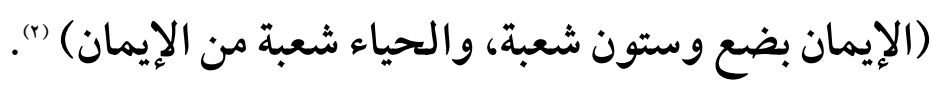

وجه الدلالة: كسابقه.

الرد: هـذا الخبر مـن أخبـار الآحـاد التي تفيـد الظن، وهـو غير موجـبـ

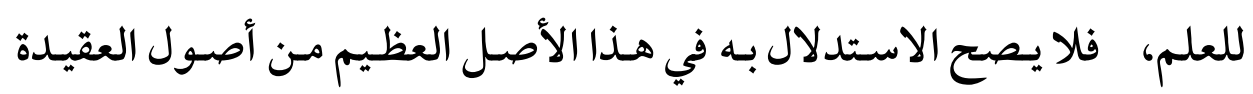

التي تحتاج إلى يقين.

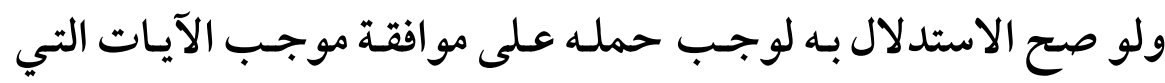

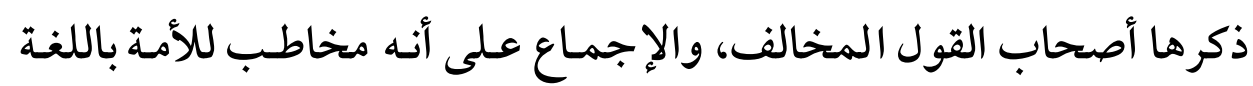

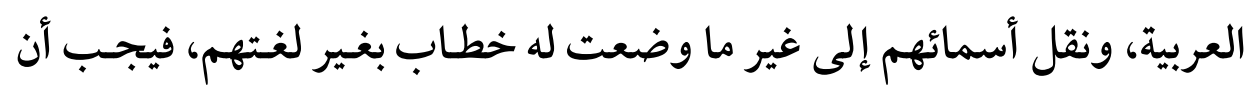

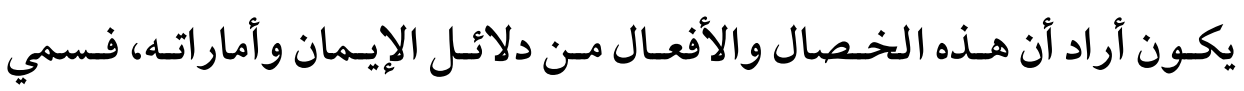

الثيء باسم ما دل عليه مجازا واتساعا (م).

رد الباقلاني على المعتزلة في الأسماء اللدينية والشرعية:

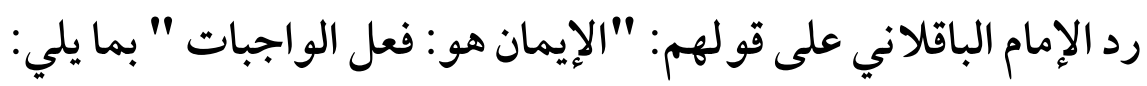

$$
\begin{aligned}
& \text { (1) يراجع: التقريب والإرشاد / / به بr. }
\end{aligned}
$$

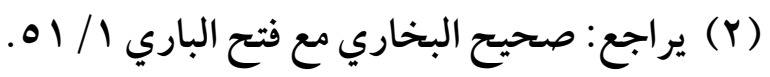

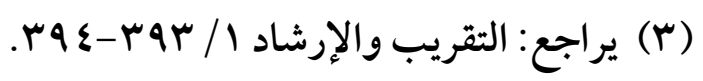


(119)

قال: إن القدرية (1) اختلفوا في الطاعات التي هي الإيمان.

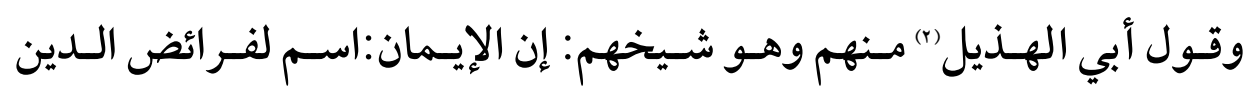
ونو افله.

\section{وإن الإيمان ثلاثة أقسام:}

1 - قسم منه يكفر تاركه، وهو المعرفة والتصدئ. Y - وقسم يفسق تاركه ولا يكفر، وهو الصلاة، والزكاة، والحـج، وغير ذلك من فرائض الدين التي ليست بتصديق.

(1) القدرية: هم أتباع محمد بن الهذيل، أبو الهذيل المعروف بالعلاف، زعم أن نعيم

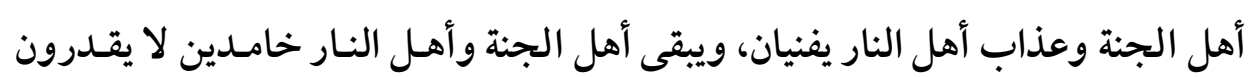

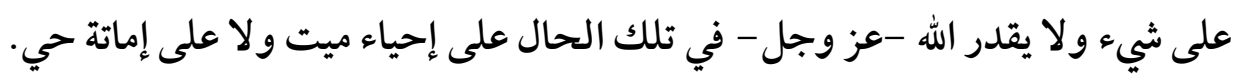

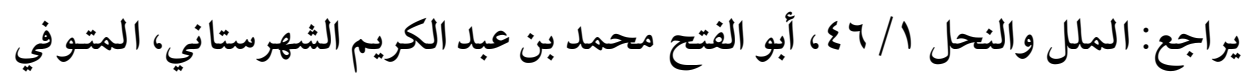

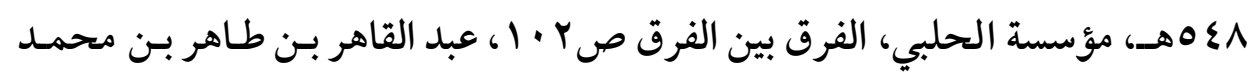

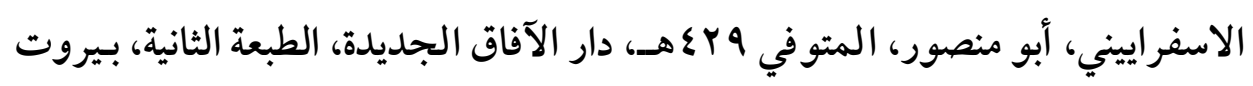
plavV (Y) أبو الهذيل : هو محمد بن الهذيل بن عبيد الله بن مكحول، مولى عبد القيس شيخ

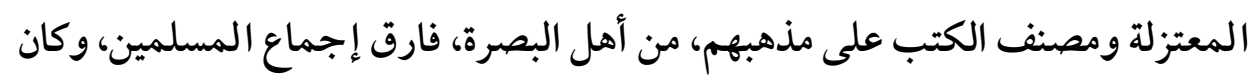

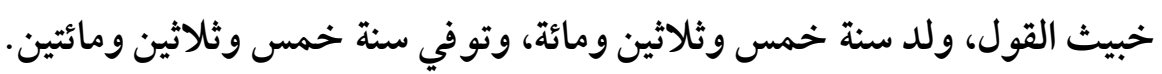

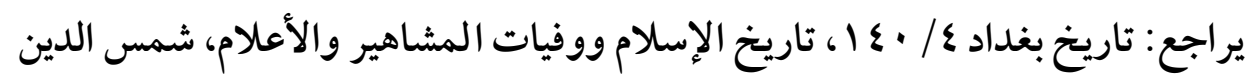

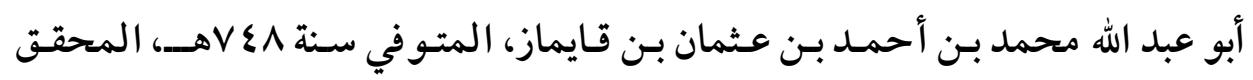

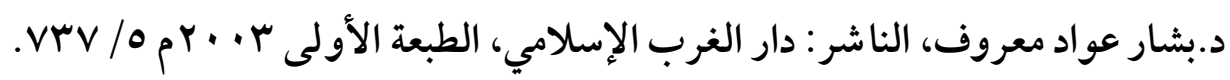


ץ- وقـسم لا يكفــ تاركـه ولا يفـسق، وهـو النو افـل مـن الطاعـات، وســائر

$$
\text { المعتزلة تكذبه في هذه الدعوى. }
$$

ونقول: بل إنما جعل الشرع اسم الإيمان واقعًا على فر ائض الـدين دون

$$
\text { نوافله مع ترك المحرمات فيه. }
$$

فلو كانت الحجة عن الرسول - فئس

$$
\text { الطاعات لوجب علمهم به ورفع اختلافهم فيه. }
$$

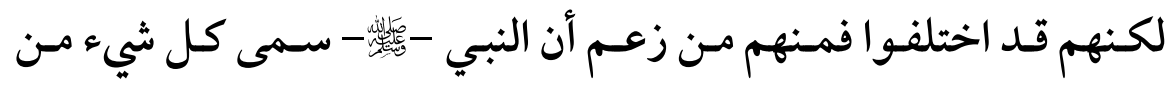

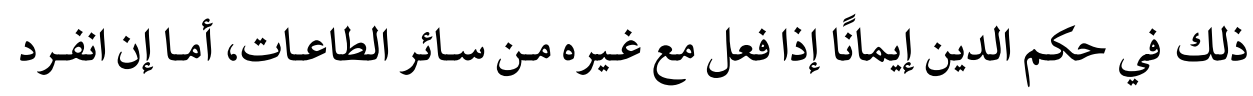

$$
\text { عنها لم يُسم بذلك. }
$$

و كذلك فإنه -عليه السلام - إنما حكم بـأن جميع هـذه الطاعـات مسماة

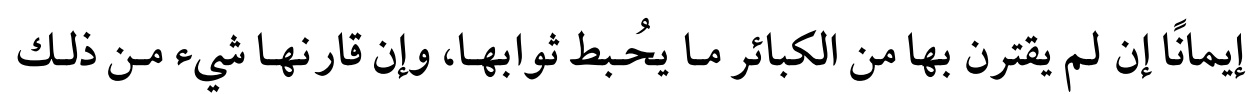

$$
\text { لم يحكم بتسميتها إيمانًا (1). }
$$

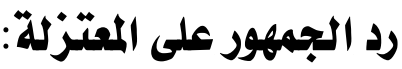

لقد رد جمهور العلماء على المعتزلة في قولهم: عـن الإيمان هو فعـل

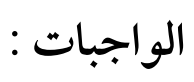

فقـالوا: إن الإيـمان في الشرع -أيضا- هـو التصديق كماهـو في اللغـة،

لكنه تصديق خاص وهو تصديق محمد - فئس به، فيكون مجازا لغويا من باب تخصيص العام ببعض مفهوماته كالدابة.

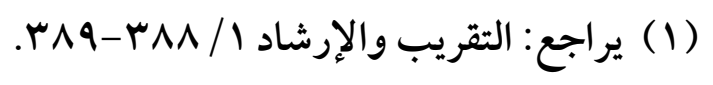


(IYI)

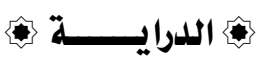

والإيمان بهذا التفسير غير الإسلام وغير الدين، فبإن الإسـلام والدين في

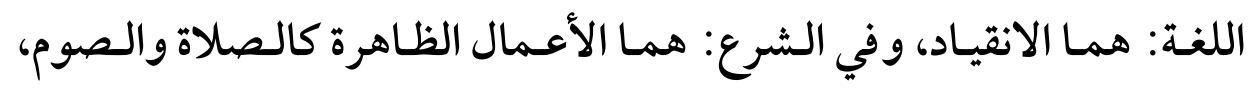

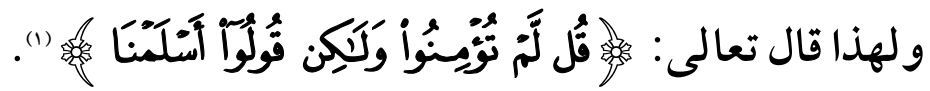
فأثبت لهم الإسلام ونفي عنهم الإيمان فدل على المغايرة.

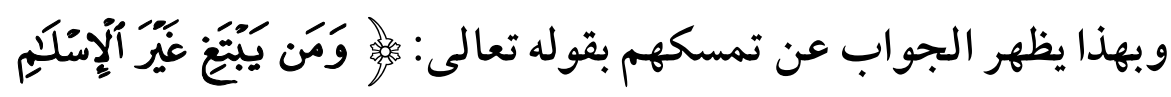

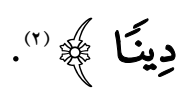
فإن مدلول الآيـة: إن ابتغى دينا يغـاير الإسلام فهو غير مقبـول، فياذا لم يكن الإيمان دينا كما بينا لم يلزم عدم قبوله.

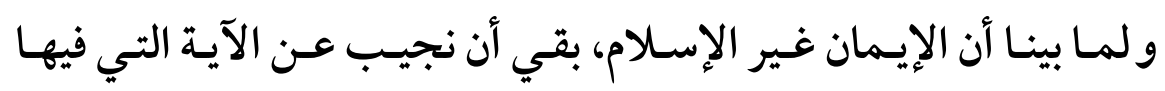

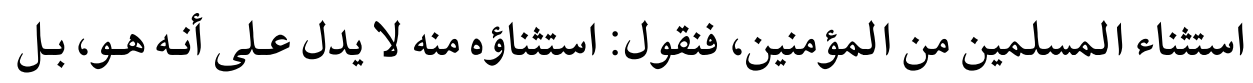

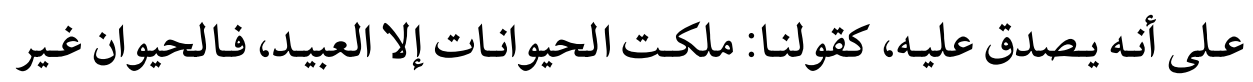

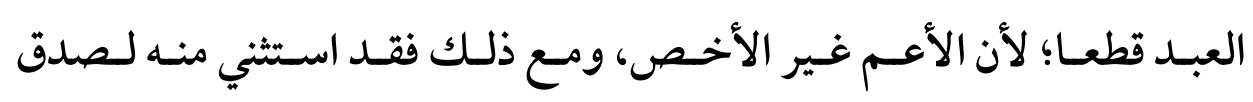
الحيوان عليه.

إذا كان ذلك كذلك فإن الصدق حاصل في المؤمن مع المسلم؛ لأن شرط صحة الإسلام وهو العمل الظاهر كالصلاة وغيرها وجـود الإيمان،

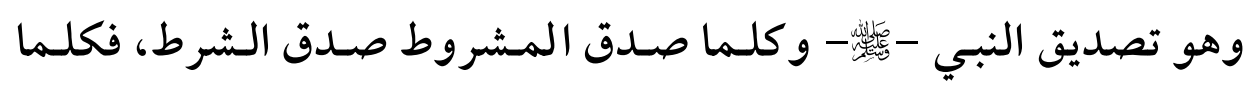
صدق المسلم صدق المؤمن، ولا ينعكس، فلما ثبت صدق المؤمن على ولى صلئ

$$
\begin{aligned}
& \text { (1) جزء من الآية رقم: § ا من سورة الحجرات. } \\
& \text { (Y) جزء من الآية رقم: } 1 \text { من من سورة آل عمران. }
\end{aligned}
$$


(IYr)

مناسبة اللفظ للعنى عند الأصوليين وأثرها في توجيه خطاب المجتهلين

المسلم صح الاستثناء، ولا يلزم من كون المسلم مؤمنا أن يكون الإسلام

هو الإيمان (1).

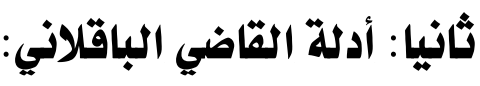

استدل القاضي أبو بكر الباقلاني على مذهبه بأدلة منها:

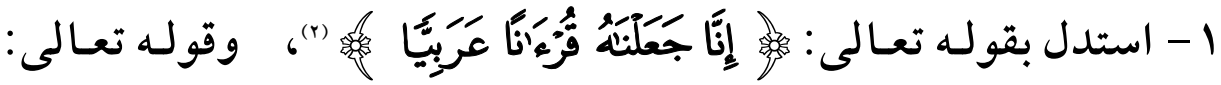

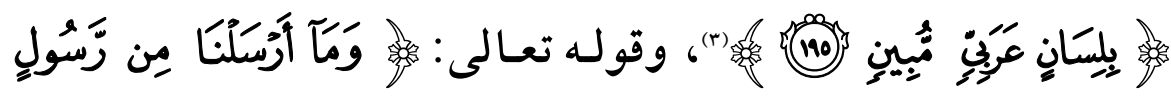

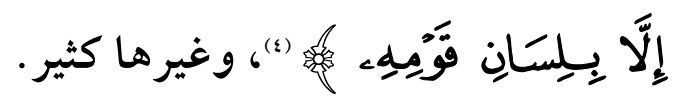

وجه الدلالة: أخبر الله - تعـالى - في هـذه الآيـات بـأن الخطاب للأمـة لم

يتوجـه إلـيهم إلا باللـسان العـربي، وظـواهر هـــه الآيـات يوجــب كـون

الخطاب كله عربيا، مستعملا فيما استعمله العرب، وإلا كـان خطابًا بغير

لغتهم، على أن الأمة مطبقة على إطلاق القول بـأن الله -سببحانه - مـابعـث

نبيه وخاطـب المكلفين عـلى لسانه إلا باللسان العـربي. وإذا كـان ذلك

كذلك بطل ما قالوه.

r - ولأنـه إذا نقـل الأسـماء اللغويـة إلى أحكـام وعبـادات شرعيـة، ولم تكـن

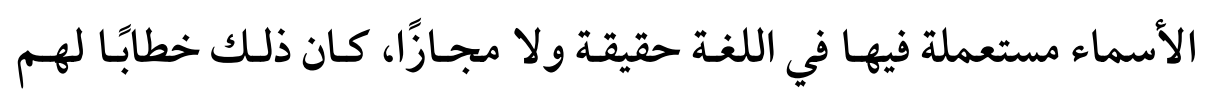

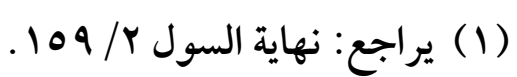

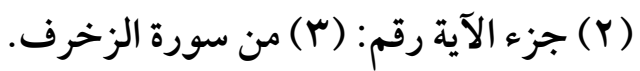

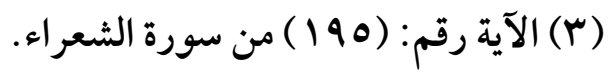

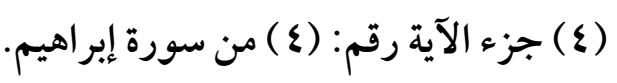


(Irr)

بغير لغتهم، وبمثابة إحداث أسماء يخاطبهم بها، ليست بألفاظ عربية ولا مستعملة على ما استعملوه، وهذا مخالف لظواهر الآيات السابق ذكرها. ץ- لـو قـال لهـم: اقتلوا المشـركين وهـو يريــ المؤمنين، واقطعوا السارقين

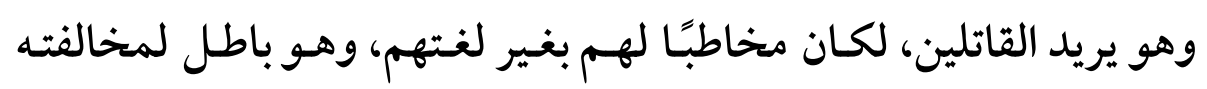
ظواهر الآيات السابقة أيضا.

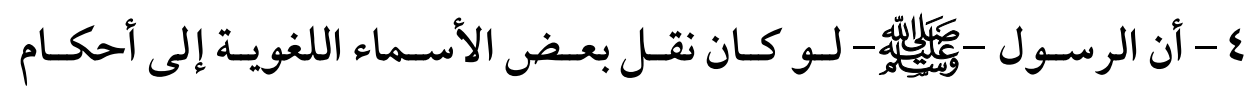
شرعية أو إلى أفعـال توصف في حكـم دينه بأنها كفـر وإيـمان وفسوق،

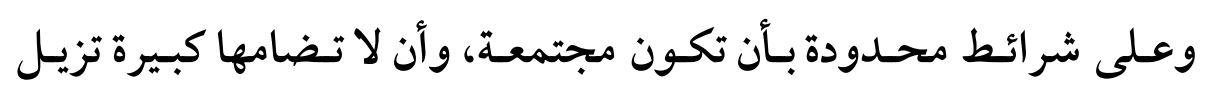

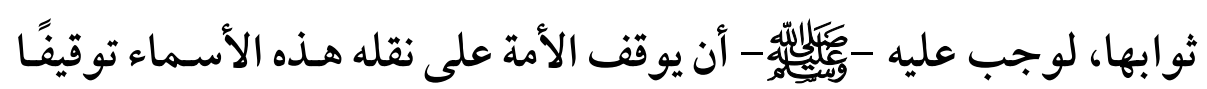
يوجب العلم، ويقطع العذر، ويُنقل نقـلًا تقوم بـه الحجـة، ويوجـب العلـم ضرورة أو دليًا.

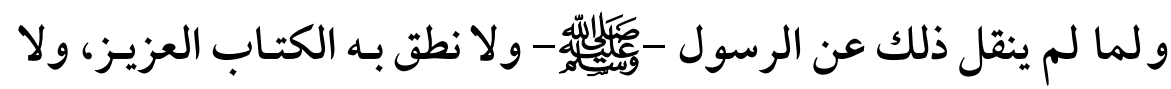

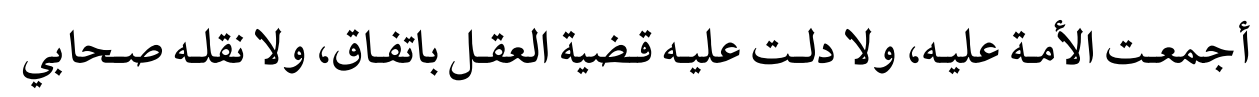
بحضرة جماعة شاهدوه ، وجـب القطع على كذب هـذه الدعوى، وقـد قـر

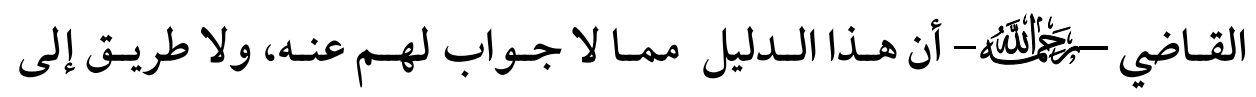
القدح فيه (1).

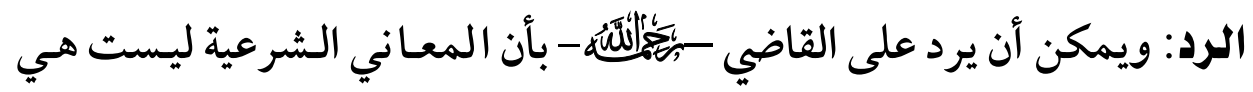
اللغويـة عـلى سـبيل الحقيقـة؛ لإلغـاء الحقيقـة الـشرعية حينــــ، وإنـما هـي

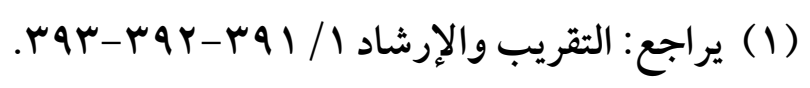


مجازات لغوية، فيكفي التجوز بـما وضعته العرب لحصول المقصودوهـو الإفهام، ولما اشتهر هذا المجاز حتى يتبادر إلى الذهن دون غيره عند ذكر الاسم، قلنا: إنـه أصبـح حقيقـة شرعية في هـذا المعنى، والاشـتهار كاف في جعله حقيقة فيـه، والتبـادر علامـة الحقيقة، مـع وجود المناسبة بـين المعنى اللغوي والمعنى في الشرع لهذا اللفظ (1). ثالثا: أدلة جمهور الأصوليين: استدل الجمهور على ما ذهب إليه من أن الأسماء الشرعية هي مجـازات

$$
\text { اشتهرت في معانيها الشرعية بما يأتي: }
$$

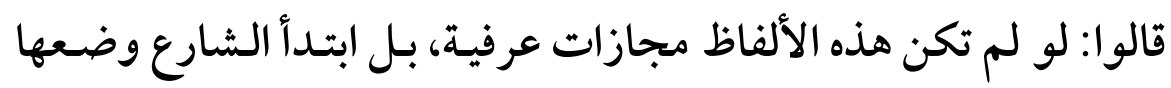

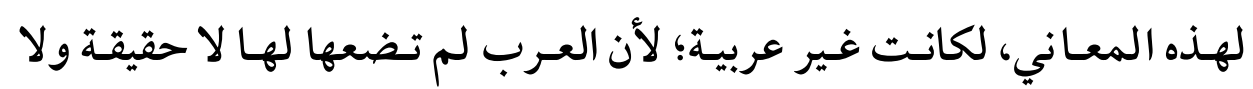
مجازا.

وإذا لم تكن عربية فلا يكون القر آن عربيا، لكن القـر آن عـربي؛ للآيـات التي ذكرناها في أدلة القاضي السابق ذكرها (r). فأنت ترى أن الجمهور قد استدل بقياس استثنائي مفاده: إن إفادة هذه الألفاظ لهذه المعاني لو لم تكن عربية لما كان القر آن كله عربيا، وإفساد اللازم يدل على فساد الملزوم.

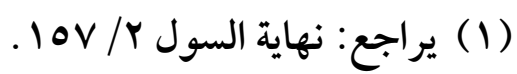

$$
\begin{aligned}
& \text { (Y) ير اجع: المرجع السابق نفسه. الموضع نفسه. }
\end{aligned}
$$


(IYO)

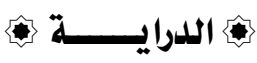

أما الملازمة: فلأن هذه الألفاظ مذكورة في القـرآن، فلو لم تكن إفادتها

$$
\text { لهذه المعاني عربية، للزم أن لا يكون القرآن عربيا. }
$$

وأما فساد اللازم: وهـو أن لا يكسون القـر آن كله عربيا، فلقوله تعـالى:

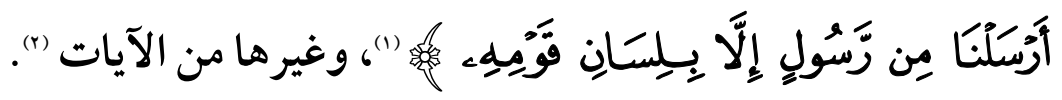

$$
\begin{aligned}
& \text { وواضح أن هذا الدليل يبطل قول المعتزلة فقط. } \\
& \text { اعتر المعتزلة عليه بأربعة أوجه: }
\end{aligned}
$$

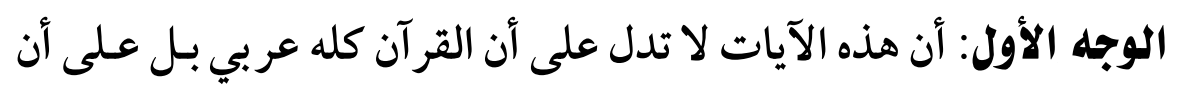
بعضه عربي؛ لأن القر آن يطلق على مجموعه وعلى كل جزء منه؛ ولهـذا لو

$$
\text { حلف: لا يقر أ القرآن حنث بقر اءة بعضه. }
$$

الجــواب: أجـاب الجمهـور بــأن اســدلالكم بـالحلف وإن دل عـلى أن

المر اد بالقر آن البعض فهو معارض لقولنا للسورة والآيـة: إنه بعض القرآن، فإنه لو أطلق عليه بعض القرآن حقيقة لما كان لإدخال البعض معنى، وأيضا فلأن بعض الثيء غير الثيء، وإذا تعارضا تساقطا، وسلم ما قلناه أولا.

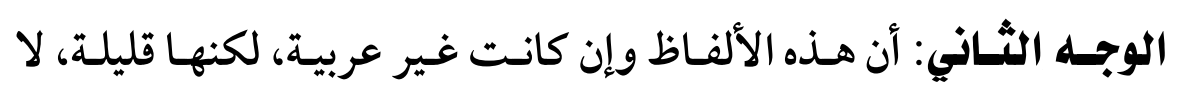
تخرج القرآن عن كونه عربيا، كقصيدة فارسية فيها ألفـاظ عربية، فإن ذلك

$$
\text { لا يخر جها بذلك عن كونها فارسية. }
$$


(Iry) مناسبة اللفظ للعنى عند الأصوليين وأثرها في توجيه خطاب المجتهلين

الجواب: أجاب الجمهور: أنا لا نسلم، بل يخرج عن كونه عربيا قطعا، بـليل صحة الاستثناء، فيجـوز أن يقـال: القـر آن عـربي إلا كـذا وكذا، ومثلـه

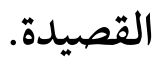

الوجه الثالث: أنه يكفي في كون هذه الألفاظ عربية استعمال العرب لها

مـن حيـث الجملة، وعليه فاستعمال الشارع لها في غير المعنى اللغوي لا يخر جها عن ذلك.

الجـواب: ويجـاب عـن ذلك بـأن تخـصيص الألفــاظ بكونهـا عربيـة أو

فارسية ليس حكما حاصلا لذات الألفاظ مـن حيـث هي هي، بـل بحسب دلالتها على تلك المعـاني في تلك اللغـة، فلا يصير اللفظ عربيـا إلا إذا دل على المعنى الذي وضعه العـرب لـه، وذلك هـو عين اعتبـار مناسبة اللفظظ للمعنى.

الوجه الرابع: أنه منقوض بألفاظ واقعة في القـرآن ليست عربية بـل هي معربة، فإن لفظ "المشكاة " حبشية كما قال في المحصول، وهندية كما قال الآمدي وابن الحاجب، وهي: الكوة ، والقسطاس رومية، وهي: الميزان، والإسـبرق فارسسية، وهي: الـديباج الغلـيظ، وسـجيل أيسضا فارسـية، وهي: الطين المطبوخ. 
(IrV)

الجواب: لا نسلم أن هذه الألفاظ ليست عربية، بل غايته أن وضـع العـرب

لها وافق وضع غيرهم ، ولئن سلمنا خروج هذه الألفاظ عن مقتضى الـدليل، فيبقى ما عداها على الأصل (1).

بعـد عـرض المـذاهب وأدلتها يتبين لنـا أن المـذاهب آلـ إلى مـذهبين

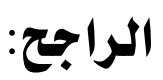

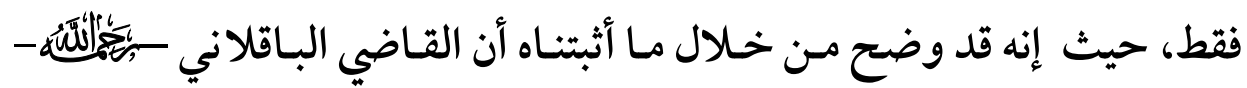

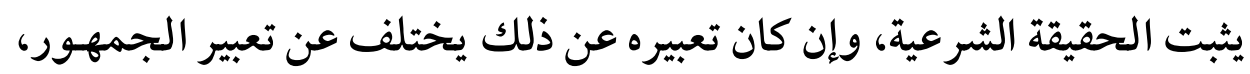

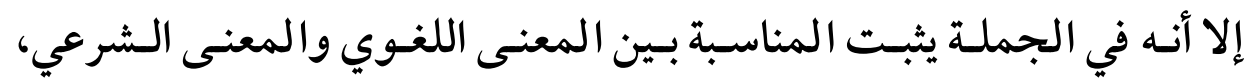
و يجعل اللفظ يستعمل في المعنى الشرعي بزيادة عن المعنى اللغوي.

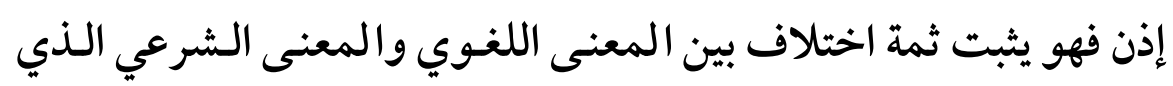
يستعمل فيه اللفظ.

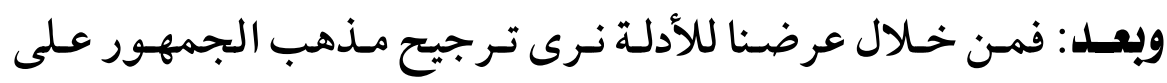

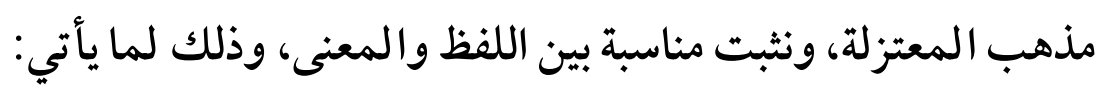
1 - قوة أدلة الجمهور الذي يثبت هذه المناسبة.

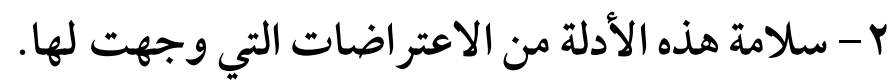

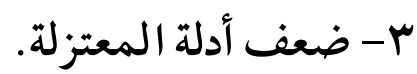
ع - عدم سلامتها من الاعتر اضات التي وجهت لهعته

والعلم عند الله تعالى ل - ملى

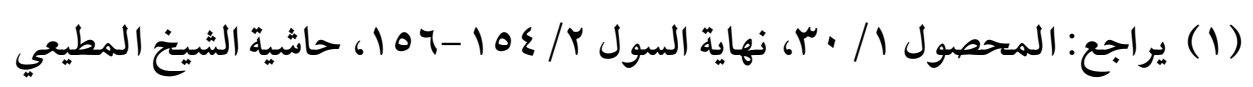
على نهاية السول r / V ا ما وما بعدها. 
(IYA)

مناسبة اللفظ للعنى عند الأصوليين وأثرها في توجيه خطاب المجتهلين

\section{الامطاب الثاني}

\section{أثر هناسبة اللفظ للمعنى في الأسماء الشرعية}

\section{في توجيه خطاب الجمتهدين}

رأيت فيما سبق حقيقة النزاع بين العلماء في وجود الحقيقة الشرعية،

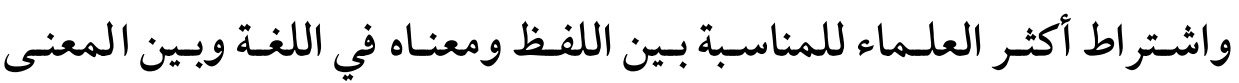

المنقول إليه اللفظ في الثرع، وعدم اشتر اط البعض لهذه المناسبة.

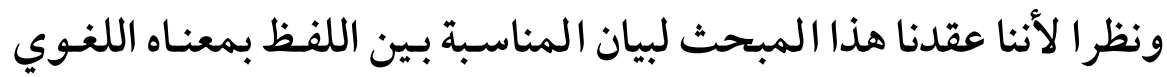

وبين المعنى المنقول إليه في الشرع، فإن الأثر المترتب على ذلك عظيم في

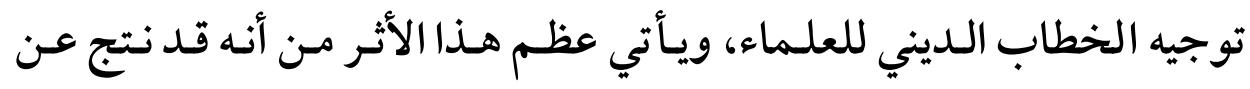
اعتبار المناسبة أو عدم اعتبارها خلاف بين العلماء في مسائل تتعلق بـالإيمان والكفر مما يمس العقيدة في المقام الأول.

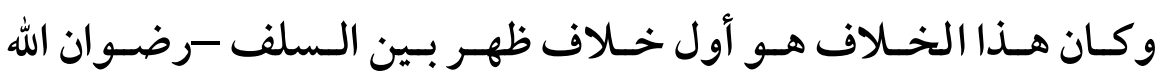

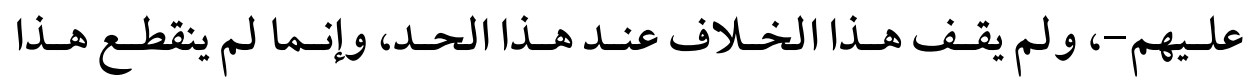
الخلاف وأثره على مر التاريخ حتى صارت قضية التكفير هي قضية العصر

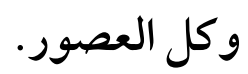

ولم يكن الأثر المترتب على الخـلاف في اعتبـار المناسبة -هنـا-هـو

ذلك الخلاف المتعلق بالمـسائل العقائدية فقط، بـل مس مسائل كثيرة مـن

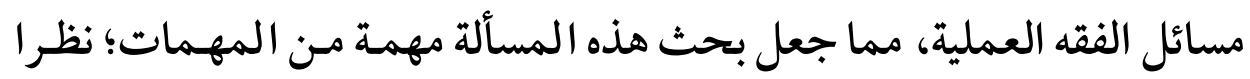

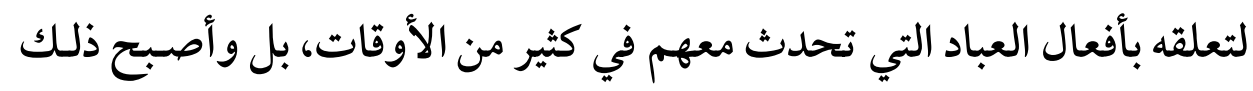


لـه أثر فيما استبحد مـن فكـر تحـول بعـد ذلك إلى واقـع في كثير مـن بلـدان

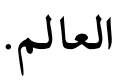
فمـثلا مسألة نكـاح المثلين التي أصبحت شـبه واقع في كثير مـن بـلاد العالم غير المسلم، فإنها تبحـث -هنـا- تحـت عنوان القياس في اللغـات، بمعنى: أننـا لـو اعتبرنـاوجسود المناسبة بين اللفظ في معنـاه اللغوي وبيسن المعنى الشرعي، فهل وجدت هذه المناسبة بين اللفظ ومعناه اللغوي وبين

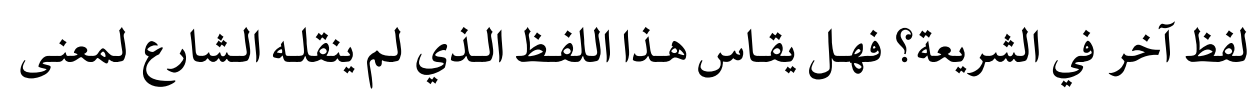
شرعي على لفظ آخر نقله؟. مثال ذلك: لفظ "الزنا " هـل يقـاس عليه لفظ "اللـواط " ؟ وتكـون آيـة

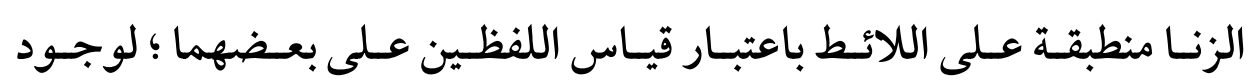

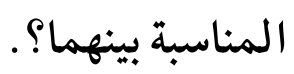

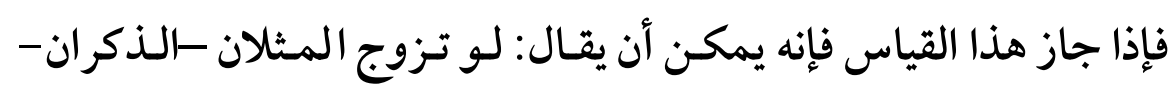

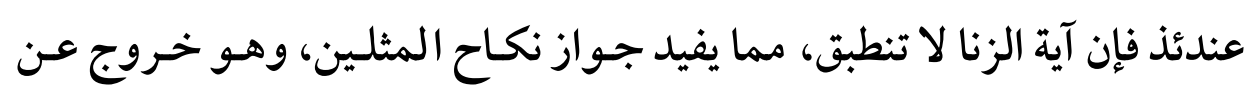
حد الشرع الصحيح، والتفكير السديد، والعقل السليم.

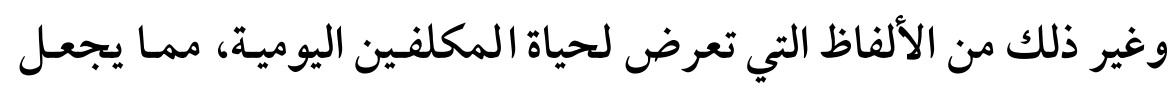
بيان أثر هذه المناسبة -هنـا- مـن الأمور كثيرة الفائدة، وسـوفي يـزـداد الأمـر

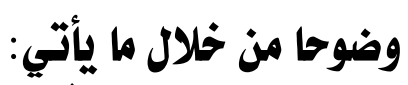

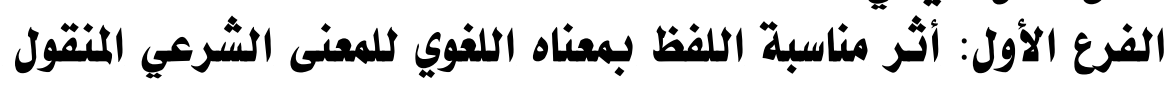
إليه التي هي الفيصل في قضية الثئ التكفير.

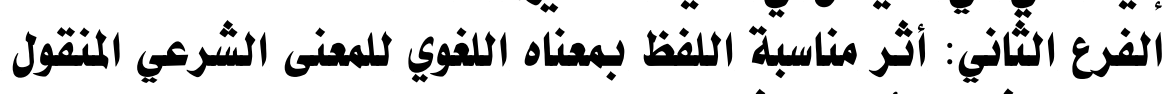
إليه في إثبات الأسماء الشرعية بالثياس. 


\section{الفرع الأول}

\section{أثر هناسبة اللفظ بمعناه اللغوي للمعنى الشرعي}

\section{المنقول إليه التي هي الفيصل في قضية التكفير}

رأينا فيما سبق أن الخلاف بين المعتزلـة والخوارج مـن جهـة وبين أهـل

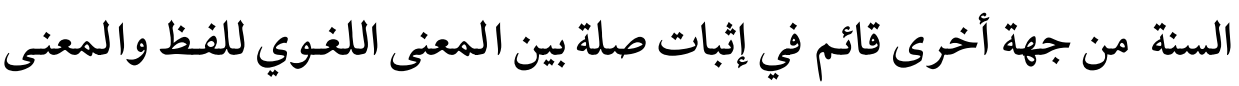
الـشرعي لـه، وأن المعتزلـة والخـوارج ينفـون الـصلة بـين المعنسى اللغـوي والمعنى الشرعي، وأن أهل السنة يثبتون تلك المناسبة بينهما.

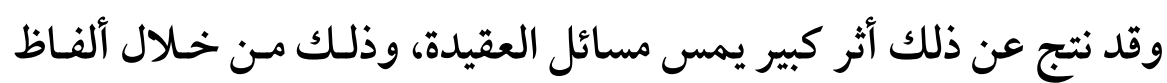
مثل: لفظ الإيمان، الكفر، الفسق.

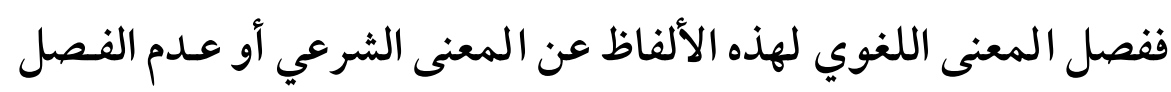
أدى إلى خطاب مختلف بـين العلـماء، مفـاده: خـروج المؤمن عـن الإيـمان بمجرد ارتكابه ذنبا متوعد عليه بالعقاب الأليم، أو عدم خروجه.

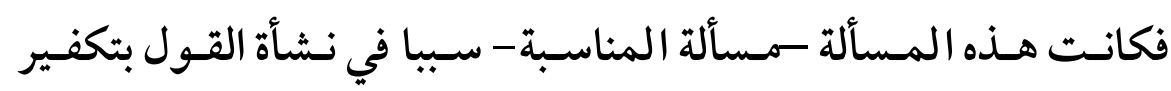
المؤمنين مما يبيح قتالهم، فنتج عن ذلك شرعنة العنف الذي نشأ بين أوائل

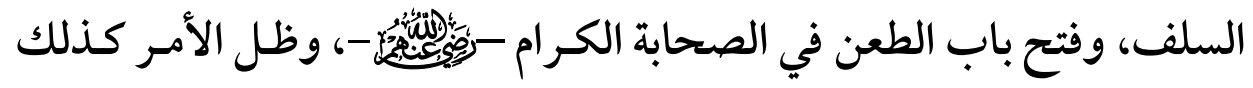

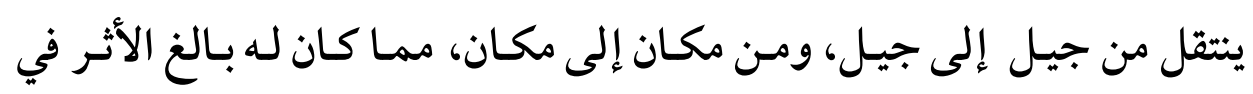
انتشار القتال تحت مستمى الجهاد، وقتل المسلمين تحـت مسمى كفرهم لارتكابهم المعاصي الكبيرة، وأدى ذلك إلى الفساد ما أدى.

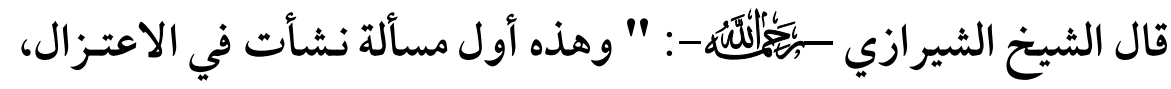

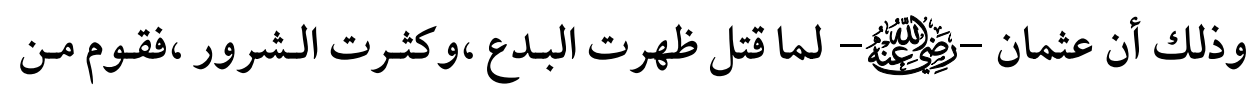


(|r|)

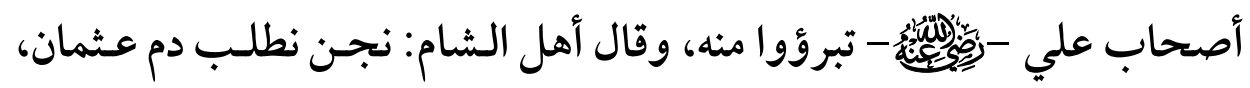
وجرت بيـهما مـن الحـروب مـا لا يخفي، فجـاءت المعتزلة بعـدهم بقليـل، فقالوا: ننزلهم منزلة بين المنزلتين، فـلانسميهم كفـاراولا مؤمنين، ونقول:

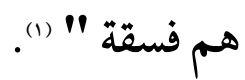

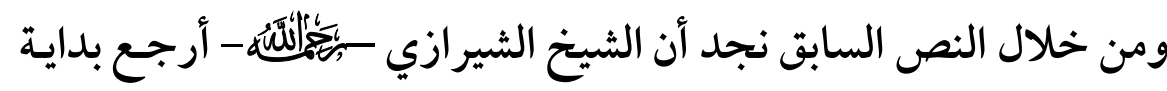

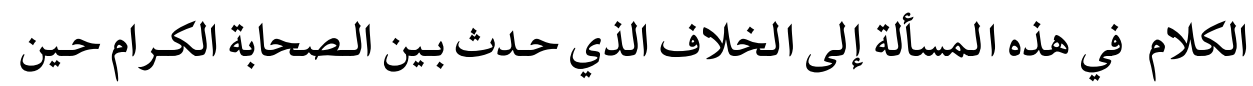

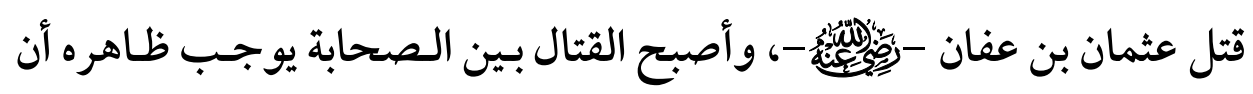

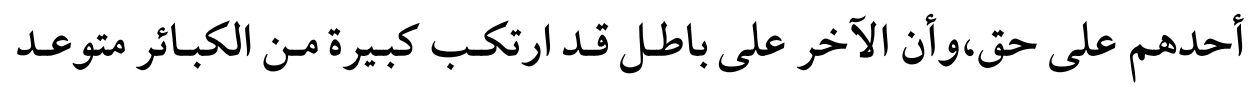
عليها بالعقاب وهي قتل المسلم بغير حق.

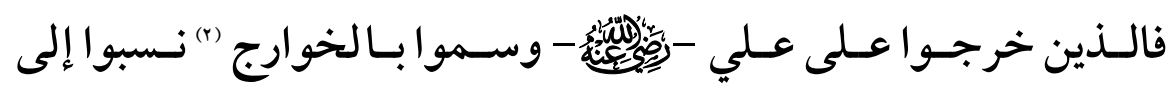
مرتكب الكبيرة الكفر، وسموه كافرا، وأخرجوه من الإيمان إلى الكفر.

(1) يراجع: شرح اللمع أبو إسحاق إبراهيم بن علي بن يوسف الشيرازي (المتوفي:

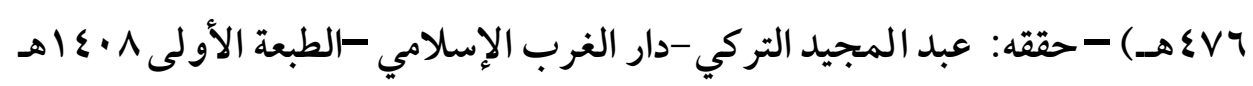
.IVY// 1911-

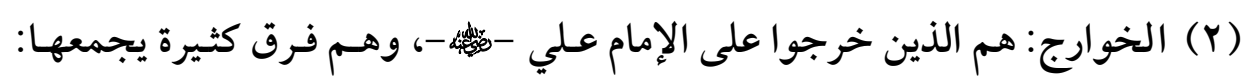

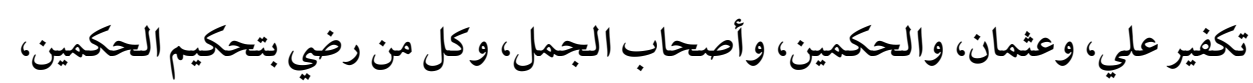

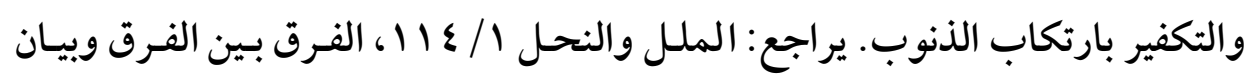

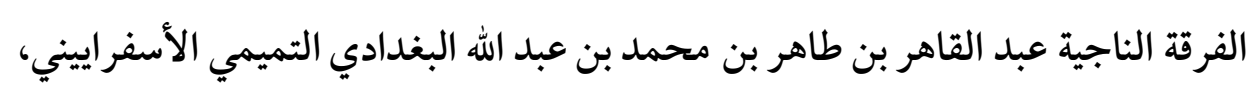

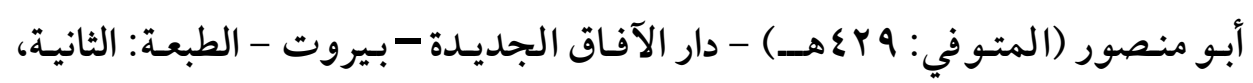

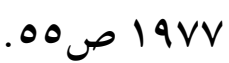


(IrY)

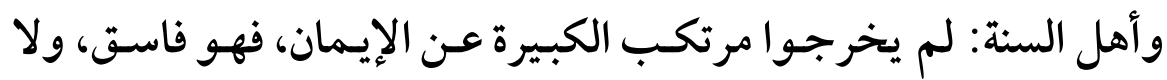

يخرج من الإيمان بمجرد فسقه، ولا يخلد في النار في الآخرة، بـل هـو تحـت

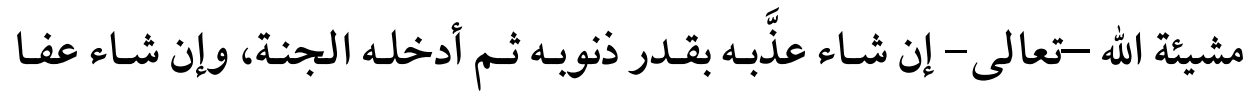

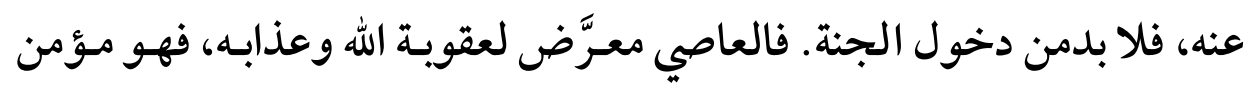
بإيمانه وتصديقه، فاسق بكبيرته (1). ثم جاء من بعـدهم المعتزلة: وقالوا: مرتكـب الكبيرة خـرج مـن حظيرة

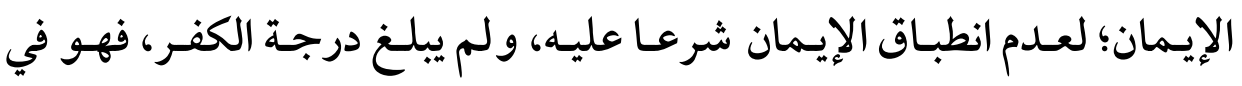
منزلة بين المنزلتين، وهي: فاسق، مع خروجه عن الإيمان.

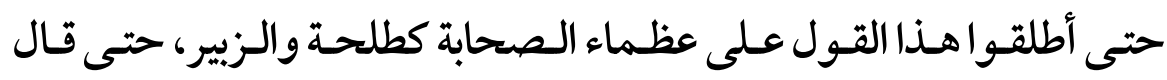
كبر اؤهم مثل: واصل بن عطاء (): لو شهد عندي علي وطلحة على باقة بقل لم

(1) يراجع: لوامع الأنوار البهية وسواطع الأسرار الأثرية لشرح الدرة المضية في عقدـ

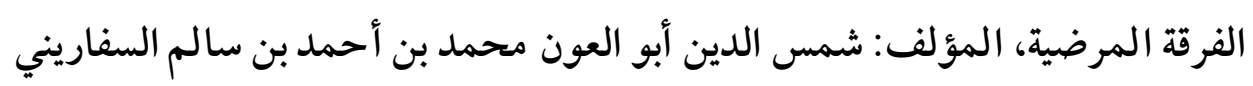

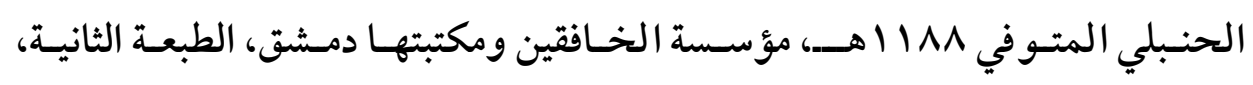

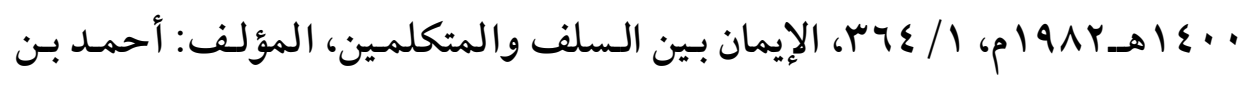

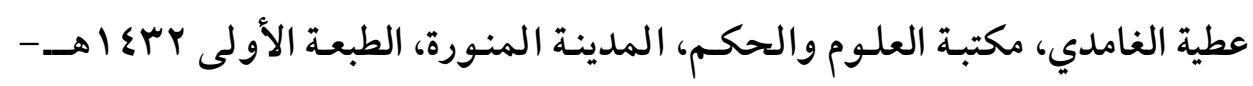
.00/ / 1 cr..r (Y) واصل بن عطاء: هو أبو حذيفة واصل بن عطاء المعتزلي، المعروف بالغزال، كان

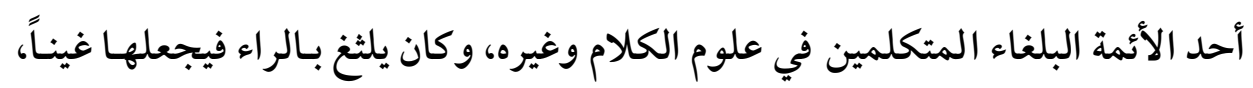

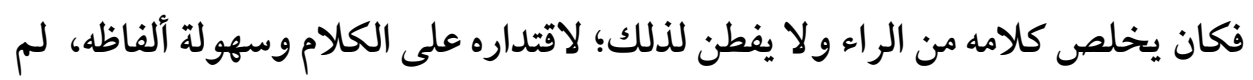

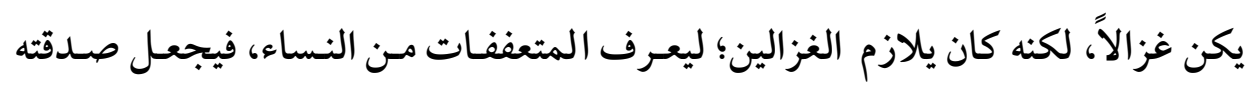

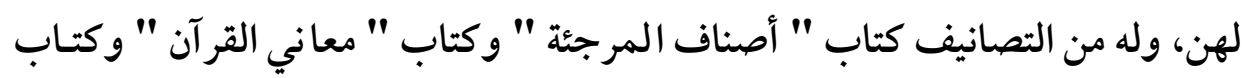


(Irr)

أقبل حتى يكون معهما ثالث؛ لأن أحدهما فاسق (1).

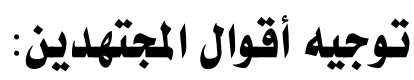

علينا الآن أن نبين معنى الإيمان والكفر والفئ الفسق لغة، ثم بيان ذلك شرعـا

على قول كل مذهب، وذلك على النحو التالي:

فالإيمان معناه في اللغة: الإقرار والتصديق.

واسم الكفر معناه في اللغة: الجحد والإنكار، وهو التغطية.

واسـم الفست معنـاه في اللغـة: فعـل كل معـصية يستحق عليها العقـاب

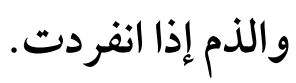

" الخطب في التوحيد والعدل " وغير ذلك، كانت ولادته سنة ثمانين للهجرة بمدينة

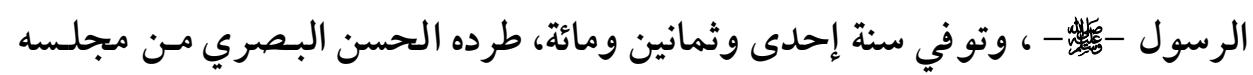

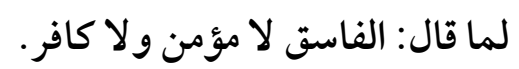

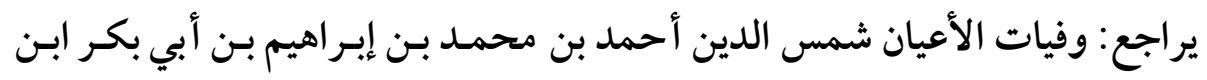

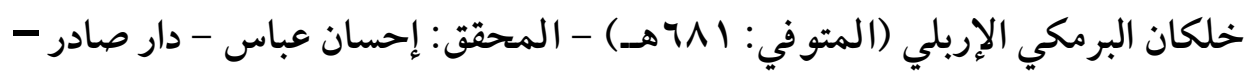

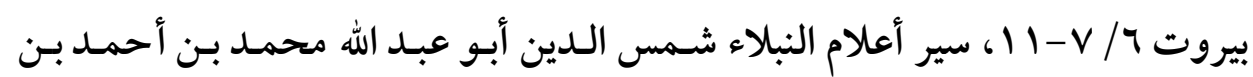

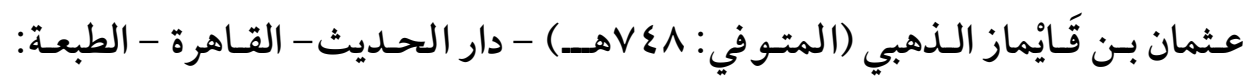

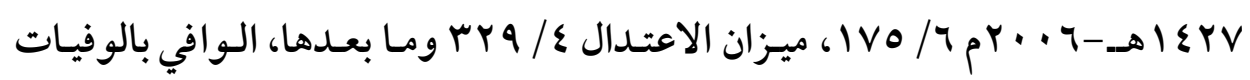

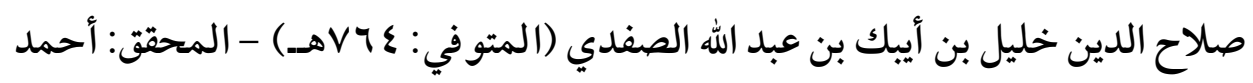

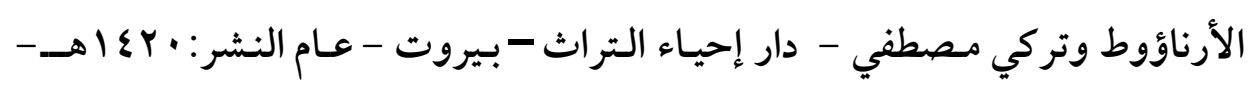

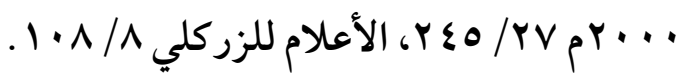

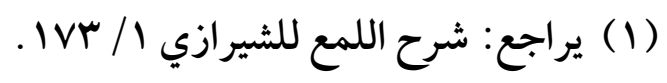


$(1 r \varepsilon)$ مناسبة اللفظ للعنى عند الأصوليين وأثرها في توجيه خطاب المجتهلين

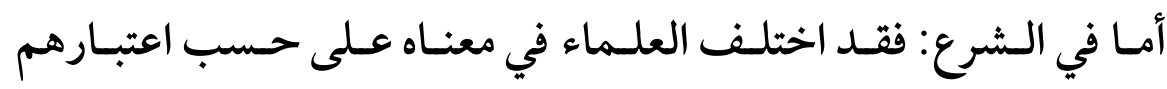

$$
\text { للمناسبة بينه وبين المعنى اللغوي أو عدم اعتبارها. }
$$

فأهل السنة : يرون أن الإيمان في الشرع هو التصديق كما هـو في اللغـة ،

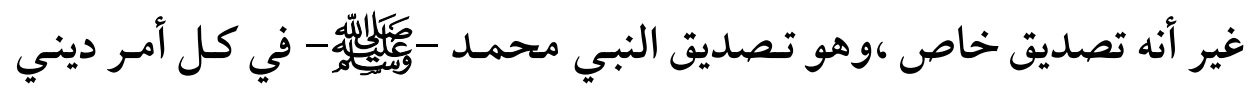
علم مجيئه به، فيكون مجازا لغويا من باب تخصيص العام ببعض مفهوماته . فـالمعنى الشرعي ارتبط بـالمعنى اللغـوي، فمرتكـب الكبيرة مـصدق،

فلذلك قالوا: لم يخرج عن الإيمان، فهو مؤمن نقص إيمانه، فكيف يقاتل؟

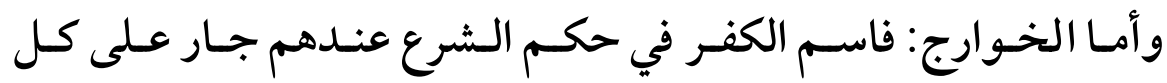
معصية، والقول كافر جار على كل عاص، فلاعبرة عندهم بـالمعنى اللغوي،

$$
\text { ولذلك فمرتكب الكبيرة عندهم كافر. }
$$

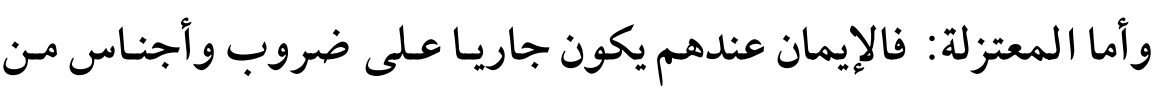
الأفعال لم يكن الاسم في اللغة جاريا عليها، فهو في الشرع: فعل الواجبات. وأن القول مؤمن: وضع في الشرع لمن يستحق ثوابا عظيما.

والقول كافر: وضع في الشرع لمن يستحق ضربا من العذاب عظيما.

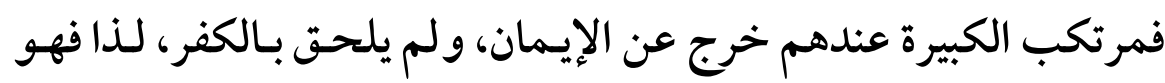
في منزلة بين المنزلتين وهي الفسق (1).

الترجيج: فئهن

رأيت فيما سبق أن سبب اختلاف العلماء في حكـم مرتكب الكبيرةووجود

منزلة بين المنزلين هو اعتبار مناسبة اللفظ للمعنى أو عدم اعتبارها.

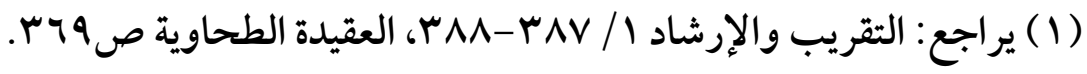


(Iro)

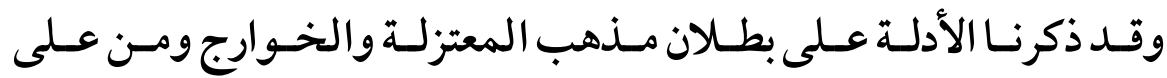

شاكلتهم، ورجحنا أدلة أهل السنة، وعليه فيرجح قول أهل السنة على نحو ما مر.

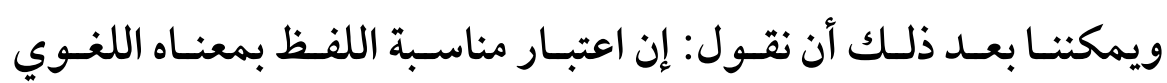
للمعنى الشرعي تصلح لأن تكون قاعدة أصيلة من القواعـد التي يعتمـد عليها عنـد تجديـد الخطـاب الـديني، وتوجيهـه الوجهة الصحيحة، وتنقيـة الـتراث

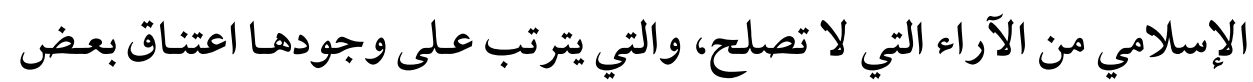
من لا يفهم الدين لها، فيترتب على ذلك من المفاسد ما يترتب.

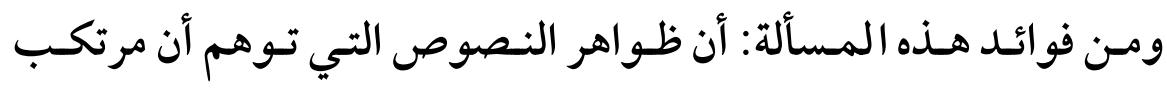

الكبيرة مخلد في النار يجب عرضها على هذه المذاهب، فمثلا:

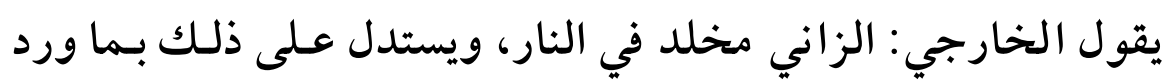

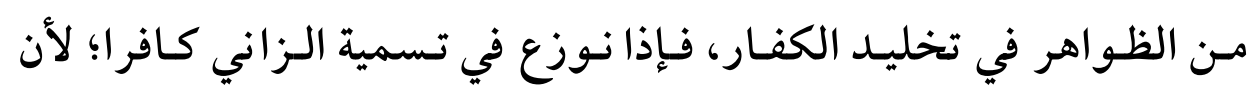
العـرب لا تعـرف الكـافر إلا مـن غطى الـشيء وسـتره، كالجاهـل بـاله الجاحد لنعمه، قال: غير هذه، ونقلها عن موضوعها في اللغة، واستدل بما

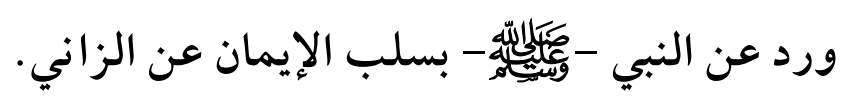

ويقول المعتزلي: ليس سلبه الإيمان يثبته كافرا، بل الزاني لا مؤمن ولا كافر . ويقول أهل السنة: الحديث متأول، بمعنى: من زنا مستحلا، أو بغير ذلك. فمنع بالتأويل كون الشرع مغير اللغة (1).

(1) يراجع: إيضاح المحصول من برهان الأصول، لأبي عبد الله محمد بـن علي بـن

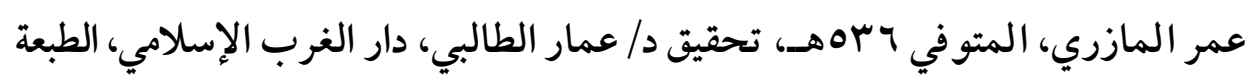

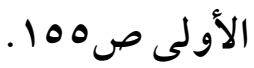




\section{الفرع الثاني}

\section{أثر هناسبة الافظ بمعناه اللغوي للمعنى الشرعي}

\section{المنقول إليه في إثبات الأسمهاء الشرعية بالقياس}

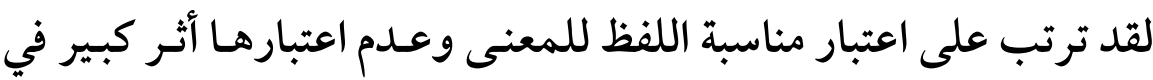

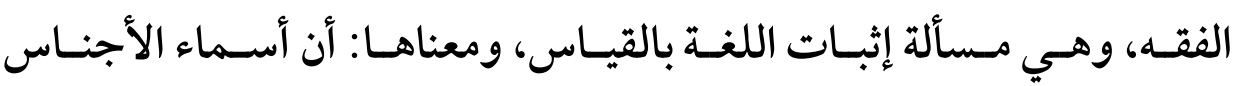

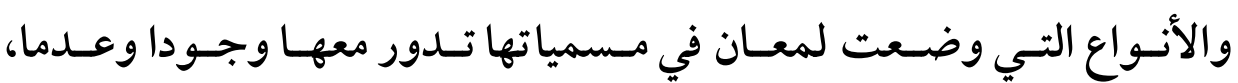
كالخمر الذي دار اسمه مع التخمير، هل يجوز إطلاقه على النبـذ قياسـا بعلة التخمير والإسكار؟؟ (1) - (1)

فيقاس النبيذ على الخمر، فيكون هو هو، فننطبق آية تحريم الخمـر على النبيذ مباشرة؛ لأن النبيذ قسناه على الخمر فصار هو هو.

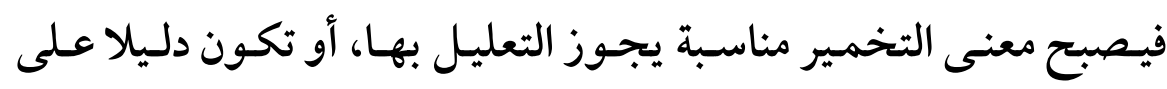
العلة كما هو معروف عند الأصوليين.

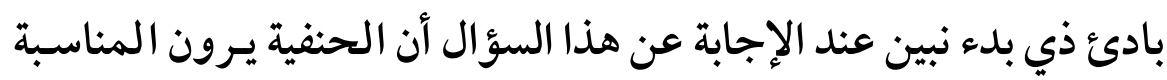

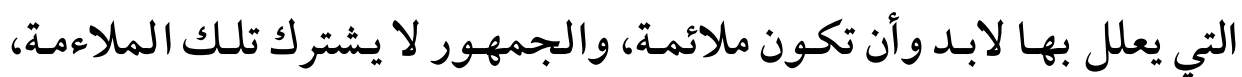
وقد بينا ذلك في بداية البحث عند الكلام على معنى المناسبة.

(1) يراجـع: شرح مختـصر الروضـة سـليمان بـن عبــ القـوي بـن الكـريم الطوفي

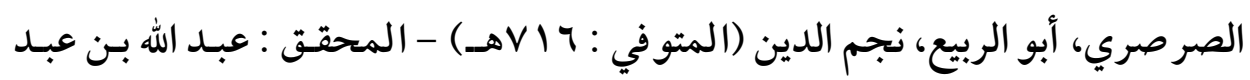

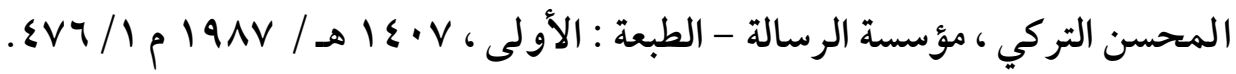


وعليـه: فتــد اختلـف الحنفيـة في مناسبة اللفـظ بمعنـاه اللغـوي للمعنى الشرعي المنقول إليه مع جمهور العلماء في نوع هـذه المناسبة، هـل تصلح

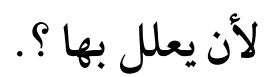

فيرى بعض العلماء: أنها تصلح لأن يعلل بها.

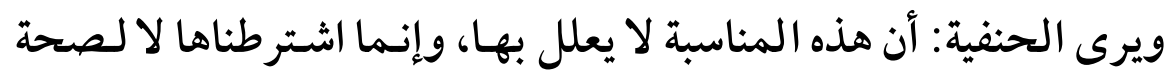
الإطلاق وإنما لأولوية وضع هذا اللفظ لهذا المعنى.

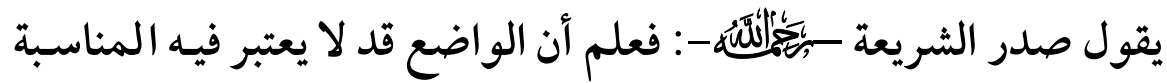
كالجدار، والحجر، وقد يعتبر فيه كالقارورة، والخمر، واعتبار المعنى الأول في الوضع الثاني لبيان المناسبة والأولويـة، لا لصحة الإطلاق، وإلا يلزم أن يسمى الدن قارورة، فلهذا السر لا يجـري القيـاس في اللغـة، فلا يقـال: إن

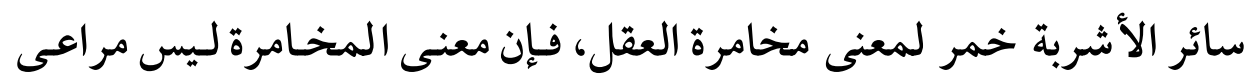
في الخمر؛ لصحة إطلاق الخمر على كل ما يوجـد فيه المخـامرة، بـل لأجـل

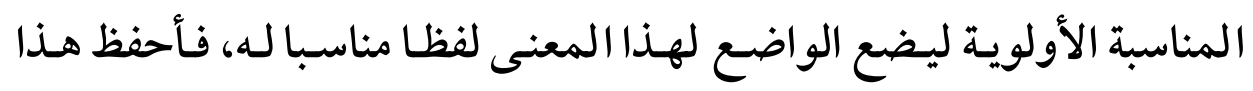

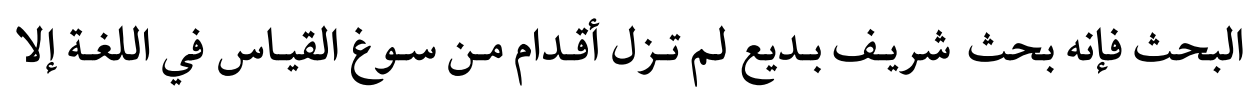
لغفلة عنه (1) ويوضح صاحب التلويح هذا الكلام فيقول: إن اعتبـار المعنى الأول فيه ليس لصحة إطلاقه على أفر اد المعنى الأول، ولا لصحة إطلاقه على أفراد

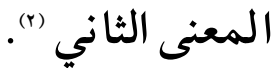

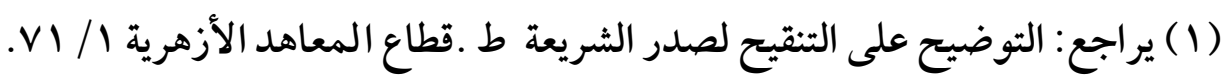

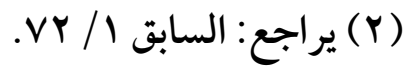


(IrA)

مناسبة اللفظ للعنى عند الأصوليين وأثرها في توجيه خطاب المجتهلين

إنما كانت المناسبة موجودة لأولوية هذا اللفظ مـن بين الألفـاظ بـالتعيين

لذلك المعنى الثاني.

مثل: لفظ "دابـة " فهو مناسـب لـذوات الأربـع؛ لوجـود معنى الـدبيب

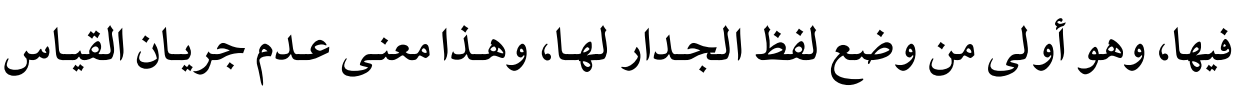

في اللغة (1).

وسوف نستعرض مسألة إثبات اللفة بالقياس، وما يـترتب على ذلك من

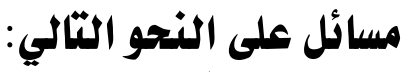
أولا: إثبات الأسماء الشرعية الثيأ بالثياس.

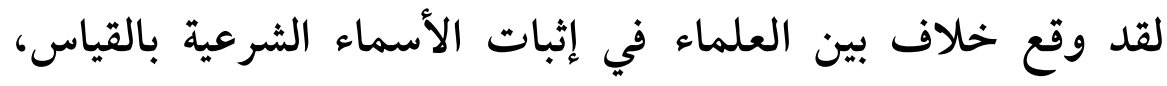
وسوف نستعرض ذلك من خلال ما يأتي: 1 - تحرير محل النزاع.

r- r تحقيق أقوال العلماء في المسألة.

r- أدلة الأقوال، والراجح منها.

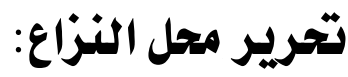

اتفق العلماء على امتنـاع جريـان القياس في أسـماء الأعلام؛ لأنها غير معقولة المعنى، والقياس فرع المعنى، فهو كحكم تعبدي لا يعقل معناه.

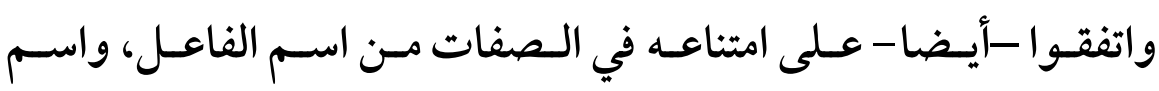

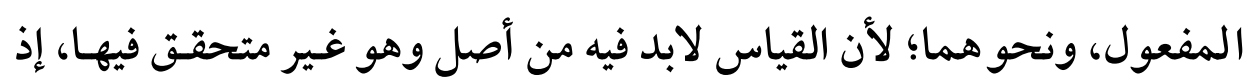

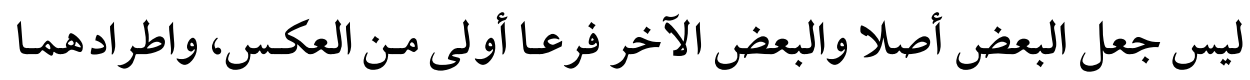


في محلهما مستفاد من الوضع لا القياس، فإنهم وضعوا القائم والقاعـد بـإزاء كل من : قام، وقعد. واتفقوا كذلك على امتناعه فيما يثبـت بالاسـتقر اء إرادة للمعنى الكلي، كقولنا: الفاعل مرفوع، والمفعول منصوب. وإنما محل الخلاف فيما إذا أطلقوا اسما مشتملا على وصفي، واعلى واعتقدنا أن التسمية لذلك الوصف، فأردنا تعدية الاسم إلى محل آخر مسكوت عنه. مثل: إذا اعتقدنا أن إطلاق اسم الخمر باعتبار التخمير فعديناه إلى النبيذ.

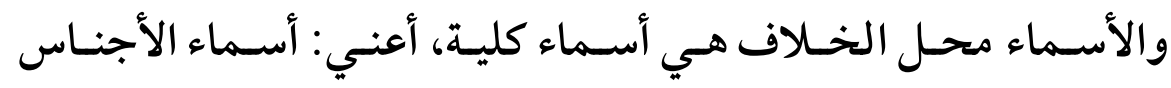
والأنواع التي وضعت لمعان في مسمياتها تدور معهاوجودا وعدما (1).

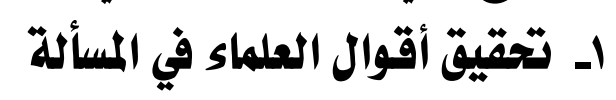
اختلف العلماء في إثبات الأسماء الشرعية بالقياس على النحو الذي بينا في تحرير محل النزاع إلى قولين:

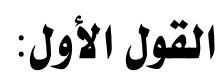

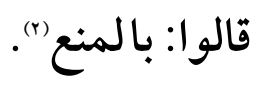

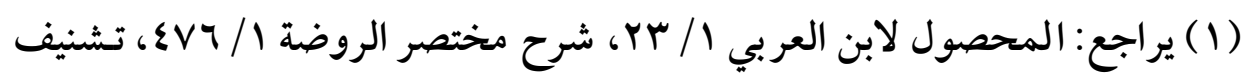

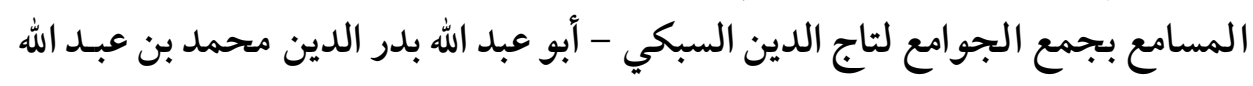

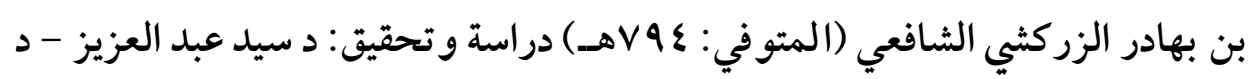

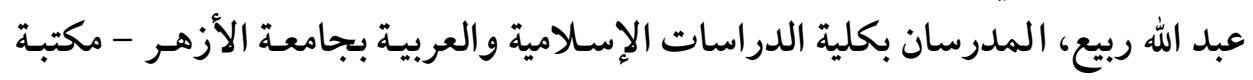

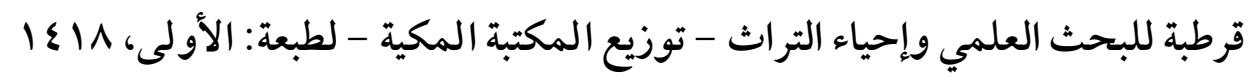
هـ -

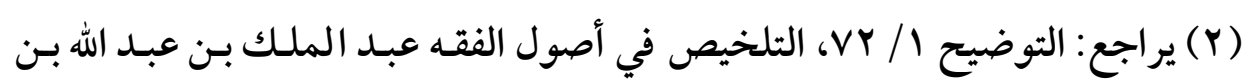

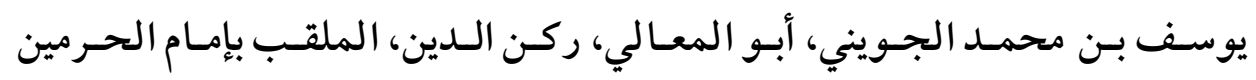


(।६•)

مناسبة اللفظ للعنى عند الأصوليين وأثرها في توجيه خطاب المجتهلين

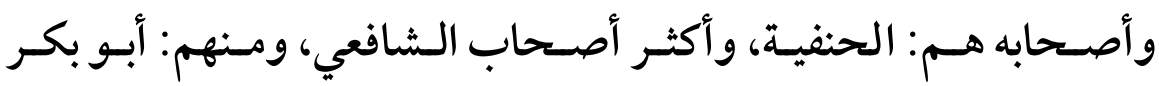

الصيرفي"، والقاضي أبو بكر ......

(المتوفي: أح هـ ) - المحقق: عبد الله جولم النبالي وبشير أحمد العمري - الناشر:

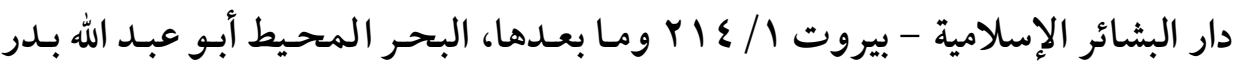

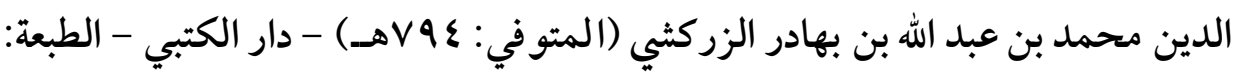

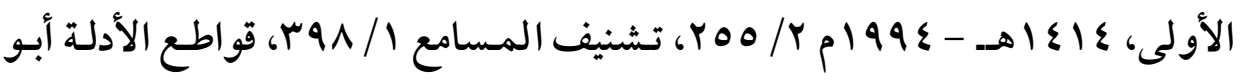

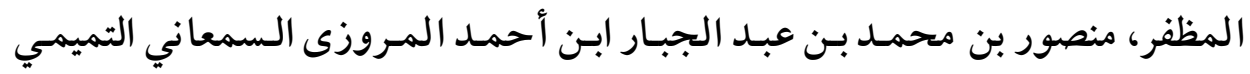

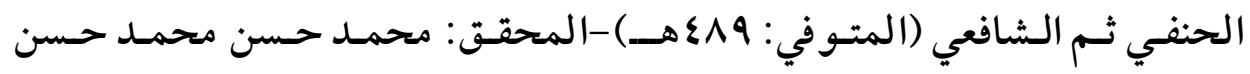

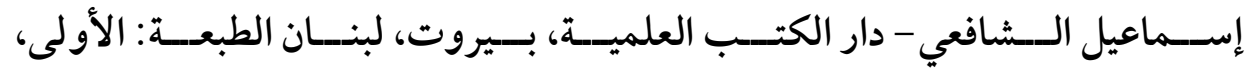

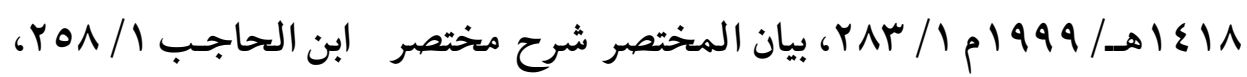

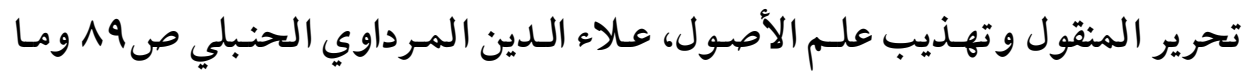

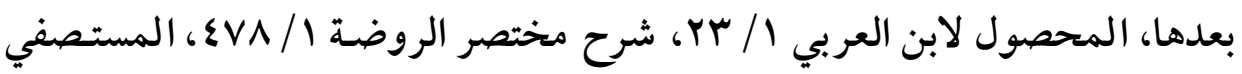

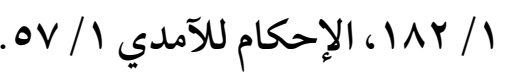

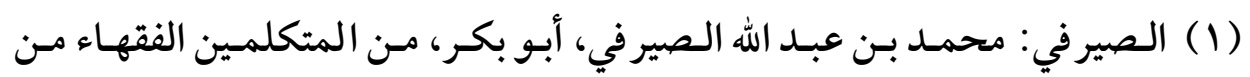

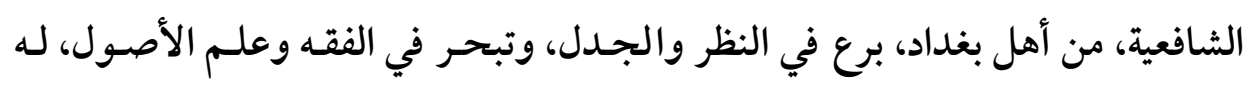

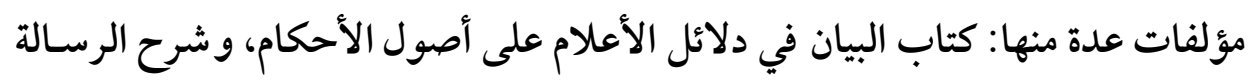
للشافعي، وغير هما، تو في بمصر سنة ثلاثين وثلاثمائة.

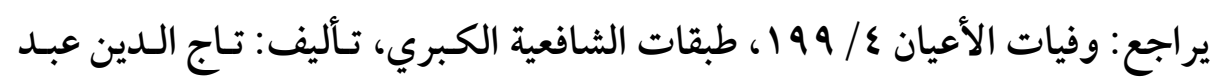

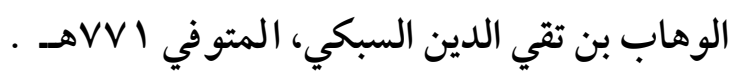

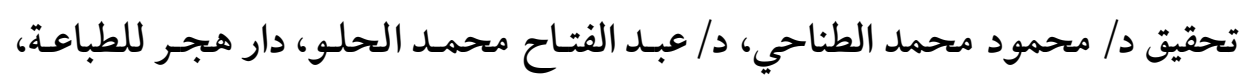

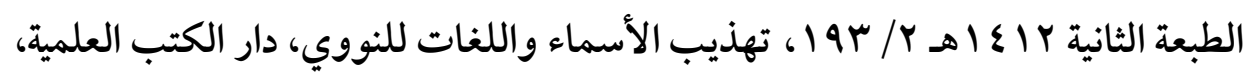

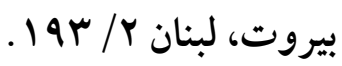


(1\&।)

وأبـو الحسين ابـن القطان(1)، وإمـام الحـرمين، والغـزالي، وابـن القـشيري وإلكيـا الطبري (r) ونقله سليم (r)عن العر اقيين وأكثر المتكلمين، واختاره ابن خويز

(1) القطان: محمد بن أحمد بن القطان، أبو الحسين القطان، مـن كبار الشافعية، لـه

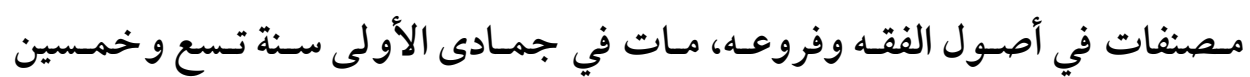

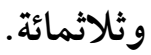

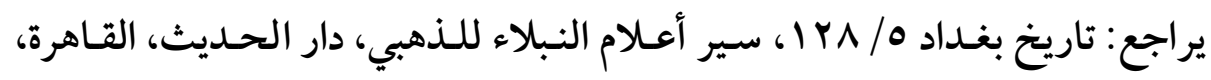

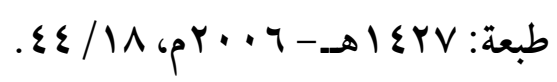

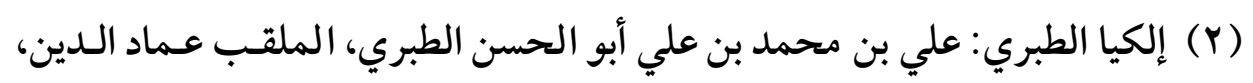

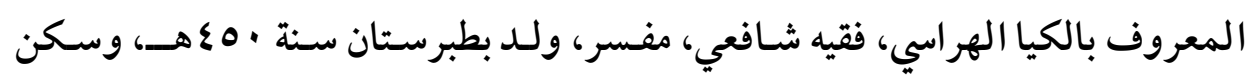

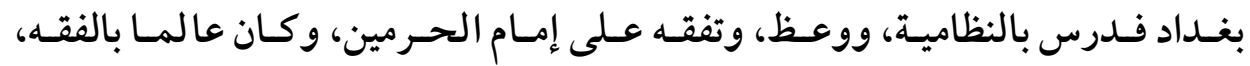

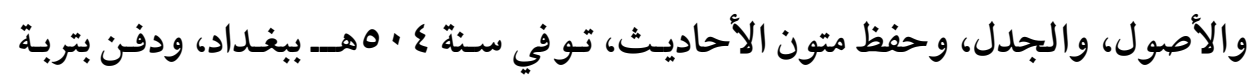

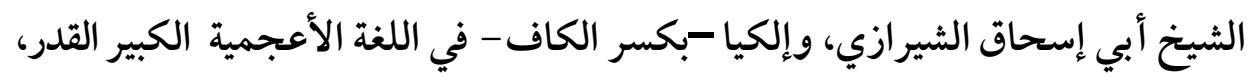
والهراسي فارسية بمعنى: الذعر.

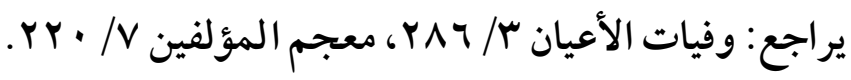

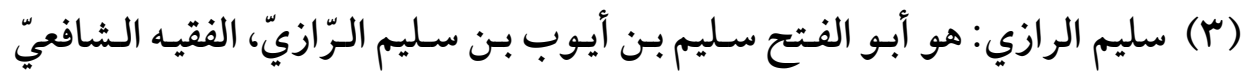

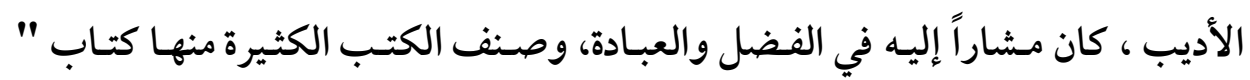

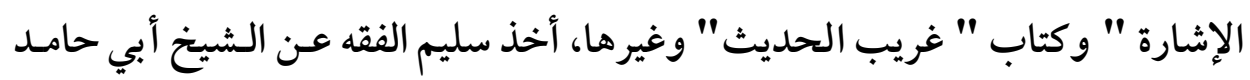

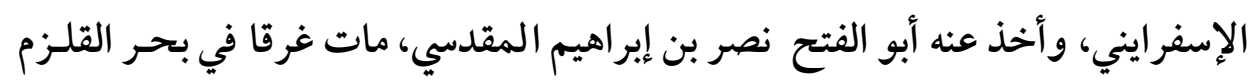

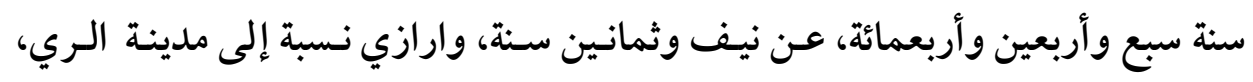
وألحقوا بها الزاي كما ألحقوها في المروزي نسبة إلى مرو. 
والآمدي، وابن الحاجب وبعض أهل الأدب كابن جني، وابن سيده (().

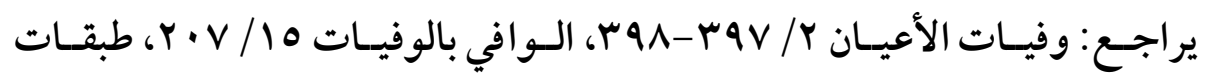

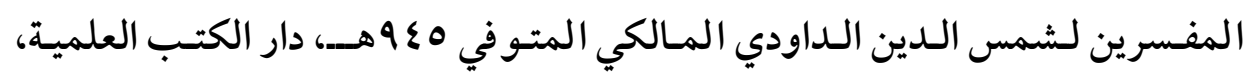

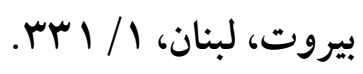

(1) ابن خويز منداد: هو محمد بن أحمد بن عبد الله بن إسحاق بن خويز منداد، الفقيه

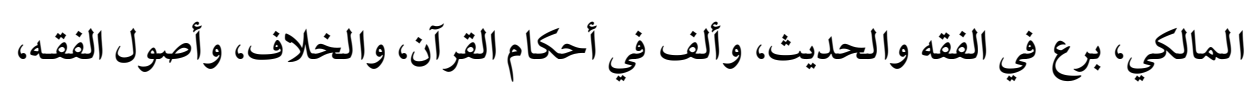

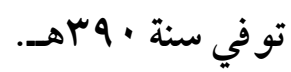

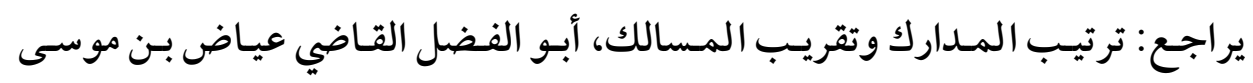

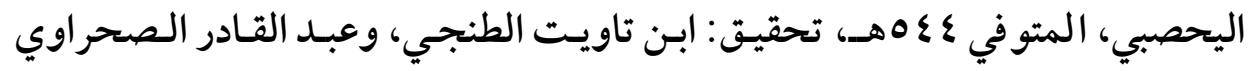

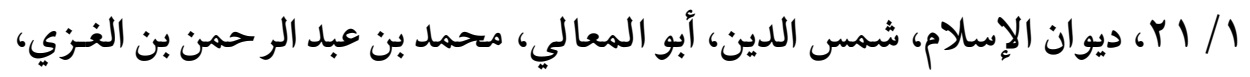

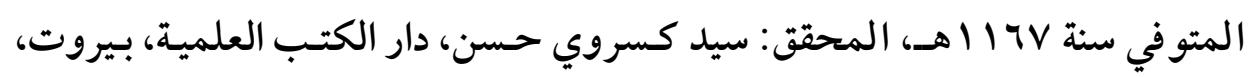

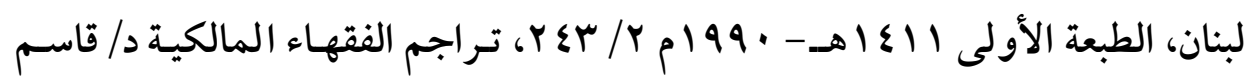

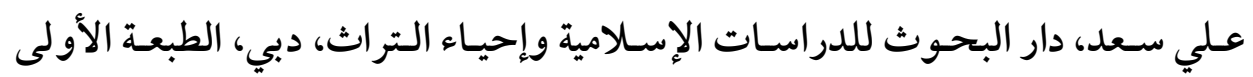

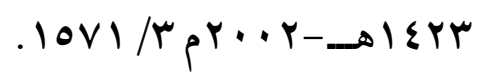

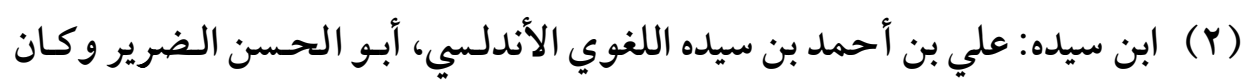

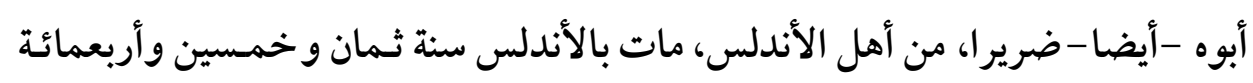

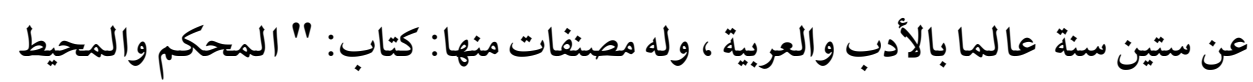

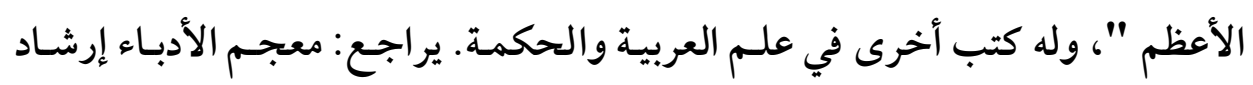

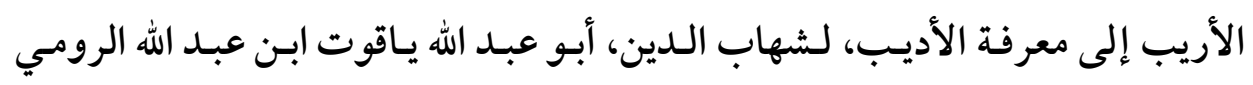

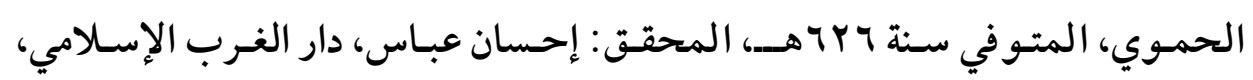

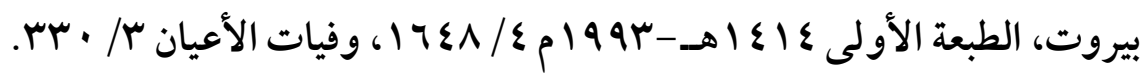


وأصحابه هم: وجه عند الشافعية منهم: ابن سريج("............. وابن أبي هريرة (r)، وأبو إسحاق الثيرازي ، والإمام الرازي، والقاضي

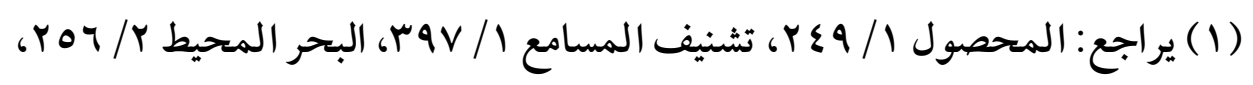

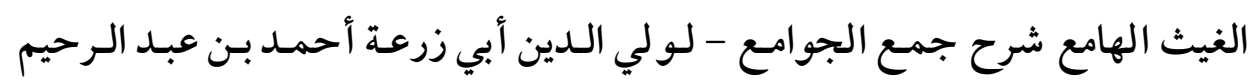

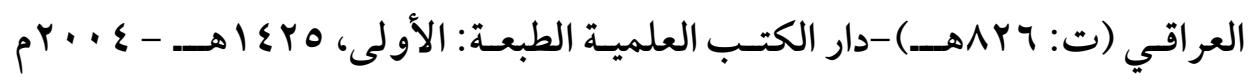

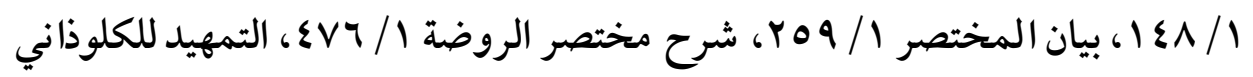

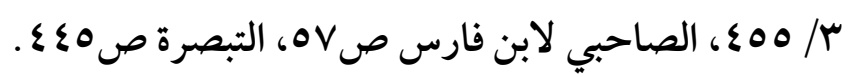

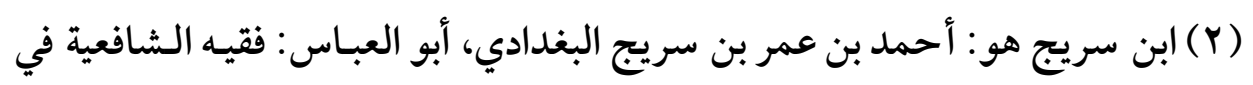

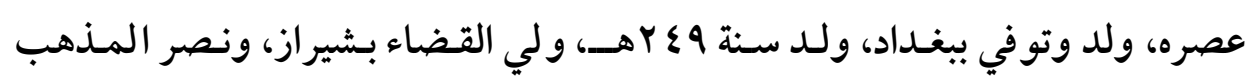
الشافعي، و كان يلقب بالباز الأشهب، وتتلمذ عليه كثير من العلماء، وله مؤلفات كثيرة أكثرها في نصرة المذهب الشافعي، وتو في ببغداد سنة ست وثلاثمائة هجرية.

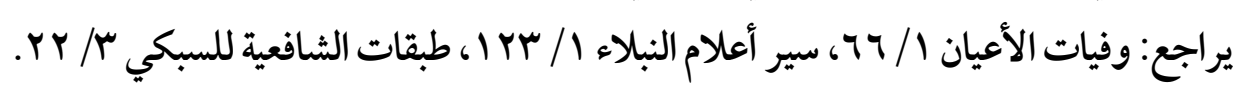

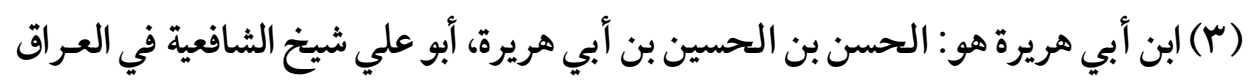

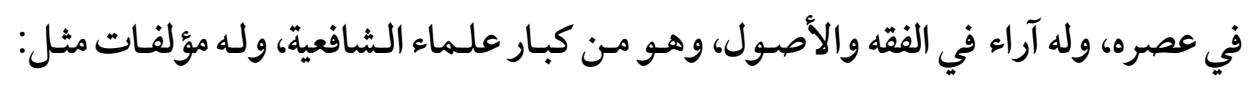

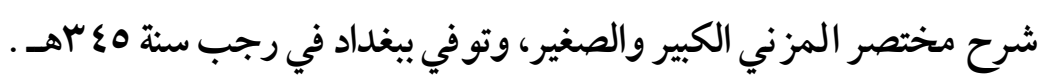

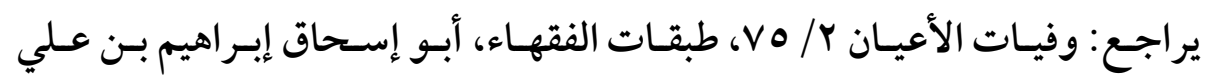

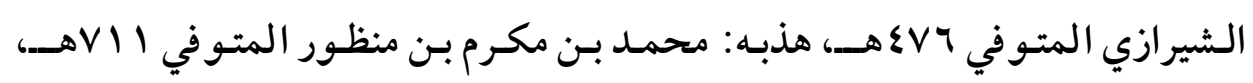

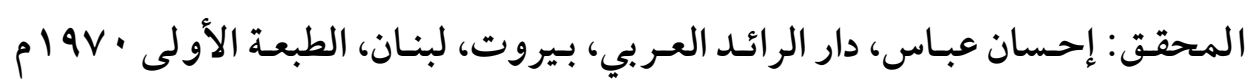

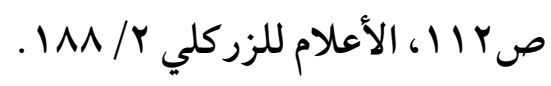


( $1 \varepsilon \varepsilon)$

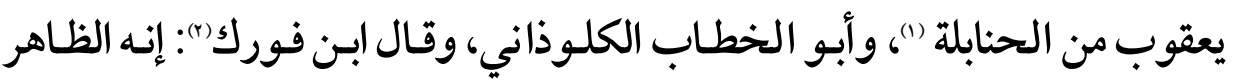
من مذهب الشافعي، ونقله سليم عن البصريين من النحويين.

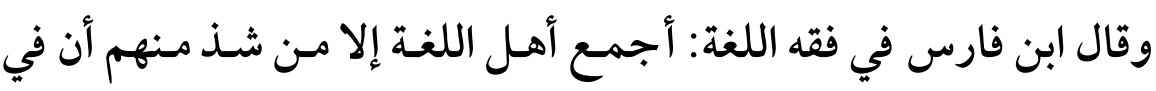
لغة العرب قياسا ونقل عن أكثر علماء العربية كالمازني ا(s) وأبي علي الفارسي"(s).

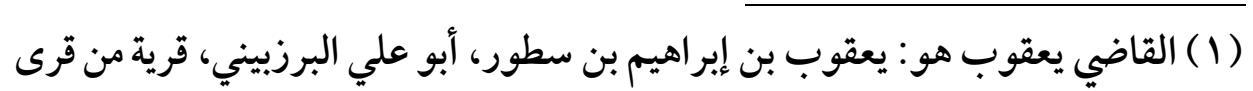

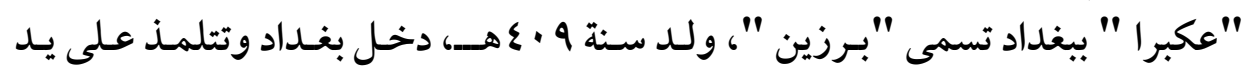

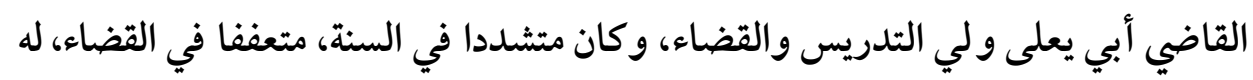

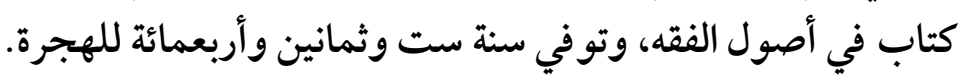

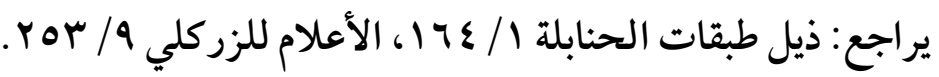

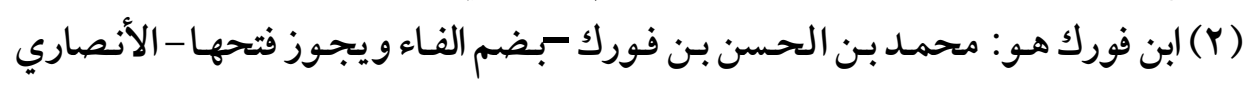

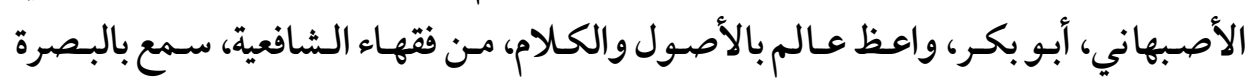

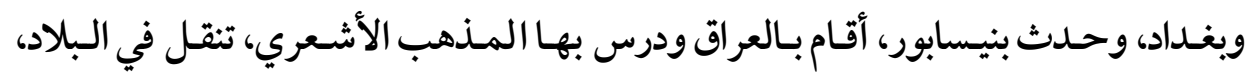

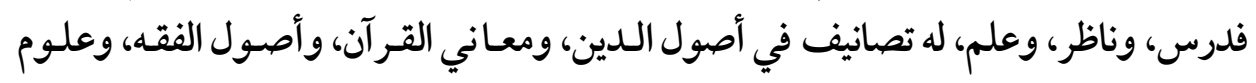

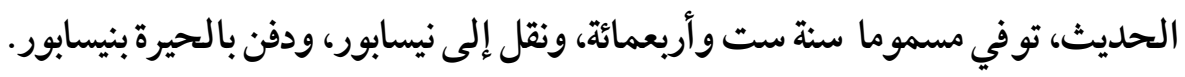

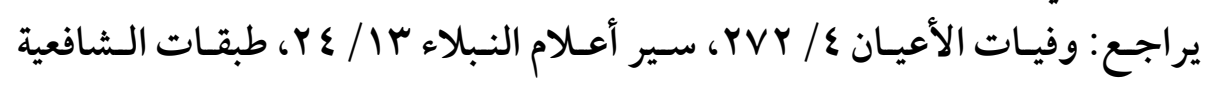

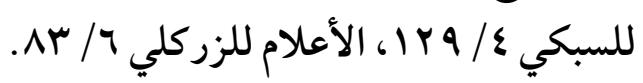

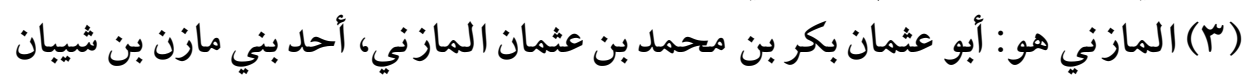

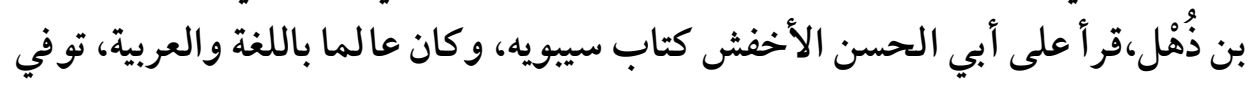

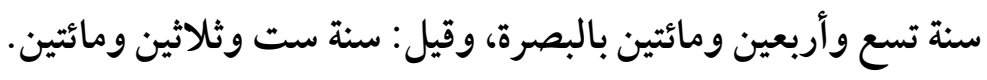

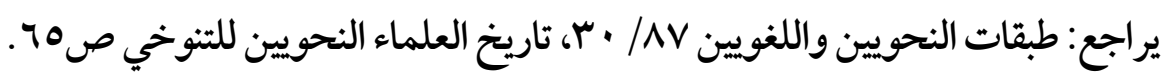

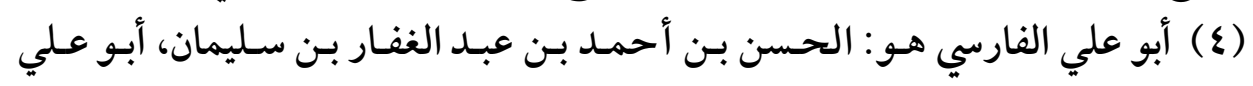

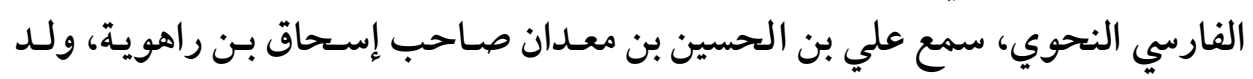

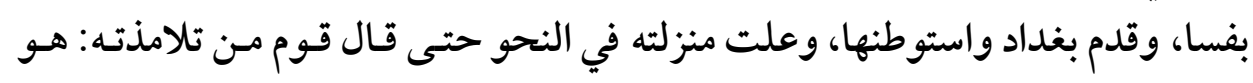




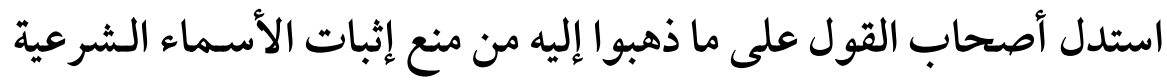

بالقياس، ونعني بذلك: منع إثبات الاسم الشرعي بالقياس على اسمّ شرعي،

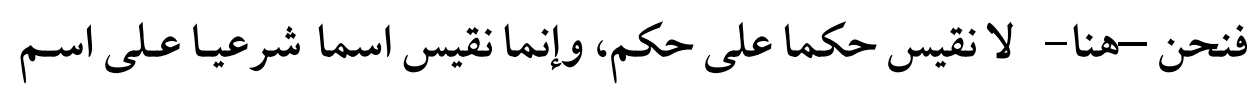

شرعي، فهو قياس في اللغة من هذه الجهة، وذلك بالأدلة الآتية:

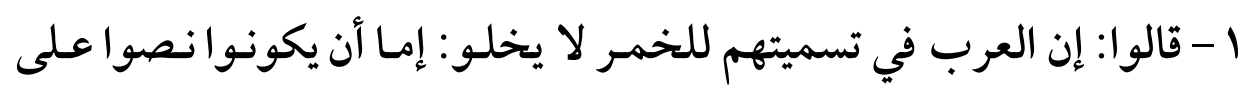
أن التخمير هو علة تسميتهم لها خمر أو لم ينصوا.

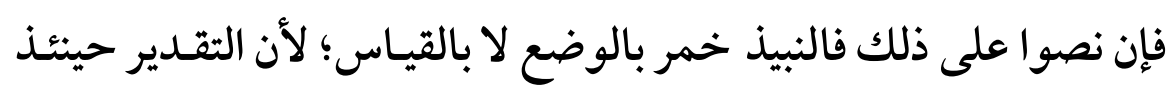

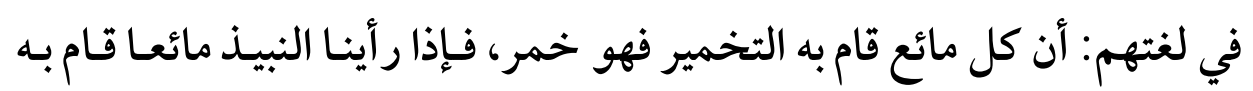
التخمير، وجب أن يكون خمر ا بنص أهل اللغة على جنسه ووضعهم لـه، كما

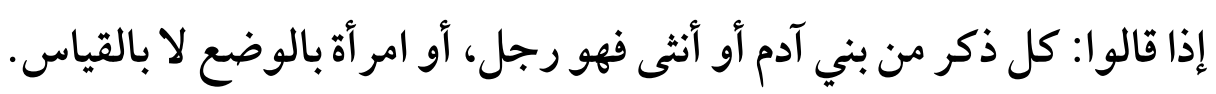

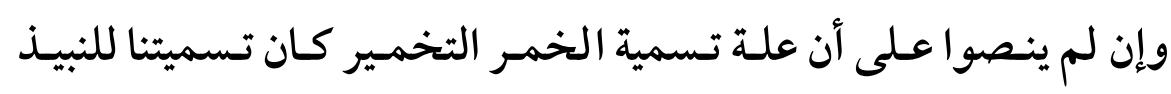

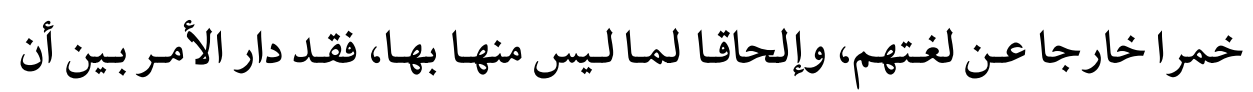

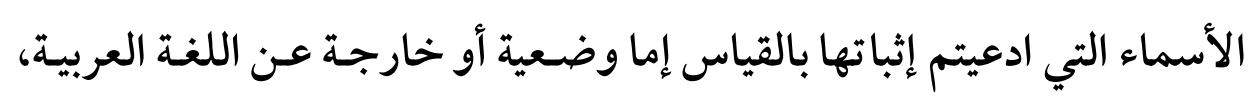

فـوق المـبرد، وأعلـم منـه، مـن مـصنفاته: الإيـضاح في النحسو، وكتـاب: المقـصور

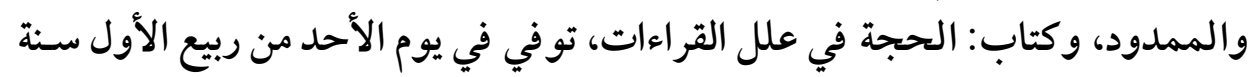
سبع وسبعين وثلاثمائة.

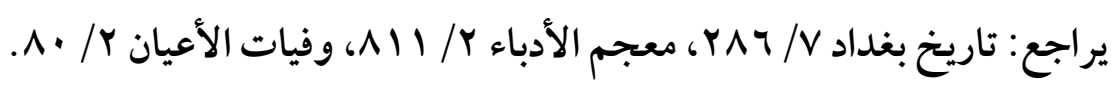


(1\&7)

مناسبة اللفظ للعنى عند الأصوليين وأثرها في توجيه خطاب المجتهلين

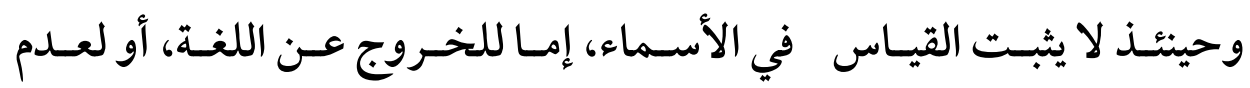

مصادفة القياس قابلا (1).

الجواب عن هذا الدليل: تقريره: لا نسلم أن شرط الجامع بين الأصل

والفرع أن يكون منصوصا عليه من جهة الوضع، بل شرطه: أن يكون مـدلولا عليه بالنص أو التنبيه، ويستخرج بالاستقراء أو الاستدلال. وبالاستقر اء في لغة العرب وجدناهم يضعون الاسـم الكلي لمعنى قائم

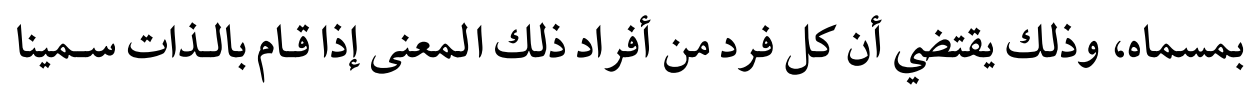
تلك الذات بذاك الاسم، مثل نص الشارع تحـريم الربـا في النقدين، وفهمنـا

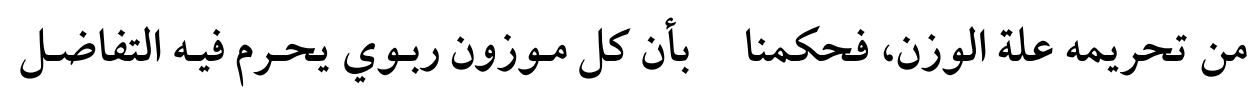

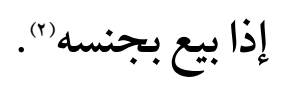

الرد على الجواب: تقريــره: لو استقل فهـم الجـامع بـحة القياس في

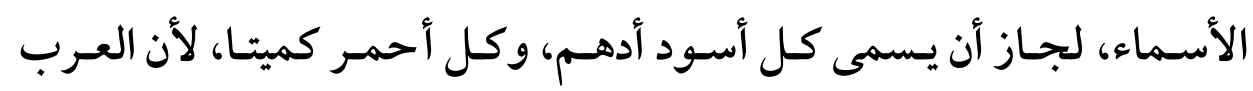
سمت الفرس أدهم لسواده، وكميتا لحمرته، ثـم لم يلحق بهـما غير هما في تسميته أدهـم و كميتـا. وذلك يمنـع مـن استقلال فهـم الجـامع بالقياس، فـلا يصح القياس في الأسماء (r).

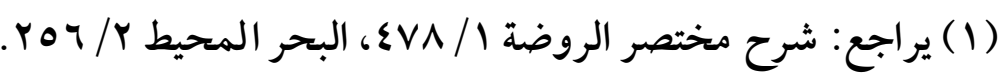

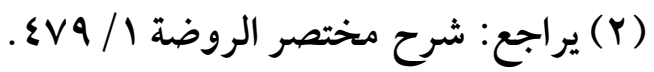

$$
\begin{aligned}
& \text { (r) (r) يراجع: المرجع السابق نفسه. }
\end{aligned}
$$


ץ - ما من شيء إلا وله اسم في اللغة توقيفا، فلا يجوز أن يثبت لـه اسـم آخـر بالقياس، كما إذا ثبت لثيء حكـم بـالنص لم يجـز أن يثبـت لـه حكـم آخـر بالقياس (1)

ب-لأن الخلاف إنما هو في الأسماء المشتثقة، والعـرف لا يلزم طرد القياس في الاشتقاق، فإنهم سموا الدابة لدبيبها، ولم يسموا كل ما دب دابة (r). ع - ولأن الخمر فسر في معنى اسمها الاضطراب، وإنما هي مـن المخـامرة أو

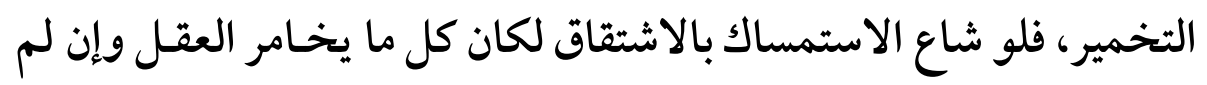

$$
\text { يضطرب يكون خمرا الن. }
$$

ه- لو جاز إثبات اللغة بالقياس لجاز إثباتها بمجرد الاحتمال، والتالي باطل

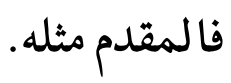
أما الملازمة: فلأنه من الجائز أن لا يكـون ذلك المعنى اللازم للمسسمى

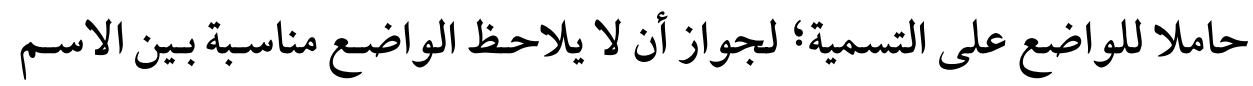

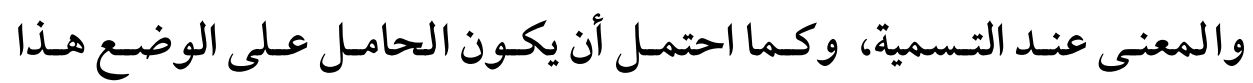

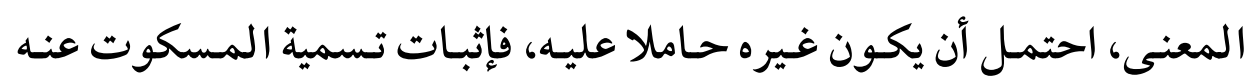
بسبب ذلك المعنى إثبات اللغة بالمحتمل .

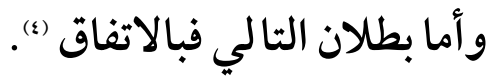

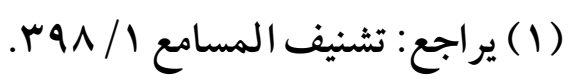

$$
\begin{aligned}
& \text { (Y) ير اجع: المرجع السابق نفسه، الموضع نفسه. }
\end{aligned}
$$

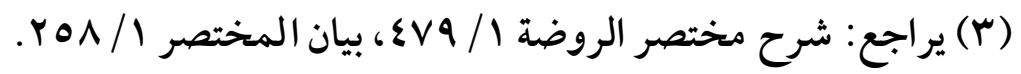

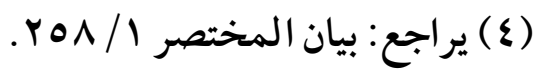


( $1 \varepsilon \wedge)$

مناسبة اللفظ للعنى عند الأصوليين وأثرها في توجيه خطاب المجتهلين

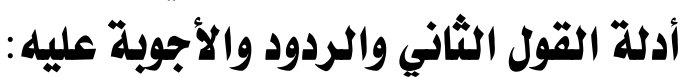
استدل أصحاب التقول الثاني على جواز إثبات الأسماء الشرعية بالثية الثياس بما

يأتي: 1 - لأن الاشـتقاق في الاســم بمنزلــة التعليـل، فكـأنهم جعلــوا المـشتق بمنزلــة الفرع، والمشتق منه بمنزلة الأصل، والمناسبة بين المعنيين بمنزلة العلة (1). الرد: لا نسلم لكم أن المناسبة بين المعنيين هنا تصلح للتعليل، فهي هنا لأولويـة تسمية الاسـم بهذا الاسـم، وليس لصحة الإطلاق حتى يقـاس عليها (). r - احتجوا -أيضا - بالإجماع على جواز القياس في الاشتقاق والنحو. الرد: ويرد بأن القياس النحوي تصرف في أحسوال الكلـم، فليس وضسا

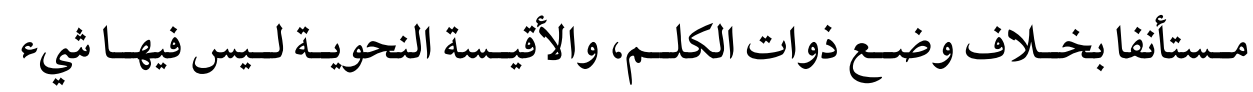
مسكوت عنه ب- قالوا: إن اسم الخمر دار مع التخمير وجودا وعدما.

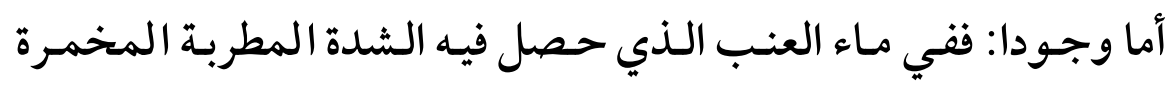
على العقل، فإنه وجد التخمير فيه ووجد الاسم ؛ فإنه يسمى في تلك الحالة

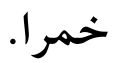

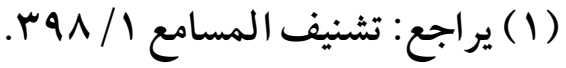

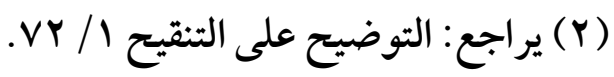

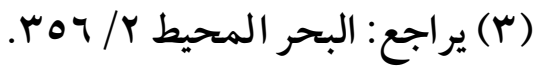


(1₹q)

وأما عدما: فقي ماء العنب الذي لم توجـد فيـه الشدة المطربـة المخمـرة للعقل، فإنه لم يوجد فيه التخمير، ولم يطلق عليه اسم الخمر.

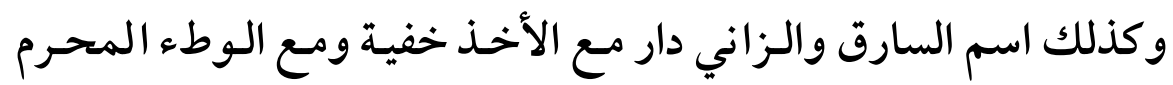

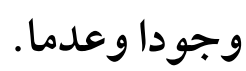
ودوران الثيء مـع الشيء آيـة كون المـدار علة للـدائر، فتكـون المعـاني المـذكورة علـة للتسمية بالأسـامي المـذكورة. فبإذا وجـدت في صسور أخـر، أطلق عليها الأسماء، وإلا يلزم تخلف المعلول عن العلة وهو محال (1). الجـواب: أن الأسماء المـذكورة كما دارت مـع مـا ذكرتم مـن المعـاني المـذكورة، كـذلك دارت مـع مـا يكسون مختـصا بالـصور المـذكورة وجـودا وعدما (r) فإن لفظ الخمر دار مع تخمير مـاء العنب، ولفظ السارق مـع أخـذ مـال الحي خفية، ولفظ الزاني مع كون الوطء المحرم قبلا.

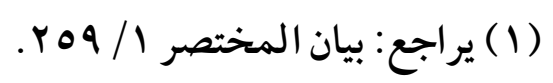

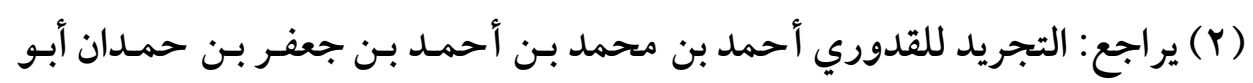

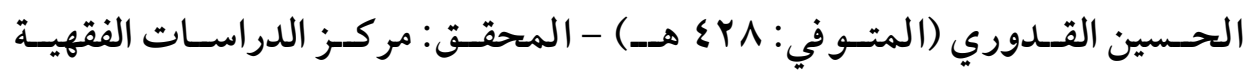

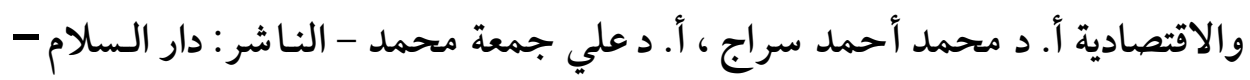

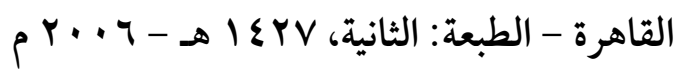


(10.) مناسبة اللفظ للعنى عند الأصوليين وأثرها في توجيه خطاب المجتهلين

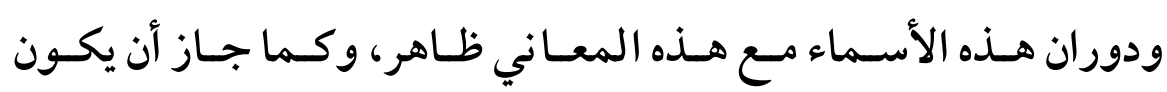

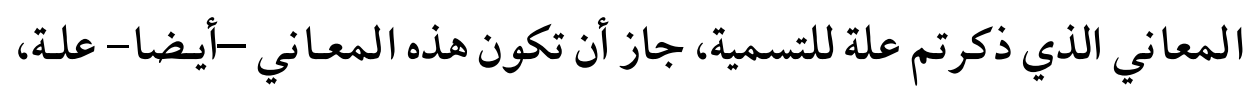
فإثبات التسمية بالمعاني التي ذكرتم إثبات بالمحتمل، وهو غير جائز (1). ع - ثبت القياس الشرعي، ومعنى القياس في الشرع وفي اللغـة واحـد؛ لأنه إثبات مثل حكم الأصل في صـورة أخـرى لأمـر مشترك بينهما، كما في ودئ

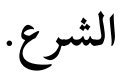

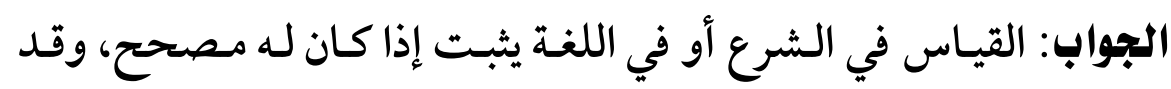
وجد مصحح لـه في الشرع وهو الإجماع، ولم يوجـد الإجماع في القياس اللغوي،لذلك لا تثبت الأسماء الشرعية بالقياس اللغوي (r).

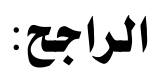
بعد عرض الأقوال والأدلة في المسألة يـترجح لـدينا القول الأول الذي : بــي

$$
\begin{aligned}
& \text { يقول: بمنع غثبات الأسماء الشرعية بالقياس، وذلك : } \\
& 1 \text { - لقوة أدلته، وسلامتها مما ورد عليها من اعتر اض. }
\end{aligned}
$$

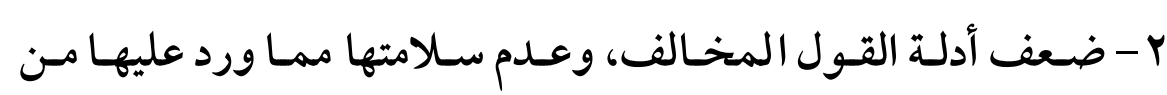

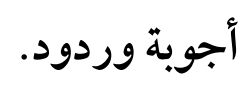

ثانيا: أثر إثبات الأسماء الشرعية بالقياس في توجيه خطاب المجتهلين:

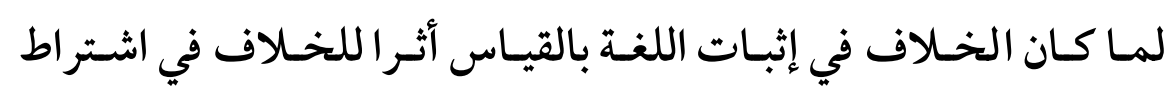
مناسبة اللفظ للمعنى، ولما كان هناك خلاف بين القائلين بوجـود المناسبة

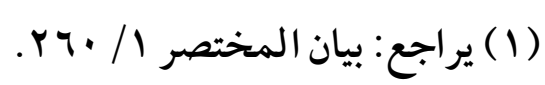

$$
\begin{aligned}
& \text { (Y) يراجع: المرجع السابق نفسه، الموضع نفسه. }
\end{aligned}
$$


بين اللفظ بمعناه اللغوي وبين المعنى الشرعي المنقول إليه في صلاحية هـذه

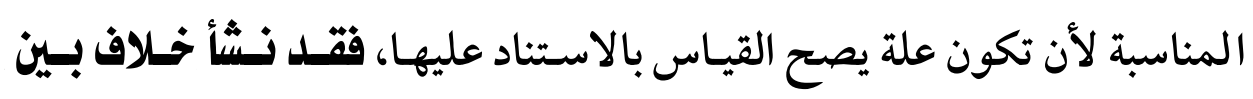
المجتهلين في علدة مسائل منها:

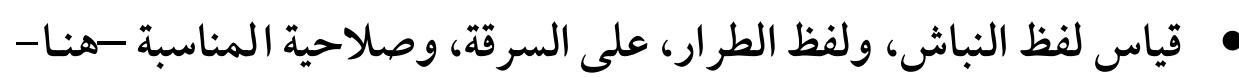

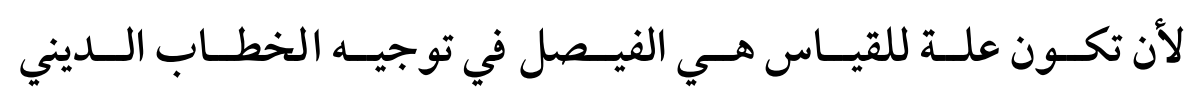
لمتجتهدين.

وقياس لفظ اللواط على الزنا، بحيـث أن كـلا مـنهما ينطبـق عليه آيـة الزنا

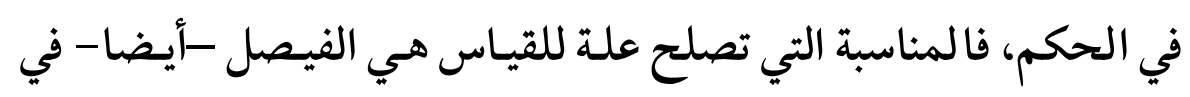
توجيه خطاب المجتهدين في هذه المسألة.

وقياس لفظ النبيذ على لفظ الخمر، فهل المناسبة تصلح لأن تكون علة فئة لهـذا القيـاس؟ خـلاف حصل بـين المجتهـدين في ذلك، يغنينـا اعتبـار المناسبة عن الحيرة عند ترجيح أقوال المجتهـين، وتكون القاعدة التي إليها يرد توجيه الخطاب الديني عند المجتهدين. وسـوف نستعرض هـذه المـسائل باعتبارهـا الأثر المترتـب عـلى إثبـات الأسماء الشرعية بالقياس في توجيه خطاب المجتهـدين، وذلـك على النحسو

المسألة الأولى: قياس النباش على السارق. المسألة الثانية: قياس الألائط على الزاني. المسألة الثالثة: قياس النيانيذ: قياس الانيط على الخمر. 


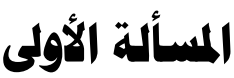

\section{قيساس النباش على السارق}

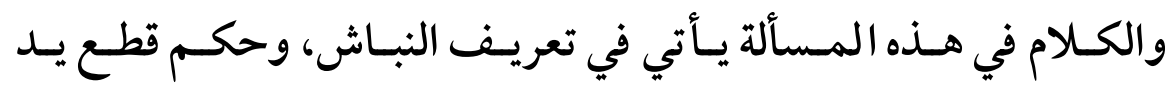

النباش، الأقوال وأدلتها، والر اجح منها، وذلك كله على النحو الآتي:

النبـاش في اللغــة: النبـاش فعلـه: نـبش، والنـبش: اسـتخر اجك الـشيء

المدفون، ومنه سمي النباش.

ونبش البقل والميت: أي: استخر جه، وبابه: نصر ومنه: النباش.

والنبش: إبراز المستور و كثف الثيء من الثيء.

والمختفي: النباش؛ لأنه يستخرج الأكفان (1).

ويشتبه معنى النباش -بالمعنى الذي ذكرناه- بمعنى الطر ار، والسارق.

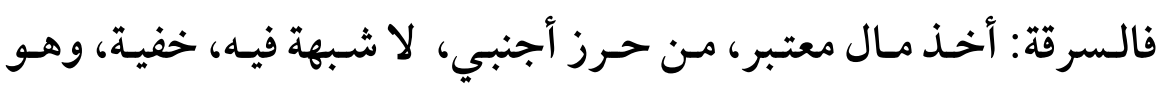

قاصد للحفظ في نومه أو غيبته.

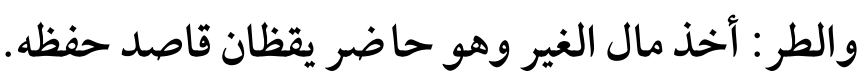

(1) يراجع: جمهـرة اللغـة أبو بكـر محمـد بـن الحسن بـن دريـد الأزدي (المتوفي:

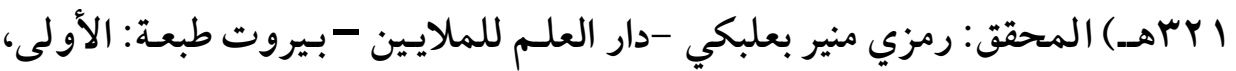

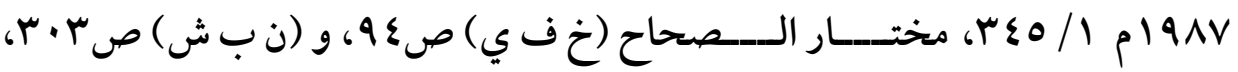
والقاموس المحيط مجد الدين أبو طاهر محمدل بـن يعقوب الفيروزآبادى (المتوفي:

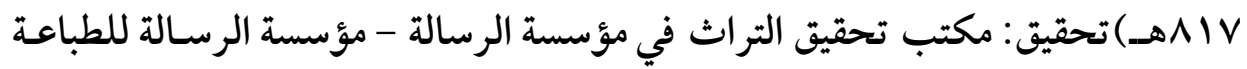

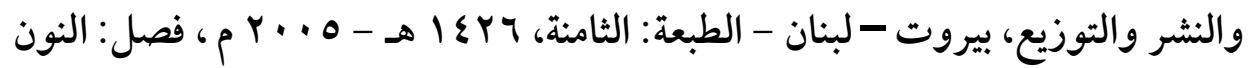

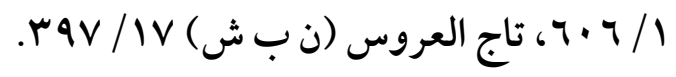


(lor)

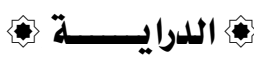

وفعل كل واحد مـنهم وإن كان يشبه فعـل الآخـر، لكـن اخـتلاف الاسـم

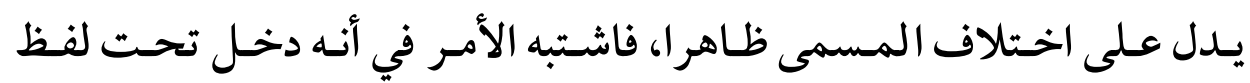
السارق حتى يقطع كالسارق أم لا.

فنظـر بعـض العلمماء في السرقة فوجـــها جنايـة لها عقوبـة مقـدرة مسن

$$
\text { الشارع وهي قطع اليد. }
$$

أما الطر : فهو -أيضا- جناية، وهو في المعنى أقوى مـن السرقة؛ لزيادة

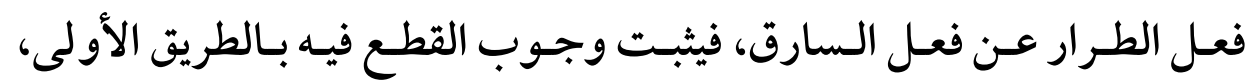
كثبوت حرمة الضرب في حق الأب بحرمة التأفيف.

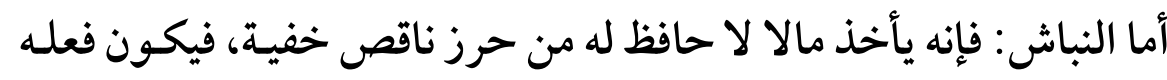

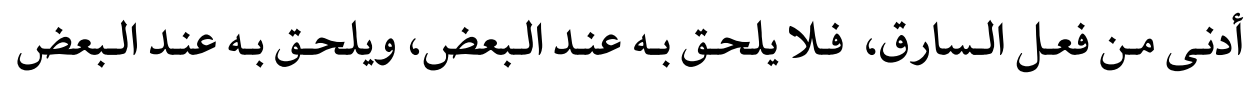

الآخر (1).

فالنباش اصطلاحا: هو الذي ينبش القبور، ويأخذ كفن الميت.

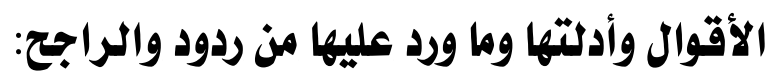

اختلف المجتهدون في إلحاق لفظ النباش بلفظ السارق، حتى إنه تقطع

يده كالسارق، وتنطبق آية السرقة عليه إلى قولين:

(1) يراجع: الكليات لأبي البقاء الكفوي، فصل: السين صع اهـ، البناية شرح الهداية

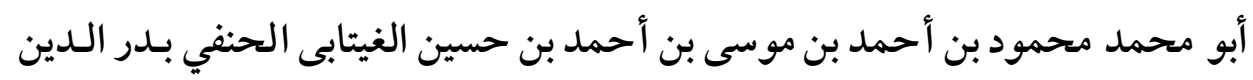

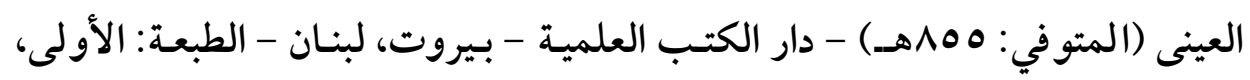
.rV/VPr...- - D I I r. 
$(10 \varepsilon)$ مناسبة اللفظ للعنى عند الأصوليين وأثرها في توجيه خطاب المجتهلين

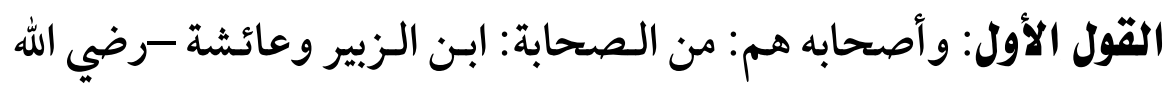
عنهما. ومسن التابعين: عمـر بـن عبـد العزيزز، والحسن البـري -ـرحمهما اله تعالى -. ومن الفقهاء: إبر اهيم النخعي، وحمـاد بـن أبي سـليمان، وربيعـة بـن أبي

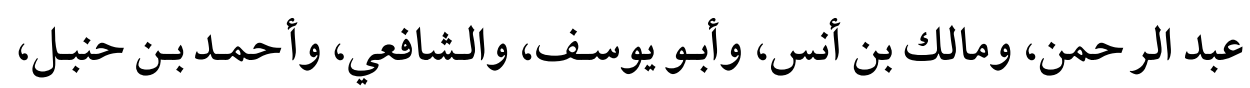
وإسحاق بن راهوية، وأبو ثور، وابن المنذر. قالوا: النباش: هو الذي ينبش القبور ويسرق الأكفـان، فيجـب قطع يـده، ويأخذ حكم السارق ....... وتنطبق عليه آية السرقة، ويكون كالسارق سواء بسواء (1).

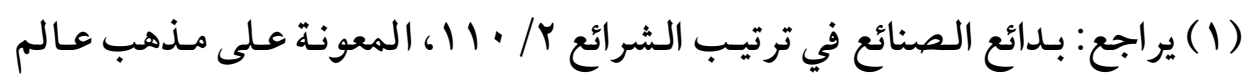

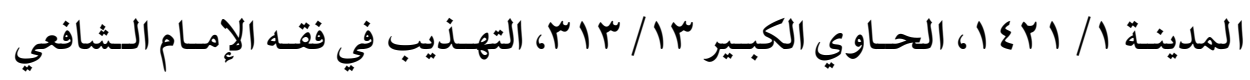

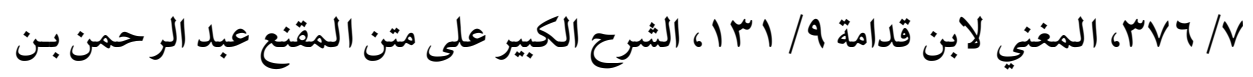

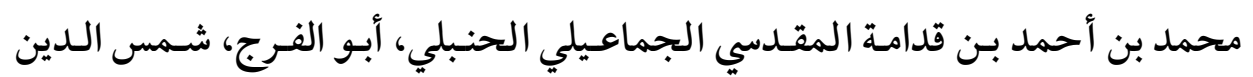

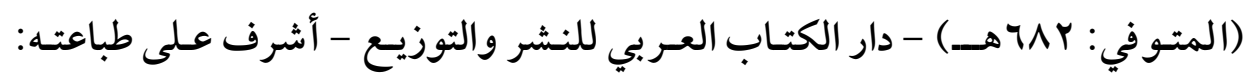

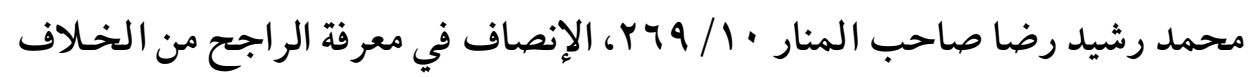

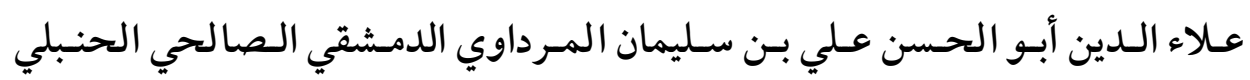

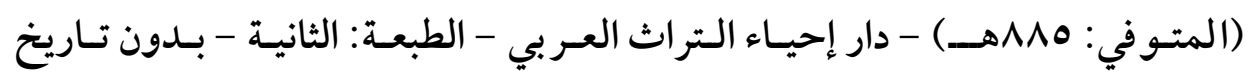

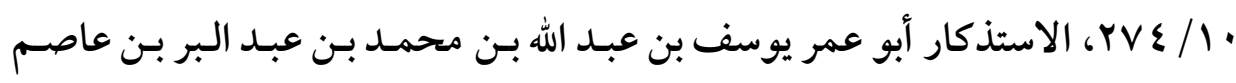

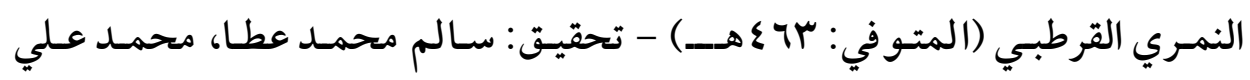

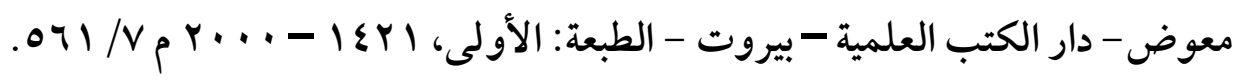


$(100)$

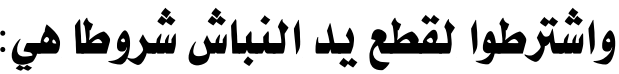

1 - أن يكون القبر في مقابر البلد الأنيسة، فإذا كان القبر منقطعاعـاعن الأمصار

فلا قطع فيه.

Y - أن يكون القبر عميقا على معهود القبور، فبإن كان الـدفن قريبـا مـن ظاهر

$$
\text { الأرض فلا قطع فيه. }
$$

ץ- أن يخرج الكفن من جميع القبر بعد تجريده عن الميت، فيإن أخرجهه مـع

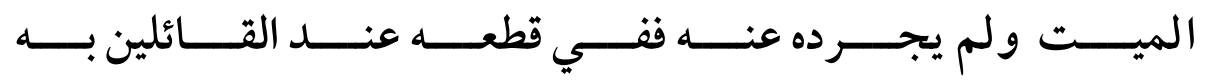

وجهان(1).

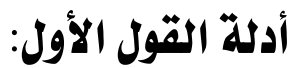

\section{استدل من قال بقطع يد النباش بأدلة منها ما يأتي:}

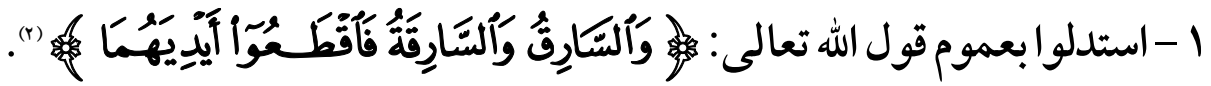

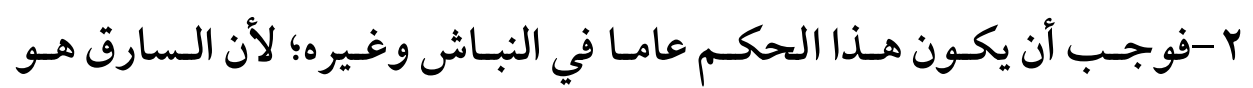

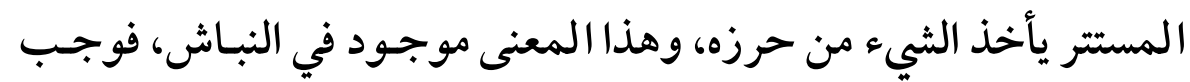

$$
\text { أن يكون سارقا (r). }
$$

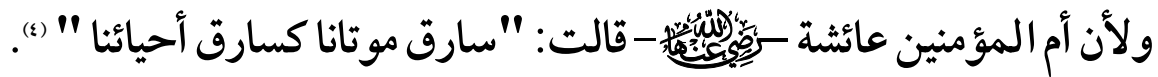

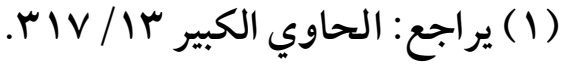

$$
\begin{aligned}
& \text { (Y) جزء الآية رقم: ^^ من سورة المائدة. }
\end{aligned}
$$

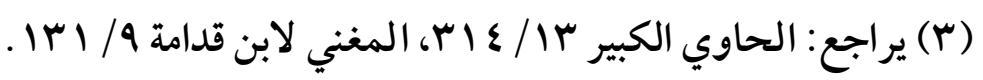

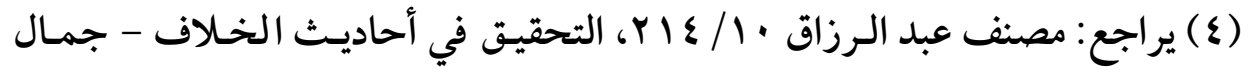

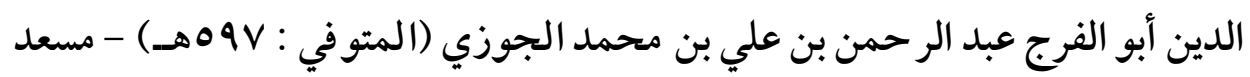

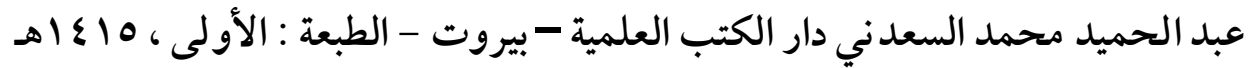


$(107)$ مناسبة اللفظ للعنى عند الأصوليين وأثرها في توجيه خطاب المجتهلين

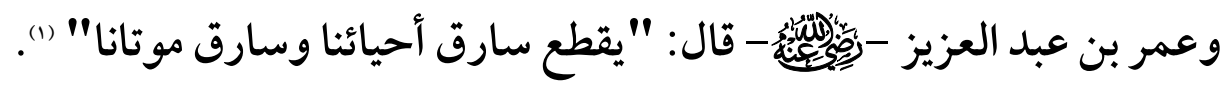
فسمياه سارقا، وقو لهما حجة.

الجواب: أجـاب المخـالفون بأن النباش ليس بسارق لاختصاصه باسـم النبـاش دون السارق، فلا قيـاس عنـدنا في اللغـات؛ لأن المناسبة بـين اللفظ والمعنى لا تصلح لأن يعلل بها حتى يحكم بالقياس، ولأن إفراد الفعل باسـم يدل على أنه لا يشارك غيره في اسمه.

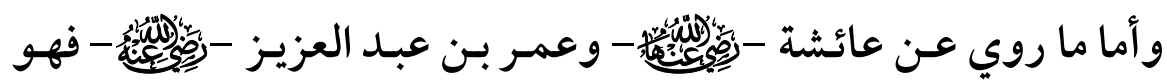
محمول على سارق مال البيت، ولو ثبـت أنها قالت ذلك في الكفـن فلـيس بيانا للاسم، وإنما هو بيان للحكم؛ لأنهم لا يعلمون الأسماء، فكأنها قالت حكمه حكم السارق (r)

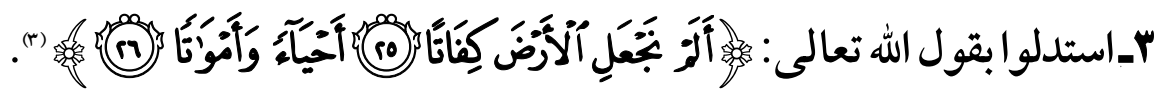

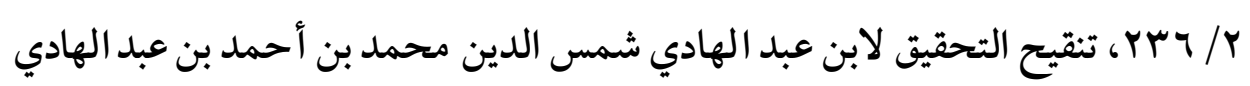

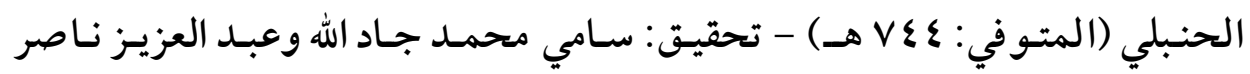

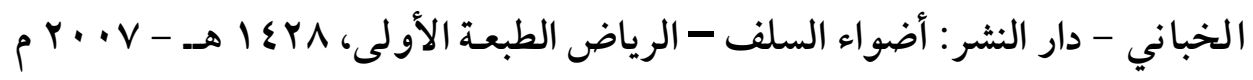
.07r/乏

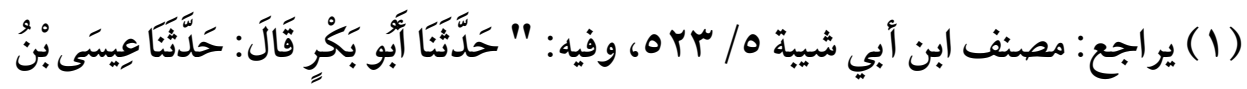

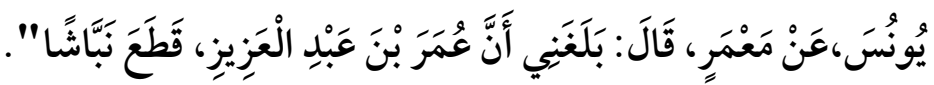

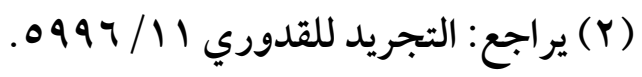
(r) الآيتان: O-Y-צr من سورة المرسلات. 
وجه الدلالة: إن معنى الآية: أي: نجمعهم أحياء على ظهرهـا، ونضمهم أمواتـا في بطنها، فجعل بطنها حرزا للميت كما جعل ظهرها حرزا للحي، فاستويافي

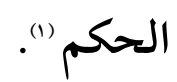
الجواب عن هذا الدليل: أجاب المخالفون عن هذا الاستدلال بقو لهم:

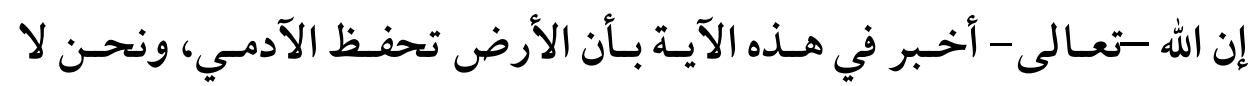
نخـالف في ذلك، فإذا كانت الأرض حـرزا للآدمي فلا يلزم ذلك أن تكـون حـرزًا للكفـن؛ لأن المخــالف يـــى أن الموضـع قـد يكـون حـرزًا لـشيء دون شيء. ثـم الكفـن معنـاه: الـضم، فـأخبر الله -سـبحانه تعـالى - أن الأرض تـضم

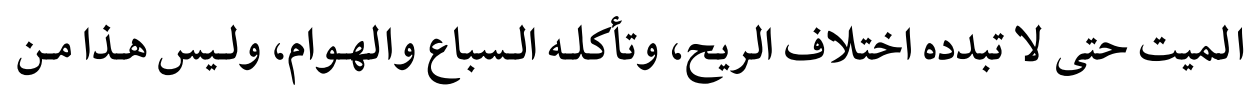
الحرز في شيء (r) - مئ.

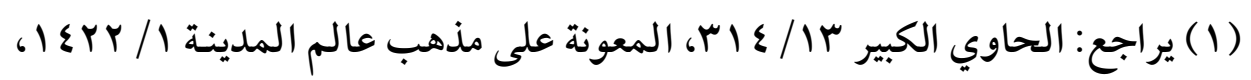

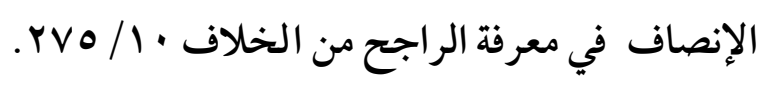

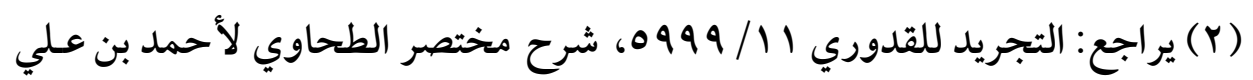

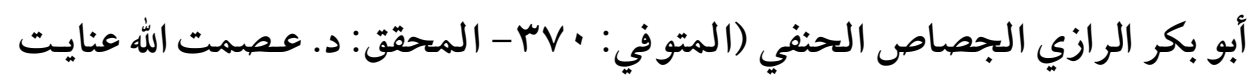

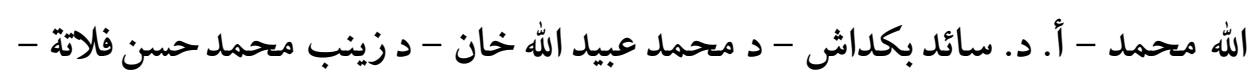

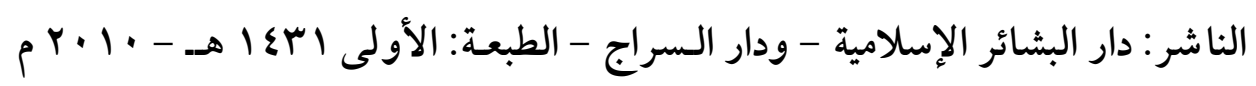

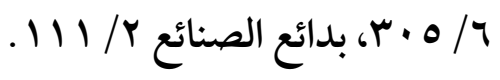


$(101)$ مناسبة اللفظ للعنى عند الأصوليين وأثرها في توجيه خطاب المجتهلين

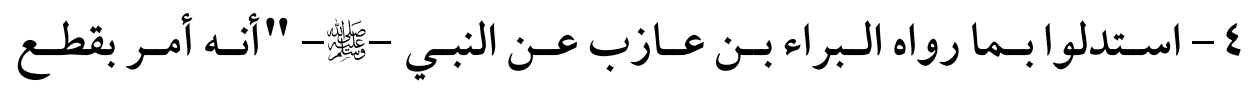
المختفي"

قال الأصمعي: " وأهـل الحجـاز: يسمون النبـاش المختفي؛ لاختفائهـ

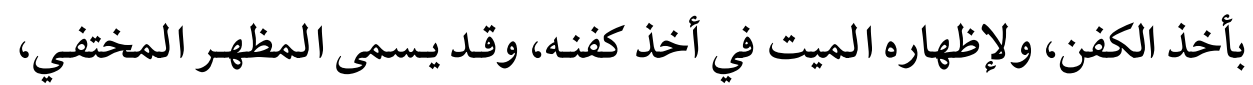

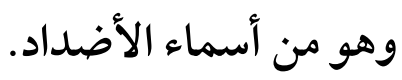

الجـواب: أجـاب المخــالفون بـأن هـذا الخـبر منكـر، لا أصـل لـه، ومثلـه أخر جه البيهقي وصرح بضعفه عن عمـران بـن يزيـد بـن البراء بـن عـازب عـن أبيه عن جـده: " مـن سرق حرقنـاه، ومـن غرق غرقنـاه، ومـن نبش قطعنـاه " فني سنده من يجهل حاله كبشر بن حازم وغيره (1).

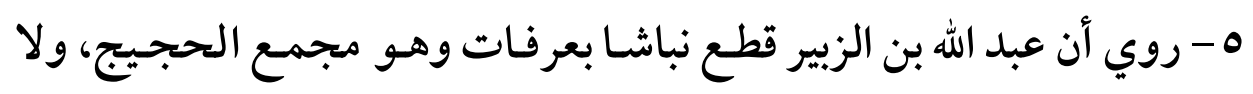
يخفي ما يجري فيه على علماء العصر، فما أنكره منهم منكر (r). الجواب: أن هذه الرواية ضعيفة، فقد ذكر البخاري في تاريخه هـذا الخبر ثم أعله بسهيل بن ذكوان المكي، قال عطاء: كنا نتهمه بالكذب.

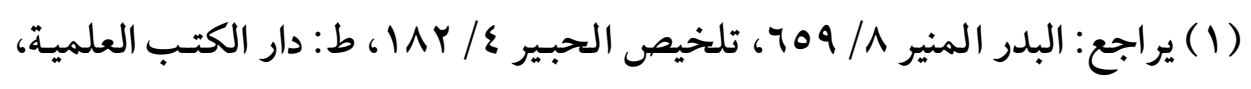

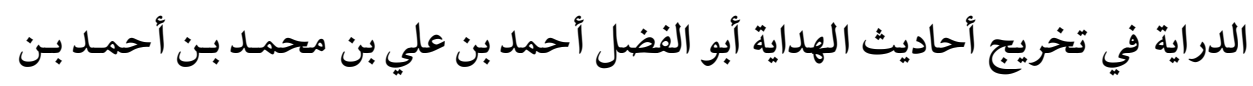

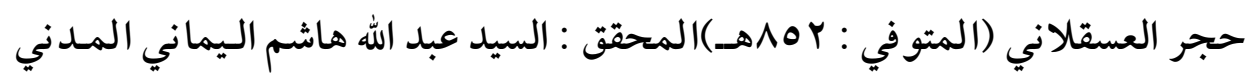

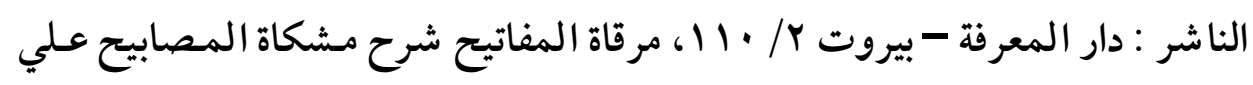

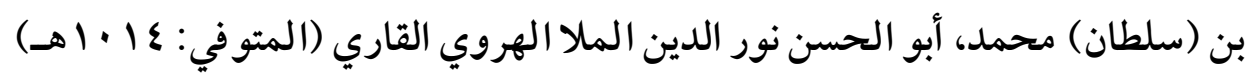

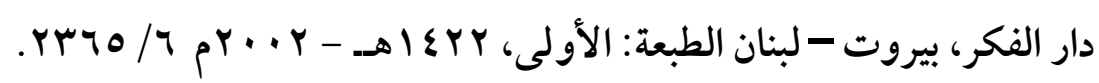

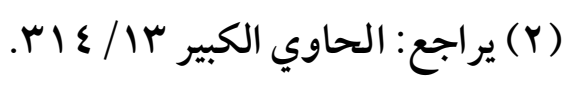


(109)

وعلى القول بصحة الاستدلال به: فإنه يجوز أن يكون نباشـا سرق فقطع

$$
\text { بسرقته، وعرف فعل النبش وإن قطع بغيره. }
$$

أو يحمل ذلك على السياسة، أو على أنه من الساعي في الفساد (1).

ج - قالوا: إن الميت عورة يجب سترها، فجاز أن يجـب القطع في سرقة مـا

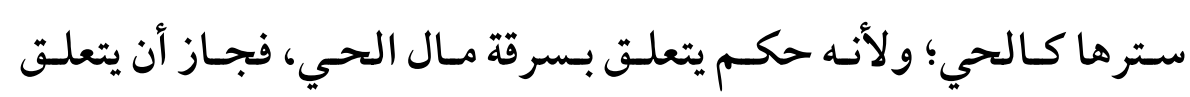

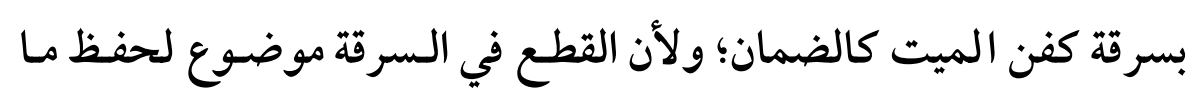

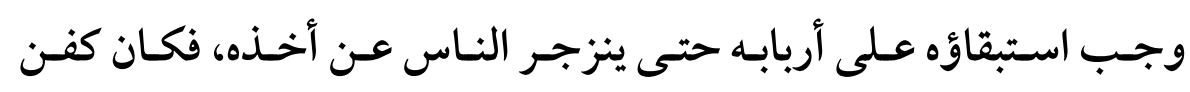

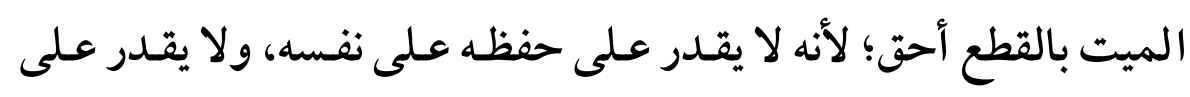
مثله عند أخذه (r). الجواب: يجـاب عـن الأقيسة السابقة بأنها أقيسة مـع الفـارق، فبإن بـاب الضمان أوسع، والقطع أضيق لت.

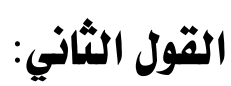

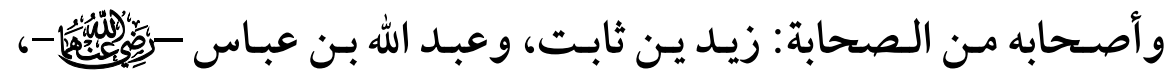
وبعض التابعين، ومن الفقهاء: أبو حنيفة، و محمد، والثوري.

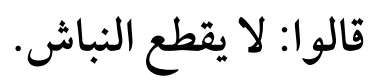

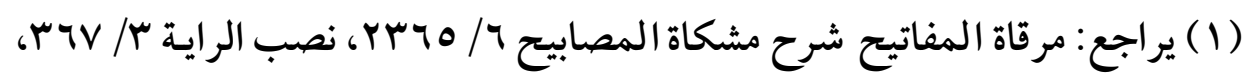

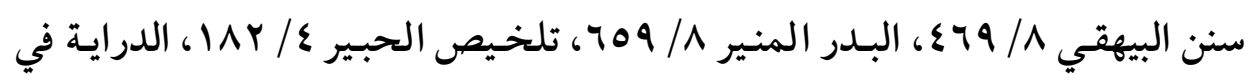

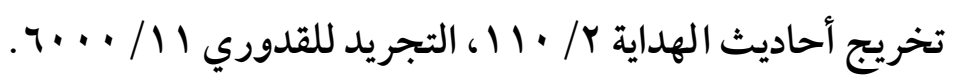

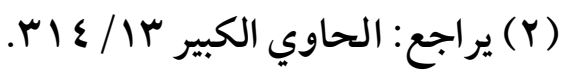

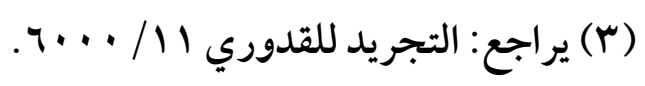


استدل أصحاب القـول الثاني بـأن النبـاش يعزر، ولا تقطع يـده؛ لأنه لا

$$
\text { يعد سارقا، وذكروا أدلة كثيرة منها: }
$$

1 - أنهم خصوه باسـم فقالوا: نباش، فلا يسمى سـارقا، وطريق التفريق في

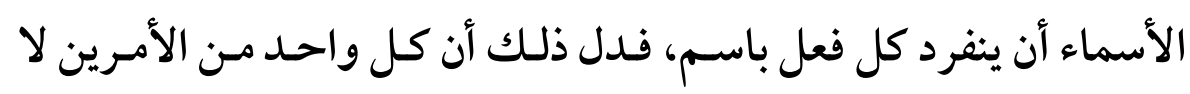

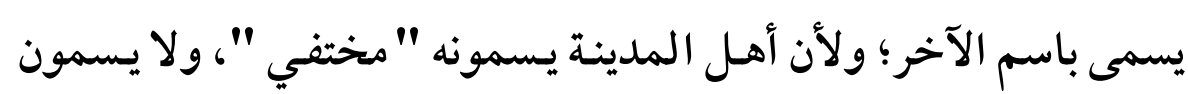

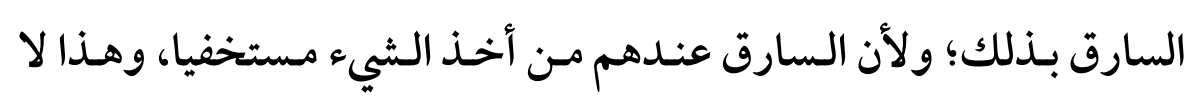
يكون إلا فيما أخذ وهو محفوظ، وهذا لا يوجد في الكفن.

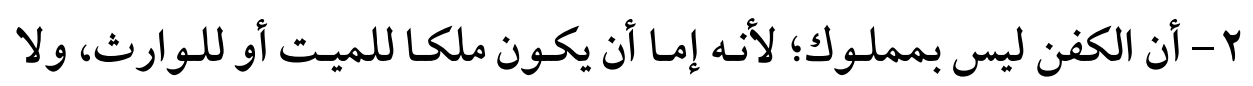

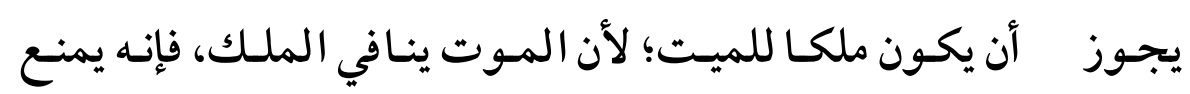
البقاء على الملك، فأولى أن يمنع الابتداء، وليس ملكا للوارث باتفاق.

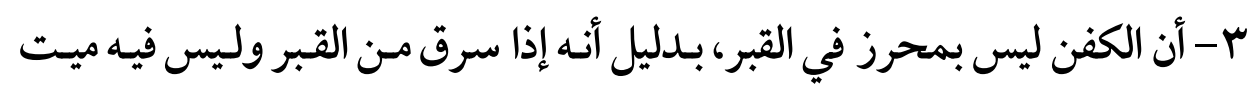

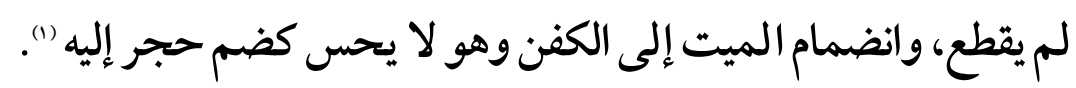

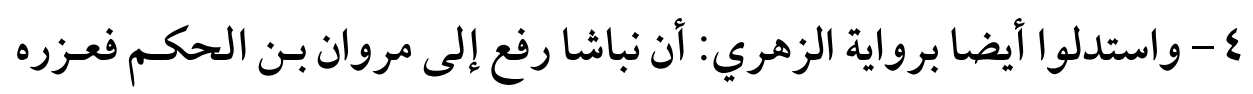

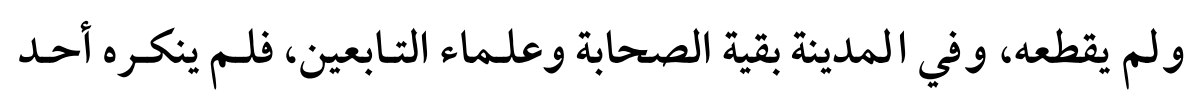
منهم

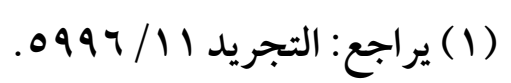

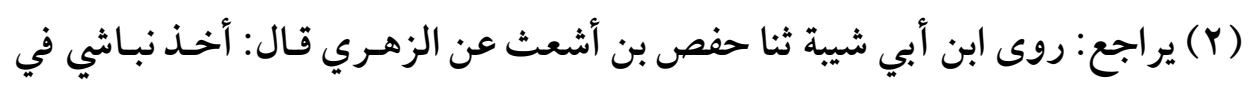

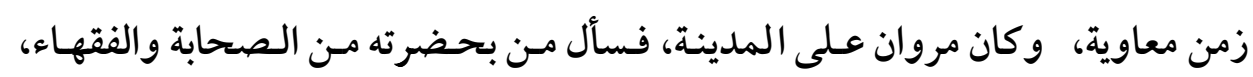


بعد عرض الأقوال السابقة في حكم النباش، نلاحظ أن القول فيها مبني على الخلاف في مسألة القياس في اللغة. فبيـنما يـرى الحنفيـة وبعـض الـشافعية أنـه لا قيـاس في اللغـات؛ لعـدم

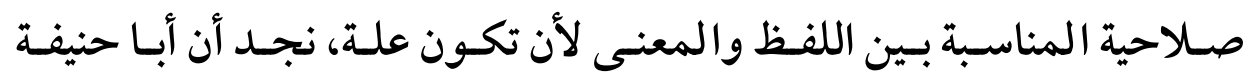

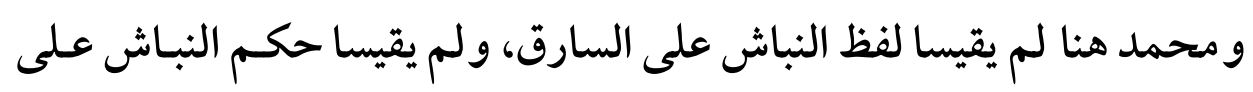
حكم السارق أيضا. بيـما يـرى الجمهـور مـن العلـماء أن لفظظ النبـاش يقـاس على السارق، وهناك ثلاثة طرق لإثبات حكم النباش: 1 - قياس لفظ النباش على السارق وهو قياس في اللغة.

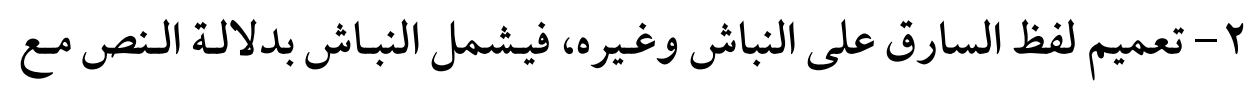
تحقق شروط تطبيقها. ب- قيـاس النبـاش عـلى السارق في الحكـم، وهـو قيـاس في الحـدود، وفيـه خلاف بين العلماء. وبناء على ما ذكرناه ورجحناه في مسألة مناسبة اللفظ للمعنى، ومسألة عدم صلاحية المناسبة لأن تكون علة، ومسألة عـدم جـواز القياس في اللغـة، فأجمع رأيهم على أن يضرب ويطاف به. يراجع: مصنف ابن أبي شيبة / ع ؟ ه، مرقاة

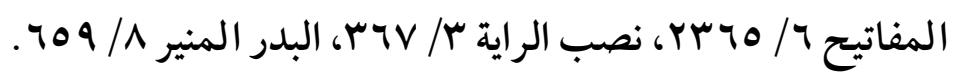


$(17 r)$

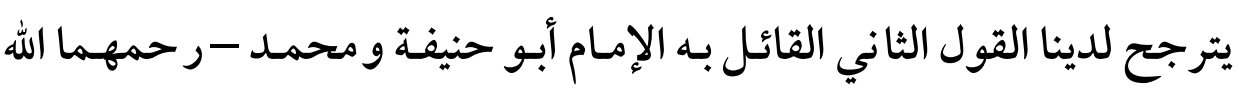
تعالى -؛ وذلك لما يلي: 1 - قوة أدلته وسلامتها من الاعتر اضات. r - ضعف أدلة القول الأول؛ لعدم سلامتها من الردود عليها. r- قوة الآثار التي استدل بها أصحاب القول الثاني.

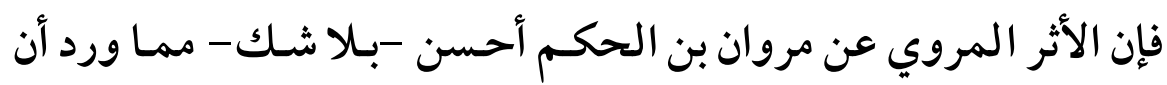

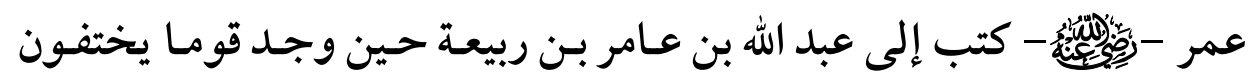
القبور باليمن" أن اقطع أيديهم" "(1). وهكذا نجد أن الحنفية لم يتوسعوا في باب الحدود؛ لأن بابها التضييق، وظهر أن المناسبة بين اللفظ والمعنى هي التي وجهت أقوال المجتهدين. 楼楼楼

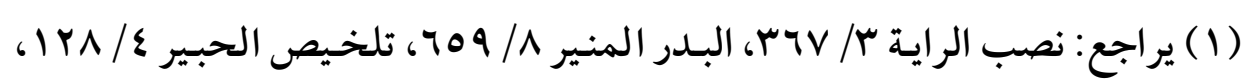

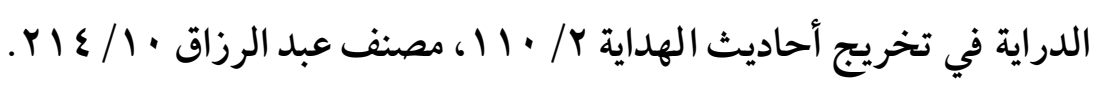




\section{المسألة الثانية}

\section{قياس اللائط على الزاني}

اختلف العلماء في حكم اللائط، فمـن قـال بالقياس في اللغة قاسه عـل

الزاني، ومن منع القياس في اللغة منع اعتبار اللائط زانيا.

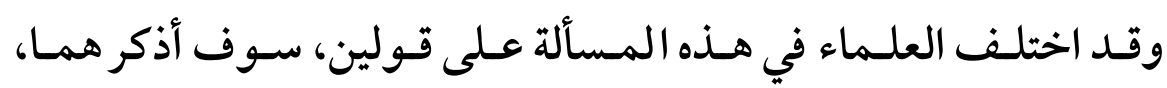

وأذكر الأدلة، والر اجح منهما، وذلك على النحو التالي:

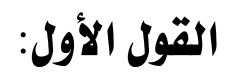

و أصحابه هم: الإمام مالك ، والإمام الشافعي، والإمام أحمد.

$$
\text { قالوا: إن اللواط يوجب الحد. }
$$

وحده عند المالكية والحنابلة في أظهر الروايتين عـن أحمـد هـو الرجم الرجم

$$
\text { بكل حال. }
$$

$$
\text { وعند الشافعي قولاز: }
$$

أصحهما: عليه حـد الزاني إن كـان محصنا يـرجم، وإن لم يكسن محصنا

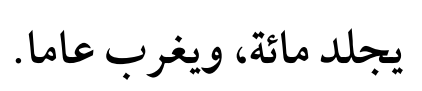

ثانيهما: يقتل الفاعل والمفعول به، وفي كيفية قتله أوجه:

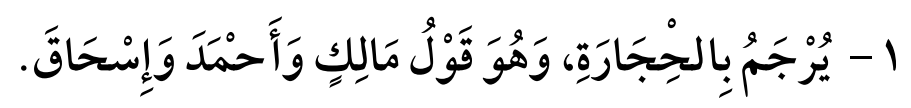

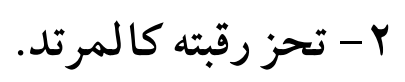

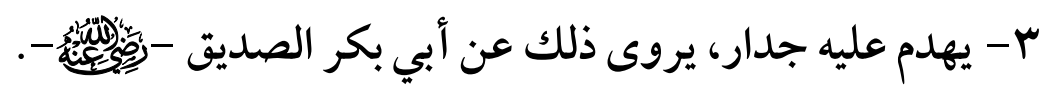

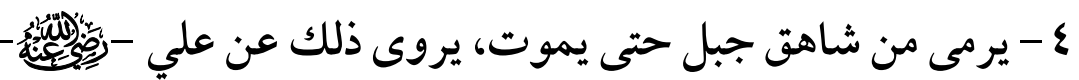


(17६) مناسبة اللفظ للعنى عند الأصوليين وأثرها في توجيه خطاب المجتهلين

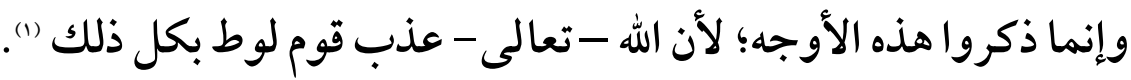

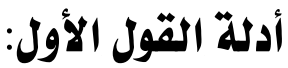

استدل أصحاب القول الأول على أن اللوطي يحد بأدلة منها:

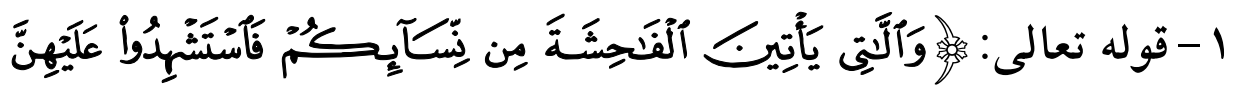

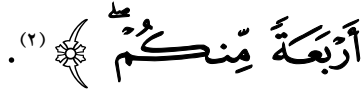

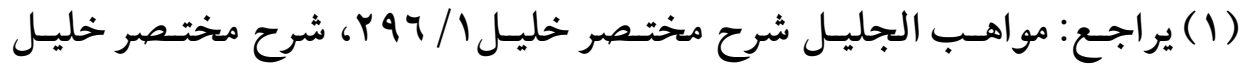

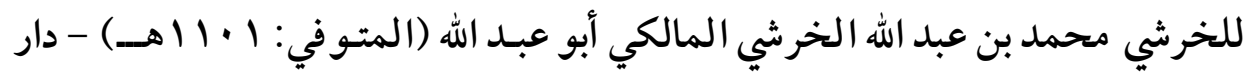

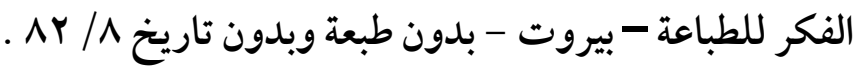

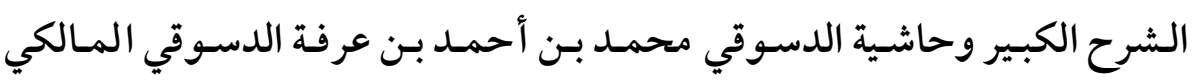

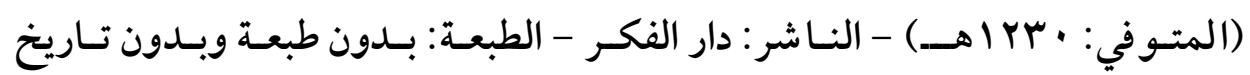

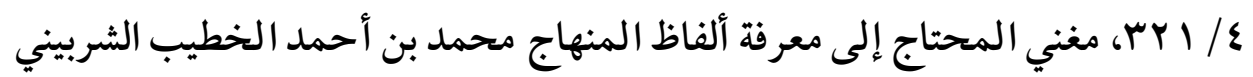

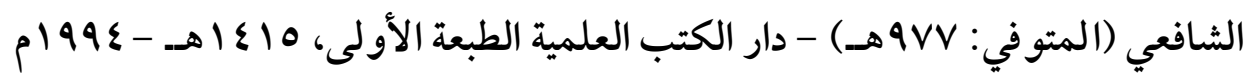

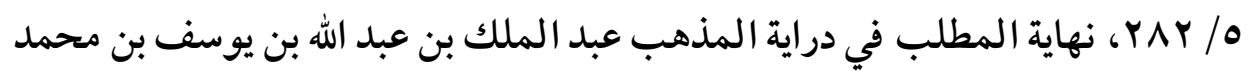

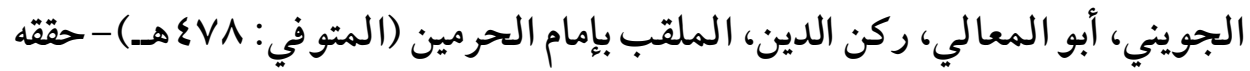

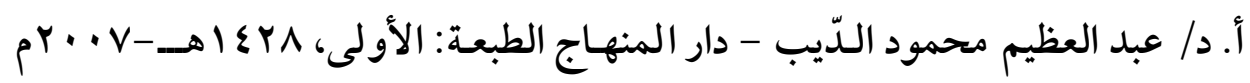

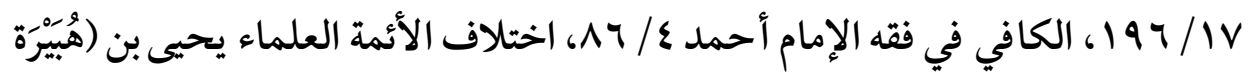

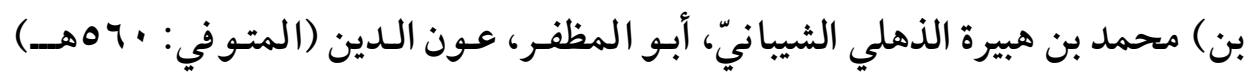

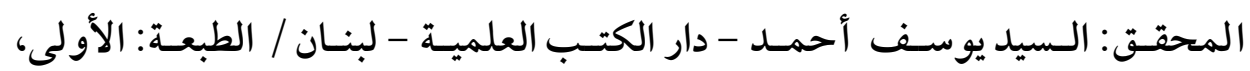

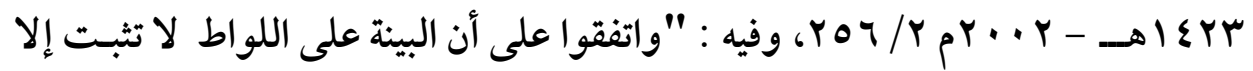

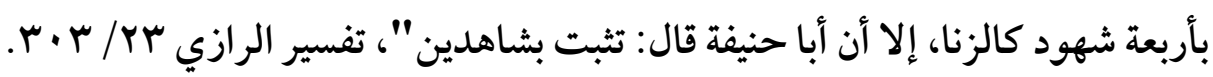
(r) جزء الآية رقم: 10 من سورة النساء. 
(170)

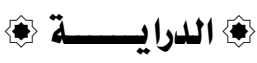

وجه اللدلالة: أن الله - تعالى - سمى الزنا فاحشة، واللـواط فاحشة، قال

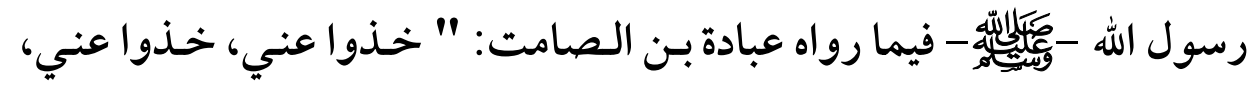
قد جعل الله لهن سبيلا، الثيب بالثيب جلد مائـة ورجـم بالحجـارة " والبكـر بالبكر جلد مائة ونفي سنة" ، فهذا الحـديث نسخ حكـم الآية، وأثبـت الحـد للفاحشة التي هي لواط أو زنا (1). الرد: يرد عليه: بأن الفاحشة اسـم لكل كبيرة، والنسخ بخبر الواحـد لا

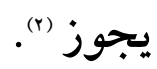

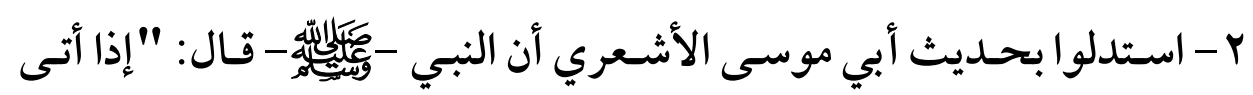

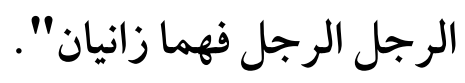

وجسه الدلالــة: أن اللفـظ دل عـلى كـون اللائسط زانيـا، واللفـظ الــدال

بالمطابقـة عـلى ماهيسة دال بـالالتزام عـلى حسول جميـع لوازمها، ودلالـة المطابقة والالتزام مشتر كان في أصل الدلالة، فاللفظ الدال على حصول الزنا دال على حصول جميع اللوازم، ثم بعد هذا إن تحقق مسمى الزنا في اللواط

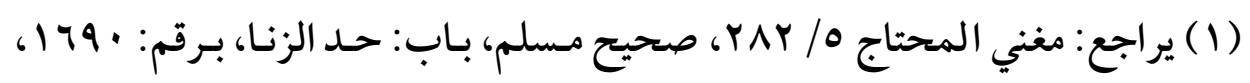

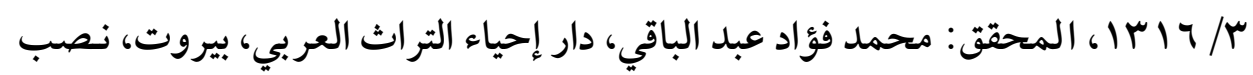

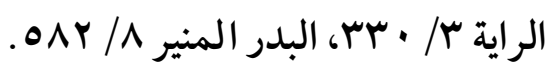

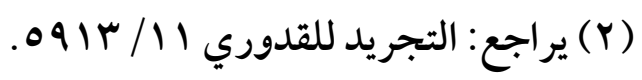


(177)

دخـل تحـت آيـة الزنـا، وإن لم يتحقـق مسمى الزنا وجـب أن يتحقـق لـوازم مسمى الزناوهو وجوب الحد، فوجب أن يتحقق ذلك في اللواط (1). الرد: روى هذا الحديث البيهقي عـن أبي موسى، وفيه محمـد بـن عبـد

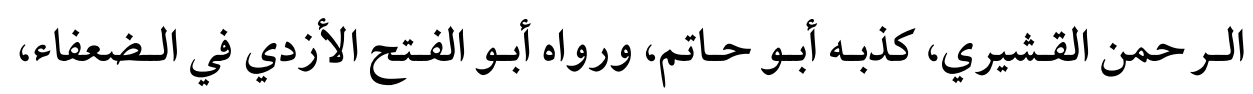
والطبراني في الكبير مـن وجـه آخـر عـن أبي موسى، وفيسه بـشر بـن الفضل البجلي وهو مجهول (r).

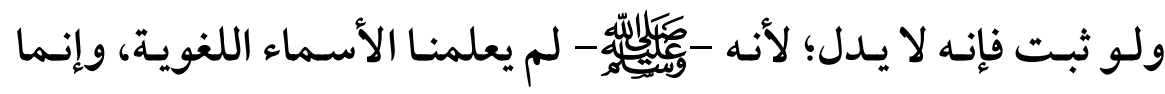
يعلمنا الأسماء الشرعية والأحكام. ولم يقل أحسد: إن هـذا اسـم منقول، فلـم

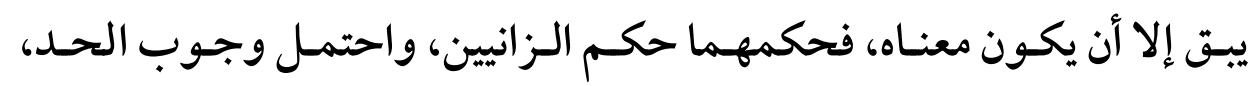

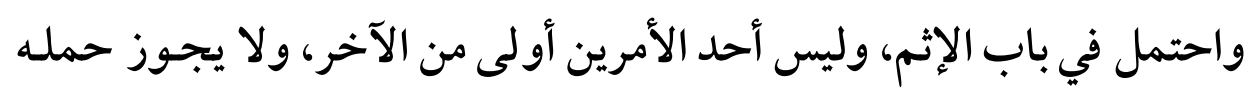

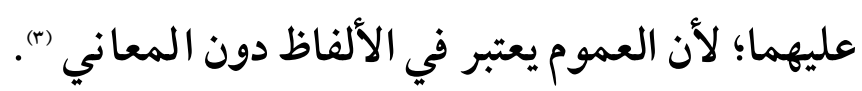

(1) يراجع: تفسير الرازي - أبو عبد الله محمد بن عمر بن الحسن بـن الحسين التيمي

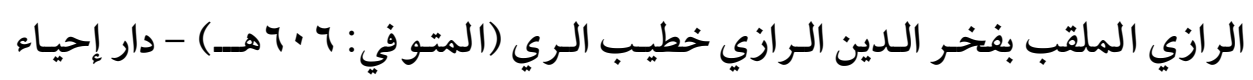

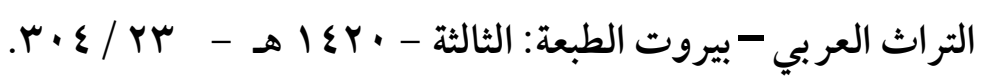

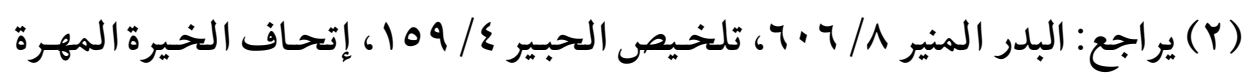

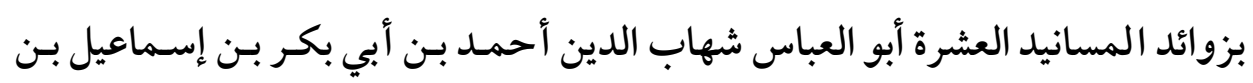

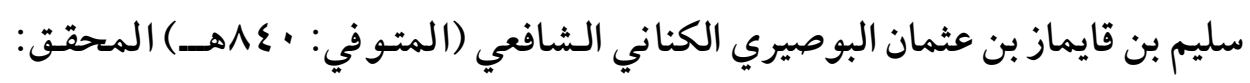

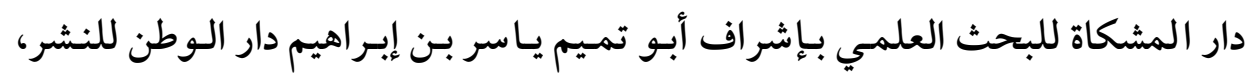

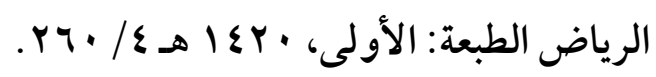

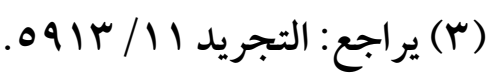




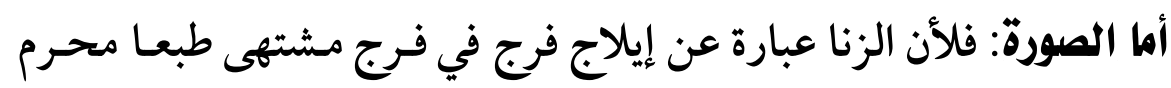
قطعا،والدبر -أيضا- فرج؛ لأن القبل إنما سـمي فرجـا لما فيه مـن الانفراج، وهذا المعنى حاصل في الدبر.

الرد: إن الفرج وإن سمي فرجا؛ لما فيه من الانفراج، فلا يلزم أن يسمى كلما فيه انفراج بالفرج، وإلا لكان الفم والعين فرجا. أما المعنى: فلأن الزنا قضاء للشهوة مـن محل مشتهى طبعـا على جهة الحرام المحض، وهو موجود في اللواط؛ لأن القبل والدبر يشتهيان؛ لأنهما

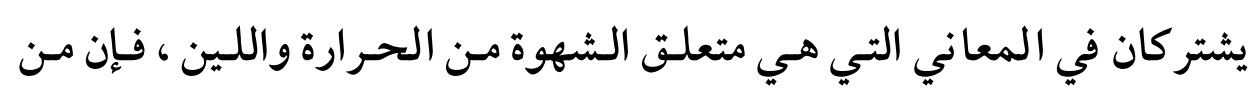
يقول بالطبائع لا يفرق بين المحلين "(1)

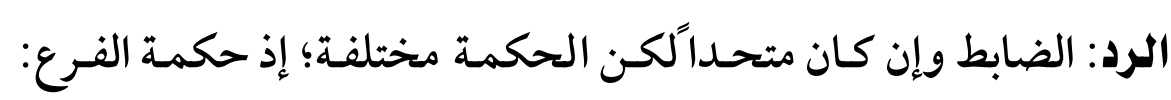
الـصيانة عـن رذيلـة اللـواط، والحكمـة في الأصـل : دفـع محــذور اخـتلاط الأنساب، فقد يتفاوتان في نظر الشرع، فيناط الحكـم بإحـدى الحكمتين دون

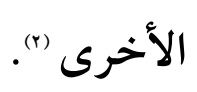

كـ واحتج من قال منهم بوجوب القتل على كل حال بما يأتي:

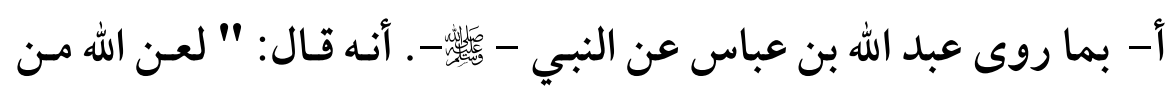

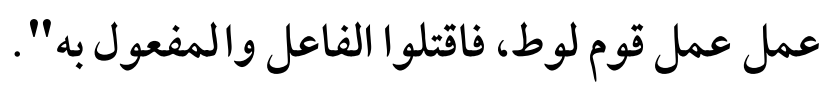

$$
\begin{aligned}
& \text { (1) يراجع: تفسير الرازي بr/r/r.r. (Y) }
\end{aligned}
$$

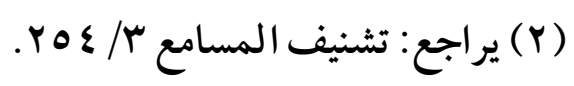


(174) مناسبة اللفظ للعنى عند الأصوليين وأثرها في توجيه خطاب المجتهلين

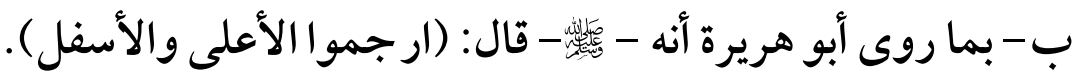
فقد دل الحديثان على قتل الفاعل والمفعول به على كل حال (1). الـرد: يـرد على مـا سبق بـأن حـديث ابـن عبـاس هـو المعروف في هـذا الباب،وهو خبر واحد مداره على عمرو عن عكرمة، واستنكره النسائي. وحديث أبي هريرة: رواه عاصم عن عمرو عن سهيل بن أبي صالح.

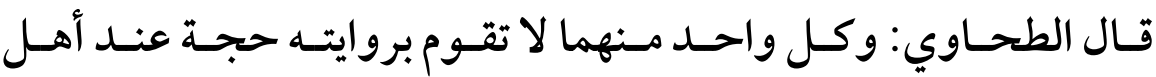

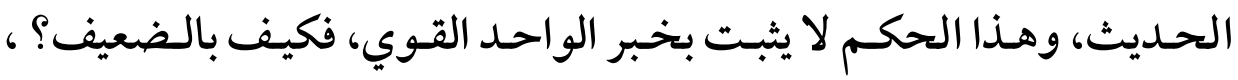

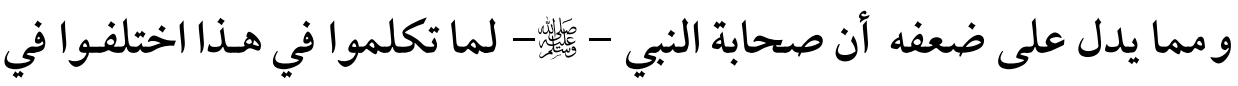
عقوبته، فلو صح خبر في ذلك ما اختلفوا. ولو ثبـت لم يـدل؛ لأن الذـي يعمـل عمل قوم لـوط هـو المستحل لهـذا الفعل، ومن فعل ذلك مستحلا ارتـد، ووجـب قتله بـالردة تـارة رجمـا، وتـارة غير رجم. كما يجوز أن يمثل بالمرتد (r).

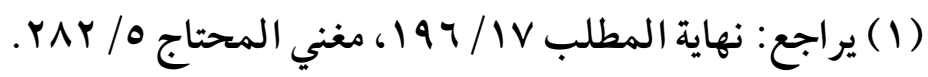

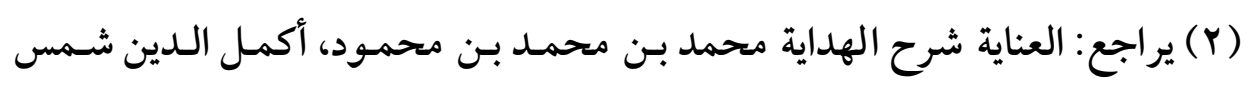

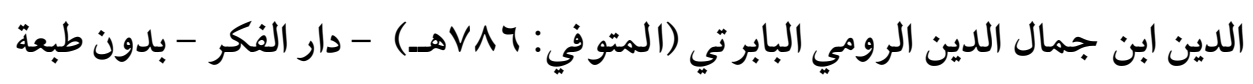

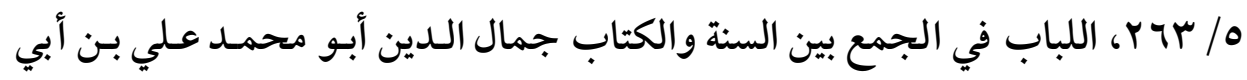

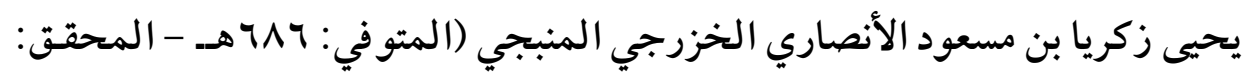

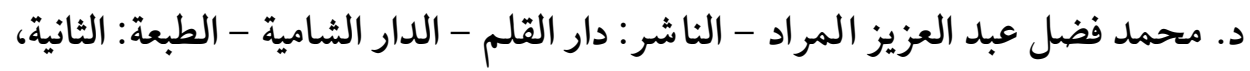

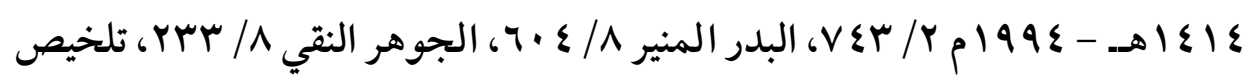

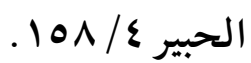


(179)

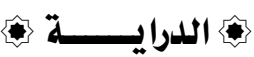

هـ أنه لما وجب قتتله وجب أن يكوز زانيا، وإلا لما جاز قتله.

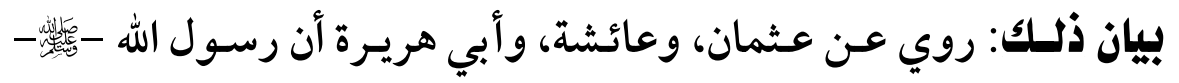

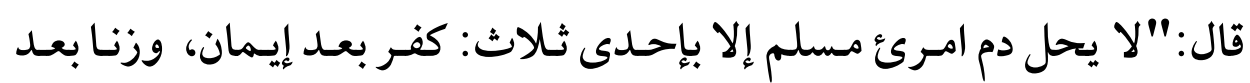

إحصان، أو قتل نفس بغير نفس ". لو

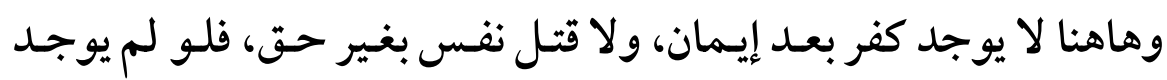

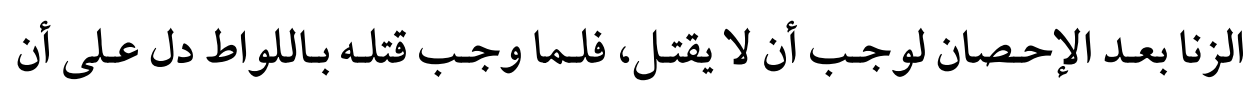

اللواط زنا (1).

الرد: ويرد على الاستدلال السابق بما سبق أن بيناه من أن حسديث قتل أو

رجم اللوطي لم يثبت، ولو ثبت لم يدل لما ذكرناه.

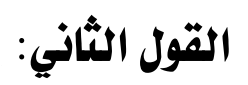

وأصحابه هم: الإمام أبو حنيفة و أصحابه.

قالوا: إن اللوطي يعزر فقط.

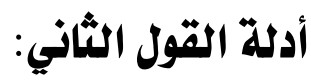

استدل أصحاب القول الثاني بأدلة منها ما يأتي:

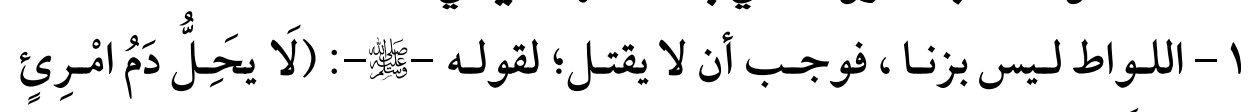

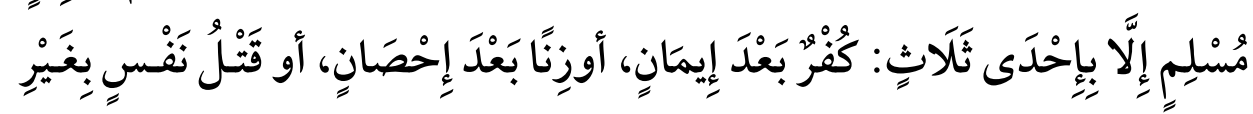
نفس).

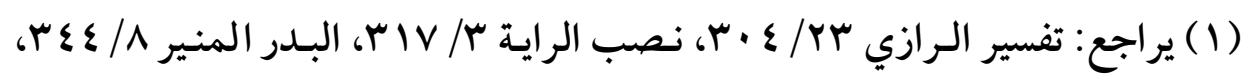

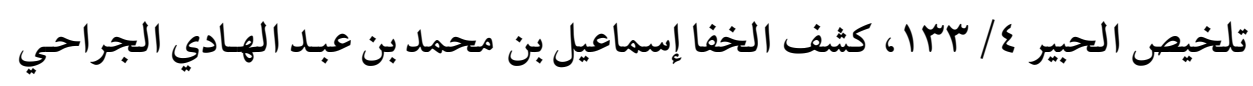

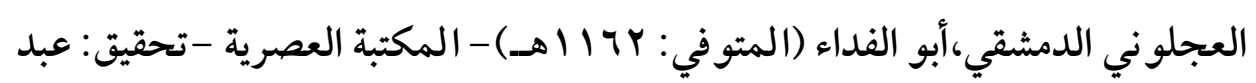

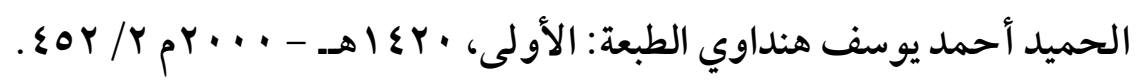


(IV.) مناسبة اللفظ للعنى عند الأصوليين وأثرها في توجيه خطاب المجتهلين

فإن اللواط لا يساوي الزنا في الحاجة إلى شرع الزاجـر ولا في الجنايـة، فلا يساويه في الحد.

بيان عدم المساواة في الحاجة: أن اللواطة وإن كانت يرغب فيها الفاعل

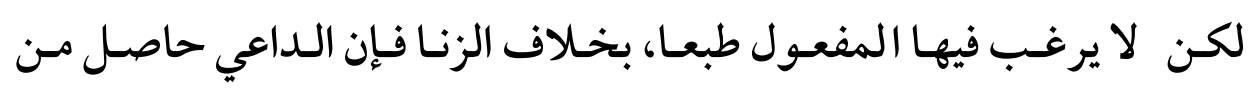

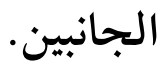

وأما عدم المساواة في الجناية: فلأن في الزنا إضـاعة النسب ولا كذلك

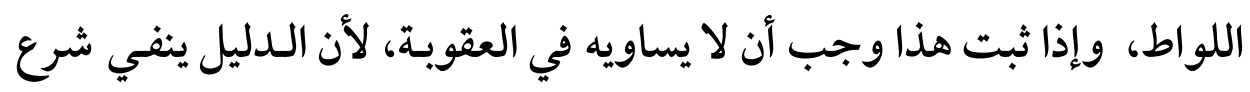

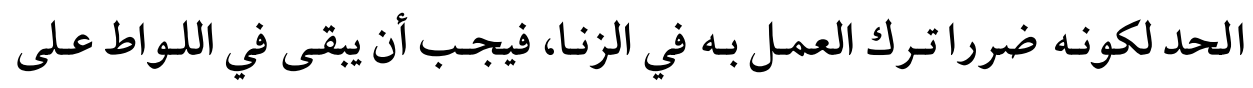
الأصل، وهو ينفي القتل بوجه رابع (1).

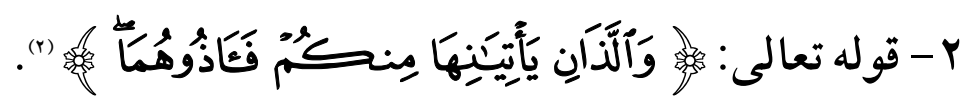
وجه الدلالة: أن الله -تعالى - أوجـب على الرجلين الفـاعلين الفاحشة الأنى، وهـذا

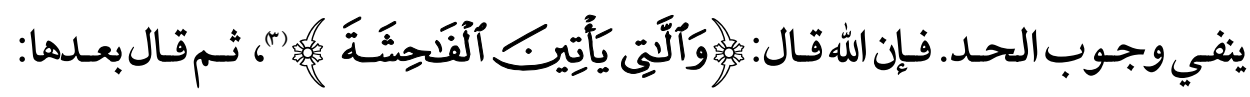

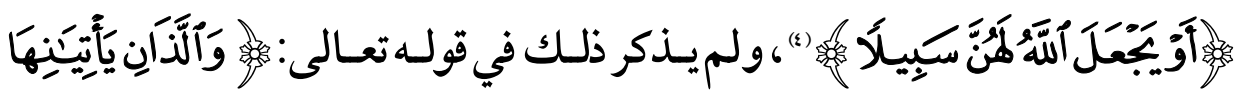

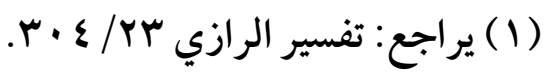

$$
\begin{aligned}
& \text { (Y) جزء الآية رقم: } 17 \text { (Y) من سورة النساء. } \\
& \text { (Y) جزء الآية رقم: } 10 \text { من سورة النساء. } \\
& \text { (؟) جزء الآية رقم } 10 \text { من سورة النساء. }
\end{aligned}
$$




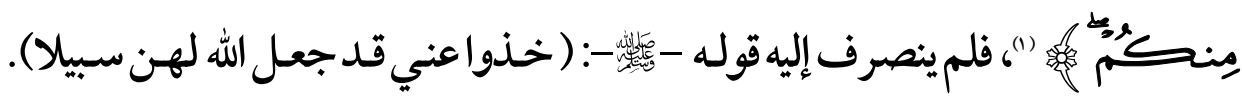

$$
\text { وقد سبق ذكره (r). }
$$

ץ- أن اللواط لا يسمى زنـا؛ لأن أهـل اللغـة أفردوه باسـم، وسـموا الوطء في

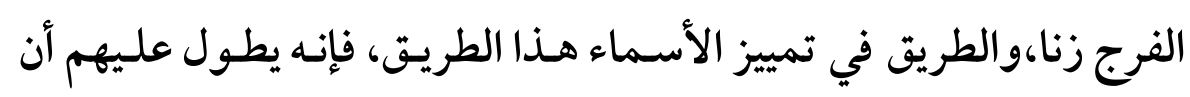
يقولوا: هذا لا يسمى كذا ولا كذا، فكل مفرد باسـم لا يتناوله باسـم غيره إلا أن يدل على ذلك دليل؛ لأنه إن وجـد في زوجتـه لم يسم زنـا مـع قبحسه

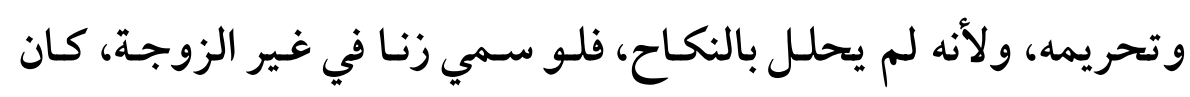
زنى فيها؛ لوجود التحريم وعدم الملك (r).

\section{الراجح:}

بعد عرض الأقوال و أدلتها والردود يتبين لـدينا أن تسمية اللوطي " زان

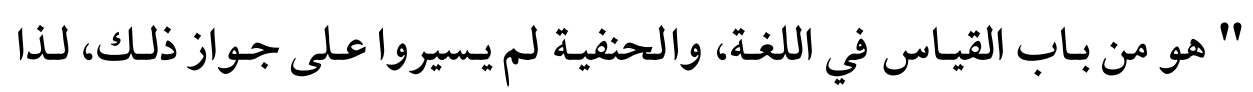

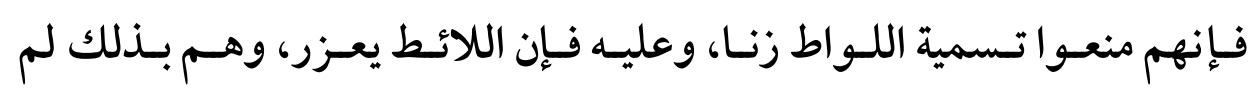

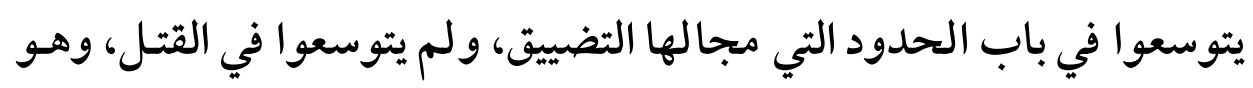

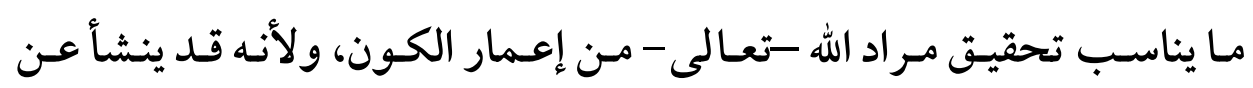

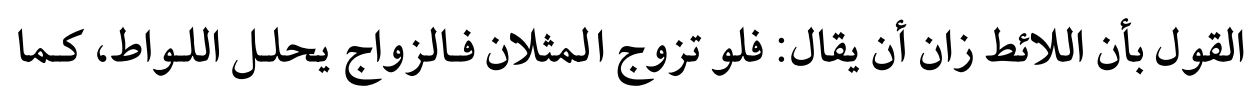
يحلل النكاح وطء الرجل للمر أة، وفيه ما فيه من الفساد.

(1) (1) جزء الآية رقم: 17 من سورة النساء.

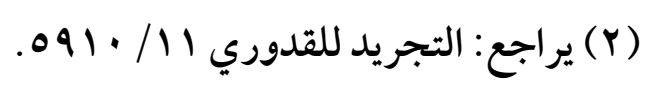

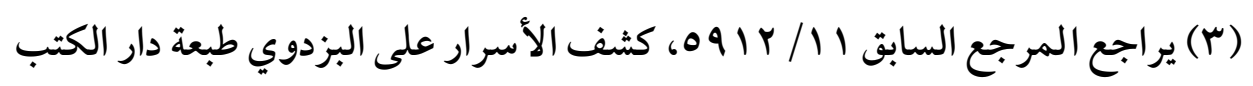

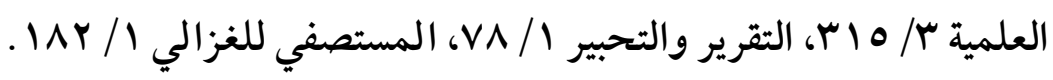




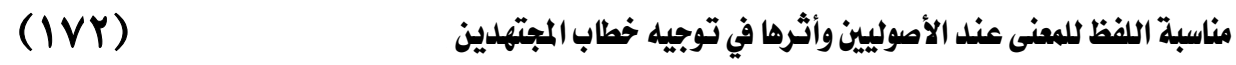

فكان رأي الحنفية أوفق، و أدلتهم أقوى، وضـف أدلة المخـالفين، لـذا:

$$
\text { نرى ترجيح قول الحنفية. }
$$

والعلم عند اللهُ تعالهــــ 
(IVr)

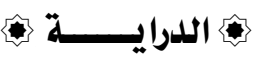

\section{المسألة الثالثة}

\section{قياس النبيذ على الخمر}

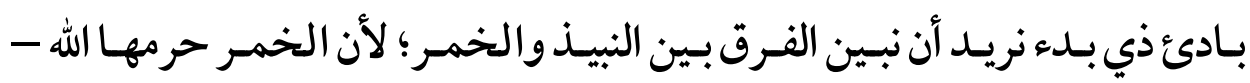
سبحانه وتعالى - لكونها خمـرا، والنبيذ لم ينزل الشارع في تحريمه شيئا لكونه

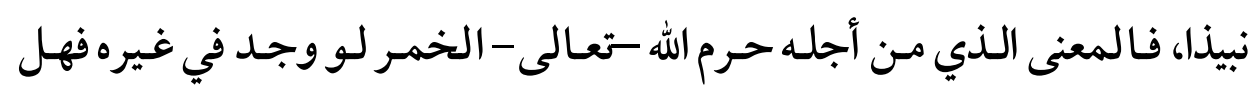
يقاس حكمه على حكم الخمر؟. بلا خلاف بين العلماء يجوز هذا القياس.

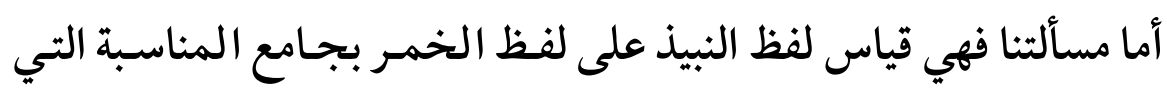
بين اللفظ بمعناه اللغوي وبين المعنى الشرعي المستعمل فيه اللفظ، حتى تصير آية تحريم الخمر تنطبق على النبذ دون قياس في الحكم.

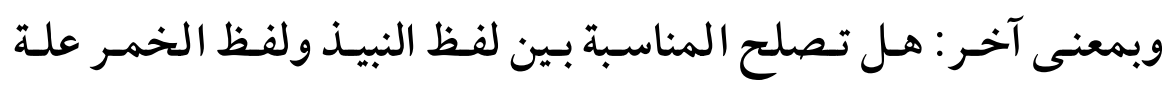
لقياس اللفظين على بعضهما؟ ولبيـان أقـوال العلـماء في المـسألة وأدلـتهم يلزمنــا أن نـذكر أولا محـل النزاع، ثم الأقوال والأدلة والترجيح ثانيا.

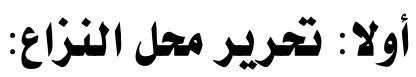

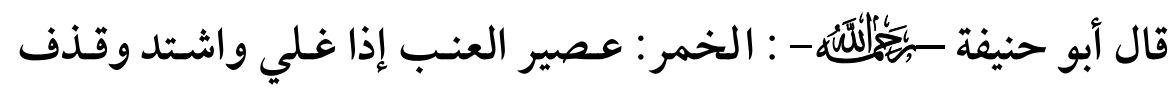
بالزبد (1).

أما النبيذ فهو: ما يلقى فيه تمر، أو زبيـب، أو نحوهمـا؛ ليحلو بـه المـاء

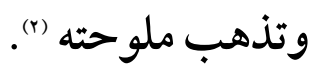

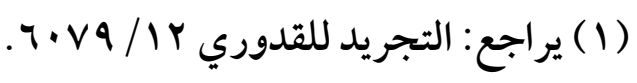

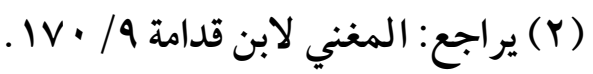


$(I \vee \varepsilon)$

أما إذا ألقي في المـاء نوعـان مثل: تمـر وزبيـب، أو حنطة وشعير، فهذا يسمى بالخليطين، وقد اتفق العلماء على أنه منهي عنه.

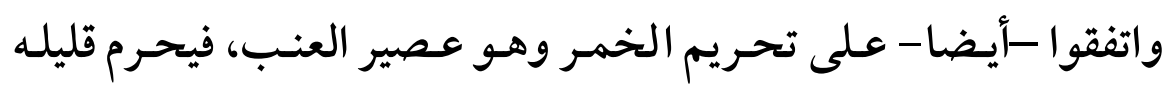
و كثيره (1)

واختلفوا في النبيذ في خمس مسائل:

1 - هل ينطبق على الأنبذة المسكرة اسم الخمر؟.

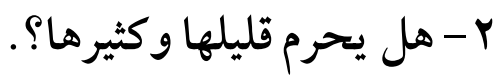

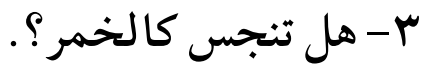
ع - هل يتعلق وجوب الحد بالشرب أو بالسكر؟. ه- هل تحريم الخمر معلل أو غير معلل؟ ب(r).

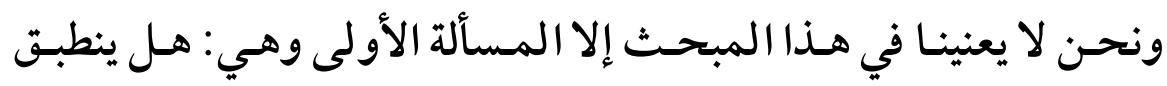
على الأنبذة المسكرة اسم الخمر أو لا؟.

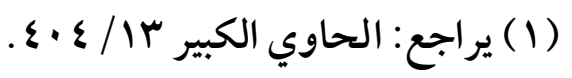

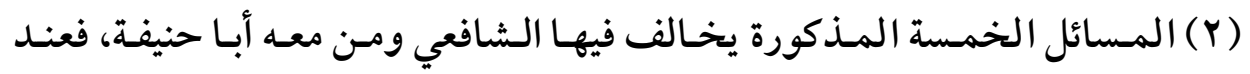

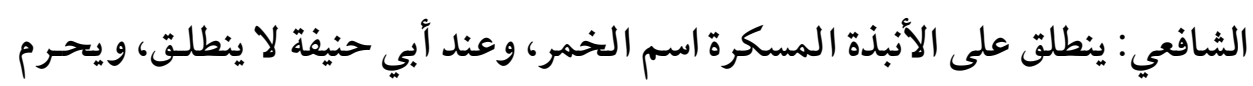

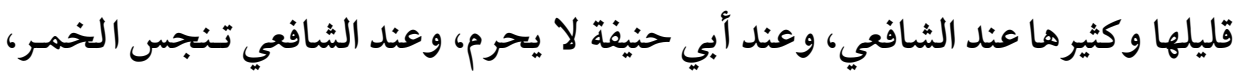

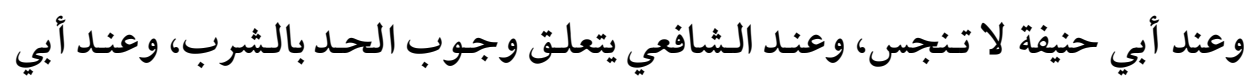
حنيفة بالسكر، و تحريم الخمر معلل عند الشافعي، غير معلل عند أبي حنيفة.

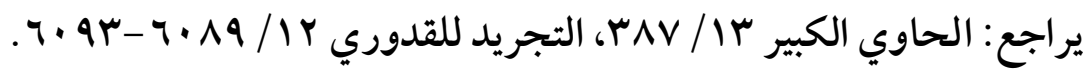


(IVo)

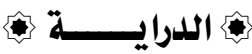

خلاف دار بين العلماء في هذا الأمر، وسوف نذكر الأقوال وأدلتها على

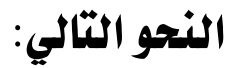

ثانيا: الأقوال وأدلتها والراجح منها:

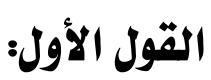

و أصحابه: جمهور العلماء مـن المالكية، والشافعية، وفقهاء الحرمين،

وبعض فقهاء العراق.

قالوا: يسمى النيـذ خمـرا، فالمناسبة بـين اللفظين توجـب قيـاس النبيذ

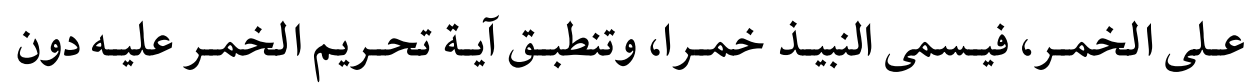
الحاجة إلى قياس في الحكم أو غيره").

(1) يراجع: البيان والتحصيل والشرح والتوجيه والتعليل لمسائل المستخرجة - أبو

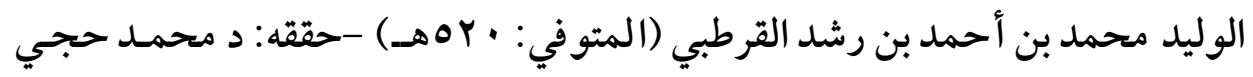

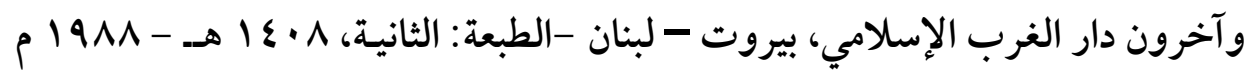

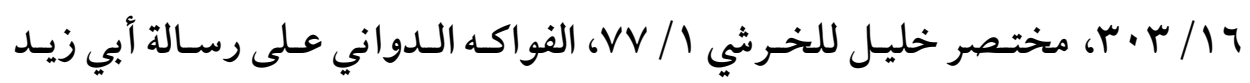

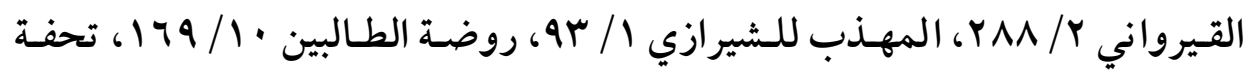

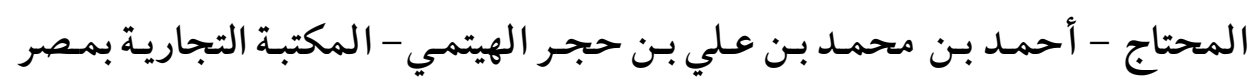

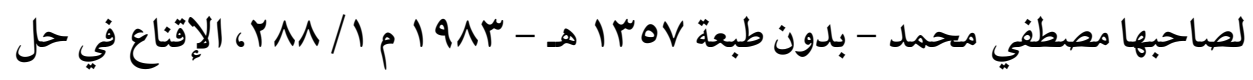

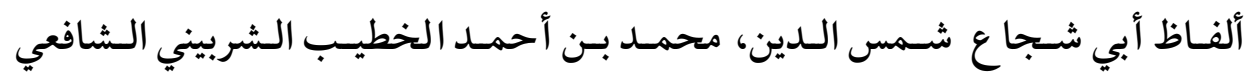

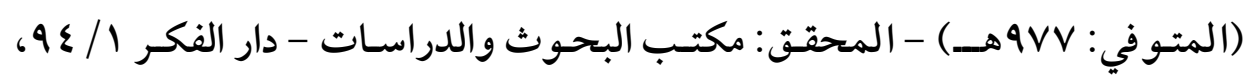

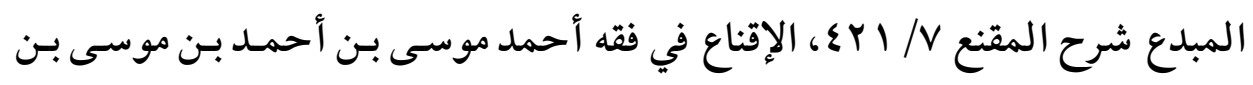

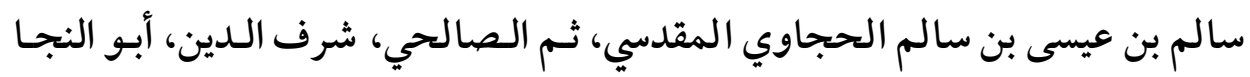

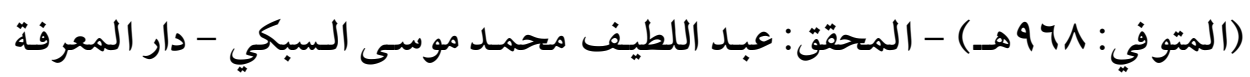

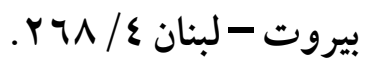


(IVY)

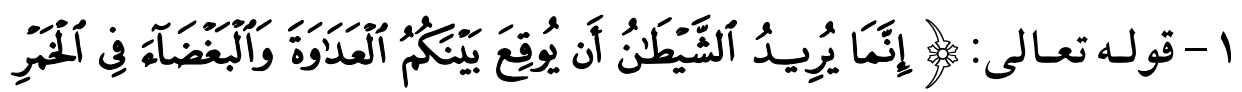

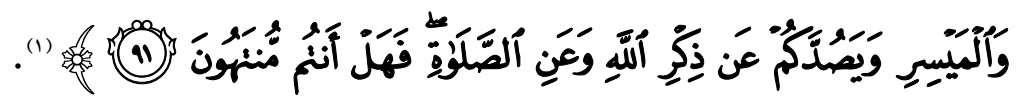

وجه الدلالـة: هذا المعنى الذي ذكره الله -تعالى - في الآية الكريمة

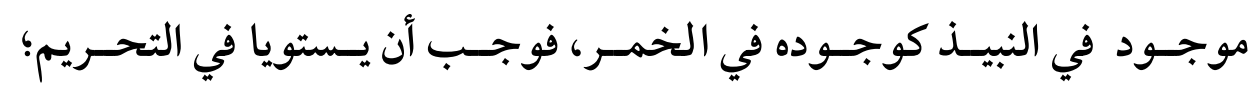

لاستوائهما في التعليل.

الرد: هذا قياس في الحكمم ونحن لا نمنعه، والممنوع القياس في اللغة.

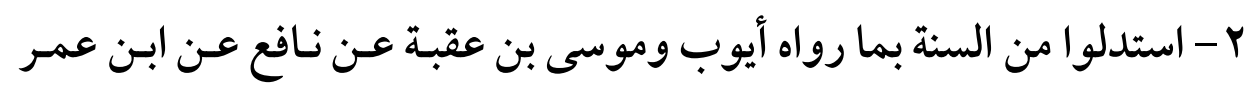

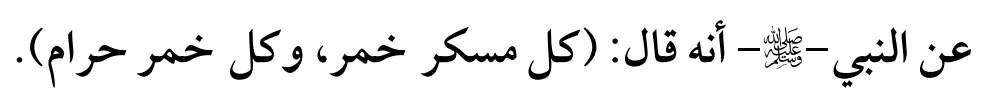

الرد على السلديل : روى عباس الدوري عن يحيى بن معين أنه قال:

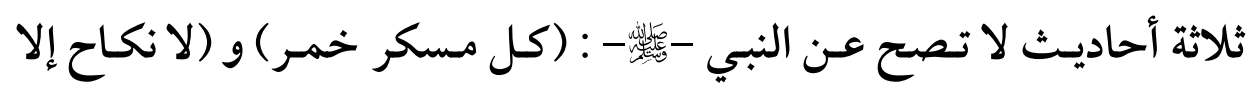
بولي) و (ومن مس ذكره فليتوضأ) .

فهـذا الحـديث لاحجة فيه؛ لطعن ابن معين وهو مـن علماء الجرح

والتعديل الموثوق بهم (").

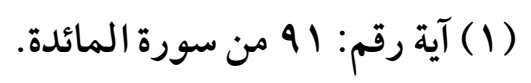

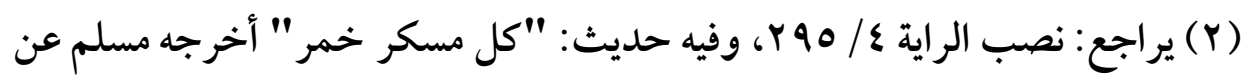

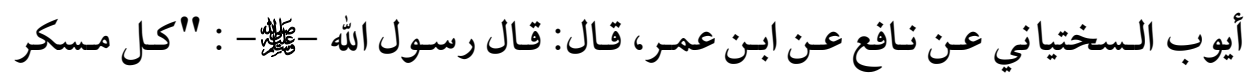

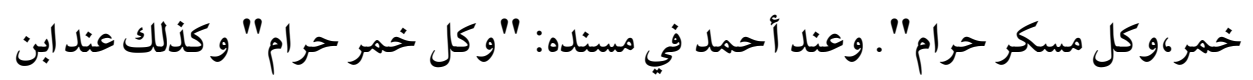

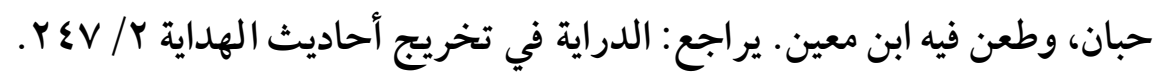


الجـواب على الـرد: أن الإمـام أحمـد قـد روى هـذا الحـديث في كتـاب

الأشربة، وهو اعلم بصحة الحديث وطرقه من يحيي بن معين (1).

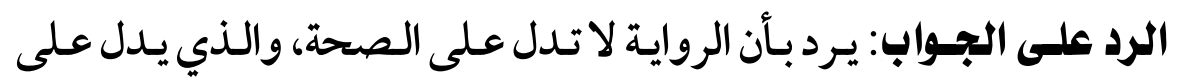

صحة طعن ابن معين أن الإمام البخاري لم يخرج هذا الحديث في الصحيح ().

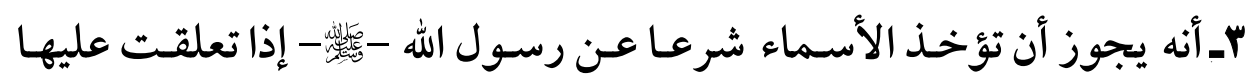
الأحكام كما تؤخذ الأحكام، كما أن النبيذ نوع من الخمـر، واسـم الخمـر

أعم، ودخل النبيذ في اسم الخمر عموما، وانقرد باسم النبيذ خصوصا ("). الرد: إن العرب إن عرفتنا بتوقيفها أنـا وضعنا الاسـم للمسكر المعتصر من العنب خاصة، فوضعه لغيره تقول عليهم واختراع، فلا يكون لغتـهم بـل

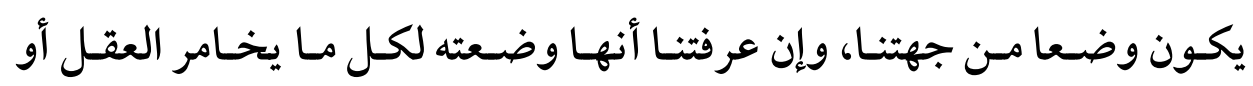
يخمره، فكيفما كان فاسم الخمر ثابت للنبيذ بتوقيفهم لا بقياسنا (5). والعرب قد وضعت لكل معنى اسما يدل عليه، فليس لنا قياس في ذلك.

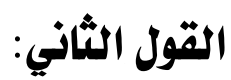

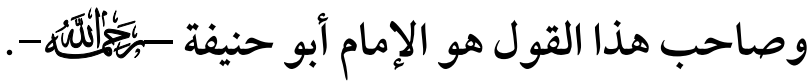

$$
\begin{aligned}
& \text { (1) يراجع: الحاوي الكبير r/ / } 91 \text { م. }
\end{aligned}
$$

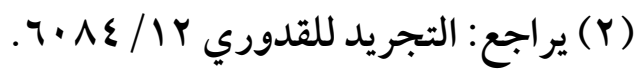

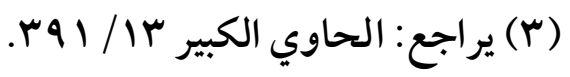

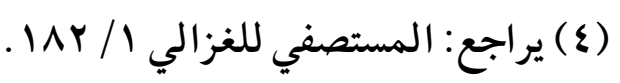


(IVA) مناسبة اللفظ للعنى عند الأصوليين وأثرها في توجيه خطاب المجتهلين

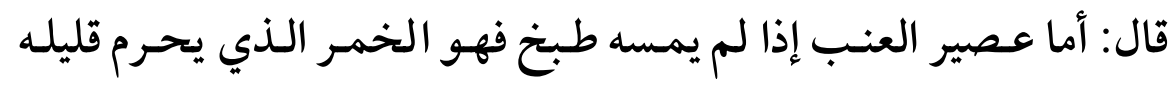
وكثيره، ومـا عمـل مسن التمـر والزبيـب والعسل والحنطـة والشعير والـذرة،

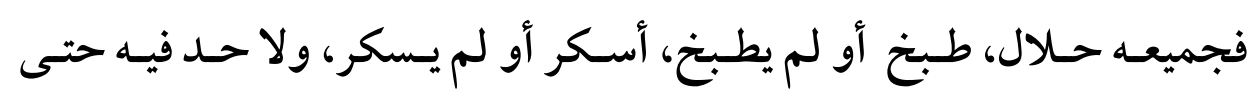
يسكر، و يحرم منه القدح المسكر. فأبو حنيفة لا يرى قياس لفظ النبيذ على الخمر؛ لأن المناسبة بين اللفظ

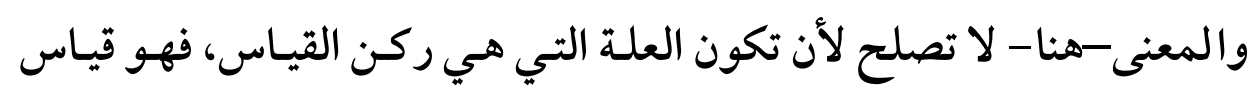
في اللغة، والقياس في اللغة لا يجوز عنده.

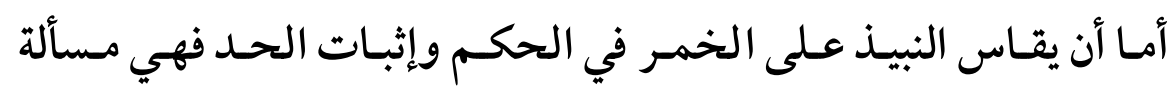
أخرى، تخضع للخلاف الوارد في حكم القياس في الحدود والمقادير.

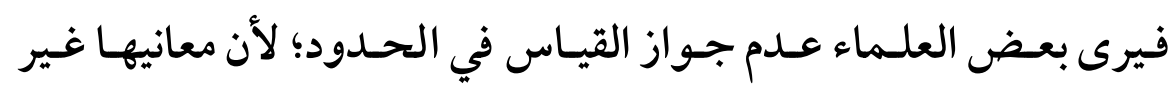

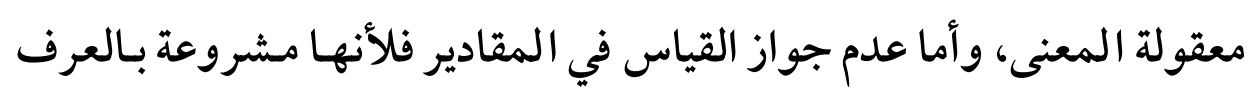
الموجودد". المعول.

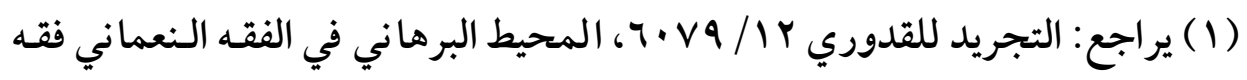

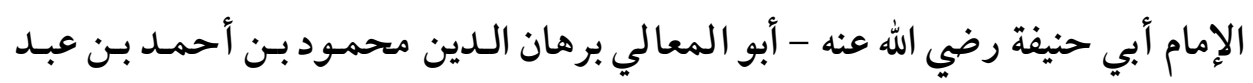

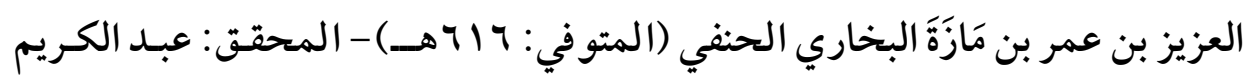

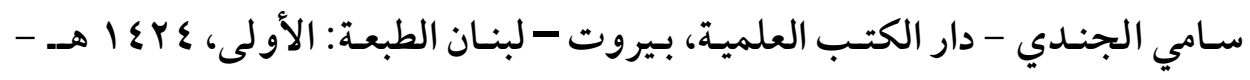

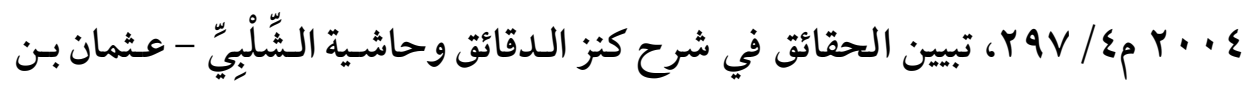

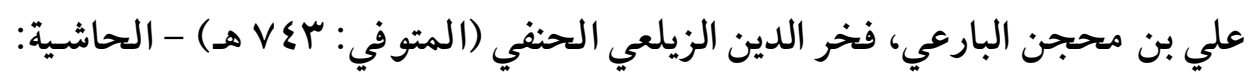

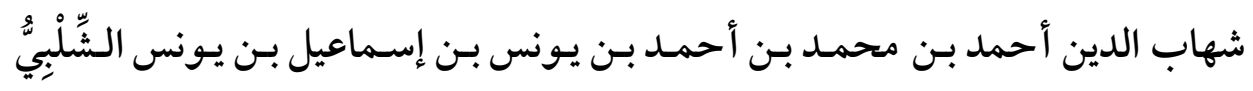

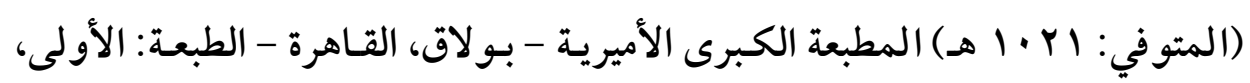

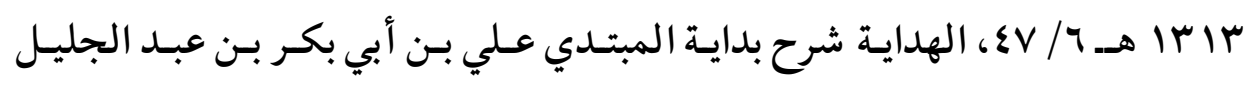




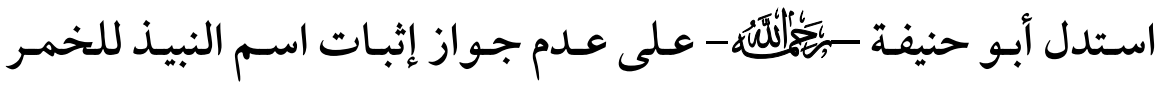

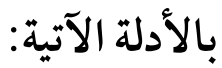

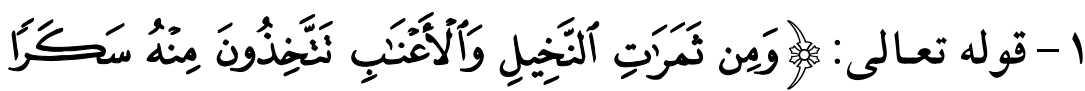

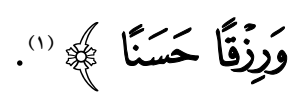

وجسه الدلالـة: أن الله - تعـالى - ذكر إياحة اتخـاذ السكر، والسكر هـو

المسكر في قول ابن عبـاس و مجاهـد وسعيد بـن جبير وقتـادة، فهو يـدل

$$
\text { على إباحة النبيذ في الجملة (r). }
$$

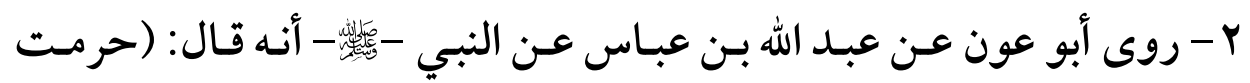

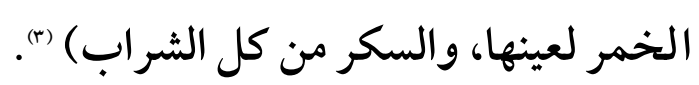

ققد دل هذا الحلديث على ثلاثة أحكام:

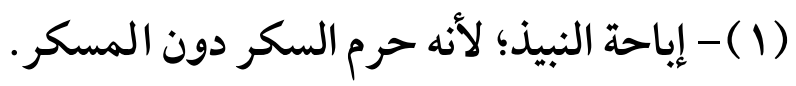

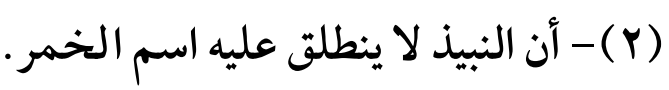

(r)

الفرغاني المرغيناني، أبو الحسن برهان الدين (المتوفي: بهههــ) - المحقق: طلال

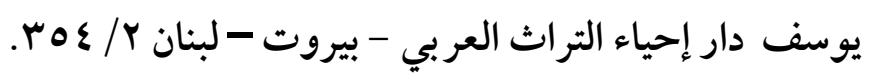$$
\text { (1) (1) جزء الآية رقم: VI آح من سورة النحل. }
$$

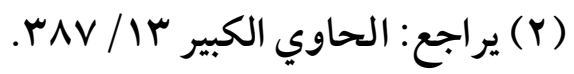

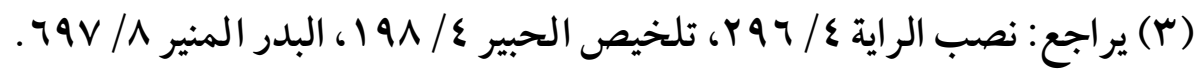

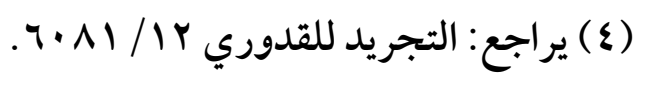


$(1 \Lambda \cdot)$ مناسبة اللفظ للعنى عند الأصوليين وأثرها في توجيه خطاب المجتهلين r- أن اسم الخمر لا ينطلق على ما عداه من الأنبذة لأمرين لغة و شرعا.

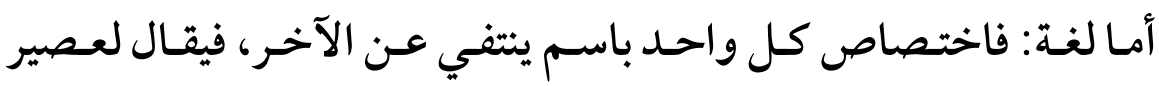
العنب: خمر وليس بنبذ، ويقال لغيره من الأشربة: نبيذ وليس بخمر .

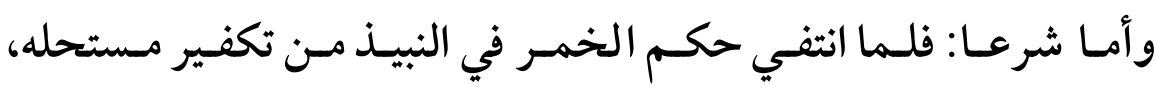

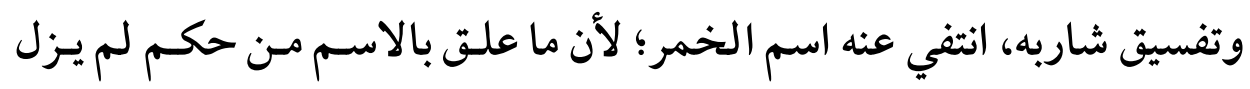
موجودا مع الاسم، كما أن الحكم إذا علق بعلة لم يزل مع وجود العلة'). الراجح: بعـدعــــ الأقوال في مسألة إثبـات اسـم الخمــر للنبيذ، يـترجح لـدينا القـول الثـاني الـذي لا يـرى إثبـات الأسـماء الشـرعية بالقيـاس؛ لقـوة أدلتـه، وضعف أدلة المخالفين؛ لورود الردود عليها.

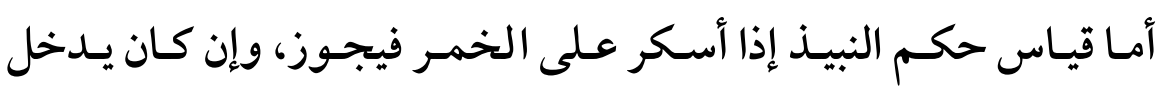
مباشرة تحت الأحاديث التي تفيد حرمة المسكر. والعلم عند الله نعالم 
(IAI)

\section{المبحث الخاهس}

\section{هناسبة اللفظ للمعنى في المجاز وأثره}

\section{في توجيه خطاب الجتتهدين}

ذكرنا فيما سبق أن الاستعمال من صفة المتكلم، والحمل على الحقيقة

أو المجاز أو غير هما من صفة السامع، وأن الوضع قبلهما.

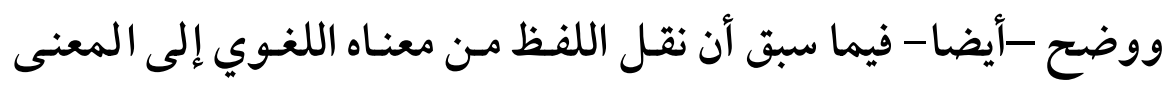

الشرعي أو العـرفي مـع هجـران المعنى اللغـوي وعـدم استعماله، يجعـل

اللفظ في المعنى المنقول إليه حقيقة فيه.

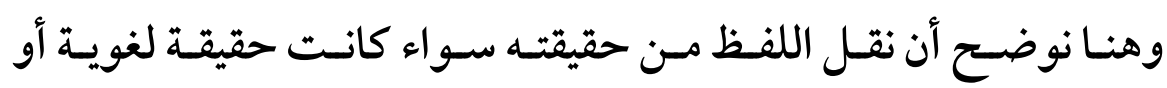

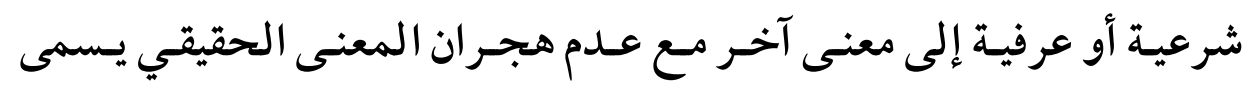

اللفظ في المعنى المنقول إليه مجازا.

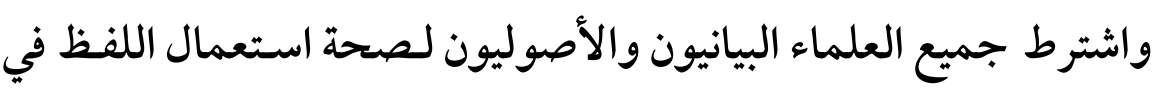

معنى غير معنـاه الحقيقي -وهـو المعنى المجـازي - أن تكسون هنـاك قرينة

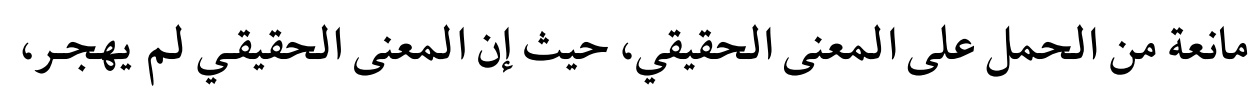
وموجبة لحمل اللفظ في المعنى المجازي المنقول إليه.

وهذه القرينة يمكن در كها عقلا، أو حسا، أو عادة، أو شرعا، أو لغة.

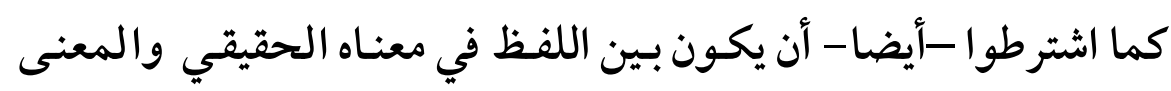

المجازي المنقول إليه علاقة ومناسبة مجوزة للاستعمال (1).

(1) يراجع: البحر المحيط r/ بـ. 


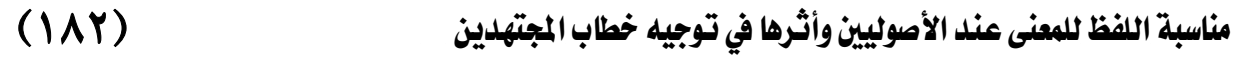

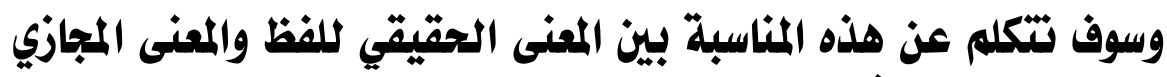
المنقول إليه اللفظ، وأثرها، وذلك من خلال المطالب الآتية: المطلب الأول: تحقق مفهوم المجاز باشتراط المناسبة. المطلب الثاني: شروط مناسبة اللفظ للمعنى في المجاز، وأثره في توجيه خطاب المطلب الثالث: علاقات المجاز 
(IAr)

\section{المطلب الأول}

\section{تهقق هفهوم المجاز باشتزاط المناسبة}

ومعناه: أننا لا يمكننا استعمال اللفظ في أي معنى غير الذي وضـع مـن

أجله إلا إذا كان بين المعنى الحقيقي والمعنى المجازي المنقول إليه اللفظ

علاقة ومناسبة تجمع بينهما، وسوف يتضح ذلك من خلال ما يأتي:

\section{أولا: المجاز لفة:}

المجاز طريـق المعنى بـالقول، تقـول: جـاز يجوز جـوازاو مجحازا، وإن

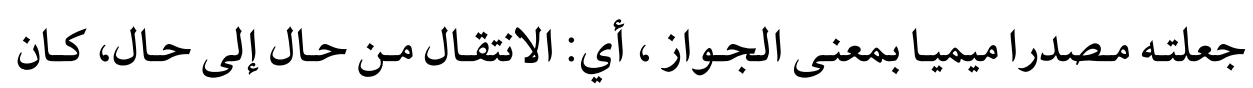
الجواز كالسلوك، فكأنه سلوك المعنى باللفظ.

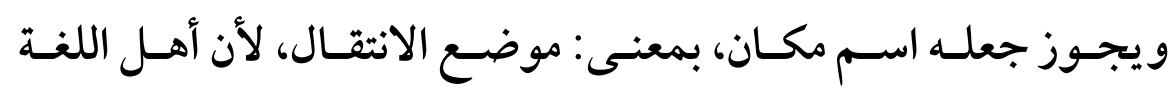

يجاوزون به عن أصل الوضع توسعا مـنهم، كتسمية الرجل الشجاع أسـدا، والبليد حمارا (1).

\section{ثانيا: المجاز في الاصطلارح:}

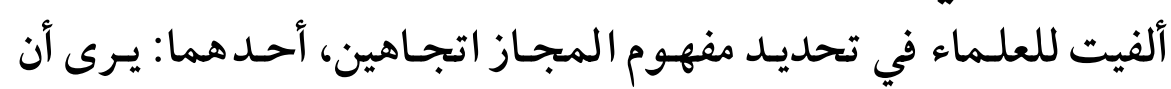

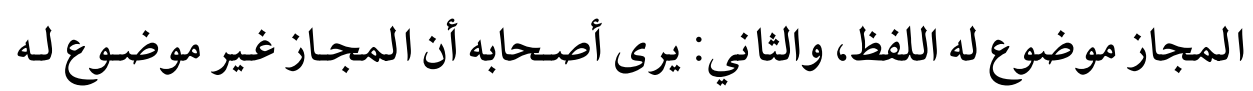

اللفظ.

وجدير بالذكر نوضح أن الوضع في المجاز خلاف الوضع في الحقيقة.

فالوضع في الحقيقة: تعلق اللفظ بإزاء المعنى الذي جعل اللفظ حقيقة له.

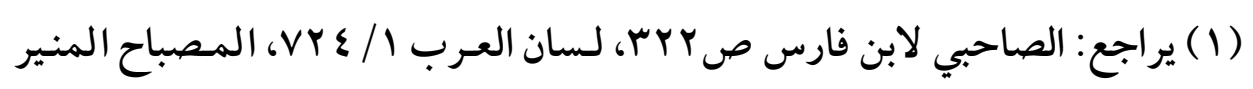

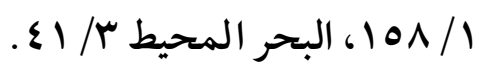


$(1 \wedge \varepsilon)$ مناسبة اللفظ للعنى عند الأصوليين وأثرها في توجيه خطاب المجتهلين والوضع في المجاز: أن يكون ذلك المجاز منقو لا استعماله عن العرب (1). الاتجاه الأول: يرى أصحابه أن المجاز: هو اللفظ المستعمل في غير وضع أول، على وجه يصح، أي: بحسب غير وضع أول، بل بمجرد المناسبة ().

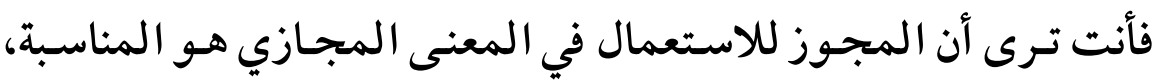
وأن تحديـد مفهوم استعمال اللفظ مـن المعنى الحقيقي للمعنى المجـازي موقوف على وجود المناسبة بين المعنيين. الاتجاه الثاني: ويـرى أصسحابه أن المجاز موضـوع بوضـع ثـان ملحوظ فيه الوضـع السابق، فبعضهم: يـرى أنه موضـع كالحقيقـة موضسوعة، إلا أن الحقيقة بوضع أصلي، والمجـاز بوضـع طاري؛ لأن المجاز مـن بـاب اللغـة، حتى يقال: إنه أحـد نـوعي الكلام، وإنه أحـد اللسانين، ولو لم يأكل بوضـع أرباب اللغة لا يكون من اللغة. ويرى البعض الآخر : أن طريق المجاز بوضـع أربـاب اللغـة دون الألفـاظ

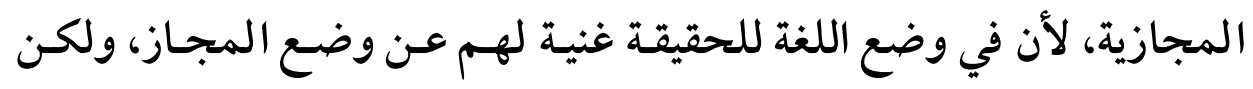
وضعوا الطريق توسعة على الناس في الكلام، فيكون التكلم بالمجـاز بعـدهم بناء على طريقهم الموضوع بإذنهم ورضاهم، فيكون من باب اللغة (م).

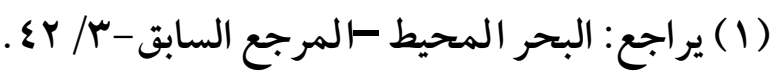

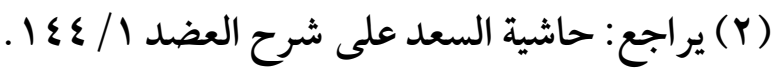

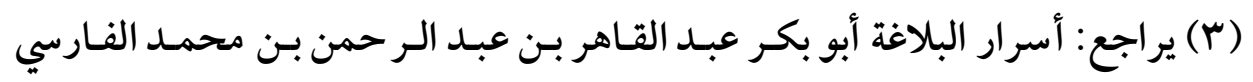

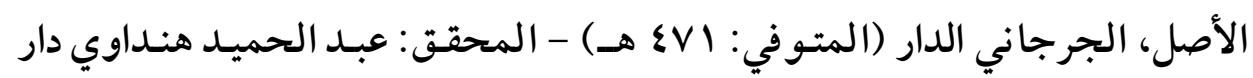


(1^0)

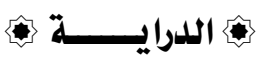

فأنت ترى: أن الر ابط الموضح لاستعمال اللفظ في الحقيقـة أو المجـاز هـو تلـك المناسـبة الحاصـلة بـين اللفــ بمعنــاه الحقيقـي واللفــ بمعنــاه

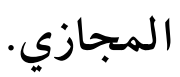

نـوع الخـلاف الـسابق: هـذا الخـلاف لفظي، ومنـشأه: أن وضـع اللفظظ للمعنى فسر بوجهين: - إن

الأول: تعيين اللفظ بنفسه للمعنى، فعلى هذا: لا وضع في المجاز أصلا

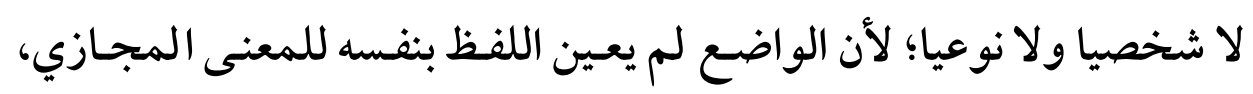
بل بالقرينة الشخصية أو النوعية، فاستعماله فيه بالمناسبة لا بوضع.

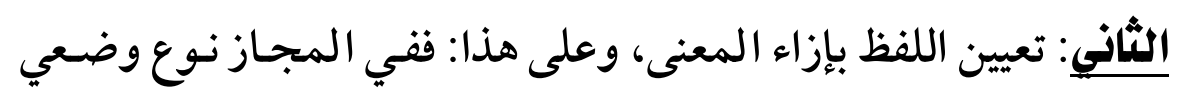

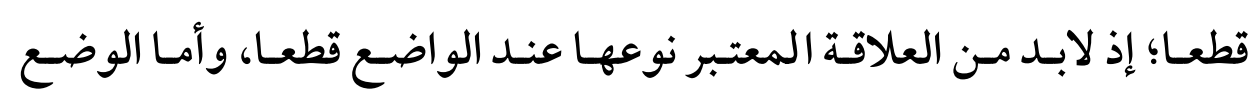
الشخصي فربما يثبت في بعض"(1).

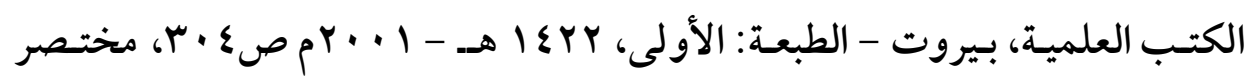

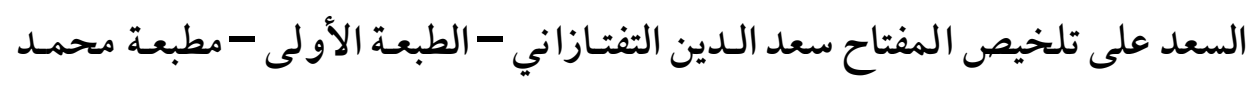

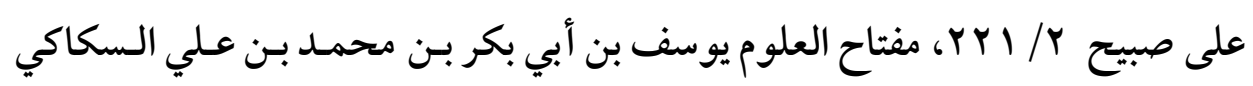

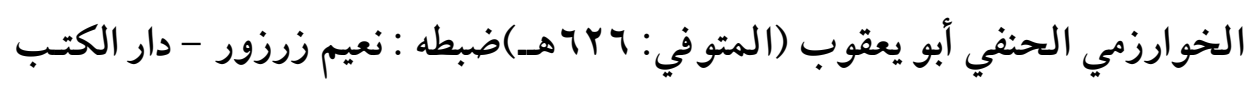

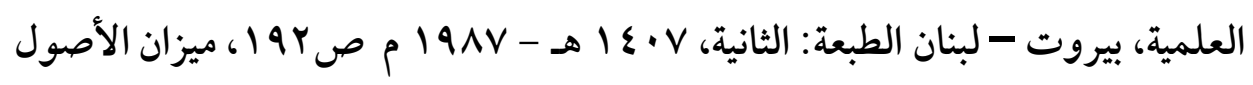

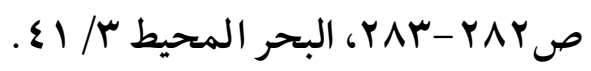

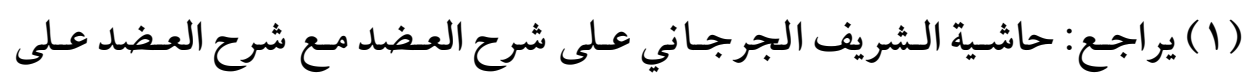

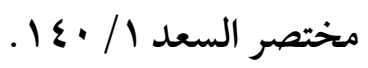


(1^y)

مناسبة اللفظ للعنى عند الأصوليين وأثرها في توجيه خطاب المجتهلين

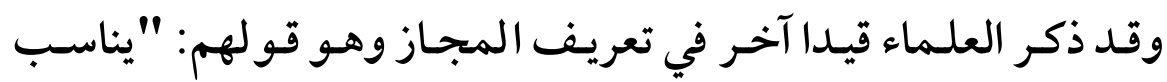

المصطلح ".

وقد أشاروا بذلك إلى شـمول حـد المجاز لكسل مـن: المجاز الشرعي،

المجاز العرفي في العام والخاص، والمجاز اللغوي، وأن العلاقة شرط (1).

مفهوم المجاز عند الأصوليين:

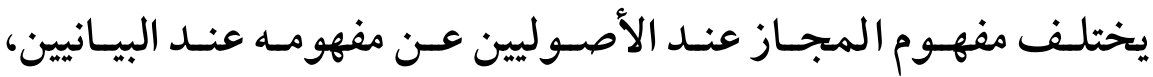

فالمجاز المرسل عند البيانيين هو ما كانت علاقته غير المشابهة.

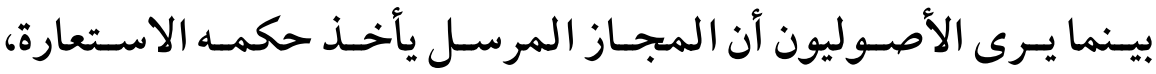

والكناية، فتحقق المناسبة بين المعنى الحقيقي للفظ والمعنى الذي خرج

إليه يكفي في جواز استعمال اللفظ في هذا المعنى.

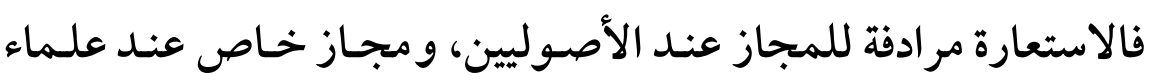
البيان، فإن المجاز عندهم نوعان:

1 - مجاز مرسل: وهو ما كنت علاقته غير المشابهة.

r - استعارة: وهو ما يكون علاقته المشابهة|"(r).

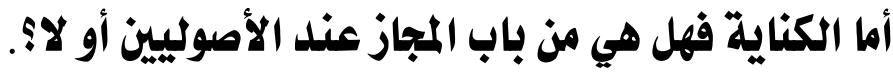

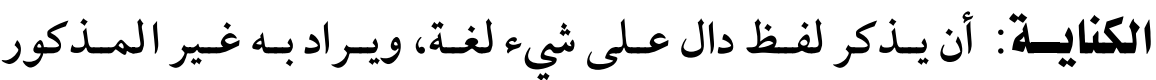

لملازمة بينهما و مجاورة خاصة، مثل لفظ "الغائط " .

(1) يراجع: البحر المحيط r/ اع.

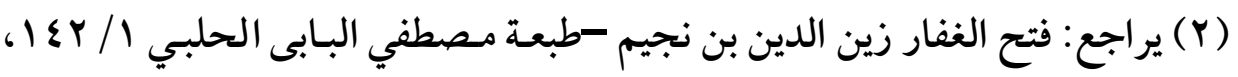

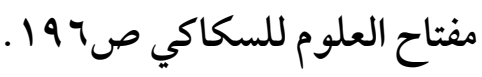


(IAV)

فالفـائط: اسـم لمكـان مطمسئن مـن الأرض، وهـو كنايـة عـن الحـدث؛ لمجاورة لازمة بينهما، فإن الحدث لا يكون إلا في مثل هذا المكان غالباً.

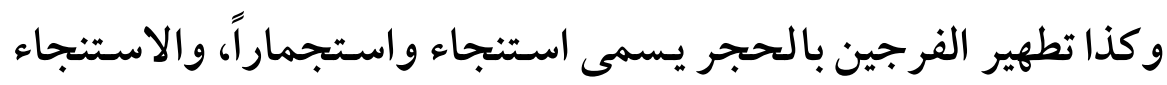
في وضع اللغـة: طلب النجـوة، والاستجمار : طلب الجمـرة، وهي الحجر، لملازمة بينهما في العادة.

وإنما الداعي إلى الاشتغال بالكناية قبح ذكر النجاسة والعورة ههنا. وقد اختلف الأصوليون في إدخال الكناية في المجاز:

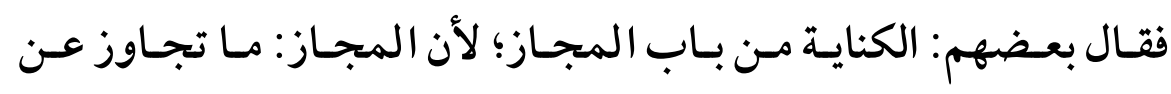

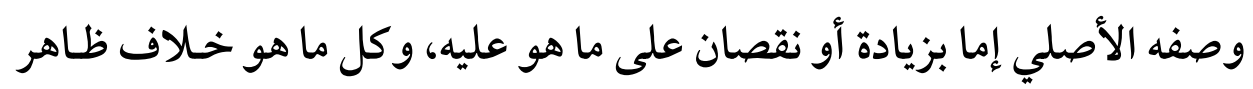
الموضوع فهو مجاز. والصحيح أنه ليس بمجاز خالص، بل هو حقيقة، لكـن الحقيقة نوعـان: صريح، وكناية، وكذا المجاز نوعان: صريح، وكناية.

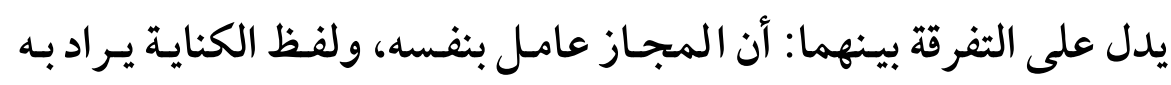
غيره. فقي المجاز المرسل: تكون المناسبة والعلاقة غير المشابهة. و في الاستعارة والكناية: تكون المناسبة والعلاقة هي المشابهة'). 
$(1 \wedge \wedge)$ مناسبة اللفظ للعنى عند الأصوليين وأثرها في توجيه خطاب المجتهلين الإطلب الثاني

\section{شروط هناسبة اللفظ للامعنى في المجاز} وأثره في توجيه خطاب المجتهدين

لابـــ للتجـوز مـن العلاقـة بـين المعنـى الحقيـق والمجــازي، ولا يكفي

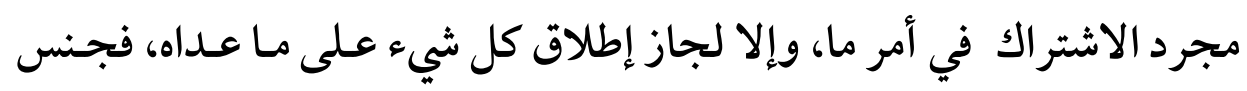
العلاقة شرط بالإجماع.

فإذا رأيناهم أطلقوا الشجاع على على رجل لم يحتج إلى إطلاقهـم بالنسبة إلى آخر، وأصبح الخلاف بين العلماء هو في أنواع العلاقة (1).

فالعلاقة: مناسبة معتبرة تلاحظ بين المعنيين لا مطلق المناسبة ().

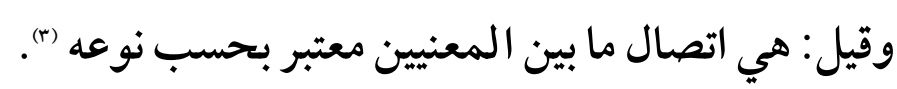
وفي اعتبار هذه المناسبة و شروط تحققها وأثر ذلك في توجيه خطاب المجتهدين نعقد المسائل الآتية:

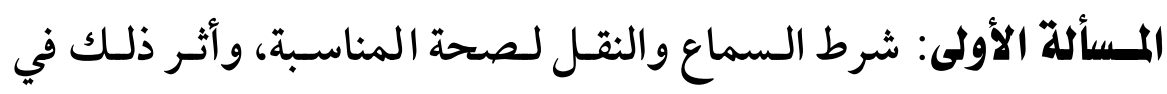
توجيه خطاب المجتهدين. المسألة الثانيـة: شرط اللزوم الـذهني لصحة المناسبة، وأثر ذلك في توجيه خطاب المجتهدين.

$$
\begin{aligned}
& \text { (1) يراجع: البحر المحيط r/ • •T. }
\end{aligned}
$$

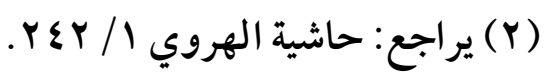

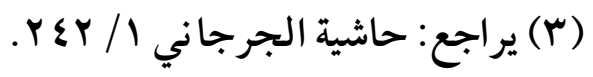


$(1 \wedge 9)$

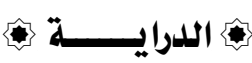

المسألة الثالثـة: شرط شهرة المناسبة، وأثر ذلك في توجيـه خطـاب

المجتهدين.

المسألة الرابعـة: صلاحية المناسبة للتجوز بها في الأسماء الشرعية،

$$
\text { وأثر ذلك في توجيه خطاب المجتهدين. }
$$

\section{المسألة الأولى}

\section{شرط السيماع والنقل لصحة المناسبة}

\section{وأثر ذلك في توجيه خطاب المجتهدين}

اختلف الأصوليون في إطلاق الاسـم على مسماه المجـازي، هـل يفتقر

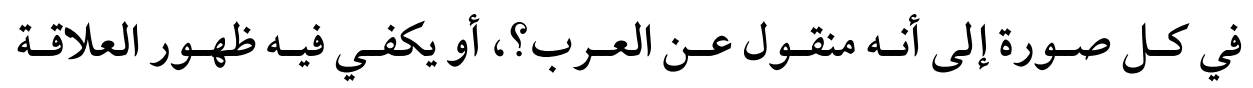
المعتبرة في التجوز أولا؟. أولا: اختلفوا في ذلك على قولين: القول الأول: اشترط بعض الأصوليين في ذلك النقل مع العلاقة. دليله: احتج الشارطون للنقل بأنه لو اكتفي بالعلاقة لجـاز تسمية غير الإنسان نخلة؛ لمشابهته لها في الطول كما جاز في الإنسان. ولجـاز تسمية الـصيد شـبكة، والثمـرة شـجرة، وظـل الحسائط حائطسا،

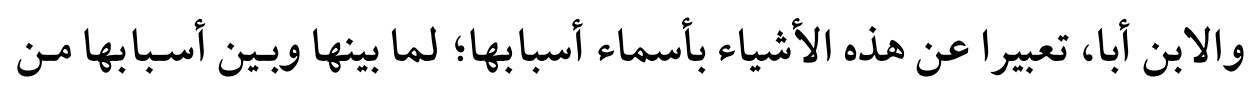
الملازمة في الغالب، وهي من الجهات المصححة للتجوز. 
$(19 \cdot)$ مناسبة اللفظ للعنى عند الأصوليين وأثرها في توجيه خطاب المجتهلين

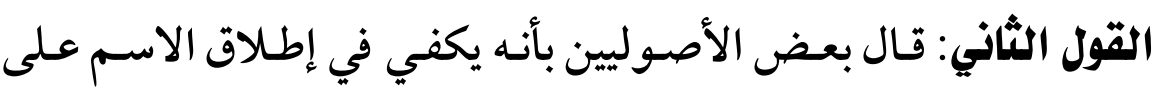
مسماه المجازي مجرد المناسبة والعلاقة التي تجمـع بين المعنى الحقيق والمعنى المجازي، ولا يشترط النقل في ذلك عن العرب.

دليله: أن إطلاق المجاز مما لا يفتقر إلى بحث ونظر دقيق في الجهات المصححة في التجوز، والأمر النقلي لا يكون كذلك. وأيضا: فإنسه لـو كـان نقليـا لمـا افتقـر فيـه إلى العلاقـة بينه وبـين محسل

الحقيقة، بل لكان النقل فيه كافيا (1).

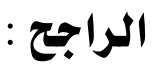

\section{وأثر هذا الشرط في توجيه خطاب المجتهلدين:}

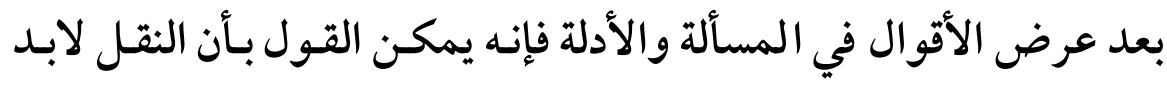

$$
\text { منه، واشتر اط وجود المناسبة لابد منه أيضا. }
$$

فالنقـل واجـب بالاتفـاق في نـوع العلاقـة، أعنـي : النـوع الأصسلي، فـإذا وجدت علاقة تجـوز بها العـرب، كما إذا ثبـت إطلاق الأسـد على الشجاع للشجاعة، فإن هذه المشابهة أينما وجدت يجوز التجوز بهوز بها، مـع تحققى بـاقي الشروط التي سنذكرها بعد من شهرة هذه المناسبة، وذهنيتها إلخ. لكن النقل غير شرط بالاتفاق في مشخصات اللفظة الواحدة المستعملة مجازا في شخص بعينه.

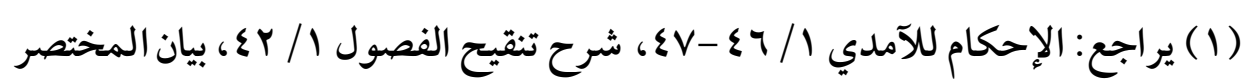

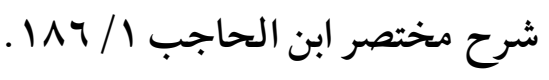


(191)

فيجوز استعمال اللفظة في المعنى المجازي لوجـود العلاقـة التي تجوز

بها العرب، ونقل عنهم التجوز في نوعها لا مشخصاتها' (1).

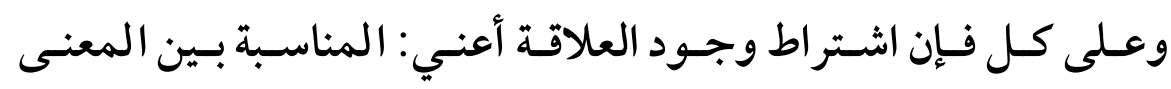

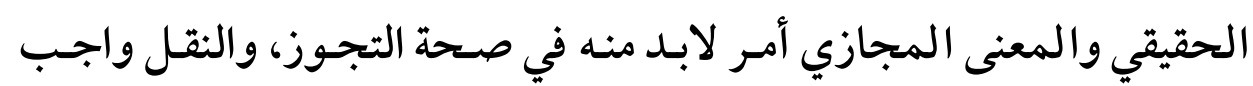
في نوع العلاقة لا في مشخصاتها.

أثر اشتراط النقل عن العرب مع العلاقة في صحة التجـوز في توجيـه خطـاب

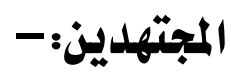

كان السلف الصالح في غنيـة عن وضـع قواعد يفهمون بها كـلام الله -

تعالى -؛ حيث إنهم كانوا من العرب الخلص، فيفهمون كلام الله -تعالى - عالى على ما هو عليه.

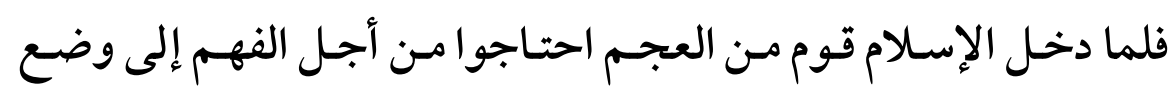

القواعد التي يمكن من خلالها فهم كلام الله -تعالى - باعتباره كلاما عربيا.

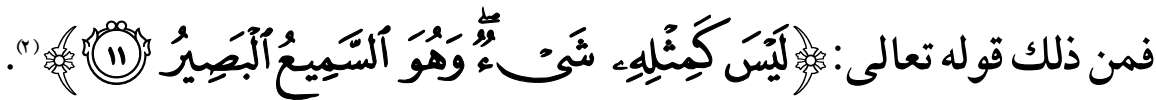
تفيد هذه الآية: تنزيه الله -تعالى -عن المماثلة للحوادث.

ثم تأتي آيات أخرى توهم تشبيه البـاري -سبحانه وتعالى - بـالحوادث، منها:

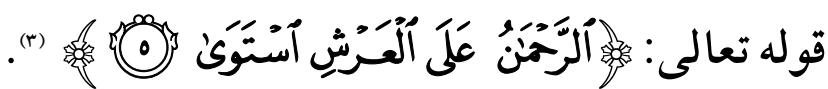

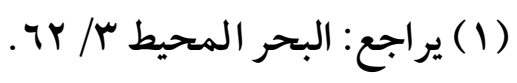

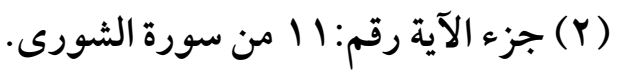

(r) (r) (الآية رقم: ه من سورة طه. 


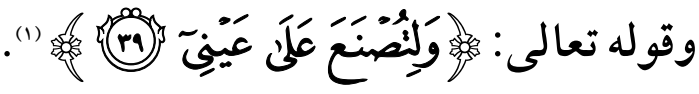

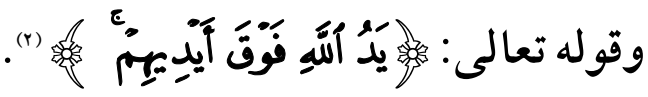

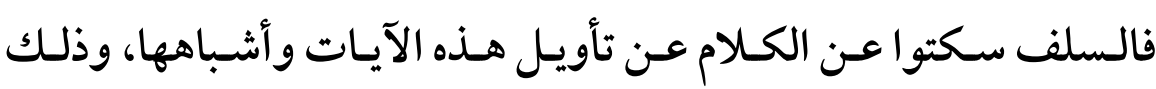

بأنهم لم يقولوا بأن المعنى المجازي هو المـراد لتوافق هـذه النصوص الآيـة التي تنفي المشابهة، والسبب أنه لم ينقل عن الله - تعـالى - ولا عن رسوله

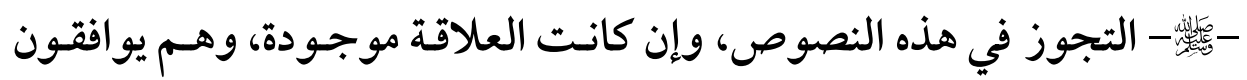
بذلك القول القائل: بأنه يشتر ط لصحة التجوز العلاقة مع النقل.

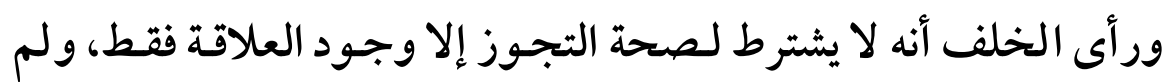
يشترطوا النقل، ولذلك فإنهم أولوا النصوص السابقة لتوافق الآيـة التي تنفي المماثلة عن الباري - سبحانه وتعالى - (r). والخـلاف في تأويل الصفات الحسنى لله - تعالى - الموهمة لتشبيهه

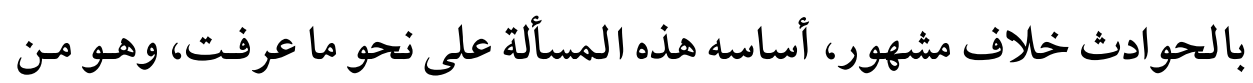
الخلاف الذي ينفذ منه كل من يريد أن يفرق بين أهل السنة ويجعلهم شيعا.

$$
\begin{aligned}
& \text { (1) جزء الآية رقم: 9 ه من سورة طه. }
\end{aligned}
$$

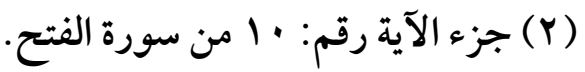

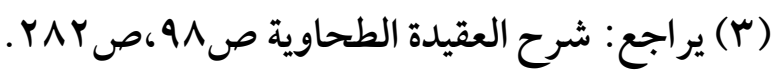




\section{المسألة الثانية}

\section{شرط اللزوم الذهني لصحة المناسبة}

\section{وأثره في توجيه خطاب المجتهدين}

اشترط قوم من الأصوليين لصحة المناسبة أن تكون هذه العلاقة ذهنية.

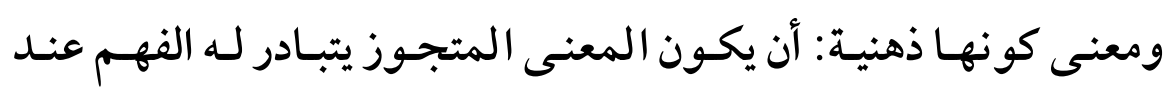
سماع اللفظ.

ونحــن نعلــم أن التبـادر أي: تبــادر المعنــ إلى الـــهن مــن علامــات

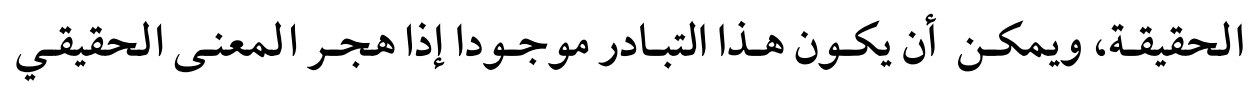
واشتهر المعنى المجـازي حتى تبـادر هـو إلى الذهن عند إطلاقه، وهـذا هـو الذي حققناه عند إثباتنا للحقيقة العرفية والثرعية. أما في المجـاز: فإن المعنى الحقيقي مـراد ومستعمل لم يهجرـ، ولـذلك اشترطنا في المجاز وجود قرينة تمنع من إرادة المعنى الحقيقي.

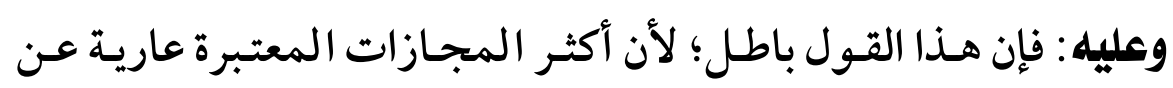

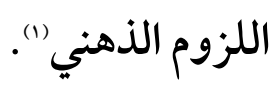

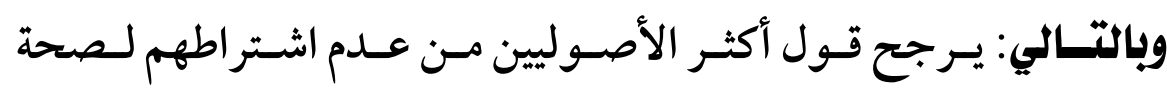
المناسبة كون هذه العلاقة أن تكون ذهنية.

(1) يراجع: البحر المحيط א/ §7، بيـان المختصر شرح مختصر ابن الحاجـب .119/1 
(19६) مناسبة اللفظ للعنى عند الأصوليين وأثرها في توجيه خطاب المجتهلين

وهذا الشرط ينضم إلى سابقه في الأثر المترتبب عليه في توجيه خطاب

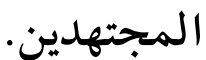

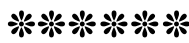

\section{المسألة الثالثة}

\section{شرط شهرة المناسبة}

لم يختلف الأصوليون في اشتر اط هذا الشرط للمناسبة.

ومعنساه: أنسه يجـب أن تكـون العلاقـة والمناسبة بـين المعنى الحقيقي

والمعنى المجـازي مناسبة معتبرة تلاحظ بـين المعنيـين، بمعنى: أن تكـون

ظـاهرة الثبوت للمعنى الحقيقي، ولها بـه مزيـــ اختصاص وشـهرة؛ لينتقل

الـذهن مـن المعنى الحقيقي أعني: الموصسوف إلى الصفة، فيفهم المعنى

$$
\text { الآخر أعني: المجازي باعتبار ثبوت الصفة له. }
$$

وذلك مثل: إطلاق الأسد على الشجاع؛ للاشـتر اك في صـفة الشجاعة؛ إذ

لها فيه ظهور، ومزيد اختصاص، فينتقل الذهن منه إلى هذه الصفة.

بخلاف إطلاق الأسد على الأبخر -والبخر : هو الرائحة المنتنة- فإنـه لا

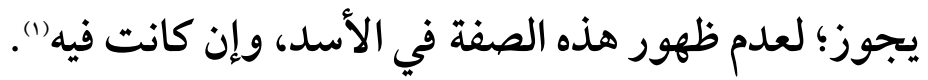

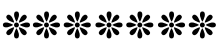

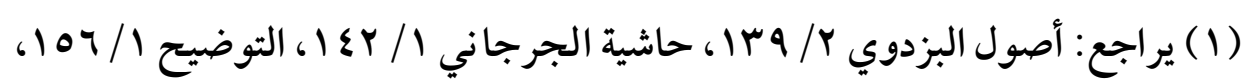

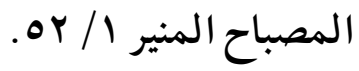


(190)

\section{المسألة الرابعة}

\section{صلاحية المناسبة للتجوز بها في الأسمهاء \\ الشرعية وأثره في توجيه خطاب الجمتهدين}

ومعنى هـذه المسألة: أنـهـ كـما يجـوز المجـاز في الأسـماء اللغويـة إذا

وجدت العلاقات المذكورة بين معانيها، فهل يجـوز في الأسماء الشرعية إذا

$$
\begin{aligned}
& \text { وجد بين معانيها نوع من العلاقات المذكورة بحسب الشرع؟. } \\
& \text { اختلف العلماء في ذلك على قولين: }
\end{aligned}
$$

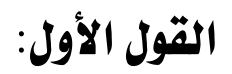

وهو قول الجمهور: قـالوا: بأنه يجـوز المجـاز في الأسـماء الشرعية إذا

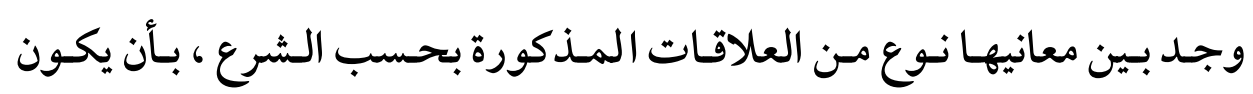
تصرفان شرعيان يشتر كان في وصف لازم بين، أو يكون معنى أحسدهما سببا

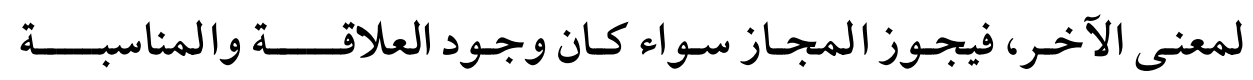

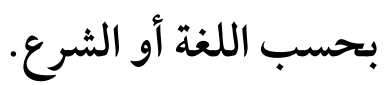
دليلهي: أن العرب لما وضعت طريق الاستعارة، واستعملت المجاز في كلامهم، وعرف بالتأمل طريقه، يكون إذناً مـنهم بالاستعارة لكل مـتكلم مـن جملتهم أو من غيرهم، كصاحب الشرع: متى وضع طريق التعليل، كان إذناً

$$
\text { بالقياس لكل من فهم ذلك الطريق. }
$$

قول بعض الفقهاء: قالوا: إن المجـاز لا يجـري في الألفـاظ الشرعية مـن البيع، والهبة، والنكاح، والطلاق، ونحوها. 
(197) مناسبة اللفظ للعنى عند الأصوليين وأثرها في توجيه خطاب المجتهلين

دليلهه: أن هذه الألفاظ إنشاءات في الشرع، وأنها أفعال جارحة الكـلام وهو اللسان، وهي مخارج الحروف بمنزلة أفعال سـائر الجـوارح، ومسن فعل فعـلا حقيقـة وأراد أن يكسون فـاعلا فعـلا آخــر لا يكسون. فكـذلك أفعـال هـــه الجارحة، وإنـما تـدخل الاسـتعارة والمجـاز في الألفـاظ التي هي مـن بـاب

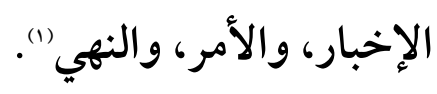

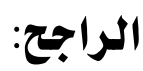

والـراجح هـو القـول الأول؛ لقــوة دليله، ولأنسه لا فـرق بـين الأســماء الـشرعية واللغويسة متسى تحقـق شرط التجــوز وهــو وجـود المناسـبة بــين المعنيين.

أثر صاحية المناسبة للتجوز في الأسماء الشرعية في توجيه خطاب المجتهلين:لقد كان للخلاف في صلاحية المناسبة للتجوز في الأسماء الشرعية أثر كبير في توجيه خطاب المجتهدين، حيـث اختلف العلماء في انعقـاد النكاح

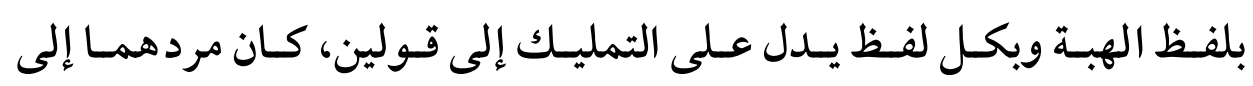
صلاحية المناسبة للتجوز أو عدم صلاحيتها. كـذلك اختلفـوا في وقـوع العتـاق بلفــ الطـلاق عـلى سـبيل التجـوز، وصلاحية المناسبة لذلك التجوز أو عدم صـلاحيتها، وسوف نتناول ذلك وفيك فيما يأتي:

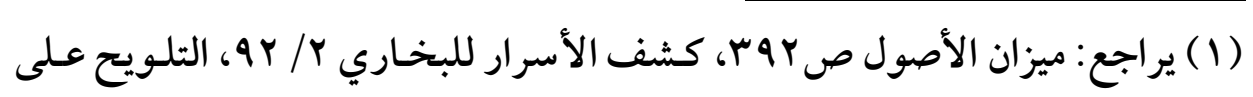

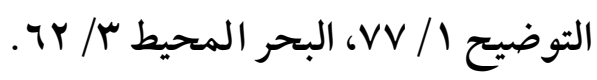


(19V)

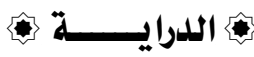

\section{أولا: انعقاد النكاح بلفظ الهبة}

اختلف الفقهاء في انعقاد النكاح بلفظ غير لفظة النظ النكاح، وهـو استعارة

$$
\begin{aligned}
& \text { ألفاظ التمليك للنكاح على قولين: } \\
& \text { القول الأول: } \\
& \text { وهو قول الحنفية ومن معهم من المالكية'). }
\end{aligned}
$$

قالوا: يجوز أن ينعقد النكاح بلفظ النكاح، والنزويج، والهبة، والصدقة،

والتمليك.

$$
\text { واشترط المالكية أن يبين المهر. }
$$

الأدلة: استدلوا على ذلك بما يأتي:

1 - قوله تعالى :

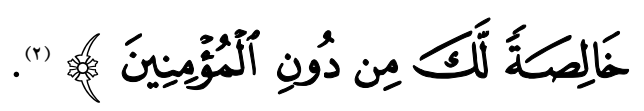

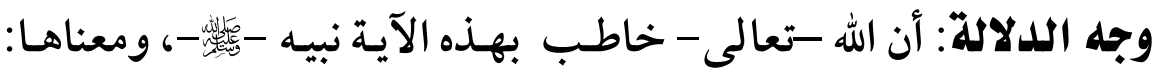

أحللنـا لـك مـن وقع لها أن تهـب لك نفسها، ولا تطلـب مهـرا مـن النساء

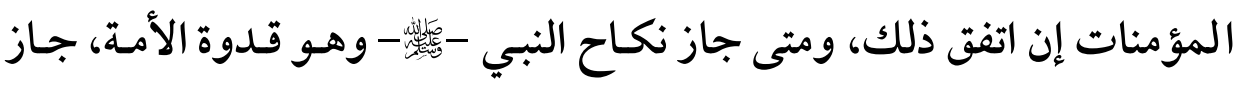
للأمـة إلا حيـث تثبـت الخصوصية، وقولـه: "خالصة " مـصدر مؤكـد، أي: خلص لك إحلال ما أحللنا لك خلوصا.

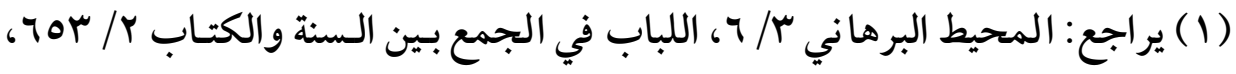

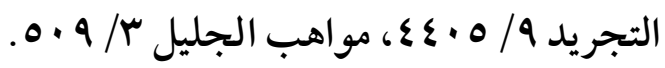

$$
\begin{aligned}
& \text { (Y) جزء الآية رقم: · • من سورة الأحزاب. }
\end{aligned}
$$


(191)

مناسبة اللفظ للعنى عند الأصوليين وأثرها في توجيه خطاب المجتهلين

وقوله: "وهبت " أي: هبة خالصة لك بغير بـدل، وكان -عليه السلام-

مخـصوصا بـذلك بخـلاف سـائر المهؤمنين، فـإن الهبـة لا تخلـص لهـم، بـل يجب البدل حكما، فالخلوص له هـو: الإباحة بغير مهر، وأن لا إباحة لغيره

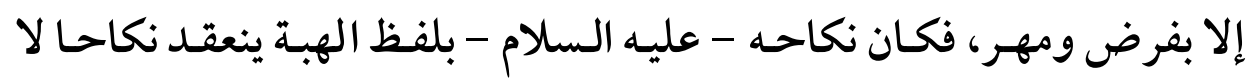

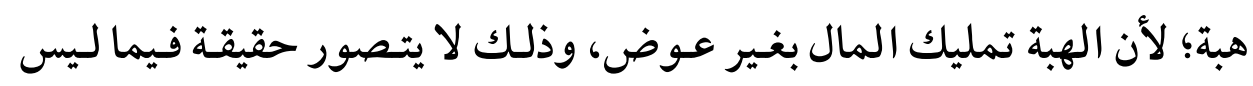

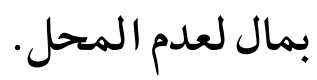
ولذا: لم يكن أحكام الهبة ثابتة مـن توقف الملك على القبض، وحق الرجـوع للو اهبة بعـد القبـض، حتى لم يكـن لمـن وهبـت نفسها منه -عليـه السلام - أن تتزوج بزوج آخر قبـل تسليم النفس، ولا أن ترجع عـن الهبـة

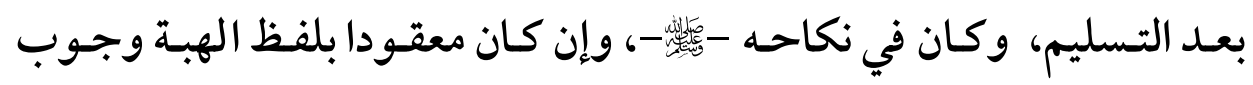
القسم. فعرفنا أن نكاحسه انعقــ نكاحـا لا هبـة، فثبـت أن لفظ الهبـة كـان مستعارا للنكاح

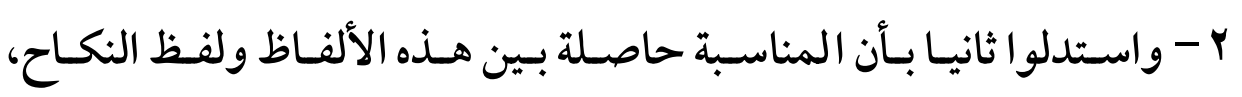
فيجوز استعار تها لانعقاد النكاح. وبيانه : أن لفظظ الهبـة والبيع وسـائر ألفـاظ التمليك، وضـع أي كـل واحد منهما لملك الرقبة، وملك الرقبة سبب لملك المتعـة، أي: موجـب له إذا كان المحل قابلا له؛ لأن ملك المتعة يثبت به تبعـا لـه، فكـان ألفـاظ

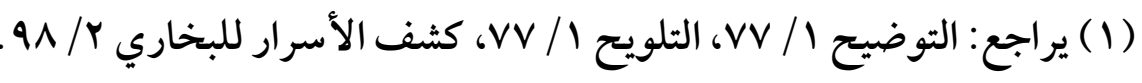


التمليك سببا لملك المتعة، وقد ثبت من مذهب العرب استعارة اللفظ

$$
\text { لغيره إذا كان سبيا له القول }
$$

وهو قول الشافعي ومن معه من الحنابلة والظاهرية (r).

$$
\text { قالوا: لا ينعقد النكاح إلا بلفظ النكاح أو التزويج. }
$$

دليلهه: قال الشافعية بجواز جريان الاستعارة في الألفاظ الشرعية، وهـذا

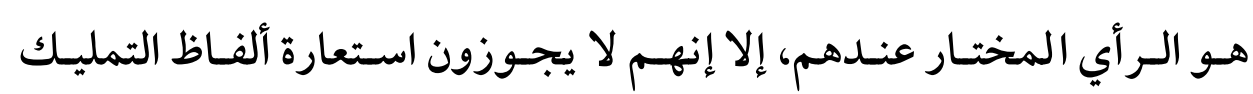
للنكاح؛ وذلك لعدم وجود المناسبة بين هذه الألفاظ وبين لفظ النكاح. وبيانه: أن النكاح شرع لمقاصد كثيرة لا تحصى مما يرجع إلى مصالح الــين والــنيا مـن حر مـة المـصاهرة، ووجــوب النفقـة والمهـر، وجريــان التوارث، وتحصين الدين، وثبوت صفة الإحصان وغيرها. وإنـما يثبـت الملك فيـه تبعـا ضرورة تحصيل هـذه المقاصـد المطلوبـة

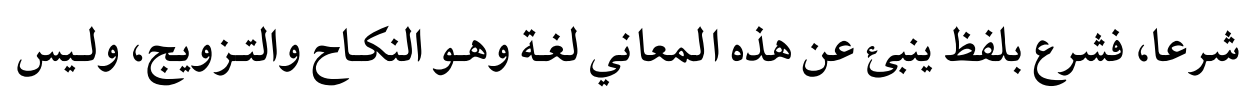

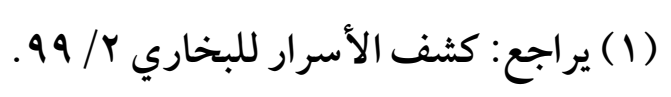

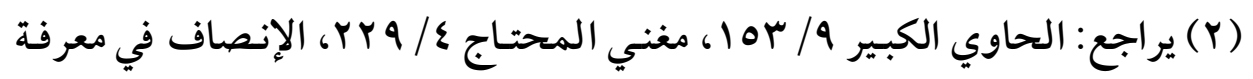

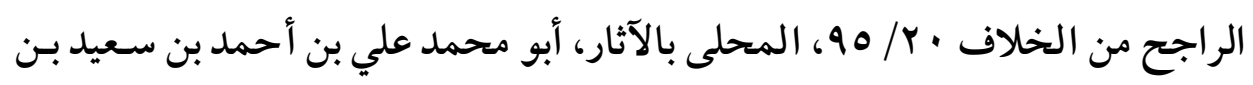

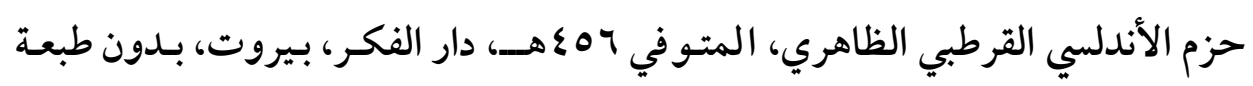

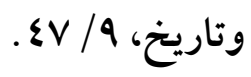


$(r+\cdot)$

مناسبة اللفظ للعنى عند الأصوليين وأثرها في توجيه خطاب المجتهلين

في هـذين اللفظين مـا يـدل عـلى التمليك، ولهـذا لا يثبـت بهـما ملـك العين

أصلا.

والهبة وسائر الألفـاظ الموضسوعة للتمليك لا ينبئ عـن هـذه المقاصـد،

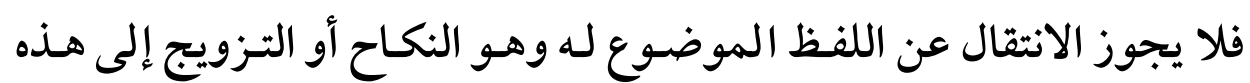

الألفاظ؛ لقصورها عن اللفظ الموضوع له وهو النكاح والتزويج".

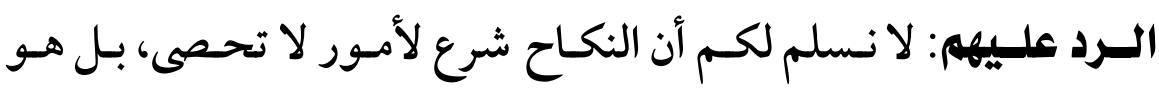

مشروع لأمر واحد وهو ملك المتعة، ومـا وراءه مـن فـروع النكاح وثمر اته لا مـن الأمور الأصلية فيس؛ لأنها غير محصورة لا يمكسن ضبطها، فلا يصلح وضع النكاح لأمور غير معلومة").

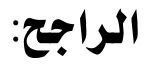

الر اجح هو القول الأول؛ لقوة أدلته وسلامتها من الرد عليها.

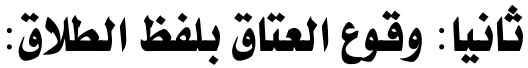

اختلف الفقهاء في جواز استعارة ألفاظ الطلاق للعتاق على قولين:

القول الأول: - اختين

يجوز استعارة ألفاظ الطلاق للعتاق، وهو قول الثافعي"(r).

فلو قال رجل لأمته: أنت طالق، أو أنت بائن، أو حرام، ونوى بـه الحريـة،

فإنها تعتق بذلك.

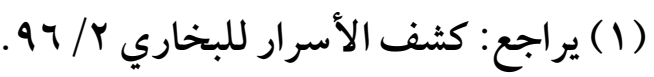

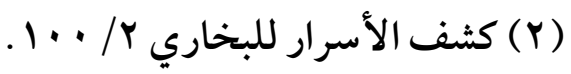

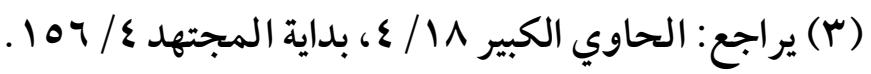


دليله: أن التشابه والتشاكل في المعاني من طرق الاستعارة، وقـد ثبتـت المشاكلة بين الطلاق والعتاق في المعنى لغة و شرعا. أما لغة: فلأن الطلاق معناه: التخلية والإرسال، والعتاق كذلك.

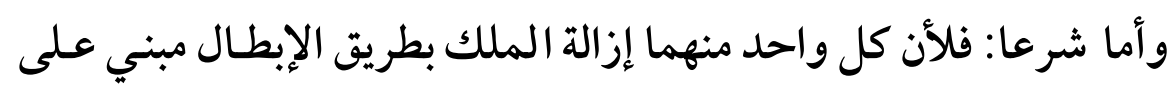

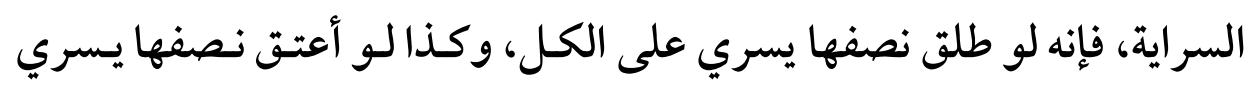

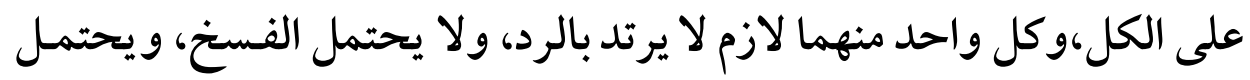

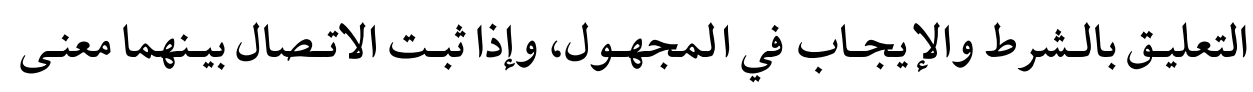
جاز استعارة الطلاق للعتاق كما جاز عكسه.

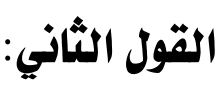
لا يجوز استعارة العتاق للطلاق عند الحنفية (1). دليلـهـ : اسـتدل الحنفيـة عـلى عـدم جـواز هـذه الاسـتعارة؛ لعـدم وجـود

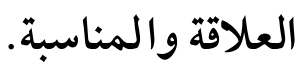

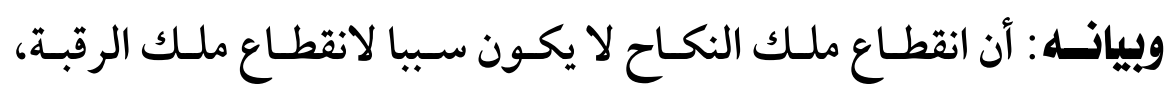

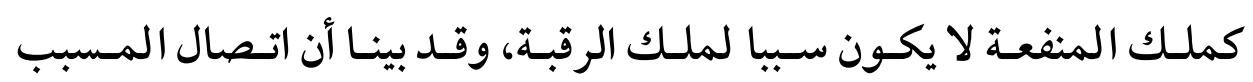

(1) يراجع: درر الأحكام شرح غرر الأحكام، محمـد بـن فرامـرز الشهير بملاخسرو،

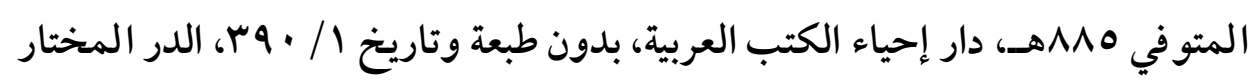
. $r \leqslant 7 / r$ 
بالسبب لا يصلح طريقا للاستعارة، فليس بينهما اتصال من ناحية السبية، فلا

$$
\text { يصح الاستعارة بهذا الطريق"). }
$$

هو القول الثاني؛ لعدم وجود المناسبة والعلاقة المصححة للتجوز.

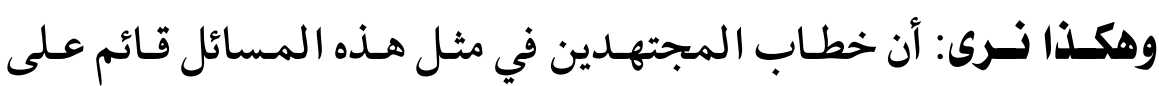

وجـود المناسـبة أو عـدم وجودهـا، فالمناسـبة لهـا الــور الأهــم في توجيسه

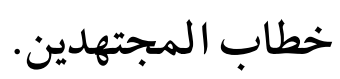

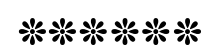

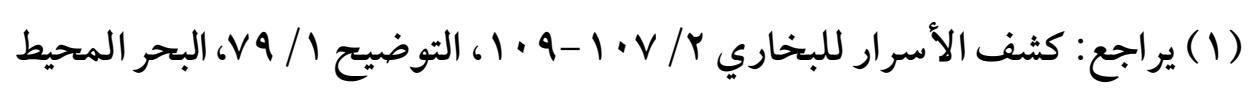




\section{المطالب الثالث}

\section{علاقات المباز}

مهم جدا أن نبين نوع العلاقات والمناسبات التي صـح بها التجوز؛ لأنهـ

$$
\text { نقل عن العرب التجوز بمثلها. }
$$

وللعلماء في حصر هـذه العلاقات جملة وتفصيلا اتجاهـات مختلفـة،

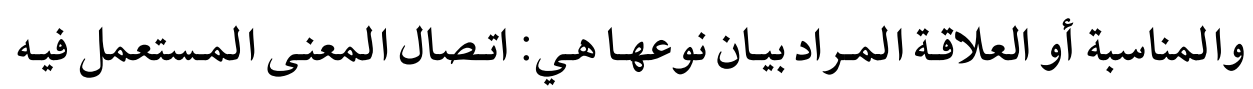
بالمعنى الموضوع له، والعمدة فيها الاستقر اء.

ويرتقي ما ذكره القوم إلى خمسة وعشرين نوعـا، وضبطه ابـ الحاجـبـ

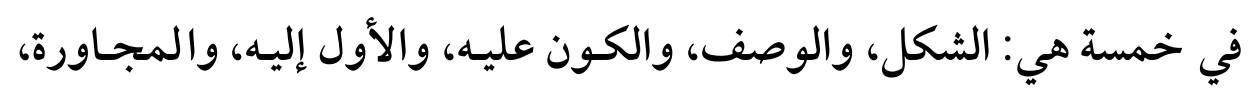

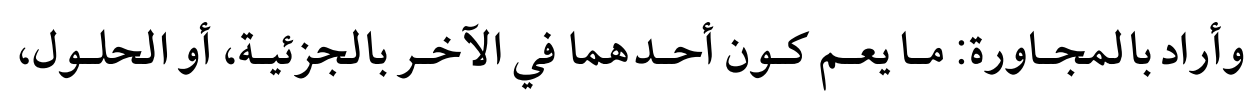
وكونهما في محل، وكونهما متلازمين في الوجود أو العقل أو الخيال.

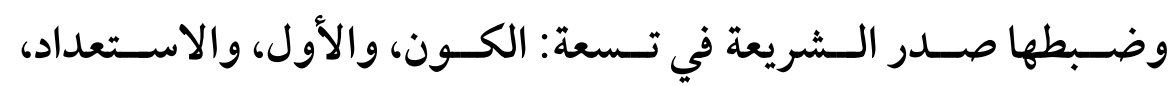
والمقابلة، والجزئية، والحلول، والسببية، والثرطية، والوصفية.

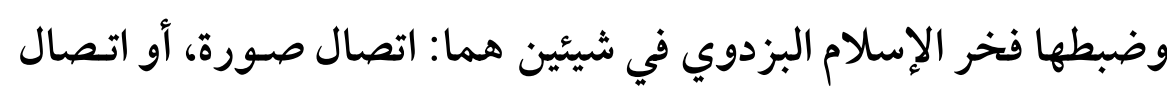
معنى (1) وذكر هذه الأنواع إنما هو لبيان الأنواع التي عرفت بالاستقر اء أن العـرب

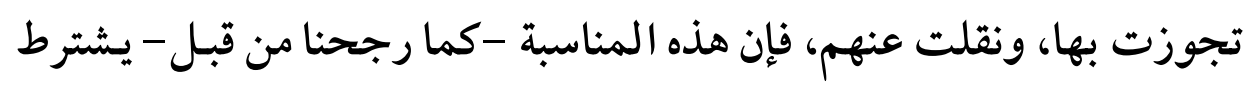
لصحتها النقل في أنواعها لا في آحادها.

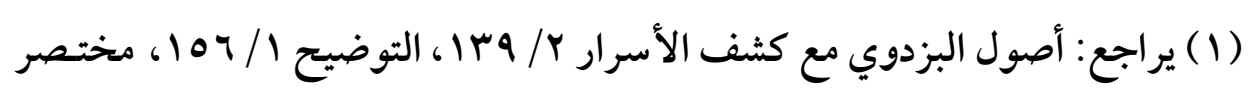

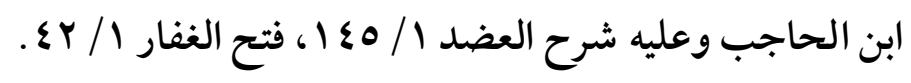



ويصح التجوز بها كلما وجدت في حالة من الحالات.

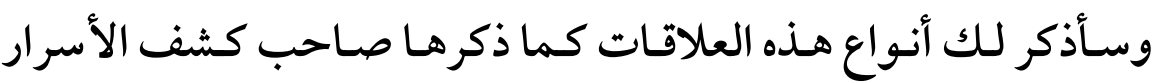
على شرحه للبزدوي، وذلك على النحو الآتي: أنواع علاقات المجاز:ثبت بالاستقراء أن هذه الأنواع على خمسة وعشرين نوعا، وهي: 1 - إطلاقاسم السبب علم المسبب.

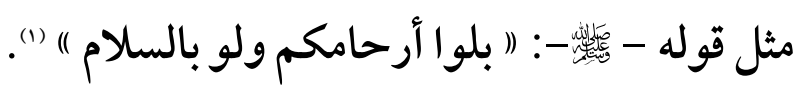

والمعنسى: أي: صـلوها، فـإن العـرب لمـا رأت بعـض الأشـياء يتـصل بالنداوة استعارت عنه البل لمعنى الوصل. r - إطلاقا المسبب علح السبب. مثل قول الشاعر:

كذاك الإثم يذهب بالعقول (r) - (r)

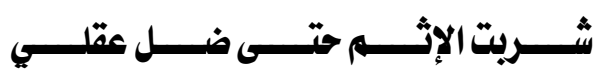

(1) رواه البزار والعسكري عن أنس رفعه، وعند الطبراني عن أبي الطفيل عن سويدبن عامر، وله طرق يقوي بعضها بعضا.

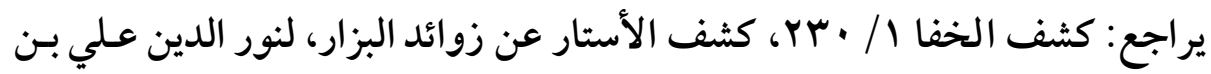

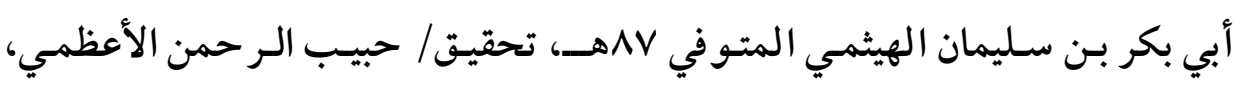

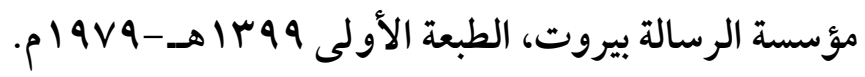

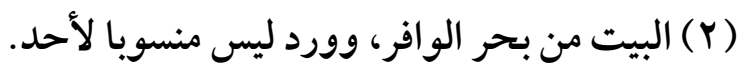

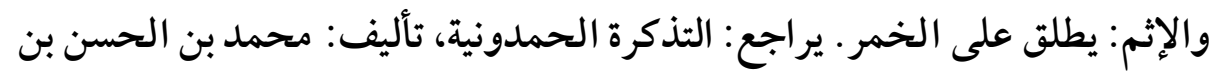

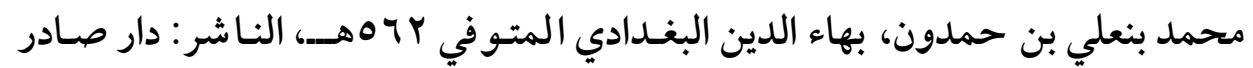


والمعنى: أنه سمي الخمر إثما؛ لكونها مسببا لها.

\section{r- بإطلاق اسم الكل علح البعض.}

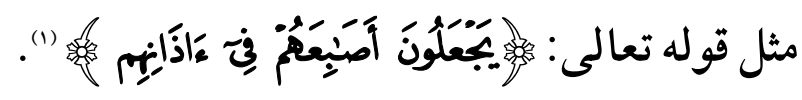

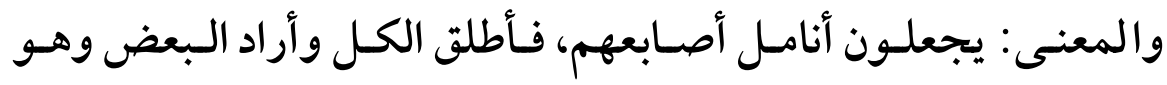

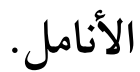

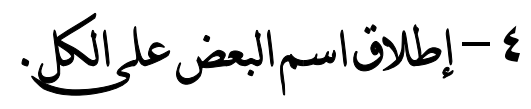

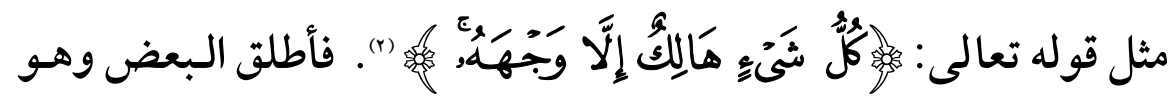

الوجه، وأراد الكل وهو ذات الله تعالى.

•- - مإطلاقاسم الملزومعلح اللاززم.

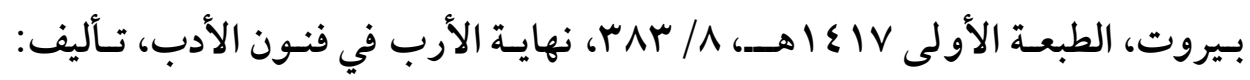

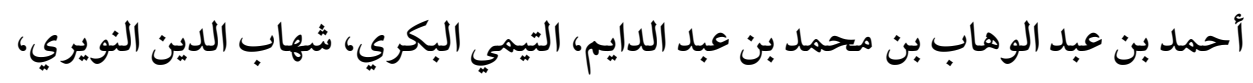

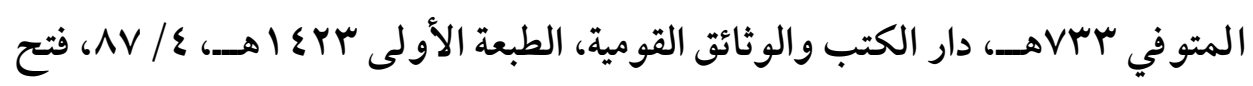

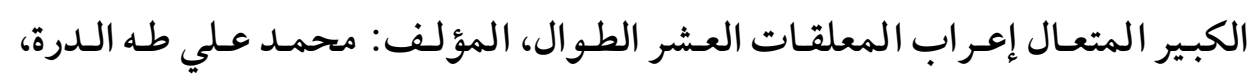

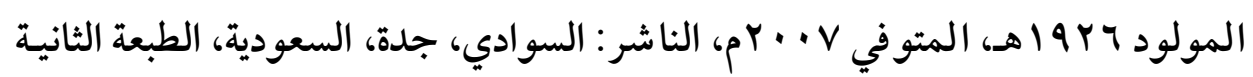

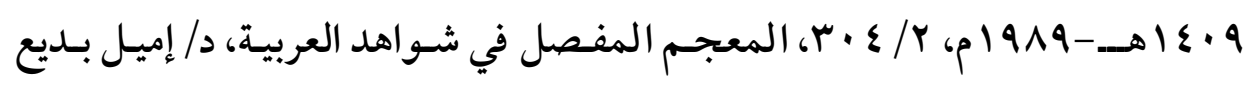

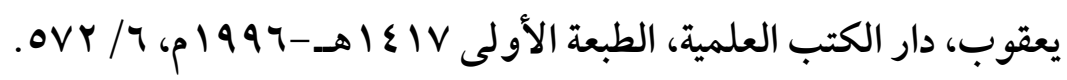

$$
\text { جزء الآية رقم: } 19 \text { من سورة البقرة. }
$$

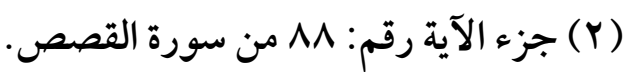




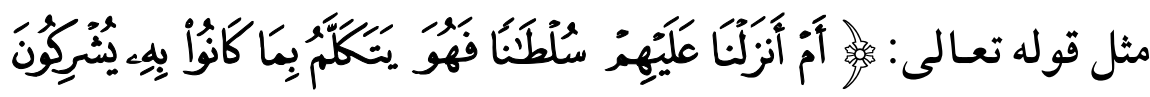

(1) 留

فقد سميت الدلالة كلاما؛ لأنها من لوازمه.

7 - إطلاق اسم اللازمعلح الملزوم.

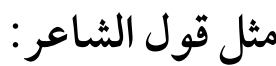

قوم إذا حاربوا شدوا مآزرهم دوز النساء ولو باتت بأطهار(r) أريــد بـشد المئـزر: الاعتـزال عــن النـساء؛ لأن شـــ الإزار مـن لــوازم

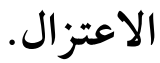

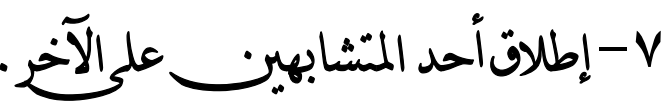

مثل : إطـلاق اسـم الإنسان عـلى الصصورة المنقوشـة لتشابهـما شكلا،

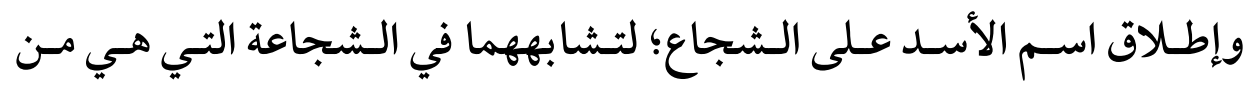

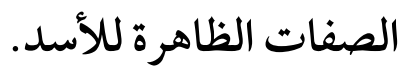

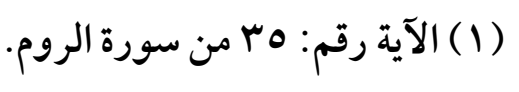

(Y) البيت من بحر البسيط للأخطل التغلبي.

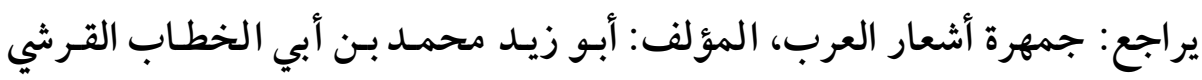

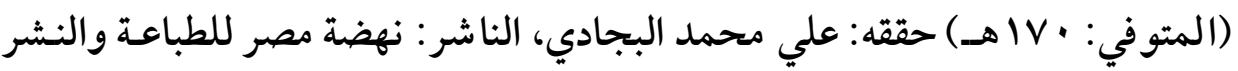

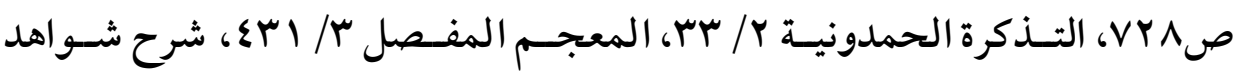

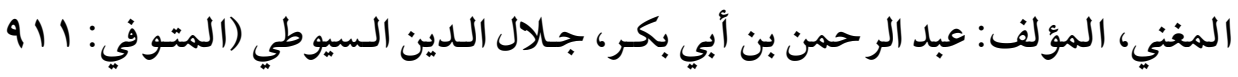

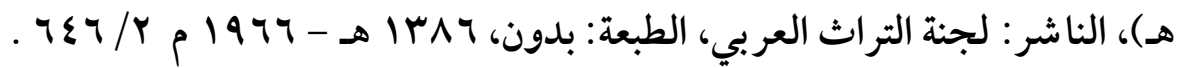




\title{
1- إطلات اسم المطلقّ علم المقيد . \\ مثل قول الشاعر:
}

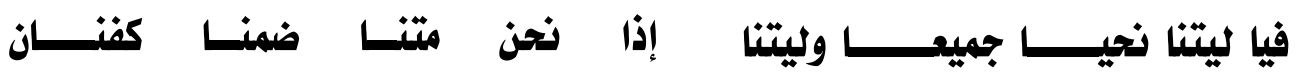

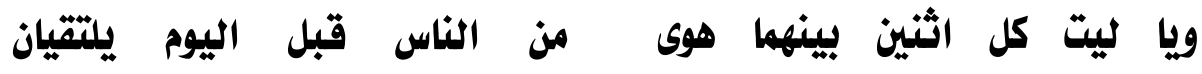

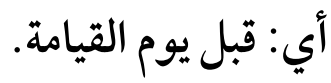 \\ 9 - إطلاق اسم المقّد علم المطلٌّ . \\ مثل قول شريح: أصبحت ونصف الخلق علي غضبان (r).

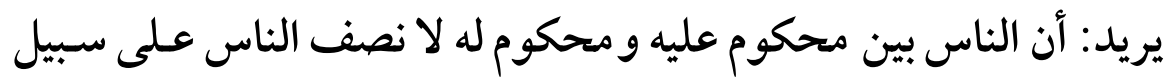 \\ التعديل والتسوية. ومثل قول الشاعر:
}

(1) الشعر لعروة بن حزم من قصيدته النونية الطويلة، قالها في ابنة عمه عفراء.

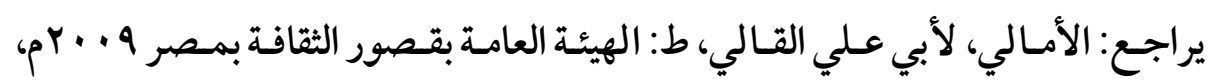

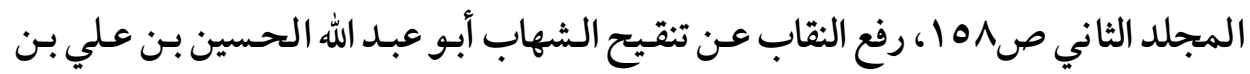

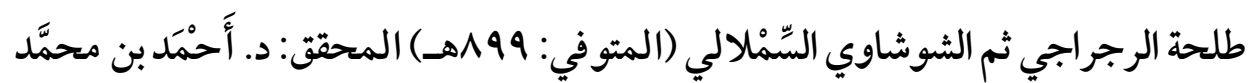

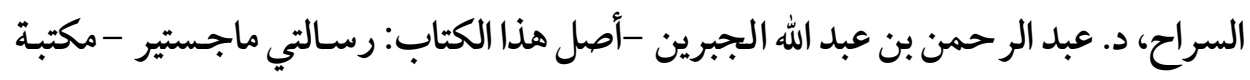

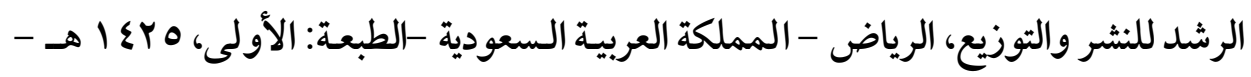

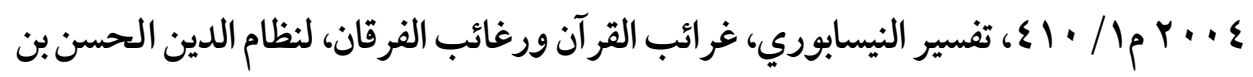

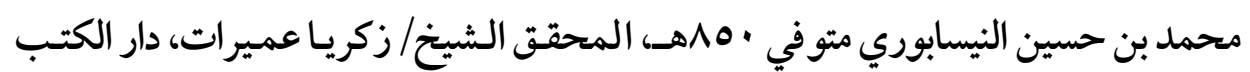

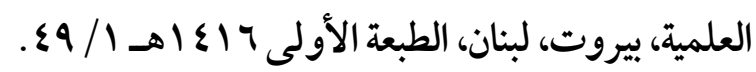

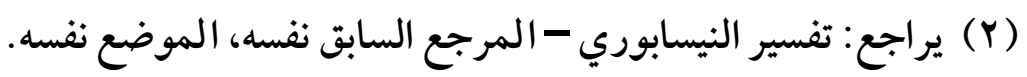


$(r \cdot \Lambda)$

مناسبة اللفظ للعنى عند الأصوليين وأثرها في توجيه خطاب المجتهدين

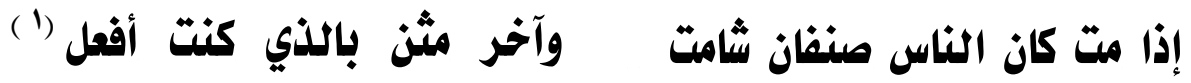

فقد أضمر في كان الشأن والحديث، وأوقع الجملة بعده مفسرة.

• 1 - إطلاقاسم الخاص علم العام.

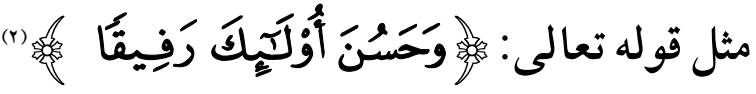

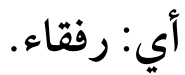

11 - 1 -إطلاقاسم العامعلم الحاص .

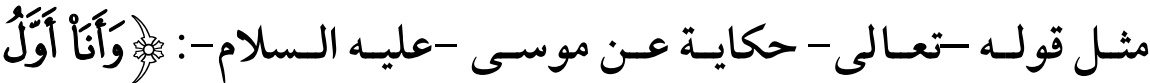

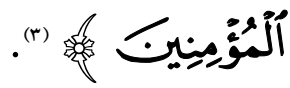

لم يرد الكل؛ لأن الأنبياء كانوا قبله مؤمنين.

(1) البيت من بحر الطويل، وهو قصيدة للعجير السلولي، كانت للعجير بنت عـم كـان

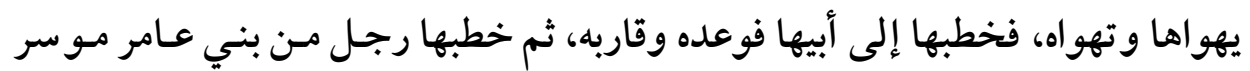

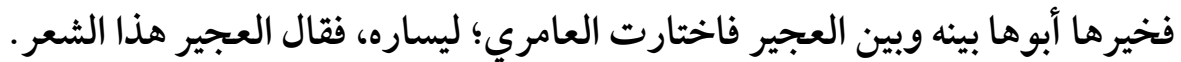

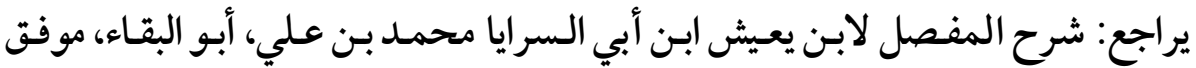

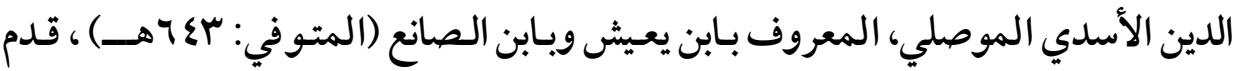

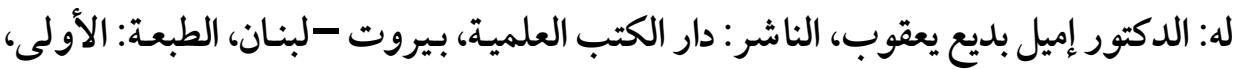

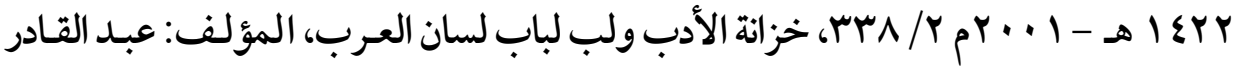

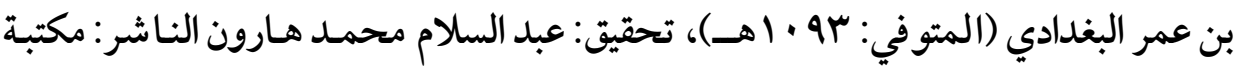

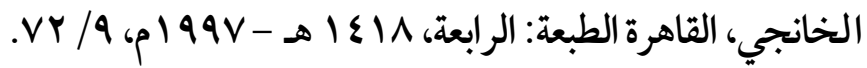
(Y) جزء الآية رقم: 79 من سورة النساء.

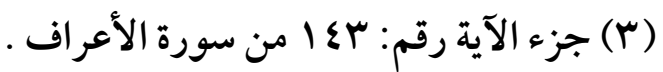




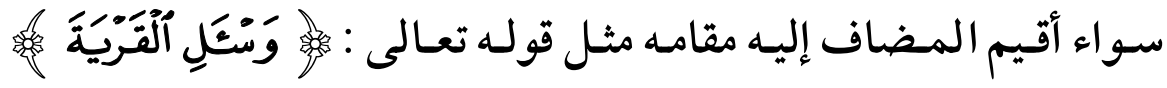
جزء الآية رقم: Y 1 من سورة يوسف، والتقدير في غير القـرآن: واسـأل أهـل القرية. وسواء لم يقم المضاف إليه مقام المضاف، مثل قول الشاعر:

ونار توقد بالليل نارا (1)

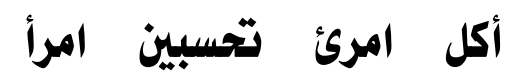
ويسمى هذا " مجازا بالنقصان" اليرن r ا إحذف المضاف إليه. مثل قول الشاعر:

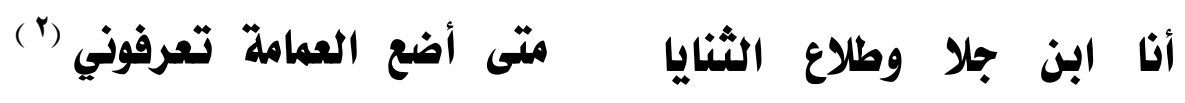
أي: أنا ابن رجل جلا، أي: وضح أمره.

(1) البيت من بحر المتقارب، وهو للشاعر أبى دؤاد، جويريى بـن الحجـاج الإيـادي،

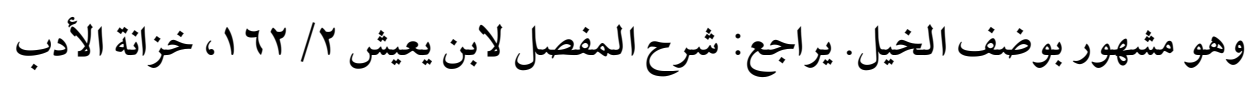
.乏) / /

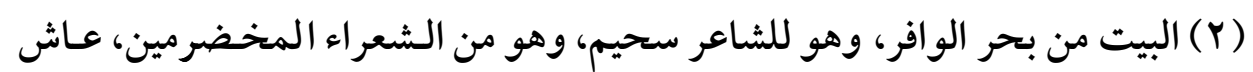
في الجاهلية ·ـ سنة، وفي الإسلام • ب سنة، وليس في آباء سحيم من اسمه جلا.

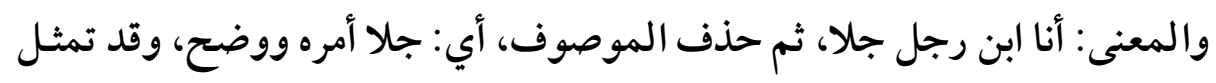
بهذا البيت الحجاج في خطبته في أهل الكوفة.

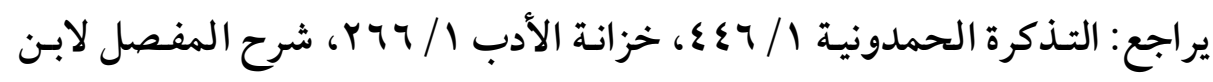

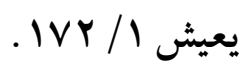


$(Y \mid \cdot)$

مناسبة اللفظ للعنى عند الأصوليين وأثرها في توجيه خطاب المجتهلين

$$
\text { ع } 1 \text {-تسمية الشيء باسمما لهبه تعلق المجاورة. }
$$

مثل: تسميتهم قضضاء الحاجـة بالغـائط الذذي هو المكـان المطمئن مـن

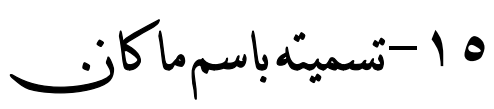

$$
\text { مثل: تسمية الإنسان بعد الفراغ من الضرب ضاربا. }
$$

مثل : ( لا يفضض الله فاك ) (1) أي: أسنانك.

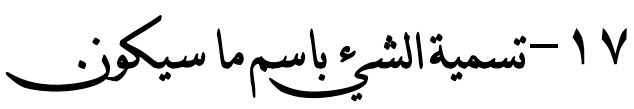

مثل: تسمية الإنسان قبل الضرب ضاربا.

1 1 - إطلات اسم الحال علح المحل.

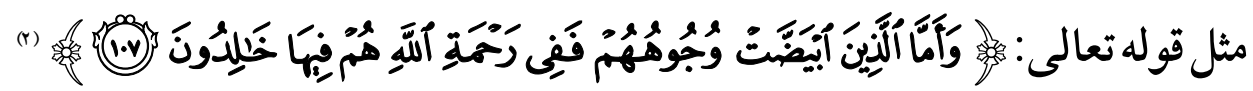

$$
\begin{aligned}
& \text { أي: في الجنة؛ لأنها محل نزول الرحمة. } \\
& 9 \text { } 1 \text {-إطلاقاسم الآلةعلم الشيء. }
\end{aligned}
$$

(1) حديث إسناده ضعيف. يراجع: اتحـاف الخيرة المهرة بزوائد المسانيد العشرة

$$
.1 \leqslant V / T
$$

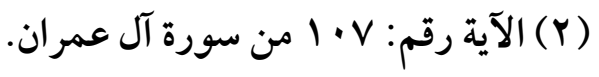


(YII)

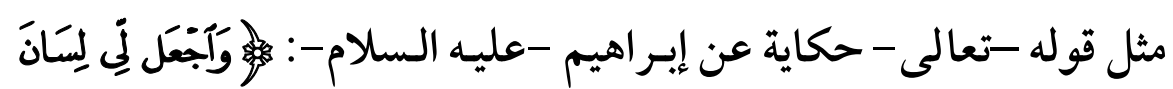

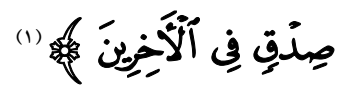

أي: ذكرا حسنا، أطلق اسم اللسان وأراد به الذكر ؛ لأن اللسان آلته.

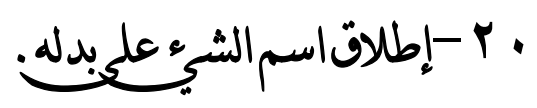

مثل قولهم: فلان أكل الدم إذا أكل الدية.

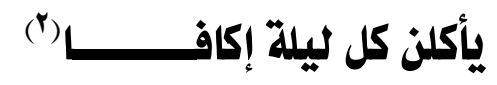

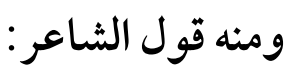

والمعنى: أننا نبيع كل ليلة أكافا مـن أكنفها، ونعلفها ثمنهه، فأطلق لفظ الإكاف وهي: البردعة التي توضع على ظهر الحمار على العلف الذي تلى تأكله

$$
\text { هذه الأحمرة. }
$$

\section{ا r - إطلاق النكرة فُموضع الإثبات للعموم .}

مثل قوله تعالى : : (r)

$$
\text { (1) (1) الآية رقم: \&^من سورة الشعراء. }
$$

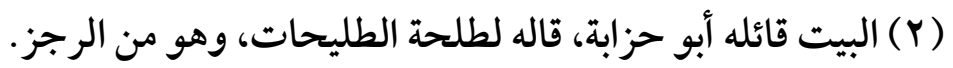

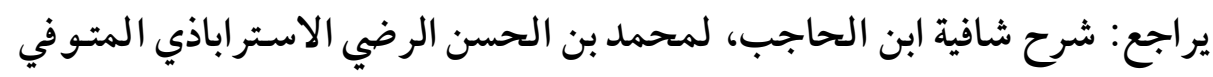

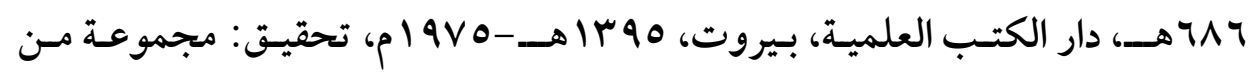

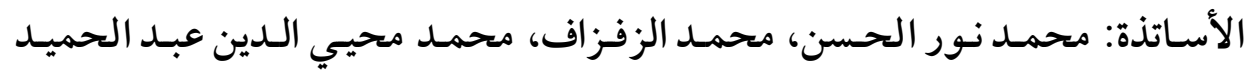

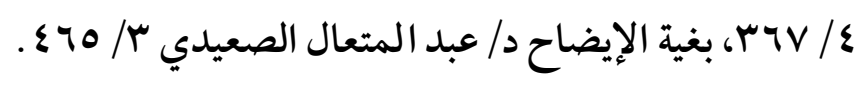

(r) الآية رقم: § ا من سورة التكوير. 
$(Y \mid Y)$

مناسبة اللفظ للعنى عند الأصوليين وأثرها في توجيه خطاب المجتهلين

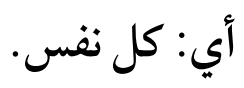

r r - إطلان المعرف باللاموإرادةواحد منكر.

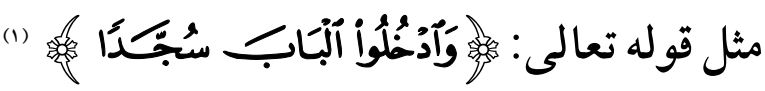

$$
\text { أي: بابا من أبوابها. }
$$

r r - إطالان اسم أحد الضديزعلى الآخح .

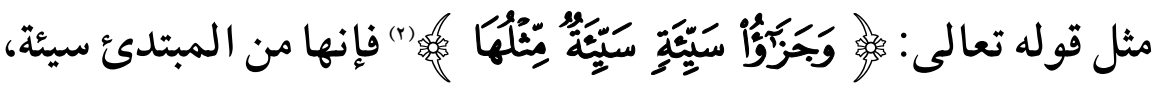

$$
\text { ومن الله حسنة. }
$$

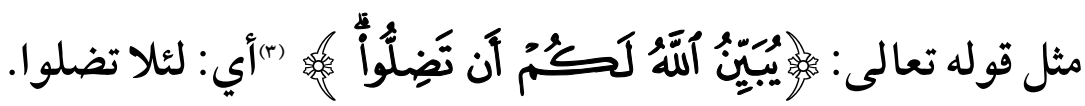

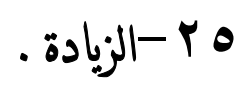

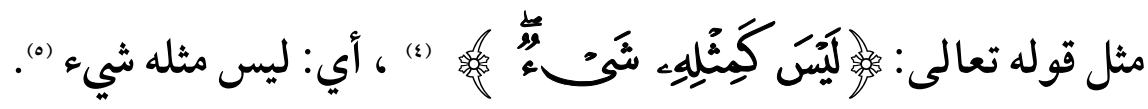
وصل الله علحسيدنا محمد وعلم اللهوصحبه أجمعب.

$$
\begin{aligned}
& \text { (1) جزء الآية رقم ^ه من سورة البقرة. } \\
& \text { (Y) جزء الآية رقم: · · ع من سورة الشورى. } \\
& \text { (r) جزء الآية رقم: IVT من سورة النساء. } \\
& \text { (ع جزء الآية رقم: } 11 \text { من سورة الشورى }
\end{aligned}
$$

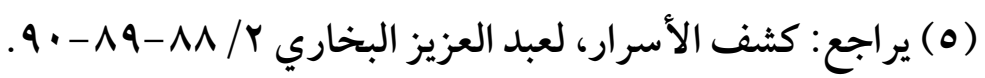




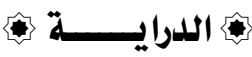

\section{الخاتمة \\ (سأل الله -تعالرحسنها)}

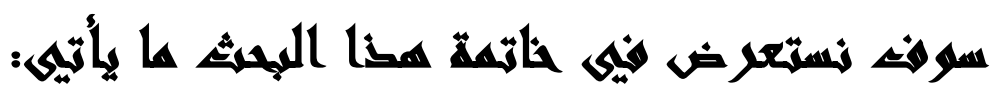

أولا: نتائز الميشث.

ثانيها: همار س البهثي. 
(Y)\&) مناسبة اللفظ للعنى عند الأصوليين وأثرها في توجيه خطاب المجتهلين

\section{أولا: نتائج البحث}

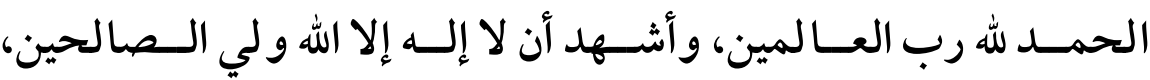

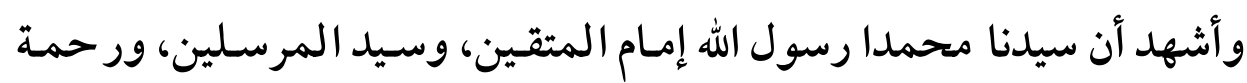

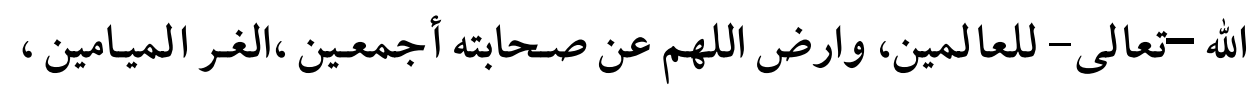

وعلى كل من تبعهم بإحسان وهدى وتقى وعفاف وغنى إلى يوم الدين.

فإني قد انتهيت من بحث مناسبة اللفظ للمعنى عند الأصسوليين وأثره

في توجيه خطاب المجتهدين، وقد توصلت في هـذا البحـث إلى عـدة نتـائج،

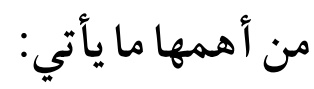

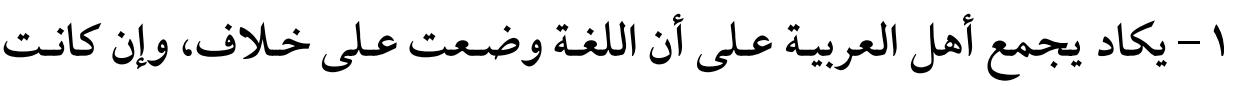

مسوقة على صحة وقياس، وأنهم أحدثوا فيها أشياء كثيرة للحاجة إليها،

غير أنها على قياس ما كان وضع في الأصل.

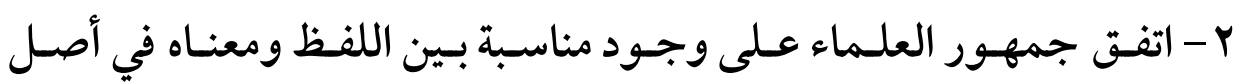

الوضع، وأن هذه المناسبة مكتسبة.

ץ- خالف عباد بن سليمان الصيمري - المعتزلي - جمهور العلماء فقـال:

إن مناسبة اللفظ للمعنى في أصـل الوضـع ذاتية، وكلامـه باطل؛ لأنه مبني

$$
\text { على أصله الاعتزالي. }
$$

ع - يترتب على ذلك أن اللغـة العربيـة في أصل الوضـع تتطور وترتقي على اصلى

مر العصور طبقا للبيئة التي يكتسب اللفظ فيها المعنى. 
$(Y \mid 0)$

ه-لا يمكن تطبيق هذه النظرية على ألفاظ القرآن الكريم؛ لأن اللفظ والمعنى

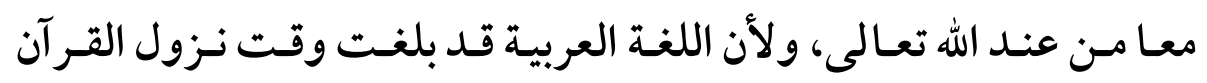

الكريم ذروة الترقي، ولم تعد هناك مر احل من الترقي تستشرف اللغـة إليها

$$
\text { بعد نزول القرآن الكريم. }
$$

T- وجـوب اعتبـار مناسبة اللفظ ومعنـاه في اللغـة للمعنى المنقول إليه في

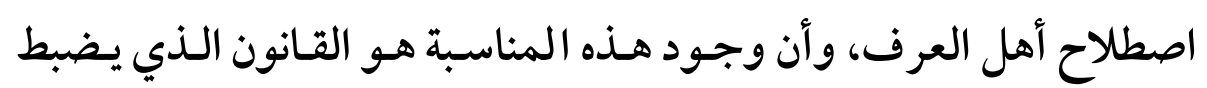
المصطلحات.

V - وجـود المناسـبة بـين اللفـظ ومعنـاه في الاصـلاح يـضبط المـصطلح، فتتجدد المفاهيم و المضامين، فيقل الاختلاف بين العلماء.

1- اعتبـار المناسـبة بـين اللفظظ ومعنـاه في اللغـة ومعنـاه في الاصطلاح هـو وسـيلة يمكسن مـن خلالها تنقية الـتراث الإسـلامي والعـربي، فالمصطلح الذي يوجد بـين معنـاه في العـرف ومعناه في اللغـة مناسبة هـو المصطلح الصحيح، والمصطلح الذي انقطعت العلاقة بين معناه في العرف ومعنـاه

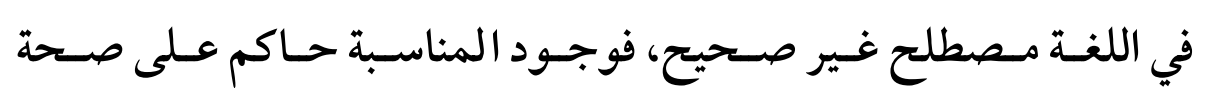
المصطلح.

9 - عند تطبيق ذلك على مصطلح الجهاد وجـدنا أن اعتبار المناسبة وعدم اعتبارها أثر في توجيه خطاب المجتهلين. فمن رأى وجود المناسبة بين معنى الجهاد لغـة واصطلاحا قرر أن علة الجهاد هي الكفـر، فعند نزول هـذا المصطلح مـن ميـدان الفكر إلى ميـدان الواقع نتج عن ذلك تفجر العنف الـدموي تحت مسمى الجهاد، وهو غير 
(Y $\mid Y)$ مناسبة اللفظ للعنى عند الأصوليين وأثرها في توجيه خطاب المجتهلين

صحيح؛ لعدم تحقيقه مصلحة حفظ الدين، فالذي يهدم الدين هو محاربـة الكفار لنا، وليس مجرد كفرهم. • 1 - حـــث خـلاف بـين العلـماء في اعتبـار مناسبة اللفظظ الشرعي لمعنـاه اللغـوي، فـذهب أهـل السـنة إلى اعتبـار مناسـبة اللفــ الـشرعي لمعنــاه اللغوي.

وذهب الخوارج والمعتزلة إلى عدم اعتبار مناسبة اللفظ الشرعي لمعنـاه

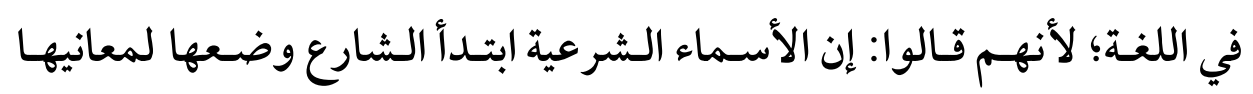
الشرعية.

11 - أثر ذلك في توجيه خطاب المجتهدين، فمرتكب الذنوب الصغائر أو الكبائر خرج عن بوتقة الإيـمان إلى الكفـر عند الخـوارج، وإلى منزلة بـين

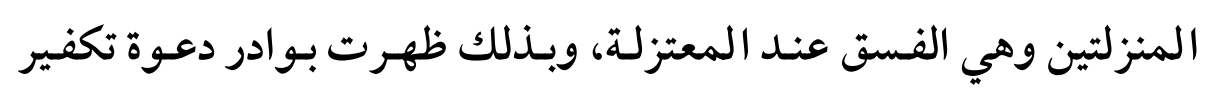
المسلمين،والتي انطلقت على ألسنة بعض الناس في المـاضي والحـاضر، وسبحان من يوقفها - نسأل الله - تعالى - السلامة. بينما مرتكب الذنوب عند أهل السنة لا يخر جـه ذلك عـن بوتقـة الإيمان والإسلام، وإن وصف بأنه مسلم عاص . باصن

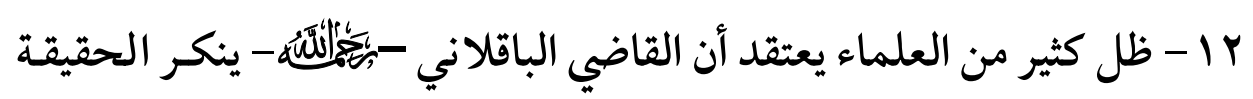

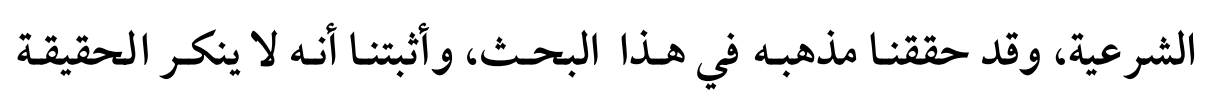
الثرعية، وأنه مثل جمهور العلماء يـرى بأنه يجـب أن توجـد مناسبة بـين اللفظ ومعناه في اللغة وبين معناه في الشرع. 
(YIV)

rا - اختلف جمهور العلماء الذين قالوا: بوجوب وجود مناسبة بين اللفظ

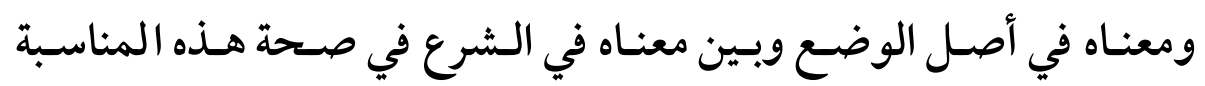

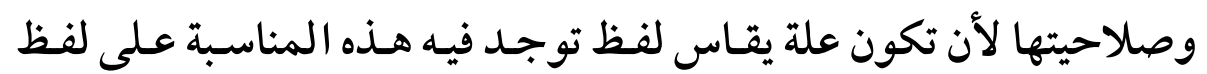
آخر توجد فيه نفس المناسبة، بمعنى صسحة هـذه المناسبة لأن تكون علدة يقاس بها الألفاظ في اللغة إلى فريقين: الفريق الأول: ويتزعمـه الحنفيـة، ويـرون: أن هـذه المناسبة هي لصحة فئة أولوية إطلاق اللفظ على هذا المعنى، ولا ترقى لأن تكون علة، ولـذلك قالوا: لا تثبت اللغة بالقياس.

الفريق الثاني: ويتزعمه بعض الثافعية، ويرون: أن هـذه المناسبة ترقى بـى لأن يقاس بها في اللغة، ولذلك أثبتوا اللغة بالقياس.

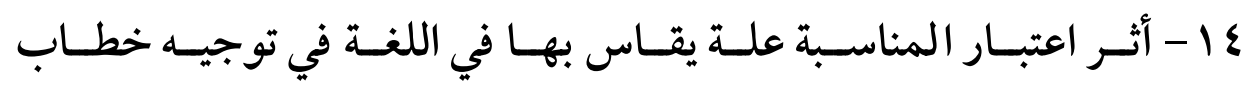

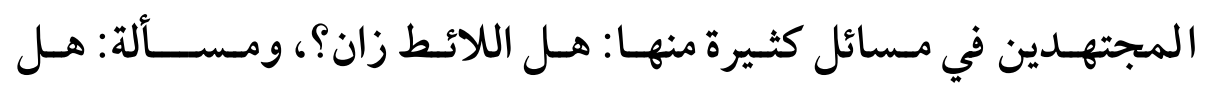
النباش سارق؟، ومسألة: هل النبيذ خمر؟.

10 - اتفـق العلماء على استعمال اللفظظ في معنى مجـازي، وتـرك المعنى الحقيقـي إذا وجــت علاقـة بيـهـما، أي: مناسـبة، وقرينـة مانعـة مـن إرادة المعنى الحقيقي. 17 - اختلفوا في هذه المناسبة: هل هي صالحة للتجوز بها دون النقل عن

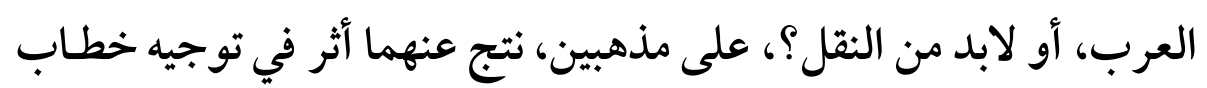

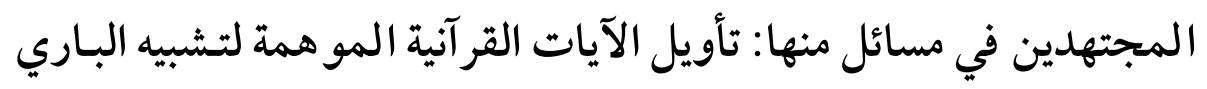

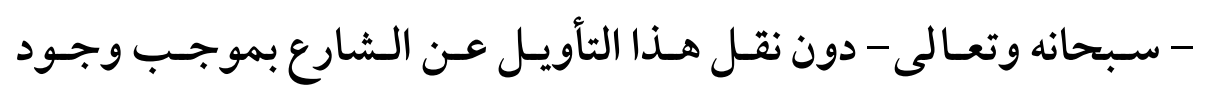


(YIA) مناسبة اللفظ للعنى عند الأصوليين وأثرها في توجيه خطاب المجتهلين

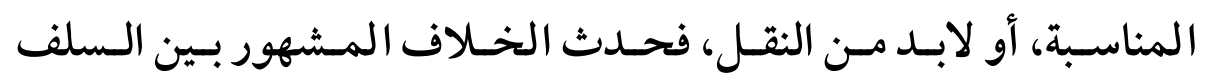

والخلف.

كسما نـتج عـن ذلـك أثـر في توجيسه خطـاب المجتهـدين في صـلاحية

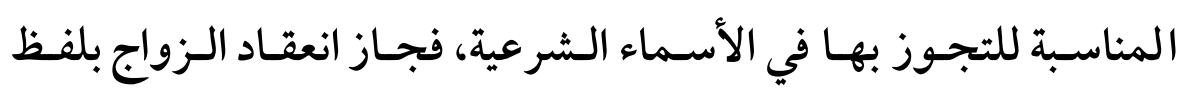
الهبـة، ووقـوع الطلاق بلفظظ العتـاق، أو عـدم صـلاحيتها للتجـوز بها في الأسماء الشرعية، فلم يجز ما ذكرنا. 


$$
\begin{aligned}
& \text { الهنمـارو } \\
& \text { : }
\end{aligned}
$$

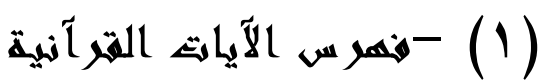

$$
\begin{aligned}
& \text { (r) - (r) (r) (r) } \\
& \text { - خهمر س الآثار }
\end{aligned}
$$

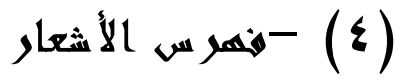

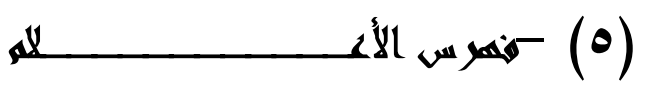

$$
\begin{aligned}
& \text { - (7) (7) (7) }
\end{aligned}
$$

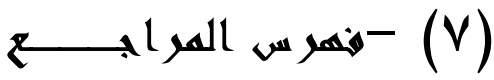

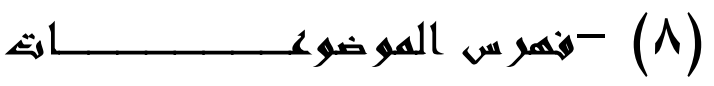


$(Y Y \cdot)$

مناسبة اللفظ للعنى عند الأصوليين وأثرها في توجيه خطاب المجتهلين

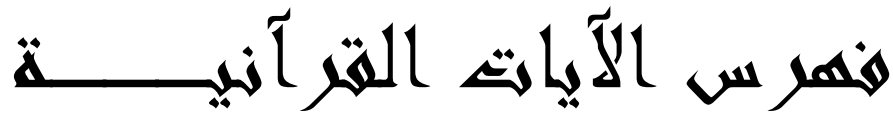


(YYI)

\section{همرس الآياتي القرب آنية}

\begin{tabular}{|c|c|c|c|c|}
\hline الصفحة & رقم الآية & الآية القر آنية & السورة & p \\
\hline$r \cdot 0$ & 19 & 罗 & المبقرة & 1 \\
\hline 0. & r & 罗 & & $r$ \\
\hline rIr & $0 \wedge$ & 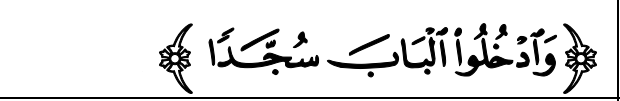 & & $r$ \\
\hline $11 \mathrm{~V}$ & $1 \leqslant r$ & 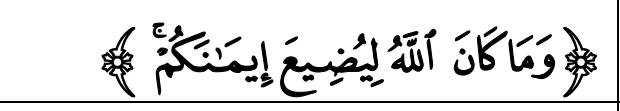 & & $\varepsilon$ \\
\hline$\Lambda 1$ & 19. & 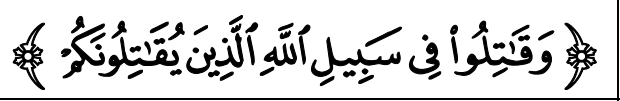 & & 0 \\
\hline 91 & roY & 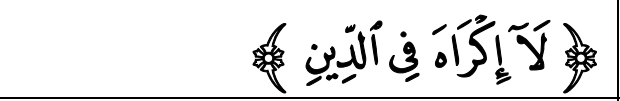 & & 7 \\
\hline 110 & 19 & 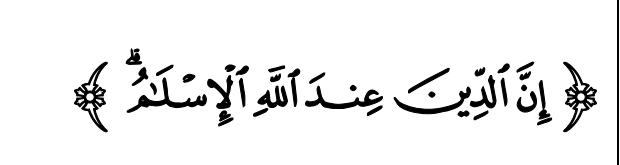 & عمران & V \\
\hline $11 \varepsilon$ & ^॰ & 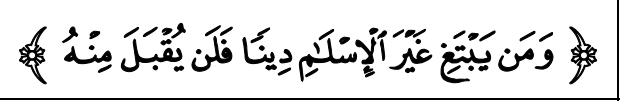 & & $\wedge$ \\
\hline rl. & $1 \cdot V$ & 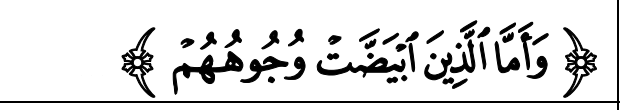 & & 9 \\
\hline $17 \varepsilon$ & 10 & 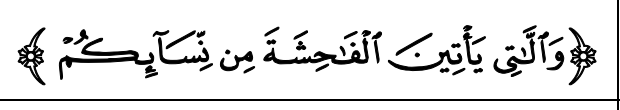 & النساء & 1. \\
\hline IV. & 17 & 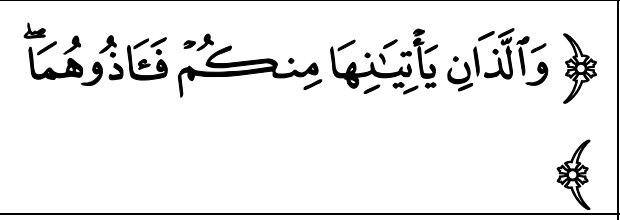 & & 11 \\
\hline$r \cdot r$ & 79 & 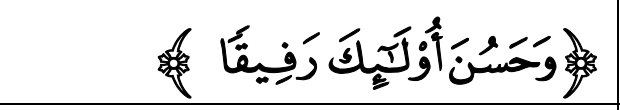 & & ir \\
\hline rIr & 187 & 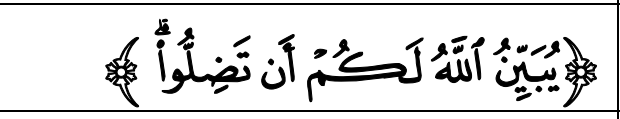 & & r \\
\hline$r \cdot \Lambda$ & $1 \leqslant r$ & 兒 & الأحر الهي & $1 \varepsilon$ \\
\hline
\end{tabular}




\begin{tabular}{|c|c|c|c|c|}
\hline (YYY) & & لد الأصوليين وأثرها في توجيه خطاب المجتهلين & اللفظ للعنى ء & مناسبا \\
\hline الصفحة & رقم الآية & الآية القر آنية & المبورة & b \\
\hline$\wedge \varepsilon$ & 0 & 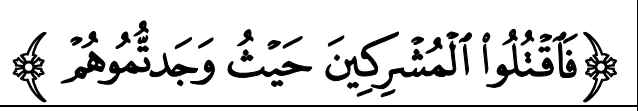 & 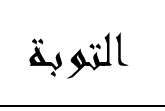 & 10 \\
\hline$\wedge \varepsilon$ & rq & 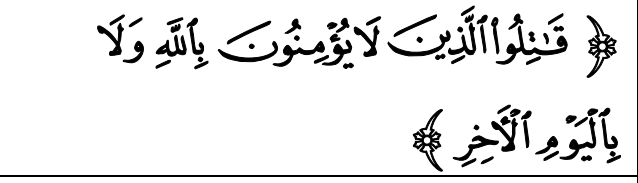 & & 17 \\
\hline 100 & rᄉ & 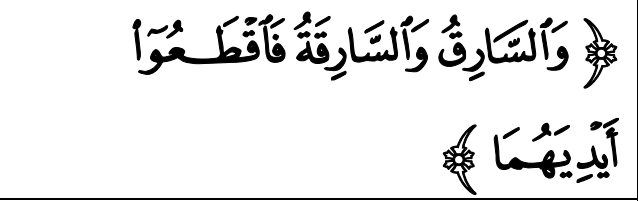 & المائدة & IV \\
\hline IVT & 91 & 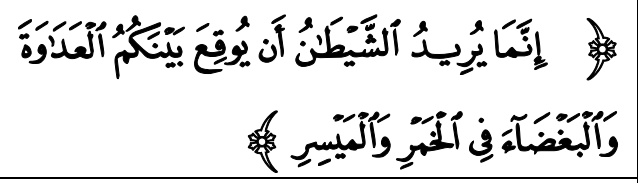 & & 11 \\
\hline rq & $1 \cdot r$ & 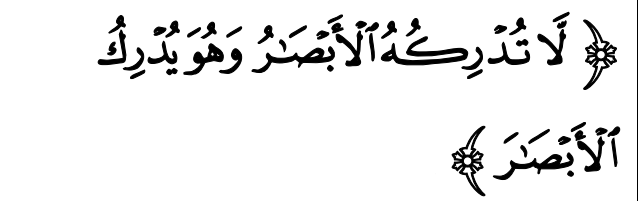 & الأi ماهم & 19 \\
\hline $11 \varepsilon$ & IV & 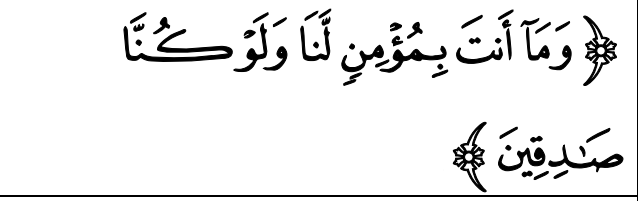 & بيو سفنغ & r. \\
\hline$r \cdot q$ & $\wedge r$ & 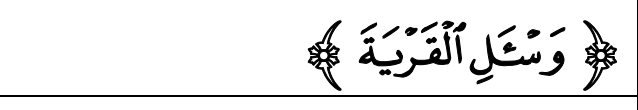 & & Y \\
\hline 189 & IV & 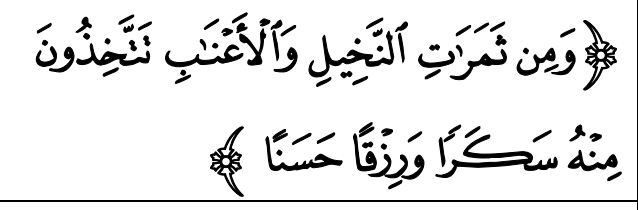 & النحل & Yr \\
\hline IrY & $\varepsilon$ & 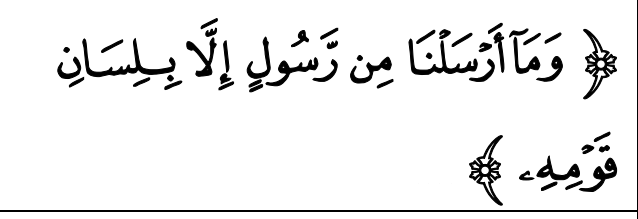 & إبع الهيه & $r$ \\
\hline 191 & ○ & 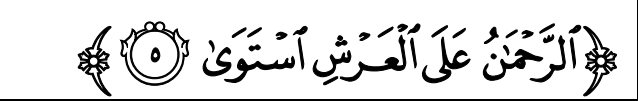 & طه & $r \xi$ \\
\hline
\end{tabular}




\begin{tabular}{|c|c|c|c|c|}
\hline \multicolumn{3}{|l|}{ (YYY) } & \multicolumn{2}{|c|}{ 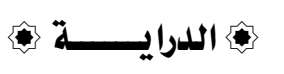 } \\
\hline الصفحة & رقم الآية & الآية القر آنية & السورة & b \\
\hline 194 & rq & 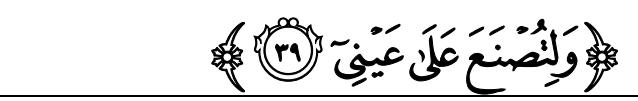 & & ro \\
\hline$r \cdot 0$ & $\wedge \wedge$ & 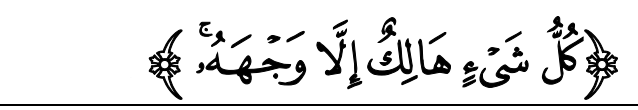 & 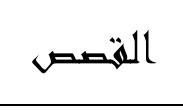 & ry \\
\hline$r \|$ & $\Lambda \varepsilon$ & 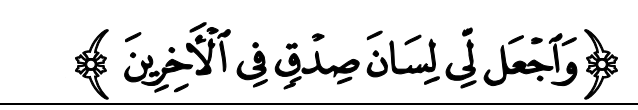 & الشعر اء & $r V$ \\
\hline Irr & 190 & 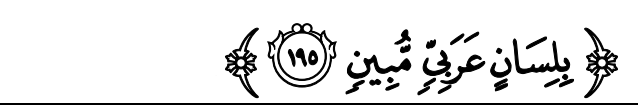 & & rA \\
\hline $19 V$ & 0 . & 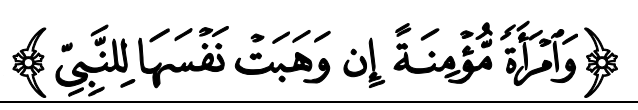 & الألبرابي & rq \\
\hline$r \cdot T$ & ro & 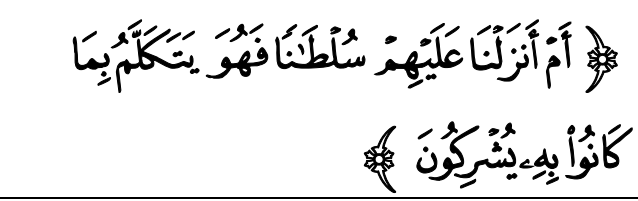 & اللروه & $\mu$. \\
\hline 191 & 11 & 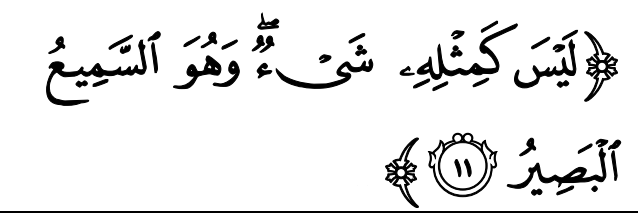 & الشهرىى & M \\
\hline rIr & $\varepsilon$. & 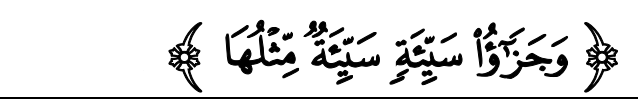 & & rr \\
\hline Irr & $r$ & 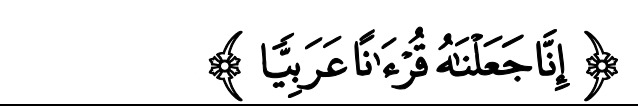 & الزالغر هـ & r \\
\hline $19 r$ & 1. & 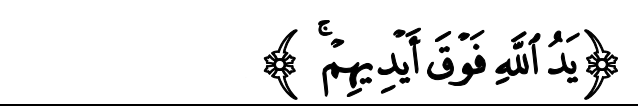 & اللهتح & $r \varepsilon$ \\
\hline$|r|$ & $1 \varepsilon$ & 慗 & اللجبر اتث & ro \\
\hline 110 & 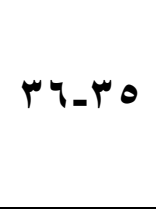 & 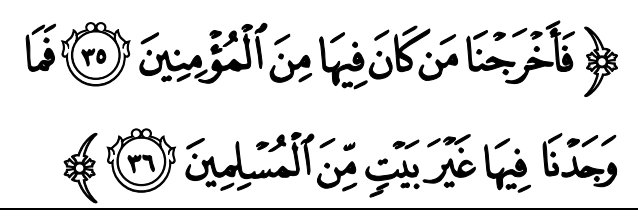 & الذارياتث & rt \\
\hline$\mu$. & 7.0 & 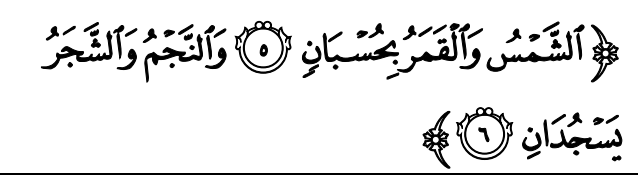 & الر بهن & rv \\
\hline
\end{tabular}




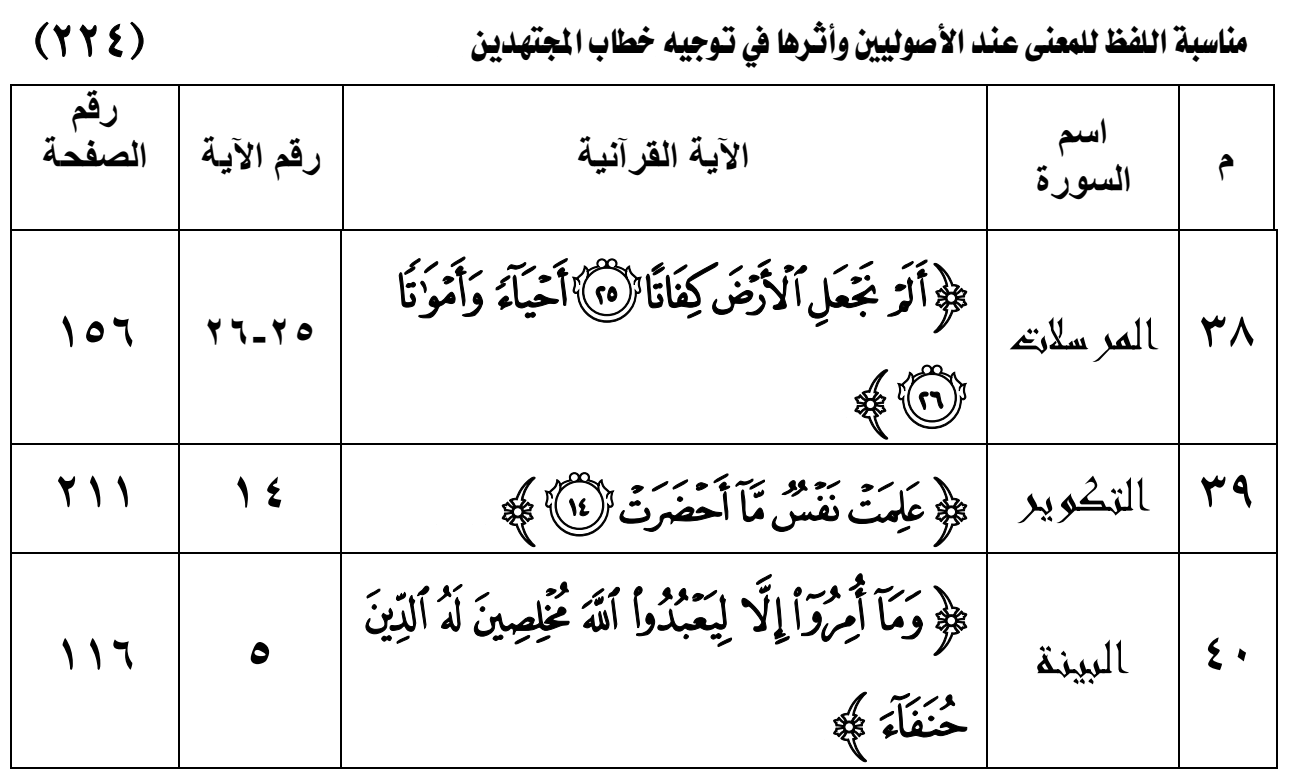




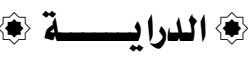

\section{هلهر س الأحاديمث المنيوية}


(YYY) مناسبة الفظ للعنى عند الأصوليين وأثرها في توجيه خطاب المجتهلين

\section{همرس الألماكيثش النهيوية}

\begin{tabular}{|c|c|c|}
\hline رقم الصفحة & الحديث & p \\
\hline$\wedge \mathrm{T}$ & "|قتلوا شيوخ المشر كين واستبقوا شرخهم " & -1 \\
\hline 111 & "الإلإيـمان بـــع وسـتون شـعبة، والحيـاء شـعبة مـن & $-Y$ \\
\hline$\wedge \varepsilon$ & ". "أمرت أن أقاتل النـاس حتى يشهدوا أن لا إلـه إلا الله & $-r$ \\
\hline$\Lambda Y$ & "انطلقو اباسم الله، وباله، وعلى ملة رسول الله .... " & $-\varepsilon$ \\
\hline 101 & "أمر بقطع المختفي" & -0 \\
\hline$r \cdot \xi$ & "بلوا أرحامكم ولو بالسلام " & -4 \\
\hline $11 Y$ & 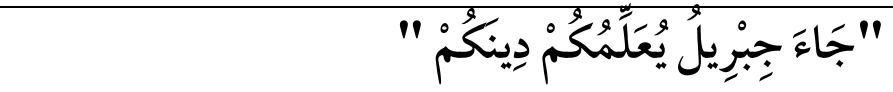 & $-\mathrm{V}$ \\
\hline 170 & "خذوا عني، خذواعني، قد جعل الله لهن سبيلا .... " & $-\Lambda$ \\
\hline $17 V$ & 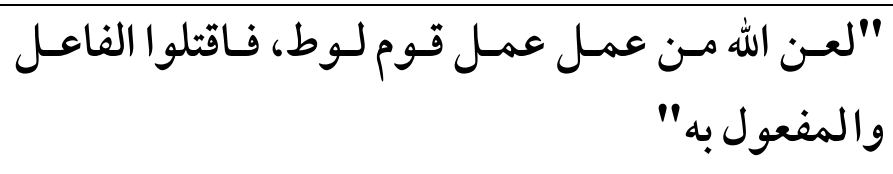 & -9 \\
\hline 170 & "إذا أتى الرجل الرجل فهما زانيان" & -1 \\
\hline 171 & "ارجموا الأعلى والأسفل " & -11 \\
\hline 179 & 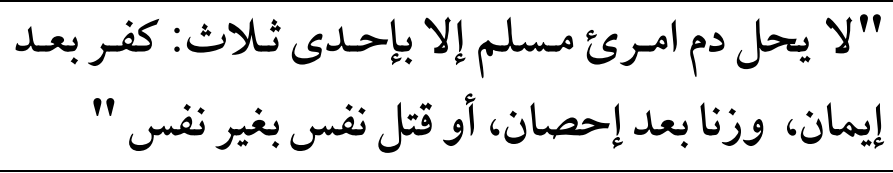 & -14 \\
\hline rl. & "لا يفضض الله فاك " & -14 \\
\hline IVT & "كل مسكر خمر، وكل خمر حرام " & $-1 \varepsilon$ \\
\hline $11 \mathrm{~V}$ & "نهيت عن قتل المصلين " & -10 \\
\hline
\end{tabular}




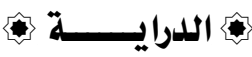

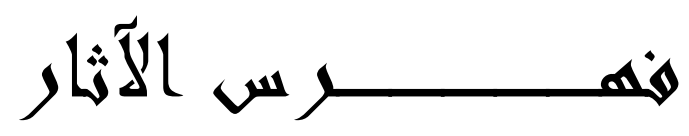




\begin{tabular}{|c|c|c|}
\hline$(Y Y \wedge)$ & لفلفظ للعنى عند الأصوليين وأثرها في توجيه خطاب المجتهلين & \\
\hline رقم الصفحة & الأثر & p \\
\hline $17 \%$ & 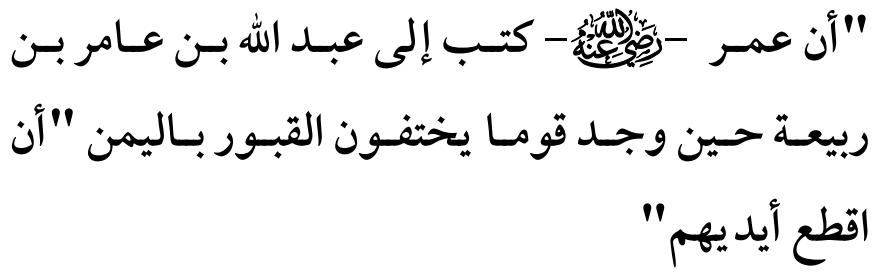 & 1 \\
\hline 17. & 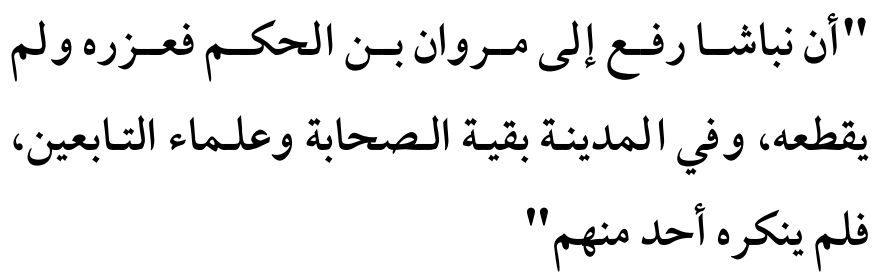 & $r$ \\
\hline 101 & "أن عبد الله بن الزبير قطع نباشا بعرفات " & r \\
\hline$r \cdot V$ & قول شريح: "أصبحت ونصف الخلق علي غضبان " & $\varepsilon$ \\
\hline 100 & 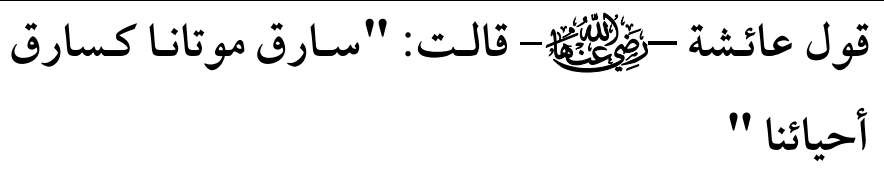 & 0 \\
\hline 107 & 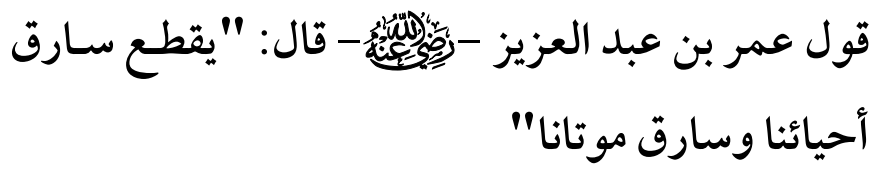 & 7 \\
\hline
\end{tabular}




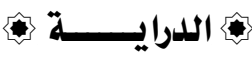

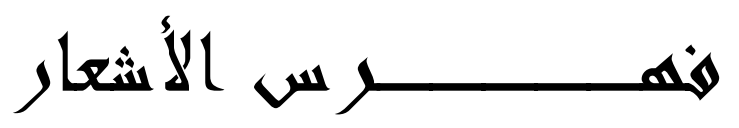




\begin{tabular}{|c|c|c|}
\hline (YM.) & اللفظ للعنى عند الأصوليين وأثرها في توجيه خطاب المجتهلين & \\
\hline راثم الصهنة & الشاهذ الشعريى & s \\
\hline$r \cdot \Lambda$ & إذا مت كان الناس صنفان شامت وآخر مثن بالذي كنت & -1 \\
\hline$r \cdot q$ & 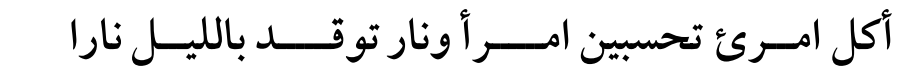 & $-r$ \\
\hline$r \cdot q$ & أنا ابن جلا وطـلاع الثــــايا متى أضـع العمامة تعرفوني & $-r$ \\
\hline YII & 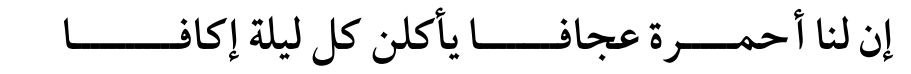 & $-\varepsilon$ \\
\hline$r \cdot \varepsilon$ & شربت الإثم حتى ضل عقلي كذاك الإثم يذهب بالعقــول & -0 \\
\hline$r \cdot V$ & 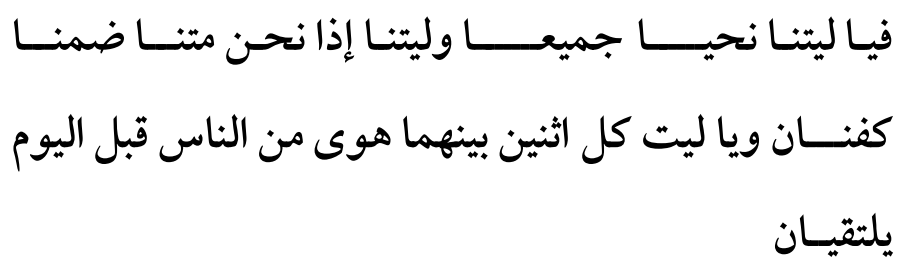 & -7 \\
\hline$r \cdot T$ & قوم إذا حاربوا شدوا مآزرهم دون النساء ولو بانت بإظهار & $-V$ \\
\hline
\end{tabular}




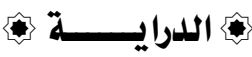

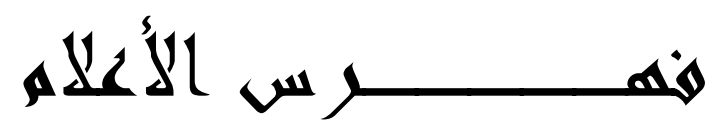


$(Y r Y)$

مناسبة اللفظ للعنى عند الأصوليين وأثرها في توجيه خطاب المجتهلين

همرس الألعاب

\begin{tabular}{|c|c|c|}
\hline رهم الصفهة & 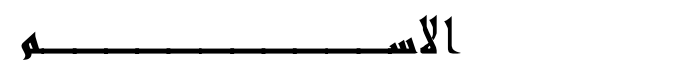 & $a$ \\
\hline $1 \leqslant r$ & ابن أبي هريرة & 1 \\
\hline$\varepsilon 7$ & ابن جني & r \\
\hline TV & ابن خلاون & $r$ \\
\hline $1 \leqslant Y$ & ابن خويز منداد & $\varepsilon$ \\
\hline $1 \leqslant \mu$ & ابن سريج & $\bullet$ \\
\hline $1 \leqslant r$ & ابن سيده & 9 \\
\hline $1 \leqslant \varepsilon$ & ابن فورك & v \\
\hline $1 \leqslant 1$ & أبو الحسين القطان & $\wedge$ \\
\hline $1 \leqslant \varepsilon$ & أبو علي الفارسي & 9 \\
\hline 0. & أبو هاثم & 1. \\
\hline 119 & أبو الهذيل & 11 \\
\hline $1 \cdot r$ & أبو بعلى & ir \\
\hline$\varepsilon \vee$ & الأخفش & ir \\
\hline 9. & الحجاج بن أرطأة & $1 \varepsilon$ \\
\hline 0$\}$ & الخطيب القزويني & 10 \\
\hline Y $\varepsilon$ & الابوسي & 19 \\
\hline $1 \leqslant 1$ & سليم الرازي & iv \\
\hline
\end{tabular}




\begin{tabular}{|c|c|c|}
\hline (YrM) & 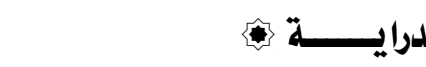 & \\
\hline$\varepsilon \curlyvee$ & السيوطي & $1 \wedge$ \\
\hline $1 \varepsilon$. & الصيرفي & 19 \\
\hline or & عباد بن سليمان الصيمري & $r \cdot$ \\
\hline $1 \leqslant \varepsilon$ & القاضي يعقوب & Y \\
\hline $1 \cdot 1$ & الكلذانى & $r Y$ \\
\hline $1 \leqslant 1$ & الكيا الطبر ي & $r$ \\
\hline $1 \leqslant \varepsilon$ & المازني & $Y \varepsilon$ \\
\hline IrY & واصل بن عطاء & Yo \\
\hline
\end{tabular}


(Yr\&)

مناسبة اللفظ للعنى عند الأصوليين وأثرها في توجيه خطاب المجتهلين

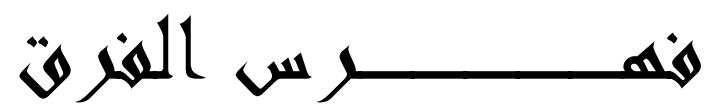




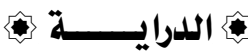

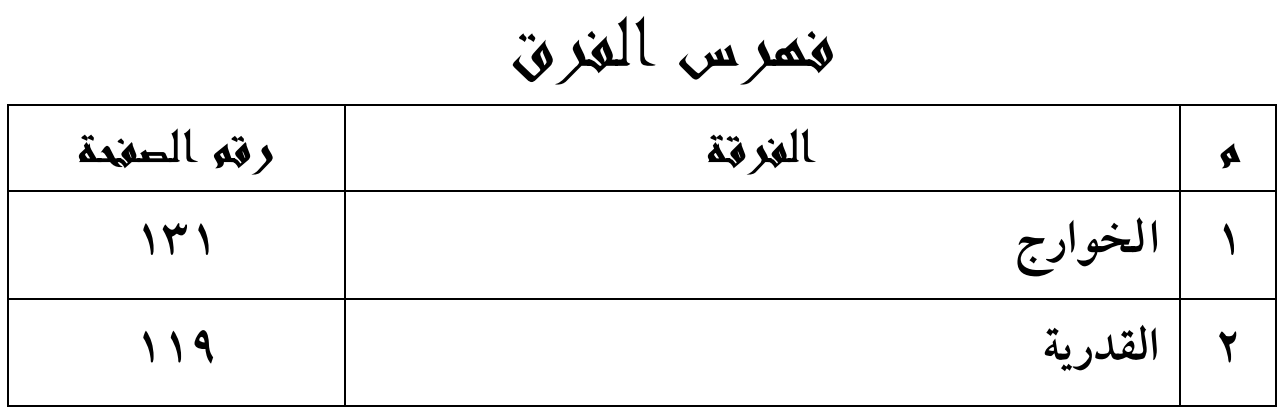


(YrY) مناسبة اللفظ للعنى عند الأصوليين وأثرها في توجيه خطاب المجتهلين

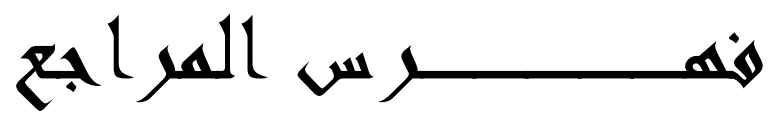




\section{فهرس هراجع البحث}

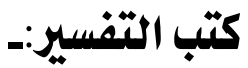

1 - جامع البيان في تأويل القرآن - محمد بن جرير بن يزيد بن كثير بن غالب

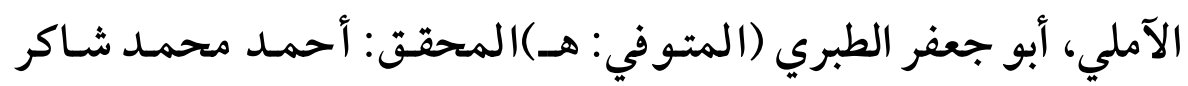

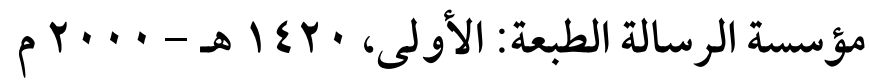

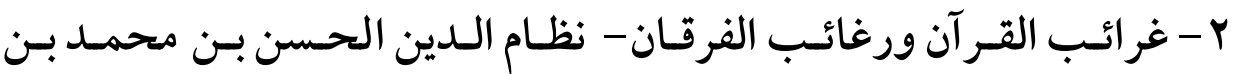

حسين القمي النيسابوري (المتوفي: ·10هــالمحقق: الشيخ زكريـا

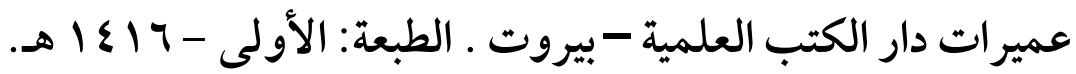

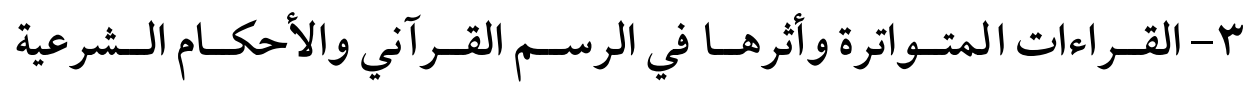

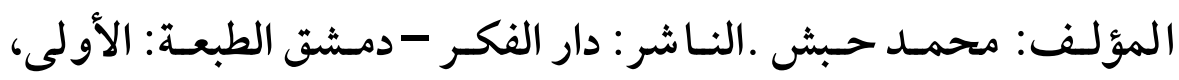

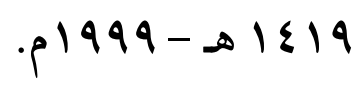

ع - مفاتيح الغيب - التفسير الكبير - أبو عبد الله محمـد بـن عمر بـن الحسن

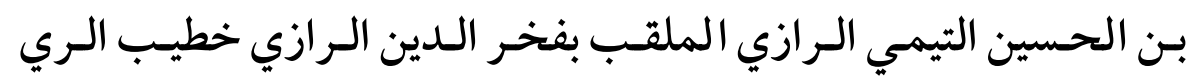

(المتوفي: ج · ج هـ) دار إحياء التراث العربي - بيروت الطبعة: الثالثة -

ا هـ

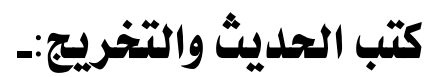

1- إتحـاف الخـيرة المهـرة بزوائـد المـسانيد العـشرة - أبـو العبـاس شهـاب

الدين أحمـد بـن أبي بكـر بـن إسـماعيل بـن سـليم بـن قـايماز بـن عـثمان

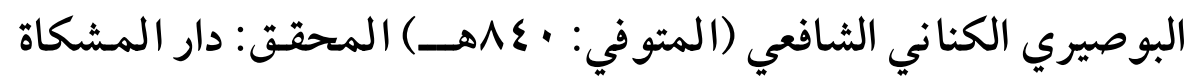


(YrA) مناسبة اللفظ للعنى عند الأصوليين وأثرها في توجيه خطاب المجتهلين

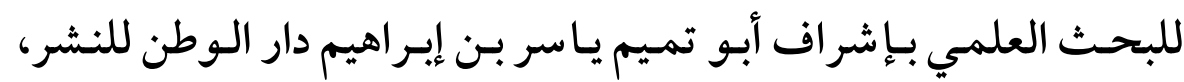

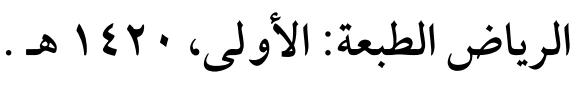

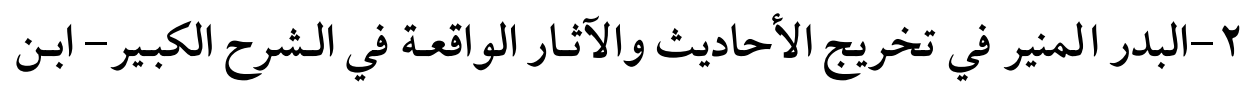
الملقن سراج الدين أبو حفص عمر بن علي بن أحمد الشافعي المصري (المتوفي: ع · ^هـ) المحققق: مصطفي أبو الغيط وعبد الله بـ سليمان وياسر بن كمال دار الهجرة للنشر والتوزيع - الرياض - الطبعة: الأولى،

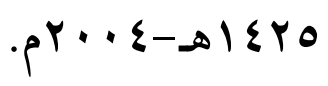
r-التحقيق في أحاديث الخلاف - جمال الدين أبو الفرج عبد الرحمن بـ

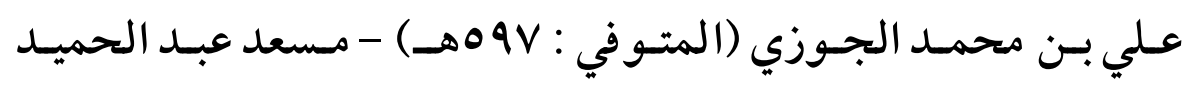

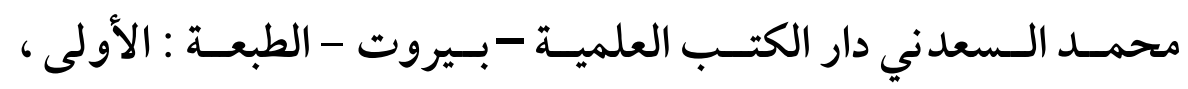
$.1 \leqslant 10$ ع -التلخيص الحبير في تخريج أحاديث الر افعي الكبير أبو الفضل أحمـد بـن

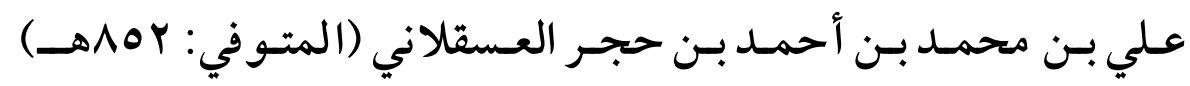

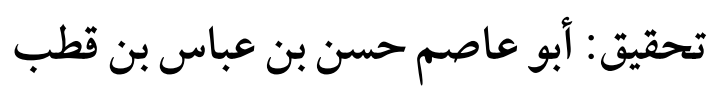

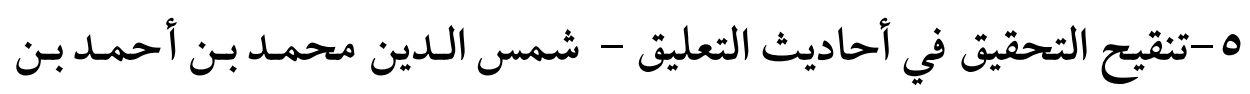

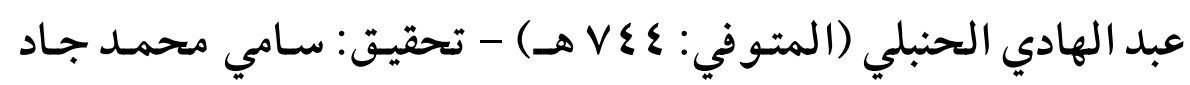

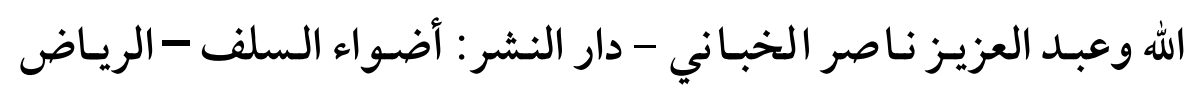

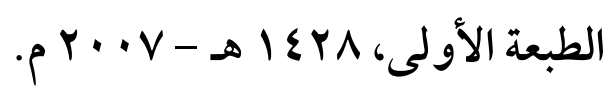

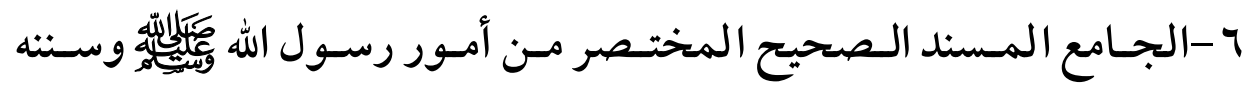

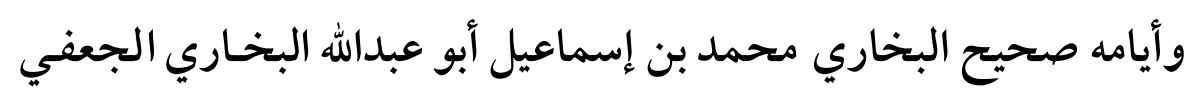


المحقـق: محمــ زهير بـن نـاصر النـاصر دار طوق النجـاة (مصورة عـن السلطانية بإضـافة ترقيم تـرقيم محمــد فؤاد عبـد الباقي) لطبعـة: الأولى، . IEYr

V- الجوهر النقي على سنن البيهقي - علاء الدين علي بـن عثمان بـن إبـراهيم بن مصطفي المارديني، أبو الحسن، الشهير بـابن التركماني (المتوفي:

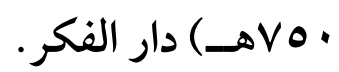

^-الدراية في تخريج أحاديث الهداية- أبو الفضل أحمد بن علي بـن محمـد

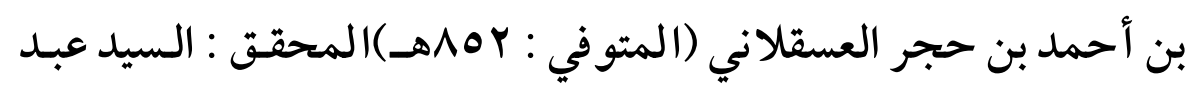
الله هاشم اليماني المدني الناشر : دار المعرفة -بيروت.

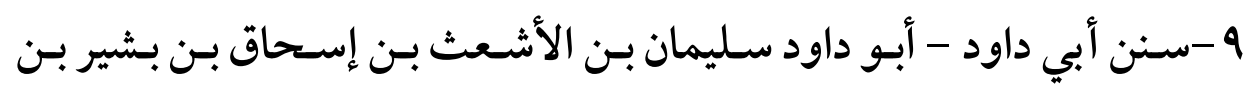

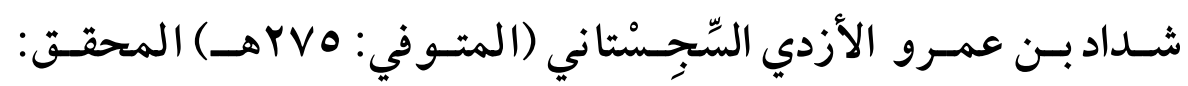
شعَيب الأرنؤوط - محَمَّـد كامِل قره بللمي دار الرسـالة العالميـة الطبعـة:

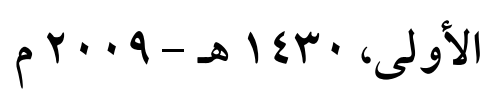

• 1 - سنن الترمـذي - محمــــــن عيسى بـن سَوْْرة بـن موسى بـن الضحاك،

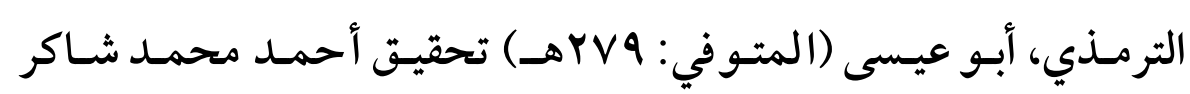
و محمـد فؤاد عبـد الباقي وإبـراهيم عطوة عـوض شركـة مكتبـة ومطبعـة

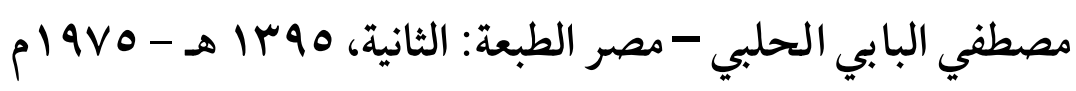

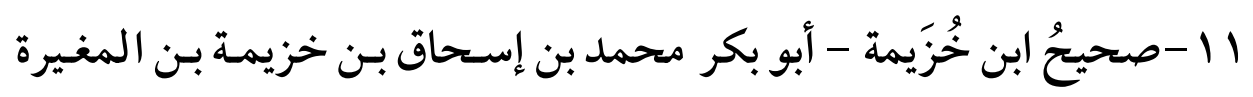

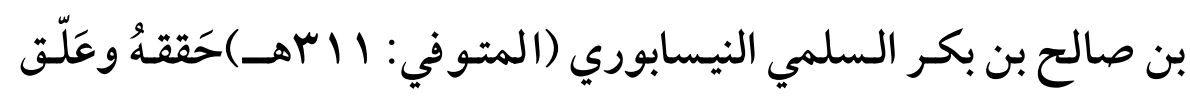




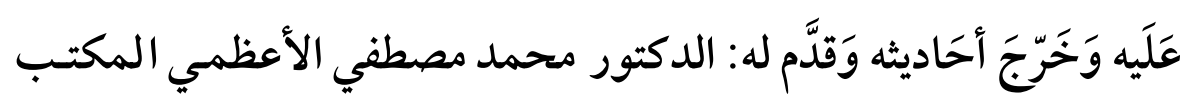

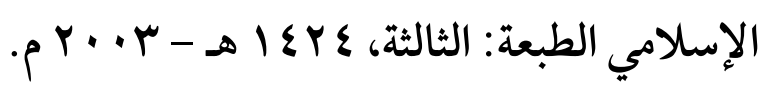

r ا - صحيح البخارى وشرحه فتح البـارى لابن حجر العسقلاني طبعة دار

$$
\text { الريان. }
$$

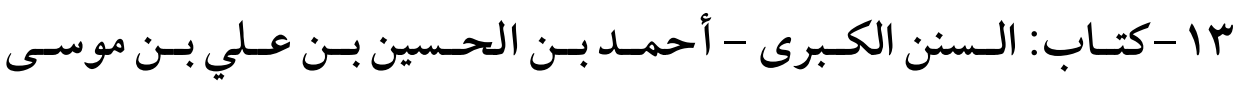

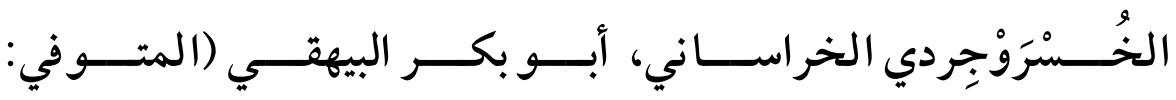

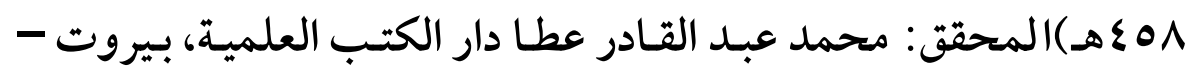
لبنات الطبعة: الثالثة، § \& ا هـ التراث العربي - بيروت.

ع ا -الكتاب المصنف في الأحاديث والآثار - أبو بكر بـن أبي شيبة، عبد الله بـن محمــد بـن إبـر اهيم بــن عـثمان بـن خواسـتي العبـسي (المتـوفي:

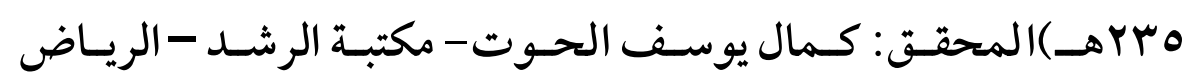

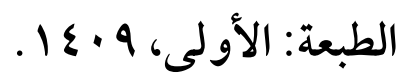

10 -كثف الأستار عن زوائد البزار - نور الدين علي بن أبي بكر بـن سليمان

الهيثمي (المتوفي: V V Nهـ) تحقيق: حبيب الرحمن الأعظمي - مؤسسة

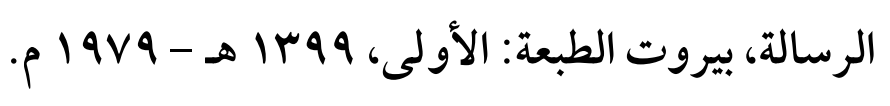

17 -كثف الخفاء ومزيل الإلباس - إسـماعيل بـن محمـد بـن عبد الهادي

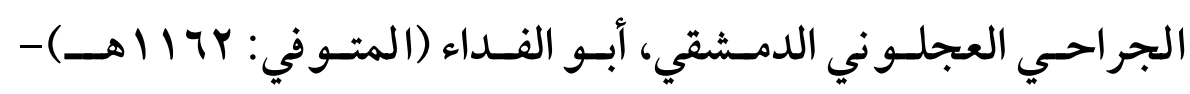

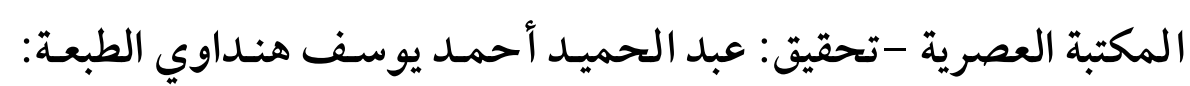

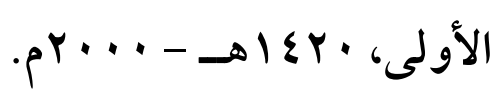


(Y\&1)

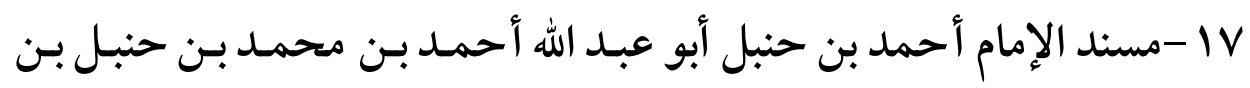

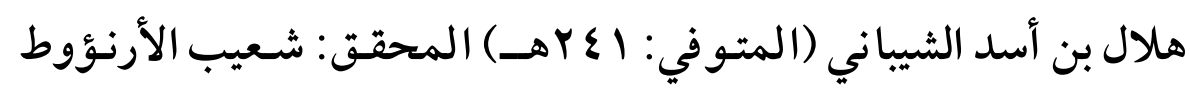

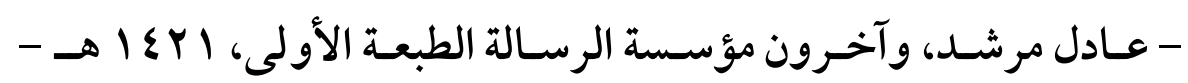

$$
\text { p r.. } 1
$$

11 - مرقاة المفاتيح شرح مشكاة المصابيح - علي بن (سلطان) محمـد، أبو الحسـن نـور الـدين المـلا الهـروي القـاري (المتـوفي: ؟ 1 ـ اهـــ دار

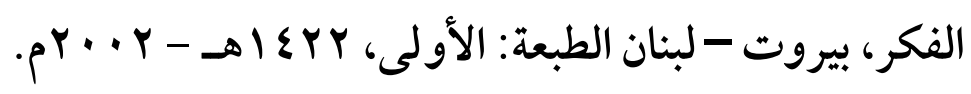
19 -مسند البزار المشهور باسم البحر الزخار - أبو بكر أحمـد بـن عمرو بـن التبن

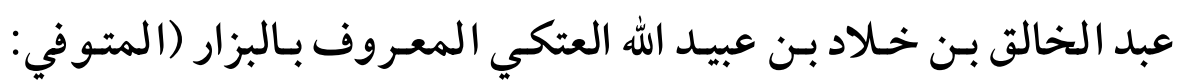

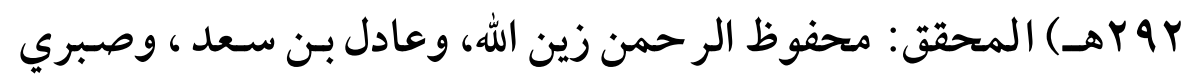
عبد الخـالق الشافعي مكتبـة العلوم والحكـم - المدينة المنـورة الطبعـة:

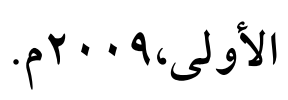

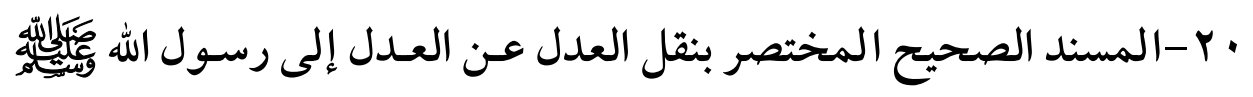
مسلم بن الحجاج أبو الحسن القشيري النيسابوري (المتوفي: الجبوهـ)

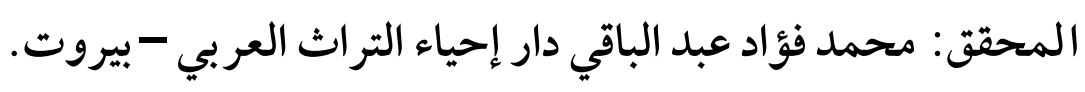

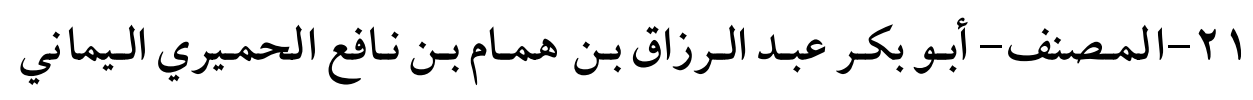

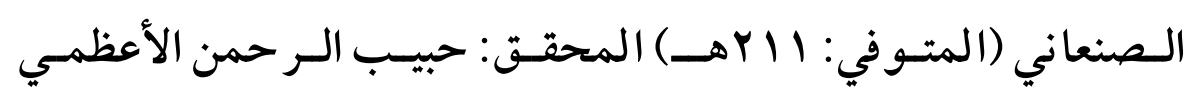
المجلس العلمي - الهند المكتـب الإسلامي - بيروت الطبعـة: الثانيـة، $.1 \leqslant \cdot r$ 
$(Y \xi Y)$ مناسبة اللفظ للعنى عند الأصوليين وأثرها في توجيه خطاب المجتهلين

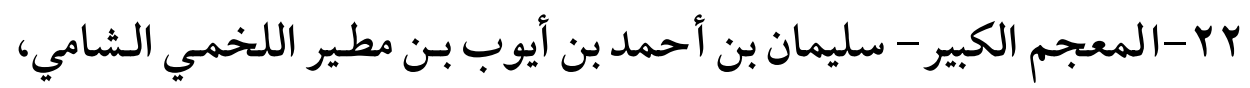

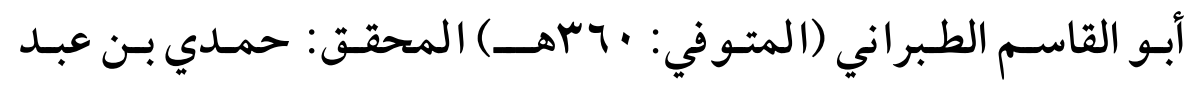
المجيد السلفي مكتبة ابن تيمية - القاهرة الطبعة: الثانية.

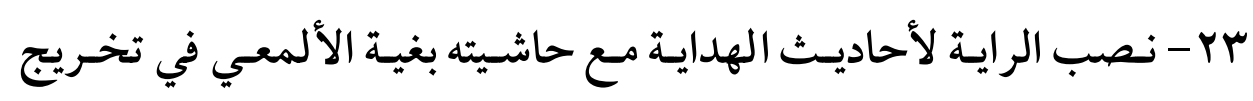

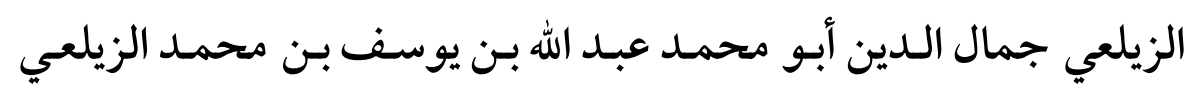

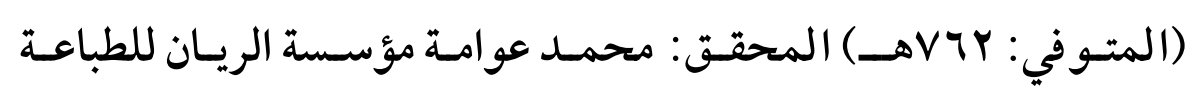
والنشر - بيروت -لبنان/ دار القبلة للثقافـة الإسـلامية- جـدة - السعودية

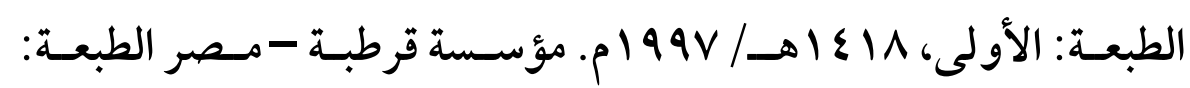

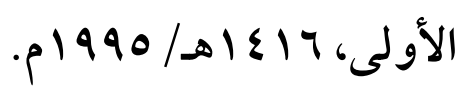

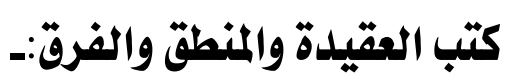

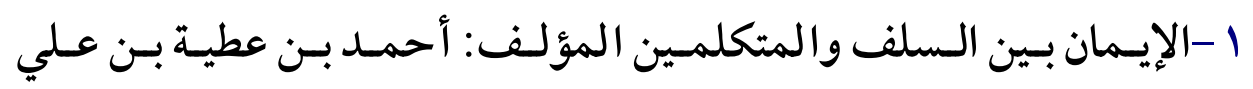

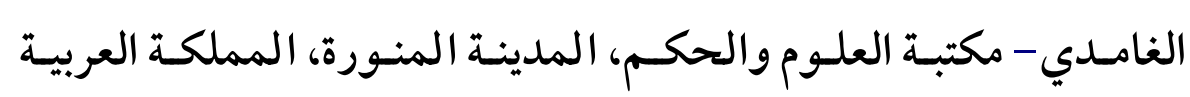

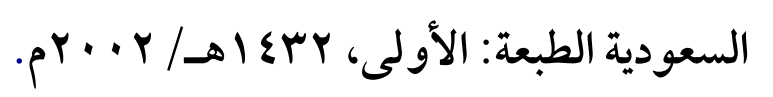

r - شرح السلم للملوى ،طبع على نفقة قطاع المعاهد الأزهرية • 199 1م.

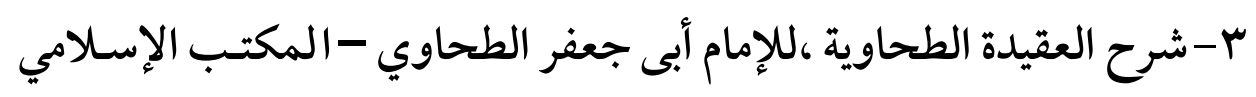

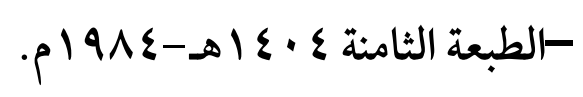
ع -الفرق بين الفرق وبيان الفرقة الناجية عبد القـاهر بـن طـاهر بـن محمـد بـن

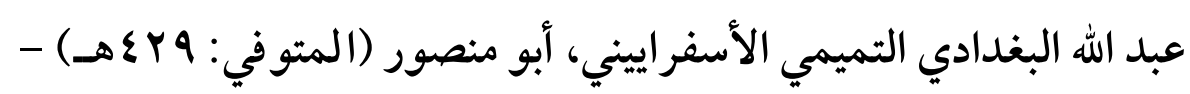

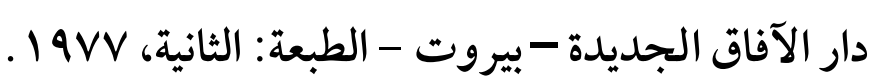


ه-لوامع الأنوار البهية وسواطع الأسرار الأثرية لشرح الدرة المضية في عقدـ

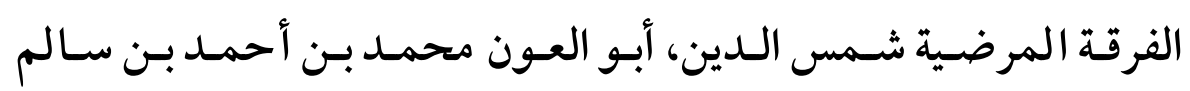
السفاريني الحنبلي (المتوفي: 1111 اهـ) مؤسسة الخـافقين ومكتبتها -

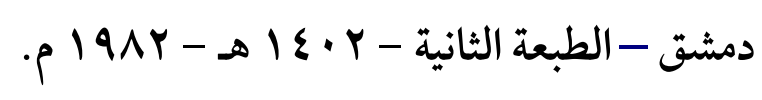

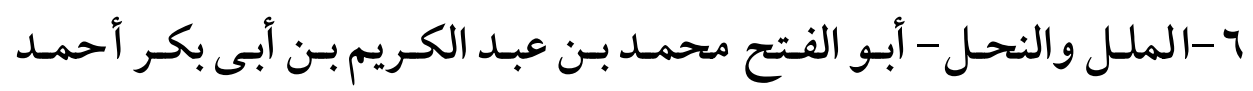

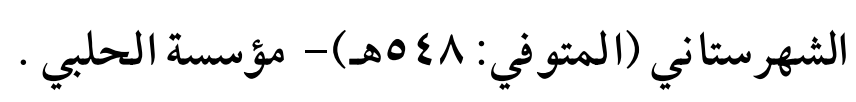

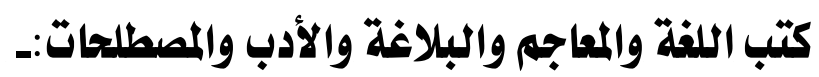

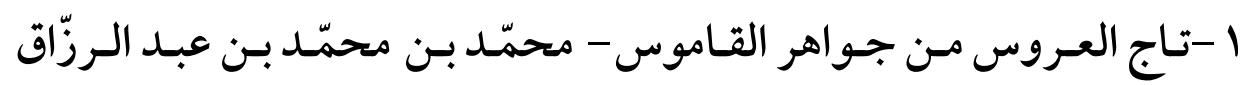

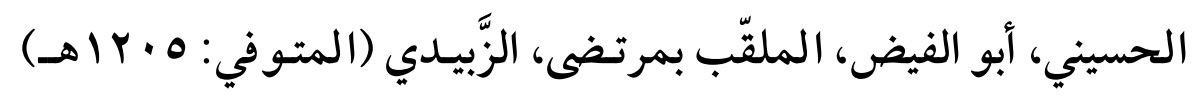

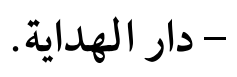

Y-دستور العلماء جامع العلوم في اصطلاحات الفنون - القاضي عبد النبي

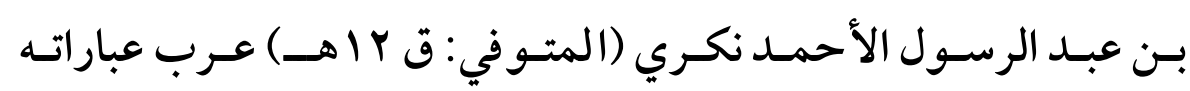

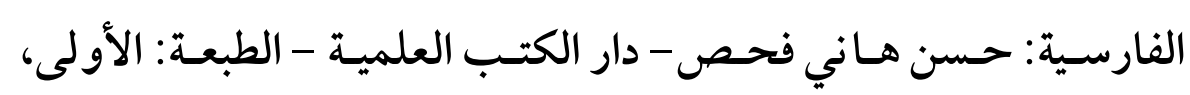

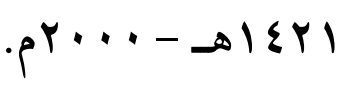

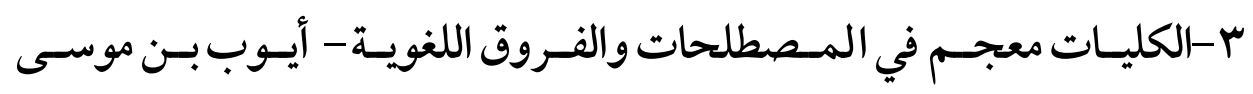

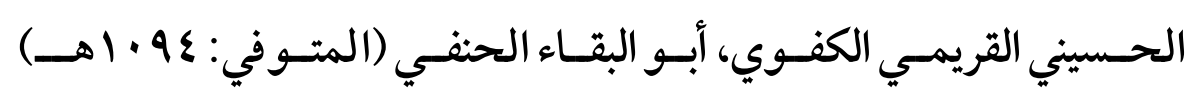
المحقق: عدنان درويش - محمد المصري - مؤسسة الرسالة -بيروت .

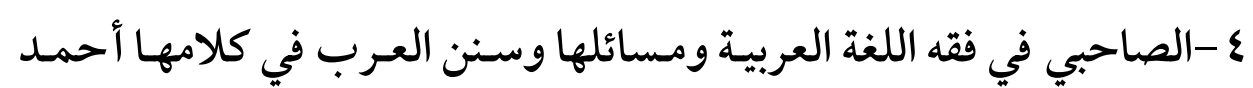

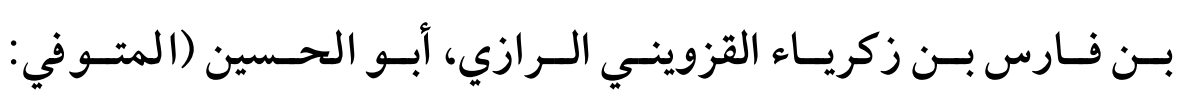




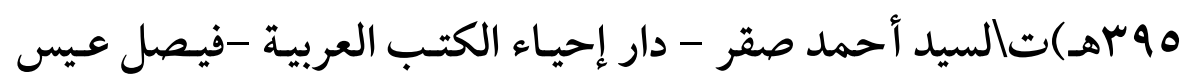

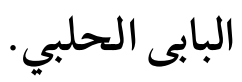

ه- المزهر في علوم اللغة وأنواعها- عبد الرحمن بن أبي بكر، جـلال الدين السيوطي (المتوفي: 111 91) هقققه-فؤاد علي منصور دار الكتب العلمية

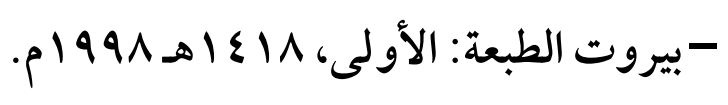

دراسات في فقه اللغة- د. صبحي إبر اهيم الصالح (المتوفي: V•• ـ اهـ)دار

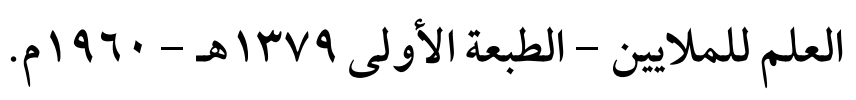

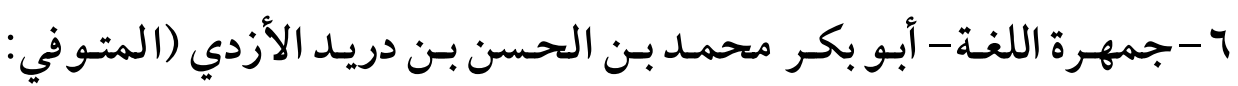

ا اYMــ المحقـق: رمزي منير بعلبكي -دار العلـم للملايسين -بيروت

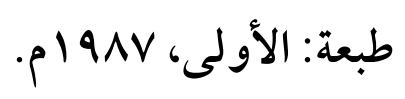

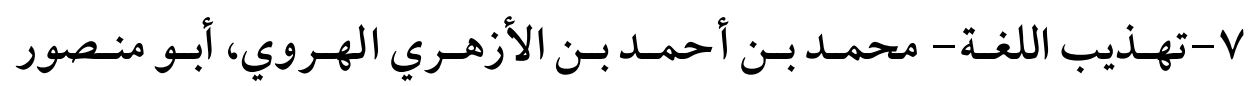

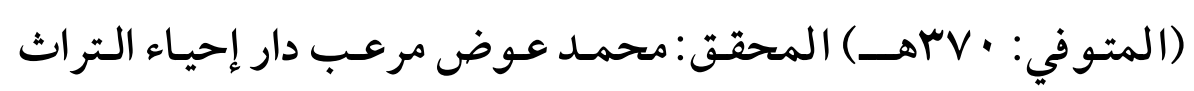

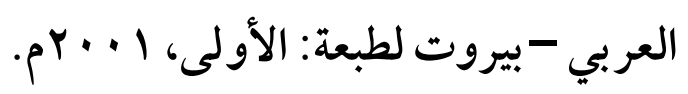

1- مختار الصحاح - زين الدين أبو عبد الله محمد بن أبي بكر بـن عبد القـادر

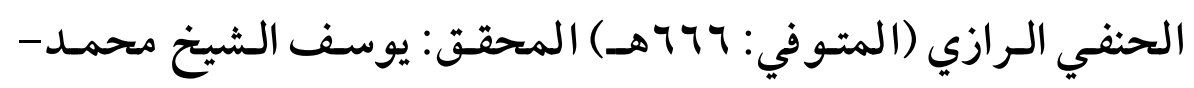

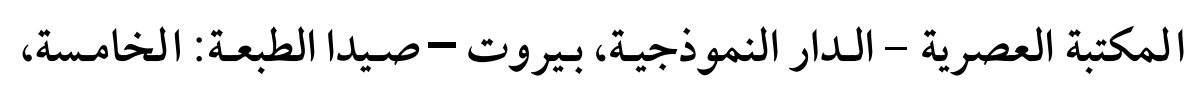

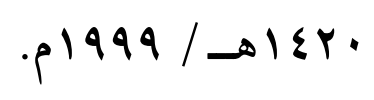

9 - مجمل اللغة لابن فارس - أحمد بن فارس بـن زكرياء القزويني الرازي،

أبو الحسين (المتوفي: هوبهـ) تحقيق: زهير عبد المحسن سلطان -

$$
\text { مؤسسة الرسالة -بيروت. }
$$




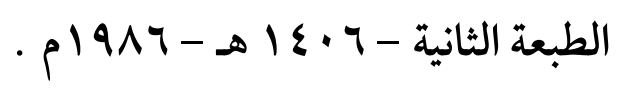

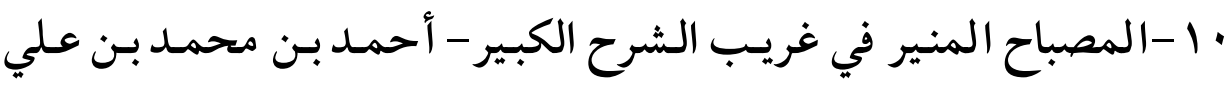

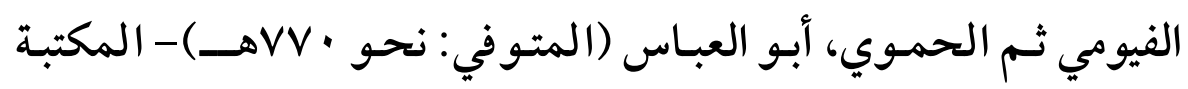

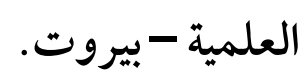

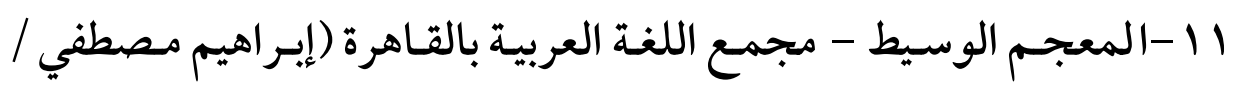
أحمد الزيات / حامد عبد القادر / محمد النجار ) الناشر: دار الدعوة

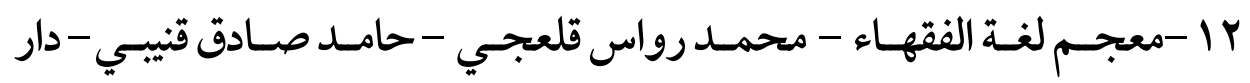
النفائس للطباعة والنشر والتوزيع - الطبعة: الثانية، ^ • ع ا هـ - 1911 1 م. ها - معجم الصواب اللغوي دليل المثقـف العـربي - الدكتور أحمـد مختـار

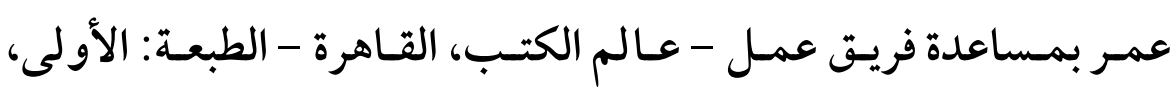

$$
\text { p } r \cdots \wedge-1 \leqslant r q
$$

ع ا -موسـوعة كشاف اصطلاحات الفنـون والعلـوم - محمــد بـن عـلي ابـن

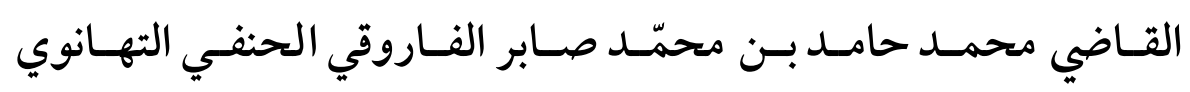
(المتوفي: بعـد 101 اهــ) تقـديم وإشراف ومراجعـة: د. رفيتق العجـم تحقيـق: د. عـلي دحـروج - نقـل النص الفـارسي إلى العربيـة: د. عبـد الله الخالدي- مكتبة لبنان ناشرون - الطبعة: الأولى - 1997 ام.

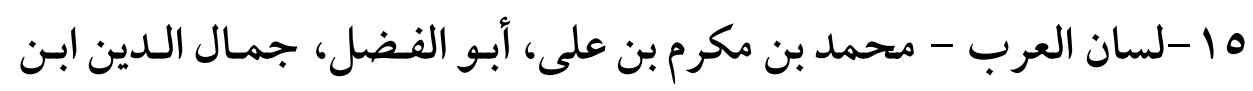

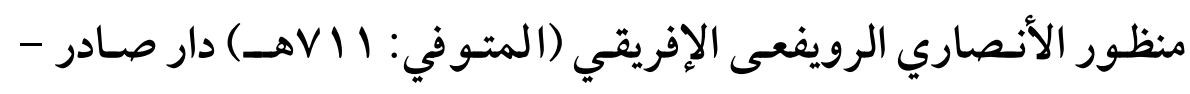

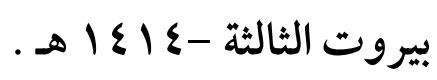


$(Y\{Y)$

مناسبة اللفظ للعنى عند الأصوليين وأثرها في توجيه خطاب المجتهلين

17 - المخـصص - أبـو الحسـن عـلي بـن إســماعيل بـن سـيده المـرسي

(المتوفي: 10 § هـ) خليل إبـراهيم جفـال - دار إحياء التراث العربي -

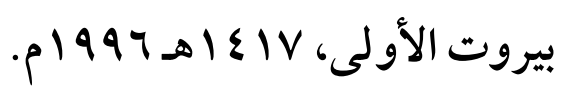

IV

الفيروزآبـادى (المتـوفي: N V Vهـ) تحقيـق: مكتـب تحقيـق الـتراث في

مؤسسة الرسـالة - مؤسسة الرسـالة للطباعـة والنشر والتوزيـع، بيروت -

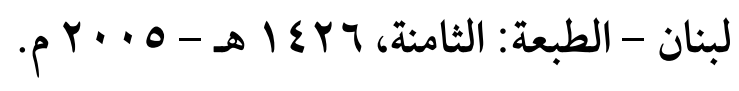

11 - الهدايـة الكافيـة الـشافية لبيـان حقـائق الإمـام ابـن عرفـة الوافيـة. (شرح

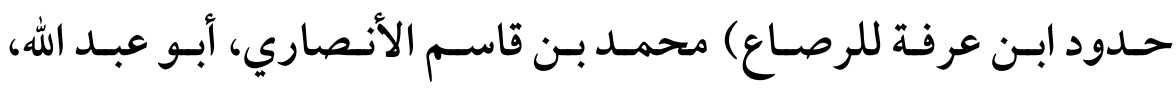

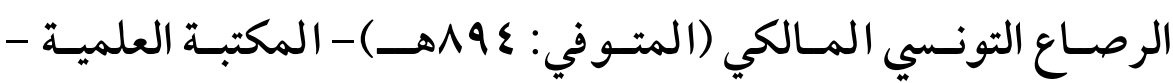

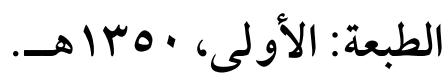

9 - الخصائص - أبو الفتح عثمان بـن جني الموصلي (المتوفي: بوهــ - الهيئة المصرية العامة للكتاب - الطبعة: الرابعة.

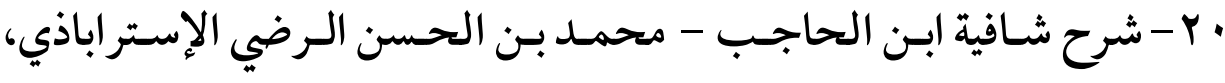

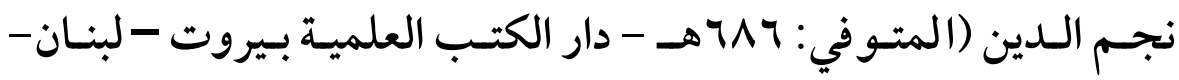

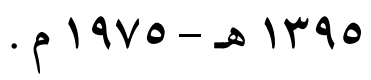

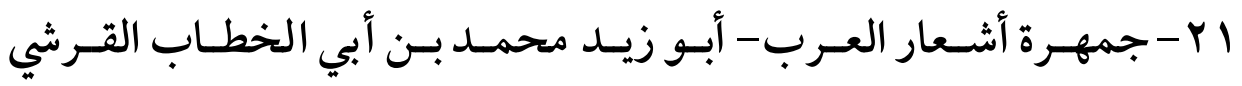

$$
\text { (المتوفي: · الهـ). }
$$

حققه وضبطه : علي محمد البجادي نهضة مصر للطباعة والنشر والتوزيع 
r r-الأمالي شذور الأمالي النوادر - أبو علي القـالي، إسماعيل بـن عيذون

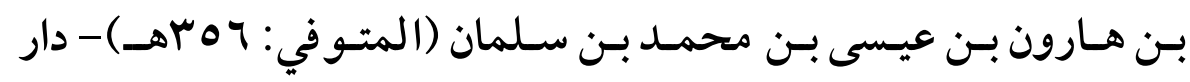

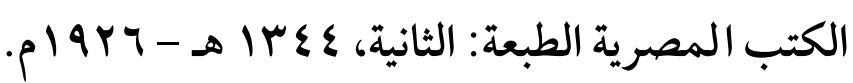

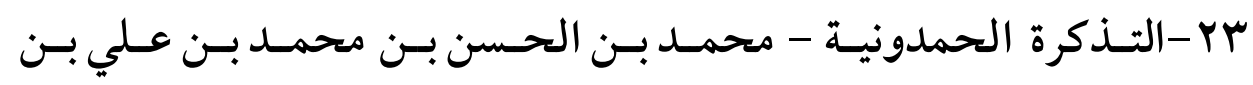

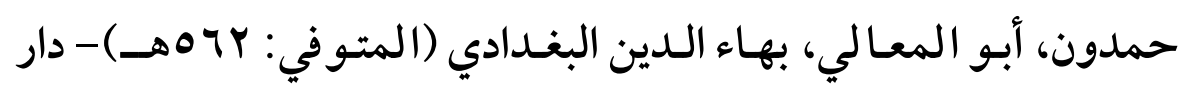

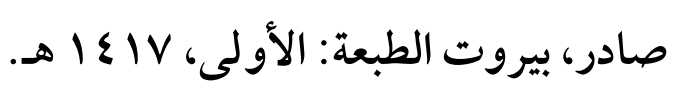

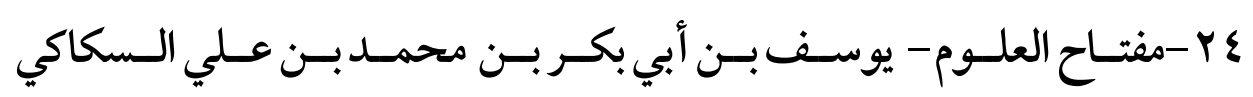
الخوارزمي الحنفي أبو يعقوب (المتوفي: ج جآهـ) ضبطه : نعسيم زرزور -

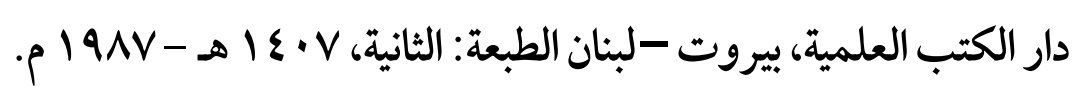

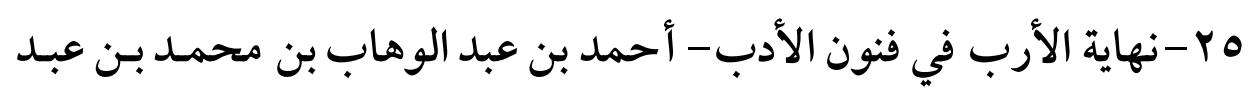

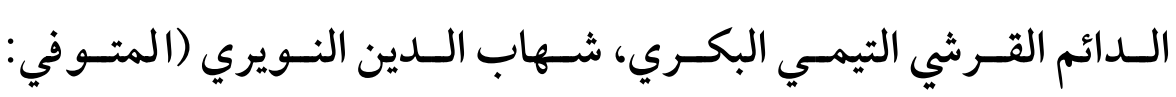

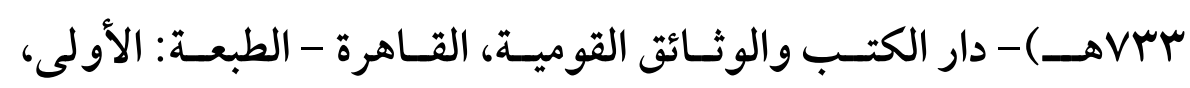
. جY-خزانة الأدب ولب لبـاب لسان العـرب-عبـد القـادر بـن عمـر البغـدادي

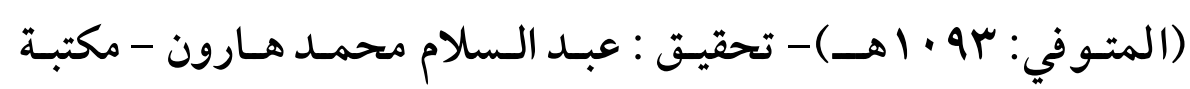

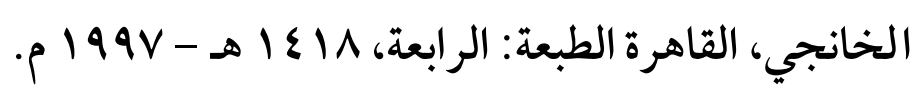
-YV

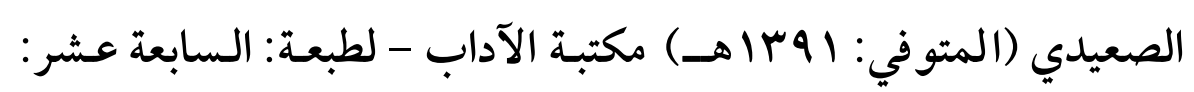

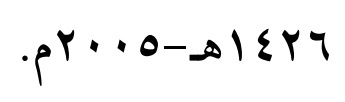


$(r\{\Lambda)$

مناسبة اللفظ للعنى عند الأصوليين وأثرها في توجيه خطاب المجتهلين

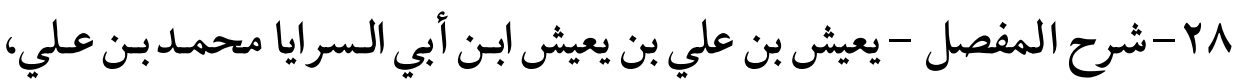

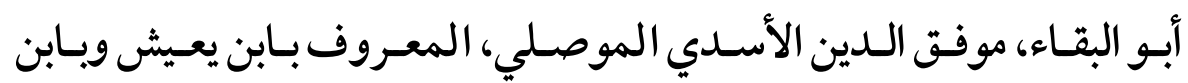

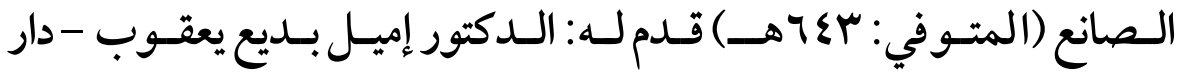

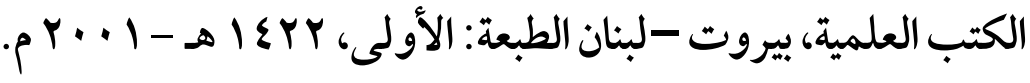

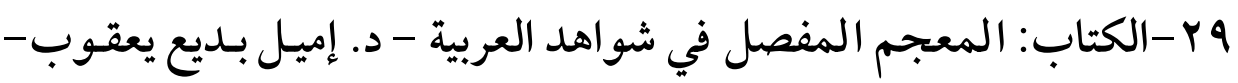

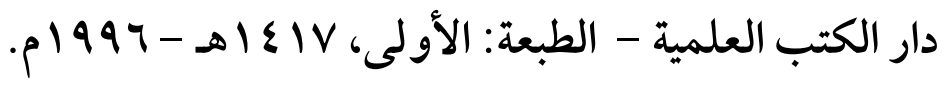

•r-فتح الكبير المتعال إعراب المعلقـات العشر الطوال- محمـد علي طه

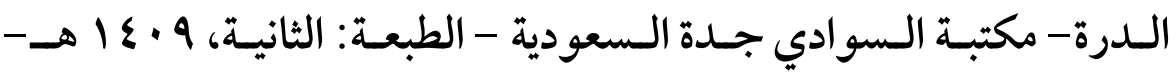

. 1919

اس-أسرار البلاغة في علم البيان - أبو بكر عبد القـاهر بـن عبد الر حمن بـن

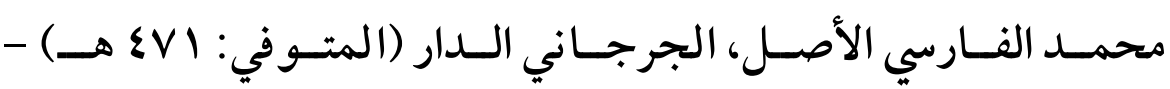

المحقـق: عبـد الحميـد هنــداوي دار الكتـب العلميـة، بـيروت - الطبعـة:

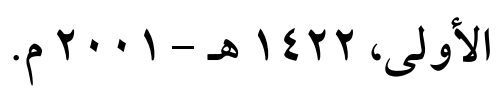

Y Y-مقدمـة ابـن خلـدون - عبـد الـر حمن بـن محمــــــن خلـدون - الطبعـة

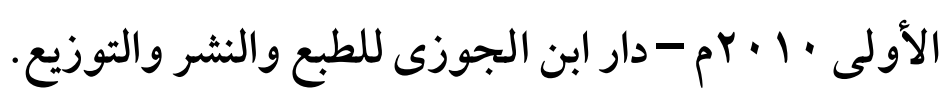

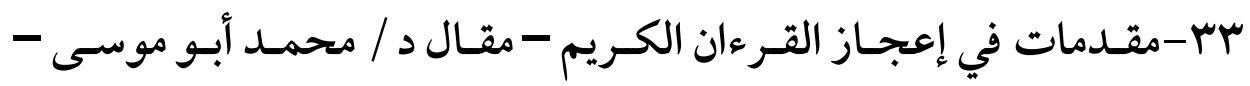

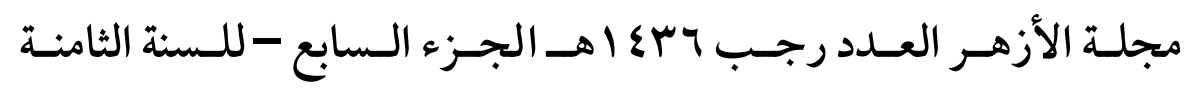

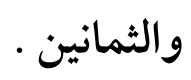

ع ب-المـصطلح الأصـولي ومسشكلة المفــاهيم - أ.د / عـلى جمعـة - دار

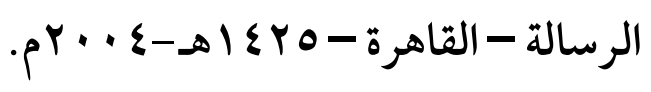


هـ-علم الاشتقاق نظريا وتطبيقيا- I.د / محمـد حسن حسن جبل - مكتبـة

$$
\text { الآداب-r Y r ميدان الأوبرا - القاهرة. }
$$

جب- مختصر السعد على تلخيص المفتاح - سعد الدين التفتـازاني - الطبعة

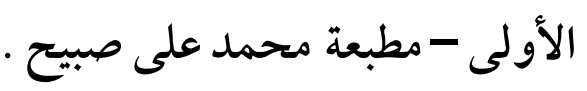

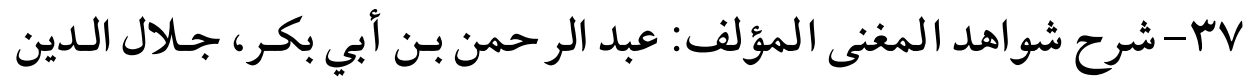

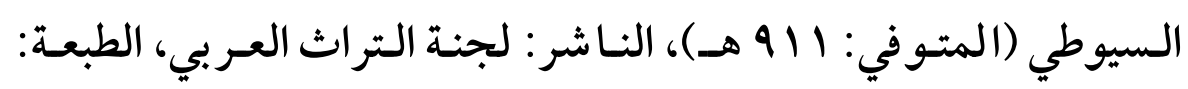

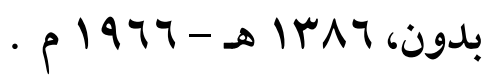

^ץ-إزالة الثبهات عن معـاني المصطلحات - أ.د / محمـد عمارة -مجلة

$$
\text { الأزهر. }
$$

\section{كتب أصول الفقه :.}

1-المعتمد في أصول الفقه - محمـد بـن علي الطيـب أبو الحسين البَصْرِي

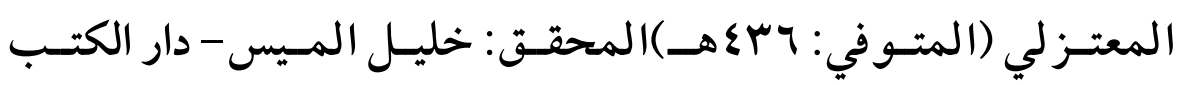

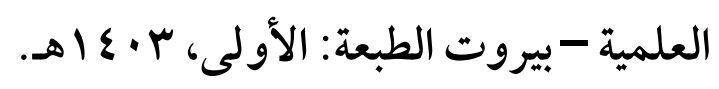

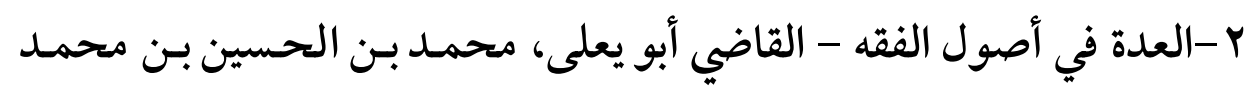

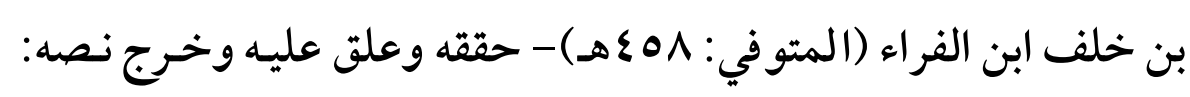
د أحمد بن علي بـن سير المباركي، الأسـتاذ المششارك في كليـة الشريعة

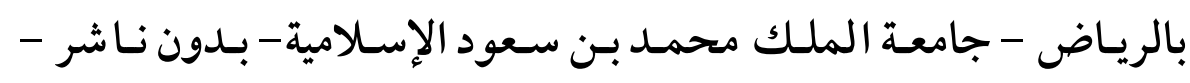

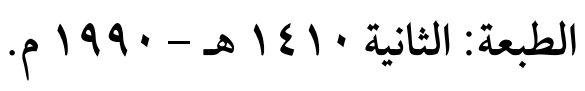

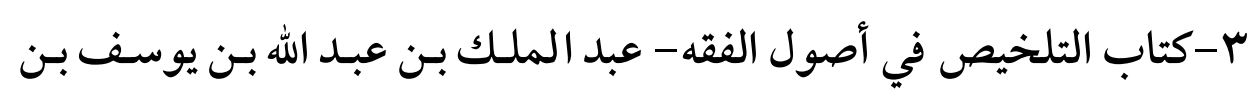

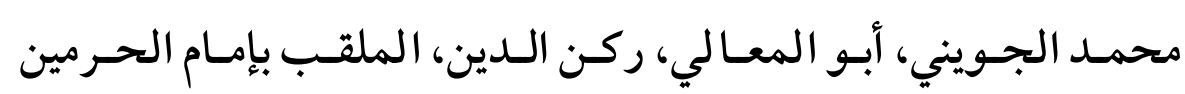




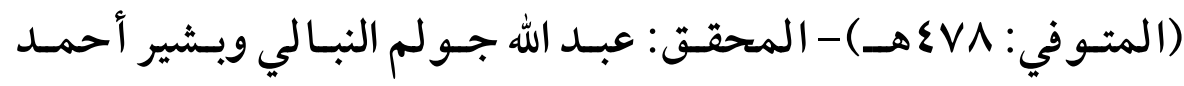

$$
\text { العمري - الناشر : دار البشائر الإسلامية -بيروت. }
$$

ع -قواطع الأدلة في الأصول - أبو المظفر، منصور بن محمد بن عبد الجبار

ابن أحمد المروزى السمعاني التميمي الحنفي ثـم الشافعي (المتوفي:

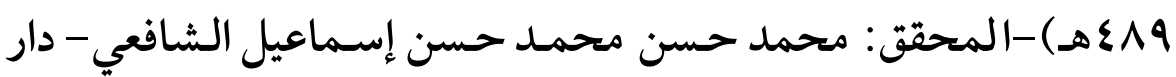

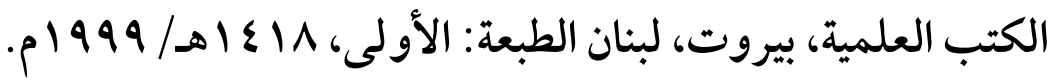

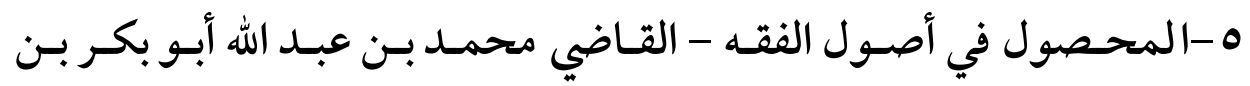

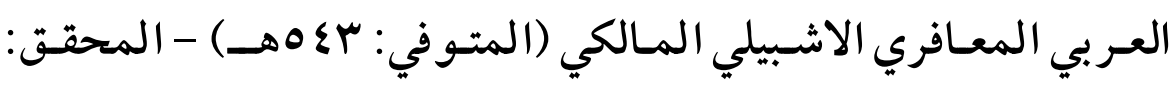
حسين علي اليدري - سعيد فودة- دار البيارق -عمان الطبعـة: الأولى،

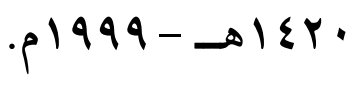

7 - المحصول - أبو عبد الله محمـد بـن عمر بـن الحسن بـن الحسين التيمي الرازي الملقب بفخر الدين الرازي خطيب الري (المتوفي: ج ·. هــ) دراسـة و تحقيـق: الـدكتور طـه جـابر فيـاض العلـواني النـاشر : مؤسـسـة الرسالة - الطبعة: الثالثة، 11 1 1 أهـ - 199V م. V التمهيد - محفوظ بن أحمد بن الحسن أبو الخطاب الكلوذانى الحنبلي

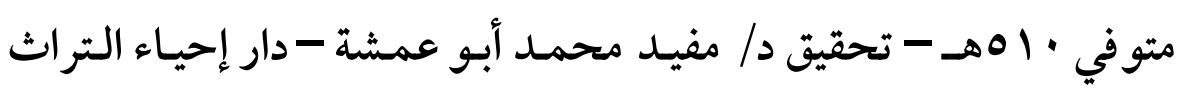

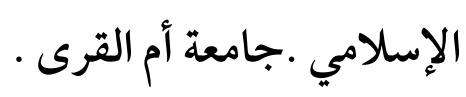
1-المسودة في أصسول الفقـه - آل تيمية [بــأ بتصنيفها الجـدّ: مجـد الـدين عبد السلام بن تيمية (ت: Y Y 7هـ) ، و أضـاف إليها الأب، : عبد الحليم

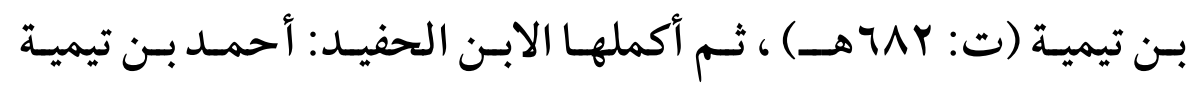




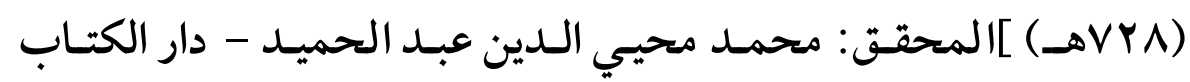
العربي -

9 - شرح تنقيح الفصول - أبو العباس شهاب الدين أحمد بن إدريس بـن عبد

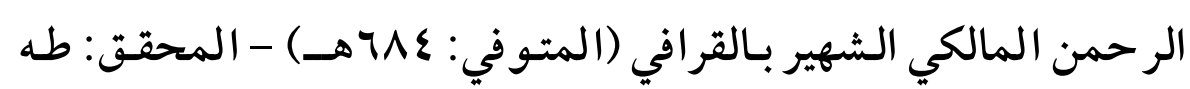

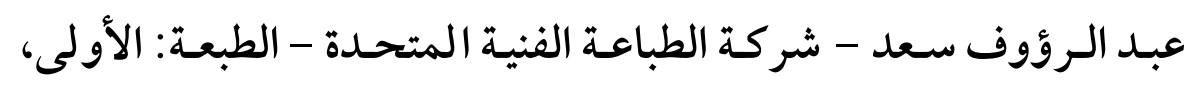

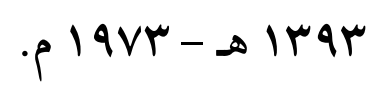

• 1 - شرح مختصر الروضـة - سـليمان بـن عبـد القـوي بـن الكـريم الطوفي

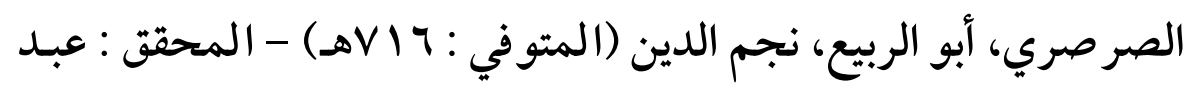

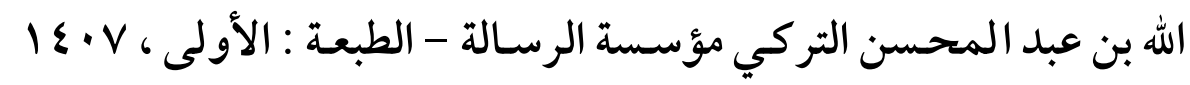
هـ /

1 | 1 بيان المختصر شرح مختصر ابن الحاجب - محمود بـن عبد الرحمن (أبي القاسم) ابن أحمد بن محمد، أبو الثناء، شمس الدين الدمبن الأصفهاني

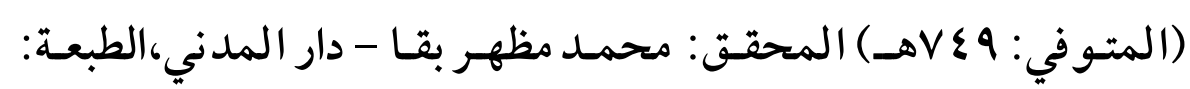

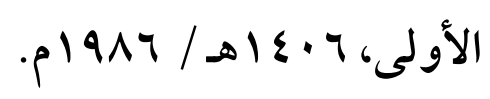

r ا -البحر المحيط في أصول الفقه - أبو عبد الله بـدر الدين محمـد بـن عبد

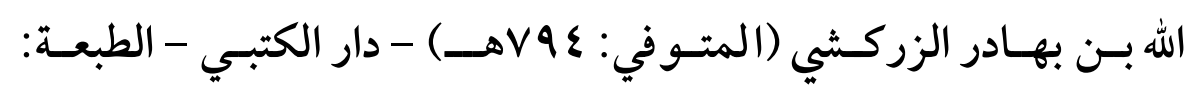

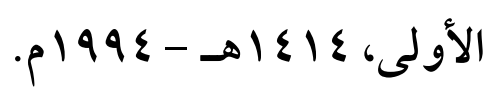

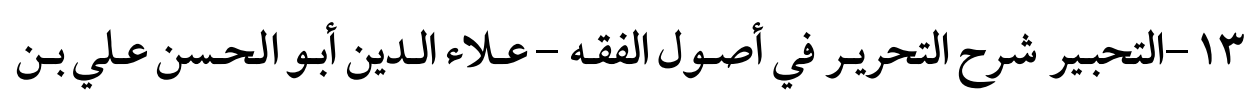

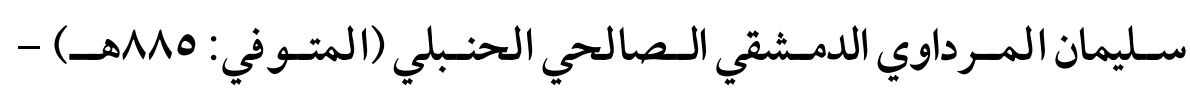


(YOY) مناسبة اللفظ للعنى عند الأصوليين وأثرها في توجيه خطاب المجتهلين

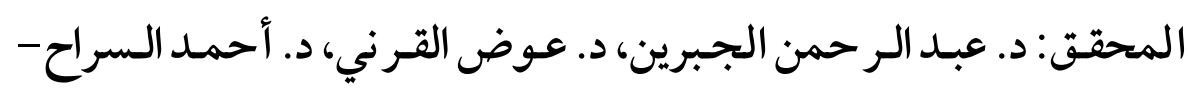

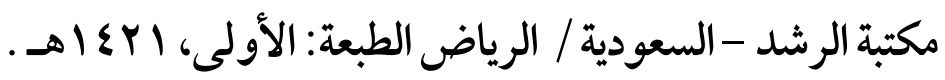

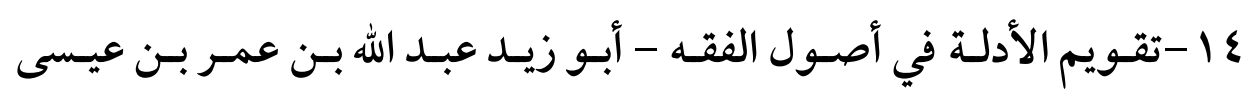
الدّبوسيّ الحنفي (المتوفي : · بعهـ) - المحقتق : خليل محيي الدين

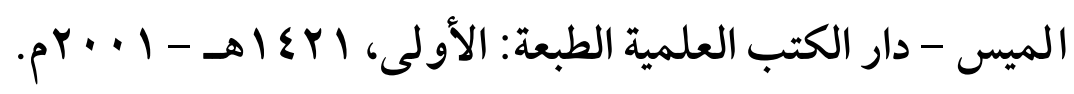
10 -الغيث الهامع شرح جمع الجوامع - لـولي الدين أبي زرعـة أحمـد بـن الدين

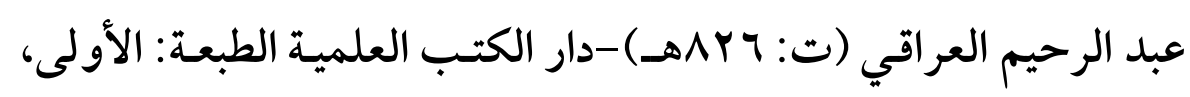

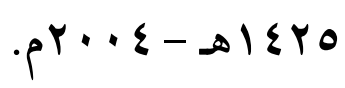
17 - إيضاح المحصول من برهان الأصول - أبو عبد الله محمـد بـن علي بـن

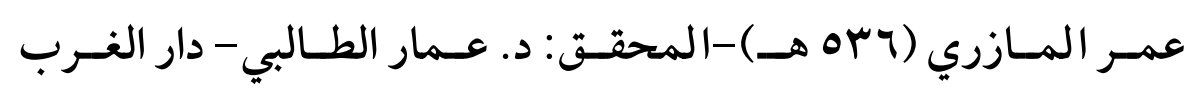
الإسلامي الطبعة: الأولى.

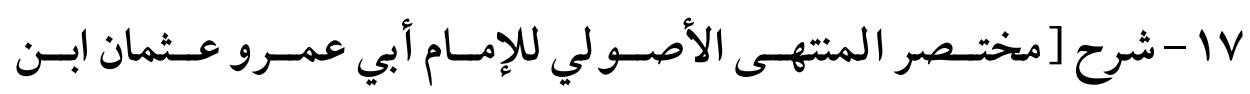

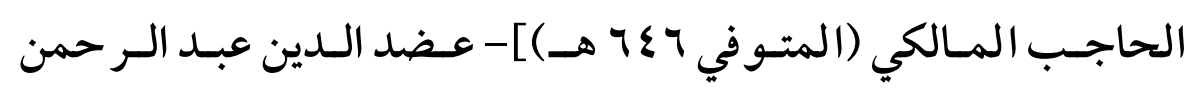
الإيجي (المتوفي: V0Y هـ) وعلى المختصر والشرح حاشية سعد الدين

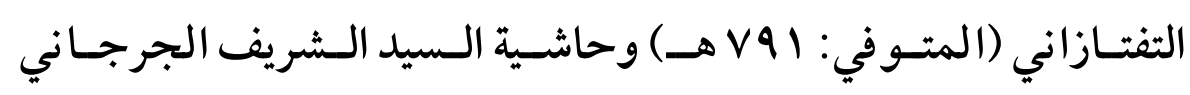

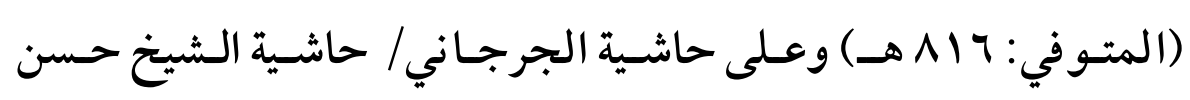

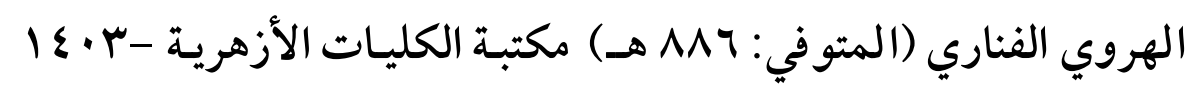

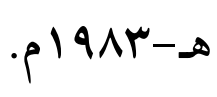
11 -تشنيف المسامع بجمع الجوامع لتاج الدين السبكي - أبو عبد الله بـدر

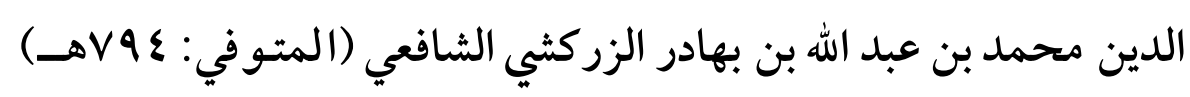


دراسة و تحقيق: د سيد عبد العزيز - د عبد الله ربيع، المدرسان بكلية الدراسات الإسلامية والعربية بجامعة الأزهر - مكتبـة قرطبة للبحـث العلمي وإحيـاء الـتراث - توزيسع المكتبـة المكيـة - لطبعـة: الأولى، م 1991- - 1 1 1

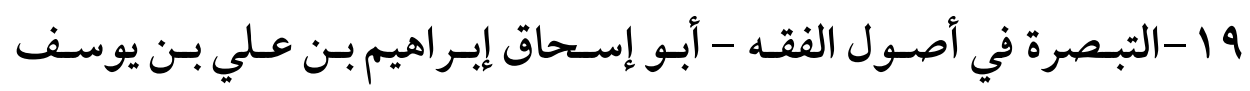

الشيرازي(المتوفي: TVV هـ) حققـه: د. محمـد حسن هيتو دار الفكر -

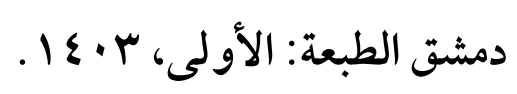

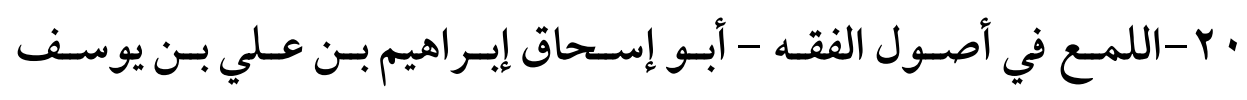

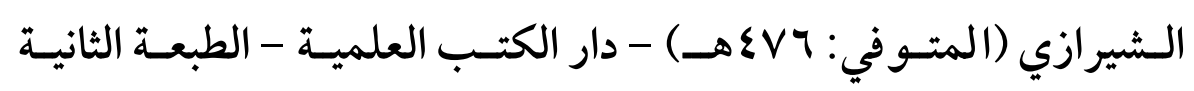

$$
\text { هـ }
$$

اYY - شرح اللمـع - أبـو إســحاق إبــراهيم بــن عـلي بــن يوسـف الـشيرازي

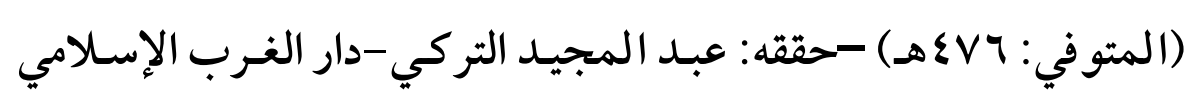

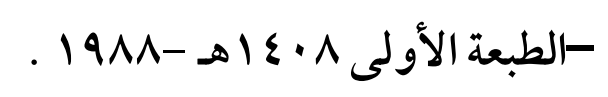

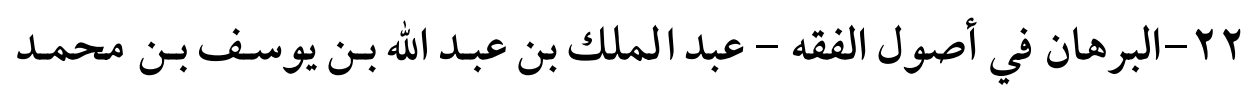
الجويني، أبو المعالي، ركن الدين، الملقبـ بإمام الحـرمين (المتوفي:

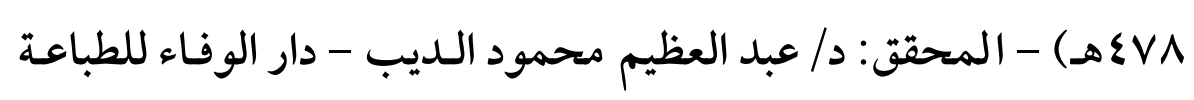

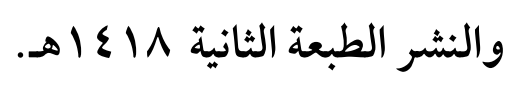

بr - المستصفي - أبو حامد محمـد بـن محمـد الغزالي الطوسي (المتوفي:

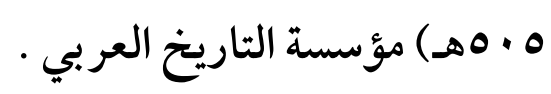


( $९ \circ \varepsilon)$

مناسبة اللفظ للعنى عند الأصوليين وأثرها في توجيه خطاب المجتهلين

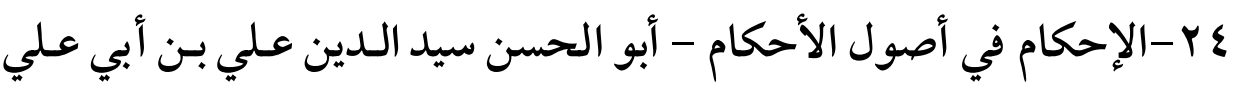

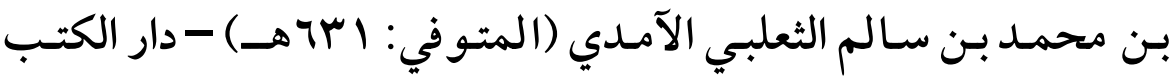

$$
\text { العلمية - بيروت . بن. }
$$

ه - كثثف الأسرار شرح أصول البزدوي - عبد العزيز بن أحمد بن محمـد،

علاء الدين البخاري الحنفي (المتوفي: · ·rهــ) دار الكتب العلمية -

$$
\text { بيروت -لبنان . }
$$

جY - نهاية السول شرح منهاج الوصسول -عبد الرحيم بـن الحسن بـن علي

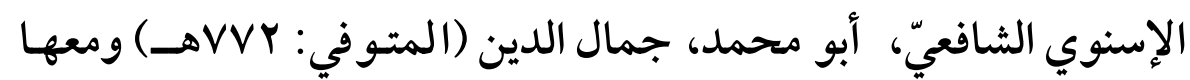

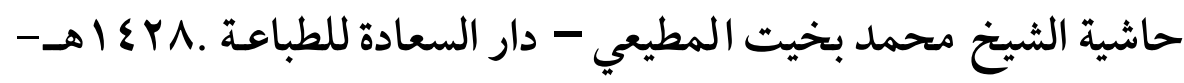

$$
\text { pr..v }
$$

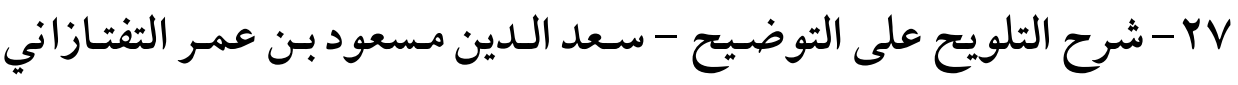

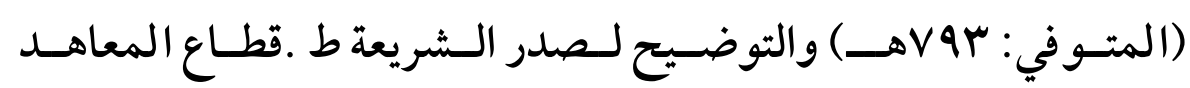

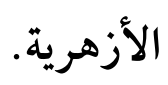

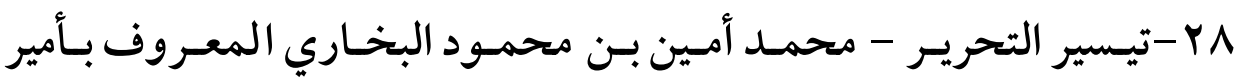

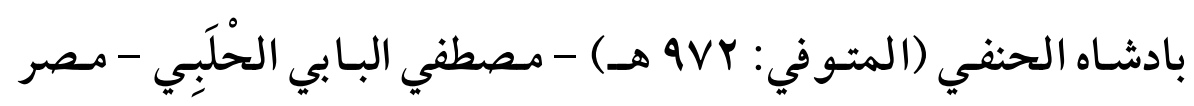

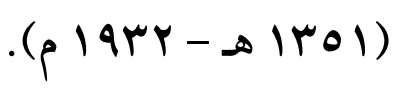

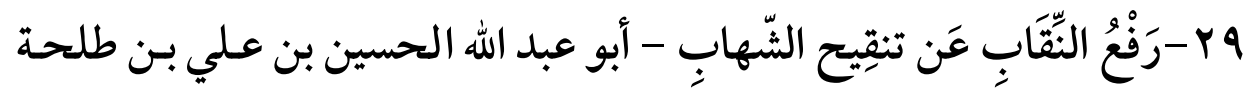

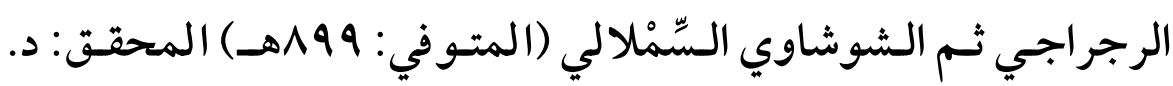

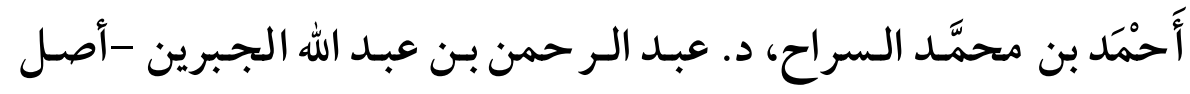


هذا الكتاب: رسالتي ماجستير - مكتبة الرشد للنشر والتوزيع، الرياض -

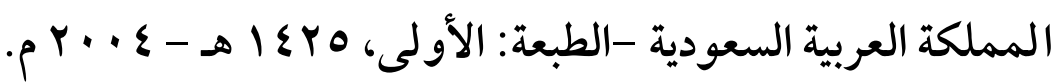
• ب-التقريب والإرشاد (الصغير )- - محمد بن الطيب بن محمد بن جعفر بـن

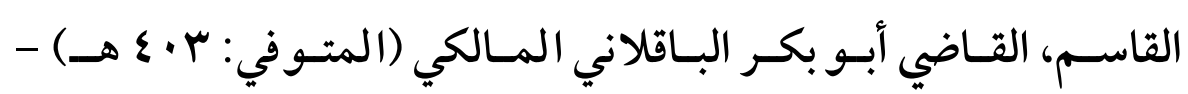
المحقق: د. عبد الحميد بن علي أبو زنيـد - مؤسسة الرسـالة - الطبعـة:

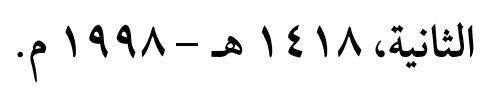

اب-ميزان الأصسول في نتـائج العقول - عـلاء الـدين شـمس النظر أبـو بكـر

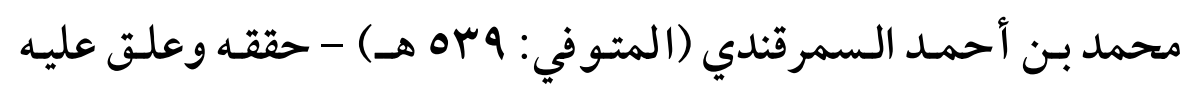
وينشره لأول مرة: الدكتور محمد زكي عبد البر، الأستاذبكلية الشريعة جامعـة قطر، ونائـب رئسيس محكمـة الـنقض - مطـابع الدوحـة الحديثـة،

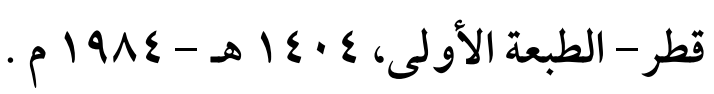

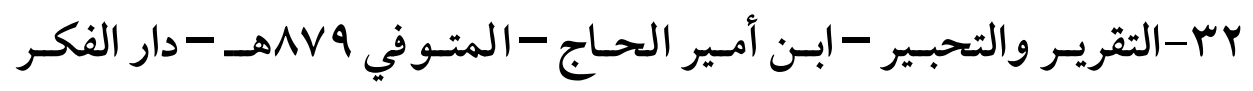

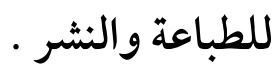

بr-فواتح الرحموت لعبد العلى محمد بن نظام الدين الأنصاري -مؤسسة

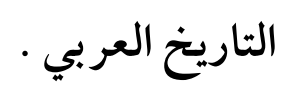

ع - فتتح الغفار - زين الدين بن نجيم -طبعة مصطفي البابى الحلبي .

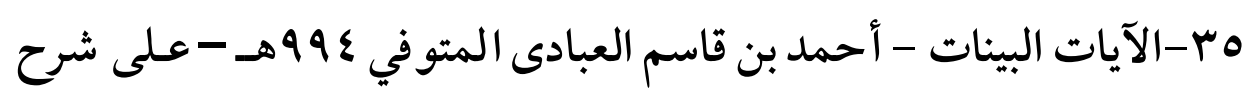
جمع الجوامع لجـلال الـدين المحلى - دار الكتب العلمية - بيروت لبنان 
بr-نبراس العقول في تحقيق مسائل القياس عند علماء الأصول -عيسى منون -مطبعة التضامن الأخوى لصاحبها حـافظ محمـد داوود - شـارع الزغارى عطفة الشماع نمرة ^ مصر . كون

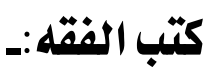
أولا : الفقه الحنفي: ا-بدائع الصنائع في ترتيب الشرائع - عـلاء الـدين، أبو بكر بـن مسعود بـن

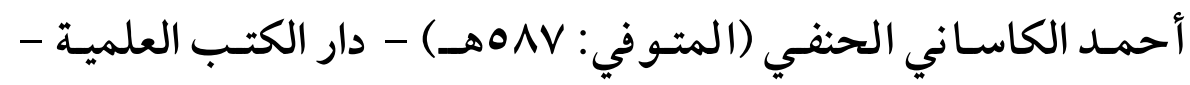

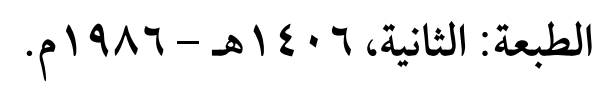

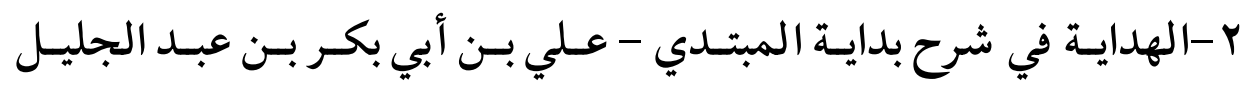

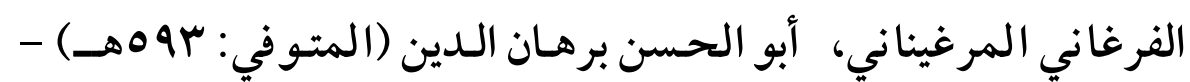
المحقق: طلال يوسف دار إحياء التراث العربي - بيروت - لبنان .

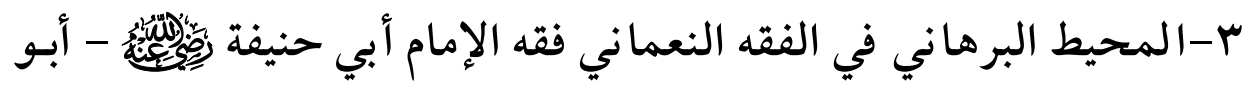

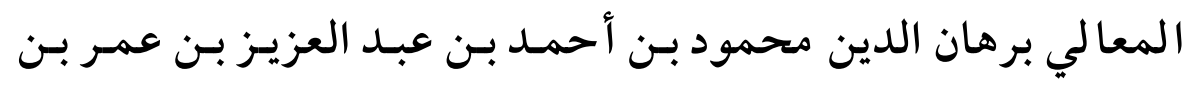

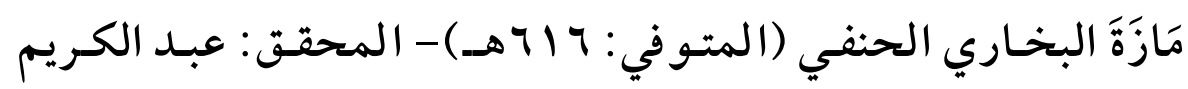
سامي الجندي - دار الكتب العلمية، بيروت - لبنان الطبعة: الأولى،

$$
\text { م } r \cdots \varepsilon-\Delta 1 \leqslant\} \varepsilon
$$

ع -اللباب في الجمع بين السنة والكتاب - جمال الـدين أبو محمـد علي بـن أبي يحيى زكريـا بـن مسعود الأنصاري الخزرجي المنبجي (المتوفي:

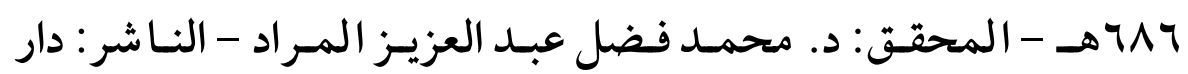

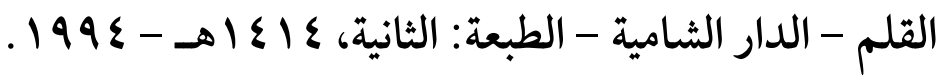




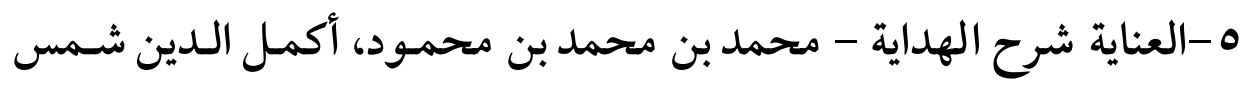

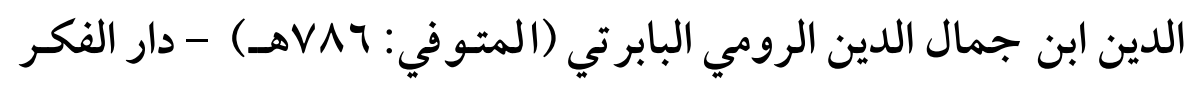

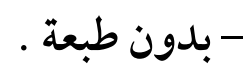
ج-البناية شرح الهداية - أبو محمد محمود بـن أحمـد بـن موسى بـن أحمـــ

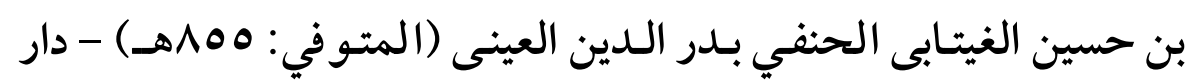

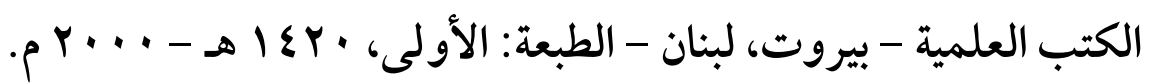

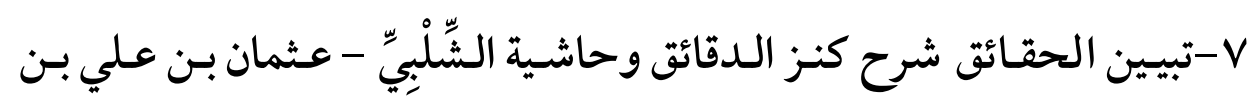

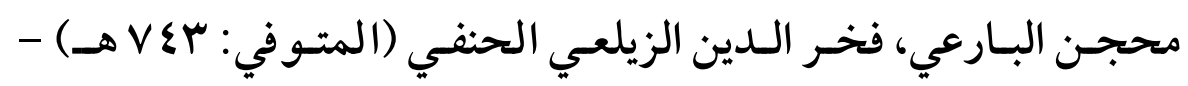
الحاشية: شهاب الدين أحمد بن محمد بن أحمد بن يونس بـن إسـماعيل

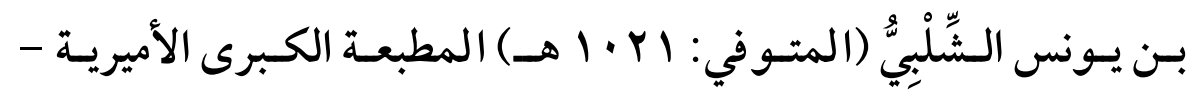

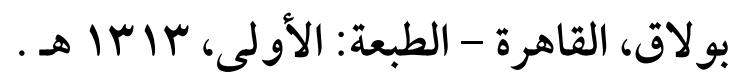

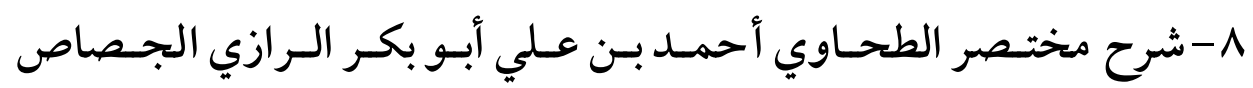

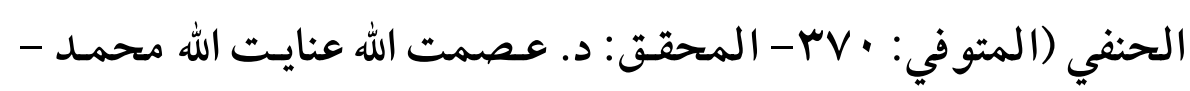

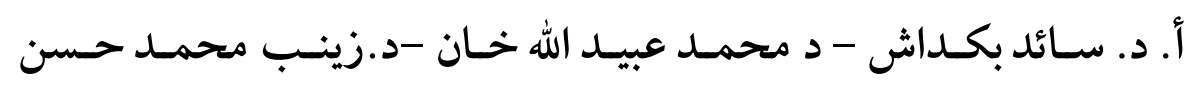

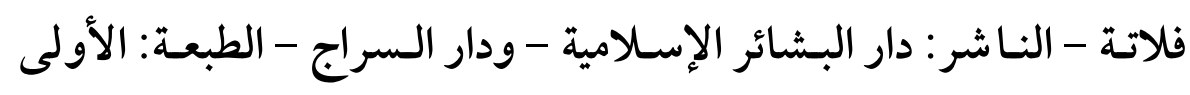

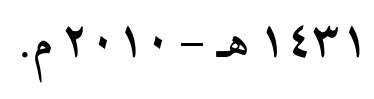

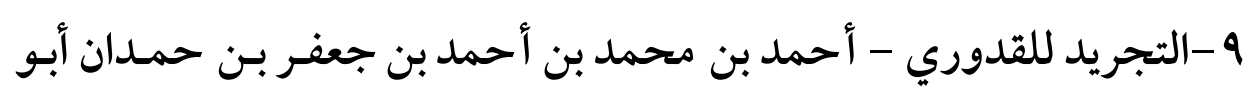

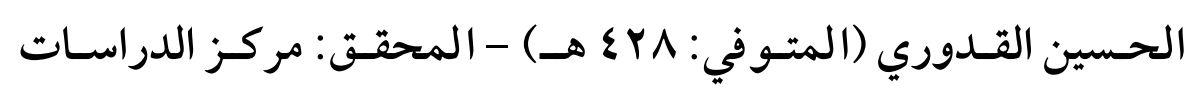

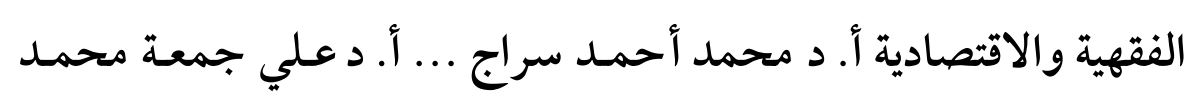
- الناشر : دار السلام - القاهرة - الطبعة: الثانية، VY I I هـ - Y + . Y م. 
$(Y \circ \Lambda)$

مناسبة اللفظ للعنى عند الأصوليين وأثرها في توجيه خطاب المجتهلين

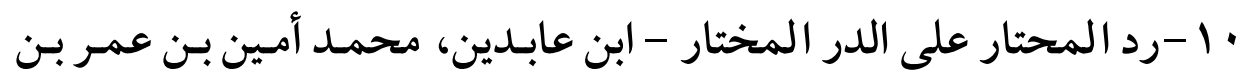
عبد العزيز عابدين الدمشقي الحنفي (المتوفي: Y Y Y اهـ) - الناشر : دار

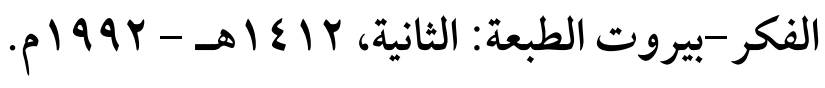

11 - 1 -درر الحكام شرح غـرر الأحكام - محمــد بـن فرامـرز بـن علي الشهير بملا - خسرو (المتوفي: 111هـ) - دار إحياء الكتب العربية - بـدون طبعة وبدون تاريخ.

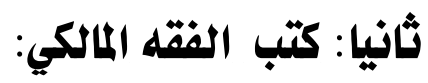

1 -البيان والتحصيل والثرح والتوجيه والتعليل لمسائل المستخر جة - أبـو

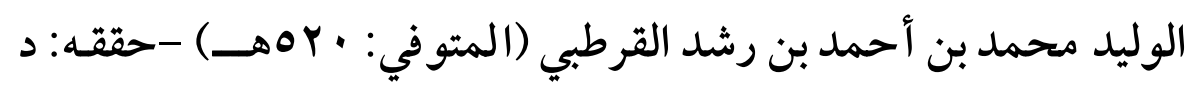
محمـد حجي وآخـرون دار الغـرب الإسـلامي، بيروت - لبنـان -الطبعـة:

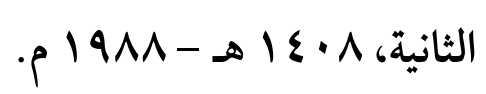

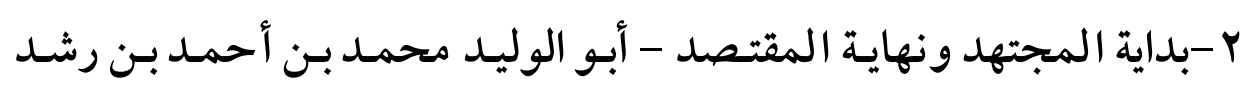
القرطبي الشهير بابن رشـد الحفيد (المتوفي: القاهرة - بدون طبعة.

م-مواهـب الجليـل في شرح مختـصر خليـل - شـمس الـدين أبـو عبـد الله

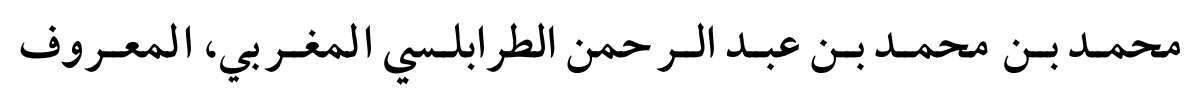

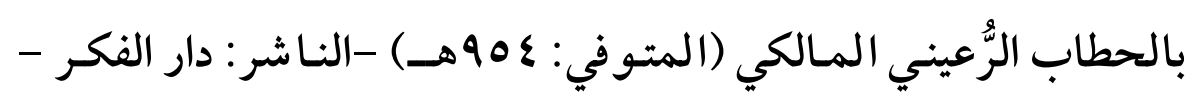

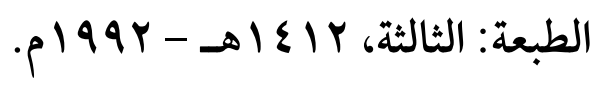

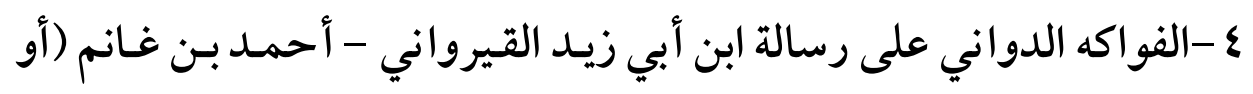

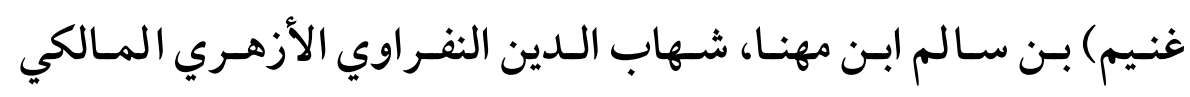


$(Y \circ q)$

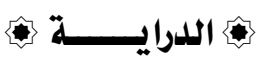

(المتوفي: ج | | |هـ) - الناشر: دار الفكر - الطبعة: بـدون طبعة - تـاريخ

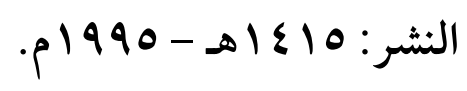

ه- المعونة على مذهب عـالم المدينة (الإمام مالك بـن أنسس) ، أبو محمـد عبـد الوهـاب بـن عـلي بـن نـصر الثعلبي البغـدادي المـالكي (المتـوفي:

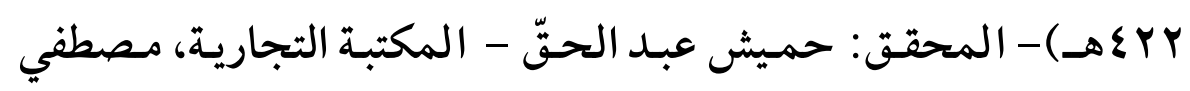

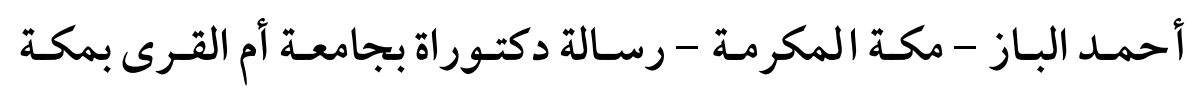

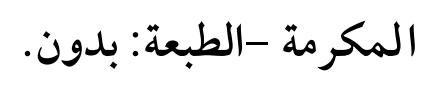

ج - شرح مختصر خليل للخرشي - محمد بن عبد الله الخرشي المـالكي أبو عبـد الله (المتـوفي: 1 • 11 اهـ) - دار الفكـر للطباعـة - بـيروت - بــدون

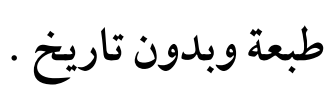

Vاشية الدسوقي على الشرح الكبير - محمد بن أحمد بن عرفة الدسوقي

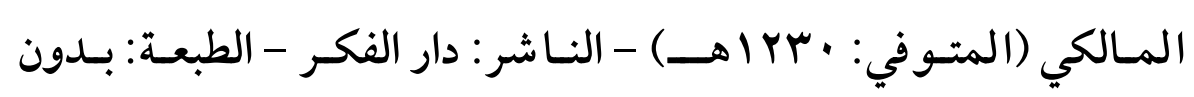
طبعة وبدون تاريخ. ثالثا : كتب الفقه الشافي:

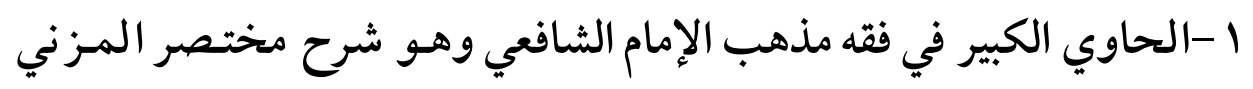

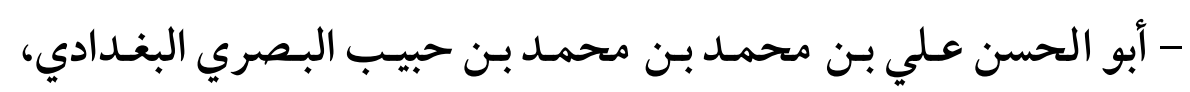

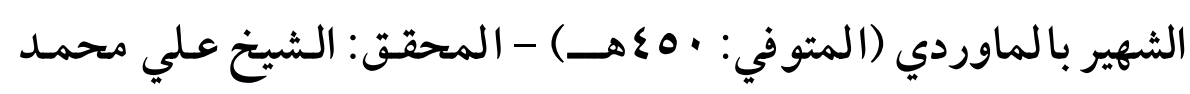

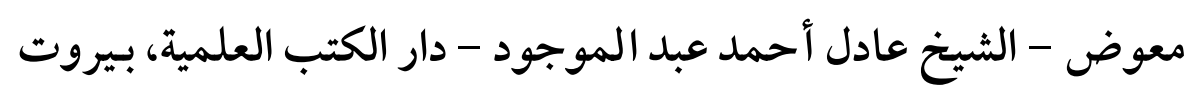

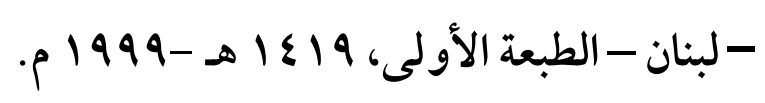


(YT.)

مناسبة اللفظ للعنى عند الأصوليين وأثرها في توجيه خطاب المجتهلين

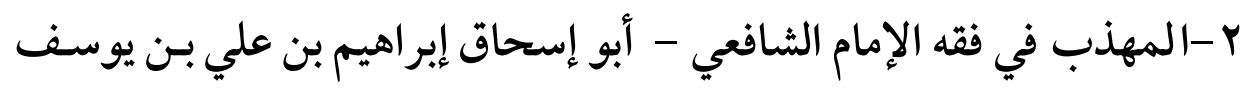

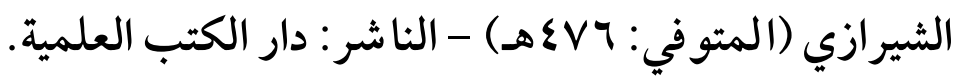

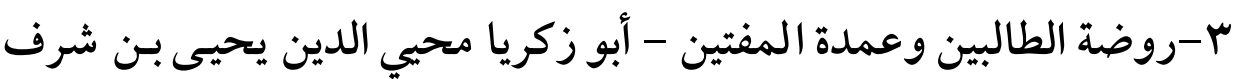

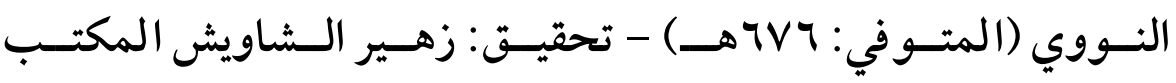

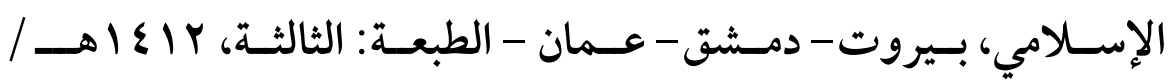
.$p 1991$

ع -تحفة المحتاج في شرح المنهاج - أحمـد بـن محمـد بـن علي بـن حجر الهيتمي - المكتبـة التجاريـة بمـصر لـصاحبها مـصطفي محمـد - بــدون

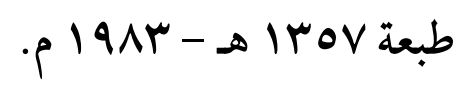

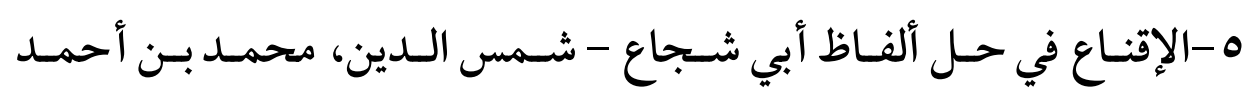
الخطيـب الـشربيني الـشافعي (المتـوفي: 9VVهـ) - المحقـق: مكتـب البحوث والدراسات - دار الفكر.

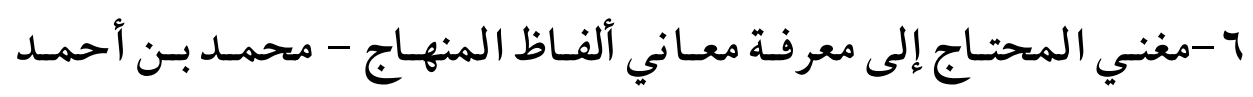
الخطيسب الشربيني الشافعي (المتـوفي: 9VVهـ - دار الكتـب العلميـة

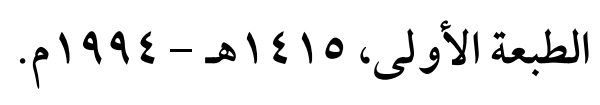

Vاشية البجيرمي على الخطيـب - سـليمان بـن محمـد بـن عمـر البُجَيْرِمِيّ

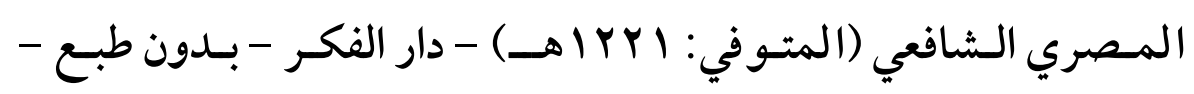

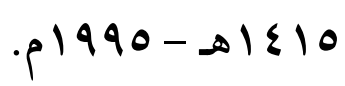
^-نهاية المطلب في دراية المذهب - عبد الملك بن عبد الله بـ يوسف بـن

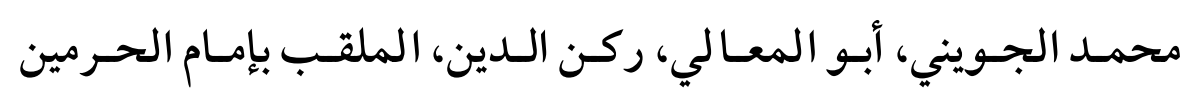


(YTI)

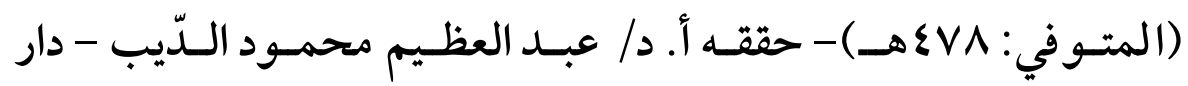

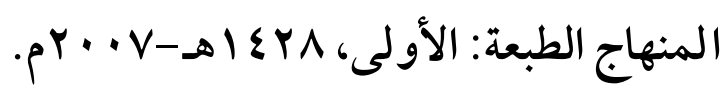

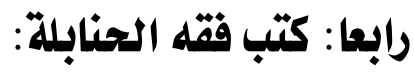

1-الكافي في فقه الإمام أحمد - أبـو محمدل موفتق الـدين عبد الله بـن أحمـد بن محمد بن قدامة الجماعسيلي المقـدي ثـم الدمشقي الحنبلي، الشهير بابن قدامة المقدسي (المتوفي: · بآهــ) - دار الكتب العلميـة- الطبعـة

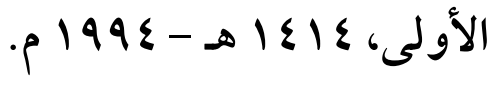

Y-المغني لابن قدامة - أبو محمد موفق الدين عبـد الله بـن أحمـد بـن محمـد

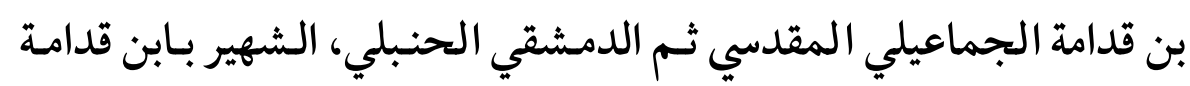
المقدسي (المتوفي: · با7هـ) - الناشر: مكتبـة القـاهرة - الطبعة: بـدون طبعة.

ץ-العدة شرح العمدة - عبد الرحمن بن إبراهيم بن أحمد، أبو محمـد بهاء

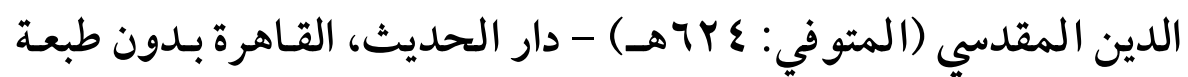

$$
\text { م r. r r }
$$

ع -الثرح الكبير على مـتن المقنع - عبـد الر حمن بـن محمـد بـن أحمـد بـن قدامة المقدسي الجماعيلي الحنبلي، أبو الفرج، شمس الدين (المتوفي:

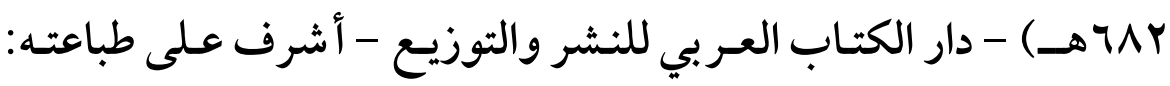
محمد رشيد رضا صاحب المنار. 
(YTY)

مناسبة اللفظ للعنى عند الأصوليين وأثرها في توجيه خطاب المجتهلين

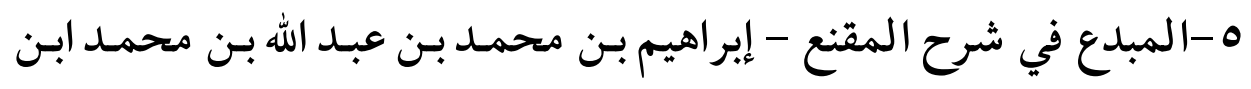

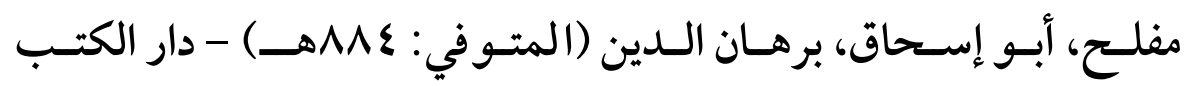

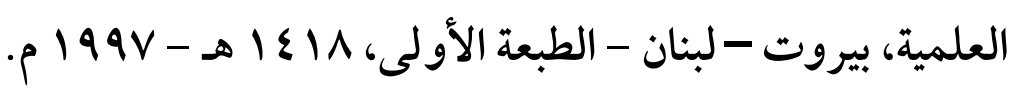
ج-الإنصاف في معرفة الراجح من الخـلاف - عـلاء الـدين أبو الحسن علي بن سليمان المرداوي الدمشقي الصالحي الحنبلي (المتوفي: 111هــ) دار إحياء التراث العربي - الطبعة: الثانية - بدون تاريخ.

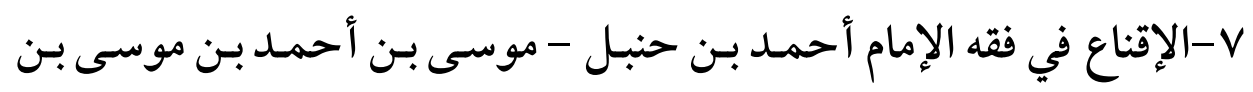

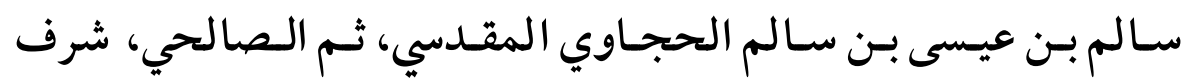

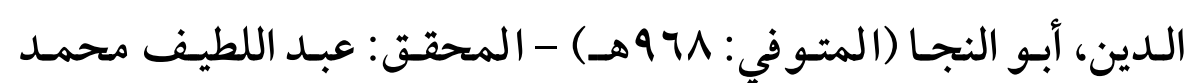

$$
\text { موسى السبكي - دار المعرفة بيروت - لبنان. }
$$

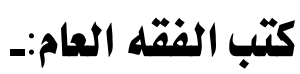

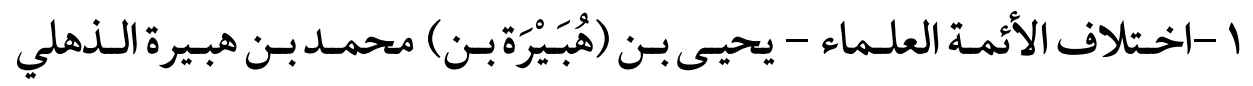

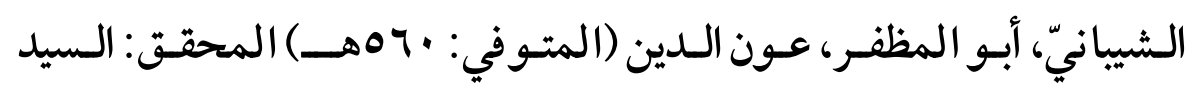

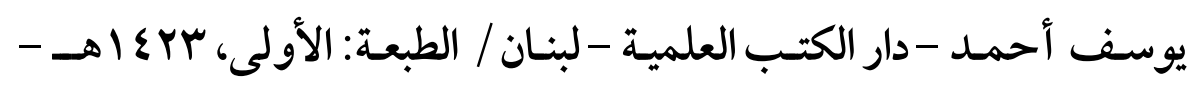
مr. r

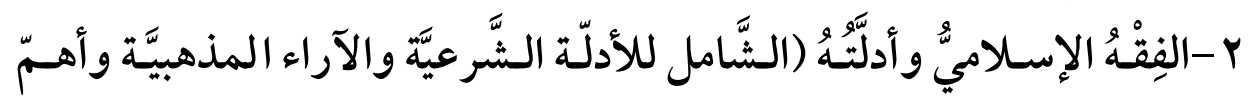

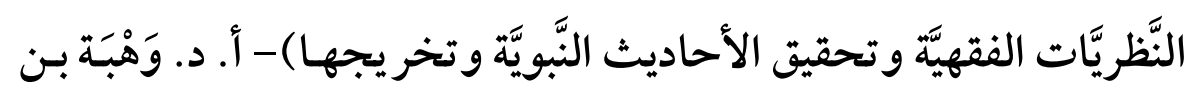

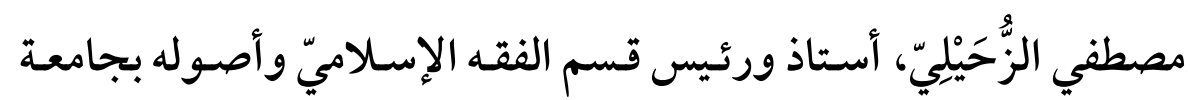

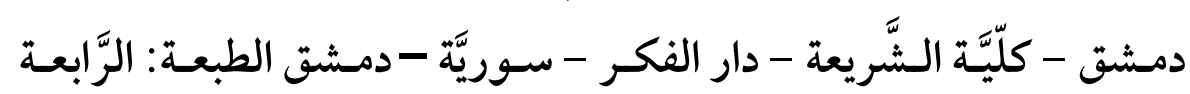


المنقّحة المعدَّلة بالنّّبة لما سبقها (وهي الطبعة الثانية عشرة لمـا تقدمها

$$
\text { من طبعات مصورة). }
$$

ب-موسـوعة الإجمــاع في الفقــه الإســلامي إعـــاد: د. أســامة بــن سـعيد

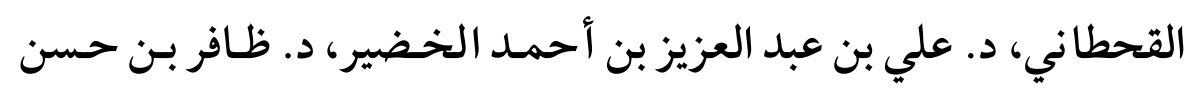

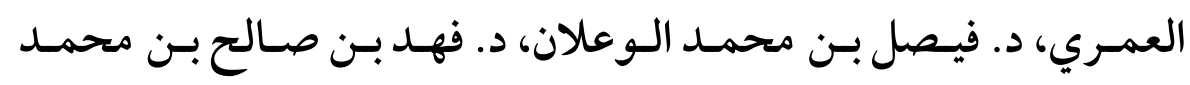

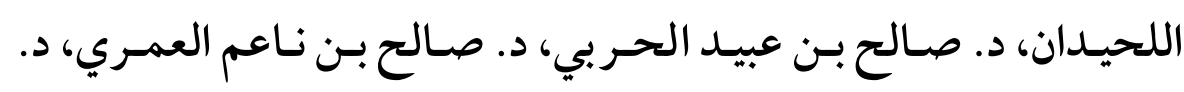

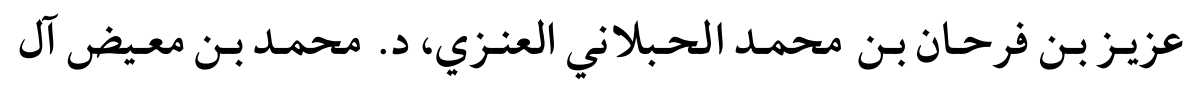
دواس الشهراني، د. عبد الله بن سعد بن عبـد العزيز المحـارب، د. عـادل

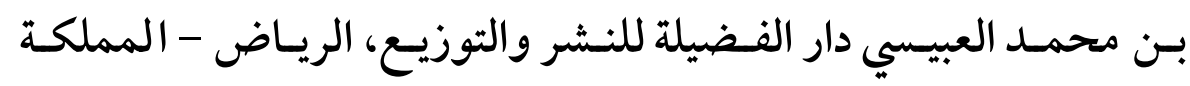

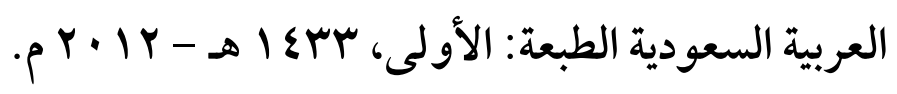
ع - الاستذكار - أبو عمر يوسف بن عبد الله بن محمد بن عبد البر بـن عاصـم

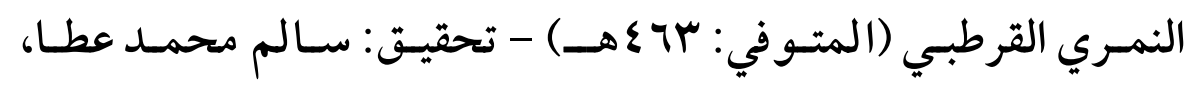

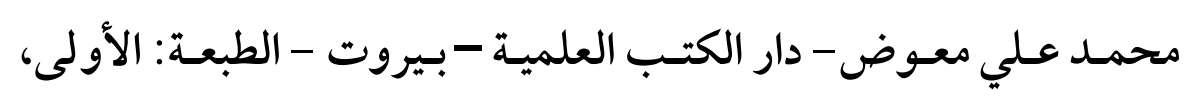
.r...- $|\leqslant Y|$ ه-المحلى بالآثار - أبو محمد علي بن أحمـد بـن سعيد بـن حزم الأندلسي

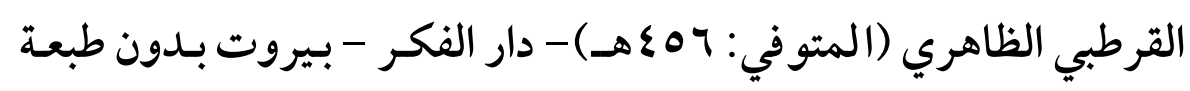
وتاريخ.

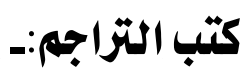

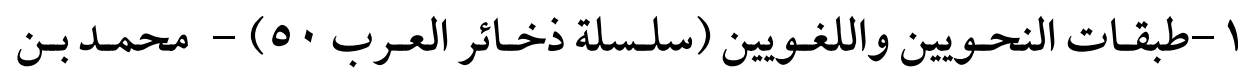

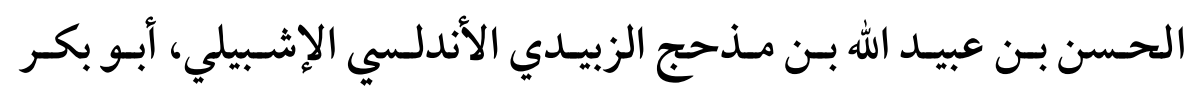


(YT\&) مناسبة اللفظ للعنى عند الأصوليين وأثرها في توجيه خطاب المجتهلين

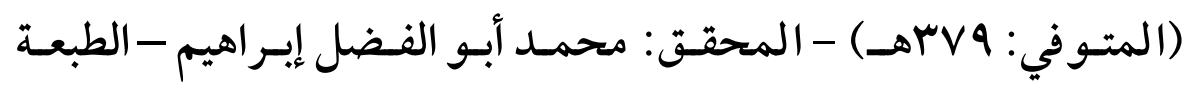

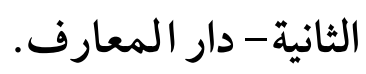

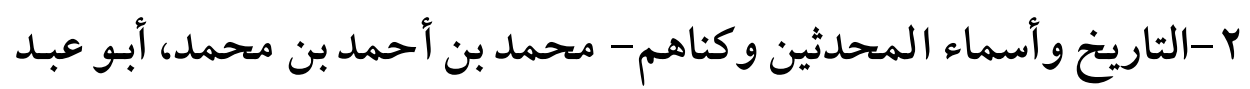

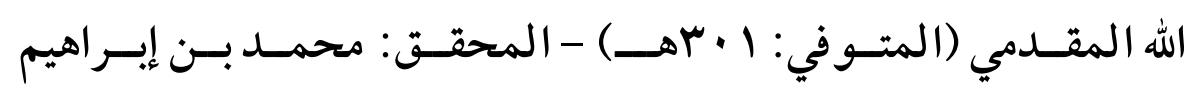

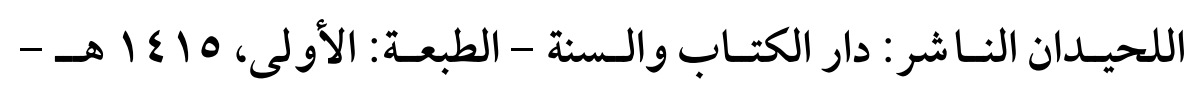
. $199 \varepsilon$

ץ-تـاريخ بغـداد - أبـو بكـر أحمـد بـن عـلي بـن ثابـت بـن أحمـد بـن مهـدي الخطيب البغدادي (المتوفي: سج §هـ) - دار الكتب العلمية - بيروت دراسة وتحقيق: مصطفي عبد القادر عطا الطبعة: الأولى، IV I I اهـ.

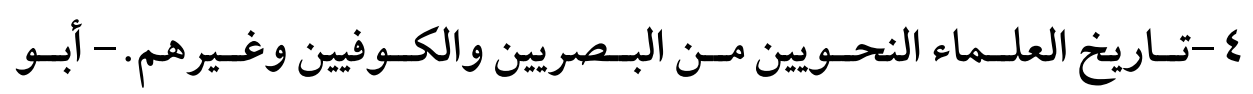
المحاسـن المفضضل بـن محمــــــن مسعر التنوخي المعـري (المتـوفي:

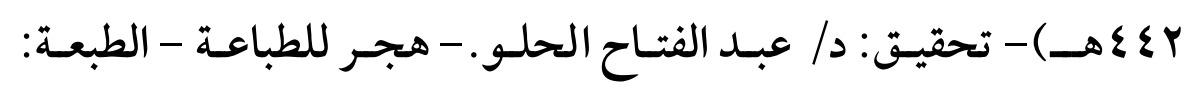

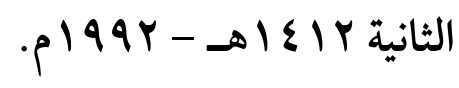

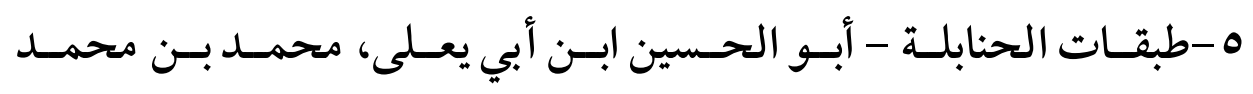

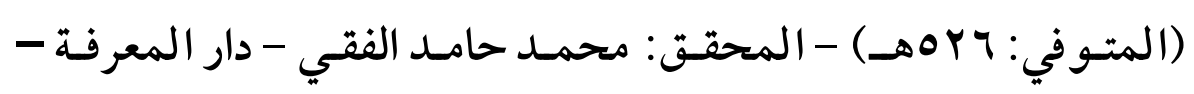

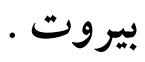

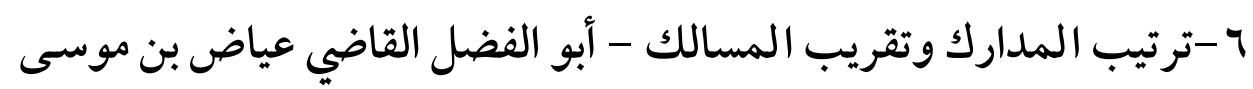

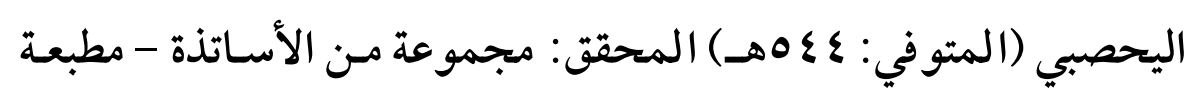
فضالة - المحمدية، المغرب - الطبعة: الأولى. لمعنى 
(Yro)

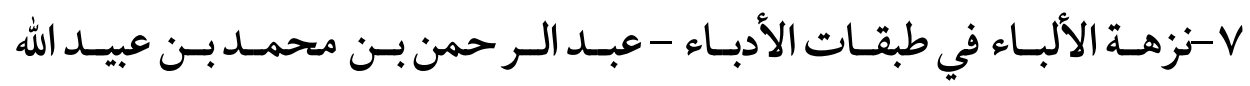

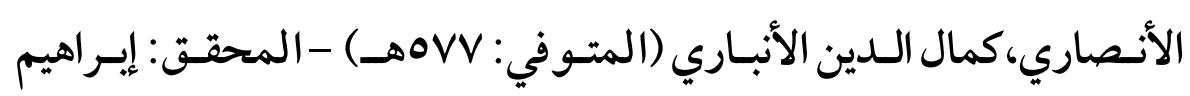

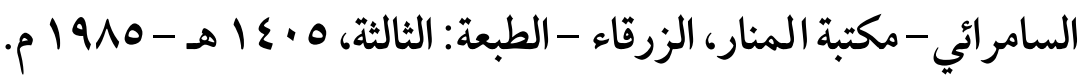

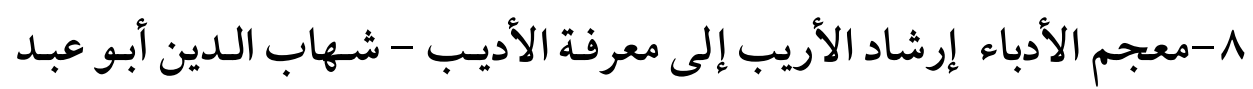

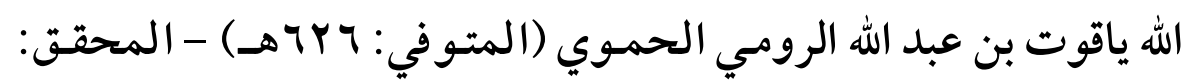

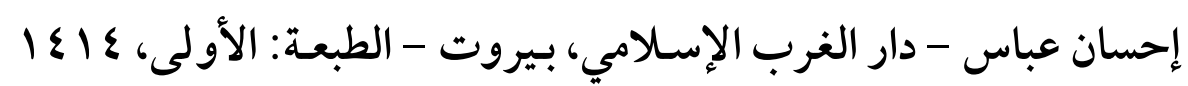

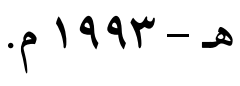

9-تهـذيب الأسـماء واللغـات - أبـو زكريـا محيـي الـدين يحيس بـن شرف النووي (المتوفي: جVT Tــ) - دار الكتب العلمية، بيروت - لبنان.

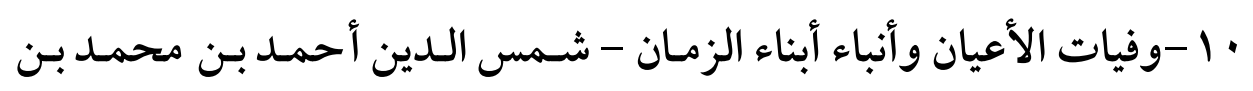

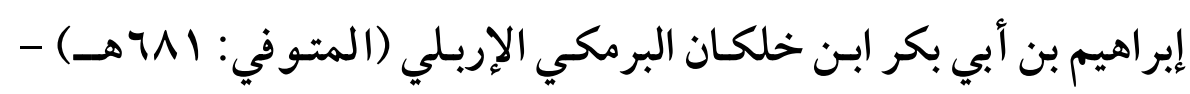
المحقق: إحسان عباس - دار صادر - بيروت.

11 - 11

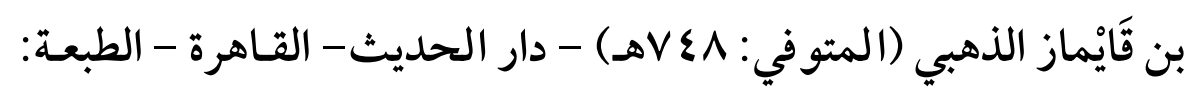

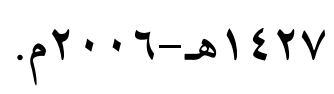
r ا -ميزان الاعتـدال في نقــد الرجـال - شـمس الـدين أبـو عبـد الله محمـد بـن

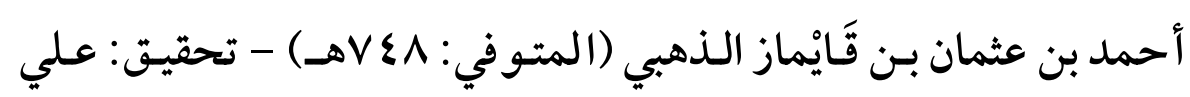
محمد البجاوي - دار المعرفة للطباعة والنشر، بيروت - لبنان - الطبعة:

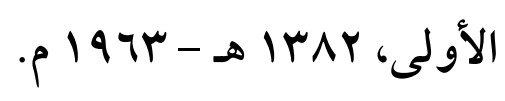


(YTY)

مناسبة اللفظ للعنى عند الأصوليين وأثرها في توجيه خطاب المجتهلين

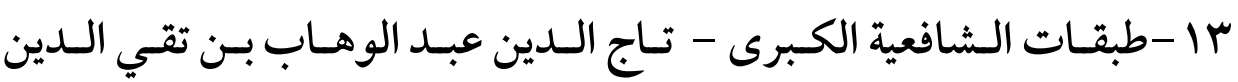
السبكي (المتوفي: هVVI IVI) - المحققى: د. محمـود محمـد الطناحي د.

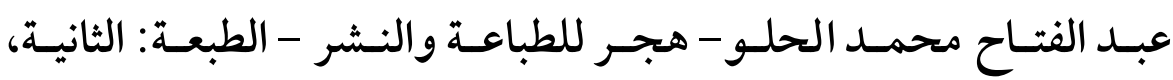
.

ع ا-الجواهر المضية في طبقات الحنفية - عبد القـادر بـن محمد بـن نصر الله القرشي، أبو محمد، محيي الدين الحنفي (المتوفي: VVVOهـ) النـاشر: مير محمد كتب خانه - كر اتشي.

10 -لسان الميزان - أبو الفضل أحمد بن علي بن محمد بن أحمد بـن حجر

العسقلاني (المتوفي: بهمهـ) - المحقـق: دائرة المعـرف النظاميـة -

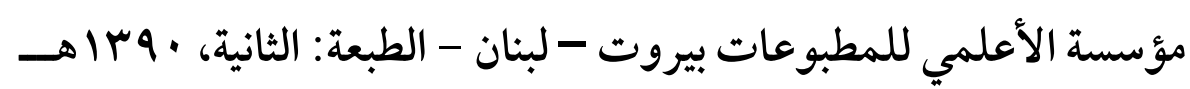
. $19 \times 1 /$

17 - الضوء اللامع لأهل القرن التاسـع - شـمس الـدين أبـو الخير محمـد بـن

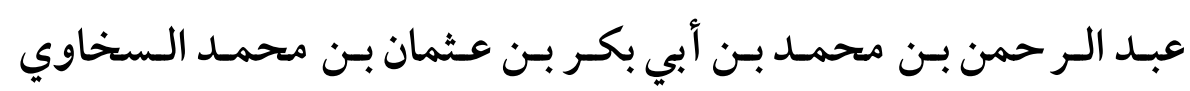
(المتوفي: r •وهـ) - الناشر: منثورات دار مكتبة الحياة -بيروت. IV السيوطي (المتوفي:

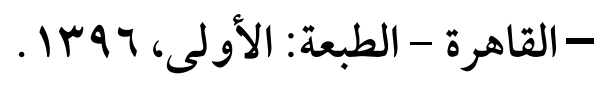

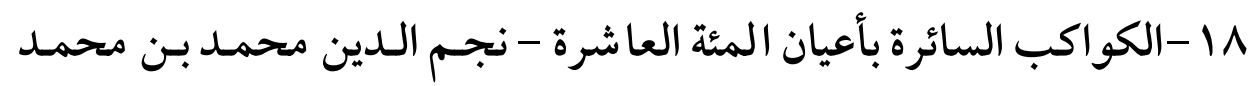

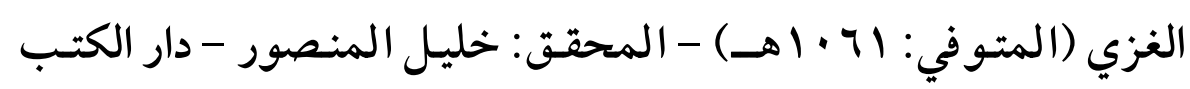

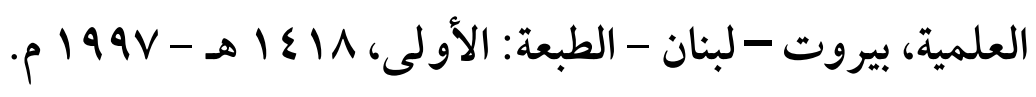


19 - الأعلام - خير الدين بن محمود بن محمد بن علي بـن فارس، الزركلي الدمشتي (المتـوفي: جو باهـ) - النـاشر : دار العلـم للملايسين الطبعـة:

$$
\text { الخامسة عشر - أيار / مايو Y +. P م. }
$$

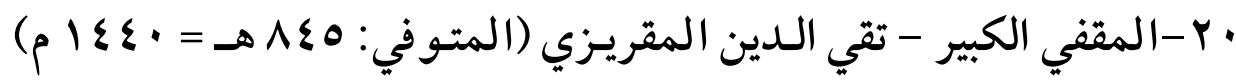

المحقق : محمـد اليعلاوي - دار الغـرب الاسـلامي، بـيروت - لبنـان -

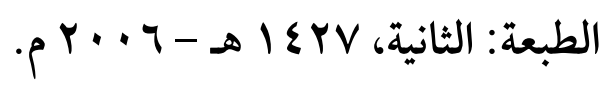

ا ا-معجم المؤلفين - عمر رضا كحالة- مكتبة المثنى - بيروت، دار إحياء

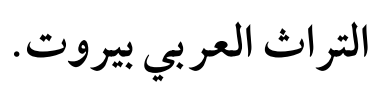

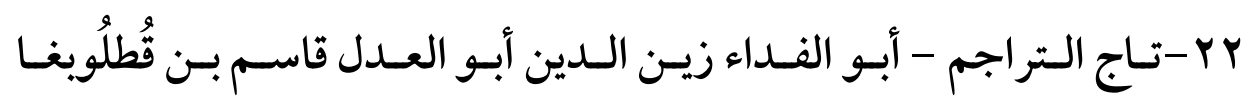
السودوني الجمالي الحنفي (المتوفي: AV9هـ) - المحقق: محمـد خير المير

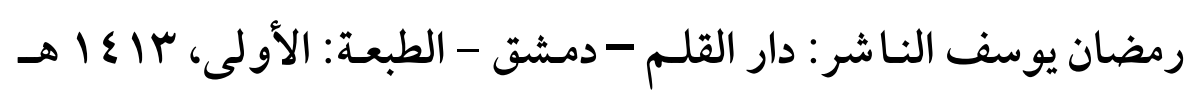

$$
\text { . } 199 r-
$$

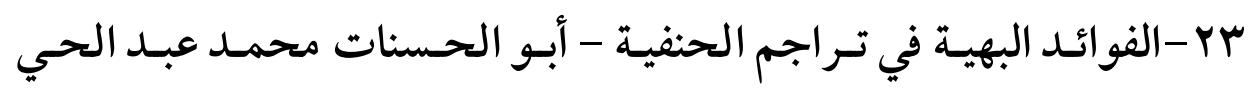
اللكنوي الهندي - مطبعة دار السعادة بجـوار محافظة مصر - لصاحبها

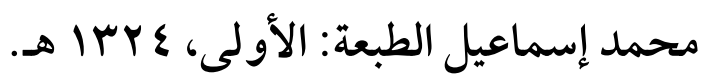
ع - - تاريخ الإسلام ووفيات المشاهير والأعلام - شـمس الـدين أبـو عبد الله

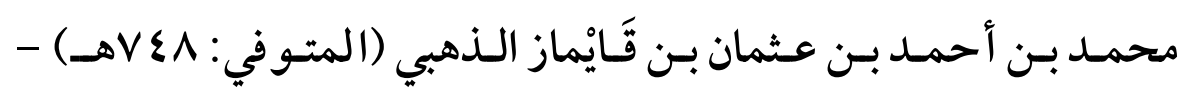

$$
\text { المكتبة التوفيقية. }
$$

0YY-جمهـرة تــراجم الفقهـاء المالكيـة - المؤلـفـ: د. قاسـم عـلي سـعد - دار

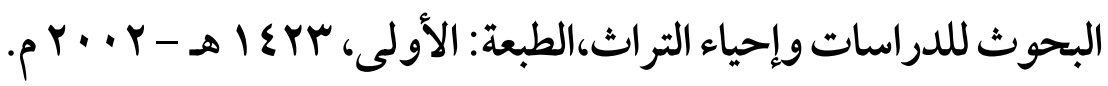


(YTA) مناسبة اللفظ للعنى عند الأصوليين وأثرها في توجيه خطاب المجتهلين

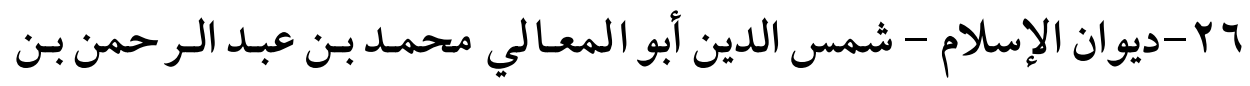

الغـزي (المتـوفي: ITV الهـ) - المحقـق: سـيد كـسروي حسن - دار

الكتب العلمية، بيروت - لبنان - الطبعة: الأولى، || | 1 هـ - . 199 م.

- ط - Y V

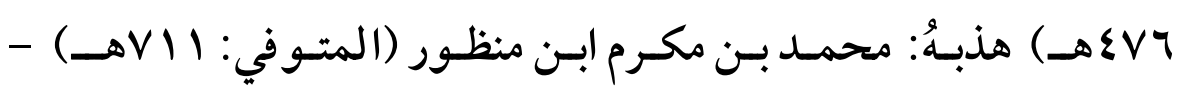

المحقق: إحسان عباس - دار الرائد العـربي، بيروت - لبنـان - الطبعة:

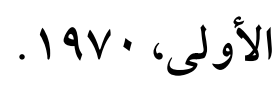

^Y - الوافي بالوفيات - صـلاح الـدين خليل بـن أيبك بـن عبـد الله الصفدي

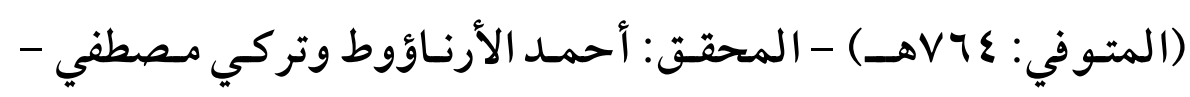

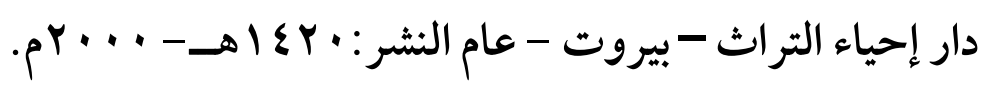




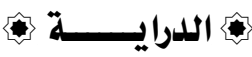

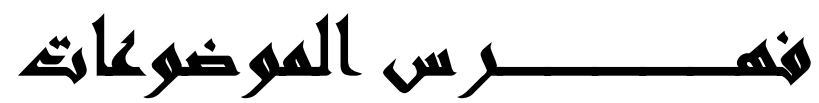




\begin{tabular}{|c|c|c|}
\hline$(Y V \cdot)$ & \multicolumn{2}{|c|}{ مناسبة اللفظ للعنى عند الأصوليين وأثرها في توجيه خطاب المجتهلين } \\
\hline رفم السفنة & الموغورج & 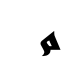 \\
\hline ○ & المقدمة & 1 \\
\hline 10 & تمهيد: تعريف العلة وطرق إثباتها & r \\
\hline$r \cdot$ & والمبحث الأول: تعريف المناسبة والألفاظ ذات الصلة، & $r$ \\
\hline YI & 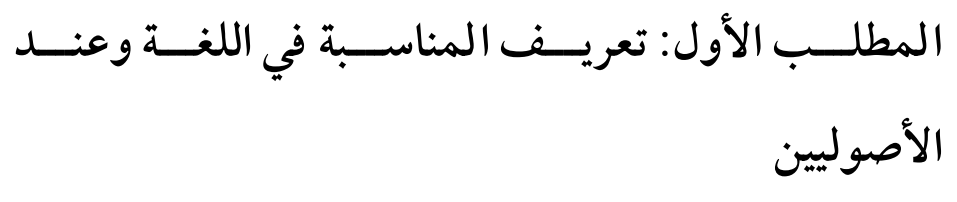 & $\varepsilon$ \\
\hline Y & أولا: تعريف المناسبة في اللغة & 0 \\
\hline rr & ثانيا: تعريف المناسبة عند الأصوليين & 7 \\
\hline$r \wedge$ & المطلب الثاني :التعريف بالألفاظ ذات الصلة & V \\
\hline$r \wedge$ & ع - النسبة & $\wedge$ \\
\hline rq & 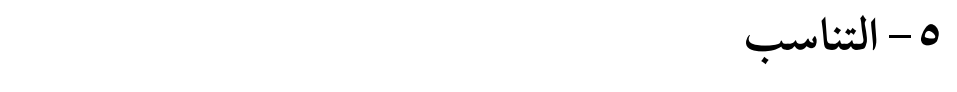 & 9 \\
\hline r. & 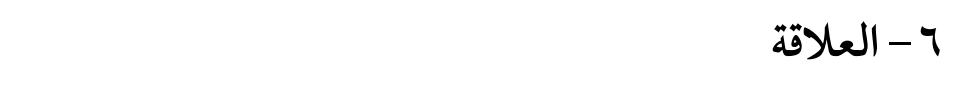 & 1. \\
\hline rr & المطلب الثالث: وضع اللفظ واستعماله & 11 \\
\hline$r \varepsilon$ & الفرع الأول: تعريف الوضع & Ir \\
\hline r & الفرع الثاني: نقل الألفاظ للمعاني & ir \\
\hline rv & 1 - تعريف النقل & $1 \varepsilon$ \\
\hline
\end{tabular}




\begin{tabular}{|c|c|c|}
\hline rVI) & 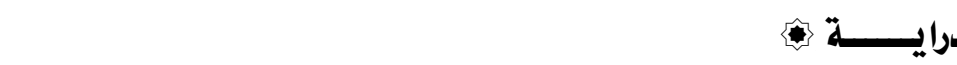 & \\
\hline رثمه الصفنة & 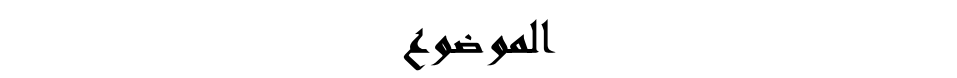 & 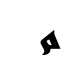 \\
\hline r^ & 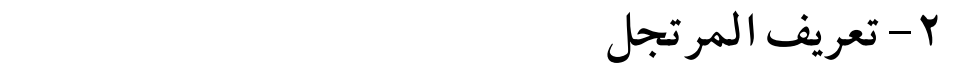 & 10 \\
\hline rq & ت الحقيقة & 17 \\
\hline$\varepsilon \uparrow$ & 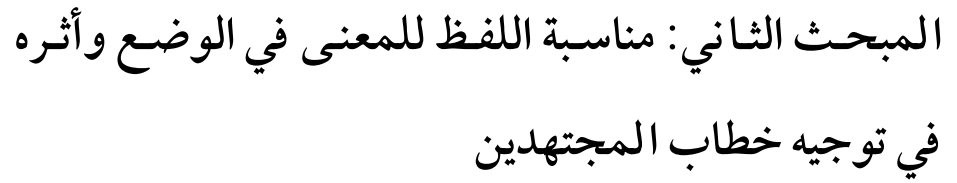 & IV \\
\hline 0. & 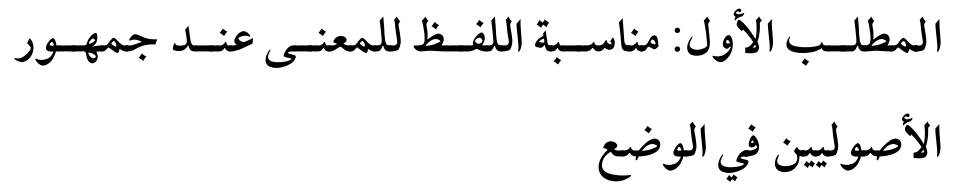 & 11 \\
\hline or & 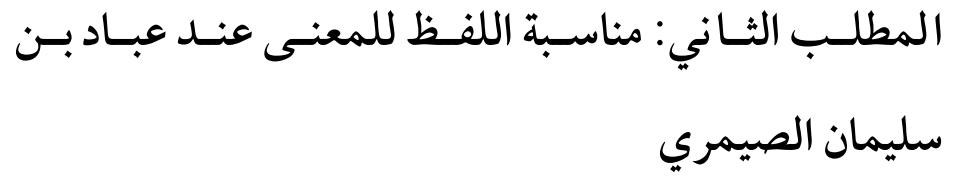 & 19 \\
\hline 09 & 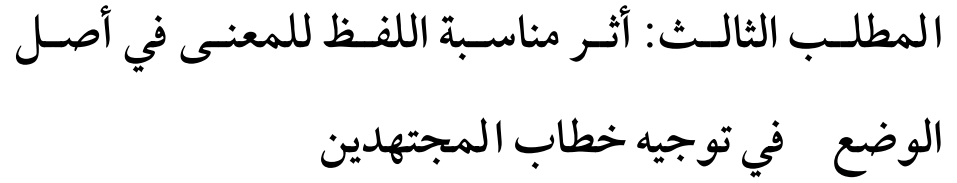 & $r$. \\
\hline TY & وأثره في توجيه الثالث: مناسبة اللفظ للمعنى في الحقيقة العرفية المجتهدئ & YI \\
\hline זי & المطلب الأول: تعريف الحقيقة العرفية & rr \\
\hline TV & و المطلـب الثـاني: شروط نقـل اللفــ اللغـوي إلى العــف & $r r$ \\
\hline Vo & 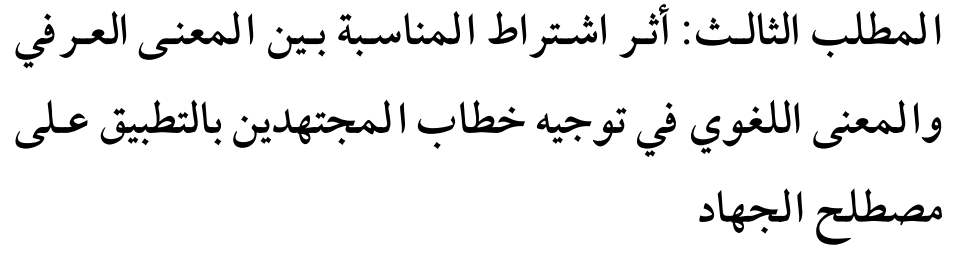 & $Y \varepsilon$ \\
\hline
\end{tabular}




\begin{tabular}{|c|c|c|}
\hline (YVY) & اللفظ للعنى عند الأصوليين وأثرها في توجيه خطاب المجتهلين & مناسب \\
\hline (رمه الصفنة & 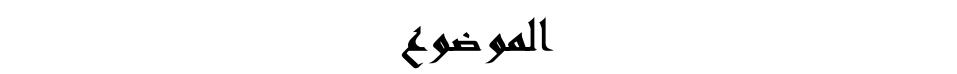 & 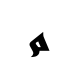 \\
\hline$V V$ & 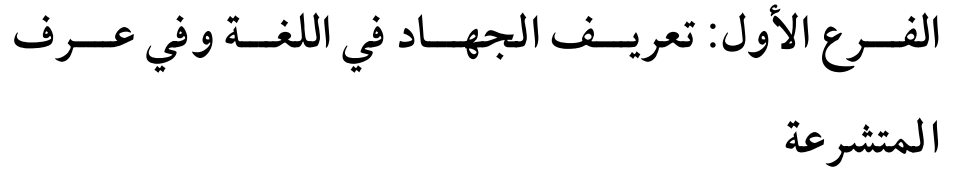 & ro \\
\hline$\wedge$. & لاء و أدلتهم في علة الجهاد & ry \\
\hline$\wedge \wedge$ & 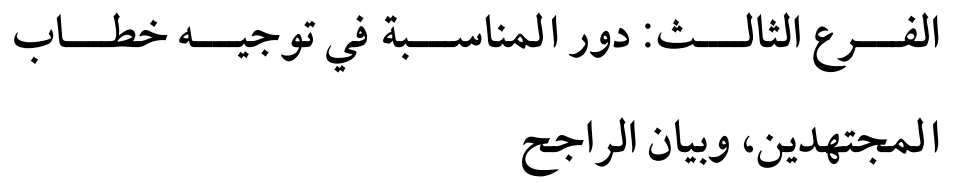 & $Y V$ \\
\hline 94 & 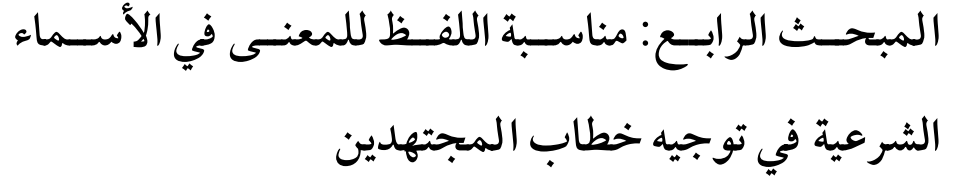 & $r \wedge$ \\
\hline 90 & : & Yq \\
\hline $1 \cdots$ & هب العلماء في وجود الحقيقة الشرعية & r. \\
\hline 111 & : أدلة المذاهب والر اجح منها & 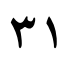 \\
\hline IYA & 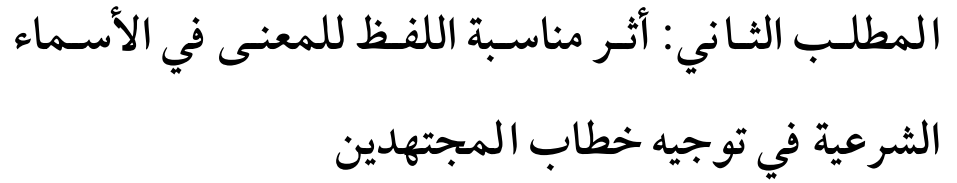 & rY \\
\hline Ir. & 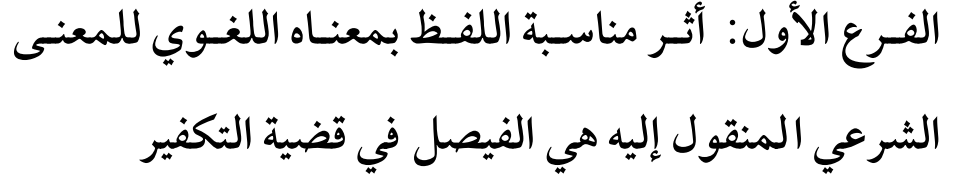 & rr \\
\hline 4ri & 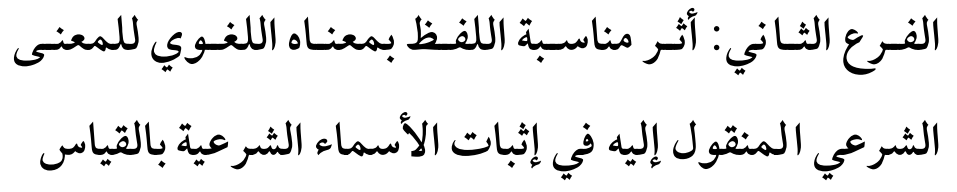 & r६ \\
\hline
\end{tabular}




\begin{tabular}{|c|c|c|}
\hline$(Y \vee Y)$ & 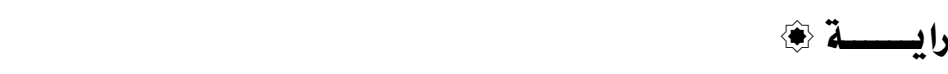 & \\
\hline (رمه الصفنة & 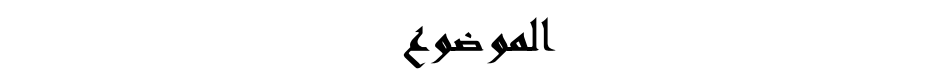 & 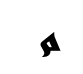 \\
\hline IrA & أولا: إثبات الأسماء الثرعية بالقياس & ro \\
\hline 10. & ثانيـا: أثـر إثبــات الأسـماء الـشرعية بالقيـاس في توجيـهـ & rq \\
\hline lor & المسألة الأولى: قياس النباش على السارق & rv \\
\hline 17r & المسألة الثانية: قياس اللائط على الزاني & rA \\
\hline IVr & المسألة الثالثة: قياس النبيذ على الخمر & rq \\
\hline 111 & 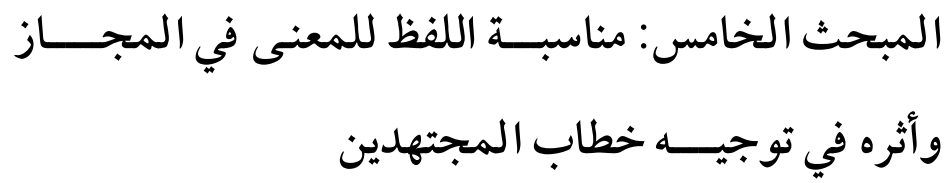 & $\varepsilon$. \\
\hline $1 \wedge r$ & المطلب الأول: تحقق مفهوم المجاز باشتر اط المناسبة & \& \\
\hline $1 \wedge \Lambda$ & 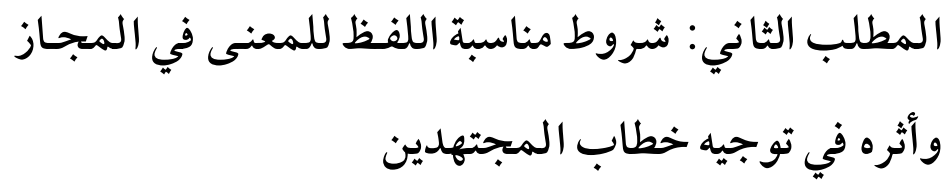 & $\varepsilon Y$ \\
\hline$r \cdot r$ & المطلب الثالث: علاقات المجاز & $\varepsilon r$ \\
\hline rir & 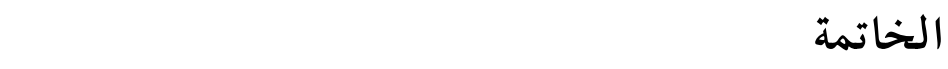 & $\varepsilon \varepsilon$ \\
\hline YIE & 1 - أهم نتائج البحث & $\varepsilon 0$ \\
\hline Y19 & 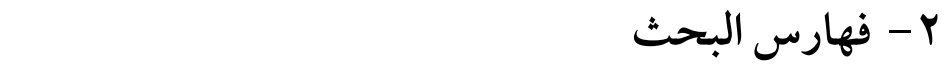 & $\varepsilon \uparrow$ \\
\hline YYI & فهرس الآيات القر آنية & $\varepsilon \vee$ \\
\hline YYT & فهرس الأحاديث النبوية & $\varepsilon \wedge$ \\
\hline
\end{tabular}




\begin{tabular}{|c|c|c|}
\hline (Yマ\&) & اللفظ للعنى عند الأصوليين وأثرها في توجيه خطاب المجتهلين & مناسب \\
\hline رثم الصفنة & الهو ضورح & s \\
\hline YYA & فهرس الآثار & $\leqslant 9$ \\
\hline rru & & 0 . \\
\hline 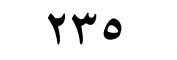 & فهرس & 01 \\
\hline 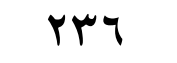 & 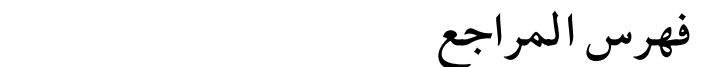 & or \\
\hline$r V \cdot$ & وضوعات & or \\
\hline
\end{tabular}

